\author{
UNIVERSIDAD POLITÉCNICA DE MADRID
}

ESCUELA TÉCNICA SUPERIOR DE ARQUITECTURA DE MADRID

\title{
GOETHE Y LA ARQUITECTURA. \\ La dialéctica de la autonomía \\ entre el clasicismo y la modernidad
}

TESIS DOCTORAL

Alberto Rubio Garrido

Arquitecto y Doctor en Filosofía 



\title{
GOETHE Y LA ARQUITECTURA.
}

\section{La dialéctica de la autonomía}

\section{entre el clasicismo y la modernidad}

\author{
Alberto Rubio Garrido \\ Arquitecto y Doctor en Filosofía \\ Directores de la tesis doctoral: \\ Juan Calatrava Escobar. Universidad de Granada \\ Juan Calduch Cervera. Universitat d'Alacant
}



Tribunal nombrado por el Magfco. y Excmo. sr. Rector de la Universidad Politécnica de Madrid, en día de de 2020.
Presidente:
D. Manuel Blanco Lage
Secretario:
D. Javier Arnaldo Alcubilla
Vocal 1:
D. Jorge Torres Cueco
Vocal 2:
Dñ. Camila Mileto
Vocal 3:
D. Michele Cometa
Vocal suplente 1:
Dñ. Ana Esteban Maluenda
Vocal suplente 2:
Dñ. Mar Loren Méndez

Realizado el acto de defensa y lectura de la tesis el día de de 2020 en Madrid.

Calificación:

El Presidente:

El Secretario:

Los Vocales: 

Dedicado a mis padres

València, invierno de 2020 
A comienzos de 2015 defendí la tesis doctoral Autonomía y expresión en la arquitectura. La antinomia de la modernidad al hilo de la obra de Claude-Nicolas Ledoux en la Facultad de Filosofía de la Universitat de València, bajo la dirección de Julián Marrades Millet, Catedrático de Metafísica de la Universitat de València, y Juan Calatrava Escobar, Catedrático de Composición Arquitectónica de la Universidad de Granada. Un periplo de cinco años me había llevado hasta allí, alejándome temporalmente de mi formación y práctica profesional como arquitecto.

Por aquel entonces, en uno de los seminarios anuales del Grupo de Arquitectura y Pensamiento de la Universitat Politècnica de València, Juan Calduch Cervera, Catedrático de Composición Arquitectónica de la Universitat d'Alacant, me introdujo indirectamente en una deriva de la que este trabajo es su principal resultado. Recuerdo bien cómo, en aquella ocasión, vinculó con la agudeza y precisión que caracteriza su obra la escultura Stein des guten Glücks (1777) de Johann Wolfgang Goethe con la tensión moderna entre la caducidad y la permanencia. Fue una mención de pasada, pero bien bastó para que iniciásemos entonces una colaboración que se ha prolongado hasta ahora.

Juan estaba interesado en un breve manuscrito de Goethe que había consultado durante una estancia de investigación en el Goethe und Schiller Archiv de Weimar. Había sido solo parcialmente traducido y, por tanto, mi inicial colaboración consistió en realizar una traducción completa. Así es como me introduje en un personaje que, pese a la cercanía a mis referentes en la tesis doctoral anterior, apenas si había sido objeto de análisis en aquella ocasión. Lo que inicialmente fue una 
puntual colaboración acabó cogiendo cuerpo y dio lugar al trabajo que encabezan estas líneas: una segunda tesis doctoral, esta vez presentada en la Escuela Técnica Superior de Arquitectura de la Universidad Politécnica de Madrid y dirigida por Juan Calduch y, una vez más, por Juan Calatrava Escobar.

Si para dilucidar en clave filosófica qué papel jugó la arquitectura en las diatribas autonomicistas elegí a un arquitecto, es decir a Ledoux, para dilucidar en clave arquitectónica qué papel jugó la filosofía elegí a un literato, es decir a Goethe. No es baladí este juego especular habida cuenta del tema que se investiga. En el seno del autonomicismo late una potente paradoja según la cual las disciplinas luchan por sostenerse en su autonomía al tiempo que, tal y como pude entonces $y$ he querido ahora mostrar, requieren de hibridaciones para sostenerse. Arquitectura y filosofía resuenan virtuosamente a la hora de afrontar la cuestión de la autonomía. La validez del resultado de esta hibridación queda ahora a merced del lector.

Toda obra es, en esencia, una obra colectiva. Uno se debe a las influencias recibidas, a sus lecturas, a las conversaciones sostenidas durante años... pero en este caso, la afirmación cobra quizás una validez adicional. Si es evidente mi deuda hacia Juan Calduch, quien me inició y guio en este terreno, no menos relevante lo es hacia Juan Calatrava, admirado e incansable investigador en los ámbitos más dispares, además de muy querido amigo. Alguien que siempre me brindó ayuda y apoyo.

Apoyo y ánimos me ha brindado también Begoña Serrano Lanzarote, directora del Instituto Valenciano de la Edificación, durante estos años prácticamente coincidentes con mi relación con ella. También debo mucho a dos apreciados amigos, Jürgen Misch y Manuel E. Vázquez, quienes generosamente me asesoraron en las traducciones. Michele Sbacchi, querido colega palermitano, me acogió durante mi estancia de investigación en su tierra con caluroso afecto y quisiera correspondérselo mínimamente en estas líneas.

En un terreno más íntimo son muchas las personas a las que querría mencionar. A riesgo de caer en lo evidente diré que todo esto es posible gracias a compartir mi vida con Aixa. Sin ella no solo esta tesis no sería lo que es, sino que ni yo mismo podría reconocerme. Sé que no es necesario, pero me gustaría también mencionar a mi familia, que han seguido con atención y cariño el progreso de este trabajo. Mis tíos y tías, mi hermana y hermano, sus respectivas parejas. $Y$ especialmente a mi padre, atento lector de mis textos, y mi madre, incondicional como siempre. A ambos he querido dedicarles este trabajo. 



\section{ÍNDICE}

ÍNDICE

$\begin{array}{lr}\text { RESUMEN I ABSTRACT } & 15\end{array}$

INTRODUCCIÓN

Autonomía y modernidad. Un desafío para la arquitectura $\quad 21$

Goethe. La arquitectura y su autonomía $\quad 25$

Objetivo e hipótesis $\quad 26$

Bibliografía básica y metodología $\quad 27$

PARTE I. LA AUTONOMÍA COMO DESAFÍO DE LA MODERNIL 31

1. LA IRRUPCIÓN DE LA AUTONOMÍA EN EL ARTE 39

La ambigüedad del "conocimiento sensible" $\quad 42$

Desinterés y finalidad interna $\quad 45$

2. EL DOBLE SENTIDO DE LA AUTONOMÍA

A. La autonomía trascendental $\quad 54$

Motivación de la tercera crítica $\quad 54$

La "finalidad sin fin" en el arte $\quad 57$

Autonomía en Kant $\quad 59$

B. La autonomía moderna $\quad 63$

El vértigo de la modernidad $\quad 64$

$\begin{array}{ll}\text { El papel de la estética y del arte } & 67\end{array}$

Inmunidad e indiferencia en el arte $\quad 73$

$\begin{array}{ll}\text { 3. LA AUTONOMÍA EN LA ARQUITECTURA } & 79\end{array}$

A. Estética arquitectónica en Vitruvio $\quad 80$

Los diez libros de arquitectura $\quad 80$

Contenido estético del tratado de Vitruvio 89

B. Crisis de la imitatio y arquitectura del efecto 96

La querelle y la crisis del clasicismo $\quad 97$

El principio estético de la "relación" 100

Estética del carácter y de la expresión 103

C. La revolución kantiana en la arquitectura 106

El "giro" kantiano: funcionalidad y belleza 106

Expresión y moral: la exigencia de la autonomía $\quad 110$

D. La recepción de Schiller. símbolo y moral $\quad 113$ 
PARTE II. GOETHE Y EL ARTE DE LA CONSTRUCCIÓN

A. "Lo que no se comprende no se posee" 122

B. "Este pequeño mundo del arte" 125

$\begin{array}{ll}\text { Conocedor, diletante, artista } & 125\end{array}$

$\begin{array}{ll}\text { Juicio, creación, genio } & 128\end{array}$

$\begin{array}{ll}\text { Arte y arquitectura } & 129\end{array}$

$\begin{array}{ll}\text { Texto y dibujo } & 130\end{array}$

C. "Arte otra naturaleza..." 133

$\begin{array}{ll}\text { Naturaleza, arte, razón } & 134\end{array}$

$\begin{array}{ll}\text { Historia natural } & 135\end{array}$

$\begin{array}{ll}\text { Historia del arte } & 136\end{array}$

$\begin{array}{ll}\text { Historia de la arquitectura } & 139\end{array}$

D. "Siendo arquitecto..." 144

$\begin{array}{ll}\text { Dibujos arquitectónico } & 146\end{array}$

$\begin{array}{ll}\text { Monumentos, ruinas } & 150\end{array}$

Tratados, escritos $\quad 157$

$\begin{array}{ll}\text { Arquitectos, artista } & 162\end{array}$

$\begin{array}{ll}\text { Proyectos, obras } & 164\end{array}$

2. HACIA UNA TEORÍA DE LA ARQUITECTURA 173

A. "Ya veo la posibilidad ante mí..." 176

$\begin{array}{ll}\text { Aclaraciones previas } & 177\end{array}$

Las tres categorías de la arquitectura $\quad 180$

$\begin{array}{ll}\text { Las tres partes de la arquitectura } & 190\end{array}$

$\begin{array}{ll}\text { El Baukunst (1795) } & 204\end{array}$

Borrador del Baukunst (1795) 248

B. "He empezado a cultivar más seriamente la arquitectura..." 258

La serie sobre la arquitectura alemana $\quad 258$

$\begin{array}{ll}\text { Baukunst (1788) } & 268\end{array}$

Über den Dilettantismus (1799) 284

3. INCURSIONES EN LA ARQUITECTURA 293

A. El paisaje en la ciudad $\quad 295$

La casa de Goethe en el campo $\quad 296$

El Puente de la Estrella [Sternbrücke] y el parque 298

La Casa Romana [Römisches Haus] (1791-1797) 300

$\begin{array}{ll}\text { B. Arquitectura teatral y escenografía } & 304\end{array}$

$\begin{array}{ll}\text { El edificio } & 305\end{array}$

$\begin{array}{lr}\text { La escenografía } & 313\end{array}$ 
Arte y naturaleza: la idea de arquetipo 323

Arquitectura y naturaleza $\quad 328$

Mito y arquetipo $\quad 330$

D. Proyectos de escaleras 332

La escalera como tema plástico 333

La escalera como tema arquitectónico 336

La escalera como obra $\quad 339$

Goethe, arquitecto diletante $\quad 344$

ÚLTIMAS REFLEXIONES I FINAL THOUGHTS

Entre el clasicismo y la modernidad $\quad 349$

Goethe y la autonomía de la arquitectura 352

Mediación y tragedia $\quad 354$

Between classicism and modernity $\quad 357$

Goethe and the autonomy of architecture $\quad 360$

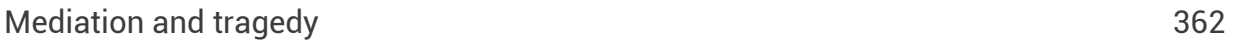

BIBLIOGRAFÍA DE REFERENCIA 365

CRÉDITOS FOTOGRÁFICOS 

RESUMEN

ABSTRACT 
El interés de Johann Wolfgang Goethe por la arquitectura se remonta a su juventud. Pero fue, en especial, durante su viaje a Italia (1786-1788) cuando se volcó en la arquitectura con una renovada dedicación. Bajo un prisma marcadamente clasicista, Goethe estudió los principales tratados y escritos (Vitruvio, Palladio, Winckelmann,...), así como aprendió y ejercitó el dibujo arquitectónico y la perspectiva, algo que se prolongó durante los años posteriores a su regreso. Por aquel entonces, su responsabilidad en los proyectos y obras oficiales en Weimar supusieron un estímulo añadido a su atención por cuestiones no sólo conceptuales o teóricas sino también por sus implicaciones en la práctica concreta de la construcción.

En lo que al discurso autonomicista se refiere, Goethe mantuvo tanto en su producción teórica como práctica una ambigua distancia. Diríase incluso que nunca se adentró con decisión en la polémica, de tan relevantes frutos entre sus contemporáneos. Por una parte, Goethe asumió el dictum kantiano de la "finalidad sin fin" del arte y la prelación de la utilidad en la arquitectura. Por otra, con Schiller, otorgaba al arte en general un papel soberanista en la sociedad, incitándolo a "regir la época". Ambas posturas no podían, evidentemente, asumirse en su simultaneidad sin fricciones.

En este contexto, la arquitectura en general, y muy especialmente la arquitectura construida, cobra un especial protagonismo. Sus requerimientos materiales (véase técnicas constructivas, usos de materiales de construcción...), su inserción en la tradición y las costumbres o la combinación entre su carácter útil con el artístico permitieron a Goethe adentrarse en una interpretación del autonomicismo que le liberaba de las contradicciones internas a las que le impelía la irreconciliable combinación del discurso autónomo aislacionista o el comprometido. Todo ello precipitó en su aportación más significativa en el terreno de la arquitectura, su inconcluso Baukunst (1795), paradójicamente el producto más sofisticado de su aproximación al clasicismo.

El presente trabajo consta de tres apartados. En primer lugar se contextualizan los desafíos que trajo consigo para la arquitectura la irrupción de la autonomía. En segundo lugar se extrae un posicionamiento de Goethe en aquel periodo respecto de la arquitectura, para lo cual se recurrirá puntualmente a otras aportaciones suyas. $Y$ en tercer y último lugar se dilucida en qué medida el choque entre el clasicismo y la modernidad a caballo del XVIII y XIX puede aportar luz sobre la cuestión de la autonomía en la arquitectura. Visto así, la obra arquitectónica de Goethe se muestra como un claro síntoma del desafío que supuso para la arquitectura la irrupción de la modernidad, y muy particularmente la autonomía, y anuncia una tensión que difícilmente puede evitarse sin cesiones. 
Johann Wolfgang Goethe's interest in architecture dates back to his youth. But it was, especially, during his trip to Italy (17861788) when he turned to architecture with a renewed dedication. Under a markedly classicist prism, Goethe studied the main treatises and writings (Vitruvius, Palladio, Winckelmann, ...), as well as learned and exercised architectural drawing and perspective, something that lasted during the years after his return. At that time, his responsibility for official projects and works in Weimar was an added stimulus to his attention for not only conceptual or theoretical issues but also for his implications in the concrete construction practice.

As far as autonomicist discourse is concerned, Goethe maintained an ambiguous distance in both theoretical and practical production. It would even be said that he never entered the controversy decisively, of such relevant fruits among his contemporaries. On the one hand, Goethe assumed the Kantian dictum of the "endless purpose" of art and the priority of utility in architecture. On the other, with Schiller, he gave art in general a sovereign role in society, prompting him to "rule the time." Both positions could obviously not be assumed in their simultaneity without friction.

In this context, architecture in general, and especially built architecture, takes on a special role. Its material requirements (see construction techniques, uses of construction materials ...), its insertion in tradition and customs or the combination between its useful and artistic nature allowed Goethe to enter into an interpretation of autonomicism that freed him from internal contradictions. to which he impelled the irreconcilable combi- nation of isolationist or committed autonomous discourse. All this percipitated in his most significant contribution in the field of architecture, his unfinished Baukunst (1795), paradoxically the most sophisticated product of his approach to classicism.

This work consists of three sections. In the first place, the challenges that the irruption of autonomy brought to architecture are contextualized. Secondly, a positioning of Goethe in that period with respect to architecture is extracted, for which other contributions will be promptly used. And in the third and last place it is clarified to what extent the clash between classicism and modernity on horseback of the XVIII and XIX can bring light on the question of autonomy in architecture. Seen this way, Goethe's architectural work is shown as a clear symptom of the challenge posed to the architecture by the irruption of modernity, and very particularly autonomy, and announces a tension that can hardly be avoided without cessions. 

INTRODUCCIÓN 

La idea de autonomía, en tanto que concepto filosófico, hunde sus raíces en la llustración e irrumpe estrechamente vinculada al proyecto moderno de emancipación del sujeto. De hecho, Kant ya usó el término "autonomía" en sus escritos sobre la razón práctica y, en tanto que "autonomía de la voluntad", constituyó el fundamento del juicio moral. Combinando la idea de que cada sujeto es un fin en sí mismo con la idea de ley universal, la autonomía de la voluntad garantizaba que los agentes racionales fuesen responsables de sus propias decisiones. En su derivación en el arte, la autonomía abrazó este marco estratégico. La estética y la autonomía están interrelacionadas en la medida en que la creciente separación entre arte y vida puso en entredicho la práctica misma del arte. No estando ya al servicio de la religión, no representando ya la jerarquía o los valores sociales, el arte no podía desempeñar su papel tradicional en la sociedad. Así, la estética cubrió la necesidad de dar cuenta de las funciones y objetivos del arte, y la autonomía del arte era una forma de legitimarlos. La falta de obviedad del arte en la llustración vino a ser suplida con la justificación de su existencia autónoma, en rigor la motivación primera del nacimiento de la disciplina estética.

Esta nueva legitimidad del arte estuvo, no obstante, sujeta a su reverso: no teniendo ya más que dar cuenta de sí mismo por sí mismo, el arte se mostró en su más cruda prescindibilidad y quedó amenazado por la solipsista auto-referencialidad. El siglo XIX y sus postrimerías vanguardistas en lo que ha venido a llamarse "el largo siglo XIX" supuso un autentico campo de batalla entre la reivindicación del lugar del arte en la sociedad y la defensa de su aislamiento. En este contexto, y así ha sido heredado en el siglo XX, la autonomía del arte vino mayormente asociada a la interpretación decimonónica de l'art pour l'art, en tanto que el movimiento inverso, aquel encabezado por los revolutionären Kunstbewegungen, vieron en la fusión del arte y la sociedad un potencial transformador. El resultado de ello ha sido una disolución de la categoría matriz del arte moderno que ha arrastrado la autonomía del arte a un delicado estatus de indefinición.

El objeto de este trabajo es dilucidar en qué medida el choque entre el clasicismo y la modernidad a caballo del XVIII y XIX puede aportar luz sobre esta cuestión. El estudio se limita al caso concreto de la arquitectura en el contexto de la obra de Johann Wolfgang Goethe. Dos restricciones que exigen sendas aclaraciones.

\section{Autonomía y modernidad. Un desafío para la arquitectura}

como la arquitectura no es sólo autónoma, sino que al mismo tiempo es funcional, no puede negar simplemente a los seres humanos tal como son, aunque tiene que hacer esto en tanto que autónoma.

Theodor W. Adorno

A la hora de tratar la arquitectura no puede hacerse un uso literal de las estéticas generales, un claro síntoma de la fragilidad de lo que se entiende en la modernidad por "arte". No es casual que las teorías más relevantes se hayan ocupado de la arquitectura como una excepción, como un caso particular de arte, reconociendo sus diferencias pero remitiéndolas siempre a la generalidad. Es este el caso de la teoría de la pulchritudo adhae-
1. Adorno (2008, "Funcionalismo hoy", 10.1: 342)

2. Hay tres interpretaciones distintas del funcionalismo en la arquitectura moderna: la que identifica función con actividad, el funcionalismo mecanicista; la que piensa en funciones orgánicas de adaptación, esto es, el funcionalismo organicista; $y$ la que considera la utilidad como requisito de la belleza en el sentido sorcático de lo bello en cuanto útil para su propio fin. El funcionalismo como doctrina se alinea, por tanto, con el funcionalismo mecanicista. De ahí que se apele a continuación a la adecuación entre forma y función como su característica más destacable.

3. La idea de que la forma de la arquitectura "expresa" la función ha sido posteriormente recogida como fundamento de la modernidad arquitectónica. Esta tesis -muy cercana, como se verá, a las idealistas- fue defendida por Viollet-le-Duc en Entretiens sur l'architecture de 1863 al referirse a funciones portantes, a estructura y construcción, y no tanto a "actividades". Bajo este enfoque se entronca, por un lado, como el racionalismo constructivo y, por el otro, con el rigorismo veneciano.

4. En connivencia con las corrientes anglosajonas pragmatistas, la sempiterna "form follows fonction" ha sido interpretada por autores como Morrison como la pro- 
mesa del Movimiento Moderno (Morrison, 1952). Por su parte, Sullivan lo defendió en Kindergarten Chats de 1901, sin la vehemencia que se le ha atribuido a posteriori, en referencia a las teorías de las ciencias naturales. Así, dice: "Es la ley invariable de todas las cosas [...] en que la vida es reconocible, en su expresión, que la forma siempre sigue a la función. Esto es la ley." O: "En un estado natural la forma existe debido a la función [...]. Así como cada forma contiene su función, y existe en virtud de ella, así también cada función halla o trata de allar su forma". Igual que en la vida, "la forma 'se adapta' a la función".

5. Sería harto complicado desenmarañar aquí la compleja red de dimes y diretes en las vanguardias arquitectónicas con el fin de despejar aquellas posiciones propiamente "funcionalistas". Baste decir que se trata de una tesis mucho menos presente de lo que análisis historiográficos posteriores han intentado otorgar, predomina un talante híbrido en la vanguardia arquitectónica. Quizás Meyer es el representate más conspícuo del funcionalismo mecani-

cista, aquel inspirado en una interpretación determinista proveniente de las matemáticas. Esta sería la versión más estricta, según la cual la forma es el resultado directo de las funciones al margen de toda operación estética. Para rens de Kant del párrafo 16 de su Crítica del Juicio o del apéndice sobre la arquitectura de Schopenhauer en el segundo volumen de El mundo como voluntad y representación. Otros muchos no le conceden especial atención y la arquitectura, si aparece mencionada, pasa a ocupar un lugar instrumental de clarificación de fenómenos particulares de otras artes. A este tenor es llamativa la excepción de la obra de Hegel. Quizás el único gran teórico de la estética moderna que dedicó un estudio pormenorizado a la arquitectura, analizando sus particularidades desde la asunción de su singularidad, la relegó a un papel muy secundario en la modernidad. Para Hegel, la arquitectura era un arte que arrastraba intrínsecamente una limitación expresiva que no podía ser superada: en tanto que arte simbólico, la arquitectura no puede dar expresión articulada de la Idea y, por ello, ha de ser suplantada por las artes de la representación. De hecho, en el caso concreto de la recepción de la autonomía del arte en la arquitectura queda claramente de manifiesto su singularidad y la intrínseca dificultad por parte de la arquitectura de acceder plenamente a la modernidad estética, hasta el punto de que es necesario esperar hasta el siglo XX para poder localizar el primer decidido intento de elaborar una teoría sobre la autonomía en la arquitectura.

En efecto, la arquitectura establece un particular desafío a las teorías estéticas generales $y$, muy particularmente, a la aplicabilidad de la autonomía del arte a su ámbito. Por sus cualidades propias es indudable que la arquitectura constituye un caso singular entre las artes, hasta el punto de ser probablemente la única que repetidamente reivindica su exclusión de los géneros artísticos. Efectivamente, la arquitectura combina una serie de cualidades que la llevan con irremisible frecuencia a afrontar internas contradicciones. Respecto de la cuestión de la autonomía, esta difícil condición no solo se repite sino que se ve incluso potenciada dado que, simultáneamente, las limitaciones a la autonomía de la arquitectura son numerosas y pueden considerarse de facto cualidades esenciales de la arquitectura. De suerte que no es de extrañar que las interpretaciones de las teorías ilustradas respecto del concepto de autonomía hayan sido con frecuencia plurales, si no ambiguas.

En primer lugar, y quizás la más evidente de entre sus limitaciones, la autonomía formal de la arquitectura tiene que afrontar el hecho de que la arquitectura esté orientada a satisfacer una función. A nadie se le escapa que los edificios, las ciudades, los jardines... son, antes que nada, lugares donde se dan actividades humanas, lugares que acogen necesidades humanas. Las posibilitan. En la medida en que el producto de la arquitectura ha de responder a esta condición previa y exterior, su forma está ya en mayor o menor medida pre-determinada. Huelga decir que, con ello, no se hace mención a un determinismo en sentido estético -algo que supondría la renuncia por parte de la arquitectura a su condición artística-, sino que en alguna medida su forma ha de estar condicionada por la función que se le presupone. Es esta una característica única de la arquitectura respecto del resto de artes -que, de hecho, la ha llevado a ser comparada con las disciplinas exclusivamente técnicas-: su instrumentabilidad. Si en la literatura, en la escultura o en la música pueden encontrarse casos de piezas u obras con una función, lo 
será de forma accesoria, es decir, no es esta una condición de posibilidad, no queda sujeta la consideración de tal obra como artística al hecho de satisfacer dicha función. 0 dicho a la inversa: así como en el resto de artes es ineludible la creación de un objeto estético, en la arquitectura es perfectamente concebible la construcción de un edificio ajeno a toda cualidad estética, es decir, un mero producto utilitarista. Esta distinción, aquella que posibilita la construcción de un edificio que desde un punto de vista estético no es más que un edificio ( $\mathrm{y}$ no tanto arquitectura en tanto que arte) encuentra similitudes con aquella postulada por Valéry entre el caminar y el danzar, o entre el lenguaje cotidiano y la poesía.

De hecho, no es cierto que la arquitectura pueda "oponerse a", "ceder a" o "reivindicar" sus inclinaciones funcionales. La arquitectura es necesariamente funcional, o no es. De ahí que sea tan confusa la terminología habitual para designar aquella doctrina que asocia la belleza arquitectónica con la adecuación entre la forma y la función del objeto arquitectónico, esto es, el mal llamado "funcionalismo", interpretación moderna de la utilidad clásica. ${ }^{2}$ En rigor, toda arquitectura es por fuerza utilitaria. Forzando un poco los términos, más acertado sería hablar en este caso de arquitectura "adecuacionista" en tanto que un intento singular por resolver la inestable relación del contenido con la forma en la arquitectura que pretende renunciar por completo a la autonomía formal. Sería este el caso de las versiones más ingenuas y radicales de Viollet-le-Duc, ${ }^{3}$ Sullivan ${ }^{4}$ o ciertos representantes del Movimiento Moderno, ${ }^{5}$ donde lo funcional es erigido como categoría estética, como verdad necesaria. Pero lo cierto es que tan absurdo sería reducir la arqui- tectura a este adecuacionismo radical como obviar que el valor de un edificio ha de estar condicionado por su utilidad (en claro desafío a la tradición estética purista derivada de una cierta interpretación de Kant).

Lo que lleva a la segunda limitación: aquella que afecta a la autonomía de la disciplina. Así como con la disolución de las categorías estéticas durante el XIX cayó la distinción entre las artes, en la arquitectura se han dado casos de transgresión de los límites impuestos por la tradición arquitectónica como "arte". ${ }^{6} \mathrm{La}$ atribución de valores escultóricos a la arquitectura sería una prueba de ello. ${ }^{7}$ Pero no solo. De hecho, la arquitectura es claramente un arte de conjunto: no se puede hablar de la arquitectura como una forma de arte independiente del resto. Quizás las más inmediatas transgresiones de sus límites como disciplina sean la incorporación de competencias dependientes del urbanismo, la jardinería, la decoración o el diseño industrial. Y es que en tanto que arte localizado, la arquitectura no puede sustraerse ni de su entorno, ni de la sociedad. Incluso, a diferencia de otras artes, la arquitectura incorpora adelantos provenientes de otras disciplinas sin que estos hayan respondido previamente a motivaciones estéticas siquiera. Así ocurrió con la apropiación del hormigón armado o del hierro desde sus innovaciones ingenieriles, dando lugar a cambios sin precedentes en la concepción estética de la arquitectura. ${ }^{8}$ Luego, la idea de una autonomía de la disciplina arquitectónica se ve claramente rebajada por esta condición localizada de este arte particular: la capacidad de la disciplina arquitectónica de dar cuenta de sí-misma por sí-misma, de ser capaz de establecer sus propios fundamen- más detalle, consúltese De Zurko (1970)

6. Véase el análisis de la caída de los absolutos y, por tanto, el establecimiento de una dialéctica entre "las artes" y "el arte" en A. Rubio Garrido y A. Takkal (2014), "Arte Sonoro y la dialéctica entre las artes y el arte", en ¡Chum, chum, pim, pam, pum, Olé! Pioneros del Arte Sonoro en España, de Cervantes a las Vanguardias, Miguel Molina (ed.). Lucerna: Weekend Proms, pp. 24-32.

7. Durante los debates formalistas de principios de siglo XX (Vischer, Lipps, etc.) y su asunción por la Gestalt (por ejemplo, Arnheim) se estableció una cierta frontera, pese a ser inevitablemente difusa, entre arquitectura y escultura. Tres cualidades son esenciales: la escala, el espacio interior y el hecho de que, ambos, condicionen la estrucutra sustentante y la construcción. Ciertas esculturas pueden albergar un espacio interior, incluso ciertas funciones, pero su estructura-construcción no está condicionada por el "espacio interior" sino por su volumen exterior. En la arquitectura, en cambio, la estructura y la construcción dependen del espacio interior según su propia escala.

8. En contra de lo que defienden críticos como Pevsner o Giedion, la destreza técnica en la arquitectura antecede a las concepciones estéticas. Los debates en torno a la 
voluntad de ennoblecer los nuevos materiales, por ejemplo en el caso de Labrouste, evidencian esto. En las bibliotecas de Sta. Genoveva y la Nacional, contemporáneas de las primeras grandes estructuras metálicas de las estaciones de tren de los ingenieros, incorpora las posibilidades técnicas de los nuevos materiales desde claves arquitectónicas. Esto es, primero son las innovaciones $y$, posteriormente, una adecuación estética desde la disciplina que se se las apropia. De lo contrario serían resultado interno de procesos estéticos arquitectónicos.

9. Véase en especial Vers une architecture de Le Corbusier o Die neue Baukunst de Bruno Taut. tos sin recurrir a nada ajeno a la arquitectura no puede llegar a ser una aspiración plena de la arquitectura. Asimismo, como corolario, la autonomía profesional o la capacidad por parte de los arquitectos de intervenir con arreglo a su voluntad sin coacción de fuerzas externas es un postulado radicalizado de una autonomía entendida en su sentido estrictamente formal que no cabe en esta disciplina por las razones antes aducidas.

Es más, el carácter social de la arquitectura, es decir, el hecho excepcional entre las artes de imponerse en su entorno, sin alternativa, lleva a la arquitectura a tener que asumir al menos dos restricciones más. En primer lugar y en tanto que tercera limitación, siendo pública, la arquitectura no puede reivindicar un lenguaje privado como sí podrían artes como la música o la literatura. Ha de hacer uso de algo así como una "lengua común". La tradición o los estilos no tienen la misma relevancia que en otras artes. La arquitectura no puede desprenderse de ellos como una materia a libre disposición, ni como una interpretación subjetiva. Incluso en los intentos quizás más valientes de desprendimiento de la tradición, como es el caso de Ledoux y sus arquitecturas visionarias, pueden identificarse rasgos de la tradición clásica, de las teorías fisionomistas o del enciclopedismo. Arrastra un cierto grado de objetividad que impide entender la arquitectura como una expresión personal o como un elemento aislado de su contexto socio-histórico. De un modo general y más allá de la tradición de la propia disciplina, son ineludibles igualmente las expectativas cotidianas de la sociedad, incluídos aquellas personas ajenas a los debates culturales. En segundo lugar y cuarta limitación, el carácter impositivo de la arquitectura -nadie puede sustraerse a su influencia, lo quiera o no- potencia su valor político. De ello dan buena muestra los intentos vanguardistas de establecer una doctrina estética basada en teorías políticas. ${ }^{9}$ Ciertamente pueden otras artes ceder a los fines políticos, pero en ningún caso alcanzarán el grado de necesidad de la arquitectura. No en vano, la arquitectura establece en su irrumpir un tipo de vida, un tipo de autocomprensión del hombre, sin la intervención directa de la voluntad de los afectados. La arquitectura exige, pues, un compromiso de partida con la sociedad que no es otra cosa que una nueva limitación a su autonomía.

Estas al menos cuatro limitaciones a la autonomía de la arquitectura son, de hecho, cualidades esenciales de la arquitectura. Es decir, forma parte ineludible de la arquitectura asumir estas restricciones a su autonomía tanto en el plano formal (por su orientación funcional y por ser un arte político) como en el plano disciplinario (en tanto que arte de conjunto y público). Es más, más allá de la obviedad de que la arquitectura en un sentido amplio es, entre todas las artes, aquella que tiene un acceso más tortuoso al ideal de autonomía, poco puede afirmarse con rotundidad al respecto. De suerte que desde el comienzo mismo de este trabajo se asume la aspiración a la autonomía en la arquitectura como una imposibilidad, aunque no por ello se pueda cancelar su aspiración. Adelantando ahora la argumentación que aun tardará en llegar, la asunción de esta inicial imposibilidad ha de ser considerada el único camino que puede trazarse para una arquitectura que quiera abrazar el ideal de autonomía, por paradójico que pueda sonar inicialmente. De lo contrario, y se traerán ejemplos a este 
respecto, se corre el riesgo de, o bien desdibujar lo que propiamente se entiende por arquitectura, o bien revertir el proyecto inicial y consolidar su reverso.

\section{Goethe. La arquitectura y su autonomía}

La manera en que Goethe afrontó este intrínseco desafío de la modernidad a la arquitectura hace de él un digno objeto de atención, incluso desde una perspectiva contemporánea. Cabe recordar, por una parte, que Goethe a lo largo de su vida cultivó una muy activa atención por la arquitectura, tanto en la teoría como en la práctica, y, por otra, que se encontró inmerso de lleno en las grandes polémicas del discurso autonomicista de su tiempo.

El interés de Goethe por la arquitectura se remonta a su juventud, alcanzando un notable impacto entre sus contemporáneos y en la historiografía de la modernidad arquitectónica desde sus inicios. Indudablemente, su ensayo Von Deutscher Baukunst (1772) marcó un periodo histórico. Pero fue, en especial, durante su viaje a Italia (1786-1788), cuando Goethe se interesó por la arquitectura con una renovada dedicación. Durante los años inmediatamente posteriores a su regreso se despertó en él un gran interés por el conocimiento y estudio de la arquitectura en los tratados y escritos así como por el aprendizaje y ejercicio del dibujo arquitectónico y la perspectiva. Sin duda su responsabilidad en los proyectos y obras oficiales en Weimar y en la reconstrucción del Schloss de Weimar incendiado años antes supondrían un estímulo añadido a su atención por cuestiones arquitectónicas no sólo conceptuales o teóricas sino también por sus implicaciones en la práctica concreta de la construcción.
Aunque su interés por la arquitectura nunca desapareció completamente a lo largo de toda su vida, sin embargo, es posible sostener que la década que se inició con su viaje a Italia representó el periodo más fecundo.

En lo que al discurso autonomicista se refiere, Goethe no fue en su producción teórica un explícito defensor. Diríase incluso que nunca se adentró con decisión en la polémica, de tan relevantes frutos entre sus contemporáneos. De ahí que no deba extrañar que incluso hoy se excluya a Goethe de los grandes relatos que pergeñaron por aquel entonces el concepto de autonomía. No obstante, se pueden encontrar en sus grandes obras -ensayos, novelas o dramas indistintamente- referencias a las grandes cuestiones que implica el desafío autonomicista. No en vano, entre sus más allegadas amistades constan desde precursores como Karl Phillip Moritz a potenciadores de la autonomía moderna como Friedrich Schiller. Por añadidura, la piedra basal de la autonomía en el arte, Immanuel Kant, resultó ser para Goethe el "filósofo más importante de la cultura alemana de la época", tal y como mentó a Eckermann, en especial en su aportación estético-teleológica.

Por una parte, Goethe asumió el dictum kantiano de la "finalidad sin fin" del arte y la prelación de la utilidad en la arquitectura. Por otra, con Schiller, otorgaba al arte en general un papel soberanista en la sociedad, incitándolo a "regir la época". Ambas posturas no podían, evidentemente, asumirse en su simultaneidad $\sin$ fricciones. $Y$ es, a este respecto, donde la arquitectura concreta cobra un especial protagonismo. No es casualidad que coincidiese el inicio de su amistad con la gestación de la aportación goethiana más 
significativa a la arquitectura: su inconcluso ensayo Baukunst (1795). Siendo un arte útil para la sociedad y un inevitable vehículo rector de la misma, Goethe pudo en su aproximación a la autonomía de la arquitectura liberarse de las contradicciones internas a las que le impelía la irreconciliable combinación del discurso autónomo aislacionista o el comprometido. En este complejo entramado de intenciones y conceptos, la arquitectura concreta cobra un especial protagonismo tanto por sus requerimientos materiales (véase técnicas constructivas, usos de materiales de construcción...) como por su inserción en la tradición (en este sentido el Baukunst de 1795 es un decidido empeño por rescatar la vigencia del clasicismo). Pero déjese esto, por el momento, en el terreno de la hipótesis.

\section{Objetivo e hipótesis}

El objetivo de este proyecto de investigación radica en la dilucidación del posicionamiento de Goethe respecto de la intrínsecamente moderna polémica de la autonomía de la arquitectura. Desde los años 70 (extensivo al siglo XX si se incorporan discusiones próximas a la cuestión de la autonomía) pueden localizarse un buen número de estudios, fundamentalmente desde el área de la filología, que han orientado sus esfuerzos en la enunciación de un posicionamiento de Goethe respecto de la autonomía del arte en general. No obstante, hoy por hoy, no ha habido un trabajo centrado en esta cuestión en el ámbito de la arquitectura, en tanto que disciplina artística con unas demandas internas que imposibilita la translación inmediata de estas conclusiones en el área de la literatura a la arquitectura. No en vano, en estos artículos especializados no se encuentra referencia alguna a la arquitectura.

En este sentido se pueden destacar al menos tres ejes principales que han de articular el desarrollo de este trabajo:

1. La función social del arte. En la literatura especializada no hay un consenso destacable: ciertos autores defienden que Goethe apostó por una función social del arte, en tanto que otros afirman que se opuso a toda asunción de fines ajenos al propio arte. Este clásico dilema de toda aproximación autonomicista al arte cobra especial importancia en el caso concreto de la arquitectura en la medida en que, en tanto que arte particular, exige de partida una orientación a fines: satisfacer las necesidades de habitabilidad a la sociedad.

2. La autonomía de las artes. Por un lado, Goethe siempre insistió en la necesidad de separar las reflexiones y prácticas respecto de las diferentes artes por las que mostró interés. Se resistió, en efecto, en homologar literatura a poesía, artes plásticas o música. Para Goethe no hay un concepto "arte" que pueda arropar a todas, de ahí que sea necesario atender al caso específico y dotarlo de la debida singularidad. No obstante, en el caso concreto de la arquitectura, tal y como quedó explícitamente formulado en su ensayo Baukunst (1795), la arquitectura guarda en su estado más evolucionado un cierto parentesco con la poesía, en la medida en que contiene una parte poética. 
3. Arte y epistemología. Para Goethe, toda reflexión y práctica artística ha de estar subsumida a una teoría general del conocimiento. Es más, ha de estar sometida al conocimiento de la Naturaleza. La charnela que permite articular la tendencia de este postulado declaradamente organicista y la exigencia de la creación en el arte reposa en su teoría de la metamorfosis, de incuestionable relevancia también en el terreno de la arquitectura.

En cualquiera de estos tres ejes, tanto en sus textos como en sus propuestas arquitectónicas concretas, Goethe deja a las claras la intrínseca ambigüedad con la que afronta el paradójico dilema de la autonomía en la arquitectura. Algo que le acompañó igualmente en su experiencia vital más inmediata. Ciudadano de dos mundos, el burgués y el feudal, el artístico y el político, en su seno chocan las épocas moderna y clásica. Goethe atrapa, casi con desesperación, una época que se escapa al tiempo que defiende la voz del artista moderno. Desde el recién alcanzado estatus del arte moderno, Goethe formula quizás como último estertor la pérdida que supone el mundo que se derrumba frente a él. En su obra se entiende cómo en la modernidad se conjuga la amenaza y la salvación, al tiempo.

\section{Bibliografía básica y metodología}

Habida cuenta de las claves apuntadas, la cuestión de la autonomía en la arquitectura encierra ciertas particularidades que conviene exponer. Por ello, en una primera parte, con base en los teóricos más relevantes del periodo, se presentará la irrupción de la autonomía en el arte en general para, en lo siguiente, establecer la siempre difícil y ambigua traslación de estos criterios al ámbito concreto de la arquitectura. En este sentido, la obra de Kant y Schiller cobran especial importancia, sin menoscabo de apuntar las claves presentadas por otros contemporáneos de Goethe ( $y$ en muchos casos amigos íntimos) como puedan ser Moritz o Winckelmann.

En la segunda parte de este trabajo, se profundizará específicamente en la obra de Goethe en su relación con la arquitectura. Dado que teoría y práctica en Goethe se entrelazan no es posible reducir el análisis de las implicaciones estéticas de su posicionamiento respecto de la autonomía de la arquitectura atendiendo exclusivamente a sus trabajos teóricos. Nunca quiso concebir la teorización como una actividad desvinculada de la práctica artística. Esta cuestión dificulta notablemente la delimitación del campo de estudio en su extensísima obra, hasta el punto que bien puede encontrarse implicaciones de incuestionable calado en esta cuestión en novelas como el Wilhelm Meister o en obras teatrales como Torquato Tasso. Es más, en Goethe, tanto en su producción teórica, como en su producción artística puede detectarse una deliberada falta de sistematicidad en sus posicionamientos estéticos, de suerte que sea inevitable plantear un estudio transversal en su producción.

Con el fin de poder aportar una mirada rigurosa se ha optado por centrar el análisis al periodo en el que con mayor intensidad Goethe se dedicó a la arquitectura, esto es, el periodo que va desde su viaje a Italia hasta la renuncia a concluir su obra más pregnan- 
te en la materia, el Baukunst (1795). Con tal fin se recogerá, tras una contextualización más amplia, un estudio pormenorizado de esta obra que incluye su traducción completa y reproducción del material gráfico para, a partir de ella, establecer una articulación teórica en relación a las grandes discusiones del momento histórico. Todo ello se medirá posteriormente con la autonomía de la arquitectura y se completará con textos adicionales en su relación con el Baukunst (1795), de los que en los casos que se precise se aporta una nueva traducción actualizada. Entre ellos, cabe destacar, por su precisión, las tres grandes obras dedicadas a la arquitectura, concebidas a modo de dos series. La serie sobre la arquitectura alemana, Von Deutscher Baukunst (1774 y 1823) y el texto homónimo al Baukunst (1795) publicado en 1788. Por último, se recoge otro texto inconcluso, esta vez escrito a cuatro manos junto a Schiller, que de alguna manera cierra este periodo tan fértil de la producción de Goethe: Über den Dilettantismus (1998).

Adicionalmente, son de relevancia y se aludirá a ellas tangencialmente otra serie de obras en las que pueden entresacarse aportaciones relevantes en el ámbito de la arquitectura: "Dritte Wallfahrt nach Erwins Grabe" (1775), "Material den bildenden Kunst" (1788), "Von Arabesken" (1789), "Zur Geschichte der Peterskirche. Nach Bonanni" (1795), "Diderots Versuch über die Malerei" (1799), "Denkmale" (1804), "Altdeutsche Baukunst" (1817), "Schloß Marienburg" (1824), "Boisseréesches großes Domwerk und Kölner Karneval" (1824), "Sendungen aus Berlin" (1827), "Südöstliche Ecke des JupitertempeIs von Girgenti" (1828) y "Der Oppenheimer Dom (1828). A esto se debe sumar un repaso de las actas de Geheimen Consilium, y de sus proyectos y dibujos arquitectónicos, para evaluar también desde la práctica, su posicionamiento. El intercambio epistolar entre Goethe y Schiller contiene igualmente pasajes memorables a este respecto. En lo relativo a su propuesta teórica sobre la autonomía en general, son obras de incuestionable peso Werther (1774), "Monólogo del aficionado" (1789), Torquato Tasso (1790), Conversaciones de emigrados alemanes (1795), "Arte y artesanado" (1797), la introducción a la revista Propyläen (1798), "Sobre verdad y verosimilitud en las obras de arte" (1798), "Sobre Laocoonte" (1798), traducción comentada de El sobrino de Rameau (1805), Poesía y verdad. III (1814), "Sobre el poema didáctico" (1827), Suplemento a la Poética de Aristóteles (1827), Fausto I (1806) y II (1828-1829) y el texto inédito "Sobre el diletantismo", en co-autoría con Schiller. A estos textos, para cuya edición de referencia se usará la Sämtliche Werke. Vierzig Bände, Frankfurt: Deutscher Klassiker Verlag, hay que añadir una serie de referencias secundarias, recogidas en la bibliografía.

La segunda parte de este trabajo se cierra con el análisis pormenorizado de cuatro incursiones teórico-prácticas en la arquitectura, vistas desde las claves desentrañadas con anterioridad: su relación con el paisaje, la arquitectura teatral y la escenografía, su relación con la mitología clásica y, por último, los proyectos de escaleras de Goethe. 


PARTE I:

LA AUTONOMÍA COMO

DESAFÍO 

En un sentido amplio, se entiende por autonomía la no dependencia de algo o alguien a la hora de determinar sus propias leyes. Así, se dice de alguien que es autónomo en la medida en que se vale por sí mismo; referido a un estado, autónomo es aquel que tiene la potestad de regirse mediante normas y órganos propios; y así en adelante. En sintonía con esta acepción, en la tradición filosófica cabe distinguir, al menos, dos amplios sentidos en su uso. ${ }^{10}$ En un primer sentido, que podría ser llamado ontológico, la autonomía responde a la propiedad de ciertas esferas de la realidad de regirse por leyes propias, esto es, distintas de las de otras esferas de la realidad. Aquello que distinguiría esta propiedad de la independencia sería el hecho de que junto con estas leyes que le son propias (que no exclusivas) pueden coexistir otras consideradas de rango más fundamental, que a su vez pertenecen a otras esferas. El segundo sentido en el que se emplea la autonomía pertenece al ámbito ético. Procede originariamente del ámbito político -y a partir del siglo XVII también del jurídico- y no será hasta principios de la Edad Moderna cuando puede encontrarse mención explícita en referencias aisladas de diferentes autores. ${ }^{11}$ En líneas generales, se habla de una ley moral autónoma cuando "tiene en sí misma su fundamento y la razón propia de su legalidad" (Ferrater Mora, 1964: 161). Son, pues, dos sentidos que pueden entenderse simultáneamente. Y este es el caso del desarrollo del concepto de autonomía en la estética. Es, de hecho, precisamente en la convergencia de estos dos sentidos cómo en la estética se alcanzarán las teorías de mayor impacto; una convergencia, por otra parte, que adquiere relevancia en la medida en que se da cargada de una cierta ambigüedad.
Bien sea en un sentido ontológico, bien en un sentido ético, la autonomía exige de una esfera de la realidad o de una ley moral que tenga en sí misma su fundamento y la razón propia de su legalidad. Pero lo cierto es que la recepción de este concepto ha sido plural y conviene dar cuenta en un primer momento de sus intrínsecas dificultades, acrecentadas si cabe en el caso de la estética.

Es a partir de Kant cuando la autonomía ocupa una posición central como concepto filosófico y cobra un sentido enfático (Ritter (ed.), 2007: 702-703 y Feil, 1987). En efecto, Kant sitúa el concepto de autonomía en el centro de su filosofía práctica. Afirma que la razón humana es una fuente autónoma de principios de conducta, a cubierto de los halagos de inclinación sensual, tanto en sus determinaciones de valor como en sus decisiones de actuar. Así, la autonomía humana es el valor más alto y la condición de posibilidad de todos los otros valores y la autonomía de la voluntad [Autonomie des Willens] es entendida como supremo principio de la moralidad. En su Fundamentación de la metafísica de las costumbres de 1785, la autonomía de la voluntad se define como "el estado por el cual ésta [la voluntad] es una ley para sí misma, independientemente de cómo están constituidos los objetos del querer." Y, así, "el principio de la autonomía no es más que elegir de tal manera que las máximas de la elección del querer mismo sean incluidas al mismo tiempo como leyes universales" (1990: 120). Por oposición, la heteronomía de la voluntad constituiría el origen de los principios ilegítimos de la moralidad. Asimismo, será Kant quien insista en la necesidad de delimitar objetivamente las esferas de la realidad, algo que quedará definitivamente
Nota. En gran medida, el contenido de la Parte I proviene de la tesis del autor, Autonomía y expresión en la arquitectura. La antinomia de la modernidad al hilo de Claude Nicolas Ledoux, presentada en enero de 2015 en la Facultad de Filosofía y Ciencias de la Educación de la Universitat de València en el marco del Programa de Doctorado de Pensamiento Filosófico Contemporáneo. En líneas generales, se ha recuperado el contenido de aquella exposición enmarcándolo estrictamente al periodo histórico objeto de este trabajo. Se han incluido explicaciones adicionales de autores apenas tratados en aquella ocasión que adquieren relevancia en el marco de la obra de Goethe.

Este material ha sido parcialmente publicado en los artículos A. Rubio-Garrido (2017), "Hibridación y refundación en la arquitectura: parámetros de una paradójica relación desde el concepto de autonomía", en Arquitectonics. Mind, Land \& Society. 30, pp. 169-182; A. Rubio-Garrido (2016), "Enigma as Moral Requirement in the Wake of Ledoux's Work: Autonomy and Expression in Architecture", en Architecture Philosophy. 2-1, pp. 63-82; A. Rubio-Garrido (2015), "EI desafío de la expresión en la arquitectura", en Actas I Congreso internacional de la Red Española de Filosofía. 
València: Universidad de Valencia, pp. III: 49-61 10. Véase la entrada "autonomía" en José Ferrater Mora (1964), Diccionario de filosofía. Buenos Aires: Editorial Sudamericana, p. 161, tomo I. 11. Ernst Feil defiende que el uso que hicieron del concepto de autonomía los griegos, vinculado a un sentido ético y estético nada tiene que ver con aquel que ocupará la tradición filosófica a partir fundamentalmente de la Edad Moderna. Señala como autores precursores de su uso a Hugo Grotius, Johannes Althusius o Heinrich von Cocceji. Ver Ernst Feil (1987), "Autonomie-Heteronomie", en Antithetik neuzeitlicher Vernunft: "Autonomie-Heteronomie" und "rational-irrational". Götingen: Vandenhoeck \& Ruprecht.

12. Kant menciona en ocho ocasiones el concepto de "autonomía" en la Crítica del Juicio.

La primera vez se sitúa al comienzo mismo de su obra, en el capítulo V de la Introducción: "El Juicio tiene, pues, también un principio a priori para la posibilidad de la naturaleza, pero sólo en relación subjetiva, en sí, por medio del cual prescribe una ley, no a la naturaleza (como autonomía), sino a sí mismo (como heautonomía) para la reflexión sobre aquélla" (2007: 97-98). Lo que Kant establece aquí, de hecho, es un adelanto de la distinción a la que recurrentemente regre- diagnosticado por Max Weber. En este sentido, el proceso de racionalización en occidente conllevó la progresiva diferenciación de las esferas (ciencia, ética y estética) y, así, el arte habría alcanzado un grado de autonomía en la modernidad en la medida en que dispone de su propia historia, al margen de las esferas de la ciencia o la ética.

Pero este sentido enfático arranca desde su gestación cargado de una sintomática ambigüedad. En efecto, es llamativo que en la Crítica del Juicio Kant nunca empleara términos como "autonomía del arte" o "autonomía de la estética", pese a que en numerosas ocasiones se haya recurrido a su obra para justificarlas. De hecho, cuando Kant hace mención explícita al concepto de "autonomía" en esta obra las refiere a la autonomía del gusto y del Juicio reflexionante, la autonomía del sujeto como condición previa, la naturaleza como autonomía o el vínculo entre autonomía y ética (en la medida en que la voluntad autónoma equivale a la libertad). ${ }^{12}$ De ahí que al aproximarse al concepto de la autonomía en el ámbito de la estética sea ineludible enfrentarse a una paradoja: no es posible elaborar una historia del concepto de autonomía antes de Kant y, simultáneamente, Kant nunca apeló explícitamente a algo como una "autonomía del arte". ${ }^{13}$

En rigor, son aquellos autores que reelaboraron las teorías estéticas de Kant a lo largo del reducido periodo entre el Weimarer Klassik y el früher Romantik -Schiller, Schelling o Schlegel, entre otros- aquellos que consolidaron esta tradición filosófica. De hecho, muy pronto, el giro del romanticismo alemán recluirá la idea originaria de autonomía a un segundo plano (Ribbat, 1978: 92142), cobrando protagonismo en cambio en
Francia -y más tarde en Inglaterra y en España- al imponerse lo formal del L'art pour l'art como continuación del ámbito conceptual de la autonomía en tanto que ausencia de fin. El origen del término "autonomía" puede aclarar esta problemática en la medida en que se entienda en el contexto de crisis de los sistemas estéticos posteriores a la caída del clasicismo. En efecto, la adopción del concepto por parte de Kant del ámbito político-jurídico y su postulado de una autodeterminación de la racionalidad del sujeto, está abiertamente relacionado con la gestación de los conceptos de sujeto y de la individualidad. De esta forma, los desajustes arrastrados desde la llustración entre lo individual (o empírico) y lo universal (o trascendental) cobrarán protagonismo a la hora de abordar la cuestión de la autonomía en el arte. En analogía con la transmisión al sujeto de la libertad absoluta reservada al Dios, la aplicación del concepto de autonomía al arte -como emancipación de la religiosidad - tiene que ver con la fundación de una idea secular de arte en la Edad Moderna. Y no menos relevante será la polémica aproximación ilustrada a la cuestión de la fragmentación de las esferas de la realidad (visto desde la ampliación de la crítica a la dialéctica de la llustración) y su desajuste con el ideal de totalidad. Este proceso se saldará en la Querelle des Anciens et des Modernes con la crisis de la imitatio (es decir, la autonomización respecto de la tradición) y a finales del XIX con la drástica crisis de la mímesis (es decir, autonomización respecto de la naturaleza).

Así, la primera dificultad a la hora de enfrentarse al concepto de autonomía estriba en la difícil delimitación de su significado. De hecho, no ha de perderse de vista que su 
significado originario evolucionó a lo largo de principalmente el siglo XIX, extendiéndose en una muy variada terminología. Términos como la pureza, lo absoluto, la perfección, la libertad, la autodeterminación, la inutilidad, el L'art pour l'art, pueden desde un cierto punto de vista entenderse como sinónimos... Esta es, pues, una primera dificultad en toda genealogía del concepto de "autonomía" en el arte. Una primera dificultad, por lo dicho hasta ahora, estrechamente vinculada con la ambigua resonancia de Kant.

La segunda dificultad proviene del hecho de que el concepto de autonomía se haya empleado asimétricamente en diferentes artes. En las artes plásticas y pintura se ha empleado desde tiempo atrás la autonomía como concepto meta-histórico y, al igual que en la literatura, se desarrolla en paralelo con la emancipación respecto de la religión y la corte (Busch, 1987: 230-256). El concepto no establece una estética concreta ni tiene un devenir histórico claro sino, antes bien, se abre en abanico en multiplicidad de interpretaciones. Es sintomático, por ejemplo, que justo donde cabría esperar su utilización -esto es, fundamentalmente en relación a la pintura abstracta y los precursores en el cubismo o futurismo- está ausente. En la teoría de la música, en cambio, solo en el $X X$ se hablará de "música autónoma", entendiendo por ello simultáneamente la liberación de la música respecto de las funciones socioculturales y la independencia estilística del artista. Anteriormente, la superación de las teorías de la imitación se dio a cabo desde Herder y el romanticismo alemán, aunque fuese bajo el término "absoluto", alcanzando a mediados del XIX su punto álgido con Eduard Hanslick (1854/1990). Desde este punto de vista, la sará entre el entendimiento y el Juicio. Más concretamente aquel Juicio que exige una crítica: así como el entendimiento es autónomo porque desde sí mismo establece los principios de la naturaleza, el Juicio reflexionante establece desde sí mismo las leyes propias, y de ahí que sea heautónomo.

La segunda referencia, asimismo en la Introducción, en el punto IX, trata del enlace de la legislación del entendimiento con la de la razón por medio del Juicio: “Con relación a las facultades del alma, en general, en cuanto son consideradas como superiores, es decir, como las que encierran una autonomía" (2007: 110), donde detalla las esferas que corresponden a cada facultad del espíritu.

La tercera se localiza en Nota general a la primera sección de la analítica: "Pero que la imaginación sea libre, y, sin embargo, por sí misma, conforme a una ley, es decir, que lleve consigo una autonomía, es una contradicción" (2007: 158).

La cuarta, en §31. Del método de la deducción de los juicios de gusto: la validez universal de un juicio singular "debe descansar, por decirlo así, en una autonomía del sujeto que juzga sobre el sentimiento del placer (en la representación dada), es decir, en su propio gusto" (2007: 203). De lo que se desprende que el juicio de gusto tiene una característica doble: "validez universal a priori" y "una necesidad [...] mediante cuya representación la aprobación que el juicio de gusto exige de cada cual pudiera ser forzada" (2007: 204).

La quinta, en §32. Primera característica del juicio de gusto, deriva de la anterior: "El gusto tiene solamente pretensión a la autonomía. Hacer de juicios extraños [juicios emitidos por otros sujetos] el motivo de determinación del propio sería heteronomía" (2007: 205). La autonomía del sujeto a la hora de emitir su juicio es considerada la primera característica del juicio de gusto: "El juicio de gusto determina su objeto, en consideración de la satisfacción (como belleza), con una pretensión a la aprobación de cada cual, como si fuera objetivo" (2007: 204). Por ello la influencia que puede representar la tradición (el hecho de poder "Ilamar clásicos" a los autores de la antigüedad) no es considerada como imitación sino como sucesión. Especialmente necesaria en el gusto, que necesita de ejemplos que hayan sido aprobados a lo largo de la historia, con el fin de moverse amenazado recurrentemente por su originaria rudeza (habida cuenta que no puede determinarse por conceptos o preceptos). Mención a heteronomía en §40. Del gusto como una especie de sensus communis: cuando Kant enuncia las máximas del "entendimiento común", en el sentido de común a todos, es decir, un juicio que en su reflexión tiene a priori en consideración la representación que los demás hacen sobre lo juzgado. Algo característico del gusto que busca ser regla universal sin renunciar a su subjetividad. Son, pues, "1. Pensar por sí mismo; $2 .^{\circ}$ Pensar en el lugar de cada otro; $3 .^{\circ}$ Pensar siempre de acuerdo consigo mismo" (2007: 218). Lo contrario de la primera máxima correspondería al prejuicio, como forma de heteronomía de la razón. La sexta en §58. Del idealismo de la finalidad de la naturaleza y del arte como principio único del Juicio estético, "La cualidad de la naturaleza de encerrar para nosotros ocasión de percibir la interna finalidad en la relación de nuestras facultades del espíritu, de juzgar ciertos productos de aquélla y de percibirla como una finalidad tal que deba ser declarada, por un fundamento suprasensible, necesaria y universalmente valedera, no puede ser fin de la naturaleza, o, más bien, no puede ser juzgada por nosotros como tal, porque, de serlo, el juicio que por ello se determina tendría por base una heteronomía, pero no, como conviene a un juicio de gusto, una autonomía, y no sería libre" (2007: 281-282)

La séptima, ya en la crítica del Juicio teleológico, §69. Qué sea una antinomia del Juicio: “EI Juicio determinante no tiene por sí principios algunos que funden conceptos de objetos. No es ninguna autonomía, pues sólo subsume bajo leyes o conceptos dados como principios". 
En cambio, el Juicio reflexionante "debe subsumir bajo una ley que no está aún dada" pero "como no puede ser permitido uso alguno de las facultades de conocer, sin principios, en tales casos, el Juicio reflexionante deberá servirse a sí mismo de principio", luego ser autónomo (2007: 318). De hecho, la octava y última de las menciones a la autonomía cierra esta argumentación sobre la antinomia del Juicio, en §71. Preparación para la solución de la anterior antinomia: "Toda la apariencia de una antinomia entre las máximas del modo de explicación propiamente físico (mecánico) y del teleológico (técnico) descansa, pues, en que se confunde un principio del Juicio reflexionante con uno del determinante y la autonomía del primero (que vale solo subjetivamente para nuestro uso racional, en consideración de las leyes particulares de la experiencia) con la heteronomía del otro, que debe regirse según las leyes (universales o particulares) dadas por el entendimiento" (2007: 323). Así como el Juicio determinante está supeditado a las leyes del entendimiento, el Juicio reflexionante -tal y como había sido previamente demostrado- ha de buscar en sí mismo las leyes que lo regulen, de ahí su autonomía.

13. Efectivamente, quizás solo pueda aplicarse un sentido estricto de "autonomía" al dominio de la razón práctica. Pero, de alguna forma más laxa quizás y, sobre todo, sujerentemente ambigua, Kant sí defiende la autonomía del juicio del gusto como facultad del alma respecto del entendimiento y de la razón. Desde el punto de vista del arte, como ha sido ya mentado, Kant reconoce unos principios a priori, es decir, de alguna manera (aunque cuando se desarrollará la teoría del genio de Kant obligará a matizar) el arte se otorga a sí mismo sus propias leyes o reglas. Así el arte sería autónomo respecto del conocimiento (no aporta conocimiento) y de la moral (es desinteresado). Esto evidenciaría una insalvable diferencia entre las producciones humanas que, como es el caso de la artesanía, no son propiamente autónomas puesto que están orientadas a un fin, pero incluso de otras producciones como la gastronomía que, aun siendo independientes de la ciencia o de la moral, no por ello son autónomas en el sentido en que lo es el arte.

14. Tanto Hanslick como Edward Lippman defienden que este absolutismo formal se sitúa como contraposición a lo sensitivo y definen este tipo de música como el contemporáneo L'art pour l'art: la forma como fin en sí mismo (1992: 291-319). "música absoluta" se opone al programa y concepción de la obra de arte total y se anticipa a la idea de "poesía absoluta" del simbolismo europeo. Fundamentalmente se trata, como en la estética autónoma de la literatura, del Ilamamiento a la "forma pura" y a un concepto de objetividad matemático y estructural. ${ }^{14}$

El caso de la arquitectura es especialmente singular. El hecho de que la arquitectura sea requerida a dar cumplimiento de ciertas necesidades ajenas a ella misma -entendida como disciplina artística- es, sin lugar a dudas, razón suficiente para dar cuenta de su peculiar decurso. Y por ello mismo, por esa necesaria resistencia a la implementación de la autonomía en la arquitectura, con la irrupción de la autonomía en el arte, la arquitectura tuvo que hacer frente a unos nuevos retos magnificados por sus condiciones internas. Habitualmente se ha interpretado esto como una limitación de la arquitectura respecto de la modernidad y prueba de ello es la escasa atención que le depararon grandes pensadores del XIX y del XX. No será, de hecho, hasta bien entrado el siglo XX cuando se empiece a investigar en profundidad sobre el concepto de "autonomía" en el caso concreto de la arquitectura, algo que no puede dejar de interpretarse como un síntoma de su interno rechazo hacia su incorporación.

En cualquier caso, el periodo a caballo entre el siglo XVIII y XIX, con el indiscutible protagonismo de Kant, eclosiona esta novedosa manera de aproximarse al arte. Coincide por tanto el surgimiento de la autonomía estética con el periodo de más intensa producción arquitectónica de Goethe y la gestación de su teoría arquitectónica más completa. En lo que sigue se presen- 
tarán las teorías más destacables de sus contemporáneos en relación a la autonomía del arte. Posteriormente se analizará cómo, precisamente por sus condiciones internas, el desafío de la autonomía en la arquitectura llevó a unas consecuencias no equiparables al resto de artes y, en acuerdo con esto, cómo las antinomias de la autonomía hacen revivir las quimeras arquitectónicas. El horizonte de esta aproximación, forzosamente parcial, es poder evaluar, posteriormente, en qué medida se puede establecer una teoría autonomicista en Goethe. 


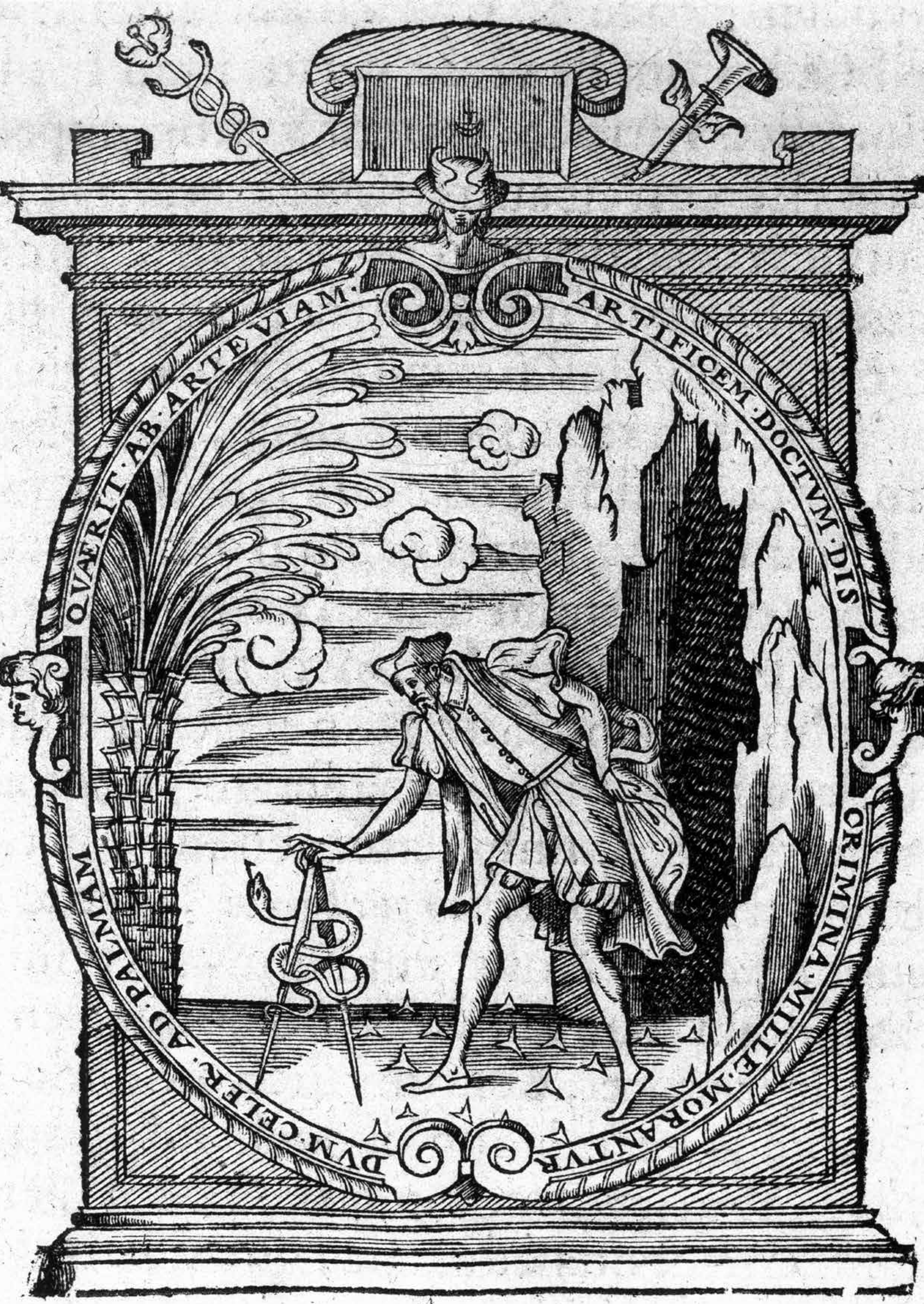




\section{La irrupción de la autonomía en el arte}

Durante la Baja Edad Media y principios del humanismo queda patente un giro que con el tiempo se consolidará en la llustración. Muchos autores consideran este periodo la etapa germinal (en un sentido sociocultural) de la autonomía en el arte. Por ejemplo, Freccero señala como punto de inflexión la figura de Petrarca en la medida en que la concepción alegórica propia de la Edad Media da paso a una concepción autorreferencial -de firmainédita hasta entonces (Freccero, 1986: 2032). O, como señala Müller, es propiamente en el humanismo cuando se da la teoría del diseño como expresión de la negación de la materialidad de la obra y de la producción anterior, pasando la obra a un segundo plano y liberándose de las ataduras de su orientación práctica (Müller (ed.), 1972: 59 y 63). Muestra 
15. Autores como Giordano Bruno concebían un dios que es interno a su creación, infundiéndole desde su seno su movimiento divino: "Dios no es una inteligencia externa que pasa por encima de las criaturas para manipularlas; conviene más que sea el principio interno de movimiento, que es su propia naturaleza, su propia apariencia, su propia alma, que tienen cuantas criaturas habitan en su seno", citado en Cassirer (1997: 41). 16. En su decimocuarto libro de la Genealogia deorum gentilium, al mencionar el origen religioso de la poesía por primera vez se iguala a nivel del derecho la teología y la literatura (o texto de ficción) (Neumeister, 1997: 233-243) 17. Para completar con rigor este salto desde el siglo XIV al XVII, véase Ritter (ed., 2007: 438-439)

18. Shaftesbury distingue entre la llana producción mimética del arte social y la genial producción individual de cada artista "who study the graces and perfections of minds",

entendiendo así al poeta como "a second Maker: a just Prometheus, under Jove".

Vinculando la perfección a la moral queda, pues, el "moral artist" al nivel del creador divino y la "universal Plastick Nature" en la medida en que la naturaleza es "the Source and Principle of all Beauty and perfection" (2010). En este ensalzamiento estético de la naturaleza, del que resulta una forma interna de ello es la reivindicación de los artistas en tanto que autores individuales (evidenciado, por ejemplo, en la obra de Giorgio Vasari Le vite de' piu eccellenti Pittori, Scultori e Architetti italiani de 1550), algo que algunos autores interpretan como la equivalencia institucional del cambio interno en la disciplina (Luhmann, 1995: 215-300). La superación del dualismo entre la naturaleza como creación divina y el Dios como creador instaura efectivamente un nuevo orden de entendimiento en el que ya tiene cabida una concepción interna de la creación en el sentido de reconocerla en cada uno de los creados. ${ }^{15}$

En efecto, partiendo de las corrientes neoplatónicas puede identificarse ya desde el siglo XIV en Italia (con Boccaccio, ${ }^{16}$ por ejemplo) la representación del hombre creativo como una segunda divinidad. A partir del XV (con Alberti especialmente) se extiende esta novedosa concepción del artista Rüfner (1955). Tan es así que para ciertos autores el desarrollo a lo largo del Renacimiento de la concepción autónoma del arte va de la mano de la nueva recepción de la tradición platónica, imponiéndose un giro subjetivo sobre la red representacional de la corte y el clero. No por casualidad cuajó con antelación en Inglaterra la pérdida de la función representativa del arte: la Cambridge Platonist, el palladianismo o el sincretismo en la arquitectura de campiña, el pintoresquismo en los jardines y el ideal del diletantismo artístico (como, por ejemplo, a través de los viajes de formación), son muestra de un tipo de estetismo ampliamente extendido en Inglaterra que tardó en introducirse en otros países, como es el caso por ejemplo de Francia (con la estética del gusto de Charles du Bos y con la separación por Charles Batteux entre lo útil y el placer estético). ${ }^{17}$

En el caso alemán, el proceso de autonomización se desarrolla en paralelo con la fundación de una esfera autónoma de la experiencia estética, que no será hasta Kant cuando alcance su más explícita rotundidad. En este sentido tiene que entenderse la obra de Baumgarten Aesthetica: el establecimiento teórico de la necesidad de la autonomía de la estética se desarrolla junto con el proceso institucional y epistemológico de delimitación entre las "bellas artes" y las "bellas letras" respecto del sistema unitario humanístico de las "artes y letras", es decir, la voluntad de separación entre lo bello y lo útil en contra de su vínculo asumido desde la antigüedad. Con el trasfondo de la creciente defensa del "self-interest" o del "amour-propre" en la filosofía moral del XVIII (en autores como Adam Smith o Bernard de Mandeville) se impulsa al arte a adquirir la posición contraria a la búsqueda de beneficios y bienestar de la sociedad burguesa. Todo ello entra en clara resonancia con la tendencia hacia la especialización, ya acusada durante el siglo XV y que durante la Ilustración en general se plasmará en la delimitación de las esferas de conocimiento.

La independencia del arte -ya presente en Shaftesbury, ${ }^{18}$ tanto en su dimensión poética como política- viene a equivaler a la libertad del arte en sí mismo, una idea que se popularizó a lo largo de la segunda mitad del XVIII. Edmund Burke, renunciando a la categoría de la perfección definida por Shaftesbury, define en este sentido tanto lo bello como -muy especialmente- lo sublime a través de la noción de la no-utilidad ("without any reference to use") y sitúa, por ello, la negatividad de lo estético en el terreno de lo 
social desde claves empiristas. Así, por ejemplo, la obra de arte orgánica (entendida como forma natural) se opone al producto industrial (extendiéndose incluso a la artesanía) (Fontius, 1977: 409-529). Este carácter reivindicativo de lo artístico dará lugar en el siglo XIX a movimientos de gran repercusión en la estética arquitectónica con autores como Ruskin o Viollet-le-Duc. En cualquier caso, este impulso de reacción frente a lo social permanecerá con mayor o menor literalidad desde entonces y puede considerarse una de las características más persistentes de toda interpretación de la autonomía en el arte.

En oposición a esta corriente de talante platónico se sitúa la fundación de la representación de la autonomía en Kant en el concepto de sujeto. En el periodo clásico-romántico alemán, el ideal de autonomía ha de entenderse en el contexto de los posicionamientos morales (con claros precedentes en Shaftesbury, por ejemplo) respecto del ideal de individualidad y de educación. No en vano muchos autores señalan la importante influencia de la Revolución Francesa en este giro del pensamiento alemán. Especialmente notable en las teorías de la literatura, el concepto de autonomía adquirirá un papel nuclear en la reflexión sobre el sentido, las posibilidades y los objetivos del arte (Mandelkom, 1982: 51). Por vez primera, la autonomía no se sostendrá contra la instrumentalización ilustrada -como aún era el caso en Moritz-, sino que se localiza en el centro mismo de la reflexión.

A este respecto, los dos grandes representantes del periodo clásico alemán, Schiller y Goethe, desarrollan trayectorias divergentes. Mientras que Schiller, deudor de la estética kantiana, tematiza explícitamente la cuestión de la autonomía en el arte y propone una intercesión entre la posición idealista y la ilustrada, Goethe vincula lo bello - sin hacer mención al concepto de autonomía- a la ley de la naturaleza hecha accesible para el entendimiento y se sitúa, pues, en la tradición prekantiana o clasicista: "Kunst, eine andere Natur, auch geheimnisvoll, aber verständlicher; denn sie entspringt aus dem Verstande" o "das Schöne ist eine Manifestation geheimer Naturgesetze, die uns ohne dessen Erscheinung ewig wären verborgen geblieben". ${ }^{19}$ En Schiller, en cambio, la escisión, la falta de armonía constatable en la sociedad moderna, moviliza su proyecto estético. Se hace eco en su obra de la oposición entre vida y arte tematizada por Moritz: la experiencia de la fragmentación y enajenación del sujeto espolea la búsqueda de una alternativa que sea capaz de sanar las heridas provocadas por la modernidad en la cultura. Este escepticismo respecto de la esfera de lo político explica por qué en el ámbito alemán se ha insistido recurrentemente en la búsqueda de una alternativa en el arte como ámbito independiente, como vía de acceso a la pérdida de la totalidad y su consideración como reducto de libertad en última instancia. Esto se hará explícito posteriormente en la obra de autores como Friedrich Schlegel.

Este acercamiento subjetivista al arte, donde la educación estética cobra especial protagonismo, debe entenderse desde la influencia -explícitamente mencionada por Schiller- de la obra de Kant y la centralidad que otorgó a la autonomía en su filosofía moral en primer lugar y en su teoría del gusto posteriormente. Ya desde Fundamentación de la metafísica de las costumbres (1785), Kant considera la libertad del sujeto desde autónoma de la comprensión orgánica de la obra de arte, se localiza uno de los saltos más importantes desde la objetividad de la estética clásica y de la teoría de la imitación hacia la autodeterminación de las leyes de la obra de arte y la reivindicación de la individualidad del artista. 19. "Arte, otra Naturaleza, misteriosa también, pero más inteligible, ya que brota del intelecto" y "la belleza es una manifestación de las leyes naturales secretas, sin cuya aparición hubiese permanecido oculta para nosotros" (Goethe, 1991: 441). 
el concepto de la autonomía en tanto que el "oberstes Prinzip der Sittlichkeit" [el principio más elevado de la moralidad]. A mediados del siglo XX, Adorno ya señaló cómo, especialmente en Kant, el concepto de autonomía (del arte en este caso) es inseparable de una semejanza secularizada con el Dios creador. De hecho, autores como Rüfner dan cuenta de ello apoyándose en la deuda kantiana a la monadología de Leibniz y la autodeterminación del espíritu humano (Rüfner, 1955: 176 , nota 48). Kant retoma esa noción, pero troceando la monada leibniziana con arreglo a la tradición psicologicista de la llustración: la división de las facultades del espíritu en entendimiento, razón y Juicio.

En este sentido, el juicio estético participa también del concepto de autonomía en la medida en que se le otorga un ámbito propio, un lugar exclusivo en la arquitectónica kantiana. Alejada de las concepciones anteriores, la estética kantiana renunciará al establecimiento de leyes, es decir, el juicio estético dejará de tener por objeto la "Gesetzmäßigkeit" y se orientará hacia la "Zweckmäßigkeit". Sobre cómo se opera este giro de crucial importancia en la estética se tratará en los capítulos que siguen. Baste adelantar que el peculiar estatus que queda reservado para el juicio estético en la arquitectura kantiana le lleva a adoptar un papel mediador entre las facultades del entendimiento y de la razón, en tanto que lo bello -objeto del Juicio- es considerado un placer sin concepto, desinteresado y -lo más relevante aquí- libre. El carácter autorregulativo de lo bello implica, pues, el concepto de libertad, en tanto que libertad respecto de los fines heterónomos.

\section{La ambigüedad del "conocimiento sensible"}

La irrupción de la autonomía en el arte no puede desvincularse del nacimiento de la estética como disciplina. Ambas se dan en el marco epistémico moderno de principios del siglo XVIII en el que se enfrentaba el conocimiento sensible (falible e individual) con el conocimiento racional (sujeto a la posibilidad de la crítica y con pretensión de universalidad), o, lo que es lo mismo, la discusión entre las escuelas filosóficas empiristas frente a las racionalistas en lo relativo al concepto de gusto. La proclamación del carácter autónomo del sujeto moderno como principio fundamental de la llustración dejó en un ambiguo terreno-de-nadie a lo sensible, que por su naturaleza misma se escapaba a la medida impuesta por la Razón. El cuadro de las ciencias filosóficas había sido dotado de un complejo aparato conceptual desarrollado a lo largo de los siglos precedentes donde lo sensible y, por extensión, aquello relativo al gusto reclamaba un hueco.

La empresa que se intentó iniciar en este contexto era ingente: demostrar que dentro de ese marco concreto - sistemático y racionalista- cabía lo que hasta entonces no había podido incorporarse con rigor: el conocimiento sensible. Es decir, que la estética puede independizarse del saber científico imperante, reivindicando un saber propio exclusivo del arte. Así, la distinción entre lo sensible y lo racional, los límites entre ambos, devendrá pronto la condición de posibilidad de la estética, así como su más recurrente talón de Aquiles, y abre la posibilidad de la emergencia de la autonomía en el arte. Lo que estaba en juego era la posibilidad de acoger por méritos propios en el sistema filosófico 
una nueva disciplina, desarrollar unas reglas que pudiesen reivindicar la esfera de los sentidos que no cayese en la aleatoriedad (que fuese ciencia) ni que acabase absorbida por las facultades del espíritu ya reconocidas (la lógica, la ética, la ontología...).

Pese a que su nacimiento está estrechamente vinculado con el problemático estatus epistemológico del arte en la modernidad (la relación del arte con la verdad), la estética adquirirá rápidamente relevancia como pieza indispensable de la arquitectónica del espíritu. De hecho, el carácter reivindicativo que ya asoma en su nacimiento como disciplina, le acompañará en su desarrollo. En Baumgarten, la cuestión que debía abordar la estética (en su fundamentación objetiva como disciplina por derecho propio) era la ambigua relación entre el carácter indiscutiblemente subjetivo del juicio estético y su no-aleatoriedad, es decir, su tendencia hacia una forma de universalidad. Luego, desde el comienzo mismo, la estética ha de afrontar un papel mediador y de difícil delimitación. Juzgado este proyecto como inconcluso, será Kant quien recupere el testigo de este "excelente analítico" -en sus propios términospara reconducir la polémica a un terreno mucho más amplio.

Si para Baumgarten la posibilidad de la estética en la modernidad estribaba en la fundamentación objetiva de la facultad del gusto basada en la singularidad del conocimiento al que da acceso, con Kant y su tercera crítica, la facultad del Juicio adquirirá un valor estructural en el intento trascendental de fundamentación de la Razón. De la reivindicación de un valor epistemológico singular (y de ahí la reivindicación de la autonomía de la facultad del gusto respecto de otras) se pasará al establecimiento de puentes entre los extremos establecidos por las facultades del entendimiento y de la razón práctica (y de ahí que sea crucial para el establecimiento en Kant de la posibilidad de la autonomía frente a la necesidad de lo real). De la defensa de una autonomía interna -como disciplina- se pasó a la defensa de la posibilidad misma de la autonomía -de cómo, frente a la necesidad natural, puede establecerse la autonomía del sujeto-. Tomando el testigo de este giro se expondrá en lo que sigue un tipo de reivindicación de la autonomía desde la inicial e inestable propuesta de Baumgarten y diversos autores germanos, hasta la conceptualización kantiana de la antinomia del gusto con el fin de establecer el marco conceptual de la irrupción de la autonomía en el arte.

Al margen de la fundamentación de la estética como disciplina, el nacimiento del término "estética" sí puede localizarse en un preciso momento de la historia de la filosofía occidental. Aparece por primera vez como adaptación de un término griego al latín en la tesis doctoral Meditationes philosophicae de nonnullis ad poema pertinentibus en 1735 . Su autor, Alexander Gottlieb Baumgarten, hizo suyo el proyecto de completar el sistema de las facultades humanas propuesto por Christian Wolff en su gran enciclopedia filosófica. Añadió a esta un tratamiento exhaustivo de lo que se llamaba -y aun él así las nombrabalas "facultades inferiores", entre las que se contaba el "conocimiento estético". A partir de 1750 , con su obra más madura Aesthetica, este término recién acuñado quedará ya indisolublemente ligado al proyecto ilustrado y adquiere desde su origen un carácter de teoría del conocimiento de segundo orden. 
20. El vínculo de Baumgarten con Wolff y Leibniz está fuera de toda duda, tal y como certifican numerosos estudios. En Casula (1974: 547-575) puede encontrarse una competente defensa de la proximidad de Baumgarten a la metafísica de Leibniz así como una relativamente extensa bibliografía de referencia.

21. Este breve ensayo es considerado uno de los primeros textos en el que se expresa el sistema definitivo de Leibniz, $y$, en concreto, las bases de su teoría del conocimiento. Citado y traducido en Marchán Fiz (2000: 38).

22. Citado y traducido en Marchán Fiz (2000: 38).
La propuesta de Baumgarten reconoce al conocimiento estético un estatus diferente al racional, ya que se adquiere por medio de la sensibilidad, es decir, no es contrastable y es individual. Pero simultáneamente no puede asumirse como un conocimiento aleatorio o sujeto al capricho. Esto sería un contrasentido. Así, deudor de la teoría leibniziana sobre el conocimiento sensible, ${ }^{20}$ Baumgarten defenderá la posibilidad de una ciencia estética. Véase a este respecto la tesis de Leibniz en "Meditaciones sobre el conocimiento, la verdad y las ideas" a la hora de ilustrar lo que entiende por "conocimiento confuso" ["cuando no puedo enumerar por separado las notas necesarias para distinguir esas cosas de otras"], en contraposición a la "noción distinta":

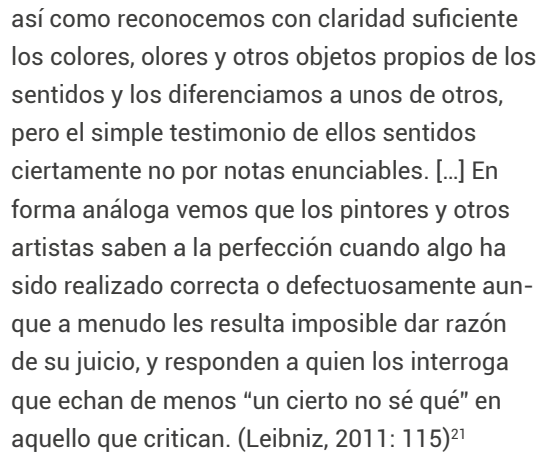

El conocimiento es para Leibniz simultáneamente claro y confuso en el reconocimiento de los elementos particulares de un objeto sensible. Esta paradoja, por la que se puede tener un conocimiento claro del conjunto de un objeto sensible y a la vez confuso en las partes, quedó irresuelta por Leibniz motivando a muchos de los filósofos que le siguieron a emprender esa empresa clarificadora. Aun cuando dentro de su sistema monadológico sensibilidad y entendimiento pertenecen a una misma fuente de conocimiento, la imposibilidad de tender hacia la claridad por parte de ciertas fuerzas perceptivas (las más sensitivas) daba lugar a un problema en su teoría del conocimiento.

Una de las primeras soluciones que se barajaron fue la planteada por Baumgarten. Propuso la posibilidad de un conocimiento sensible como tal, por derecho propio. Este planteamiento tenía la virtud de dar solución a la paradoja presentada por Leibniz al tiempo que completaba el proyecto wolffiano: la estética como ciencia que se ocupa de la belleza. Efectivamente, Wolff omitió en su enciclopedia el análisis del arte y la belleza, el conocimiento sensible. Baumgarten reivindica en su propuesta la estética como una facultad, gozando por tanto de unas reglas que le son propias. Este requisito era hasta tal punto crucial para la posibilidad de la estética que de no encontrar su marco propio de legitimación quedaría de nuevo absorbida por la facultad Lógica, como venía siendo el caso en los sistemas de Wolf o Leibniz. Basándose en la experiencia de lo sensible, defenderá Baumgarten, es posible elaborar un sistema de validez para el acceso al conocimiento. La estética se distinguiría de la Lógica en la medida en que la segunda no tiene acceso a lo sensible, en tanto que la primera: "es la perfección del conocimiento sensible en cuanto tal: esto es, por tanto, la belleza" (1961: 6). ${ }^{22}$ Si a través de la facultad Lógica (o Gnoseología superior) el conocimiento racional permite el acceso al concepto, la estética da acceso a la belleza a través del conocimiento sensible.

En Reflexiones filosóficas acerca de la poesía y más tarde de forma definitiva en Aesthetica, Baumgarten trata de proporcionar 
un fundamento a la facultad estética (que aquí es reducida a lo poético) con el fin de garantizar su validez epistemológica. Es decir, en primer lugar y como requisito ineludible, la estética ha de poder proporcionar conocimiento. Pero esta pretendida clarificación no consigue erradicar la huella de la ambigüedad heredada por los sistemas anteriores. Se reconoce a lo poético su autonomía con respecto a lo lógico por encontrar en lo individual o lo sensible la fuente de su discurso. Atributos como "lo cambiante", "lo imaginativo", "lo onírico" o "lo maravilloso" garantizarían su desvinculación de los estrechos márgenes trazados por la Razón. Pero, en cambio, lo poético ha de seguir ciertas reglas como la "coherencia", el "ritmo" o la "inteligibilidad" si ha de poder proporcionar conocimiento. Es decir, ha de someterse a una cierta lógica.

Lo sensible adquiere así un status del que nunca antes gozó: está capacitado para acceder al conocimiento. Pero, con todo, la estética en Baumgarten no supera la contradicción inherente a la reflexión estética: “La estética -teoría de las artes liberales, gnoseología inferior, arte del bien pensar, arte análogo a la razón- es la ciencia del conocimiento sensitivo" (1961: 1). ${ }^{23}$ Es decir, Baumgarten no puede sustraer radicalmente la estética de la razón y acepta, por tanto, que en la estética han de encontrarse simultáneamente una ciencia de lo sensible y de lo racional. La inicial reivindicación de la alternativa a la univocidad de la Razón, esto es, la necesidad del complemento de lo sensible, no puede llevar -en clara asunción de los preceptos racionalistas- a la aleatoriedad de lo irracional. En definitiva, Baumgarten no acabó por decantarse entre una teoría estética que fuese deudora del conocimiento científico o una que planteara un nuevo conocimiento.

\section{Desinterés y finalidad interna}

En suelo alemán irrumpe, por tanto, la concepción moderna de estética con figuras como la de Baumgarten que supo interpretar la crisis de la imitatio en clave epistemológica. Este necesario giro hacia el estudio de las sensaciones se complementará en la segunda mitad del siglo XVIII con tres figuras claves de la ilustración germana y estrechamente relacionadas con la formación estética de Goethe: Winckelmann, Lessing y Herder. Sobre el primero se regresará más adelante, siendo él quien introdujo de manera decisiva a Goethe en la novedosa historia del arte. Lessing y Herder, por su parte, aun sin llegar a mencionarlo explícitamente, ya adelantaron algunas de las claves que posteriormente alumbrarían el concepto de autonomía en el arte.

$$
\text { El pensamiento de Gothold Ephraim }
$$
Lessing, cumbre de la llustración germana, influyó notablemente en sus contemporáneos. Dejó una huella reconocible en la obra de Herder y, posteriormente, en Schiller y Goethe. Inseparable de su aproximación teológica, su propuesta estética entronca con su proyecto de establecer una síntesis entre la racionalidad ilustrada y las categorías fundamentales de la cultura para un renacer de la Humanidad en la que las partes quedasen, no obstante, diferenciadas. De ahí su esfuerzo en el Laocoonte, o sobre los límites en la pintura y la poesía (1766) por recuperar los ámbitos propios de disciplinas como la poesía y la pintura. Las manifestaciones barrocas guiadas por el lema horaciano ut pictura poesis
23. Citado y traducido en Marchán Fiz (2000: 38). 
24. En línea con lo que se desarrolará a continuación, la cuestión central de estas discusiones es si esa dualidad se plantea como incompatibilidad o simultaneidad. En este sentido, tal vez la clave sean las ambiguas palabras "rasgos demasiado visibles de". 25. Será Kant quien aplique por primera vez (aun con matices) el concepto de "autonomía" al arte. Véase para más detalle el capítulo "La autonomía trascendental". habían conducido en su opinión a una falsa síntesis en la que ambas quedaban desdibujadas en la "manía descriptiva" de la poesía y el "prurito de la alegoría" de la pintura. La diferencia entre el grupo escultórico descrito por Winckelmann con apasionamiento y aquel cantado por Virgilio en la Eneida provendría, pues, de las diferentes exigencias del lenguaje de cada uno de los géneros. Esta distinción en lo sucesivo, la hará extrapolable a la literatura y artes plásticas, y, pese a que no oculte su preferencia por el drama, le llevará a postular una cruda mirada a la historia del arte, cuyas manifestaciones deberían ser revisadas, cuando no incluso rechazadas. En el siguiente extracto no llega a mencionar el concepto de autonomía, pero es evidente que la exigencia de obrar en libertad por parte del artista y el reconocimiento de la belleza como finalidad anuncian su eclosión. Así lo plantea en el capítulo IX:

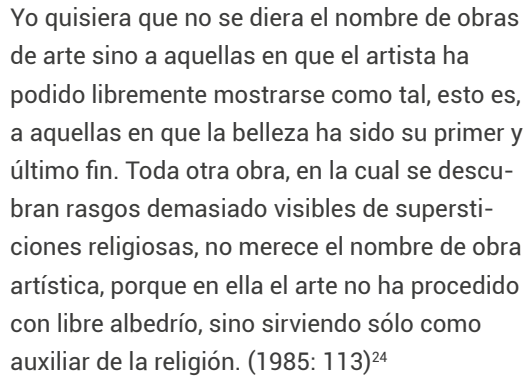

Admirador de los postulados de Lessing, Johann Gottfried Herder profundizará en sus matizaciones a la llustración germana adelantándose, si cabe dramáticamente, al romanticismo del Sturm und Drang. Nunca llegará a decantarse por ninguno de los polos de tensión. Su proyecto de estética se centró fundamentalmente en ensalzar la experiencia individual, la acción y sensibilidad particular, a una dimensión totalizadora. En el contexto de las discusiones en torno al Laocoonte de Lessing llegó a establecer su propia teoría sobre los límites entre las artes en la cuarta de las Silvas. Partiendo de la sensibilidad individual, relaciona cada uno de los sentidos con cada manifestación artística: vista, oído y tacto, con la pintura, música y escultura, respectivamente. La poesía sería el único arte que remite al alma individual. En una mordaz crítica al clasicista Christian Adolf Klotz, dice:

$$
\begin{aligned}
& \text { En todos sus escritos el Sr. Klotz mezcla cruel- } \\
& \text { mente monedas, gemas, pinturas y estatuas: iy } \\
& \text { no puede haber nada más distinto por su natu- } \\
& \text { raleza, su finalidad y sus leyes! Una obra de arte } \\
& \text { existe a causa del arte: pero en un símbolo, sea } \\
& \text { dedicado a la religión, a la Constitución política } \\
& \text { o a la historia, el arte presta un servicio, es un } \\
& \text { siervo para otra finalidad, y así sucede con la } \\
& \text { moneda. (1994, III: 419) }
\end{aligned}
$$

Pero es sin duda Karl Philipp Moritz quien con mayor agudeza supo formular la autonomía del arte. Su propuesta reposa en la conceptualización de lo "acabado en sí mismo" (Sauder, 1982: 133). ${ }^{25}$ Ya en 1785, en su breve Ensayo de unificación de todas las bellas artes y ciencias bajo el concepto de lo "acabado en sí mismo" plantea las claves del juicio estético moderno, adelantándose por tanto a la sistematización kantiana en al menos un lustro. Haciendo clara referencia a la obra de Charles Batteux, Les Beaux-Arts réduits à un même principe (1746), en su Ensayo Moritz establece por primera vez que el principio de todo arte ha de reposar en el "placer" [Vergnügen]. Sentencia así la deriva que se consolidará desde entonces, que se aleja inexorablemente del principio de la imitación en el que Batteux hace descansar las Bellas Artes. Así arranca su argumentación: 
Se ha descartado el principio de la imitación de la naturaleza como finalidad última y principal de las bellas artes y ciencias, subordinándoselas a la finalidad del placer, que se ha convertido a tal fin en el fundamento primero de las mismas. Las bellas artes, se dice, tienen propiamente por objeto el mero placer, así como las artes mecánicas tienen el suyo en la utilidad. Mas hete aquí que hallamos placer tanto en lo bello como en lo útil: ¿cómo se distingue entonces lo primero de lo segundo? (Moritz, 2009: 169)

Reconoce desde el comienzo de su escrito la dificultad de discernir entre lo bello y lo útil por cuanto ambos proporcionan placer y, de ahí, su argumentación versará fundamentalmente en el establecimiento de los límites entre ambos. Su propuesta gira en torno a la justificación por sí mismo del fenómeno artístico, ajeno por tanto a "finalidades externas" como puedan ser la utilidad. Lo bello, por tanto, provocaría placer por causas inherentes a la obra misma. No debe concurrir más interés que el de la mera contemplación de la obra:

\begin{abstract}
Mientras lo bello atrae completamente hacia sí nuestra contemplación, la aparta por un momento de nosotros mismos y hace que parezca que nos perdemos en el objeto bello; y ese perderse, ese olvidar nuestro yo es precisamente el máximo grado del placer puro y no egoísta que nos proporciona lo bello. En ese instante, le ofrendamos nuestra limitada existencia individual a una especie de existencia superior. Por ende, el placer de lo bello debe aproximarse cada vez más al amor no egoísta, si es que ha de ser auténtico. (Moritz, 2019: 170)
\end{abstract}

Por vez primera en su texto pueden identificarse los criterios fundamentales de autonomía del espectador y autonomía de la obra de arte. ${ }^{26}$ Ciertamente pueden intuirse ya en los primeros autores románticos, como es el caso del joven Goethe, elementos que apoyan la tesis autonomicista (véase, en especial, el Von Deutscher Baukunst de 1772), pero es quizás Moritz quien supo vincular como mayor precisión el desinterés frente a la obra de arte con el placer estético, algo que retomará posteriormente Kant en su Critica del Juicio. Establece así un ámbito propio de lo estético, ajeno a las constricciones propias de la razón o la moral. Al igual que Kant, Moritz tomará como modelo para definir el ámbito de la estética a la naturaleza. El artista crearía, no ya por imitación de la naturale$\mathrm{za}$, sino emulando su proceso creativo. En su obra Sobre la imitación formante de lo bello condensa en el concepto de "fuerza activa" [Thatkraft] la capacidad autónoma del artista:

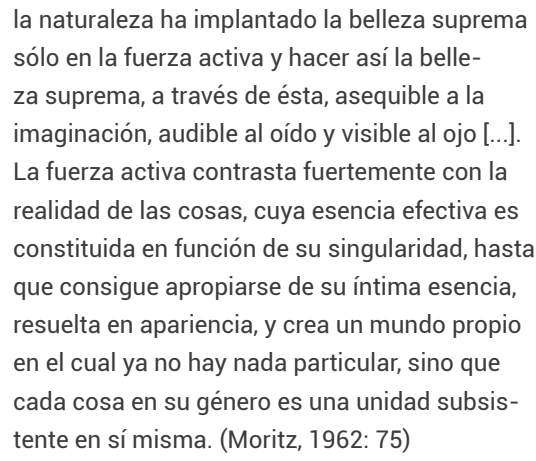

La "fuerza activa" constituye por tanto simultáneamente aquello que otorga a todas las cosas una existencia plena al tiempo que es la "fuerza activa" lo que toda obra de arte ha de imitar para serlo. Tal y como apunta Jordi Claramonte, Moritz "dibuja la doble condición, autónoma y relacional de la obra de arte: el arte es una potencia-en sí en la medida en que no pierde de vista la potencia-en sí de todas las criaturas." (2010:
26. "Fuera de Moritz mismo con su pequeño artículo Ensayo de unificación de todas las bellas artes y ciencias bajo el concepto de lo "acabado en sí mismo" (1785), nadie había fundamentado el ya anunciado valor propio y superior del arte con la evidencia de que las obras maestras poseen: 1) otros dominios vitales, y 2) una posición autónoma respecto del receptor, así como 3) un modo de ser autónomo en sí mismas." (Wittkowski (ed.), 1990). 
47) Sobre este carácter relacional de la obra de arte insistirá, nuevamente, Kant. Es quizás lo que más caracteriza la propuesta de Moritz el hecho de adelantarse, igualmente, a Schiller en la medida en que la autonomía del arte puede concebirse como reducto de la dignidad de la humanidad, aunque sea solo con el carácter del residuo dado que se presenta como contra-imagen del principio de racionalidad instrumental que rige la cotidianeidad:

Cuando lo bello atrae hacia sí nuestra contemplación, la sustrae un tiempo de nosotros mismos y hace que nos parezca que nos perdemos en el objeto bello; y precisamente esta pérdida, este olvido de nosotros es el más alto grado de goce puro y desinteresado que proporciona lo bello. Sacrificamos en un momento nuestra existencia individual y limitada en aras de una instancia superior. (Moritz, 1962: 5) 



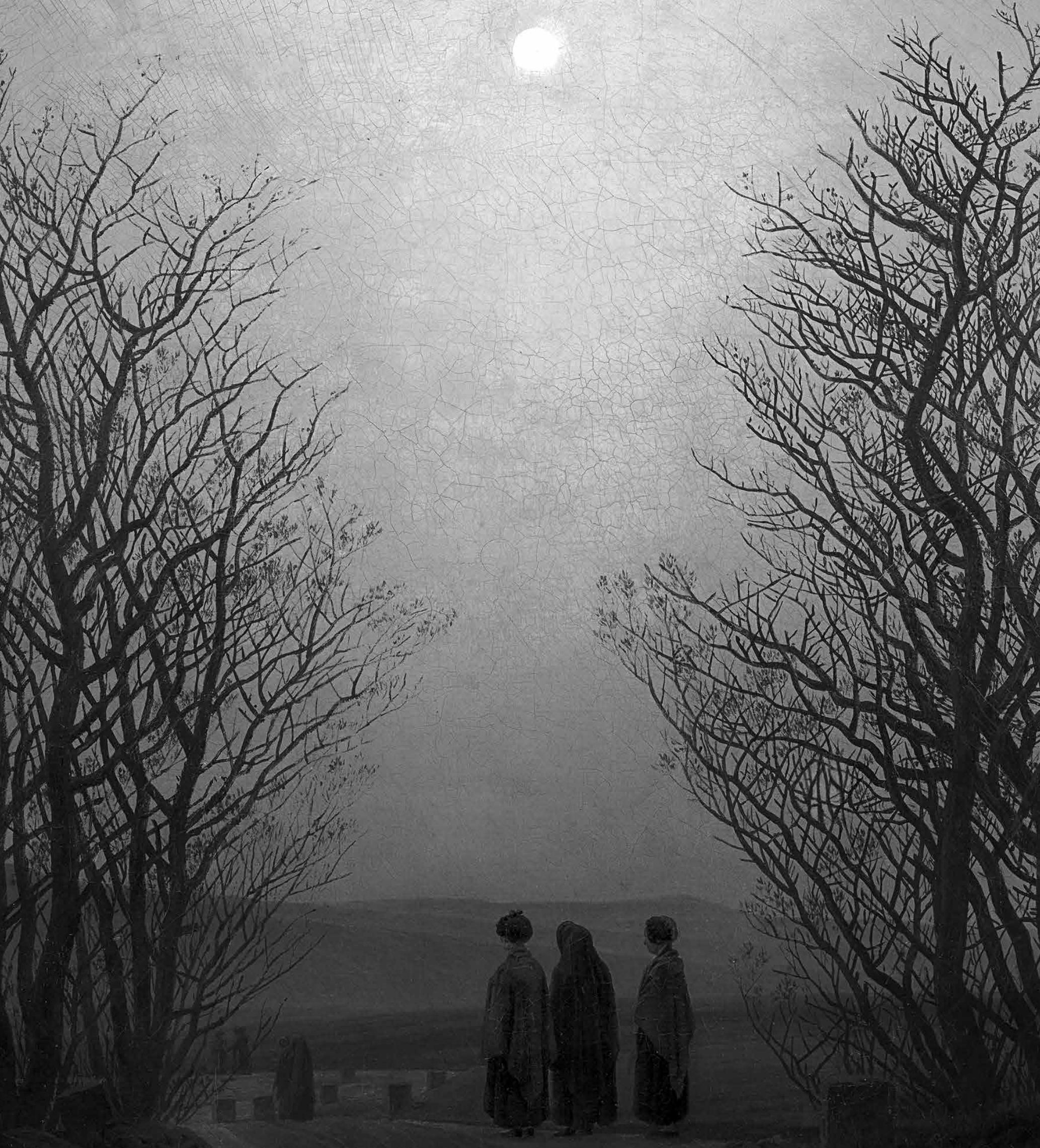




\section{El doble sentido de la autonomía}

A lo largo de la tradición estética cabe destacar fundamentalmente dos formas de entender la autonomía en el arte.

En el primer caso, la autonomía es interpretada como libertad e independencia de cualquier manifestación artística respecto de restricciones socioculturales e institucionales (estado, sociedad, Iglesia, partidos...). Es característica de la lucha por la liberación del arte y los artistas en la Edad Moderna e Ilustración de todo ámbito que no sea específicamente artístico, que no tenga propiamente fines artísticos. El núcleo de este proceso ideológico emancipatorio se encuentra fundamentalmente en la creciente dependencia de los artistas respecto del mercado que, paradójicamente, posibilitó y amenazó simultáneamente la autonomía del arte 
27. “C'est l'argent, c'est le gain légitimement réalisé sur ses ouvrages qui l'a délivré de toute protection humiliante, qui a fait de l'ancien bateleur de cour, de l'ancien bouffon d'antichambre, un citoyen libre, un homme qui ne relève que de lui-même. Avec l'argent, il a osé tout dire, il a porté son examen partout, jusqu'au roi, jusqu'à Dieu, sans craindre de perdre son pain". Para concluir: "L'argent a émancipé l'écrivain, l'argent a créé les lettres modernes" (Zola, 1881: 190).

28. "Si cada uno se le da las leyes de su identidad cultural, no hay lugar para una identidad cultural común [...]

La autodeterminación sólo es posible en la mediación entre el haberse convertido, la experiencia con lo otro y el auto-diseño" (Koslowski, 1987: 80)

29. Así lo defiende Bourdieu, para quien Flaubert es el mo delo de la "esthétique pure". 30. "Las obras de arte aventajan al mundo de las cosas por su propia coseidad, por su objetivación artificial. Hablan en virtud de la inflamación de la cosa y la aparición. Son cosas que tienen que aparecer. Su proceso inmanente sale hacia fuera como su propia actuación, no como lo que los seres humanos han hecho en ellas y no simplemente para los seres humanos" (Adorno, 2004: 113).
(Warneken, 1973: 79-115). Emile Zola ya diagnosticó en su artículo "L'argent dans la littérature" de 1880 la particular dialéctica en el estatus autónomo a través de la intermediación del mercado, reivindicando la capacidad emancipadora que detentaba la liberalización del mercado literario respecto de la estructura del Ancien Régime (1881: 157-202). ${ }^{27}$

Más recientemente, esta paradójica relación entre la radicalización de la autonomía y su movimiento contrario de reaproximación del arte al mundo de la vida ha sido objeto de estudio, especialmente a partir de la crisis de las vanguardias. Paradigma de ello es la obra de Peter Bürger, donde la dialéctica entre la autonomía del arte y la sociedad tiene como única salida la distinción entre lo moderno (lo que para él implica insistir en la pureza de lo estético) y la vanguardia (que defiende el objetivo de la transformación de la vida a través del arte) (1995: 20-27). De hecho, forma parte del programa de la posmodernidad el aplanamiento de las diferencias entre el arte autónomo y la cultura de masas, la estética negativa de la resistencia y la homogeneidad comercial. Estas dicotomías quedan superadas en los intentos de autores como Umberto Eco (1965 y 1983) o Leslie Fiedler (1984), por ejemplo. Además de esto, desde la perspectiva de la definición de la función del arte y su relación con la tradición, la posmodernidad manifiesta una tendencia a problematizar el concepto de autonomía. Por ejemplo, con Peter Koslowski: “Wenn jedes Individuum sich selbst die Gesetze seiner kulturellen Identität gibt, kommt keine gemeinsame kulturelle Identität zustande[...]. Selbstbestimmung ist nur in der Vermittlung von Gewordensein, Außenwelterfahrung und Selbstgestaltung möglich". ${ }^{28}$
En segundo lugar, desde un punto de vista subjetivista, el concepto de autonomía concierne, por una parte, al creciente movimiento de autonomización del arte respecto de sus posibilidades poéticas $y$, por otra, su emancipación respecto de su originaria función representativa. Sus raíces han de encontrarse en el establecimiento del concepto de "genio" en la filosofía kantiana y, muy especialmente, en su recepción francesa a lo largo de la generación de Flaubert y Baudelaire. ${ }^{29}$ Su estela prosigue con Mallarmé y el simbolismo, cuando la teoría del genio se radicalizará y culminará en la abstracta autorreferencialidad del arte en la modernidad. El cubismo sería desde esta perspectiva un tipo de autonomía radical respecto de la verdad y del artista al distanciarse definitivamente de la mimesis (esto es, entre otras, de la tradición renacentista de la perspectiva) y realizarse independientemente de toda explicación lingüística.

En esta línea de radicalización de la autonomía del arte puede situarse la obra de Adorno cuando defiende que, precisamente, el carácter de coseidad de la obra de arte -al independizarse de lo social- es aquello que le otorga ventaja frente al mero mundo de las cosas, en la medida en que al alejarse de lo humano a través de lo humano, al hacerse objetivo (por lo humano), se presenta -"aparece", dice Adorno- como lo extraño en su pertenencia. $Y$ ahí reside su momento correctivo: por medio de la objetivación impuesta, la obra de arte es para Adorno cosa que se trasciende ${ }^{30}$ fugazmente, irradiando una "aparición expresiva". Como el fenómeno de los

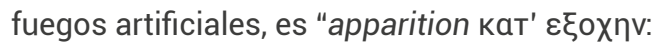
algo que aparece empíricamente, liberado del peso de la empiria, de la duración, a un tiem- 
po signo celeste y producido, advertencia, escritura que se enciende y desaparece, pero que no se puede leer en cuanto a su significado" (2004: 113), independiente del contenido, independiente de lo humano, condicionado por lo humano y exigiendo un contenido (bajo la forma de esta aparición).

En este doble sentido de la autonomía coinciden autores contemporáneos de muy diversa orientación. Jason Gaiger (2009), por ejemplo, distingue la "social autonomy" como el momento de independización del arte respecto de los intereses de la Iglesia o la aristocracia y la "aesthetic autonomy" como la reivindicación del valor intrínseco del arte por sí mismo (sin necesidad de más justificación o finalidad). Eileen John (2012) suscribe esta clasificación al insistir, aunque con términos diferentes, en la evolución dual del término "aesthetic autonomy". Por una parte, lo que podría ser llamada una "autonomía de la recepción" (formas de autonomía del juicio estético) y por otra una "autonomía de la obra de arte". Esta sería igualmente la propuesta de interpretación de Eisenman cuando, haciéndose eco de Derrida, habla de "disciplinary autonomy" y "formal autonomy" en la arquitectura. Luego, queda claro a la luz de estos testimonios que un cierto consenso puede rescatarse de la polisémica interpretación de la autonomía. Básicamente son identificables - aun en su diversidaddos tendencias respecto de la repercusión e interpretación de la autonomía en el arte que son de especial relevancia en el caso de la arquitectura.

Con el alejamiento por parte de Kant de las corrientes platónicas, presentes desde Shaftesbury hasta Moritz o Schelling, se abren nuevas posibilidades para la incorpora- ción a la estética del concepto de la autonomía que dan pie a estas dos corrientes. Así pues, desde la centralidad de su obra, en lo que sigue se persigue presentar la autonomía del arte en su problemática original. En este sentido, en segundo lugar, se traerá a colación la propuesta estética de Schiller en tanto que una radicalización de ciertos aspectos de la kantiana y que, a la postre, constituye un referente especialmente clarificador de la deriva concreta emprendida por la arquitectura. 
31. En rigor corresponde a la "segunda introducción" que redactó Kant, habiendo quedado la primera inédita hasta su recuperación por parte de Cassirer y publicación en las Obras Completas de Kant de 1913

\section{A. La autonomía trascendental}

La estética se sitúa desde su irrupción como disciplina en un terreno ambiguo entre la racionalidad y lo que se resiste a ella, entre lo universal y lo individual. Parecería que solo es comparable la necesidad de incluir al arte (y la estética como reflexión sobre el arte) dentro del sistema filosófico moderno con su resistencia a verse incorporado. En el caso de Baumgarten, la condición residía en la necesidad de aportar conocimiento, lo que simultáneamente conlleva para el arte la supeditación a ciertas reglas que garanticen la posibilidad de acceso a este conocimiento y el reconocimiento de su excepcionalidad dentro de estas reglas. La estética encuentra, pues, un ámbito propio que la legitima al alejarse de la Lógica y, al tiempo, no puede dejar de reconocer una cierta dependencia hacia ella. No puede confundirse con ella ni puede desligarse radicalmente.

Luego, la estética en su acta fundacional manifiesta ya una dualidad que va a acompañarla y en cuyo seno se dirime la encarnizada batalla por la justificación del arte. La tensión que internamente generan los polos de esta dualidad regresará, en su ambigüedad, como terreno abonado para la polémica a lo largo de la modernidad. Por una parte, la estética forma parte del proyecto ilustrado -en su inconsumible intento de abarcar la complejidad de lo real en su totalidad- y, por otra, la estética se resiste a verse elevada al rango de ciencia del gusto, regida por principios racionales.

\section{Motivación de la tercera crítica}

Fue Kant quien tome el relevo de esta empresa de Baumgarten. Su doctrina estética viene recogida fundamentalmente en la tercera de sus críticas, la Crítica del Juicio de 1790. En la edición canónica de la traducción de García Morente, el cuerpo de la obra viene precedido de una introducción, ${ }^{31}$ donde Kant explicita, entre otros aspectos relevantes, su engarce con la tradición que le precedió y, en concreto, con los logros y fracasos de Baumgarten. El séptimo párrafo “De la representación estética de la finalidad de la naturaleza" empieza como sigue:

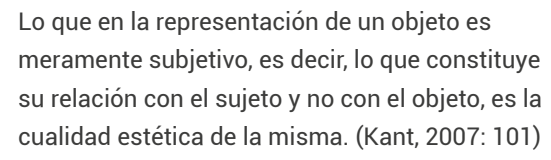

Lo que en la representación de un objeto es meramente subjetivo, es decir, lo que constituye su relación con el sujeto y no con el objeto, es la cualidad estética de la misma. (Kant, 2007: 101)

En primer lugar, resuena en Kant, pues, la voluntad de Baumgarten de considerar la estética como exclusivamente subjetiva. Para este, la estética debía tratar de la "perfección del conocimiento sensible", aunque no lograse establecer en qué ámbito cabía encontrar esa perfección. Coinciden asimismo, en segundo lugar, al reconocer a lo estético un cierto carácter ajeno a lo racional. No obstante, en Kant el alejamiento respecto de la pura razón -vinculándose, por tanto, al dominio de lo sensible- se afirma con mayor rotundidad al evitar taxativamente toda capacidad propositiva epistemológica:

\footnotetext{
Lo subjetivo, empero, en una representación, lo que no puede de ningún modo llegar a ser un elemento de conocimiento, es el placer o el dolor que con ella va unido, pues por medio de él no conozco nada del objeto de la represen-
} 
tación, aunque él pueda ser el efecto de algún conocimiento. (Kant, 2007: 102)

La estética -entendida como la investigación de las condiciones trascendentales de la sensibilidad- asume a tenor de la precedente cita un doble papel en el proceso de conocimiento: por una parte, se le niega la posibilidad de ofrecer conocimiento alguno, por otra, adquiere una función aun por precisar en el proceso de representación del fenómeno. Ciertamente no cabe ya en Kant el discurso poetizante de Baumgarten, en la medida en que su proyecto de fundamentación de la Razón no puede asumir la ambigüedad del desbordamiento poético. La arquitectónica kantiana, sofisticación extrema de la sistematización ilustrada, tiene como fin incluir de forma estructurada toda vía de acceso a la realidad y, visto así, no sorprende la insistencia de Kant respecto de la negación de toda potencialidad epistemológica de lo estético.

De hecho, en Kant se opera un giro desde la aproximación epistemológica de Baumgarten hacia el análisis de la obra de arte en su relación con la finalidad que fue gestándose en los últimos años de la década de los 80 . Es esclarecedora a este respecto la cita de la Crítica de la razón pura en la que Kant se posiciona respecto del -a su juiciofallido intento de Baumgarten de elevar la estética a ciencia:

Los alemanes son los únicos que emplean ahora la palabra estética para designar, por medio de ella, la que otros llaman crítica el gusto. Fúndase esta denominación en una esperanza fallida, que el excelente analítico Baumgarten concibió: la de traer el juicio crítico sobre la belleza a principios racionales y elevar a ciencia las reglas del mismo. Mas el empeño es vano, pues las citadas reglas o criterios son, en sus [principales] fuentes, meramente empíricos y no pueden servir nunca, por lo tanto, de leyes a priori [determinadas], según las cuales tuviera que regirse nuestro juicio de gusto; más bien constituye éste la piedra de toque propia para la exactitud de aquellas. Por esto es de aconsejar [o bien] dejar caer de nuevo esta denominación y reservarla para aquella doctrina, que es una verdadera ciencia (con lo cual nos acercaríamos más al lenguaje y al sentido de los antiguos, entre los cuales era muy famosa la división del

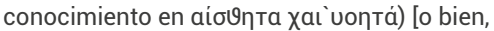
compartir la denominación con la filosofía especulativa y tomar la estética parte en sentido trascendental, parte en sentido psicológico]..$^{32}$

Como indican Juan José García Norro y Rogelio Rovira, es notable la evolución de Kant respecto de la necesidad de una tercera crítica entre los años 1781 -cuando publicó la primera edición de la Crítica de la razón pura- y 1787 en ocasión de la segunda edición. De una inicial negativa, Kant pasa al reconocimiento (aun con cautelas) de la existencia de principios a priori en el juicio estético. Y no será hasta la tercera crítica, en 1790, cuando definitivamente Kant afirma: "el Juicio tiene que encerrar en sí algo a priori, porque de otro modo, aun para la crítica más vulgar, no sería puesto como facultad particular de conocimiento", aunque sea en la forma de una perplejidad: "Esa perplejidad por un principio (sea este subjetivo u objetivo) encuéntrase, sobre todo, en aquellos juicios llamados estéticos, que se refieren a lo bello y lo sublime de la naturaleza o del arte" (Kant, 2007: 74-75)

En la primera crítica, Crítica de la razón pura, Kant trata las condiciones epistémicas del conocer humano frente a un mundo que se presenta gobernado por leyes ajenas a su entendimiento: la necesidad natural, y determina al sujeto como la fuente que
32. Cita original procedente de la Crítica de la razón pura (A 21 - B 36-37). Citado por los editores en la nota 6 (2007: 74-75) 
33. Tesis desarrollada en el tercer capítulo de la segunda introducción "De la crítica del Juicio como un medio de enlace en las dos partes de la filosofía en un todo" (Kant, 2007: 86-89)

34. "un producto organizado de la naturaleza es aquel en que todo es fin y medio, alternativamente. Nada en él es vano, carente de finalidad o atribuible a un ciego mecanismo de la naturaleza" §66. Es decir, los sistemas de la naturaleza se comportan para nuestro entendimiento como producciones intencionadas -techné- que les confiere la forma que adoptan (bien sea por ejemplo los cristales o

la estructura de las plantas), como si contuviesen una Idea. construye el conocimiento del objeto a través de la representación que el sujeto, mediante la sensibilidad inherente a su naturaleza, toma del objeto. En la segunda crítica, Crítica de la razón práctica (1788), Kant establece los principios éticos por medio de la razón práctica de tal forma que dicho mundo pueda dar cabida a sujetos autónomos. En este sentido, todo ser ha de ser un fin en sí mismo y no un medio para fines ajenos a sí mismo. En la tercera crítica, Crítica del Juicio, Kant da respuesta a la necesidad de establecer una relación entre la asunción de la necesidad natural y la posibilidad del sujeto autónomo. Reconocido su papel mediador desde el comienzo mismo de la obra, ${ }^{33}$ la tercera crítica pretende establecer vínculos entre ambos extremos, de ahí que el juicio estético sea indisoluble respecto del teleológico: Kant postula que la necesidad natural ha de entenderse como una razón interna, es decir, como una razón autónoma. El reto sería, desde estos presupuestos, establecer una distinción entre el conocimiento y el juicio estética sin por ello renunciar al vínculo con la subjetividad. Para ello Kant propone dos tipos de juicios.

Si se considera que una rosa es bella, ¿se aporta con este juicio algún tipo de conocimiento sobre el objeto en cuestión? De ser así, el juicio estético determinaría a la rosa mediante una cualidad, de igual forma que la madera es más ligera que el acero, permitiendo el acceso a un conocimiento sobre el objeto por medio del Juicio. Sería tanto como asumir que, en el juicio de la rosa, ha sido subsumido el objeto particular "rosa" bajo un criterio general "bello". Pero en la cita precedente, Kant apunta hacia otra dirección:

\begin{abstract}
Lo subjetivo, empero, en una representación, lo que no puede de ningún modo llegar a ser un elemento de conocimiento, es el placer o el dolor que con ella va unido, pues por medio de él no conozco nada del objeto de la representación, aunque él pueda ser el efecto de algún conocimiento. (Kant, 2007: 102)
\end{abstract}

En efecto, Kant señala más bien el vínculo de lo estético con "el placer o el dolor": lo que interviene en un juicio estético es, por tanto, algo específicamente subjetivo. De hecho, en relación a la motivación de la tercera crítica, la cuestión central dentro de este problema que afronta el Juicio es el acceso a la multiplicidad que presenta lo real. La facultad de juzgar adquiere, en este sentido, el carácter mediador entre lo particular y lo general, operación de síntesis que puede llevarse a cabo -defiende Kant- por medio de dos tipos de juicios: el determinante y el reflexionante. En el primer caso, el juicio se aplica por medio de una ley general preexistente; en el segundo, en cambio, las leyes se elaboran desde lo particular. En términos de Kant, el juicio estético no ha de ser determinante, puesto que no constituye objeto ni "conoce" objeto: "[s]i lo universal (la regla, el principio, la ley) es dado, el Juicio, que subsume en él lo particular [...], es determinante" y por esta razón, puede dar lugar al conocimiento. En cambio, "[s]i sólo es dado lo particular, sobre el cual él [el Juicio] debe encontrar lo universal, entonces el Juicio es solamente reflexionante" (Kant, 2007: 179).

Así, en el caso del juicio determinante, no se garantiza por su aplicación que la multiplicidad conste en efecto de una unidad previa. En el caso del juicio reflexionante, en cambio, Kant (§26) parte de la premisa de que la naturaleza está orientada con arreglo 
a un fin, identificable por nuestro entendimiento como leyes y, por tanto, afectas a la capacidad cognoscitiva. ${ }^{34}$ Es decir, que con arreglo a esta conjetura necesaria, el juicio reflexionante puede elevar de lo particular de la naturaleza leyes que de forma efectiva estén ya presentes. Luego, por una parte, el juicio estético no es dador de conocimiento pero por otra interviene de alguna forma en el proceso cognoscitivo. De hecho, el juicio estético es reflexionante en la medida en que, sin aportar conocimiento sobre el objeto, hace posible el conocimiento al proclamar el orden de la naturaleza como presupuesto trascendental: 35

un juicio estético es único en su clase, y no da absolutamente conocimiento alguno (ni siquiera confuso) del objeto, conocimiento que ocurre solamente mediante un juicio lógico; en cambio, refiere la representación, mediante la cual un objeto es dado, solamente al sujeto, y no hace notar propiedad alguna del objeto, sino sólo la forma final en la determinación de las facultades de representación que se ocupan con éste. (Kant, 2007: 143)

En definitiva, pues, Kant reconduce la polémica sobre el valor epistemológico de lo estético a un terreno mucho más amplio que permite, entre otras, la inclusión de la naturaleza en el objeto del Juicio. Esta es, de hecho, la motivación central -como defiende Cassirer (1948: 336-358)- de la necesidad de esta tercera crítica: el establecimiento de un vínculo entre lo estético y la finalidad que se presupone tanto a la obra de arte como a la naturaleza.

\section{La "finalidad sin fin" en el arte}

Desde el comienzo del primer libro de la Crítica del Juicio, "Analítica de lo bello", Kant establece la condición que lo llevará a ser considerado como el defensor por antonomasia de la autonomía en el arte: su carácter desinteresado, entendiendo por interés "la satisfacción que unimos con la representación de la existencia de un objeto" (Kant, 2007: 115). Fiel a su método trascendental, Kant centra su análisis en la facultad que corresponde al objeto en cuestión, en este caso, la obra de arte o la naturaleza, antes que en el objeto mismo. Así, establece cuáles son los tres tipos de "satisfacción" asociados al placer y dolor en "la representación de la existencia de un objeto": "Agradable llámase a lo que deleita; bello, a lo que sólo place; bueno, a lo que es apreciado, aprobado, es decir, cuyo valor objetivo es asentado".

La primera de las representaciones podía considerarse como aquella más próxima a lo estético: lo "agradable" suscita placer inmediato y no aporta conocimiento al ofrecerse previo a toda intervención intelectual. Pero es necesario reconocer que al afirmar que un objeto de representación es agradable, se está emitiendo un juicio que, más allá de la sensación objetiva, expresa un interés subjetivo por el mismo. Decimos que algo es agradable cuando o bien "me gusta", es decir, emitimos una valoración arbitraria, o bien "lo prefiero a", en donde se introduce una comparación interesada entre unos objetos u otros. La satisfacción en lo agradable moviliza, pues, el deseo que media entre el objeto y la sensación subjetiva: es interesada y fundamentalmente sensible. Previamente se defendió que lo estético depende de la
35. Como Valeriano Bozal defiende, Kant invierte la metafísica tradicional del siglo XVIII al negar que exista una armonía preestablecida, como propuso por ejemplo Hume, entre las ideas y el mundo. Todo en Kant viene referido a un sujeto -a todo sujeto- desde el que el conocimiento se hace posible. Valeriano Bozal (ed.) (2004: 186-190).

36. De lo contrario se pondría caer en el sinsentido de atribuir características artísticas a producciones carentes de reflexión: "Según derecho, debiera llamarse arte sólo a la producción por medio de la libertad, es decir, mediante una voluntad que pone razón a la base de su actividad, pues aunque se gusta de llamar al producto de las abejas (los panales construidos con regularidad) obra de arte, ocurre esto sólo por analogía con esto último; pero tan pronto como se adquiere la convicción de que no fundan aquellas su trabajo en una reflexión propia de la razón, se dice en seguida que es un producto de su naturaleza (del instinto), y sólo a su creador se le atribuye como arte" (Kant, 2007: 257). 
reflexión sobre un objeto, que interviene en el proceso cognoscitivo y no puede, por tanto, descansar únicamente en lo sensible. ${ }^{36}$

En segundo lugar, tercero en la enumeración de Kant, en "lo bueno" cabe distinguir dos tipos: "lo útil" (lo bueno para algo) y "el bien moral" (lo bueno en sí). En ambos casos, ha de reconocerse que se orientan hacia un fin, es decir, son interesadas. Lo útil se aprueba como medio: algo es útil cuando proporciona lo que de él se espera en la medida en que nos da acceso a algo ajeno a sí-mismo. Algo es "útil para". En cambio, el bien moral es bueno absolutamente y es final en su interés: la facultad de desear, por medio de la razón, determina el bien como el más alto interés de la voluntad. Luego, aunque uno sea medio y otro fin ambos están movilizados por el interés. Se trata en definitiva de dos tipos de interés: uno inmediato, vinculado a lo instintivo que es lo relativo a lo agradable, y otro mediato en el que interviene la voluntad, esto es, la razón.

Por último, añade elocuentemente: "Puede decirse que, entre todos estos tres modos de la satisfacción, la del gusto en lo bello es la única satisfacción desinteresada y libre, pues no hay interés alguno, ni el de los sentidos ni el de la razón, que arranque el aplauso" (Kant, 2007: 121-122). El juego de las facultades que dan lugar al juicio de gusto es un juego libre de igual forma que el juicio del gusto ha de serlo de por sí. La facultad del juicio del gusto ha de autodeterminarse $y$, en ese sentido, ha de ser libre: las fuerzas subjetivas que movilizan el juicio del gusto han de ser referidas a sí mismas, han de ser finales. En definitiva, el juicio estético ha de ser, en primer lugar, juicio (no puede meramente ser instintivo) y, en segundo lugar, juicio desinte- resado. Recapitulando: el juicio de gusto es contemplativo en la medida en que no admite implicación en la representación del objeto - "es satisfacción desinteresada" en el terreno de los sentidos-, es juicio y ha de ejercerse en libertad y con concepto pero sin la intervención de la voluntad -"es satisfacción desinteresada" en el terreno de la razón-.

Kant establece, por tanto, la libre voluntad en la base del arte, e insiste en este sentido en la distinción entre el arte y la producción mecánica (obviamente referido a la artesanía como un tipo de producción humana): "Cuando el arte, adecuado al conocimiento de un objeto posible, ejecuta los actos que se exigen para hacerlo real, es mecánico; pero si tiene como intención inmediata el sentimiento de placer, llámase arte estético". El arte se distingue de la naturaleza como el facere de las obras o producir en general (agere), o como la obra (opus) se distingue del efecto (effectus). Se aleja, pues, Kant de la estética determinista de los afectos barroca así como de todo regreso a un esencialismo arcaizante del arte por medio de la artesanía. Y de ahí que:

Según derecho debiera llamarse arte sólo a la producción por medio de la libertad, es decir, por medio de una voluntad que pone razón a la base de su actividad. (Kant, 2007: §43)

Y el arte puede, en este sentido, ser agradable o bello: "Es el primero cuando el fin es que el placer acompañe las representaciones como meras sensaciones; es el segundo cuando el fin es que el placer acompañe las representaciones como modos de conocimiento" (Kant, 2007: 231). Así, el arte agradable es aquel que se orienta hacia el goce, todo 
aquel, dice Kant, que se agota en el instante de su puesta en obra, la despreocupada ocupación en hacer pasar el tiempo. La "satisfacción desinteresada" se aleja del placer "interesado" propio de lo útil o lo moral. Arroja la posibilidad de un tipo de placer puro que nace exclusivamente de la contemplación de lo bello, ensalzando así su carácter autónomo, entendido por muchos como enajenación última del arte respecto de la sociedad. De ahí que se acuse a la estética kantiana de dejar abierta la puerta a un arte que dé la espalda a lo social.

Recuperando la argumentación anterior: todo arte presupone reglas, que son necesarias para la consideración por parte del Juicio de ese objeto como arte. Pero, adicionalmente, todo arte bello -si ha de ser considerado tal- niega la posibilidad de ser juzgado por ninguna regla que tenga un concepto como "base de determinación":

\begin{abstract}
Así pues, el arte bello no puede inventarse a sí mismo la regla según la cual debe efectuar su producto. Pero como sin regla anterior no puede un producto nunca llamarse arte, debe la naturaleza dar la regla al arte en el sujeto (y mediante la disposición de la facultad del mismo), es decir, que el arte bello sólo es posible como producto del genio. (Kant, 2007: 234)
\end{abstract}

La insistencia de Kant en el papel mediador del genio es sustantiva: a diferencia de la interpretación que harán en el romanticismo de la figura del genio, en Kant no se trata de un creador novedoso capaz de dar lugar a lo que antes no era, sino antes bien aquel que estructura la obra de arte con arreglo a reglas previas, ya constatables en la naturaleza. ${ }^{37} \mathrm{Y}$ esta regla, dado que lo bello no es determinable por conceptos, no es mera copia de la naturaleza, no se puede prever científicamente -fijando así el límite de la teoría de la imitación que le antecede-. Antes bien, el genio es aquel que "sigue" la regla de la naturaleza y la incorpora a la forma estética. $^{38}$

El arte ha de ser como la naturaleza en el sentido de imitar el proceso de creación natural para que la obra pueda ser considerada como si de una producción natural se tratase. Aun siendo un producto que encierra cierta intencionalidad (el arte siempre intenta producir algo) la finalidad del arte bello no debe parecer intencionada. Aun sabiéndose arte, debe parecer naturaleza:

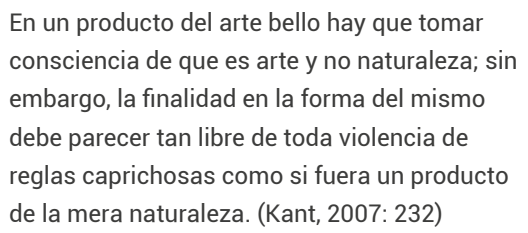

Las reglas han de entenderse, pues, como elementos de ordenación de la producción que el genio encarna: propósitos sin propósito de los organismos naturales, reglas generativas. ${ }^{39}$ El arte, aun siendo desinteresado, se orienta a fines por medio de la figura del genio (algo así como un catalizador de la naturaleza). De esto deriva la tesis kantiana sobre la "finalidad sin fin" del arte.

\section{Autonomía en Kant}

\section{La antinomia del gusto}

El juicio del gusto ha de dar respuesta a una cuestión espinosa, que por otra parte venía agitando, y mucho, toda la estética ilustrada: la exigencia de universalidad del gusto. Si se dice de una rosa que es bella, este juicio reclama un cierto tipo de validez. Pero si el
37. "Genio es el talento (dote natural) que da la regla al arte. Como el talento mismo, en cuanto es una facultad innata productora del artista, pertenece a la naturaleza, podríamos expresarnos así: genio es la capacidad espiritual innata (ingenium) mediante la cual la naturaleza da la regala al arte." (Kant, 2007: 233)

38. "la regla debe abstraerse del hecho, es decir, del producto en el que otros pueden probar su propio talento, sirviéndose de él como modelo, no para copiarlo, sino para seguirlo." (Kant, 2007: 236). 39. "sus productos deben ser...modelos, es decir ejemplares, por lo tanto no nacidos ellos mismos de la imitación, debiendo, sin embargo, servir a la de otros, es decir, de medida o regla de juicio" (Kant, 2007: §̧46) 
40. "Bello es lo que, sin concepto, es conocido como objeto de una necesaria satisfacción" (Kant, 2007: 157). consenso requerido se fundase únicamente en la opinión caprichosa de cada cual estaríamos de nuevo cayendo del lado del agrado, por no ser juicio. Por otra parte, tampoco es defendible la idea de que la rosa es bella por principios a priori, puesto que el gusto no es lógico. Luego, de alguna forma aun por clarificar, el juicio del gusto moviliza un cierto consenso, una cierta universalidad, al tiempo que se resiste a la universalidad lógica. Kant apela para salvar este escollo a la relación del interés privado con lo colectivo:

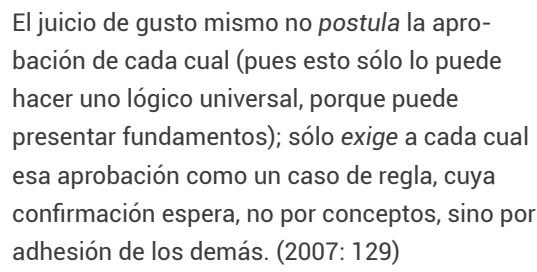

Según esta cita, el carácter de exigencia del juicio de gusto proviene del consenso individual. Se trata, pues, de una universalidad subjetiva y no una de tipo objetivo como sería el caso del concepto. Por otra parte, el juicio de gusto es necesario para el proceso cognitivo mismo. El libre juego de las facultades que moviliza es capaz de establecer un cuadro de representación en el que el orden y la armonía se manifiesten (al subsumir el conocimiento del objeto bajo leyes generales), posibilitando así el acceso a la experiencia. Si se desposee de contenido a este proceso, si queda exclusivamente el libre juego como formalidad, nos encontramos en el terreno de lo estético. Y dicho esto, no es menos cierto que este proceso, que es subjetivo y desinteresado, que no aporta conocimiento alguno, no es exclusivo de ciertos sujetos. Las facultades psicológicas que intervienen en el juicio de gusto -el entendimiento y la imaginación- son comunes a todos los humanos, postulado central en el pensamiento ilustrado. Y de ahí que sea universal. Luego, el consenso -el sensus communis del §̧40- del que Kant habla no es, finalmente, un consenso dialéctico sino la condición de posibilidad para que se pueda hablar de juicio de gusto. Su universalidad depende no de los juicios como hechos (el clásico "sobre gustos no hay nada escrito" y la imposibilidad de su clausura) sino de su necesidad interna. Si existe tal juicio, ha de ser universal:

$$
\begin{aligned}
& \text { La conciencia de la finalidad meramente formal } \\
& \text { en el juego de las facultades de conocimiento } \\
& \text { del sujeto, en una representación mediante } \\
& \text { la cual un objeto es dado, es el placer mismo, } \\
& \text { porque encierra [...] una interior causalidad, pues } \\
& \text { (que es final), en consideración del conocimien- } \\
& \text { to en general, pero sin limitarse a un conoci- } \\
& \text { miento determinado [...]. Ese placer no es de } \\
& \text { ninguna manera práctico, ni como el que tiene } \\
& \text { la base patológica del agrado, ni como el que } \\
& \text { tiene la base intelectual del bien representado. } \\
& \text { Tiene, sin embargo, causalidad en sí, a saber: la } \\
& \text { de conservar, sin ulterior intención, el estado de } \\
& \text { la representación misma y la ocupación de las } \\
& \text { facultades del conocimiento. (Kant, 2007: 136) }
\end{aligned}
$$

Así, la belleza de un objeto artístico ha de provocar por fuerza placer, pero sin la mediación de ninguna de las otras facultades, y ese placer tiene que ser universalmente provocado aunque esté condicionado por la subjetividad. ${ }^{40} \mathrm{Y}$ dado que no es posible establecer objetividad - principios objetivos- en el juicio estético, para solventar la "antinomia del juicio de gusto" Kant establece un tipo de determinación no objetiva a partir de dos características del juicio de gusto. Por una parte, "[e]l juicio de gusto determina su obje- 
to, en consideración de la satisfacción (como belleza), con una pretensión a la aprobación de cada cual, como si fuera objetivo" (2007: 204) y, por otra, "no puede en modo alguno ser determinado por bases de demostración, exactamente como si fuera meramente subjetivo" (2007: 206).

\section{Autonomía y moral}

A tenor de lo dicho hasta ahora, queda claro que el juicio estético para Kant es subjetivo, aunque a diferencia del agrado, que muestra un interés hacia el objeto por medio del placer inmediato de lo sensitivo, no se orienta respecto a interés alguno. El juicio estético, o juicio del gusto, da lugar a un placer que va más allá de lo meramente sensible. Como se vio, a pesar de ser subjetivo, el juicio del gusto aspira a la universalidad, o más concretamente, a la aprobación universal del juicio emitido: no queda, pues, en el ámbito de lo privado, sino que adquiere un rango social. La aparente contradicción así expuesta viene solventada por la movilización en el juicio de las facultades de la imaginación y el entendimiento en una armonía cercana a la dadora de conocimiento (cuando hay belleza), aun sin alcanzarlo. Queda, por así decirlo, en la forma de la finalidad propia de un proceso cognoscitivo, pero sin tener concepto como fin. De ahí que el juego de la imaginación y el entendimiento en un juicio estético sea libre y no pueda confundirse con el juicio lógico, haciéndose patente, en este sentido, la cercanía de la obra de arte respecto de la naturaleza. Ahora bien, una diferencia sustancial hace de la obra de arte algo singular respecto de la naturaleza:
Para juzgar una belleza de la naturaleza como tal no necesito tener con anterioridad un concepto de la clase de cosa que el objeto debe ser, es decir, no necesito conocer la finalidad material (el fin), sino que la mera forma, sin conocimiento del fin, place por sí misma en el juicio. Pero cuando el objeto es dado como un producto del arte, y como tal debe ser declarado bello, debe entonces, ante todo, ponerse a su base un concepto de los que deba ser la cosa, porque el arte siempre presupone un fin en la causa (y en su causalidad) y como la concordancia mutua de lo diverso en una cosa, con una determinación interior de ella como fin, es la perfección de la cosa, deberá tenerse en cuenta en el juicio de la belleza artística también la perfección de la cosa, la cual no es cuestión en el juicio de una belleza natural (como tal). (Kant, 2007: 238)

En este punto de la argumentación de Kant se apoyan autores como Paul Guyer para rebajar el carácter contemplativo que ciertos autores atribuyen a Kant. ${ }^{41}$ En contra de esta interpretación de la teoría del gusto, Kant insiste en el hecho de que el desinterés del juicio estético no tiene por qué implicar falta de interés. Aunque los juicios de gusto no establezcan interés alguno, para la sociedad sí es interesante tener gusto:42 "Arte bello, en cambio, es un modo de representación que por sí mismo es conforme a fin, $y$, aunque sin fin, fomenta, sin embargo, la cultura de las facultades del espíritu para la comunicación social" (Kant, 2007: 232). ${ }^{43}$ La obra de arte como obra de la libre voluntad está pues vinculada con la cultura en general (y con el sentido común: la validez común) y con la naturaleza.

Defiende Guyer a este respecto que, más allá del juicio puro de gusto (aquel desinteresado que no se deja atrapar con concepto alguno), en este pasaje queda claramente enunciado cómo para la apreciación
41. Es el caso, por ejemplo, de M.H. Abrams quien localiza en Kant el establecimiento más rotundo de un modelo contemplativo de recepción de la obra de arte: considerar que la obra de arte contiene un interés por sí misma con independencia del entorno. Véase Meyer Howard Abrams (1991), "From Addison to Kant" y "Art-as-Such", en Doing Things with Texts: Essays in Criticism and Critical Theory. Nueva York: Norton. 42. “Un juicio sobre un objeto de la satisfacción puede ser totalmente desinteresado y, sin embargo, muy interesante, es decir, no fundarse en interés alguno, pero producir un interés; así son todos los juicios morales puros. Pero los juicios de gusto no establecen, en sí, tampoco interés alguno. Sólo en la sociedad viene a ser interesante tener gusto", en nota * (Kant, 2007: 116).

43. En este argumentario de Kant, defendido en el §44, se apoya Casey Haskins para negar la autonomía del juicio estético en Kant en sentido estricto, dado que el arte fomenta la cultura de las facultades del espíritu para la comunicación social. Véase Casey Haskins (1989), "Kant and the Autonomy of Art", en The Journal of Aesthetics and Art Criticism, 47. 
44. Paul Guyer desarrollará esta interpretación de Kant en obras posteriores, entre las que cabe destacar Kant and the Claims of Knowledge. 45. La teoría del genio no compromete la autonomía del creador: "Como naturaleza aparece un producto del arte, con tal de que se haya alcanzado toda precisión en la aplicación de las reglas, según las cuales sólo el producto puede llegar a ser lo que debe ser, pero, sin esfuerzo, sin que la forma de la escuela se transparente, sin mostrar una señal de que las reglas las ha tenido el artista ante sus ojos y han puesto cadenas a sus facultades del espíritu." (Kant, 2007: 233). adecuada de una obra de arte no basta con considerarla producto de la armonía de las facultades (lo que por otra parte no distaría mucho de una teoría clásica del arte, de la que evidentemente Kant se aleja) sino que ha de reconocerse en la obra un fin particular, aunque el concepto no pueda determinar por completo su forma particular (de lo contrario interferiría con el entendimiento o la razón) (Guyer, 1989). ${ }^{44}$ De hecho, es este un argumento de especial relevancia a la hora de analizar el caso concreto de la arquitectura desde la teoría del gusto de Kant, como se verá en la Parte II.

En palabras de Kant, la obra de arte "no es más que la forma de la exposición de un concepto mediante la cual éste es universalmente comunicado" (Kant, 2007: 239). La "exposición de un concepto" significa en Kant la exposición de un cierto contenido en la obra de arte, "ideas de razón". Kant hace mención a la sublimidad, la majestuosidad, referencias a lo invisible (el reino de los bienaventurados, el infierno, la eternidad) o abstractas (la muerte, la envidia) como ejemplos de estas ideas estéticas. Esta exposición se realiza a través de imágenes particulares o intuiciones y el genio es aquel que conecta el concepto a esta idea y la hace comunicable en la obra:

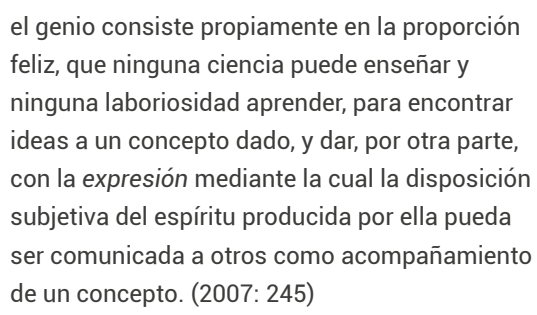

el genio consiste propiamente en la proporción feliz, que ninguna ciencia puede enseñar y ninguna laboriosidad aprender, para encontrar ideas a un concepto dado, y dar, por otra parte, con la expresión mediante la cual la disposición subjetiva del espíritu producida por ella pueda ser comunicada a otros como acompañamiento de un concepto. (2007: 245)

El talento artístico cumple como función la expresión de lo inefable en una cierta representación, haciéndolo universalmente. Como el "Águila de Júpiter" es atributo del poder y el "pavo real" de la magnificencia. Luego, la libertad en el arte es libertad del genio $^{45}$ y de ahí que la obra bella solo sea posible a través de este. Es decir, el concepto de autonomía en el arte, en tanto que autodeterminado, implica asimismo la liberación del arte del imperativo de la imitación y se otorga a sí misma su propia ley. De forma que el arte hace posible un salto entre la necesidad y la libertad, presentándose como una muestra de la compatibilidad de la libertad con las reglas:

\begin{abstract}
El gusto hace posible, por decirlo así, el tránsito del encanto sensible al interés moral habitual, sin un salto demasiado violento, al representar la imaginación también en su libertad como determinable conformemente a un fin para el entendimiento, y enseña a encontrar, hasta en objetos de los sentidos, una libre satisfacción, también sin encanto sensible. (Kant, 2007: 246)

O dicho de otra manera, el contenido subyacente de la experiencia artística es la relación entre las ideas fundamentales de la metafísica y la moralidad: la idea fundante de que la voluntad puede ser libremente determinada por el principio de moralidad. De ahí que un componente en la experiencia artística sea el fundamento metafísico de la moralidad.
\end{abstract}

La estética del gusto kantiana, arraigada aun en muchos aspectos en la tradición ilustrada, deja abierta - de forma poco visible- en su clasificación problemas y aporías que se exacerbarán en su recepción. El nexo con lo social, que descuelga del proceso de autonomización de la estética a través de la noción de ley individual, se presenta en Kant bajo la forma de la reconciliación del gusto del sujeto libre. La separación categorial de lo 
bello como un ámbito de la libertad sin afán por la utilidad o lo agradable ni por el bien aporta así, aunque resulte paradójico, una cierta funcionalidad al arte. Aunque la Crítica del Juicio no se funda en un sistema moral, en su recepción en el periodo clásico de Weimar asentará la posibilidad de una transición entre lo público crítico de la llustración (en la tradición de las estéticas morales) a lo público bello.

Lo cierto es que, tras Kant, todo vínculo entre el arte y lo moral deberá ser abordado en tanto que programa, ya nunca más como evidencia. Incluso en casos de inversión radical del método trascendental -como es el caso de Heidegger- la proximidad de estas dos esferas en su aproximación ontológica (si puede simplificarse tanto) tiene un indudable carácter reivindicativo ${ }^{46}$ En este sentido, la obra de Schiller aporta un temprano testimonio de los numerosos intentos de reconducir la tensión entre lo bello y la libertad que funda Kant.

\section{B. La autonomía moderna}

En el sistema kantiano, el Juicio ocupa un lugar preeminente, necesario en su sistema filosófico: entre las facultades superiores del alma, esta tercera media entre el conocimiento teórico (aquel que se dirige al concepto) y el práctico (aquel que se orienta hacia la consecución de la libertad). Por su carácter reflexivo permite conferir orden a lo natural al proporcionar el concepto de finalidad de la naturaleza- que posibilita tanto el concepto (el ascenso de lo particular a lo general se realiza por medio del Juicio en la medida en que hace de lo contingente y heterogéneo sistema) como la práctica (la heterogeneidad de la naturaleza impide la práctica si no es porque por medio del Juicio, la razón puede reconocerla en su unidad y por tanto hacerse manejable).

Por todo ello, el Juicio ha de cumplir con ciertos requisitos formales. Siendo el juicio del gusto un juicio particular, deriva de sus principios aunque se erija como singular. En Kant, el juicio estético se caracteriza por no dar lugar a concepto aunque lo posibilita, ser desinteresado aunque sí con orientación teleológica (la finalidad sin fin) y necesariamente universal aunque subjetivo, sustentado fundamentalmente en una teoría estética de la recepción (el gusto) y de la producción (el genio y lo sublime). En todo ello hay un reconocimiento implícito por parte de Kant de la escisión de las esferas del espíritu y su superación por medio de la figura del genio: la dislocación entre el carácter creativo de toda producción artística -desde el presupuesto de la autonomía del sujeto- y la realidad que se impone en su determinismo convergen en la idea de "reglas de producción". Desde la
46. Sobre la elaboración de un sentido ontológico de la arquitectura, véase Takkal et al. (2018). 
perspectiva de la irrupción de la autonomía en el arte, la obra de Kant goza de un indiscutido protagonismo al marcar un punto de inflexión entre las visiones moralistas o neoplatónicas que le precedieron y la radicalización utópica de su teoría del gusto.

Schiller parte de los presupuestos trascendentales de Kant para orientarlos hacia una teoría que incluyese la objetividad del hecho artístico. Para ello, simultáneamente, pretenderá superar el subjetivismo kantiano a la vez que recuperará la idea de una función social de lo estético, algo que tendrá una sustantiva influencia en Goethe. Afronta, en definitiva, el gran drama formulado por Kant en su más radical crudeza: una vez dotado al espíritu de la potencialidad creativa, se constata de facto su imposible implementación en la práctica. Schiller intentará probar que el arte, precisamente por su condición autónoma - su falta de vínculo con los fines instrumentales-, es la única instancia en el declive de la modernidad capaz de alcanzar la única lícita misión de toda empresa humana: elevar al ser humano a la humanidad plena. La autonomía del arte (y de la estética) adquiere así una orientación -consolidando el resquicio abierto en Kant con la sublimación de la belleza- que abre un abanico de posibilidades teórico-prácticas que serán ampliamente explotadas por la arquitectura.

\section{El vértigo de la modernidad}

\section{Un nuevo papel para la estética y la mirada hacia la historia}

Schiller, a diferencia de Kant, participó de la conciencia de la negatividad inducida por el proceso de racionalización en la modernidad. La evidente dislocación en la última década del siglo XVIII entre las promesas de la Ilustración y la realidad provocó diferentes movimientos críticos en el seno mismo de la llustración. En realidad, ya desde Rousseau, entre los teóricos más relevantes de la Ilustración se puede detectar la emergencia de la ambigüedad de la naciente modernidad. Si bien eran ampliamente defendidos los evidentes progresos que la llustración propiciaba, poco a poco -y los estragos de la Revolución Francesa no hicieron más que espolear esta vertiente negativa ilustrada- la racionalidad, el universalismo o el formalismo dejaron de presentarse como la cristalina alternativa de la barbarie que la Ilustración pretendía derrocar. En este contexto, Schiller se hace portavoz de la reivindicación de una unidad que se había perdido con la modernidad. La sistematización a la que había dado lugar la filosofía crítica demandaba una síntesis, una reconciliación entre sus partes. Y gran parte del empeño de Schiller irá dirigido a elaborar un marco teórico que lo posibilite.

Así, ya en obras tempranas, los polos claramente delimitados en el sistema kantiano comienzan a diluir sus límites. Los antagonistas se requieren unos a otros: ya no hay el uno sin el contrario, y ambos han de formar parte de la ecuación para alcanzar su equilibrio. En 1784, cuando Schiller contaba únicamente con 25 años, publica El teatro como institución moral, título ya de por sí claramente provocativo desde la perspectiva del sistema kantiano. Recuérdese que 3 años antes Kant publicó la Crítica de la razón pura, sentando las bases de una nueva época para la filosofía. En esta obra, Schiller apunta hacia lo que con el tiempo constituirá el núcleo teórico de su pensamiento: a tenor de la decepción constatada en el proyecto emanci- 
pador ilustrado, lo estético ha de empeñarse en constituir una alternativa viable.

La ambición de su naciente proyecto estético pretende remontar, en su sentido utópico, los antagonismos heredados de la Ilustración. Tras la disolución del Estado en el sentido propuesto por Hobbes, ${ }^{47}$ habiéndose constatado que el Estado en su acepción política no constituye una institución que pueda detentar -o al menos no en exclusivala necesaria renovación, será la estética quien haya de tomar el relevo de tan ambiciosa tarea. Frente a las pretensiones universalistas de la ciencia o la política, Schiller reivindicará años más tarde en Los artistas (1789) el carácter humano y humanizador de las artes. En definitiva, se trata incluir en el sistema kantiano un contenido antropológico que contrarreste la hegemonía de la abstracción y el formalismo.

En 1795, publicará en la revista

Die Horen nueve cartas que constituirán la primera entrega de Cartas sobre la educación estética del hombre. En estas, la reflexión histórica se eleva a discurso filosófico con el fin de determinar el origen fenomenológico de la belleza y su lugar dentro de la sociedad. ${ }^{48}$ Son, antes que nada, una crítica a la llustración, una rebelión contra un proceso que ha llevado a la enajenación del hombre respecto de su esencia. Para Schiller, el fracaso de la Ilustración estriba fundamentalmente en haberse reducido a una dinámica exclusivamente teórica que ha ido desligándose progresivamente de su aplicación. Sus principios no han llegado a ser efectivos. En este sentido, el espíritu de abstracción que ha guiado el proceso, con especial atención al "entendimiento" frente al resto de facultades del alma, es el responsable de la tendencia hacia la fragmentación de todos los ámbitos de la cultura y del hombre. Esta crítica, como se verá más adelante, la comparte con Goethe.

La "forma técnica" en la que se presentan las discusiones entre los filósofos hace visible una verdad que entre los hombres comunes no es necesario demostrar por constituir "las exigencias antiquísimas de la razón común". Esta verdad se presenta únicamente a los ojos del entendimiento, que "la oculta a su vez al sentimiento, pues al entendimiento le es necesario desgraciadamente destruir primero el sentido interior del objeto para poder apropiarse de él" (Schiller, 1990: I, 113-115). Es la época del análisis científico. El sujeto, la sociedad, se desarrolla únicamente en partes de sus capacidades, en tanto que el resto quedan atrofiadas. El espíritu práctico aviva el proceso de especialización, que aleja aun más la posibilidad de la totalidad libre.

Para apoyar su tesis, Schiller se sirve en Cartas sobre la educación estética del hombre de la Grecia Clásica como contrapunto de su desgarrada descripción de la cultura moderna. Esta no es, de hecho, la primera ocasión en la que hace mención al mundo clásico. En obras anteriores a su explícita influencia kantiana ${ }^{49}$ como son Carta de un viajero danés de 1785, Los dioses de Grecia de 1788 o Sobre lo patético de 1793, Schiller presenta ya a Grecia como el paradigma de la armonía, como cultura en la que el hombre, en plenitud de sus capacidades espirituales, podía desplegarse sin conflicto con la naturaleza y la sociedad. Esta interpretación idealizada de la Grecia clásica, deudora de los trabajos de Winckelmann y de sus amigos Goethe y Humbolt -con quien mantuvo una
47. A este respecto Schiller dirá años más tarde: "Puede censurársele al Estado que olvidara la dignidad de la naturaleza humana, cuando de lo que todavía se trataba era de defender la existencia de la propia humanidad? [...] La disolución del estado es la mejor justificación de la necesidad de su existencia. La sociedad, una vez desatados los lazos que la fundamentan, en lugar de progresar hacia una vida orgánica, se precipita de nuevo en el reino de las fuerzas elementales" (1990: V, 137-139).

48. La influencia, en este sentido, de Winckelmann se hace notar en la medida en que la naturaleza y la belleza se unifican en la historia que, en su caso, empieza con los griegos.

49. Confesada por él: “No quiero ocultaros que los principios en que se fundamentan las afirmaciones que siguen son en su mayor parte principios kantianos" (Schiller, 1990: I, 133). 
50. Schiller recupera de Winckelmann la descripción de un mundo idealizado,

como construcción escrita: “la recuperación de Grecia, el mundo clásico como anhelo, no apunta al objeto, sino a la palabra sobre él: no Grecia, sino Grecia como alegoría y mito que a fin de cuentas queda encerrado en la escritura" (Salvador, 2006: 175-181)

Por otra parte, ese llevar a la Grecia clásica más allá de sí-misma es lo que Marchán Fiz (2010) señala como la diferencia entre clásico y clasicismo, algo que Goehte también postula. extensa correspondencia durante años-, se aleja ya de los paradigmas ilustrados y constituye el punto de referencia del nuevo concepto de humanidad que en lo sucesivo se irá imponiendo. Lo griego será así encumbrado como una naturaleza universal, común a todos los hombres, a la vez que se aleja de la caracterización negativa de Rousseau y su defensa del puro estado natural. En definitiva, lo griego se presenta como el anverso de un presente opresivo y desalentador, como la condensación de todos los ideales de realización (éticos, políticos, estéticos) que la Ilustración no ha podido poner en práctica: "el mundo clásico como anhelo", como construcción verbal alegórica que lleva a la Grecia clásica más allá de sí-misma, al margen de cualquier pretensión historiográfica. ${ }^{50}$

\section{La conciencia de escisión en la modernidad: totalidad y fragmentación}

Con la modernidad, en cambio, todo se derrumba. Entre otros aspectos, el orden social sufre de desorientación y depravación. En las clases bajas "se advierten impulsos primitivos y sin ley que, una vez deshechos los lazos del orden social, se desencadenan y apresuran con furia indomable a satisfacer sus impulsos animales". Pero no mejor se presentan las "clases civilizadas" que, entregadas a la ilustración del entendimiento, antes que ennoblecer su espíritu "no hace sino asegurar la corrupción valiéndose de preceptos". Desde su pretendida autosuficiencia, los ilustrados se guían únicamente por principios racionales que esconden la emergencia de los intereses más animales. Una forzada decencia en las costumbres que "niega a la naturaleza la primera palabra todavía excusable, para concederle la última decisiva sentencia en nuestra moral materialista" (Schiller, 1990: $\mathrm{V}, 137-139)$. El panorama no mejora en otros ámbitos: una sociedad dominada por el provecho, la ciencia, la división del trabajo que exacerba la dicotomía entre lo espiritual y lo manual..., toda una serie de imposiciones que han dado lugar a una nueva formación social que no está, como cabría esperar, más cerca del Ideal.

La llustración ha instaurado una lucha fratricida entre la Naturaleza y la Cultura que no encuentra solución sin la supeditación de uno de los lados: "o bien como salvaje, si sus sentimientos dominan a sus principios; o bien como bárbaro, si sus principios destruyen a sus sentimientos" (Schiller, 1990: IV, 135). 0 es la naturaleza, el hombre en sus instintos, quien domina o es el desprecio hacia la naturaleza, estableciéndose así un enfrentamiento entre los sentidos y el espíritu. En la modernidad, la sabiduría llega envenenada. En cambio, en Grecia, se mantiene la unidad. Persiste el hombre total. Naturaleza y Cultura se aliaban en un estado reconciliado que daba pie tanto a la fantasía como a la madurez de la razón, tanto a los sentidos como al entendimiento. En definitiva, el individuo no se veía dividido entre su componente empírico, individual, y el ético, comprometido con la universalidad. En la época moderna las potencias del alma se manifiestan en la realidad divididas, "[p]orque al primero le dio forma la naturaleza, que todo lo une, y al segundo el entendimiento, que todo lo divide". Promueve un desarrollo unilateral, especializado, con terribles consecuencias para la armonía del conjunto:

El entendimiento intuitivo y el especulativo se retiraron hostilmente a sus respectivos campos 
de acción, cuyas fronteras comenzaron a vigilar entonces desconfiados y recelosos; y con la esfera a la que reducimos nuestra operatividad, nos imponemos además a nosotros mismos un amo y señor, que no pocas veces suele acabar oprimiendo nuestras restantes facultades. (Schiller, 1990: IV, 145-147)

No obstante, esta ruptura de la totalidad clásica - que desemboca en un proceso de fragmentación a todas las escalas- era históricamente necesaria. Schiller reconoce que el "fenómeno de la humanidad griega fue sin duda alguna un logro máximo, que ni podía perseverar en ese estadio, ni elevarse a cotas más altas". En la estela del progreso ilustrado, se entiende la fragmentación como condición previa, puesto que "[p]ara desarrollar todas y cada una de las múltiples facultades humanas, no había otro medio que oponerlas entre sí. Este antagonismo de fuerzas es el gran instrumento de la cultura" (Schiller, 1990: IV, 155) que ha de verse como un sacrificio ineludible de lo particular hacia lo universal. Schiller no niega los logros alcanzados por la llustración, tanto en materia científica como en el pensamiento en general. Pero también se rebela contra el hecho de asumir la pérdida de la totalidad como moneda de cambio por medio del "impulso hacia lo absoluto" que persiste en las consciencias escindidas. La humanidad ha de ser capaz de restablecer en un tercer estadio de la fragmentación la totalidad perdida. No se trata, pues, de recuperar la totalidad clásica sino instaurar una nueva civilización superior. Es, de hecho, este el programa de las Cartas: recuperar la totalidad como superación de la unidad destruida por la cultura ilustrada, pero siempre desde dentro de la cultura ilustrada.

\section{El papel de la estética y del arte}

Schiller no niega que con la llustración se haya progresado. Ciertamente, con "la mayoría de edad", el hombre ha conseguido someter el imperio de la arbitrariedad. No obstante, haciéndose eco de las sangrientas revueltas que siguieron a la Revolución Francesa, Schiller denuncia que en "el drama del tiempo actual" la aspiración a la "verdadera libertad" es solo ilusoria. No en vano su pensamiento tomará el testigo de Kant. En este sentido, su intento de vincular sus dos primeras críticas por medio de la Crítica del Juicio inaugura numerosos proyectos de recuperación de la unidad que quedó disuelta con la modernidad. Ya se vio cómo Kant tuvo que hacer frente al no resuelto salto desde su concepción trascendental de la razón al contexto efectivo en el que había de desenvolverse.

La estética de Schiller, partiendo del formalismo desarrollado por Kant, pondrá en práctica -y aquí estriba una de sus mayores contribuciones- un giro hacia una dimensión histórica más precisa. Ya en sus primeros dramas, como Fiesco o Don Carlos, el tema histórico adquiere un protagonismo sintomático. Esta renovada mirada hacia lo concreto, hacia lo efectivo, que con sus obras más maduras acabará consolidándose en una teoría estética, se fija con especial atención en la experiencia estética como mediadora. Se inscribe así en un horizonte de emancipación que resolverá los antagonismos -provocados por la modernidad- elevándolos a un nuevo Ideal de armonía reconciliada. 
51. Por citar algunos ejemplos, véase Verdad y método de Hans-Georg Gadamer (2007: 73-74) o la crítica de Adorno a Kant que se abordará más adelante. Marchán Fiz lo recoge como un lugar común en las interpretaciones de Kant (2000: 61). 52. O sobre la orientación hacia el progreso: "Una época no puede aliarse y conjurarse para dejar a la siguiente en un estado en que no le haya de ser posible ampliar sus conocimientos (sobre todo los más apremiantes), rectificar sus errores y en general seguir avanzando hacia la ilustración. Tal cosa supondría un crimen contra la naturaleza humana, cuyo destino primordial consiste justamente en ese progresar" (Kant, 2004: 88-89).

53. De hecho, un referente más cercano a la hora de plantear la orientación de la estética como educación en Cartas sobre la educación estética del hombre es La educación del género humano de Lessing de 1780 , donde la educación guía a la razón del hombre como revelación divina.

54. En Baumgarten (1961), Aesthetica beatio III: "Exercitatio Aesthetica". No obstante, la idea de Baumgarten de una educación estética está lastrada aun por su sometimiento a los principios de la Razón ilustrada.
La educación estética emancipadora Leída entre 1790 y 1793, la Crítica del Juicio produjo en Schiller un gran impacto (Marchán Fiz, 2000: 61). Las obras que le siguen constituyen el cuerpo teórico más referenciado del pensamiento schilleriano, y tienen como claro referente teórico a Kant. Algunos autores apuntan incluso que, tras la lectura de la Crítica del Juicio, fue empeño de Schiller superar la fundamentación subjetiva de la estética kantiana en una búsqueda de objetividad en el hecho estético. ${ }^{51}$ Testimonio ya maduro de este posicionamiento es Kallia o sobre la belleza. Tiene su origen en la correspondencia entre Schiller y su viejo amigo de juventud Gottfried Körner, donde, en un diálogo cuyos participantes defendieran diferentes teorías estéticas, fuese deshilvanándose su teoría propia de la belleza.

La tarea, en la que el arte adquiere un papel protagonista, consiste en un ennoblecimiento [Verdelung] de lo humano por medio de la educación del hombre y de la humanidad. Como ya hizo Kant anteriormente en su alegato "Contestación a la pregunta: ¿Qué es Ilustración?", la misión a la que ha de volcarse la filosofía estriba en la "educación para el progreso". Kant viene a equiparar la Ilustración con la educación del hombre para la emancipación, "el abandono por parte del hombre de una minoría de edad cuyo responsable es él mismo" (2004: 83). ${ }^{52}$ Pero es esta una idea de educación de la que Schiller se alejó, como no podía ser de otra forma habida cuenta de lo anteriormente expuesto. ${ }^{53} \mathrm{El}$ concepto de educación en Schiller no se apoya en la máxima de una evolución progresiva del individuo y de la sociedad. No se trata ya de alcanzar una verdad o un sistema ético infalible, ambos ideales fracasados a sus ojos. Haciéndose eco de Baumgarten, ${ }^{54}$ Schiller más bien propone que educar al hombre no puede consistir ya en formarlo sobre la base de la Razón ilustrada. Será la estética, y solo la estética, la que puede garantizar el ennoblecimiento del hombre. Será por medio de la belleza que el hombre logre superar las limitaciones de su reconciliación impuestas por la abstracción, la falta de imaginación, la fragmentación..., en definitiva, del alejamiento de la totalidad provocado por la llustración.

La fragmentación en la llustración establece una división en la conciencia humana que alcanza todas sus facetas, algo ya puesto en evidencia en Kant al delimitarse lo individual de lo colectivo, lo subjetivo de lo objetivo, lo sensible de la Razón... Y es este el tema central de la crítica de Schiller (y en gran medida retomado por Goethe), que se traduce en la defensa de una educación que permita la superación de la escisión del hombre, tanto interna (dislocación de diferentes áreas de su conciencia) como externa (del individuo respecto de la sociedad o de la naturaleza). Ahora bien, el perfeccionamiento de la humanidad no puede llevarse a cabo por medio de las instituciones políticas, puesto que son estas las que han llevado al fraccionamiento de sus facultades. La fuerza del estado se basa precisamente en esa división a la que la cultura ha de poner remedio. De igual forma, la filosofía no puede asumir esta empresa puesto que la razón en los términos en los que se ha impuesto ha sido incapaz de transformar la vida. La verdad filosófica se ha manifestado impotente en el mundo fenoménico, en lo sensible. El estado y la filosofía son impotentes porque no proporcionan las condiciones de posibilidad para el ennobleci- 
miento. Ambos suponen una humanidad que no corresponde con la realidad histórica.

Ha de partirse de la práctica como condición de la teoría. Una práctica, por ende, individual como defiende en la carta VIII, donde la idea de educación fundamentada en el principio de emancipación -el sapere aude kantiano- se sustenta por la defensa de la voluntad individual. Un perfeccionamiento político requiere previamente un carácter noble. Asimismo, la realidad es la condición de partida de la posibilidad de acceso a la verdad. De ahí que, antes que nada, sea necesaria una orientación pedagógica de la humanidad que asiente las condiciones necesarias para la realización teórica y política.

Esta nueva función ha de situarse en un término medio entre la razón y lo sensible y solo la educación estética puede alcanzar esta función pedagógica, porque sin abandonar la naturaleza puede alcanzar la razón, porque sin someter lo sensible formula teoría, porque sin someter lo individual da lugar a lo colectivo. Permite la convivencia entre los antagonismos y opera una suerte de armónico equilibrio, viva imagen de la idealizada integridad de lo humano, una totalidad sin conflictos entre lo moral y lo sensible, entre la práctica y la teoría. Solo en el "hombre estético" puede encontrarse como condición la perfección y la totalidad perdida sin renunciar a la racionalidad. De ahí que no haya una educación alternativa a la estética en las condiciones en las que ha de desenvolverse. En un estado reconciliado, no sería la belleza el único acceso posible a la perfección, pero sin el acceso a la moralidad, sin un estado que no oprima, sin una razón que no someta a lo sensible, no hay alternativa.
Por añadidura, el ideal estético tiene de por sí una función pedagógica por cuanto la belleza es el ideal de humanidad perfecta y condición de la humanidad plena, por cuanto el estado estético constituye la mediación de sus facultades y el hombre estético es la síntesis harmónica de sus antagonismos. La educación estética puede restituir sin trauma la esencia íntegra de la humanidad por medio de la belleza. Lo bello adquiere, pues, ese carácter dual: por una parte constituye un ideal y por otra es un principio pedagógico. Lo estético como mediador es la presencia sensible de la perfección, esto es, lo bello ideal como función pedagógica.

\section{La belleza y la libertad}

En un mundo donde ya no tiene cabida el ideal ilustrado, donde el arte ha cesado de todo compromiso social, no ha de sorprender que para Schiller la producción artística dejase de tener sentido. Así ha de entenderse cuando entre 1787 y 1795 Schiller suspendió su obra. En las condiciones históricas en la que se encontraba la sociedad burguesa ilustrada, el arte comprometido tenía por fuerza que entrar en crisis. Schiller se dedicó en los años sucesivos al estudio de las discusiones estéticas más relevantes del momento. Además de la ya mencionada crucial influencia de la lectura de la Crítica del Juicio, sus estudios históricos y filosóficos se centraron en un amplio abanico de autores de las más diversas tendencias, como empiristas o racionalistas e incluso los comienzos de la estética romántica (como es el caso de Winckelmann o Moritz).

A finales de 1792, cuando impartía lecciones de estética en la universidad de Jena, Schiller planeaba escribir una teoría 
55. Citado en Pareyson (1983: 70), extraído de Briefwechsel zwischen Schiller und Körner von 1784 bis zum Tode Schillers, en su edición de Ludwig Geiger de 1892.

56. $Y$ en igual medida se apoya en ella, como se desarrollará en lo sucesivo. Según algunos autores, el intento de Schiller de desarrollar un concepto objetivo de belleza fracasaría precisamente por derivar de principios kantianos (Heinrich, 1957: 527-547).

57. La distinción en Kant entre "belleza pura" y "belleza adherente" se desarrolla en el capítulo 3 subapartado "C La revolución kantiana en la arquitectura" por su crucial importancia a la hora de analizar el caso concreto de la irrupción de la autonomía estética en la arquitectura. estética en forma de diálogo donde concurriesen las discusiones recientes que le habían ocupado en sus estudios personificadas en cada uno de los participantes. Así consta en la carta enviada el 21 de diciembre a su amigo de juventud Gottfried Körner: "creo haber encontrado el concepto objetivo de lo bello, que Kant consideraba imposible de encontrar, y que se cualifica también eo ipso como principio fundamental del gusto. Ordenaré mis reflexiones al respecto en un diálogo que escribiré con el título Kallias o sobre la belleza". ${ }^{55}$

Para ello, Schiller despliega en primer lugar una completa panorámica de la estética ilustrada. Destaca que en lo relativo a la belleza se dan tres fundamentos: un fundamento objetivo racional que consiste en la finalidad objetiva del objeto, es decir, lo bello reducido a lo perfecto (doctrina metafísica de autores como Wolf, Mendelssohn o Baumgarten); un fundamento subjetivo que consiste en asimilar la belleza al modo de percepción de la sensibilidad (doctrina de los empiristas como Burke y los ingleses); y por último, la doctrina kantiana, un fundamento subjetivo racional, que reduce la belleza al juicio reflexionante, una "apreciación de la imaginación en relación con el intelecto y la razón". Para Schiller son estas tres alternativas igualmente inaceptables.

Se trataría de encontrar un fundamento que fuese en primer lugar objetivo pero que no se aleje de lo sensible como en la doctrina metafísica, de tal forma que pudiese formularse el despliegue de lo bello en lo sensible: la forma sensible de presentarse de las cosas, propiedad tanto sensible como objetiva. Para Schiller, la belleza no quedará únicamente referida al juego libre de imagi- nación y entendimiento, sino que se amplia en primer lugar a la subjetividad y en segundo lugar a la razón práctica. Schiller se aleja en esta medida de la filosofía kantiana. ${ }^{56}$

En primer lugar, critica el carácter subjetivo de la belleza en Kant, que asienta su racionalidad en el principio del gusto. Schiller intentará desarrollar una teoría estética que se apoye en el carácter objetivo de la belleza en su relación con el sujeto. Apunta pues, como también lo hizo Kant, a un concepto de belleza formal, pero en este caso su concepto de forma atenderá simultáneamente al objeto y a la representación que del mismo hace el sujeto. No se trata ya de una forma pura, que no contiene concepto alguno. La belleza se encuentra en el objeto en la medida en que el sujeto se sale de sí hacia el objeto.

En segundo lugar, Schiller no puede aceptar de la teoría estética kantiana el desinterés que este le atribuye. Es necesario para él indagar en qué medida una belleza que sí se oriente hacia una finalidad pueda superar su momento de determinación, para suprimirlo y contenerlo en la propia forma de la belleza (en el sentido de superación [aufheben]). Es decir, el tipo de belleza humana (la que Kant calificaba de belleza adherente) ${ }^{57}$ ha de ser revisada para que su forma pueda estar determinada por una finalidad sin por ello renunciar a la autonomía estética de la que parte. Para superar esta dificultad, Schiller introduce la idea de belleza como la "forma de una forma". La belleza no sería, pues, ni forma pura ni forma desinteresada, sino una forma de segundo rango que atiende simultáneamente al objeto formado y a la forma que se proyecta sobre él desde el sujeto, arrastrando una determinación intencional. Tal y como le transmite a Körner el 25 de enero: “La per- 
fección es la forma de una materia, la belleza es, en cambio, la forma de esa perfección, la cual se comporta, pues, frente a la belleza como la materia respecto a la forma" (Schiller, 1990: 7), una forma estética que superase la determinación de la primera forma orientada a un fin.

Este movimiento aparentemente contrario a los presupuestos kantianos, no puede comprometer, sin embargo, la máxima de la autodeterminación kantiana. El intento de Schiller de fundamentar una belleza objetiva ha de ser compatible, pues, con su filosofía de la razón práctica. De ahí que Schiller renuncie a la pura objetividad del conocimiento, en el sentido de determinación conceptual, y se agarre a la sugerencia de Kant del tránsito de lo sensible a lo moral por medio del gusto. ${ }^{58}$ La objetividad de lo bello, ajena a la razón teórica, encontrará en la estética de Schiller en la razón práctica su núcleo, basándose precisamente en el principio de autodeterminación kantiano. La belleza encuentra en el principio de autonomía y la función reguladora de la razón práctica el fundamento por analogía de su carácter objetivo: "[a]sí pues, tomar la forma de la razón práctica o hacerse análogo a ella significa simplemente: no estar determinado desde el exterior, sino por sí mismo, estar determinado de manera autónoma o aparecer como tal" (Schiller, 1990: 15).

En consonancia con su vocación educativa, la estética de Schiller promueve un ennoblecimiento de la sociedad de doble naturaleza: formarla estéticamente por medio de la belleza a la manera planteada por Baumgarten (aun sin la supeditación a los principios de la Razón) y formarla para la belleza, es decir, preparar al hombre para que adquiera un carácter estético. La belleza adquiere así el papel tanto de medio como de fin en sí mismo, en el que la orientación por su voluntad juega un papel protagonista: en el proyecto para alcanzar la belleza, el medio para el desarrollo estético de la sociedad es igualmente el objetivo a alcanzar. ${ }^{59}$ No en vano, Schiller concluirá que la belleza se presenta como la representación sensible de la moralidad sin que por ello comprometa en absoluto su autonomía:

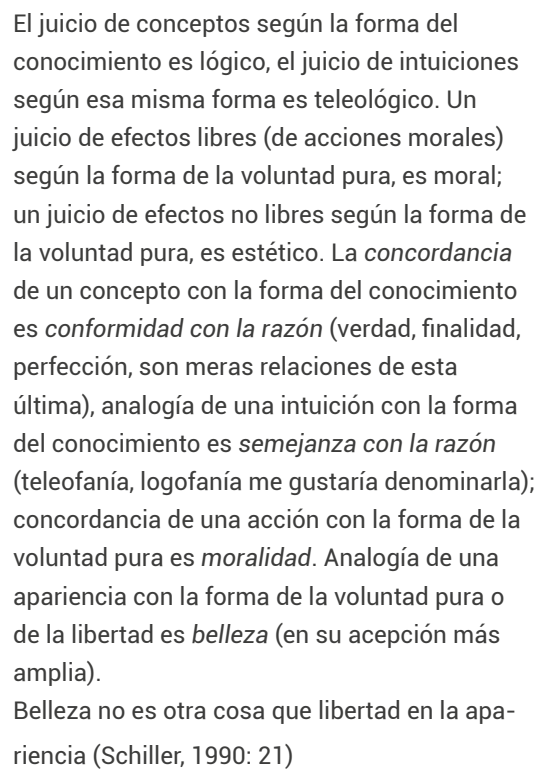

Ética y estética: la belleza como "libertad en la apariencia"

Parecería, pues, que Schiller parte de dos exigencias kantianas para resolver el vínculo entre el placer estético y la moralidad. Por una parte, la imposibilidad de reducir el fin del arte a mero placer estético y por otra que, pese a no tener un carácter moral, la contemplación estética media en el paso del goce de los sentidos al sentimiento moral.
58. "El gusto hace posible, por decirlo así, el tránsito de encanto sensible al interés moral habitual" (Kant, 2007: 286). Este aspecto de la teoría estética de Kant ha sido desarrollado en el capítulo 2 . A. y se retomará con mayor profundidad en el capítulo 3.C.

59. "porque es a través de la belleza como se llega a la libertad" (Schiller, 1990: 121). 
60. Véase en el capítulo 3, subapartado "D. La recepción de Schiller: símbolo y moral" para mayores aclaraciones sobre el empleo que hace Kant del término "símbolo". 61. Como Schiller reconoce: "la belleza no ofrece el más mínimo resultado ni para el entendimiento ni para la voluntad; no realiza ningún fin, ni intelectual ni moral, no es capaz de hallar ninguna verdad, no nos ayuda a cumplir ningún deber y es, en una palabra, tan incapaz para fundamentar el carácter como instruir a la inteligencia" (1990: 291)
La imposición en el arte de un fin moral, que ha de ser impuesto desde instancias ajenas al arte mismo, comprometería el carácter autónomo del arte al asignarle una vocación que le es extraña y contraria a su naturaleza y, al tiempo, la defendida totalidad de las facultades humanas ha de desembocar por fuerza en una relación entre el placer estético y la moral. En estas paradójicas condiciones de partida se desenvuelve por fuerza el arte para Schiller: será simultáneamente independiente de la moral, por afirmarse como valor su autonomía estética, y contendrá necesariamente una orientación moral. Ni la asunción de la moralidad del arte puede ir en detrimento de su autonomía, ni la asunción de su autonomía puede ir en detrimento de su implícita orientación moral.

Kant insistió en la diferenciación de lo estético de lo moral aun cuando no negó que existiesen ciertas analogías entre estas dos esferas, tal y como sintetizó en la tesis de la belleza como "símbolo de la moralidad", que se plasma en la libertad de la imaginación y la libertad de la voluntad. ${ }^{60}$ El compromiso explícito de la estética de Schiller incide sobre este aspecto concreto de la estética de Kant desde sus presupuestos. ${ }^{61}$ En Kant, el vínculo entre las dos esferas -la del Juicio y la de la razón práctica- se daba por analogía. Algo que no comprometía la arquitectura de las facultades del alma. Schiller radicalizará la confluencia de las dos esferas por medio de dos mecanismos.

En primer lugar, al vincular la belleza con la razón práctica (al otorgarle una orientación intencional a la estética), la forma del hecho artístico no podía ser ya meramente forma pura, de ahí que adquiera un carácter de "forma de forma" incorporando tanto la recepción como la orientación. Se trata en este caso y a diferencia de la tesis kantiana de una confluencia interna. En segundo lugar, Schiller opera una suerte de externalización del hecho artístico. La experiencia estética y creativa kantiana se basaba en el "libre juego de las facultades" por medio del cual se podía - sin concepto ni intencionalidad- mediar con el hecho estético. Una reivindicación sustancial de Schiller a este respecto era la necesidad de dar un giro "antropológico" a la estética Kantiana. Con su concepción de la belleza como "libertad en la apariencia" lleva la manifestación del libre juego de las facultades al objeto mismo, al terreno de lo sensible.

Pero, cabe insistir, esto se realiza de forma derivada: en la estética no puede hablarse de libertad si no es por analogía con lo suprasensible, dado que no hay libertad en el objeto, así como no hay belleza en la acción. Pero existe un vínculo tácito entre ambas del que depende la ya mencionada necesaria reconciliación del hombre como totalidad:

\footnotetext{
Hay un arte patético, pero un arte apasionado es un contrasentido, puesto que el infalible efecto de lo bello consiste en liberarnos de las pasiones. No menos contradictorio es el concepto de un arte instructivo (didáctico) o edificante (moral), porque nada se contrapone tanto al concepto de belleza, como otorgarle al ánimo una determinada tendencia. (Schiller, 1990: 303)
}

Luego Schiller, en consonancia con Kant, insiste en la necesidad de aislar las esferas de las facultades del alma, pero establece asimismo una aproximación entre ellas que tendrá gran importancia en años venideros. La autonomía de la estética en Schiller pende, de hecho, precisamente de esa 
delicada operación. No solo la aproximación de esferas no la compromete sino que es su sustento teórico. El principio de autodeterminación -dirá Schiller- es propio de la libertad como voluntad pura: no estar determinado por nada que no venga de sí mismo. La belleza, en el contexto de su autonomía estética, ha de entenderse de igual modo: no estar determinada por nada que sea externo al hecho artístico. En palabras de Pareyson: "aquello que moralmente interesa es la ley moral y la determinación moral de la voluntad, mientras que aquello que estéticamente satisface es la libertad de la voluntad, y la libertad de la voluntad es la condición primera de la moral". ${ }^{62}$ El comportamiento estético manifiesta de este modo una estructura análoga a la de la voluntad pura. No en el sentido estricto, puesto que los principios estéticos no lo son a priori (del orden del "debe ser"), sino más bien orientados "hacia lo que debe ser". Es decir, la autonomía en el arte ha de entenderse como un programa encaminado a recuperar la totalidad en el hombre por medio de la fragmentación como categoría, educando tanto al sujeto como a la sociedad por medio y para la estética.

En efecto, no siempre coincide la validez moral con la validez estética, y no siempre -incluso habiendo coincidido ambos en un mismo objeto- responden a las mismas motivaciones. En el ensayo Sobre lo patético, Schiller defendió que para la validez moral es necesario que el sujeto se realice en sus términos de validez moral, en tanto que para la validez estética basta que las condiciones en las que se realiza sean acordes con su validez moral. De nuevo, la característica que determina lo estético con respecto al resto de áreas del espíritu es su independencia con respecto a sus fines: lo moral exige un uso de la facultad moral, lo estético no exige uso alguno.

\section{Inmunidad e indiferencia en el arte}

Recapitulado lo dicho hasta ahora, conviene entresacar las consecuencias que esto acarrea para el concepto de autonomía. En primer lugar, cabe destacar, como no podría ser de otra manera, que la incorporación del concepto de autonomía se da en Schiller de la mano de la obra de Kant. Es notable, de hecho, como a lo largo de sus obras la autonomía kantiana cobra protagonismo entre sus categorías centrales. En Über den Grund des Vergnügens an tragischen Gegenständen de 1792, Schiller ya menciona el "freie Vergnügen" [placer libre] como "innere Prinzip unserer autonomischen Vernunft" [principio interno de nuestra razón autónoma] (1992: 236 y 241). Esta defensa de la autonomía en Schiller, que aun no es propiamente estética, resuena asimismo en obras posteriores, como Über die tragische Kunst (1792), Sobre lo sublime (1793) o Sobre lo patético (1793), en donde entiende la autonomía como la "autodeterminación de la razón". Desde sus primeras obras, lo que ocupó más intensamente los escritos estéticos de Schiller fue el intento de enlazar el concepto ético de autonomía kantiana con el estético (Henrich, 1957: 527548) y lograr una fundamentación de la libre autodeterminación (basada en la idea de un ernstens Spiels de la facultad estética).

Así, en su obra estética más kantiana, Kallias, Schiller asume la determinación de la autonomía como "libertad en la apariencia" y la belleza autónoma como "aquella for-
62. "ciò che moralmente interessa è la legge morale e la determinazione morale della volontà, mentre invece ciò che esteticamente soddisfa è la libertà della volontà, e la libertà della volontà è la prima condizione della moralità" (Pareyson, 1983: 64). 
63. El término "heautonomía" lo toma de la segunda introducción a la Crítica del Juicio, (haberse dado a sí mismo unas leyes propias), aunque lo aplique únicamente al objeto bello y no como principio a priori de la facultad de juicio.

64. A diferencia de lo perfecto: "Lo perfecto puede poseer autonomía, en la medida en que su forma haya sido determinada puramente por su concepto; pero heautonomía es sólo propio de lo bello, porque únicamente aquí la forma está determinada por su esencia interna" (Schiller, 1990: 69).

65. El carácter de resistencia del arte (con un significado marcadamente político) desde su autonomía ya fue desarrollado por Schiller en 1793 en sus Briefen an den Herzog von Augustenburg. La heautonomía significa desde esta perspectiva también la negativa al Zeitgeist y el regreso al espíritu clásico griego.

66. "El arte, como la ciencia, está libre de todo lo que es positivo y de todo lo establecido por las convenciones humanas, y ambos gozan de absoluta inmunidad respecto de la arbitrariedad de los hombres." (Schiller, 1990: 173). ma que no exige ninguna explicación, o bien aquella que se explica sin concepto" (1990: 27). Apunta así a una reconciliación entre la moralidad y la belleza, que queda sintetizada en la "belleza moral" (1990: 31) en tanto que acción bella desinteresada, retomando la función teleológica de la belleza natural defendida por Kant (como imitación de la fuerza activa y autónoma):

$$
\begin{aligned}
& \text { Por este motivo la belleza moral es el grado } \\
& \text { máximo de perfección del carácter humano, } \\
& \text { pues sólo se presenta cuando el deber pasa a } \\
& \text { formar parte de su naturaleza. (1990: 39) }
\end{aligned}
$$

La belleza moral adquiere el carácter de un deber por naturaleza, arte devenido naturaleza. La naturaleza es el "principio interno de la existencia en un objeto, considerado al mismo tiempo como el fundamento de su forma; la necesidad interna de la forma". Schiller logra con esta aproximación dialéctica a los conceptos de belleza y autonomía no solo relacionar el arte con la moral, sino que establece una norma para la belleza natural y la dialéctica de la forma y contenido: la forma "ha de ser determinante por sí misma y estar determinada por sí misma, lo que ha de darse no es mera autonomía sino heautonomía" (1990: 61). ${ }^{63}$ La heautonomía ha de ser entendida como la unidad de la forma con la existencia del objeto propia de lo bello. ${ }^{64} \mathrm{En}$ clara divergencia respecto de la idea clásica de harmonía y sus corolarios en el orden, la proporción, etc., pero igualmente alejado de la teoría idealista de la perfección, Schiller establece junto con el principio de autonomía y libertad el principio interno de heautonomía en tanto que libertad estética.

Esta insistencia en el modelo kantiano -tomar como referente en definitiva la be- lleza natural- quedará superado en la obra de Schiller a la hora de afrontar las decepciones frente a la capacidad revolucionaria de los ideales ilustrados. El impulso de negatividad frente al Zeitgeist ${ }^{65}$ desvía en Schiller la atención desde la imitación de la naturaleza como modelo (productor de autonomía) hacia una estética de la producción: a tenor de la así establecida negativa relación con su realidad, la acción del artista tiene que definirse en su autonomía con nuevos parámetros.

De resultas de esto, Schiller tiene que hacer frente a una ineludible pregunta: ¿de qué manera puede contribuir el arte en la transformación de lo real, si lo real es de donde parte el arte? Si el artista es un "hijo de su tiempo", ¿qué garantiza que lo que el arte proponga pueda realmente ser una alternativa a lo real? La excepcional condición del arte, respondería Schiller. Es precisamente el arte, defiende Schiller, un ámbito privilegiado dentro de lo real: goza de una cierta "inmunidad" respecto de la influencia de su tiempo. ${ }^{66}$ El artista es, ciertamente, "hijo de su tiempo", pero aquel que recibe con merecimiento tal nombre, sobre todo, no puede doblegarse ante su tiempo: conocedor del modelo inmortal de una época mejor, el artista puede irrumpir en su tiempo como un Orestes, para purificarlo:

\footnotetext{
Si bien toma [el artista] su materia del presente, recibe la forma de un tiempo más noble, e incluso de más allá del tiempo, de la absoluta e inmutable unidad de su ser. (Schiller, 1990: 173)
}

La inmunidad del arte está, pues, basada en su negatividad, irremisiblemente referida a un estado ideal que no concuerda con el presente. Ciertos comentaristas han querido ver en esta inmunidad del arte el carácter 
ahistórico del arte que resonará más tarde en las estéticas autorreferenciales. Pero lo cierto es que, como se ha expuesto anteriormente, el proyecto de emancipación por medio del ennoblecimiento es radicalmente contrario a esta enajenación respecto de lo real. Antes bien, se trata de una condición indispensable para la realización de la intervención del arte en la sociedad. La autonomía así posibilitada, por medio de la inmunidad del arte frente a lo natural, a lo real, puede dar cabida a una alternativa. Sintiéndose parte de la sociedad, velando por ella, pero negando decididamente el estado en el que se encuentra, "[e]ngendra la verdad victoriosa en el pudoroso silencio de tu alma, extráela de tu interior y ponla en la belleza" (Schiller, 1990: 179). Se trata, pues, de hacer surgir un modelo desde la autonomía del artista que pueda batir al que la realidad impone y realizarlo esto mismo por medio de la educación estética de la humanidad (más concretamente por medio del juego), para que la humanidad pueda recuperar los valores que no caben en la realidad actual:

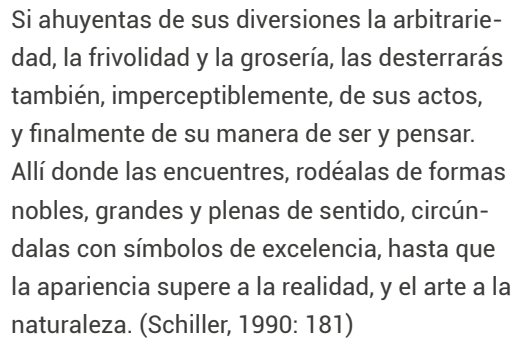

Así queda puesto de manifiesto en Schiller un giro respecto de la obra de Kant (incluso de Goethe y Moritz) al dejar atrás la defensa de la naturaleza como fuente creativa, la idea del arte como segunda naturaleza (natura naturans) para identificar en la naturaleza la brutalidad de la realidad, aquello que exige ser cambiado. La defensa de la heautonomía de Schiller es, en este sentido, la defensa de la posibilidad de una alternativa a lo natural y el ámbito donde se desarrolla esta alternativa es inicialmente en el arte de la apariencia:

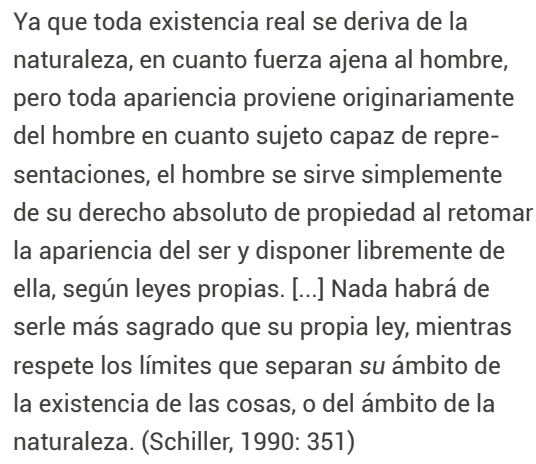

En contra de lo defendido en Ka-

Ilias, en Cartas sobre la educación estética

del hombre Schiller renuncia a la naturaleza como fuente del impulso artístico con el fin de vincular la autonomía del arte con una reconciliación utópica. De forma semejante a la emprendida por Novalis, defiende un cometido mesiánico para el poeta con el fin de restaurar una época dorada en la que se daba la anhelada totalidad. Para lograrlo, para instaurar un "estado estético", Schiller emprende un proyecto de objetivación del concepto de belleza y encuentra su fundamento ontológico -y el de la autonomía estética- en el concepto de apariencia y el juego como impulso inicial: "[a]l impulso de juego, que se complace en la apariencia, le seguirá el impulso mimético de formación, que considera la apariencia como algo autónomo" (Schiller, 1990: 349). La educación estética del hombre cobra así su perseguido protagonismo y abre la posibilidad al "ästhetischen Staat" como 
67. Por ejemplo, Marcuse heredó esa tesis positiva de la puesta en práctica de una sublimación estética no represiva y desarrolla una particular convergencia entre Schiller, Marx y Freud que fue recogida en años posteriores por las neovanguardias. Véase Herbert Marcuse (1968),

Eros y civilización, J. García Ponce (trad.). Barcelona, pp. 187-231. resultado del proceso, el cual representa -en tanto que continuación de Rousseau o Fichte- la forma política del ideal de belleza.

Tomando sus orígenes en la dialéctica ilustrada y constatando el fracaso en la situación histórica (tanto espiritual como política), lo estético se erige como un nuevo paradigma de la emancipación, como adalid de la utopía social y como medio para su advenimiento. A excepción quizás de Kallias, la tematización de Schiller de la autonomía en el arte no es ya la de fundamentarla sino la de darla por supuesta y plantearla como proyecto. Este giro frente a la estética kantiana se verá potenciado a lo largo del idealismo romántico, momento en el que se insistió en su carácter modélico como alternativa a la dominación teórica e instrumental. El afán por la "pureza estética ideal" y el objetivo de la perfección estética, característico del corto periodo de la teoría idealista del arte, serán de nuevo tematizados con esa incondicionalidad en la generación de Flaubert, Baudelaire y Mallarmé -durante la cual la "poesía pura" apunta a la resistencia contra la realidad burguesa- y el carácter mesiánico del arte por Schiller inaugurado llegará a cumplir un papel protagonista en la praxis social durante las vanguardias a través del concepto de "intervención estética". ${ }^{67}$

Se consolida con Schiller, pues, un tipo de autonomía en el arte que aquí se designa con el apelativo de moderna. Reposa en una libertad e independencia respecto de restricciones socioculturales e institucionales (estado, sociedad, Iglesia, partidos...) como reducto de esperanza frente al vértigo de la modernidad. Con anterioridad se ha desarrollado aquella que quedó sintetizada por
Kant y a la que se ha atribuido el carácter de trascendental. En ella se apoyaron múltiples revisiones del autonomicismo y quizás se ha querido ver en L'art pour l'art su más clara manifestación. Ha quedado claro, no obstante, que en Kant late una pulsión hacia el carácter relacional del arte que, pese a no comprometer la arquitectura interna de su autonomía respecto del entendimiento y la razón práctica, apunta hacia un tipo de autonomía alejado del formalismo que se le atribuye. Esta doble tensión entre autorreferencialidad y compromiso social, en el ámbito de la autonomía trascendental y la moderna, adquieren un potencial aclarativo relevante a la hora de examinar el caso concreto de la arquitectura. 



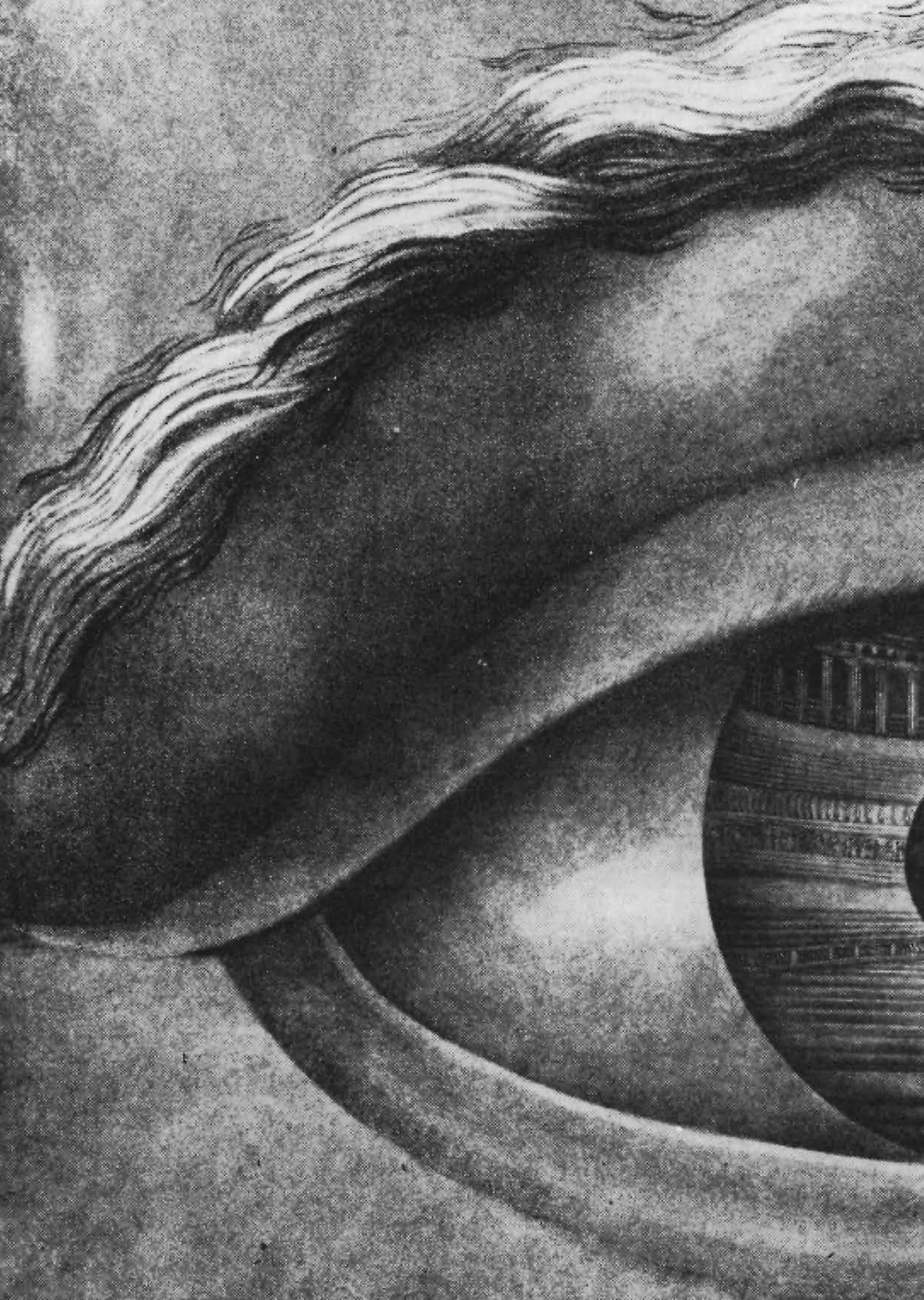




\section{La autonomía en la arquitectura}

Probablemente el puro y riguroso concepto de arte deba tomarse tan sólo de la música, mientras que la gran poesía y la gran pintura -la grande precisamentearrastran consigo, necesariamente, un cierto material, un algo que sobrepasa la jurisdicción estética, algo no resuelto en la autonomía de la forma.

Adorno, 2006: 231

La arquitectura es un arte que está inserto en la sociedad, algo que no se puede eludir dado que constituye su naturaleza. Si su complicidad con los medios de producción, estructura social o sistema económico es su freno más evidente e inmediato en su realización como arte autónomo, la obligada atención a su función es el conflicto clave. Quizás fue Adorno aquel que con mayor concisión supo formular la aporía a la que la arquitectura se enfrenta desde claves autonomicistas: "como la arquitectura no es 
68. Pese a que esta obra se conocía durante la Edad Media, fue a raíz de su "redescubrimiento" por Poggio Bracciolini en 1414 y muy especialmente tras la edición de la editio princeps, publicada por Giovanni Sulpicio da Verole en 1486: divinum opus Vitruvi, que se dio luga a probablemente una de las exégesis más prolíficas de la historia de la teoría de la arquitectura. En el ámbito español, ya desde el inicio del Renacimiento a finales del siglo XV se acusa un creciente interés por Vitruvio como así demuestra el hecho sintomático de que el primer tratado de arquitectura en España (y fuera de Italia) lo constituya un esquemático resumen de sus ideas en las Medidas del romano de Diego de Sabredo (1526). En torno a mediados de siglo se conocen varios manuscritos con traducciones a la lengua vernácula (un anónimo, la traducción del primer Libro de Vitruvio por Hernán Ruiz el Joven o la completa de Lázaro de Velasco). Pero la primera traducción publicada es la realizada por el arquitecto Miguel de Urrea, impresa en Alcalá de Henares por Juan Gracián en 1583. De la llustración española surgieron asimismo dos nuevas traducciones, espoleadas por la necesidad docente derivada de la creación de la Academia de San Fernando y por la actualización de los criterios arqueológicos. Es notable en sólo autónoma, sino que al mismo tiempo es funcional, no puede negar simplemente a los seres humanos tal como son, aunque tiene que hacer esto en tanto que autónoma" (2006: 342). Su naturaleza artística se rebela contra su naturaleza funcional y viceversa.

Esta dialéctica entre forma y función en el caso de la arquitectura entra de lleno en la tensión evidenciada en el capítulo anterior entre el concepto de autonomía trascendental y el moderno, tal y como ha sido expuesto en el capítulo anterior. De hecho, tal ha sido su influencia en la arquitectura, que se defenderá en lo que sigue la distinción entre una estética arquitectónica pre-autónoma y una post-autónoma. En primer lugar, se presentará la obra teórica de Vitruvio, en tanto que primer testimonio de la estética clásica en la arquitectura y de prolongada influencia desde el Renacimiento. En segundo lugar, se abordará la crisis del lenguaje y la arquitectura del efecto como fenómeno más claro del agotamiento de la imitatio clasicista para, en tercer lugar, retomar la obra de Kant y esclarecer cuál era la situación de la arquitectura dentro del primer sistema estético autónomo y ver cuáles son las dificultades que debe afrontar. De resultas de ello se verá cómo la expresión en la arquitectura es la clave para su desarrollo como arte autónomo, aunque, en tercer y último lugar, esto entrañe unos riesgos elevados. De la mano de la recepción kantiana en Schiller, la exigencia de expresión puede efectivamente tender a lo que Tafuri denunció como el "imperio del signo". El objetivo de este capítulo consiste, pues, en establecer los fundamentos teóricos necesarios para poder abordar una reinterpretación de Goethe que ilumine retrospectivamente las polémicas que han rodeado la cuestión de la autonomía en la arquitectura.

\section{A. Estética arquitectónica en Vitruvio}

El arte y su estudio no es exclusivo de ningún periodo histórico concreto. Fue una cuestión profusamente tratada desde la Grecia clásica, tanto desde la más global consideración de manifestación cultural como desde la justificación interna dentro del entendimiento del mundo. En el caso de la arquitectura, de obligada mención es la obra de Vitruvio De Architectura Libri Decem, ${ }^{68}$ obra de crucial importancia para la historia de la teoría de la arquitectura, así como profundamente polémica.

\section{Los diez libros de arquitectura}

\section{Sobre las dificultades de su recepción} Escrita y publicada en el último tercio del primer siglo anterior a Cristo ${ }^{69}$ constituye el único testimonio de la tratadística grecorromana que se ha conservado, dotándola a este tenor de una singularidad notable. Es cierto que con anterioridad se escribió mucho sobre arquitectura. Son de obligada mención los textos de carácter autobiográfico que escribieron los más célebres arquitectos sobre su propia obra: Teodoro sobre su templo de Hera en Samos, Quersifronte y Metágenes sobre el de Artemisa en Efeso, Ictinos y Carrión sobre el Partenón de Atenas y tantos otros. Por desgracia, todos estos trabajos se perdieron y no han quedado más que referencias dispersas al contenido de los mismos o, incluso, en el peor de los casos, únicamente su mención. Además de estos trabajos fundamentalmente descriptivos, autores como Fión o Sileno elaboraron manuales de arquitectura y otros muchos autores, en la mayoría de los casos 
arquitectos, transcribieron instrucciones para proporcionar los edificios por medio de cálculos aritméticos. Siempre en relación con la arquitectura antigua, durante la Edad Media existían los manuales de los maestros masones como el de Villar d'Honnecourt.

El hecho de haber llegado íntegramente (a excepción de las láminas que ilustraban el tratado) y ser el primer trabajo que pretende articular una compleja amalgama de conocimientos (provenientes de la tratadística griega, de la mecánica helénica y de la ingeniería romana republicana) en una teoría dotan al tratado de Vitruvio de una incuestionable singularidad que contrasta, no obstante, con un sorprendente desconocimiento de muchos aspectos relativos a la obra. ${ }^{70}$ Por ejemplo, apenas se sabe sobre su autor-del que se desconoce incluso su nombre completo- ${ }^{71}$ y apenas sobre sus fuentes, que de forma vaga el propio autor cita en la introducción al séptimo libro. ${ }^{72}$ Incluso se barajan fechas de publicación que oscilan 30 años. En suma, estas imprecisiones y su valor intrínseco, unido a la consabida "oscuridad" de la obra, han colaborado sin duda a su mitificación. Tan es así que desde el punto de vista historiográfico sea mayor la capacidad explicativa del Vitruvio respecto de la teoría de la arquitectura a partir del Renacimiento que del periodo clásico. De hecho, pese a ser el primero en presentar de forma sistemática la teoría clásica de la arquitectura, apenas tuvo influencia entre sus contemporáneos, en contra de lo que su autor pretendió. ${ }^{73} \mathrm{Y}$ no fue hasta la recuperación humanista del clasicismo que adquiere un valor significativo para la práctica arquitectónica.

El libro de Vitruvio ha estado sujeto, especialmente desde el Renacimiento, a una sentido la asimetría de sus respectivos impactos. La más extendida y reeditada hasta fechas recientes es la traducción del Abrégé de Perrault de Joseph Castañeda, teniente director de arquitectura de la Real Academia de San Fernando: Claudio Perrault (1761), Compendio de los diez libros de Arquitectura de Vitruvio. Madrid: Gabriel Ramírez. La segunda versión -que muy poca repercusión tuvo- fue la traducción del original realizada en Roma contra viento y marea por el presbítero Joseph Ortiz y Sanz en 1787 publicada en la Imprenta Real de Madrid bajo el patrocinio de Eugenio Llaguno.

Hasta los años ochenta, la traducción más usada -y aquella que se ha elegido como referente para este capítulo en su reedición de 1980- es la de Agustín Blánquez publicada en BarceIona en Iberia, en 1970. Desde entonces, un buen número de reediciones y nuevas traducciones han engrosado el panorama editorial. En 1978 se publica en Valencia una edición facsímil de la primera traducción española de Miguel de Urrea. La traducción de Ortiz y Sanz ha sido recientemente reeditada en facsímil con prólogo de Delfín Rodríguez Ruiz en Akal, en 1992 (reedición de la de 1987). Respecto de la traducción de Castañeda hay numerosísimas ediciones, entre las que cabe mencionar, por ser la más reciente, la realizada por la editorial Órbigo en 2011 (ediciones anteriores: Colegio Oficial de Aparejadores y Arquitectos Técnicos de Murcia en 1981, Extramuros en 2011 -reimpresión de la edición de 2007-, Maxtor en 2009,). En estas últimas décadas han aparecido, al menos, dos nuevas traducciones del latín original. La más reciente es la de José Luis Oliver Domingo, editada en Madrid por Alianza en 1995 con introducción de Delfín Rodríguez Ruiz. En 1999 se editó por primera vez la traducción al castellano de Lázaro de Velasco, con estudio introductorio de F. J. Pizarro y P. Mogollón. Para más detalle véase el capítulo de Juan Calatrava "Vitruvio y la teoría de la Arquitectura" en Estudios sobre historiografía de la arquitectura.

69. Tanto la fecha de su publicación como el periodo de redacción no han sido aun científicamente datados. En Roland Martin (1966), "Vitruvius", en Enciclopedia Universale dell'Arte, p. 832 se apunta como fecha de publicación 27-23 a. C. En tanto que el periodo de redacción oscila entre los años 33 y 15 a. C. según la fuente consultada. Desde el periodo 33-24 a. C. propuesto por Thielscher (1961: 431), a aquellos que proponen diferentes periodos de redacción y sucesivas revisiones, como en Kruft (1990: 23-34) (para quien, aceptando el periodo propuesto por Thielscher, añade que las introducciones fueron redactadas posteriormente y que los libros fueron redactados en un orden incierto) o la más reciente tesis de González Moreno-Navarro (1993: 36), para quien el texto se redactó en dos fases (la primera, los libros I a VI, escrita entre 3 I - 28 a. C. y la segunda, los libros VII a X, escrita entre I6-15 a. C.) se abre un abanico de dataciones aun no contrastadas con rigor. En cualquier caso, es harto probable que empezase la redacción en ocasión de su retiro, fechado por él mismo en el 33 a. C. y la fecha límite de su redacción es, con más razón, segura: su defunción el año 15 o 14 a. C., según las fuentes consultadas. Luego, a la espera de una mejor determinación arqueológica, puede considerarse el periodo 33-14 a. C. una muy verosímil -por conservadora-datación de la redacción de De Architectura Libri Decem.

70. Sobre las incertidumbres que rodean la figura de Vitruvio y su obra, así como para una contextualización de gran interés, véase Pierre Gros (1997), "Vitruvio e il suo tempo", en Vitruvio, De architectura, Antonio Corso (trad.). Turín: Giullio Einaudi, pp. IX-LXXVII, quizás la edición (bilingüe) del Vitruvio más recomendable.

71. Sobre la polémica de su nombre, véase Pierre Gros (1975: 986-1009). La propuesta de «Vitruvio Mamurra de Plinio» proviene de Thielscher (1961: 427-489) y fue rebatida por Ruffel y Soubiran (1961: 123-179). 
72. Los primeros tratados que le sirven de inspiración fueron los de Agatarco y sus seguidores Demócrito y Anaxágoras. Y prosigue, entre decenas de referencias, aclarando cuáles fueron sus fuentes principales entre los autores griegos (por ejemplo, para el orden dórico: Sileno, Teodoro, Ictivio y Carpión o para el jónico: Chersifrón, Metágenes y Pyteo). Tal y como señala, las fuentes romanas son mucho más escasas, de ahí la necesidad de publicar un compendio que actualice estas fuentes. Cita a tres: Fulicio, Terentio Varrón y P. Septimo (Vitruvio, 1980: 165-171).

73. Únicamente Plinio el Viejo cita a Vitruvio en su Naturales Historia, libros 35 y 36 . Y lo hace no refiriéndose estrictamente a su teoría de la arquitectura sino a la pintura y los distintos tipos de piedras. Al margen de esta referencia no hay constancia de una influencia efectiva entre los contemporáneos de Vitruvio. Habrá que esperar al siglo V, en época ya tardoimperial, para encontrar menciones explícitas a la obra de Vitruvio en compendios y tratados, por otra parte nada influyentes.

74. Viel de Saint-Maux llegó a afirmar que el texto de Vitruvio "no podía ser útil nada más que en la isla de Robinson" en sus Lettres sur l'architecture des Anciens et celle des Modernes de 1787. O la radical condena de Lodoli, que llevó a Memmo a dedicar un capítulo (el segundo) entero de Elementi d'Archittetura Lodoliana para recoger las críticas y dudas suscitadas por Vitruvio desde el Renacimiento. 0 el posterior: “¿Qué es la arquitectura? ¿La definiría con Vitruvio como el arte de construir? No. Hay en esta definición un tosco error. Vitruvio toma el efecto por la causa. Es necesario concebir para realizar", en Boullée, Étienne-Louis (1968), Essais sur l'art, J. M. Perouse de Montclos (ed.), París, p. 49. Huelga decir que precisamente este capítulo presenta la estética arquitectónica antes de la irrupción de la autonomía, y se dará cuenta, posteriormente, de las razones de tan ácida animadversión hacia Vitruvio desde la crisis del clasicismo del XVIII.

75. Baste recordar un lugar común a este respecto: cuando en el siglo XVI se quiso ilustrar el primer libro -donde Vitruvio hace mención de las "cariátides" para dar cuenta de la necesidad del conocimiento histórico para la buena práctica arquitectónica-, el pórtico del Erecteion de Atenas no se conocía aun. Finalmente, la ilustración propuesta por Jean Goujon para la primera edición al francés de 1547 responde a su personal interpretación del pasaje. De hecho, y de ahí la mención a esta "anécdota", cuando Perrault en 1684 ilustre su versión tomará la reproducción del pórtico de Goujon, como si se tratara de una materialización de la explicación de Vitruvio. Desde entonces, las diferentes versiones adquirieron un claro desarrollo autónomo, muy alejado de las obras clásicas que estaban en el origen de los comentarios de Vitruvio. Véase el artículo de Kruft (1990: 17-18). Para abundar en la idea de que en las versiones del Vitruvio el punto de vista del intérprete es lo más relevante puede consultarse varias aportaciones de Joan Calduch: (2014), "El tratado de Vitruvio ilustrado", en Cuaderno de Notas, 15, pp. 95 y sig.; (2014), "Poner ante los ojos el texto de Vitruvio: la representación de la arquitectura en el tratado", Palapa, vol I, n² 2, 3a época, pp. 84 y sig.; (2013), "Del texto al dibujo: las imágenes de la basílica de Fano", edic. digital: hhtp://etsavega.net/dibex/, 9.10.2013.

76. "así, ¡oh, César!, yo suplico, a ti y a cuantos mi libro leyeren, que si algo no está explicado con arreglo a las leyes del bien decir (de la Gramática), que me sea perdonado, toda vez que no soy ni un gran filósofo ni un elocuente orador ni un excelente gramático, sino un modesto arquitecto" (1980: 12)

La Accademia della Vitrtú de Claudio Tolomei en Roma (1542) tenía por finalidad aclarar todas estas cuestiones. Todo esto se ha agravado por el hecho de que los manuscritos que circulaban desde la Edad Media no coincidían entre sí. reincidente reinterpretación. Hasta tal punto se ha construido el aparato teórico de la arquitectura posterior al humanismo sobre la obra de Vitruvio, que no da cabida ya a la indiferencia. De suerte que o bien el acercamiento se realiza con la intención de hacerlo suyo -como un aval de una renovada revolución, como instrumento de la tradición- o bien como objeto de reproches varios. Desde la recuperación Humanista hasta la actualidad, pasando incluso por la condena por su inutilidad en el siglo XVIII, ${ }^{74}$ el texto ha estado presente en las discusiones centrales de la teoría arquitectónica.

Que no sea ya posible entender el Renacimiento en la arquitectura sin Vitruvio significa escuetamente que no es posible entender aquello que en el campo de la arquitectura se desarrolló durante ese periodo a raíz de las interpretaciones que se hicieron del tratado de Vitruvio y de la forma en que estas se materializaron, a su vez, en la arquitectura construida o en los textos teóricos. Que se tomase como referente la obra de Vitruvio para apoyar la erección de un nuevo estilo, lo vincula en un segundo rango. El estudio en paralelo de la arquitectura antigua y de los tratados clásicos, entre los que figura con indiscutible protagonismo el de Vitruvio, proporcionó una base para la fundación de la nueva arquitectura pero, al igual que no es posible entender la arquitectura renacentista sin el interés por las ruinas romanas y griegas, el interés por las ruinas no se puede desvincular de la nueva arquitectura. Ambos, complementarios e íntimamente relacionados, adquirieron un cierto grado de autonomía. $^{75}$ 
En definitiva, del tratado de Vitruvio se desconoce su invocada originalidad o sus fuentes, existen numerosas imprecisiones del propio texto (provenientes algunas de las traducciones del griego al latín que empleó Vitruvio) y son fácilmente detectables numerosas contradicciones. Por añadidura, el acceso al texto es especialmente complicado. En parte se puede achacar a una falta de claridad del autor, tal y como varios comentaristas arguyen. Caso sería este de Alberti, quien no tuvo reparo en afirmar en Re aedificatoria que la prosa de Vitruvio se hacía por momentos incomprensible. La falta de pericia, reconocida por él mismo, ${ }^{76}$ el uso de un latín vulgar, los arcaísmos, los provincialismos y los errores gramaticales han sido ampliamente criticados. No obstante, como señalan otros traductores, huelga decir que las voces técnicas que el género del asunto obliga a emplear nunca antes fueron utilizadas. De ahí que parezcan hora oscuras, hora incompletas, agravado por el hecho de que muchas fueron directamente tomadas del griego por no haber traducción latina.

\section{Hacia una autonomía de la disciplina}

El tratado se estructura en diez libros. Todos ellos están precedidos por una introducción, que poco o nada tiene que ver con el libro en cuestión, en la que se resume el libro precedente y se tratan asuntos biográficos, problemas de la arquitectura de su tiempo o los objetivos del tratado y la metodología aplicada. A lo largo de los diez libros, temas de muy variada índole son ordenados con una sistematicidad más práctica que teórica. $A$ este respecto, no se pierda de vista que, en la antigüedad, "arquitectura" tenía un sentido mucho más amplio que el actual. Abarcaba casi por completo toda producción técnica.

En palabras de Vitruvio, las "partes de la Arquitectura son tres: Construcción, Gnómica y Mecánica" (1980: 16). Por aedificatio se entendía la edificación tanto pública como privada. La primera constaba a su vez de tres vertientes: Ios edificios que servían para fines defensivos, aquellos que atendían al culto y los que cubrían necesidades de la vida pública. Gnomonice correspondía a la construcción de relojes y machinato a la construcción de máquinas. Así, temas como los orígenes de la arquitectura, los conceptos fundamentales, los diferentes tipos arquitectónicos, las técnicas constructivas, los materiales de construcción, la teoría del color, maquinaria y obra civil..., se entrelazan en la obra.

El desarrollo de una teoría de la arquitectura propiamente dicha se localiza fundamentalmente en el primer libro. En apartados posteriores, Vitruvio abordará de forma parcial, esporádica e incluso con frecuencia contradictoria esta cuestión. Por ejemplo, los conceptos básicos de estética arquitectónica que se desarrollan en los capítulos 2 y 3 -que deberían ser vinculantes para el resto de temas tratados- no son puestos en práctica a la hora de analizar asuntos relativos a la construcción arquitectónica o al análisis de determinados monumentos. Esto lleva a algunos comentaristas a concluir que no se trata, por su falta de coherencia interna, de una teoría de la arquitectura ${ }^{77} \mathrm{o}$, de una forma mucho más sugerente, a destacar el carácter relativista de su teoría frente a la histórica interpretación crudamente universalista. ${ }^{78}$
77. "La estructura conceptual parece sobreimpuesta; Vitruvio no creyó necesario utilizar los conceptos como criterios para el análisis de determinados monumentos o formas constructivas. Por ello, en su obra sólo se puede hablar con reservas de un sistema acabado de teoría de la arquitectura" (Kruft, 1990: 33).

78. Juan Calatrava rebaja el alcance universal de las prescripciones de Vitruvio -aun sin negarlo- destacando numerosas afirmaciones de corte relativista: el ajuste de los sistemas constructivos con arreglo a la disponibilidad de los materiales, la adaptación al clima y a la localización, la determinación de las medidas por exigencias perceptivas.. “Este relativismo, con todo, nunca llegaba a poner en cuestión la aspiración vitruviana a la validez universal de las normas expuestas en su tratado. Más bien, era el instrumento que, sabiamente usado por el arquitecto, garantizaba la adecuación de las mismas a la diversidad de las situaciones materiales $y$ culturales concretas y salvaba, así, su carácter esencial y necesario." (2005: 47-53). En rigor, Calatrava trae a colación la tesis relativista para dar cuenta de la dislocación evidente entre la realidad construida y el discurso teórico de Vitruvio, y lo cierto es que, como se ha apuntado, la falta de consistencia en el tratado de Vitruvio se hace 
especialmente manifiesta entre los capítulos 2 y 3 y aquellos posteriores de marcado talante técnico. De hecho la "relatividad" de las normas de Vitruvio la ponen en evidencia muy tempranamente comentaristas como Barbaro.

79. "los arquitectos que sin teoría, y sólo con la práctica, se han dedicado a la construcción, no han podido conseguir labrarse crédito alguno con sus obras, como tampoco lograron otra cosa que una sombra, no la realidad, los que se apoyaron sólo en la teoría" (Vitruvio, 1980: 5).

80. Literalmente: "La Arquitectura se compone de orden, que los griegos llaman taxis; de disposición, a la que dan el nombre de diátesis; de euritmia o proporción (simetría, decoro) y de distribución, que en griego se dice oikonomia" (Vitruvio, 1980: 12). Algo que complica mucho una explicación sistemática al no distinguir entre "euritmia", "simetría" y "decoro". En cualquier caso, teniendo en cuenta las extensas explicaciones que siguen a esta sentencia, queda claro que se trata de seis conceptos diferenciados y no cuatro.

Las traducciones de estos términos son conflictivas por varias razones, de ahí que en lo que sigue (así como en el siguiente capítulo) se haya optado por emplear los términos en su forma latina original (nombrando su
En el capítulo primero "Qué es Arquitectura y qué cosas deben saber los arquitectos", Vitruvio se extiende en las características que ha de cumplir un arquitecto que quiera alcanzar la gloria en la medida en que se entiende su carácter artístico como técnica. "Esta ciencia [la arquitectura] se adquiere por la práctica [o facultades prácticas, fabrica en el original] y por la teoría [capacidad teórica, ratiocinatio]" (1980: 5). Para los antiguos, en efecto, arquitectura no era únicamente el resultado de la actividad del arquitecto, es decir, un edificio o cualquier otra de las obras anteriormente citadas, sino que era también la práctica misma. Es decir, las habilidades necesarias así como los conocimientos que permitían al arquitecto ejercer como tal formaban parte del concepto "arquitectura". Va de sí, pues, que Vitruvio insista en la necesidad de combinar teoría y práctica en la formación del arquitecto. La capacidad ejecutiva sin teoría no eleva a la arquitectura donde merece, así como teoría sin práctica no genera más que irrealidades. ${ }^{79}$

Al necesario talento -o capacidades innatas [natura]- que un arquitecto debe tener ha de sumarse, pues, no solo sus aptitudes prácticas -o experiencia [usus]- sino una sólida formación intelectual -o conocimiento [doctrina]- que le permita desarrollar su tarea sobre principios científicos, único camino hacia el summum templum architecturae (Vitruvio, 1980: 9). Aunque esto no era exclusivo de la arquitectura. Era, de hecho, un requerimiento desde época de Aristóteles para todo aquel que cultivase un arte. En suma, el arquitecto ha de estar versado en cuestiones que llamaríamos ahora técnicas - como son el dibujo y la Geometría (para representar y proyectar con corrección objeti- va)-, la Óptica (para conseguir una adecuada iluminación), la Aritmética (para los necesarios cálculos tanto de presupuesto como para los problemas de las proporciones), la Medicina (necesaria en todo lo referente a salubridad pública, especialmente referido aquí a su adecuación al clima) y la Astrología (para entender los movimientos astrales). En definitiva, el arquitecto tenía que adquirir competencias en dibujo técnico, cálculo, física aplicada y ciencias de la salud. Adicionalmente, el arquitecto debía estar versado en disciplinas que hoy se considerarían humanistas, como las Letras (en el sentido de estar adiestrado en la escritura, para poder plasmar en memorias su experiencia y conocimiento), la Historia (para poder dar cuenta del significado de la ornamentación en la arquitectura), la Filosofía (que forjará el carácter humilde, sobrio, leal y desinteresado del arquitecto, así como el estudio de la Fisiología o la ciencia de los principios de la naturaleza) y la Música (para conocer las teorías de la tensión de cuerdas y la acústica, aplicables tanto a ingeniería militar como a la arquitectura de teatros) (1980: 6-9 y ss.).

Dentro de la tradición clásica, la arquitectura no era reconocida entre las artes liberales, aun cuando se le exigiese al arquitecto commune cum ómnibus doctis. Lo cierto es que es patente en el tratado de Vitruvio su condición de opfices -como consideraba Cicerón a los arquitectos- por la preeminencia de cuestiones más prácticas, tanto de tipo técnico [opus] como teóricos [ratiocinatio]. Algo que en principio poco o nada tiene que ver con las claves estéticas posteriormente desarrolladas, si no es por la importancia que se le concedía dentro del conjunto. En última 
instancia, se puede considerar Los diez libros de arquitectura como un intento de dotar de autonomía a la disciplina arquitectónica -en un sentido ciertamente ampliado respecto del actual- con una clara orientación hacia la práctica. No obstante, como ya ha sido mencionado, aun de forma limitada pero con una crucial importancia para los siglos venideros, Los diez libros de arquitectura sí plantea ciertos criterios estéticos que ha de cumplir la arquitectura, desde claves contemporáneas.

\section{Los seis elementos de la composición arquitectónica}

Como respuesta a la pregunta que rotula el segundo capítulo, "En qué consiste la Arquitectura", Vitruvio da a entender que son seis los puntos que han de cumplirse: ordinatio, dispositio, eurythmia, symmetria, decor y distributio. ${ }^{80}$ Estos seis conceptos constituyen la más completa relación de elementos de composición de la antigüedad referido a las artes en general. No se sabe si se trata de una lista inventada por Vitruvio -si recopiló conceptos que eran usados en su época y los ordenó con criterios propios- o si constituía una teoría de la composición arquitectónica per se. Diversos autores han señalado que Vitruvio mezcló conceptos de la teoría estética antigua de diversos periodos o que utilizó conceptos ya en desuso en el siglo I a. C., ${ }^{81}$ colaborando con ello a la ya de por sí confusa enumeración. En cualquier caso, lo que sí se puede adelantar es que la ordinatio y la dispositio eran conceptos que se empleaban con frecuencia en la técnica de construcción, decor era un término filosófico y distributio relativo a la economía. En realidad, Eurythmia y symmetria eran los únicos términos propiamente estéticos (Tatarkiewicz, 2000: 282).
De ahí que el orden en el que los enumera Vitruvio y el hecho de que no distinga entre ellos su procedencia colabore en la dificultad de interpretación. ${ }^{82}$

En primer lugar, ordinatio [Takıc] apunta hacia las reglas de composición que permiten relaciones proporcionadas a partir de un módulo en un edificio: "es lo que da a todas las partes de una construcción su magnitud justa con relación a su uso, ya se la considere separadamente, ya con relación a la proporción o a la simetría". Atiende tanto a la relación de las medidas de sus partes entre ellas como a las de sus partes respecto al

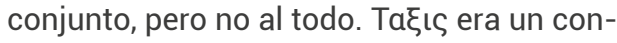
cepto para los griegos de amplio significado proveniente de la obra de Aristóteles, que abarcaba desde el más concreto sentido de orden hasta formaciones militares. En todo su abanico, empero, reina la idea de norma o código. No es casual, pues, que ciertos autores como Urrea o Blánquez optasen por traducir el término por "orden", en su sentido más exclusivo de la tratadística clásica. ${ }^{83}$ Ordinatio equivaldría a la imposición de ciertas reglas de composición a cada una de las partes de un edificio:

\section{Esta ordenación está regulada por la cantidad, que los griegos denominaron posotes. Por tanto, la cantidad [quantitas] es la conveniente distribución de los módulos adoptados como unidades de medida para toda la obra y para cada una de sus partes separadamente. (Vitru- vio, 1980: 13)}

Asimismo, tiene en consideración el uso del edificio y cifra, en definitiva, las magnitudes del mismo con arreglo a una función concreta. Se trata de proporcionar con arreglo procedencia griega cuando sea el caso). En primer lugar, no existen equivalentes actuales; en segundo, porque se desconoce con precisión el significado de cada concepto. Para una rápida consulta sobre las discrepancias entre las diversas traducciones -Urrea, Castañeda y Ortiz y Sanz-de estos seis términos, es especialmente clarificador y sintético Joaquín Arnau Amo (1987: 113-114) 81. Véase Ferri (1953: 214-224). Es relevante que muchos de los términos que utiliza procedan de la retórica. 82. Sobre esta dificultad, consúltese Scranton (1974: 494-499)

83. En francés la palabra "ordonance" tiene un sentido más preciso: orden como "ordenanza", por lo tanto, no un "orden general". La confusión entre orden y ordenanza explica algunos de los problemas debatidos posteriormente, por ejemplo el que las "medidas" de los órdenes se puedan cambiar (como el mismo Vitruvio admite) porque eso no significa tergiversar su "ordenanza". En este sentido sería en cierta medida similar a la euritmia (la corrección de las medidas que un edificio concreto necesita) y la simetría (como solución específica de una obra equilibrada). Al hilo de estas cuestiones se profundizará más adelante en el contexto de Goethe la actualización de estos términos en el seno del clasicismo. 
84. Especialmente claro en los pasajes donde Vitruvio clasifica los edificios de manera similar a como Demócrito desarrolló su teoría atómica del universo o donde desarrolla los problemas de las ilusiones ópticas. Véase Lefaivre y Tzonis (1984). 85. El debate suscitado a este respecto, y que Barbaro señala, es si escaenographia corresponde o no a la perspectiva a la que Vitruvio alude cuando habla de la escena teatral. Es decir, el debate posterior se centrará en si el texto original mencionaba la schenographia o la sciographia. Barbaro, por su parte, la identifica con el perfil (Calduch, 2014c: 87-88). a un módulo y desde el punto de vista de la utilidad del edificio. Es, pues, formal, cuantitativo y con arreglo a un fin.

En segundo lugar, dispositio "es el arreglo conveniente de todas las partes, de suerte que, colocadas según la calidad [qualitas] de cada una, formen un conjunto elegante". Consta de tres ıðॄaı (ideas o tipos de disposición): ichnographia, orthographia y scaenographia o trazado en planta, en alzado y en perspectiva, respectivamente. Es decir, dispositio concierne la representación del edificio para garantizar su belleza y calidad y los medios técnicos necesarios para llevarla a término. Si ordinatio era la norma cuantitativa para la composición de los edificios, con la dispositio el orden de las cosas puede alcanzar un valor cualitativo y lo hace por medio de los tres tipos de disposición, cada cual en su debido ámbito.

A tenor del contexto de reflexión de Vitruvio, ıઠॄaı no debe ser entendido en tanto que formas arquetípicas (o metafísicas si se prefiere) al modo de Platón, sino más bien como la forma de lo real, de lo existente. ${ }^{84}$ Más cercano, pues, a la concepción de Demócrito o Lucrecio, la idea de Vitruvio incorpora la tesis del valor de la recepción. La arquitectura, defenderá este, debe sumar a su discurso esencialista la manera en la que será percibida. La cuestión del valor estético de la arquitectura tendrá, por ello, que entenderse también como un problema de pura visibilidad.

La ichnographia es "un dibujo en pequeño, hecho a escala determinada con compás y regla, que ha de servir luego en el trazado de la planta sobre el terreno que ocupará el edificio". Es decir, la sección horizontal de un determinado piso del edificio. Adelanta, además, su actual uso para el replanteo. Tiene, pues, una clara vocación constructiva, de ahí sus exigencias de precisión (uso de instrumental y requerimiento de representación a escala).

La orthographia es "una representación en pequeño y un dibujo ligeramente colorado, de la fachada y de su figura por elevación, con las correspondientes medidas, de la obra futura". Anticipa asimismo el edificio construido pero sin tantas exigencias en la precisión. Es más, la orthographia adelanta el aspecto visual de la fachada (con la inclusión de la colorimetría, parte fundamental de todo proyecto romano) y sus medidas.

No ocurre así con la escaenographia en la que, como su propio nombre indica, prima la puesta en escena del edificio en su conjunto antes que la elevación exacta de sus medidas: "es el dibujo sombreado no sólo de la fachada, sino de una de las partes laterales del edificio, por el concurso de todas las partes visuales en un punto" (Vitruvio, 1980: 13). Ambas, a diferencia de la ichnografia que no es sino un modelo teórico, consisten en representaciones visuales, más o menos fieles al resultado final, orthographia por elevación y escaenographia por perspectiva. ${ }^{85}$ No en vano, Vitruvio prosigue con su explicación del término dispositio advirtiendo al lector que se desarrolla gracias a la combinación de la reflexión (cogitatio) y la invención (inventio), causa y efecto de un mismo fenómeno orientado a solucionar los problemas planteados por los tres tipos de disposición, con el fin de encontrar nuevas posibilidades.

En tercer lugar, eurythmia es "el bello y grato aspecto que resulta de la disposición 
de todas las partes de la obra, como consecuencia de la correspondencia entre la altura y la anchura y de éstas con la longitud, de modo que el conjunto tenga las proporciones debidas" (Vitruvio, 1980: 13). Es, pues, el resultado de la aplicación de ciertas normas compositivas, pero adaptándolas a las circunstancias de su observación, esto es, la corrección de las deformaciones de la vista humana en general por las circunstancias concretas de la visión de la obra: altura, punto de vista, etc. Proviene sin alteraciones del significado griego: las proporciones se corregirían para que el espectador las percibiera como si fueran las apropiadas.

No se encuentra ya en la esfera de la proyectación, sino que eurythmia es una palabra pasiva que indica una propiedad de lo que existe, a diferencia de ordinatio, dispositio o distributio que tienen que ver con una acción y se orientan hacia la creación de algo (Geertman, 1993: 220).

Estas normas base son, de hecho, las dictadas por el cuarto de los conceptos: la symmetria, que equivaldría al actual concepto de "conmensurabilidad" en la medida en que a razón de un módulo se establece una concordancia entre el todo y las partes. Sería simétrico aquello medible con arreglo a un módulo, a diferencia de la simetría en su significado más habitual, que equivaldría a una correspondencia precisa de dos o más elementos respecto a un punto, eje o plano de referencia: "es la concordancia uniforme entre la obra entera y sus miembros, y una correspondencia de cada una de las partes separadamente con toda la obra" (Vitruvio, 1980: 13). Tiene que ver con los dos primeros conceptos por establecer criterios objetivos de perfección en las edificaciones. Ordinatio regula las partes del edificio, dispositio articula las mentadas partes y, por último, symmetria hace corresponder las partes con el todo.

Symmetria hace referencia a la disposición armoniosa de los elementos, un criterio de belleza objetiva que no contempla ni la solidez ni la utilidad entre sus parámetros. Con arreglo a un módulo base, como puede ser el diámetro de una columna, se derivaban las dimensiones de todo el edificio y exactamente así obraban los escultores griegos cuando a partir del tamaño de un pie dimensionaban el cuerpo ideal humano (si se permite una tan apresurada simplificación). ${ }^{86}$

Estos dos polos estéticos del periodo clásico, a saber, la defensa de una estética objetiva (la tesis pitagórica según la cual la belleza sería una propiedad de las cosas, derivando en una estética cosmocéntrica) u otra subjetiva (propia de los sofistas, y de carácter antropocéntrico) vienen testimoniados por sendos conceptos que recoge Vitruvio. Ya desde el siglo $\mathrm{V}$ a. C., la belleza objetiva regulada por las leyes de la symmetria fueron perdiendo terreno frente a la belleza que no necesitaba de una justificación objetiva siempre y cuando provocara unos sentimientos agradables en el espectador, esto es, la eurythmia, pese a que haya que reconocer su entrelazamiento e interdependencia. Ejemplo de ello es cuando, a la hora de establecer los criterios de distinción entre las cinco clases de templos, Vitruvio señala la necesidad de establecer ciertos ajustes [temperaturae] en los cánones de la proporción: "Los ojos son los que buscan la belleza; por tanto, si no se satisface su gusto tanto con las proporciones como con esas adiciones [refiriéndose
86. Conviene señalar aquí que no se trata esto de una tesis racionalista, como parecería a tenor de las interpretaciones llevadas a cabo desde el Renacimiento hasta la Ilustración. Antes bien, fiel a la metafísica naturalista clásica, los órdenes (o, en el sentido antes señalado, "las ordenanzas") derivan de los principios de la Naturaleza en primera instancia para, a posteriori ser abstraídos y elevados a sistema de medidas normativo. Véase el capítulo "3. B. Crisis de la imitatio y arquitectura del efecto" para medirlo paradigmáticamente con la cuestión de la arbitrariedad del lenguaje arquitectónico 
87. Adviértase que el sentido habitual que se le atribuye a "orden" proviene del renacimiento. En concreto, proviene de la sistematización llevada a cabo por Alberti. En época de Vitruvio no consistía en un canon, como fue más tarde el caso, sino en una relación numérica más vinculada con valores experimentales -no absolutos - inspirados en el cuerpo humano. Véase a este tenor el capítulo 1 del libro IV, donde Vitruvio describe los tres genera: dórico correspondiente a la robustez del cuerpo masculino, jónico a la esbeltez del femenino y corintio a la delicadeza de una doncella (1980: 86-90).

88. En efecto, a partir del siglo XIX los tornos se invertirán y la composición en planta adquirirá un protagonismo inusitado. Ciertos autores han querido ver en esto un giro de crucial importancia en la concepción estética de la arquitectura. Desde esta perspectiva, por ejemplo, la "volatilidad" estilística del eclecticismo o del historicismo decimonónico vendría a estar posibilitada precisamente por esa falta de atención a las fachadas: hay efectivamente constancia de proyectos que, pese a mantener escrupulosamente los planos en planta, sufrieron sucesivas modificaciones en alzado pasando de estilos neogóticos a neoclásicos, como, por ejemplo, el caso de Schinkel y sus diferentes propuestas (clásica o gótica) al éntasis de las columnas], que agrandan oportunamente lo que parecería deficiente, el conjunto resultaría desproporcionado y feo a quien lo contemplase" (1980: 76). Para que la symmetria fuese percibida como tal, era necesario un ajuste de las medidas regulado por la eurythmia.

En quinto lugar, decor es "el aspecto correcto de la obra, que resulta de la perfecta adecuación del edificio en el que no haya nada que no esté fundado en alguna razón" (Vitruvio, 1980: 14). Se trata de la forma sustantivada del decorum estoico y Vitruvio lo emplea en ese mismo sentido: lo apropiado, lo conveniente. Con arreglo a, así Vitruvio, tres preceptos: el rito, las costumbres y la naturaleza.

Según el rito que deba albergar, un edificio tendrá que atenerse a las normas del decoro que atribuyen, por ejemplo, a la austeridad de la diosa Minerva, la valentía de Marte o la fuerza de Hércules el uso del orden dórico, en tanto que las delicadas Venus, Flora o Proserpina encontrarían en el corintio su orden decoroso. ${ }^{87}$ Se trata, pues, de la correspondencia entre la forma y el contenido de un templo, en connivencia al culto que allí se profese e identificándose la virtud del dios con un orden concreto.

El decoro de costumbre versa sobre la apropiada correspondencia entre las partes de un edificio, referidas en este caso a su uso (vestíbulos, por ejemplo), con el conjunto y su status. Así, por ejemplo, a un interior magnífico le corresponde un vestíbulo de holgadas dimensiones. El decoro de costumbre también vela por el respeto a la integridad de los órdenes, no permitiéndose la mezcla o transformación de los mismos.
Y, por último, el decoro natural aconseja sobre el emplazamiento del edificio con arreglo a normas de salubridad y sobre las orientaciones de las diferentes dependencias en función de su uso (dormitorios, bibliotecas, baños, museos...). Estilo, dignidad, pureza, emplazamiento u orientación son todos aspectos relativos al decoro. Luego, con decor y distributio se pasa del nivel material-tecnológico (quantitas), a través del tipo de contenido y de la representación (qualitas), al nivel social.

En sexto y último lugar, distributio [oเкоvouı] "consiste en el debido y mejor uso posible de los materiales y de los terrenos, y en procurar el menor coste de la obra conseguido de un modo racional y ponderado" (Vitruvio, 1980: 15). Con el fin de poder dar viabilidad al resto de características, el criterio óptimo de "distribución del gasto" -a no confundir con la dispositio, propiamente la "distribución" actual- permitirá un uso eficiente de los recursos tanto a nivel material (adaptación de la elección de los materiales en función de su disponibilidad y coste) como respecto de la disposición de los edificios en el terreno para satisfacer las necesidades de los usuarios así como para optimizar los recursos de los que se dispone. Es seguro, pues, que distributio se refiere exclusivamente a la utilidad del edificio, asegurando su forma y viabilidad, garantizando su adecuación a las condiciones del lugar y a los medios disponibles e incorporando las exigencias del usuario y su función. Su relación con la belleza es de segundo rango, en el sentido de, por una parte, posibilitarla y, por otra, no impedirla. 
Sintetizar esta enumeración de conceptos es dificultoso por la inestabilidad de los mismos y probablemente por la dificultad de acceso al sentido originario. Ciertas convergencias llaman, no obstante, la atención. De entre los seis conceptos, ordinatio, dispositio y symmetria forman un conjunto con cierta unidad: revelan las normas de proporción que un edificio ha de cumplir para contribuir a su belleza. Ordinatio supone la implantación de un orden a las partes (de tipo cuantitativo), dispositio la adecuada articulación de las partes respecto al todo (de tipo cualitativo) y symmetria, a modo de síntesis, acuerda las medidas de las partes respecto del todo y viceversa.

Pero, visto más en detalle, entre los cometidos reservados a la dispositio, y muy especialmente referido a la ichnografia, está el de la representación de una forma más general y por cualquier medio como, por ejemplo, un modelo o maqueta, e incluso una descripción narrada. Luego, en la dispositio no puede encontrarse la pureza formal que sí translucen ordinatio o symmetria. De hecho, para los romanos, las cuestiones compositivas -en su restringido sentido orientado hacia la belleza- concernían principalmente a las fachadas y volumen, a diferencia de épocas más recientes. ${ }^{88}$

De igual manera, decor presenta ambas vertientes. Por una parte, contribuye en un sentido semiológico a la belleza, dotándola de un contenido referido a la tradición, pero, por otra, en su sentido de decoro natural, da razones para la orientación más adecuada de cada dependencia. Luego, vela por el óptimo uso de dicho espacio. En este caso, empero, no se trata ya de normas formales, como las anteriormente expuestas, sino más bien de lo referido a la costumbre. Atiende a las condiciones materiales del momento histórico y lo posterga por principio de autoridad. Algo en común tiene, pues, eurythmia con decor en la medida en que no proporciona normas objetivas. Por otra parte, eurythmia no puede entenderse sin vincularla a la symmetria, su causa.

\section{Contenido estético del tratado de Vitruvio}

Tras haber presentado el cuerpo conceptual de la arquitectura en este segundo capítulo del primer libro, Vitruvio prosigue su explicación abordando "De las partes en que se divide la Arquitectura" en el tercer capítulo. Una vez determinado que la arquitectura consta de construcción, gnómica y mecánica -propiamente las partes a las que hace referencia el encabezamiento del capítulo-, Vitruvio introduce en poco más de diez líneas tres categorías, entre otros fines, ${ }^{89}$ a las que ha de responder la arquitectura que conviene tratar en detalle: firmitas, utilitas y venustas. ${ }^{90}$ Sobre estos tres conceptos se ha escrito desde entonces, especialmente desde el XVII hasta el siglo XIX, una inabarcable bibliografía.

\section{La tríada vitruviana}

La primera [firmitas] depende de la firmeza de los cimientos, asentados sobre terreno firme, sin escatimar gastos y sin regatear avaramente los mejores materiales que se pueden elegir. La utilidad [utilitas] resulta de la exacta distribución de los miembros del edificio, de modo que nada impida su uso, antes bien cada cosa esté colocada en el sitio debido y tenga todo lo que le sea propio y necesario. Finalmente, la belleza [venustas] ${ }^{91}$ en un edificio depende de que su aspecto sea agradable y de buen gusto por la debida proporción de todas sus partes. (Vitruvio, 1980: 17) ${ }^{92}$ para la Werdersche Kirche (Berlín, 1824)

89. Sobre cómo referirse a estos tres conceptos no hay un consenso establecido, dado que Vitruvio nunca lo especificó. Ciertos autores optan por el término "categoría" (Kruft), otros por "norma" (Arnau), otros por "partes" (Perrault) y otros por fines $u$ objetivos que debe alcanzar la arquitectura.

90. En realidad, de la famosa tríada es solo aportación de Vitruvio el concepto de firmitas. Cicerone, para subrayar la relación de las partes orationis, hace referencia a la arquitectura y a las artes técnicas enfatizando la relación entre venustas y utilitas/ necessitas. Véase Cicerone De oratore, 3, 180: "quid tam in navigio necessarium quam latera quam cavernae quam prora [...]? Quae tamen hanc habent non plus utilitatis quam dignitatis. Capitol fastigium íllud et ceterarum aedium non venustas sed necesitas ipsa fabricata est". 91. Parece claro que se refiere a "belleza física y sensible" en el sentido del griego "kalos". La traducción castiza por "hermosura" es quizás más apropiada porque la referencia a lo físico es más clara. En cambio la palabra "belleza" atiende a principios o regulaciones más intelectualizadas

92. "Haec autem ita fieri debent ut habeatur ratio firmitatis, utilitatis, venustatis. Firmitatis erit habita ratio, 
cum fuerit fundamentorum ad solidum depressio, \& ex quaq; materia copiarum sine avaritia diligens electio. Utilitatis autem, emendata \& sine impeditione, usu locorum, dispositio, \& ad regiones sui cuiusque generis apta \& commoda distributio. Venustatis vero, cum fuerit operis species grata \& elegans, membrorumq; commensus iustas habeat symmetriarum rationes", en Vitruvius (1552), De Architectura libri decem,

original procedente de la Biblioteca Estatal de Baviera, digitalizado el 29 de junio de 2009, p. 16.

93. Sobre la amplísima bibliografía relacionada con la traducción de Perrault y su impacto en la estética arquitectónica, es muy recomendable la monografía Wolfgang Hermann (1973), The theory of Claude Perrault. Londres. 94. Las reediciones hasta la fecha, así como las traducciones ya citadas, toman como referencia la segunda edición, ampliada y revisada, de mismo título, publicada ocho años después: Claude Perrault (1684), Les Dix Livres d'architecture de Vitruve, corrigez et traduits nouvellement en françois avec des notes et des figures. París:

J.-B. Coignard.

95. En realidad, toma por referencia la versión abrégé: Claude Perrault (1981), Compendio de los diez libros de arquitectura de Vitruvio, edición facsímil, Joseph Castañeda (trad.). Murcia:
Corresponde a Perrault la exaltación de la tríada vitruviana y, en gran parte, es él y no Vitruvio el responsable de situarla en el centro de la discusión moderna. ${ }^{93}$ Traducida, comentada e ilustrada por él, la obra de Vitruvio fue publicada por encargo de Courbet en 1676 bajo el título de Les Dix Livres d'architecture de Vitruve, corrigez et traduits nouvellement en françois avec des notes et des figures. ${ }^{94}$ Este libro tuvo un papel protagonista en la recepción de Los diez libros de Arquitectura y, en concreto, de la tríada. Fue tal la relevancia que Perrault concedió a este breve pasaje, que pasó a articular la primera parte de su versión libre de Los diez libros de Arquitectura, esto es, de la mitad de la obra de Vitruvio. Según la traducción de Castañeda, esta primera parte, titulada "Que contiene la Arquitectura que nos es común con los antiguos", consta de cuatro capítulos: "De la Arquitectura en general", "De la solidez de los Edificios", "De la comodidad de los Edificios" y "De la hermosura de los Edificios". ${ }^{95}$ Es decir, el segundo, tercer y cuarto capítulo corresponden a la tríada firmitas, utilitas y venustas, respectivamente.

Es, pues, llamativo cómo la forma en la que Vitruvio introduce esta clasificación contrasta con la repercusión que históricamente ha tenido. Ni siquiera forma parte de un párrafo, sino que viene referido a la explicación previa sobre los requisitos que han de cumplir las obras públicas, sean las que atienden la defensa, la religión o la comodidad del pueblo (lo que equivaldría a nuestros actuales equipamientos: puertos, plazas, baños, teatros...).

No sería pertinente extenderse aquí en un análisis hermenéutico de su recepción. No obstante, cabe advertir que entender estos tres requisitos de la arquitectura como una aproximación sistemática es a la par de erróneo, extremadamente tendencioso. Hasta el momento, si algo en claro ha de proporcionarnos una lectura atenta de Vitruvio es la falta de sistematicidad de su exposición. Bien sea por carencias teóricas del propio autor, bien por no responder a sus criterios o bien por no ser simplemente más que una proyección moderna sobre lo clásico, lo cierto es que para Vitruvio no son conceptos aislables ni autodeterminados. Es más, son mutuamente dependientes. Estas tres categorías se entrelazan, al igual que los seis conceptos analizados anteriormente. Han de entenderse, más bien, como un conjunto que no permite análisis individuales aislados.

Pero, aprovechando la oportunidad de disponer hoy de varias traducciones del latín original (contrariamente a los eruditos del XVII y XVIII) y guiados únicamente por el texto de Vitruvio, la tríada adquiere un cariz diferente si se entiende en la inmediatez de su juicio y bajo la luz de los seis conceptos anteriores. Váyase por partes:

\section{La primera [firmitas] depende de la firmeza de los cimientos, asentados sobre terreno firme, sin escatimar gastos y sin regatear avaramente los mejores materiales que se pueden elegir. (1980: 17) $)^{96}$}

La solidez de los edificios depende, pues, de la correcta construcción de los cimientos. Que el suelo sobre el que el cimiento ha de posarse deba cumplir con los esperados requisitos de solidez, así como que la elección acertada de los materiales se haga ateniéndose a las solicitaciones de los cimientos y no a otros intereses que pudiesen 
comprometer su cometido, no son más que dos derivaciones de la máxima primera. $Y$, por otra parte, que la cimentación haya de hacerse como toca moviliza tanto las leyes de la estática como los problemas constructivos derivados y la teoría de materiales. Algo que puebla profusamente las páginas de Vitruvio en capítulos posteriores. Pero queda claro en esta escueta aclaración que para Vitruvio la firmitas es simple y llanamente la garantía de estabilidad estructural de los edificios. ${ }^{97}$

Siendo esto cierto, no lo es menos que, habida cuenta de los conceptos que se manejaron previamente -y que preceden a la tríada en el tratado-, pueden trazarse vínculos entre ellos que amplíen esta primera interpretación. Aun cuando no la nombre explícitamente, el criterio de aplicar en su justa medida los medios materiales y técnicos en la construcción correspondía al sexto de los conceptos: distributio. Y de igual manera que este, firmitas tiene el carácter de un requisito previo para que la arquitectura se pueda dar con garantías. Cabría añadir que el criterio de firmitas se apoya asimismo en una concepción temporal que no atienden ni utilitas ni venustas. ${ }^{98}$ Esto viene confirmado por la traducción canónica del texto de Vitruvio al inglés, donde firmitas asume plenamente la pretensión de la arquitectura de permanencia: durability (Vitruvius, 1914: 17).

La utilidad [utilitas] resulta de la exacta distribución [dispositio] de los miembros del edificio, de modo que nada impida su uso, antes bien cada cosa esté colocada [distributio] en el sitio debido y tenga todo lo que le sea propio y necesario. $(1980: 17)^{99}$
En segundo lugar, utilitas se refiere a la correcta disposición de los espacios con arreglo a su función, con el fin de que no se produzcan interferencias entre ellos y se incluya todo aquello que sea necesario para su buen funcionamiento (orientación, dimensionado, ventilación... cabría deducir). En definitiva, vela por el cumplimiento de las funciones encomendadas a cada edificio y a cada una de sus partes.

No obstante, la referencia explícita en la traducción de Blánquez a la "distribución", es decir dispositio, le confiere una dimensión mucho más amplia que el simple cumplimiento de la funcionalidad. Quedó dicho que dispositio implicaba tanto los medios técnicos para la correcta representación y construcción del edificio como un criterio cualitativo orientado hacia la integridad del conjunto. Nada debería sorprender que, para el correcto desarrollo de los usos de un edificio, se eche mano de la ichnographia o dibujo en planta. Lo que hoy podría llamarse "distribuir" los usos en planta (o planta de distribución). Pero no solo eso, sino que la orthographia permite asimismo dimensionar en alzado los criterios funcionales, en tanto que la scaenografia proporcionaría una visión de conjunto.

Y si no es suficientemente evidente en la traducción de Blánquez, en el original latín la referencia a distributio es literal. De ahí que en utilitas haya que entender también un uso eficiente de los materiales y el ensamblaje correcto de las unidades de obra. El criterio de utilitas tiene pues, también, ese carácter de condición previa que tan evidente se mostraba en firmitas, pero con un condicionante adicional orientado hacia el cumplimiento de la funcionalidad y, por ende, de la belleza.
Colegio Oficial de Aparejadores y Arquitectos Técnicos de Murcia, pp. 27-52, pp. 53-62 y pp. 63-94, respectivamente. 96. En el original: "Firmitatis erit habita ratio, cum fuerit fundamentorum ad solidum depressio, \& ex quaq; materia copiarum sine avaritia diligens electio." (Vitruvius, 1552: 16)

97. Téngase en cuenta que "la construcción" en esos momentos se reducía, fundamentalmente, a la estructura de las fábricas: cimentación y muros portantes. Lo demás, como puedan ser pavimentos, enlucidos, carpintería de armar y de taller, etc. eran cometidos de los oficios. 98. La interpretación de González-Moreno (en El legado oculto de Vitruvio, 1993) de cada una de estas tres cuestiones es independiente y se consigue por sus propios medios: la firmitas mediante la construcción, la utilitas mediante la funcionalidad-distribución y la venustas mediante la forma. Frente a esa independencia, en Alberti (según el mismo autor) los tres fines se alcanzan con la construcción: garantiza la estabilidad-duración, permite conseguir la comodidad y confort en el uso y concreta la forma.

99. En el original: "Utilitatis autem, emendata \& sine impeditione, usu locorum, dispositio, \& ad regiones sui cuiusque generis apta \& commoda distributio." (Vitruvius, 1552: 16) 
100. "Venustatis vero, cum fuerit operis species grata \& elegans, membrorumq; commensus iustas habeat symmetriarum rationes." (Vitruvius, 1552: 16). En este sentido, "elegans" sería, más bien, "elegante" que no es exactamente el "buen gusto" ya que éste es un concepto vinculado a sensibilidad física en la recepción de la obra. El gusto atendería a uno de los cinco sentidos tal y como lo enunció en el s. XVII Gracián. 101. "Estas ocho partes se refieren [...] a las tres primeras: á saber, á la Solidéz, á la Comodidad y á la Hermosura, que suponen la Ordenacion, Disposicion, Proporcion,

Decoro ó Propiedad y Economía. Por esto se dividirá esta primera parte solo en tres capitulos, que son de la Solidéz [firmitas], de la Comodidad [utilitas] y de la Hermosura [venustas] de los Edificios" (Perrault, 1981: 26).
Por añadidura, las necesidades a cubrir para el buen funcionamiento y la correcta orientación de las estancias estaban reguladas por el decor. En su particularidad de "decoro natural", aconseja sobre el emplazamiento del edificio con arreglo a normas de salubridad y sobre las orientaciones de las diferentes dependencias en función de su uso. Luego, utilitas, lejos de ceñirse a la "utilidad" de la arquitectura, aúna criterios correspondientes a la dispositio, la distributio y el decor.

Finalmente, la belleza [venustas] en un edificio depende de que su aspecto sea agradable y de buen gusto por la debida proporción [symmetria] de todas sus partes. (1980: 17) 100

A la venustas compete el núcleo más puramente estético de la tríada: garantizar la belleza. Atendiendo al objeto, la explícita mención a symmetria -traducido por Blánquez por "proporción" para no confundir al lector con el significado más restringido en la actualidad de "simetría" - remite a la concordancia entre las partes y el todo del edificio con arreglo a un módulo específico y propio de cada obra (el diámetro de la base del fuste). Esta mención hace desplegar en cascada, a tenor de lo visto anteriormente, no solo ya al concepto de symmetria sino a ordinatio como regulador de las partes y dispositio, de nuevo, como articulador de las partes.

Por otra parte, venustas no solo atiende a los valores objetivos de belleza en el edificio, sino que contempla así mismo los subjetivos (resultado de las distorsiones de la visión). Además de garantizar "la debida proporción de todas sus partes", venustas vela por que "su aspecto sea agradable y de buen gusto". Es decir, ya no solo cumplirá el edificio las normas reguladoras de la belleza dictadas por la proporción, sino que ha de ser igualmente percibido como bella. Venustas, pues, moviliza la eurythmia y apoya el vínculo ya establecido entre symmetria y eurythmia.

La "estética de la arquitectura" de Vitruvio De resultas de esto, los seis elementos de la composición arquitectónica quedan vinculados a estas tres categorías más generales, abarcando en su complejidad el conjunto de requisitos de la arquitectura. Que Perrault ${ }^{101}$ tomase esto como punto de partida para, a su juicio, "ordenar" el Vitruvio va de suyo. Han sido muchos los intentos de extraer una serie sistemática de esta concatenación de seis conceptos más la tríada. Ciertos autores intentaron ver en la tríada las partes fundamentales de la arquitectura y con arreglo a ellas se disponían los seis conceptos previos. Sería este el caso de Perrault y todos los que en su traducción se basaron.

Lo cierto es que la mayoría de interpretaciones que proponen una síntesis estética de la tríada coinciden en aislar firmitas del resto. En este sentido, firmitas no se considera una cualidad estética sino un requisito físico de un edificio que posibilita los valores intrínsecos de la arquitectura representados en Vitruvio por la utilitas y la venustas. No es, pues, un valor en sí, sino una condición instrumental de la arquitectura. Aunque no hay forma de desvincular estos tres criterios, como ha quedado dicho -dado que están conceptualmente entrelazados-, aquello que atiende a firmitas puede, en realidad, considerarse un tipo de condicionante previo para el cumplimiento de utilitas y venustas: la edificación ha de ser sólida, ha de perdurar 
en el tiempo, para poder cumplir su misión de función y de embellecimiento.

Dicho esto, sobre la propuesta estética de Vitruvio en su interpretación moderna y la relación de las dos restantes categorías (únicas propiamente estéticas), no hay un consenso claro entre las interpretaciones modernas a partir de Perrault. La polémica estribaría a grandes rasgos en determinar en qué medida la condición social de la arquitectura alcanza en Vitruvio el estatus de valor estético. Así, autores como Tatarkiewicz o Kruft priorizan la belleza sobre la utilidad, en tanto que otros, como es el caso de Geertman equipararía una con otra. En cualquier caso, una u otra interpretación combina en mayor o menor medida ese doble carácter de la estética vitruviana. cualquier casotilidad, en tanto que otros, como es el caso de ores, como Kruft, optan por el $\mathrm{t}$

Para Tatarkiewicz, Ordinatio, dispositio y distributio se refieren a la solidez y a la utilidad y, como mucho, atañen a la belleza de forma indirecta. En cambio, los tres elementos siguientes conciernen fundamentalmente a la belleza, siendo la symmetria la condición objetiva, eurythmia la subjetiva (referida a la recepción en el espectador) y decor la social (2000: 282-283). Para justificar este orden, Tatarkiewicz hace mención a muchos otros conceptos que aparecen a lo largo del tratado y refuerzan, en su opinión, esta triple cualidad de la estética arquitectónica propuesta por Vitruvio y que proporcionaban una amplia panorámica del léxico conceptual de la estética del helenismo: el efecto que la obra de arte produce en el hombre del lado sensorial, un segundo que concernía a las cualidades racionales y un tercero que presentaba las condiciones sociales necesarias para una buena arquitectura. La orientación social y subjetiva de la estética vitruviana contrasta, de hecho, con los problemas planteados en la estética helenística de su época.

La interpretación de Kruft amplia el significado de venustas, hasta el punto de llegar a sostener que los seis elementos de la composición arquitectónica se pueden asociar en exclusiva a la venustas, aun admitiendo que distributio formaba también parte de utilitas (1990: 28-31).

Según la interpretación de Geertman, Vitruvio opera simultáneamente a tres niveles: la forma arquitectónica como estructura matemática, como belleza de contenido y de forma y como función social. Tras repasar las presuntas incongruencias en las que incurriría Vitruvio en este capítulo según numerosos comentaristas, Geertman achaca la singularidad de la exposición a su estructura circular. Así, comienza con la fase de proyecto (ordinatio y dispositio) que se orienta hacia el objetivo final de belleza (eurythmia), que confirma los mecanismos formales desarrollados en proyecto por presentarse con la calidad de la symmetria teniendo presente la función social de la arquitectura (decor) y los medios para alcanzarla (distributio) (1993: 223-245).

En síntesis, el entrelazamiento de las tres categorías respecto de los seis elementos de composición es indiscutible. En conjunto, los principios estéticos fundamentales que plantea Vitruvio se centran en el establecimiento de criterios de juicio sobre la belleza arquitectónica. Esta se asienta sobre la convicción de la existencia de una belleza verdadera y objetiva, aun cuando admitiese la corrección óptica de las leyes objetivas en 
102. El arquitecto es el que construye también máquinas militares y relojes. No será hasta la parcelación de la arquitectura desde el Renacimiento cuando ámbitos como la arquitectura civil y militar, la construcción de edificios y de obras públicas, la arquitectura y arquitectura hidráulica, la arquitectura y arquitectura naval, la arquitectura e ingeniería industrial, etc. puedan distinguirse con más claridad. Y que, finalmente, el trabajo del arquitecto se fuera restringiendo, cada vez más a cuestiones "formales". De aquí la prioridad que fueron tomando los aspectos "artístico-formales" sobre los constructivos y los utilitarios que pasaron a ser responsabilidad de otros profesionales.

103. Es el paso de "arte mecánica" a "arte noble" a fin de integrase en las tríadas escolásticas medievales: Trivium, Quadrivium, etc. En este sentido la teoría que defiende Vitruvio se convierte en la verdadera "arte noble", mientras que la práctica-construcción queda relegada a un segundo lugar como "práctica artesanal".

Con una diferencia "negativa" respecto a las obras de arte como pintura y escultura. Que estas son "practicadas" también por los mismos artistas, mientras que en la arquitectura la "práctica" deja de ser ejecutada por el arquitecto-artista y pasa a manos de los maestros-construc- beneficio de que la percepción del espectador se ajustara a la simetría. Síntoma de ello es primacía de la symmetria sobre la eurythmia. Con todo, no es esta una belleza que pueda entenderse desvinculada de la utilidad. En Vitruvio, se persigue un equilibrio entre la belleza formal y la utilidad. Debe ser lo que satisface a la vista, tanto desde su dimensión objetiva como subjetiva, pero también ha de adecuarse a su fin. La belleza abarca tanto aquello que agrada a la vista como al intelecto, pero también aquello que proporciona goce mediante su finalidad, conveniencia y utilidad.

\section{Vitruvio y la autonomía de la arquitectura} En primer lugar, cabe reseñar que en el tratado de Vitruvio se puede identificar ya una clara voluntad de dotar al arquitecto de un grado de autonomía como profesional así como un primer intento por delimitar la disciplina arquitectónica respecto del resto de artes o artesanías bajo las claves propias de su tiempo. ${ }^{102}$ Es sorprendente a este respecto la larga trayectoria que ha acumulado esta concepción del arquitecto como profesional "liberal" capaz en muy diversas áreas de conocimiento y técnicas. No obstante, como ya ha sido señalado, el arquitecto previo al Humanismo no se concebía como una individualidad creativa. Es más, las numerosas referencias de Vitruvio al deberse al entorno, a la cultura, a la religión del momento suponen una explícita indiferencia hacia los objetivos perseguidos más tarde por el proyecto de autonomía. No eran esas inquietudes del momento, en un mundo que -como defendía con vehemencia Schiller- el hombre aun se auto-concebía como totalidad.
De hecho, aquello que más repercusión tuvo en siglos posteriores no fue este aspecto de su tratado, sino su propuesta estética y como reflejo del intento de ascenso social de los artistas sobre los artesanos en el Renacimiento, ${ }^{103}$ aunque sea solo como testimonio de una época. En efecto, el tratado de Vitruvio apenas tuvo influencia en la Antigüedad. Son contadas las referencias que pueden encontrarse en los diversos textos teóricos, tanto de principios de época imperial como tardoimperial, y aun más escasa parece su repercusión en la práctica arquitectónica. ${ }^{104}$ Lo cierto es que habrá que esperar a tiempos carolingios para encontrar muestras contrastables del interés por el texto de Vitruvio. Muestras, no obstante, no exentas de polémica. Y, en cualquier caso, la cuestión estética de la autonomía no será de nuevo explícitamente abordada hasta el Renacimiento, habida cuenta de la influencia de la filosofía escolástica en la comprensión de la arquitectura medieval. ${ }^{105}$

La necesidad de apropiación de este texto, que se entendió clave para la renovación arquitectónica, se plasmó en el ámbito teórico en la elevación de la tríada vitruviana a verdadero principio de la disciplina en el Renacimiento. De suerte que la firmitas, utilitas y venustas marcarán desde entonces la aproximación estética a la arquitectura. La doble vertiente de la estética de Vitruvio previamente señalada fundamentará la teoría y la práctica de la arquitectura y la prolífica época de los tratados de arquitectura que siguió al Renacimiento recogió esta como autoridad que legitimaba el uso de un nuevo lenguaje. 
Aun cuando Poggio Bracciolini pretendió postularse como el descubridor del texto olvidado de Vitruvio, ${ }^{106}$ hay constancia de manuscritos conservados del De Architectura que datan del siglo IX. ${ }^{107}$ De lo que parece no haber duda es que la primera edición impresa del tratado vitruviano fue la editada por el filólogo Giovanni Sulpicio da Veroli a lo largo de la segunda mitad de los años ochenta del siglo XV (la fecha precisa se desconoce, aunque predomina la datación en 1486). El interés que suscita desde su redescubrimiento a principios del $\mathrm{XV}$, resonando entre autores de tanto impacto como Alberti, Francesco di Giorgio o Rafael, fue exponencialmente amplificada por esta nueva edición prínceps. Desde entonces, Los diez libros de Arquitectura constituirán una referencia obligada a lo largo de la Edad Moderna.

Nómbrese, aunque sea solo como ilustración de ello, un notable ejemplo. El re aedificatoria de Leon Battista Alberti puede considerarse el primer tratado sistemático de la arquitectura tras el de Vitruvio. Escrito en la última década de la primera mitad del XV, no fue publicado póstumamente en Florencia hasta el 1485. En este texto, Alberti recupera la estética vitruviana en el sentido anteriormente expuesto, aunque con manifiestas intromisiones del ámbito religioso (especialmente notables en el noveno libro). El compromiso entre lo útil y lo bello adquiere en este tratado un tono más riguroso que en Vitruvio y más sistemático. El ensalzamiento del arquitecto como subjetividad y la sistematización de los atributos abstractos de la forma pura en la arquitectura pueden considerarse las dos aportaciones más relevantes de Alberti en el proceso de autonomización de la arquitectura. Otros autores como Serlio o Caramuel profundizaron, con discrepancias, en la tradición vitruviana, ${ }^{108} \mathrm{de}$ suerte que así como a nivel socioeconómico pueden identificarse claros precedentes de la autonomía moderna, desde el punto de vista de la estética arquitectónica, la pregunta por la autonomía no se había aun formulado en su más radical contundencia.

Luego, en la recepción de Vitruvio durante el Renacimiento se incidió notablemente en su propuesta estética dual para la arquitectura. Predomina, como se ha visto en el apartado anterior, la concepción estética asentada en la idea de proporción, en tanto que certeza de la accesibilidad de una belleza objetiva para la arquitectura. Este íntimo vínculo con las matemáticas, y más concretamente, con las reflexiones geométricas pitagóricas, traza una cierta continuidad que, como han demostrado ciertos autores, pervive durante la Edad Media-109 desde el periodo clásico hasta la crisis de finales del XVIII. Quizás de una forma menos evidente, la idea vitruviana de indiscernibilidad entre la función de la arquitectura en la sociedad y su elevación formal perduró asimismo incólume al menos hasta finales del Renacimiento.

Con la radicalización estética a lo largo del periodo de la tratadística arquitectónica fue, no obstante, gestándose la crisis de la teoría vitruviana. Sería, de hecho, objeto de una interesante investigación demostrar lo que ahora solo se puede adelantar casi intuitivamente: la decadencia del modelo estético que desembocó en la crisis del XVIII ${ }^{110}$ se fragua en paralelo al escoramiento de la estética hacia su componente formal, es decir, la pérdida paulatina del peso que Vitruvio otorgó a la componente utilitaria en la arquitectura. De suerte que los sucesivos usos y metáforas tores. Sobre esta diferencia reposa en gran medida la revisión romántica de toda la arquitectura posmedieval de, por ejemplo, Ruskin 104. Véase Koch (1951) y, adicionalmente, Tafuri (1978: 389 y ss.). Para consultar una bibliografía más extensa sobre la recepción de Vitruvio en la Edad Media y el Renacimiento, véase la nota 3 en Kruft (1990: I-371).

105. Aunque la autonomía de la disciplina, en un sentido muy cercano al defendido por Vitruvio sí pervivió a lo largo de la Edad Media, debido en gran parte a la influencia de San Agustín y su sentido de lo clásico (von Simon, 2000:

51 y ss.).

106. Sobre el descubrimiento del tratado, el mismo Poggio Bracciolini da dos versiones contradictorias. En la primera, habría sido encontrado en

1414 en Montecasino. Según la segunda, en 1416, en ocasión del concilio de Constanza, un ejemplar habría sido encontrado en la biblioteca de la abadía de Saint-Gall (Ciapponi, 1960: 59-75).

107. Los manuscritos más antiguos que se conservan del Vitruvio son el Códice Vitruvio en Séléstat, Bibl. munic., ms. 1153 bis y el del Museo Británico, Harley 2767, ambos fechados entre los siglos IX y X. 108. Para un recorrido pormenorizado de la evolución de la autonomía en su sentido estético a lo largo del Humanismo, con especial mención 
a Alberti, Serlio y Caramuel (Lefaivre y Tzonis, 1984). 109. Los criterios de belleza, en su sentido neo-platónico, no distan (más que en un plano estilístico) apenas de lo realizado en la Catedral de Chartres o en las grandes construcciones medievales. En ultima instancia se trata de la incorporación de criterios cosmológicos a la composición arquitectónica (Scruton, 1985: 65-76).

110. Es especialmente ejemplificador de este proceso por el que la teoría de la arquitectura quedaba reducida a un estudio filológico y la arquitectura a palabras a-sintácticas el diccionario vitruviano de P. J. Márquez de finales del siglo XVIII (Rodríguez Ruiz, 1986: 20-47).

111. El concepto de "progreso" provendría, en este sentido, de la adopción de criterios propios de la ciencia y la técnica, hasta el punto de que, tal y como formula Gombrich, podría plantearse la cuestión de si el arte verdaderamente "progresa" (Gombrich, 1985).

112. Estos son los términos en que se desarrolló fundamentalmente la polémica entre ingenieros y arquitectos en Francia en el s. XIX. Los ingenieros serían por tanto asociados a técnicos científicos, en tanto que los arquitectos a artistas (Bonet et al., 1985). que fueron adhiriéndosele adquirieron poco a poco la pátina de un lenguaje sobreimpuesto a una arquitectura que ya no le correspondía.

\section{B. Crisis de la imitatio y arquitectura del efecto}

El periodo reformador de la segunda mitad del XVIII afectó a prácticamente todos los ámbitos de la vida en sociedad. Con la ciencia llegó también la medicina, el sistema judicial fue paulatinamente completándose, la presión de la industrialización dio lugar a una competencia internacional hasta entonces desconocida. En todo ello, y en un mundo que se transformaba con velocidad, el arquitecto del XVIII intentó encontrar su lugar como reformador social en gran parte gracias a la pérdida de las categorías que otrora fundamentaban su práctica. Las máximas de la mímesis o el principio de autoridad no se presentan ya como anclajes incuestionables a la sociedad, pasando tanto la naturaleza como la tradición a ser un material dispuesto para la construcción de un futuro que ya no solo se podía ver a través del prisma del progreso. ${ }^{111}$ La naturaleza, fuente antes de inspiración, proporciona ahora a la arquitectura nuevas posibilidades que dependen de la destreza y puesta en práctica de las nuevas técnicas. Se dispone de ella de forma que paulatinamente se impondrá lo artificial a lo natural. De igual manera, los lenguajes arquitectónicos y los sistemas compositivos pasarán a interpretarse como fundamentos de la investigación histórica y no ya como máximas. Y todo ello con la creciente amenaza de su desaparición como actor social. No solo el creciente y exitoso ámbito de la ingeniería, sino también otras de las profesiones liberales a las que por fuerza debía vincularse y que constituirían la floreciente clase de profesiones liberales (médicos, economistas, juristas...) amenazaban con expulsar de la vida pública 
al arquitecto que era visto como un reducto anticuado.

Es especialmente significativo en este contexto que la dialéctica entre razón y expresión o sentimiento, tan avivada en las discusiones humanísticas, regrese en la Ilustración con especial vigorosidad. ${ }^{112}$ La confianza mostrada por el humanismo en introducir la salvación de la humanidad a través del hombre se desvanece progresivamente en la misma medida en que la industrialización, el capitalismo liberal y la revolución política se consolidan. Las nuevas amenazas, entendidas como parte indispensable del progreso defendido al modo schilleriano, plantean nuevos retos que han de materializarse en una crítica social de una intensidad hasta ese momento nunca antes experienciada. El sueño de una humanidad reconciliada consigo misma y con la naturaleza se presenta cada vez más como el gran reto de la civilización occidental. Y, a la par, la experiencia de la dificultad de su advenimiento azuza el giro hacia la nostalgia. La crítica social se presentará a este tenor con crudeza, llegando al rechazo radical de lo existente.

Como consecuencia de estas convulsas décadas, en la teoría de la arquitectura se abrieron al menos dos frentes que han sido habitualmente interpretados como elementos independientes. Por una parte, la belleza clásica, basada en la doctrina de las proporciones, dio paso a la idea de una composición arquitectónica acorde con los dictados de la sociedad. Y, por otra parte, la teoría clásica de la representación, en la que la categoría de la convenance jugaba un papel central, perdió terreno a favor de un nuevo tipo de accesibilidad, de comunicabilidad social. Se espera poder mostrar en lo que sigue cómo estos dos giros no son sino epifenómenos de un mismo movimiento que cabe localizar en el seno de la búsqueda por una autonomía arquitectónica.

\section{La querelle y la crisis del clasicismo}

Ne croirait-on pas que l'art se soit endormi depuis deux mille ans?

C.-N. Ledoux (1803: 15) ${ }^{113}$

En la transición de una estética clasicista a la propiamente ilustrada tiene un papel protagonista la arquitectura. ${ }^{114}$ Reconocido por el propio Diderot como un precursor de la Encyclopédie, ${ }^{115}$ el discurso de Charles Perrault en la Académie en 1687 tendrá repercusiones profundas que pueden localizarse hasta finales del siglo XIX. La disputa, conocida como querelle, entre los representantes del orden oficial -las "gentes de Versailles"- y los defensores de un giro sin precedentes -los "bellos espíritus de París"- se saldará con la ya irremisible constatación de la debilidad de la doctrina clásica. Así comenzó su intervención:

\footnotetext{
La belle antiquité fut toujours vénérable; Mais je ne crus jamais qu'elle fût adorable. Je vois les anciens, sans plier les genoux; Ils sont grands, il est vrai, mais hommes comme nous;

Et l'on peut comparer, sans crainte d'être injuste, Le Siècle de Louis au beau siècle d'Auguste... (Perrault, 1693 : 253) ${ }^{116}$
}

Para entender la magnitud del desafío de Ch. Perrault conviene recordar, aunque sea someramente, el contexto en el que se formula. El nacimiento del proyecto ilustrado en Francia surge, efectivamente, en el contexto del Absolutismo, cuyo apogeo cabe
113. "¿No podríamos considerar que el arte se ha quedado dormido durante dos mil años?".

114. Antes que los planteamientos filosóficos de Leibniz o Baumgarten ya tratados en las últimas décadas de siglo XVII francés pueden localizarse en la teoría de la arquitectura las piedras angulares que darán lugar a la nueva disciplina estética cien años después (aunque no solo: Simón Marchán Fiz señala asimismo el declive de la Retórica entre las Bellas Artes como otro estímulo hacia la emergente estética) Esto resulta especialmente llamativo si se mira a través del prisma de la irrupción de la autonomía en la arquitectura: cómo se presenta la arquitectura precursora de movimientos en la filosofía (al igual que tres siglos después ocurriría con la posmodernidad) y, al tiempo, cómo es superada por el resto de artes en el proceso de desarrollo desde su irrupción (Marchán, 2000: 18)

115. Entrada "Encyclopédie" (VV. AA., 1751-1772: 367). 116. "La bella antigüedad siempre fue venerable; / Pero nunca pensé que fuera adorable. / Veo a los antiguos sin doblar las rodillas; / Son grandes, es cierto, pero hombres como nosotros; / $\mathrm{Y}$ uno puede comparar, sin temor a ser injusto, / El siglo de Louis al hermoso siglo de Augusto..." 
117. La Académie Française tenía como fin normalizar la lengua común del estado francés, para lo cual se concedió especial atención a la producción literaria y teatral como vehículo de control de este proceso. Su eficacia queda probada en ejemplos tan notables como el proceso contra Corneille a raíz de la publicación de Le Cid en 1636 o la ejecución de Claude Petit por la publicación de su obra París, juzgada blasfema

118. En 1648 se funda la Académie de Peinture et Sculpture; en 1661, la Académie de Danse; en 1662, la Académie des Inscriptions; en 1666, la Académie des Sciences y la Académie de France à Rome; en 1669, la Académie de Musique.

119. En efecto, no puede obviarse que la Académie Royale d'Architecture fue pionera en el estudio sistemático de la teoría de la arquitectura, ofrecía formación a los jóvenes arquitectos en conferencias públicas semanales y atendía los problemas planteados en provincias. En este sentido no es falso considerarlas un antecedente de las facultades de arquitectura $y$, por qué no, de los colegios oficiales.

120. El caso de la música es especialmente elocuente. En Rameau, por ejemplo, el orden se manifiesta en la armonía, en contraposición a la melodía, que se entiende sujeta a la falibilidad de lo sensitivo. Rameau regresará a los fun- localizar bajo Louis XIV, no por menos conocido como el "Roi Soleil". Este proyecto, a diferencia de la situación en el altamente heterogéneo conglomerado de estados reunidos en torno al Sacro Imperio Romano Germánico, se articulaba en torno a un inflexible principio de unidad que abarcaba todos los dominios de la sociedad (la ciencia, la economía, la lengua, la moneda,...) y, en especial, el arte. A diferencia de la persistencia en los territorios alemanes de una cierta fragmentación de la soberanía, en Francia el organicismo medieval fue suplantado con radicalidad por una jerarquización vertical. Se interrumpió así una suerte de autonomía informal, derivada de la parcelación de la soberanía propia del feudalismo, que había permitido a ciertas ciudades y grupos sociales -inicialmente vinculados a la artesanía y el comercio- emerger como centros de producción y distribución por derecho propio (Anderson, 1987).

En este contexto, uno de los mecanismos que se mostraron más eficaces en la consolidación del absolutismo en Francia a lo largo del siglo XVII fue la fundación de las academias nacionales, encargadas de ampliar el control estatal a todas las áreas de la cultura. La constatación de la eficacia de la Académie Française fundada por Richelieu en $1635^{117}$-órgano encargado de la normativización de la lengua oficial francesa-, llamó a la proliferación en prácticamente todas las ciencias y las artes. ${ }^{118}$ La fundación por Colbert de la Académie Royale d'Architecture en 1671 marcó un antes y un después en esta política de control (Hautecoeur, 1948: 462 y ss.). Esta institución tenía como misión fundamental formular una teoría de la arquitectura oficial de carácter vinculante. Huelga decir que la academia no era autónoma: los miembros que la constituían, así como su director, eran nombrados por decreto real y a sus sesiones asistía un representante real que velaba por el cumplimiento de sus estatutos. Aunque no puede reducirse la aportación de las academias, y en concreto en el caso de la arquitectura, a su función reguladora, ${ }^{119}$ lo cierto es que en tanto que órganos de presión, impusieron un orden oficial homogéneo que restó en definitiva legitimidad a toda alternativa.

De resultas de este proceso, la Francia del XVIII constaba de un gran número de instituciones que velaban por la legitimación de la estética clasicista, donde el orden es único, natural y racional y, al tiempo, es eterno. La belleza entendida en este sentido clásico -y apresurando una muy burda simplificación- consistiría precisamente en el deleite propio del acceso a lo divino por medio de la constatación de ese orden en el arte. ${ }^{120}$ Es decir, la belleza se entiende como un fenómeno objetivo y racional, que tiene pretensión de verdad y de perfección. La estética ilustrada irrumpirá en la medida en que se fue minando la doctrina clásica asentada a lo largo del siglo XVII. ${ }^{121}$ Durante las querelles se pone de manifiesto la escisión entre los grandes binomios que habían articulado hasta entonces la política, el arte y la economía. Así lo atestigua la intervención de Charles Perrault en la Academia y así quedará confirmado años después en su Parallèle des Anciens et des Modernes (1688-1697), que tiene como mérito fundamental la puesta en evidencia de un malestar interno en la institución. Es sintomático, de hecho, que lo que algunos autores han calificado de verdadera "revolución de toda la estética arquitectónica" (Hernandez, 1972: 56), se diese desde el 
interior de la institución contra la cual quería erigirse como alternativa. ${ }^{122}$

En realidad, el verdadero precursor de este giro moderno en la arquitectura no es Charles sino su hermano mayor Claude, autor de la columnata del Louvre (1667) y, más importante si cabe, autor de una nueva traducción comentada de Vitruvio. Por encargo de Colbert y coincidiendo con la presentación de su proyecto para la fachada del Louvre, en $1664 \mathrm{Cl}$. Perrault emprende una tarea que le llevará más allá de una interpretación histórica, pretendiendo con ello influir en su contexto contemporáneo. ${ }^{123}$ Es sorprendente a este tenor la poca polémica que suscitó su publicación en 1673, cuando la academia ya contaba con dos años bajo la dirección de François Blondel. En su Les dix livres d'Architecture de Vitruve establece una clara ruptura respecto de la arquitectura de la Antigüedad en la medida en que rechaza la máxima de que la proporciones son leyes de la naturaleza, es decir, no pueden constituir un fundamento normativo sino que son producto de un consenso entre los arquitectos, determinado por la costumbre y la tradición (Perrault, 1684: 105, n. 7). Reducir las proporciones a un concepto empírico mina sin lugar a dudas los fundamentos de la estética clásica. De hecho, no deja de ser irónico que tamaño quiebro en la estética arquitectónica fuese consecuencia de un encargo de Colbert y se redujese en su mayor parte a anotaciones al margen de una traducción del texto canónico por excelencia. Así queda formulada su propuesta:

Toute l'Architecture est fondée sur deux principes, dont l'un est positif et l'autre arbitraire.
Le fondement positif est l'usage et la fin utile et nécessaire pour laquelle un Edifice est fait, telle qu'est la Solidité, la Salubrité et la Commodité. Le fondement que j'appelle arbitraire, est la Beauté qui dépend de l'Autorité et de l'Acoûtumance: Car bienque la Beauté soit en quelque façon établie sur un fondement positif, qui est la convenance raisonnable et l'aptitude que chaque partie a pour l'usage auquel elle est destinée. (1684: 12, n. 13) ${ }^{124}$

Luego, Cl. Perrault establece dos principios -categorías estéticas- que han de regir la arquitectura y muy especialmente la belleza en la arquitectura: uno positivo y uno arbitrario. El fondement positif se fundamenta en una reinterpretación de las categorías vitruvianas que no eran propiamente estéticas; así la firmitas y la utilitas constituyen en su propuesta los criterios de solidité, salubrité, commodité, symmetrie ${ }^{125}$ y usage. ${ }^{126} \mathrm{El}$ fondement arbitraire, aquel que corresponde propiamente al ámbito artístico en opinión de Perrault, se aleja de la normatividad que le precedió y queda exclusivamente delimitado por la costumbre y relacionado con el concepto moderno de proportion, en la medida en que Perrault lo considera una magnitud convencional. ${ }^{127}$

Mientras la beauté positive agrada siempre, es objetiva e intemporal, es absoluta en tanto que racional, la beauté arbitraire está sujeta a los cambios de opinión, a las modas y convenciones del momento, al gusto particular de cada época y nación, es relativa. La articulación de ambos tipos de belleza se lleva a término por medio del bon goût, concepto clave que desarrolla Perrault en su Ordonnance y que distingue del bon sens (que rige exclusivamente el juicio sobre la beauté positive): damentos de Pitágoras para establecer así una armonía científico-matemática: "La música es una ciencia que debe disponer de unas reglas bien establecidas; dichas reglas deben derivar de un principio evidente, principio que no puede revelarse sin el auxilio de las matemáticas" (Rameau, 1722). Véase Claramonte (2010: 58-64).

También pueden rastrearse estas tensiones en la polémica en la academia de pintura entre rubenistas (defensores del color) y poussinistas (defensores del dibujo).

121. En rigor, esta doctrina sobrevivirá a la irrupción de la estética ilustrada y puede identificarse hasta hoy en día como la nostalgia de una unidad o equilibrio perdido. Incluso el enciclopedista Diderot no puede desprenderse del todo de su influjo: "Dos cualidades son esenciales en el artista: la moral y la perspectiva. [...] Toda gran obra de pintura o escultura debe ser la expresión de una máxima para el espectador; sin esto, es muda" (Diderot, 1993:

83). Diderot aun defiende las ideas clasicistas de unidad, proporción... -de hecho, lo hace desde una perspectiva eminentemente arquitectónica- pero en cualquier caso estas categorías formales no pueden considerarse ya apriorismos habida cuenta de la importancia que cobra la experiencia perceptiva.

122. Ambos términos participan de un sustrato común: la 
racionalidad. Los "antiguos" defienden que las bases racionales estaban ya planteadas por los clásicos y los modernos porque, igual que en las ciencias, aplicando la racionalidad podían superar a los antiguos. Todo y asumiendo ambos que en el arte había un exeso que no podía acotarse exclusivamente desde la racionalidad.

123. Síntoma de ello es la inclusión en la portada del libro de Vitruvio la fachada de su proyecto en el Louvre y del arco del triunfo en la Place du Thrône.

124. "Toda la Arquitectura se basa en dos principios, uno de los cuales es positivo y el otro arbitrario. El fundamento positivo es el uso y el fin útil y necesario para el cual se hace un Edificio, como es la Solidez, la Salubridad y la Comodidad. El fundamento al que llamo arbitrario es la Belleza que depende de la Autoridad y la Costumbre." 125. En efecto, Perrault desprovee el concepto de symmetria vitruviano de su carga polisémica al traducirlo por el concepto moderno de "proportion". En la nota correspondiente, Perrault se justifica: "on entend autre chose par le mot de Symmétrie en François; car il signifie le rapport que les parties droites ont avec les gauches, et celui que les hautes ont avec les basses, et celles de devant avec celles de derrière, en grandeur, en figure, en hauteur, en couleur,
Il est donc vray qu'il y a des beautez positives dans l'Architecture, et qu'il y en a qui ne sont qu'arbitraites quoy qu'elles poroissent positives à cause de la prevention dont il est bien difficile de se défendre. Il est encore vray que le bon goust est fondé sur la connoissance des unes et des autres de ces beautez; mais il est constant que la connoissance des beautez arbitraires est la plus propre à former ce que l'on appelle le goust, et que c'est elle seule qui distingue les vrais Architectes de ceux qui ne le sont pas; parce que pour connoitre la plûpart des beautez positives, c'est assez que d'avoir du sens commun. $(1683: \mathrm{XII})^{128}$

Esta distinción supone un hito de crucial importancia en la historia de la teoría arquitectónica, dado que puede considerarse el precedente quizá primero que mina la pretensión de objetividad de la belleza clásica, asentando las bases del relativismo que aun tardará en consolidarse. De hecho, no será hasta a partir del siglo XVIII cuando sus teorías empezaron a tener éxito conforme se extendió el carácter subjetivo del bon goût. No interesa aquí tanto profundizar en los pormenores de la teoría que propone Perrault, sin duda aún asentada en posiciones clasicistas, sino destacar el arranque de un movimiento que ya resultará imparable hasta nuestros días: la desintegración del código clásico y la asunción del carácter artificial del lenguaje arquitectónico (Tafuri, 1978: 243-267).

\section{El principio estético de la "relación"}

Casi un siglo después, en Diderot se hará eco de este giro cuando toma un partido decidido a favor de la belleza relativa frente a la belleza absoluta y normativa del clasicismo, consolidando un movimiento intrínsecamente moderno que alcanzará su apogeo con la apología de lo contingente y transitorio en Baudelaire. Es cierto que en Diderot aún pueden identificarse máximas clasicistas (como son la defensa de la unidad, el orden o la proporción) pero, en cualquier caso, estas categorías ya no pueden estar sujetas a a prioris objetivos, sino que se impondrá desde entonces la primacía de la experiencia perceptiva. La distinción entre lo objetivo y lo subjetivo evidenciada por los Perrault adquiere entonces un estatuto metafísico en sintonía con las pujantes escuelas empiristas y sensistas, con la llamativa diferencia de que en Francia no se renuncia a la tradición cartesiana y se le sigue concediendo un papel determinante al entendimiento.

Así, en la Francia enciclopedista y en línea con su propio proyecto de autonomía (que no es propiamente el kantiano), se articula una muy inestable relación entre la experiencia y la razón, en donde el arte reconoce su compromiso simultáneo con las facultades perceptivas y las de la razón. En Diderot resuena esta duplicidad cuando para la definición de lo "bello" en la Encyclopédie destaca dos principios fundamentales:

\footnotetext{
Placez la beauté dans la perception des rapport, et vous aurez l'histoire de ses progrès depuis la naissance du monde jusqu'aujourd'hui; choississez pour caractère différentiel du beau en général, telle autre qualité qu'il vous plaira, et votre notion se trouvera tout à coup concentrée dans un point de l'espace et du temps. ${ }^{129}$
}

Por una parte, lo bello consiste, pues, en la captura de las relaciones y por otra la absoluta objetividad de dichas relaciones. Insiste en la transitoriedad de todo criterio sobre lo bello que no tenga por objeto la relación. En la línea de este giro hacia la experiencia estética, Diderot reduce incluso las 
nociones formales procedentes del clasicismo -normas eternas, "reglas esenciales de lo bello"- a un efecto de la razón a través de los sentidos: "pasaron por nuestros sentidos para poder llegar a nuestro entendimiento" (1982: 55-56). Lo cierto es que tanto en Diderot como anteriormente en los hermanos Perrault queda patente un delicado equilibrio entre la preservación de una estética de las reglas y la naciente estética del gusto. Con la llustración ciertamente se disipa toda posibilidad de recuperación de la metafísica tradicional, pero no por menos se implementa una nueva autoridad: la elaboración de reglas universales que tengan como fin la unificación de la variedad de lo dado. Así, el principio estético de la imitación, los órdenes clásicos - la autoridad de la Antigüedad se verán desbancados por otros principios que busquen congeniar la racionalidad con la emergencia de la experiencia estética.

El conflicto entre la razón y lo sensible atraviesa en efecto toda la estética ilustrada y son varios los intentos de congeniarlas. En Diderot se adelanta ya una teoría que estará llamada a ocupar un lugar central en la estética de la segunda mitad del XVIII: asumiendo el carácter subjetivo del gusto y no por tanto renunciando a la objetividad del juicio estético, la atención se dirige hacia el establecimiento de principios para una ciencia de la determinación de los juicios estéticos compatible con lo sensible. Esta ciencia, y en esto Blondel es un caso paradigmático, se fundamentará en el carácter objetivo de los "rapports":

Quand je dis qu'un être est beau par les rapports qu'on y remarque, je ne parle pas des rapports intellectuels ou fictifs que notre ima- gination y transporte, mais des rapports réels qui y sont, et que notre entendement y remarque par le secours des sens. [...] Que je pense ou ne pense point à la façade du Louvre, toutes les parties qui la composent n'en ont pas moins telle ou telle forme, et tel ou tel arrangement entre elles: qu'il y eut des hommes ou qu'il n'y en eut point, elle ne serait pas moins belle. (Blondel, $1771: 418$ y 425$)^{130}$

En "Analyse de l'art" describe los sistemas de categorización formal de los tipos de construcciones. En lugar de la teoría de los órdenes precedida de la teoría de los módulos o de tipo axiomático como en Boffrand, J.-F. Blondel propone una tipología de los diferentes sistemas de relación. Esta tipología se refiere al carácter del edificio, a las impresiones que se espera despertar en el espectador y su correspondencia con el edificio. En Cours d'architecture proporciona de hecho largas listas donde atribuye determinados caractères a determinados tipos arquitectónicos. Por nombrar algunos, de los templos cabría esperar décence, de los edificios públicos, grandeur, de los monumentos, la somptuosité, y así en adelante, (1771: 390) incluyendo categorías como sublime, admirable, original, piramidal, agradable, conveniente, misterioso,... con arreglo a una jerarquía y relacionadas con el efecto perseguido, los ejemplos a los cuales se puede referir, así como su sistema de calibración.

Respecto del proyecto de autonomía, es importante resaltar aquí que la arquitectónica del sistema planteado por Blondel no es de tipo platónico, a través del cual se podría dar acceso a esta relación de forma intencionada: "le goût est un sentiment des règles mêmes qu'on ne connaît pas". Y tampoco se trata de una inspiración, sin vínculo axiomá- en nombre, en situation; et généralment en tout ce qui les peut rendre semblables les unes aux autres; et il est assez étrange que Vitruve n'ait point parlé de cette sorte de Symmétrie que fait une grande partie de la beauté des Edifices" (1684: 9, n. 11). El concepto de symmétrie en su significado moderno -en el sentido de axialidad- es para Perrault un criterio ineludible para la belleza y rápidamente se incorporará de forma dogmática al clasicismo

126. El uso de un edificio adquirió a lo largo del siglo XVI una creciente importancia pero fue propiamente Perrault quien la elevó a categoría estética: "I'usage auquel chaque chose est destinée selon sa nature, doit estre une des principales raisons sur lesquelles la beauté de l'Edifice doit estre fondée" (1684: 214, n. 6)

127. Es significativo para lo que viene a continuación hacer notar aquí cómo Perrault desdobla el concepto clásico de symmetria en el moderno symmétrie - axialidad, luego objetivo- y proportion -fruto de una convención, luego arbitrario-

128. "Por lo tanto es cierto que hay bellezas positivas en la arquitectura y que hay algunas que son arbitrarias, aunque parecieran positivas debido a la prevención de la cual es muy difícil defenderse. Es también cierto que el buen gusto se basa en 
el conocimiento de ambas bellezas; pero es un hecho que el conocimiento de las bellezas arbitrarias es el más adecuado para formar lo que se llama gusto, y que solo ella distingue a los verdaderos Arquitectos de aquellos que no lo son; porque para conocer la mayoría de las bellezas positivas es suficiente tener sentido común."

129. "Situad la belleza en la percepción de las relaciones y tendreis la historia de su progreso desde el nacimiento del mundo hasta el presente; elegid como carácter diferenciador de la belleza en general cualquier cualidad que deseéis y vuestro concepto se encontrará repentinamente concentrado en un punto del espacio y el tiempo." Diderot conserva en este artículo la idea del placer como signo de la presencia de lo bello, pero hace de la percepción de lo bello la "saisie des rapports", es decir una operación del entendimiento. Posteriormente: "j'appelle beau hors de moi tout ce qui contient en soi de quoi réveiller dans mon entendement l'idée de rapports, et beau par rapport à moi tout ce qui réveille cette idée" (Diderot, 1993: 418).

130. "Cuando digo que un ser es bello por las relaciones que se constatan no hablo de las relaciones intelectuales o ficticias que traslada nuestra imaginación, sino de las relaciones reales que se dan y que nuestro entendimiento constata allí por la tico. El genio en la arquitectura se da por una adhesión casi instintiva al objeto, donde el detalle, "la finesse", juega un papel central: "des nuances imperceptibles qui échapent au vulgaire mais que l'artiste instruit sait saisir et que l'amateur sait applaudir. Lui seul en donnant l'essor au génie de l'architecte, l'élève au-dessus même des préceptes et le conduit à ce jugement qui est pour les talents le plus haut degré de perfection" (1771: 420). El clasicismo se mantiene, pues, como una estética de la percepción: el principio de perfección insiste en la máxima de la unidad (que ha de ser captada de un vistazo), la claridad, la legibilidad del edificio. De la legibilidad descuelgan, de hecho, los otros dos criterios: el de unidad en la variedad, la correspondencia entre el interior y el exterior. Recuérdese cómo el gusto consiste en una operación intelectual de captura de relaciones (que produce placer en el caso de la belleza). ${ }^{131} \mathrm{De}$ ahí que estas relaciones tengan que mostrarse lo más claramente posible, y de ahí que Montesquieu, por ejemplo, criticara el gótico por ser un "énigme pour l'oeil". La transparencia de las intenciones artísticas, la fidelidad al carácter del edificio son las máximas a seguir, y por aquel entonces para Blondel solo eran alcanzables a través de la estética de los órdenes, aunque no esté exenta de sofisticaciones de los sistemas formales, como así Diderot:

Le beau qui résulte d'un seul rapport, est moindre ordinairement que celui qui résulte de la perception de plusieurs rapports. La vue d'un beau visage ou d'un beau tableau affecte plus que celle d'une seule couleur; le ciel étoilé, qu'un rideau d'azur; un paysage, qu'une campagne ouverte; un édifice, qu'un terrain uni; une pièce de musique, qu'un son. Cependant il ne faut pas multiplier le nombre des rapports à l'infini; nous n'admettons de rapports dans es belles choses que ce qu'un bon esprit en peut saisir nettement et facilement... Tous conviennent qu'il y a un beau qui est le résultat des rapports perçus: mais selon qu'on a plus ou moins de connaissance, d'expérience, d'habitude de juger, de méditer, de voir, plus étendue naturelle dans l'esprit, on dit qu'un objet est pauvre ou riche, confus ou rempli, mesquin ou chargé. (Diderot, 1993: 428-429)

Blondel pretende asignar a cada edificio, a cada arquitectura, la relación óptima y legible, ajustándola al destino social del edificio. Es de hecho sintomático cómo sigue Diderot: "mais combien de compositions où l'artiste est contraint d'employer plus de rapports que le grand nombre n'en peut saisir, et où il n'y a guère que ceux de son art, c'est'à-dire les hommes les moins disposés à luis rendre justice, qui connaissent tout le mérite de ses productions". En el terreno de la arquitectura, esta multiplicidad y desajuste con lo social (algo que, por otra parte, también preocupaba a Blondel) viene a verse corregido por la orientación social de toda arquitectura.

En este sentido cabe entender la crítica hacia la proliferación y justificación del ornamento, como era el caso en el Rococó, entendida como excentricidad. El clasicismo defendía la simplicidad del estilo, cultivada a lo largo del XVIII, y llegando a su máximo grado de sofisticación en el llamado estilo Louis XVI. Así Montesquieu (1962): “Le goût [...] n'est autre chose que l'avantage de découvrir avec finesse et prontitude la mesure du plaisir que chaque chose doit donner aux hommes". En el clasicismo se da una estética de la espera previsible y satisfecha. Con la incorporación de la idea de genio, la analogía con la naturaleza pasa del estatismo a lo 
sublime, idea de sorpresa. Diderot, al referirse a la belleza de un teorema sostiene que: "La beauté qui consiste toujours dans les rapports, sera dans cette ocasion en raison composée du nombre de rapports et de la difficulté qu'il y avait à les percevoir. [...] Une circonstance qui n'est pas indifférente à la beauté, dans cette occasion et dans beaucoup d'autres, c'est l'action combinée de la surprise et des rapports, qui a lieu toutes les fois que le théorème dont on a démontré la vérité passait auparavant pour un proposition fausse" (Diderot, 1993: 430). La belleza ya no es una revelación de súbito y global (como en Blondel) sino un desvelarse las apariencias: "A l'esthétique de la façade succède la maîtrise d'une mise en scène et d'une mise en oeuvre de la nature" (Diderot, 1993: 420).

\section{Estética del carácter y de la expresión}

Con la querelle se espera poner freno al círculo vicioso en el que el clasicismo del siglo XVII incurrió: por una parte, el modelo de la Antigüedad se presentaba como insuperable y, por otra, se proponía como modelo a imitar. Por una parte, los Antiguos llegaron a conocer las normas que rigen la belleza racional y, por ello, son insuperables. Para el clasicismo, la perfección cabía encontrarla en un referente pretérito e inalcanzable. Por otra, los modernos se otorgan la capacidad de reformular esas normas racionales $y$, por lo tanto, asumen la necesidad de imitarlos. La crisis de la estética de la imitación puede a este tenor ser vista desde el punto de vista de una revisión del concepto de "perfección" en el arte. De hecho, es llamativo, adelantando ya lo que con Kant quedará explicitado, que el movimiento negativo contrario al concepto de "perfección" clasicista no viniese junto con una alternativa. Los "modernos" abrazarán así desde entonces la promesa de una perfección aun por determinar que se alejaba del principio de la imitatio en virtud de la nueva máxima de la inventio. ${ }^{132}$ En la era del proyecto de emancipación del hombre, la estética es una de sus manifestaciones y la emergencia de la estética del gusto da buena cuenta de ello. Con arreglo a la máxima burguesa del sujeto autónomo, el "ser dueño de sí mismo" se traslada al arte por medio del cuestionamiento del principio de autoridad encarnado en la imitación. Así con la querelle se da pie al cuestionamiento ya irreversible del carácter modélico de la Antigüedad y se abre la posibilidad de la creación artística como ampliación de la realidad.

La inversión del principio de imitatio, la irrupción del gusto, la quiebra del principio de autoridad, son todas consecuencias de un movimiento que se desarrolla en paralelo con la consolidación del discurso ilustrado y afecta de forma indeleble a la concepción misma de la arquitectura. Su versión más incisiva fue aquella que supo entender la difícil conjunción de la experiencia y la razón como un giro de la estética del objeto a la estética de la relación entre las obras y el espectador. Según este cambio de rumbo, la obra de arte ya no media entre unas verdades inmutables y atemporales, proporcionando placer en la medida en que da acceso a ella, sino que se vuelve propiamente un catalizador de emociones en el espectador. De la perfección de la imitación de lo antiguo, se pasa a la perfección del efecto causado. No en vano, con la consolidación de esta tendencia, se introducirán en el arte categorías contrarias al clasicismo como podría ser lo feo, lo arbi- ayuda los sentidos [...] Ya sea que piense o no piense en la fachada del Louvre, todas las partes que lo componen no tienen por menos esta o aquella forma y esta o aquella disposición entre ellas: aunque haya o no seres humanos no sería menos bella."

131. Este punto sería especialmente relevante cuando Goethe defienda que las proporciones se captan sin necesidad de medirlas porque las medidas no siempre coinciden.

132. Son numerosas las referencias que pueden encontrarse en las principales obras del periodo a la rivalidad entre la imitatio y la inventio. En Parallèle des Anciens..., Ch. Perrault la ilustra en las discusiones entre Le Chevalier, Le President y L'Abbé. Un pasaje especialmente significativo podría ser el correspondiente al segundo diálogo, en concreto, Perrault (1688-1697: 75-87) 
133. Es sintomático que esta noción se utilice en el XIX y $X X$ como diferenciación entre las obras de ingeniería y las de arquitectura en el debate arquitectos-ingenieros. 134. En la escuela privada de Blondel estudiaron Boullée, Ledoux y De Wailly. Boullée fue discípulo de Boffrand. 135. "si el dueño piensa a pequeña escala, querrá que su casa se haga de acuerdo con su idea: estará compuesta y adornada con baratijas. Si el dueño es de carácter modesto y sublime, su casa se distinguirá más por la elegancia de las proporciones que por los ornamentos y la riqueza de la materia. Si el dueño es de un carácter irregular y extraño, su casa estará compuesta de disparidades y partes sin acuerdo; de modo que se puede juzgar el carácter del dueño de la casa, que la hizo construir para sí mismo, por la manera en que está dispuesta, adornada y amueblada." trario, lo enfermo... y lo que interesa destacar aquí, la expresión.

Esta expresión en el arte ilustrado, deudora de la psicología de la época, consiste en la transmisión por medios artísticos de estados emocionales tipificados, luego, no individuales, y antecede a la tesis romántica de la expresión como movimiento hacia la autonomía. En rigor, se sitúa aún bajo los parámetros de la estética de la imitación: establece un sistema de identidad entre los estados emotivos y ciertas manifestaciones concretas del arte. Luego, imitación y expresión conviven al pertenecer ambos al movimiento de realización artística que la une con la naturaleza. Esta expresión representacional se distingue fundamentalmente de aquella que se desarrollará a lo largo del romanticismo al desplazar el foco de la estética desde la función sensible hacia la cognoscitiva. Ese es el excedente esencial al que Kant se referirá posteriormente: el acceso a través del arte a una realidad inasible por medios lingüísticos (Marrades, 2005: 29-51).

Según lo presentado hasta ahora, una de las derivaciones posibles de la perfección en la arquitectura que atiende a la nueva baraja ilustrada, es decir, que da cuenta de la irrupción de la experiencia estética como una nueva componente ineludible de la ecuación, fue la introducción desde la teoría de los "rapports" del concepto crucial de caractère. ${ }^{133}$ Si la conceptualización más completa de esta teoría corre a cargo de Blondel "el joven", no puede obviarse el precedente de Boffrand, de especial importancia en lo que sigue. En efecto, tanto el primero como el segundo tuvieron una muy notable influencia entre los arquitectos que se han venido a llamar "re- volucionarios". ${ }^{134}$ La idea de caractère como función expresiva de un edificio entronca en efecto con Boffrand para quien las obras han de revelar en virtud de su disposición, estructura y decoración, las funciones para las que han sido construidas. En Livre d'architecture, Boffrand se apoya en sus propias construcciones -recuérdese que se trataba a diferencia de Blondel de un arquitecto con numerosa obra construida- e introduce quizás por primera vez en la arquitectura el concepto de "caractère": "J'appelle caractère l'effet qui résulte de cet objet et cause en nous une impression quelconque" (Bffrand, 1745: 26). Así, se extiende por ejemplo en cómo la arquitectura doméstica ha de reflejar el "esprit" del propietario, quien "donne le ton à l'Architecte qui doit en faire le plan, suivant ce qui convient à la dignité et à l'état du Proprietaire", tanto en los interiores de la casa como en su apariencia exterior. Algo que, por otro lado, ya defendía Vitruvio cuando dice que la casa debe ser adecuada a la dignidad y el rango del propietario. Así lo planteaba Boffrand:

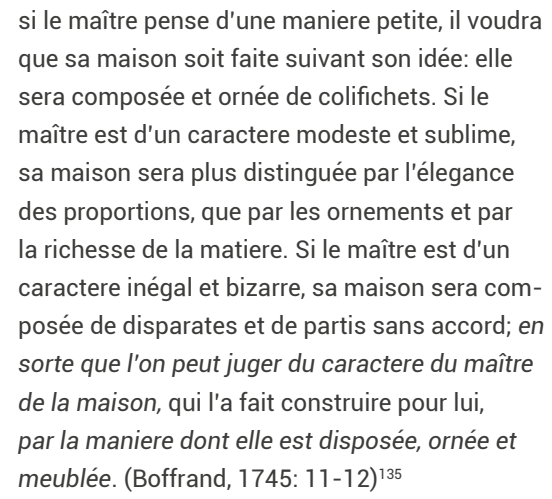
que sa maison soit faite suivant son idée: elle sera composée et ornée de colifichets. Si le maître est d'un caractere modeste et sublime, sa maison sera plus distinguée par l'élegance des proportions, que par les ornements et par la richesse de la matiere. Si le maître est d'un caractere inégal et bizarre, sa maison sera composée de disparates et de partis sans accord; en sorte que l'on peut juger du caractere du maître de la maison, qui l'a fait construire pour lui, par la maniere dont elle est disposée, ornée et meublée. (Boffrand, 1745: 11-12) ${ }^{135}$

Desde entonces en los escritos de Blondel y en los de Le Camus de Mézières se da lugar a una técnica de la expresión arqui- 
tectónica que tiene por fin controlar las impresiones a través de las formas arquitectónicas. La teoría de la proporción se integrará en una reflexión general sobre la analogía que relaciona las proporciones con los efectos, tal y como explícitamente menciona Le Camus:

personne n'a encore écrit sur l'analogie des proportions de l'architecture avec nos sensations; nous n'en trouvons que des fragments épars peu appronfondis; pour ainsi dire jetés au hasard [...] jusqu'ici on a travaillé d'après les proportions des cinq ordres d'architecture employés dans les anciens édifices de la Grèce et de l'Italie... Combien d'artistes n'ont employé ces ordres que machinalement sans saisir les avantages d'une combinaison qui put faire un tout caractérisé capable de produire certaines sensations; ils n'ont pas conçu plus heureusement l'analogie et le rapport de ces proportions avec les affections de l'âme. (Le Camus, 1780 : $1-2)^{136}$

En esta línea de reflexión, Boffrand afirma que "Les différents Edifices par leur disposition, par leur structure, par la manière dont ils sont décorés, doivent annoncer au spectateur leur destination" (1745: 16). ${ }^{137} \mathrm{Al}$ margen de que en Boffrand prime aun una idea objetiva del bon goût (contrario al subjetivismo absoluto que daría lugar al predominio de la moda frente al perfeccionamiento del arte, "La mode le tyran du Goût" (1745: 8)), la exigencia de contenido en la arquitectura -aunque no corresponda propiamente al ámbito de la estética- a través de su teoría del caractère puede considerarse como la base de los planteamientos autonomicistas en la arquitectura, entre los que destacan la así llamada "Arquitectura de la Revolución".
136. "nadie ha escrito aún sobre la analogía de las proporciones de la arquitectura con nuestras sensaciones; no encontramos más que fragmentos dispersos de poco calado; por así decirlo, lanzados al azar [...] hasta ahora hemos trabajado de acuerdo con las proporciones de los cinco órdenes de la arquitectura utilizadas en los antiguos edificios de Grecia e Italia... Cuántos artistas han utilizado estos órdenes más que mecánicamente sin aprovechar las ventajas de una combinación que podría hacer un todo caracterizado capaz de producir ciertas sensaciones. No han concebido más felizmente la analogía y la relación de estas proporciones con las afecciones del alma." 137. "Los diferentes Edificios por su distribución, por su estructura, por la forma como están decorados, deben anunciar al espectador su fin." 
138. El contenido de este apartado fue parcialmente publicado en A. Rubio-Garrido (2015), “Hacia una estética de la arquitectura. Kant y la crisis del clasicismo", en A Rubio-Garrido (ed.), Textos fundamentales de la estética de la arquitectura. València: General de Ediciones de Arquitectura, pp. 198-217. 139. Más adelante se destacará el sorprendente hecho de que obras tan significativamente "kantianas" como las de Ledoux antecedan la publicación de la Crítica del gusto de 1790. Obviamente, el referente común que supuso Rousseau es una hipótesis de lo más plausible para dar cuenta de esto. Pero, antes bien, parece confirmarse la sospecha de Hegel según la cual el vuelo de los análisis filosóficos despega tras el ocaso de los cambios culturales.

140. "de ahí que Kant pueda ser visto como responsable no solo de la idea de que la arquitectura deba expresar ideas, sino también de las discrepancias en torno a qué ideas ha de expresar la arquitectura" ["Kant might then be seen as responsible not only for the idea that architecture should express ideas but also for the competing views about what ideas architecture should express"] (Guyer, 2011: 7).

141. "Muchos pájaros (el loro, el colibrí, el ave del paraíso), multitud de peces del mar, son bellezas en sí que no

\section{La revolución kantiana en la arqui- tectura $^{138}$}

\section{El "giro" kantiano: funcionalidad y belleza en la arquitectura}

\author{
La filosofía trascendental es la idea de una \\ ciencia cuyo plan tiene que ser enteramente es- \\ bozado por la crítica de la razón pura de modo \\ arquitectónico, es decir, a partir de principios, \\ garantizando plenamente la completud y la \\ certeza de todas las partes que componen este \\ edificio. (Kant, 1997: 50)
}

Las referencias explícitas de Kant a la arquitectura en sus dos obras fundamentales en las que trata el problema de la estética pueden contarse con los dedos de una mano. No obstante, es significativo que para hacer visible la idea de filosofía trascendental que tenía, echase mano de la metáfora arquitectónica. De hecho, aunque parezca baladí, la influencia kantiana en la arquitectura será más del orden de lo no-dicho que de lo dicho, de lo sugerido - si se prefiere- que de lo explicitado.

Aun con esas, en lo que sigue se defenderá que, lejos de pasar desapercibida, la influencia de su teoría estética va a suponer un vuelco crucial para la estética de la arquitectura. Hasta el punto de que se puede hablar de una estética de la arquitectura prekantiana en contraposición a la postkantiana, que se manifiesta en autores tan dispares como Schopenhauer, Schelling o Hegel. Tras Kant, la arquitectura tendrá que enfrentarse a la milenaria terna vitruviana incorporando a la belleza y utilidad la necesidad de expresar "ideas estéticas", vuelco este de crucial importancia. En efecto, el desarrollo de la estética kantiana a lo largo del siglo XIX, así como la práctica arquitectónica que le siguió, ${ }^{139}$ quedan ya indisolublemente ligadas tanto a lo que Kant dijo sobre las artes como a lo que omitió. De suerte que se le pueda achacar a Kant esta doble responsabilidad:140 haber formulado la pregunta y no haberla contestado.

Hasta ahora, el análisis de la teoría general de la crítica del gusto de Kant pretendía aislar cuáles eran las características de tal juicio y su repercusión en la irrupción de la autonomía en la estética. Pero, ¿cuáles son las características del objeto hacia el que se moviliza este juicio? Para explicarlo, Kant se sirve de objetos naturales o de ejemplos del arte decorativo ${ }^{141}$ apoyándose en el juicio más paradigmático del gusto: aquel que atiende a la belleza (Kant, 2007: §8). Aquello que los caracteriza, y de ahí que en su explicación se sirva de ellos, es que no atienden a ningún fin más allá de sí mismos. Es decir, en el juicio estético de estos objetos, no puede verse influido por ningún interés adicional. Esto, por supuesto, excluiría todo aquel objeto que tuviese que cumplir con una función, dado que el juicio de tal objeto se vería por fuerza influido por esa orientación de su fin. Dicho de otra forma: el juicio de semejante objeto no podría cumplir con la máxima de ser desinteresado. No puede intervenir en el juicio de lo bello nada que tenga que ver con la función de un objeto.

Asimismo, el hecho de que no se pueda reclamar en estos juicios la mediación de concepto alguno, no puede ser propiamente independiente de nuestras facultades cognitivas al completo si ha de reclamarse para el juicio del gusto una validez universal. Esta tesis quedó sintetizada en el "libre 
juego de las facultades": la multiplicidad de la experiencia se presenta como objeto para la imaginación, pudiendo así satisfacer la necesidad de coherencia y unidad del entendimiento.

La universal comunicabilidad subjetiva del modo de representación en un juicio de gusto, debiendo realizarse sin presuponer un concepto, no puede ser otra cosa más que el estado de espíritu en el libre juego de la imaginación y del entendimiento [...], teniendo nosotros consciencia de que esa relación subjetiva, propia de todo conocimiento, debe tener igual valor para cada hombre $y$, consiguientemente, ser universalmente comunicable, como lo es todo conocimiento determinado, que descansa siempre en aquella relación como condición subjetiva. (Kant, 2007: 131)

De todo esto deriva el hecho de que el objeto capaz de producir dicho estado ha de tener la forma de una "finalidad sin fin", tal y como desarrolla Kant fundamentalmente en $\S 11$. Dicho esto, ¿dónde queda la arquitectura?

La exclusión de toda finalidad en un objeto que pueda alcanzar estatus de obra de arte parece dejar en un lugar comprometido a la arquitectura. No obstante, Kant no excluye la posibilidad de encontrar "belleza formal pura" en objetos de mayor complejidad producidos por el hombre (más allá de los ya citados animales, motivos decorativos o la música sin texto). ${ }^{142}$ De hecho, al principio de su Crítica del Juicio se sirve de un ejemplo arquitectónico para ilustrar lo que por juicio desinteresado de ahí en adelante ha de entenderse. ${ }^{143}$ Cuando se trata de valorar si un objeto es bello por medio del gusto, no cabe hacer referencia a aquello que une la necesidad del que juzga con el objeto. Se trata, por el contrario, de serle indiferente para poder emitir un juicio de forma pura. Preguntado por la belleza de un palacio cabría, pues, contestar:

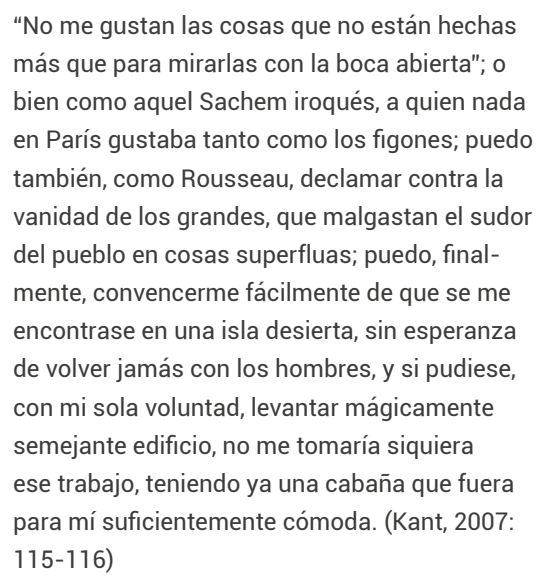

“No me gustan las cosas que no están hechas más que para mirarlas con la boca abierta"; o bien como aquel Sachem iroqués, a quien nada en París gustaba tanto como los figones; puedo también, como Rousseau, declamar contra la vanidad de los grandes, que malgastan el sudor del pueblo en cosas superfluas; puedo, finalmente, convencerme fácilmente de que se me encontrase en una isla desierta, sin esperanza de volver jamás con los hombres, y si pudiese, con mi sola voluntad, levantar mágicamente semejante edificio, no me tomaría siquiera ese trabajo, teniendo ya una cabaña que fuera para mí suficientemente cómoda. (Kant, 2007: 115-116)

El juicio del gusto no se deja -no debe dejarse- influir por el aparato social, por la fatuidad o vanidad infundada. Ni consiste en juzgar con arreglo a un interés individual relativo al objeto en cuestión, como sería el caso del jefe iroqués al que hace referencia Kant: a su llegada a París en el esplendor francés de la segunda mitad del diecisiete, mostraron perfecta y consciente indiferencia hacia la pompa y, en cambio, quedaron cautivados por la exuberancia de tienduchas de carne de la calle Huchette. ${ }^{144}$ En el juicio del gusto referido a un edificio -o así podría deducirse de este extracto- la utilidad de la obra arquitectónica, el esfuerzo social que esta acarree o su necesidad o prescindibilidad no han de intervenir si este quiere ser genuino: el juicio del gusto debería ser puramente formal, es decir, debería atender exclusivamente a la forma de dicho edificio, en su carácter de "finalidad sin fin". El juicio estético respecto pertenecen a ningún objeto determinado por conceptos en consideración de su fin, sino que placen libremente y por sí. Así, los dibujos à la grecque, la hojarasca para marcos o papeles pintados, etc., no significan nada por sí, no representan nada, ningún objeto, bajo un concepto determinado, y son bellezas libres. Puede contarse entre la misma especie lo que en música se llama fantasía (sin tema), e incluso toda la música sin texto" (Kant, 2007 144-145).

142. Véase §16: El juicio de gusto, mediante el cual un objeto es declarado bello bajo la condición de un concepto determinado, no es puro (Kant, 2007: 144-146) 143. "Cada cual debe confesar que el juicio sobre la belleza en el que se mezcla el menor interés es muy parcial y no es un juicio puro de gusto. No hay que estar preocupado en lo más mínimo de la existencia de la cosa, sino permanecer totalmente indiferente, tocante a ella, para hacer el papel de juez en cosas del gusto" (Kant, 2007: 116).

144. De acuerdo con una referencia de los editores en la nota 26 (2007: 115), Kant trae a colación esa anécdota inspirándose en Histoire et description générale de la Nouvelle France. Charlevoix, su autor, fue misionero jesuita enviado a las colonias francesas en 1720 y publicó el primer estudio sobre la 
Nueva Francia. En el pasaje en cuestión, Charlevoix desarrolla las razones por las cuales puede considerarse que los iroqueses, aun en su "condición de salvajes", han alcanzado un estado consciente de felicidad. La vida que llevan estos salvajes puede parecer inicialmente dura, pero solo desde el desconocimiento y por comparación a la europea. Su felicidad, defiende Charlevoix, es real: "premierement, parce qu'ils croyent l'être; en second lieu, parce qu'ils sont dans la possession paisible du plus précieux de tous les dons de la Nature; enfin parce qu'ils ignorent parfaitement, $\&$ n'ont pas même envie de connoître ces faux biens, que nous estimons tant, que nous achetons au prix des véritables, \& que nous goûtons si peu". Por esta razón han de ser vistos a ojos franceses como "de vrais Philosophes" por ser completamente ajenos a las comodidades, magnificiencias y riquezas. $Y$ de ahí la anécdota que debió llamar la atención a Kant: “Des Iroquois, qui en 1666 allerent à Paris, \& à qui on fit voir toutes les Maisons Royales, \& toutes les beautés de cette grande Ville, n'y admirerent rien, \& auroient préferé leurs Villages à la Capitale du plus florissant Royaume de l'Europe, s'ils n'avoient pas vû la Ruë de la Huchette, où les Boutiques des Rotisseurs, qu'ils trouvoient toujours garnies de Viandes de toutes de la arquitectura, a diferencia de la terna vitruviana, concerniría en Kant solo la belleza formal:

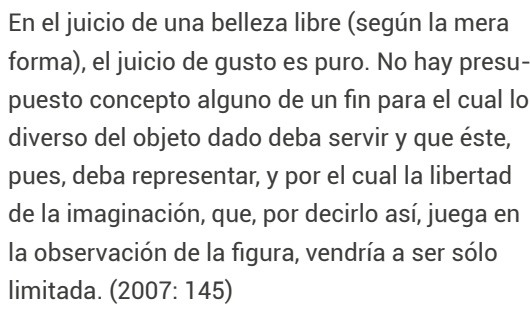
forma), el juicio de gusto es puro. No hay presupuesto concepto alguno de un fin para el cual lo diverso del objeto dado deba servir y que éste, pues, deba representar, y por el cual la libertad de la imaginación, que, por decirlo así, juega en la observación de la figura, vendría a ser sólo limitada. (2007: 145)

El gusto permite distinguir entre la belleza de dos objetos con arreglo a su orientación a un fin. Si una rosa puede ser bella, en ningún caso es esta belleza idéntica a la de un objeto artístico. En el primer caso, lo bello de una rosa no determina concepto alguno en el objeto en cuestión. Se trata de una belleza libre (pulchitudo vaga), es decir, no condicionada a proyección de fin alguno. La rosa es puramente bella. En cambio, en el caso de un edificio se presupone un concepto al mismo y con arreglo a este se orienta una idea de perfección. No cabe aislar esa obra de arte de un cierto ámbito de condicionalidad: para poder entenderse un edificio como tal ha de cumplir de antemano con unos requisitos que se anteponen a todo juicio sobre su belleza. Se trataría en este caso de una belleza adherente (pulchitudo adhaerens). Está condicionada a un fin particular.

Esta distinción adquiere una crucial importancia para el análisis kantiano de la arquitectura. El loro, el colibrí o multitud de peces son para Kant bellezas en sí mismas puesto que no han de cumplir ningún fin juzgable por el gusto (pueden, como así lo haría un zoólogo, valorar su adecuación a ciertos fines naturales como son su capacidad motriz o su adaptación al medio, pero en ningún caso para Kant serían estos fines sujetos a una perfección estética). La belleza de un edificio, en cambio, así como la humana o la de un caballo, "presupone un concepto de fin que determina lo que deba ser la cosa; por tanto, un concepto de su perfección: así pues, es belleza adherente". De ahí que no pueda hablarse en el caso de la arquitectura de un juicio de gusto puro:

Así como el enlace de lo agradable (de la sensación) con la belleza, que propiamente sólo concierne a la forma, impide la pureza del juicio de gusto, así el enlace del bien (para el cual lo diverso es bueno a la cosa misma, según su fin) con la belleza daña la pureza de esta. (2007: 145)

La cuestión gira en torno a la autonomía o no del juicio sobre la arquitectura: de igual manera que el juicio sobre los fastuosos palacios parisinos del iroqués venía mediado por lo agradable y no podía considerarse un genuino juicio de gusto, aquel juicio propio de la arquitectura que atiende $-y$ no puede ser de otra forma- a la función se ve interpelado por un juicio moral (sobre lo bueno). ${ }^{145} \mathrm{Se}$ trata de una unión entre el gusto y la razón, un enlace entre el sentimiento de placer y la facultad de desear: "[e]stas no son, sin embargo, entonces, reglas del gusto, sino solamente de la unión del gusto con la razón, es decir, de lo bello con el bien" (2007: 146).

En efecto, en un juicio de gusto no puro, como es el caso de aquel que atiende a la arquitectura -es decir, un juicio de belleza adherente-, presupone un concepto de fin final (una funcionalidad), restringiendo por ello la libertad de la imaginación. Pero esto no implica que haya de negársele la posibilidad a la arquitectura de movilizar el "libre juego 
de las facultades", en la medida en que para Kant queda claro que la belleza adherente es un tipo de belleza y la arquitectura un arte, aunque no puro. De hecho, Kant llega a ilustrar la idea de belleza adherente en el caso de la arquitectura con ejemplos explícitos:

Podrían añadirse inmediatamente en la intuición de un edificio muchas cosas que nos plugieran si no fuera porque debe ser una iglesia; podría embellecerse una figura con toda clase de rayas y rasgos ligeros, si bien regulares, como hacen los neozelandeses con sus tatuajes, si no tuviera que ser humana, y ésta podría tener rasgos más finos y un contorno de las formas de la cosa más bonita y dulce, si no fuera porque debe representar un hombre o un guerrero. (2007: 145)

El carácter añadido de la belleza adherente se refiere a la representación del objeto mediante el juicio y no al objeto en sí. Aquello que sobrepasa la mera belleza -aquello que presupone fin final-, ha de ir empero relacionado con el "fin interno" -del que depende su mera posibilidad-del objeto en cuestión. Sobre esta delicada cuestión Kant apenas adelanta argumentos. Pero es de suponer, a tenor de lo explicado hasta el momento, que el hecho de que una iglesia, dado que sirve para el recogimiento espiritual, ha de transmitir la necesaria sobriedad y humildad que corresponde a la religión (evidentemente cristiana protestante). Así, podría deducirse que un palacio mostrará arquitectónicamente el poder y riqueza de su habitante, que una fortaleza transmitirá una clara representación de su solidez y de su amenazante presencia, que un palacio de justicia inspirará rigor y contundencia... Pero sobre cómo ha de congeniarse este carácter expresivo con la belleza y la utilidad Kant apenas da pistas. Por una parte, las citas precedentes parecen sugerir que, en el caso concreto de la arquitectura, el cumplimiento por parte de un edificio de su función es una condición previa a todo juicio de gusto. Esto sería tanto como decir que el acceso a un juicio sobre su belleza quedaría anulado de no atender a su orientación práctica. En tal caso la funcionalidad en la arquitectura no sería un criterio a tener en cuenta a la hora de juzgar su belleza, lo que sería coherente con el hecho de que la belleza no implique concepto alguno.

Por otra parte, ha quedado dicho que en la belleza adherente, a diferencia de la pura, sí están implicadas unas ciertas normas apriorísticas (de tipo funcional en el caso de la arquitectura, de tipo cultural en el caso de los tatuajes...) y por eso se orienta hacia la idea de perfección. Y, aunque el estado de belleza y perfección haya de valorarse con la facultad del espíritu correspondiente, Kant reconoce que, habida cuenta de la indivisibilidad del objeto en cuestión, no puede entenderse la una sin la otra e, incluso, no puede evitarse las interferencias mutuas:

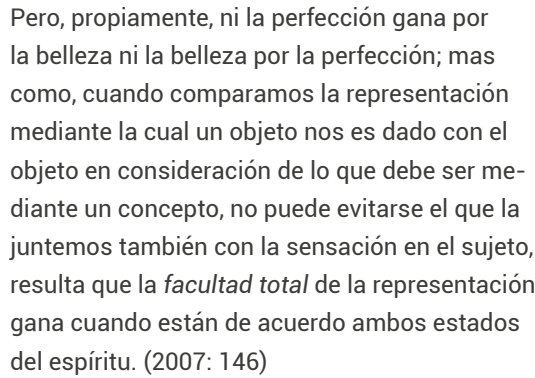

Ambas "facultades de conocer", el Juicio (que juzga la belleza formal) y la razón (que atiende a su orientación práctica) intervienen en la valoración de la arquitectura. No hay forma de juicio de la arquitectura les sortes, les charmerent beaucoup" (de Charlevoix 1744: 321-322)

145. Véase las notas al pie 6 y 126 de la Parte I para mayor aclaración sobre en qué medida se puede hablar de una cierta "autonomía del arte" en Kant, pese a su total silencio al respecto. 
146. Textualmente: "El juicio del gusto tiene que referirse a algún concepto, pues de otra manera no podría en absoluto tener pretensión de validez necesaria para todos" (2007: §57). Esto podría interpretarse, de hecho, como una contradicción interna en su sistema, dado que el juicio del gusto "no da absolutamente conocimiento alguno [exclusivo del juicio lógico] (ni siquiera confuso) del objeto" (2007: 143), si no es porque Kant se apresura a precisar que por "concepto" en el juicio del gusto ha de entenderse aquel "que no se deje determinar en nada por medio de una intuición, a través del cual nada pueda conocerse $y$, por tanto, tampoco pueda llevarse a cabo ninguna prueba para el juicio del gusto" (2007: §57).

147. Véase el apartado "2. A. Autonomía trascendental". 148. "genio es la capacidad espiritual innata (ingenium) mediante la cual la naturaleza da la regla al arte" (2007: 233). en la que no intervenga también la razón en la medida en que evalúa su adecuación al fin. $Y$, es más, quedan de alguna forma potenciadas recíprocamente en virtud de su acuerdo (Guyer, 2002: 357-366). Algo que recuerda sobradamente a los criterios estéticos vitruvianos sobre la combinación entre belleza y funcionalidad.

\section{Expresión y moral: la exigencia de autonomía}

La conclusión que trajo el análisis del primer libro de la Crítica del Juicio - "La analítica de lo bello" (§1-22)- consistía en otorgar al juicio de la belleza un carácter independiente de todo concepto para ser genuino. No obstante, en aparente paradoja, se hizo evidente que la obra de arte -como producto humano- está guiada por conceptos. Si el arte no es ni naturaleza ni artesanía es precisamente porque se trata de una producción en libertad es decir, "mediante una voluntad que pone razón a la base de su actividad". De ahí que no pueda llamarse arte el producto de un instinto, como sería el caso de un panal de abejas, ni de la necesidad (arte mercenario, así Kant) como el zapatero (2007: 228-230). ¿Cómo un producto intencional y racional, como es una obra de arte, puede en algún caso ser juzgado sin implicar conceptos?

Kant adelanta una solución a esta espinosa cuestión en su teoría de las bellas artes (en concreto, la combinación de la teoría del genio y la de la "idea estética"). Ciertamente, tanto la producción de una obra de arte como su recepción involucran conceptos, pero no los determinan: ${ }^{146}$ para que una producción humana libre (distinta de la naturaleza, distinta del oficio o artesanía) pueda alcanzar la condición de obra de arte ha de estar guiada por concepto (la técnica, entre otros) pero no debe quedar sometida a ellos. Esta delicada convivencia entre la autonomía y la imposibilidad de intervención intencionada en la obra de arte, queda solventada ${ }^{147}$ en la teoría del genio: ${ }^{148}$

Pues cada arte presupone reglas mediante cuya fundamentación tan sólo puede un producto, si ha de llamarse producto de arte, representarse como posible. Pero el concepto del arte bello no permite que el juicio sobre la belleza de su producto ser deducido de regla alguna que tenga un concepto como base de determinación, que ponga, por lo tanto, a su base un concepto del modo como el producto sea posible. Así pues, el arte bello no puede inventarse a sí mismo la regla según la cual debe efectuar su producto. Pero como sin regla anterior no puede un producto nunca llamarse arte, debe la naturaleza dar la regla al arte en el sujeto (y mediante la disposición de la facultad del mismo), es decir, que el arte bello sólo es posible como producto del genio. (2007: 234)

La naturaleza del contenido en la obra de arte, conceptual pero sin que medie concepto ni en su juicio ni en su producción, corresponde a lo que Kant define como la idea estética: "la representación de la imaginación que provoca pensamiento alguno, sin que, sin embargo, pueda serle adecuado pensamiento alguno, es decir, concepto alguno, y que, por lo tanto, ningún lenguaje expresa del todo ni puede hacer comprensible. Fácilmente se ve que esto es lo que corresponde (el pendant) a una idea de la razón, que es, al contrario, un concepto al cual ninguna intuición (representación de la imaginación) puede ser adecuada" (2007: 241). De lo que deriva que toda obra de arte con espíritu ${ }^{149}$ contiene una idea estética, que es un concepto a fin de cuentas pero con un 
carácter extralingüístico: la autonomía de la estética que se jugaba en el campo de la libertad tiene su experiencia en el libre juego de la imaginación, que gracias a las ideas estéticas puede acceder por conceptos sin supeditarse a ellos.

En definitiva, la belleza estética defendida por Kant no es tan formal como en un principio pareció. Ciertamente, su presentación de la "analítica de lo bello" podría inducir a esa conclusión, pero una vez presentadas sus teorías sobre el genio y la idea estética queda claro que la belleza, lejos de quedar al margen, sugiere un contenido conceptual. Que la autonomía de la estética, es decir, del juicio del gusto, quede indemne de semejante giro depende de la manera en la que se presentan estos conceptos: lo hacen de forma tal que no pueden reducirse a regla alguna. Se trata más bien de un libre juego de la imaginación mediada por el entendimiento, de tal forma que este fije reglas que son superadas por el genio. De ahí que no sea posible ni controlar lo que produce (de lo contrario sería producto supeditado al entendimiento), ni la recepción de la obra (de lo contrario no podría incitar al libre juego de las facultades).

En la división de las bellas artes (§51), Kant distingue las artes de la palabra (oratoria y poesía) de las figurativas [bildenden Künste] o "de la expresión de las ideas en la intuición sensible (no por medio de representaciones de la mera imaginación excitadas por las palabras)". Estas últimas "expresan ideas con figuras, en el espacio" (2007: 250). Bien sea la pintura [Mahlerkunst, literalmente "arte de la pintura"] o la plástica [Plastik], es decir, bien sea que atienda únicamente al sentido de la vista o bien a este junto al del tacto, culminan en un objeto, "una extensión corporal". Ahora bien, en las que - siendo espaciales, luego físicas- se consideran artes plásticas, cabe distinguir entre la escultura [Bildhauerkunst, literalmente "arte de tallar -behauen- imágenes"] y la arquitectura [Baukunst, "arte de construir"]. La referencia a la arquitectura de mayor extensión en la Crítica del Juicio se encuentra sintomáticamente en forma de una alambicada comparación respecto de la escultura:

En la plástica, como primer modo de las bellas artes de la forma, entran la escultura y la arquitectura. La primera es la que expone corporalmente conceptos de cosas, tal como podrían existir en la naturaleza (como arte bello, teniendo, sin embargo, en cuenta la finalidad estética); la segunda es el arte de exponer conceptos de cosas que sólo por el arte son posibles, y cuya forma tiene como fundamento de determinación, no la naturaleza, sino un fin arbitrario, y ha de ser para ello, sin embargo, al mismo tiempo, estéticamente conforme a fin. En la segunda, un cierto uso del objeto del arte es lo principal, y a él, como condición, subordínanse las ideas estéticas. En la primera, la mera expresión de ideas estéticas es la intención principal. Así, estatuas de hombres, dioses, animales, etc., pertenecen a la primera clase, $y$, en cambio, templos, edificios magníficos para reuniones públicas, o también habitaciones, arcos de triunfo, columnas, mausoleos, etc. erigidos para honrar una memoria, pertenecen a la arquitectura. Hasta los utensilios todos de la casa (el trabajo del carpintero y otras cosas semejantes para el uso) pueden contarse en ésta, porque lo esencial de un edificio lo constituye la acomodación del producto para un cierto uso, y en cambio, una mera obra de figura que no está hecha más que para la intuición y debe placer por sí misma, es, como exposición corporal, mera imitación de la naturaleza, aunque, sin embargo, tiene en cuenta las ideas estéticas, pues en ellas la verdad sensible no puede ir
149. Una obra de arte puede o no tener espíritu [Geist], algo de lo que no depende el juicio de gusto que sobre ella se formule. El espíritu es básicamente el "principio vivificante del alma; pero aquello por medio de lo cual ese principio vivifica el alma, la materia que aplica a ello, es lo que pone las facultades del espíritu con finalidad en movimiento, es decir, en un juego tal que se conserva a sí mismo y fortalece las facultades para él" (2007: 214) 
tan lejos que cese la cosa de aparecer arte y producto de la voluntad. (2007: 250-251)

Kant asume, pues, que tanto escultura como arquitectura han de combinar el objetivo de alcanzar la belleza con la expresión de ideas estéticas (es decir, ideas racionales conducidas por medios estéticos). Conviene precisar que para Kant, como no podría ser de otra forma habida cuenta de las condiciones materiales de la escultura en el siglo XVIII, la escultura solo puede entenderse como "imitación de la naturaleza". Estatuas de hombres o animales, por su propio condicionamiento previo, han de ser reconocibles como tales, y por tanto han de plasmar formas ajenas a su medio, formas propias de la naturaleza. Incluso cuando se trata de esculturas irreales (o, dicho de otra forma, sobrenaturales), como es el caso de un dios, se realizará de suerte que una composición de elementos naturales pueda dar lugar a una representación de aquello que no es natural (sería el caso conocido de las quimeras: combinación de partes naturales para dar lugar a un conjunto que se presenta como sobrenatural).

Parecería así que la arquitectura, en comparación, tiene un mayor margen de maniobra a la hora de expresar ideas estéticas, puesto que no imita a la naturaleza. Es más, en términos de Kant, la arquitectura se muestra como genuinamente estética en la medida en que las ideas que expresa son solo alcanzables por medio del arte: "es el arte de exponer conceptos de cosas que sólo por el arte son posibles". En este sentido, la arquitectura, a diferencia de la escultura, no se vería afectada por esa mengua de su autonomía.

Pese a ello, algo constriñe a la arquitectura que no afecta a la escultura: la arqui- tectura está orientada hacia el cumplimiento de un uso. Es esta una condición previa, a la que por fuerza han de subordinarse el resto de elementos que la completen, entre ellos las ideas estéticas: "un cierto uso del objeto del arte es lo principal, y a él, como condición, subordínanse las ideas estéticas". Quiere esto decir que las ideas estéticas han de acomodarse a esta condición y, de ahí, ciertas formas estéticas quedarán vedadas y otras tendrán mayor validez en la medida en que se potencien mutuamente.

En definitiva, de esta comparación puede deducirse que tanto la escultura como la arquitectura son artes que por sus condiciones internas sufren algún tipo de restricción a la libre expresión de ideas estéticas: la primera porque imita a la naturaleza, limitando por tanto el tipo de idea estética que puede representar y la manera de llevarlo a cabo; la segunda porque ha de cumplir con el mandato de funcionalidad, que ha pasado a ser "lo esencial de un edificio". 


\section{La recepción de Schiller. símbolo y moral}

Con la irrupción de la estética autónoma, y muy especialmente, con la incorporación de esquemas epistemológicos a la estética, se da un giro crucial en el devenir de la teoría arquitectónica. De manos de Kant, y su publicación clave Crítica del Juicio de 1790, las bellas artes -entre las que se encuentra la arquitectura- han de afrontar un nuevo reto: si en general el arte para Kant conlleva la expresión de ideas estéticas, es decir, conceptos que entran en libre juego con la imaginación, en el caso de la arquitectura, el reto se sitúa en su capacidad para aunar ese impulso autonomizador en las artes con su necesaria naturaleza práctica.

La estética vitruviana de la arquitectura en su interpretación moderna centró en la combinación de belleza y utilidad los objetivos que debía perseguir la arquitectura $y$, ciertamente, Kant insiste a su vez en la necesidad de combinar el valor estético de la arquitectura con su orientación funcional (un fin objetivo). Pero, a tenor de lo expuesto, es indispensable excluir del juicio estético toda intromisión de eso ajeno a la estética. $\mathrm{Y}$, aun con todo, no se puede negar que la mera posibilidad de la arquitectura impone la supeditación de lo estético a su uso. De hecho, a este tenor, se pudo argumentar en el capítulo anterior que la concepción kantiana de la belleza parece a la postre no restringirse tan radicalmente a la idea de una belleza formal, como se desprende de la "Analítica de lo bello". ${ }^{150}$ Más bien defiende que el arte bello transmite un contenido de por sí, aunque sea bajo la irreductibilidad a normas a priori. Una obra de arte tal es producto del libre juego de una idea por parte del genio, involucrando conceptos pero sin que determinen. La posibilidad de una arquitectura autónoma se reduce, pues, a la determinación de una arquitectura expresiva. Qué debe la arquitectura expresar es algo que Kant no especificó y de ahí que la filosofía kantiana en el terreno de la arquitectura diese lugar, paradójicamente, a una infinidad de intentos de determinación de un lenguaje arquitectónico propio: desde la expresión de su propia función, a la de la propia sociedad, pasando por concepciones más abstractas, que fueron tanteándose a lo largo del XIX. La repercusión del "giro" kantiano en la arquitectura queda claramente manifiesta en décadas posteriores con la consolidación de la estética idealista alemana. ${ }^{151}$

Como mediadora entre el entendimiento y la razón, la facultad de juicio en Kant constituye un ámbito singular que permite la transición entre los conceptos de naturaleza y los de libertad. Los juicios estéticos, no asimilables a los juicios cognitivos o morales, se constituyen por el principio a priori subjetivo de la finalidad sin fin: la aprehensión de la forma de un objeto de intuición, dando lugar al libre juego de las facultades del alma, de tal suerte que el arte hace posible un salto entre la necesidad y la libertad, o, dicho de otra manera, dándose en la experiencia artística el fundamento metafísico de la moralidad. La distancia, aparentemente insalvable, entre el entendimiento y la razón desarrolladas como esferas autónomas en sus dos críticas anteriores, asimilable a la de lo universal y lo particular, o a lo individual y la totalidad, puede salvarse por medio de la estética. En este sentido, el gusto, es decir, la facultad del juicio estético, adquiere una motivación comunicativa y es precisamente este punto
150. "En la pintura, escultura, en todas las artes plásticas, en la arquitectura, en la traza de jardines, en cuanto son bellas artes, el dibujo [Zeichnung] es lo esencial; $y$ en éste, la base de todas las disposiciones para el gusto la constituye, no lo que recrea en la sensación, sino solamente lo que, por su forma, place." (Kant, 2007: 140) 151. En los principales autores responsables de ese periodo persiste esa máxima kantiana según la cual la arquitectura ha de fundamentalmente ser expresiva. Las enormes diferencias que se establecen sobre lo que ha de expresarse bien sea desde Schelling, Hegel o Schopenhauer se entiende aquí como un síntoma de la repercusión de las teorías de Kant. 
152. Sintomáticamente referido a la arquitectura, entre otras: "Decimos de edificios y árboles que son mayestáticos, soberbios, o de praderas que son risueñas y alegres; hasta los colores son llamados inocentes, modestos, tiernos, porque excitan sensaciones que encierran algo análogo a la conciencia de un estado de espíritu producido por juicios morales." (2007: 286) de la argumentación que Schiller rescatará y radicalizará en su teoría estética. Recuérdese la definición del §59, donde Kant atribuye a la belleza el carácter de "símbolo de la moralidad" [Von der Schönheit als Symbol der Sittlichkeit]:

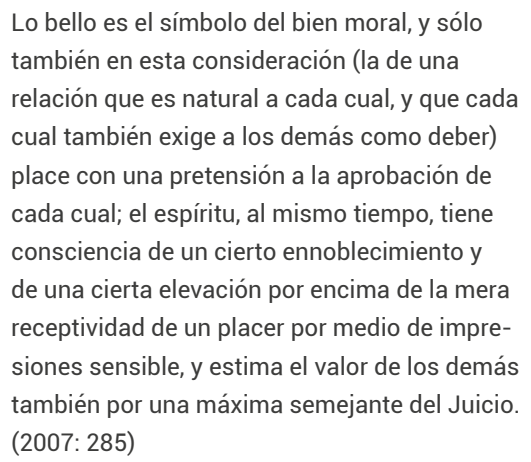

El significado de símbolo en Kant remite al carácter de analogía entre la estética y la moralidad. Por una parte, se trata de una analogía estructural desde su validez universal, tal y como ya ha sido expuesto: entre el placer desinteresado y el interés moral, entre la libertad de la imaginación y la libertad de la voluntad. Y en este sentido, la analogía tiene una orientación reguladora. Pero, al tiempo, entre la belleza y la moralidad puede trazarse un vínculo de tipo antropológico: la belleza, aun no pudiendo ser definida conceptualmente presenta una suerte de insaciabilidad conceptual -véase las "ideas estéticas"- que Kant considera símbolo de la imposibilidad de hacerse cargo intuitivamente de la libertad. De alguna forma, el vínculo que establece la belleza y lo suprasensible puede identificarse asimismo en la moralidad. De ahí que el carácter simbólico en Kant en toda exposición de un concepto $-y$ a diferencia del esquemaaluda a:

\begin{abstract}
cuando bajo un concepto que sólo la razón puede pensar, y del cual ninguna intuición sensible adecuada puede darse, se pone una intuición en la cual el proceder del Juicio solamente es análogo al que observa en el esquematizar, es decir, que concuerda con él sólo según la regla de ese proceder y no según la intuición misma; por lo tanto, sólo según la forma de la reflexión y no según el contenido. (2007: 283)
\end{abstract}

El concepto de símbolo así empleado restringe, pues, la relación que establece Kant entre la belleza con la razón (tanto práctica como teórica). Un sentido estricto de símbolo, como el que defiende Schiller, cancelaría esta restricción al establecer una unidad interna entre la belleza y la moralidad, es decir, entre propiamente el símbolo y aquello que simboliza. No en vano, como aclaración del empleo que realiza de "símbolo", Kant alude en más de una ocasión al término de "analogía". ${ }^{152}$ De no ser así, es decir, considerando en su acepción más estricta el dictum de la "belleza como símbolo de la moralidad", la apariencia sensible y la significación suprasensible coincidirían, algo que Kant en ningún caso podría suscribir, dado que la belleza no puede ser conocimiento ni estar motivada por interés alguno. Por símbolo habría que entender, más bien, una operación de tránsito meramente formal:

El gusto hace posible, por decirlo así, el tránsito del encanto sensible al interés moral habitual, sin un saldo demasiado violento, al representar la imaginación también en su libertad como determinable conformemente a un fin para el entendimiento, y enseña a encontrar, hasta en objetos de los sentidos, una libre satisfacción, también sin encanto sensible. (2007: 286)

Esta necesaria distinción será la que Schiller pretenderá superar con la objetivación de la belleza, y podrá, así fundamentar 
el principio de la belleza en la razón práctica por medio de la idea de libertad. No tanto en Kallias como en Cartas sobre la educación estética del hombre, ${ }^{153}$ frente al fracaso de las vías políticas ensalzadas con la llustración, Schiller presenta lo estético como alternativa de recuperación de la esperanza. La tesis sobre la belleza como "libertad en la apariencia" intenta salvar el abismo entre la realización práctica de los ideales emancipatorios y la experiencia de su fracaso. Así, a través de la teoría de los impulsos (y muy especialmente a través del impulso del juego), ${ }^{154}$ Schiller hace posible el acceso desmitificado (en contra del éxtasis dionisiaco, por ejemplo) a la esencia de la humanidad como intuición. Así establece en la Carta XI la tendencia a la divinidad como movimiento de ajuste entre las "dos leyes fundamentales de la naturaleza sensible-racional":

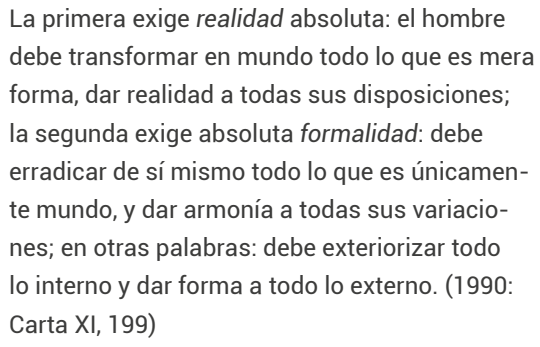

Su realización perfecta consiste en la tendencia a la divinidad, en tanto que ideal inalcanzable, formulación utópica. Ese carácter divino se da en la experiencia estética y su símbolo sensible es la belleza. Pero no se trata ya en Schiller de un símbolo de la moralidad en el sentido kantiano antes aludido (en tanto que analogía de la razón práctica) sino antes bien de un símbolo afectado por la autodeterminación del estado estético formulada en Kallias (1990: Carta XI,
199). En Cartas sobre la educación estética del hombre, de la indagación trascendental de la belleza se pasa al mundo de la experiencia con el concepto de "belleza ideal", símbolo de la divinidad humana y, como tal, también un telos inalcanzable para el hombre. Se aleja así de la fórmula kantiana de exposición de un concepto por medio de la belleza como hipotiposis, y la belleza en el caso de Schiller pasa a ocupar un mismo nivel que el de la moralidad. O, en palabras de Jaime Feijóo: "La belleza no puede ser considerada como el objeto de una intuición, sino que, en cuanto forma de una forma, necesita ella misma de un símbolo para poder ser contemplada en cuanto intuición" (Schiller, 1990: LXIX).

Así, la libertad constituye un contenido propio de lo estético y reclama su lugar en la sociedad decadente. Este impulso hacia el cambio (por medio fundamentalmente de la educación estética) puede darse desde el carácter modélico de lo estético, estableciendo una unidad interna entre la moralidad y la belleza en última instancia. De alguna forma, y siguiendo la argumentación con lo que se cerró el capítulo anterior, Schiller intenta superar la indefinición kantiana sobre el contenido de la expresión en el arte dotándole de un carácter propositivo. No en vano Schiller alude al Staatskünstler, fija la máxima de "ocuparse de la obra de arte más perfecta que cabe: el establecimiento de una verdadera libertad política" o "que para resolver en la experiencia el problema político, se precisa tomar el camino de lo estético, porque a la libertad se llega por la belleza" (Schiller, 1990: Cartas II y IV). Esta tendencia hacia la realización utópica por medio del arte ha dado lugar a interpretaciones de mayor o menor fortuna ${ }^{155}$ que han incidido en el problemático
153. Véase la evolución de la estética de Schiller entre estas dos obras en el capítulo "Inmunidad e indiferencia en el arte" del apartado 2.B. 154. La teoría del impulso del juego tiene por objeto mostrar el carácter espontáneo (en el sentido de instantáneo) de la experiencia estética: "el impulso de juego se encaminaría a suprimir el tiempo en el tiempo, a conciliar el devenir con el ser absoluto, la variación con la identidad" (Schiller, 1990: Carta XIV, 225)

155. Desde la formulada por Adorno o Benjamin a las más inquietantes del programa político nacionalsocialista como, por ejemplo, "Schiller como compañero de lucha de Hitler" de H. Fabricius en 1932. 
carácter modélico de lo estético en Schiller y llega prácticamente hasta la actualidad por medio de la teoría intervencionista del arte de vanguardia y ciertas neovanguardias. 


PARTE II.

GOETHE Y EL ARTE DE

LA CONSTRUCCIÓN 

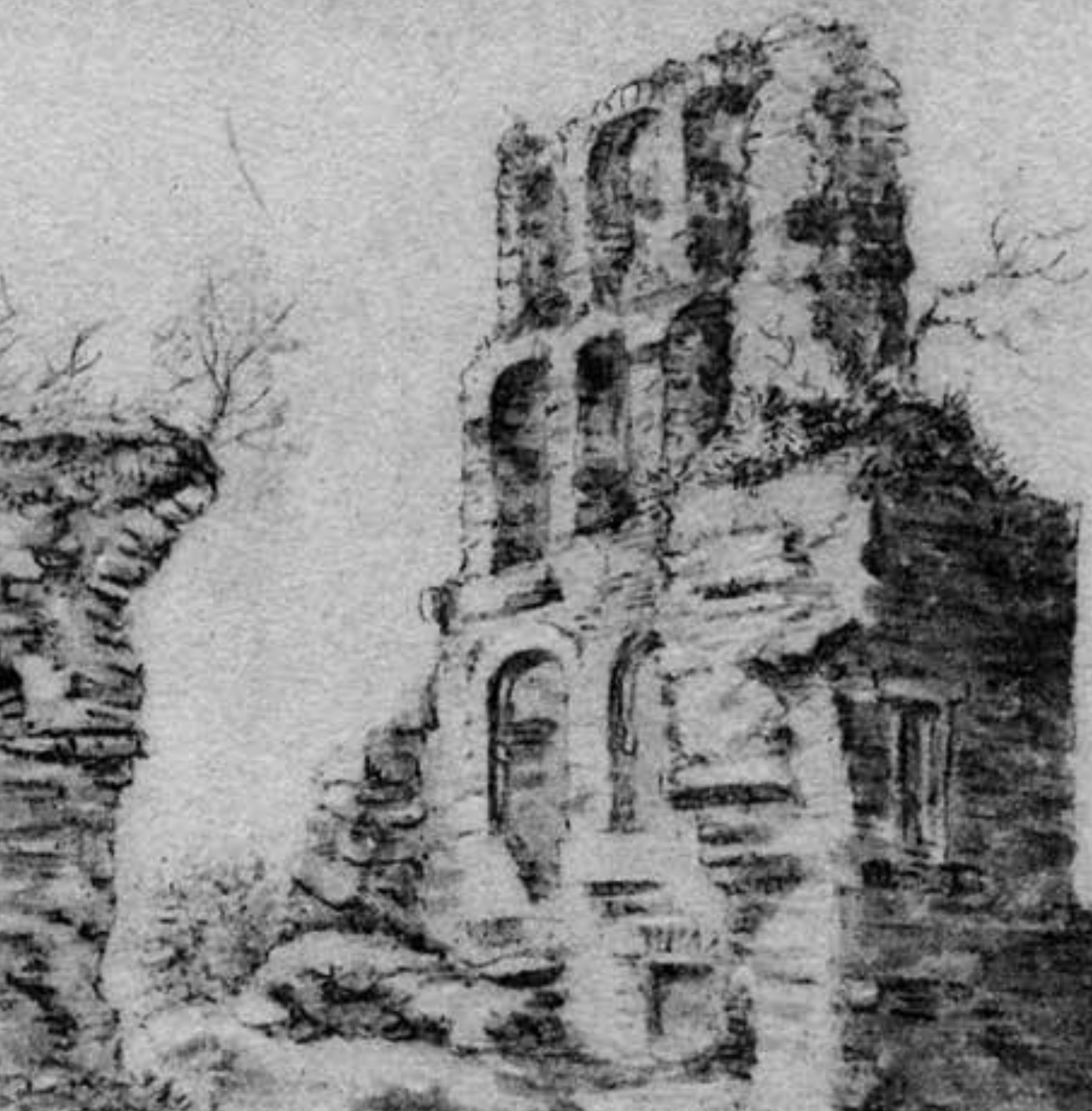

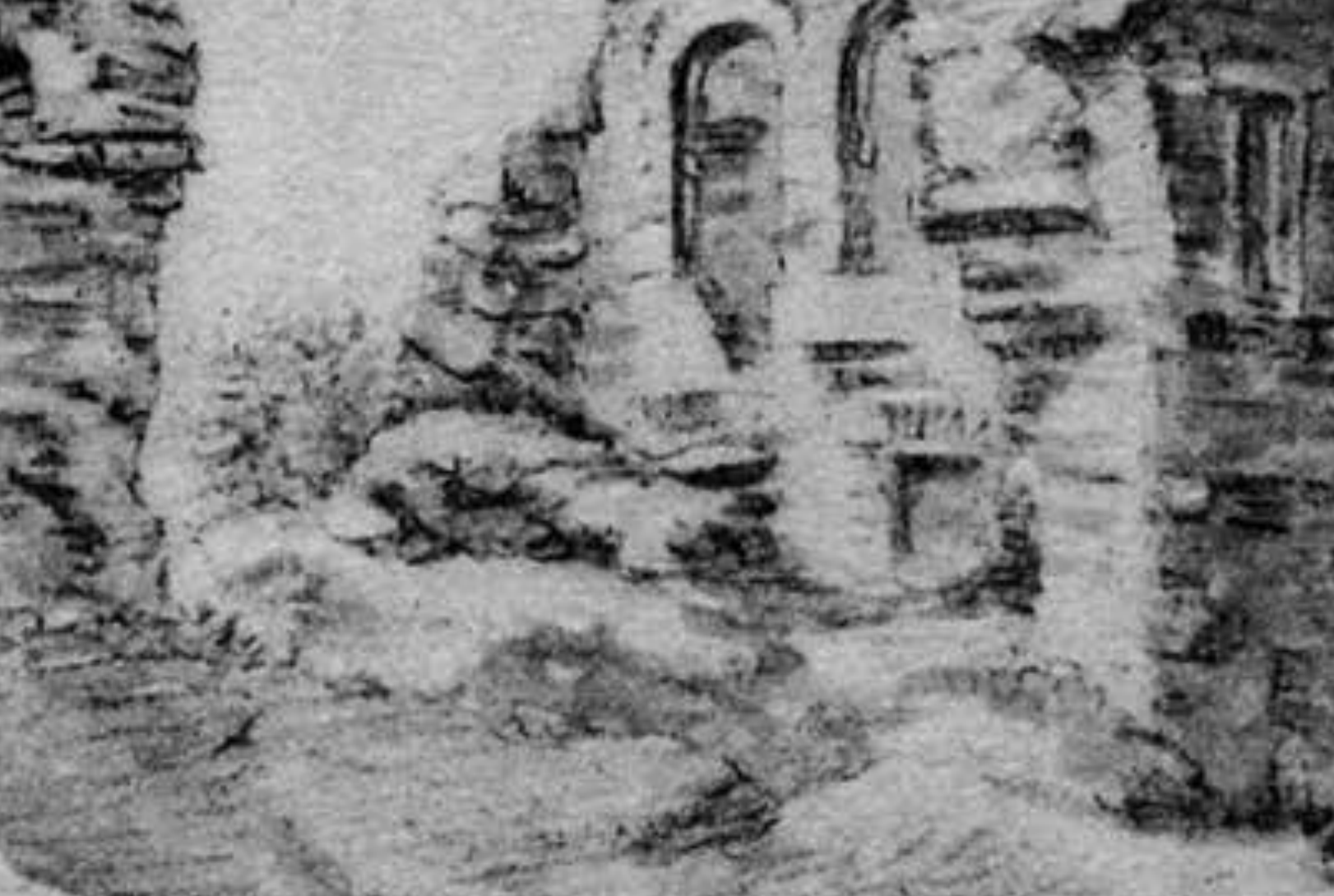

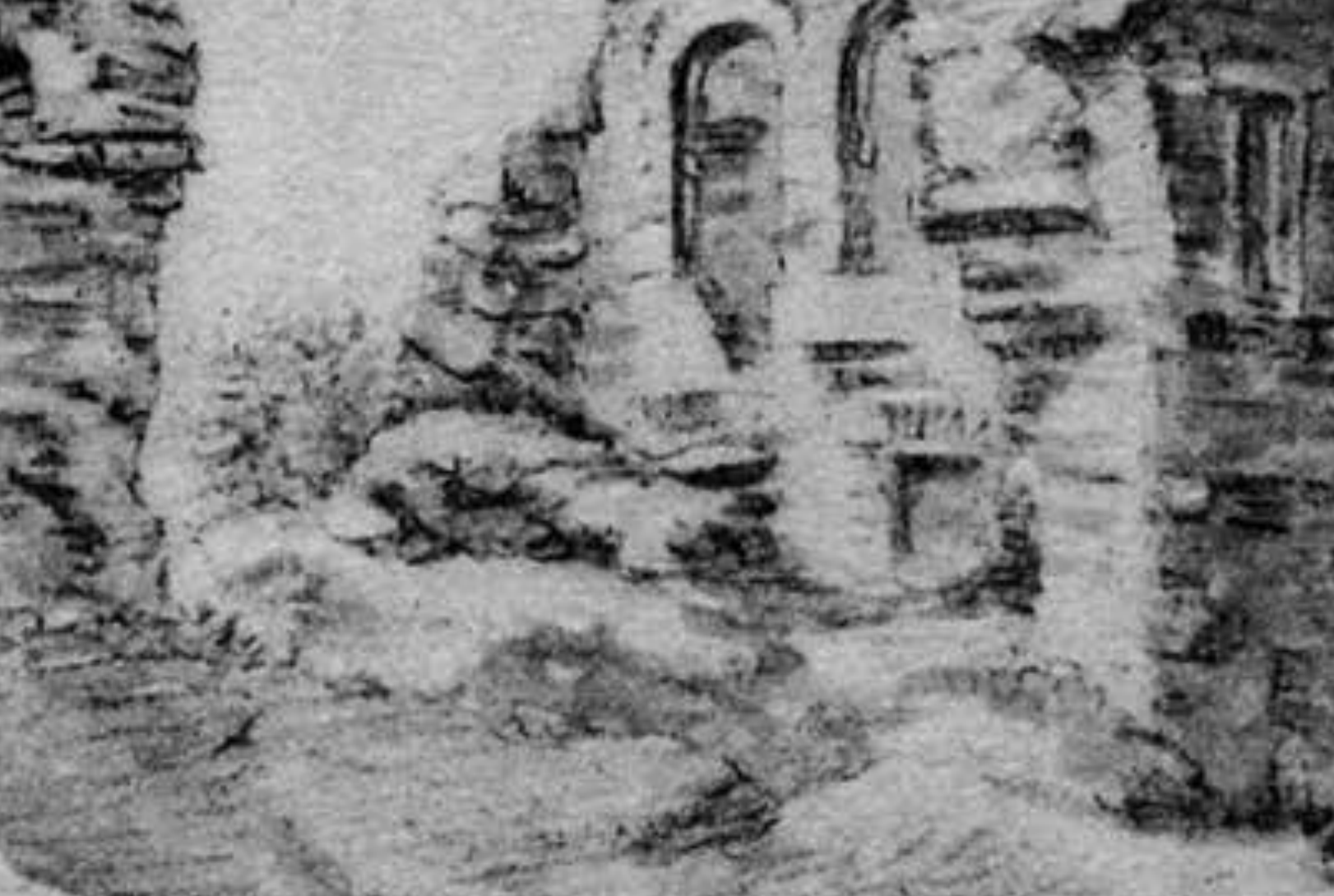

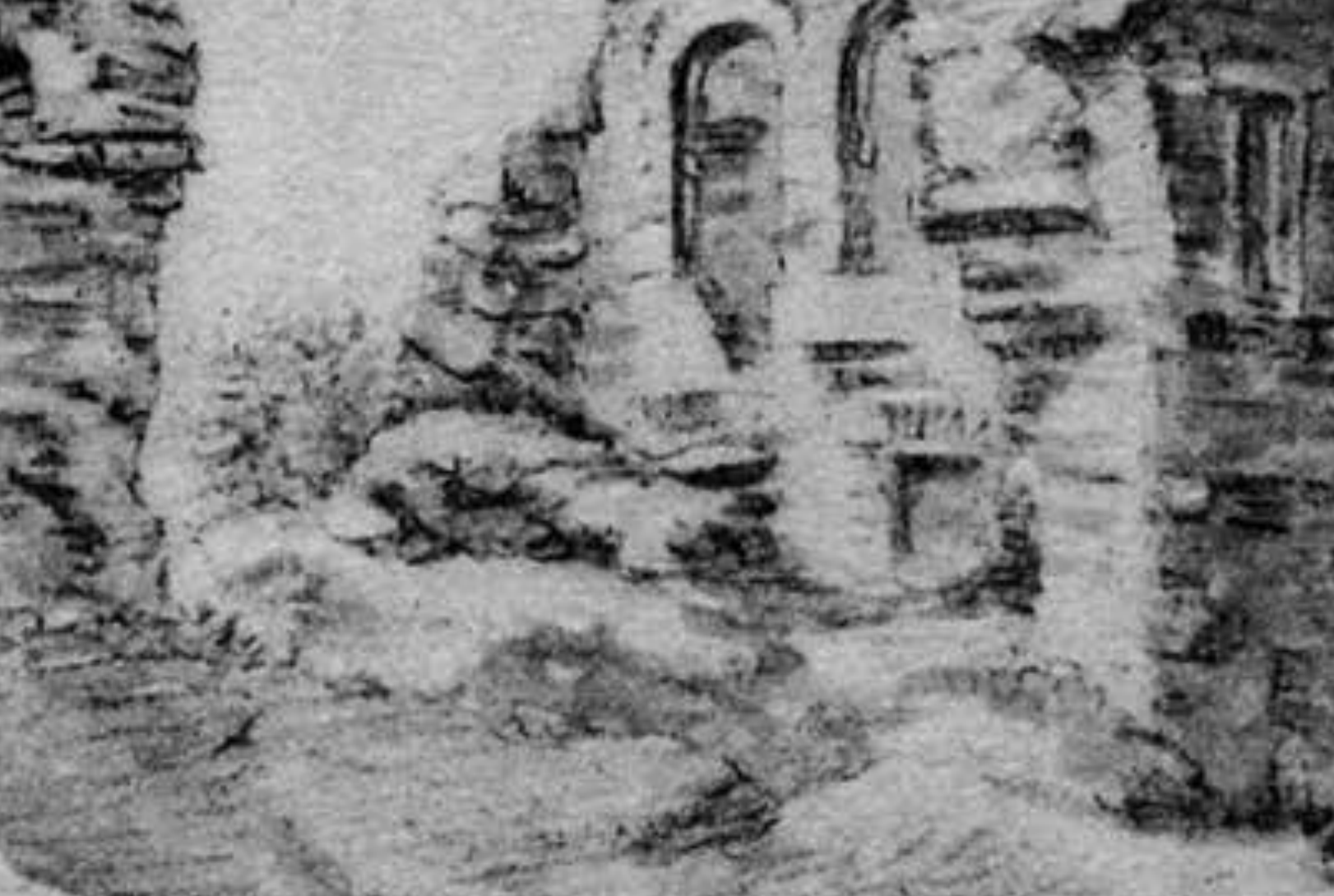

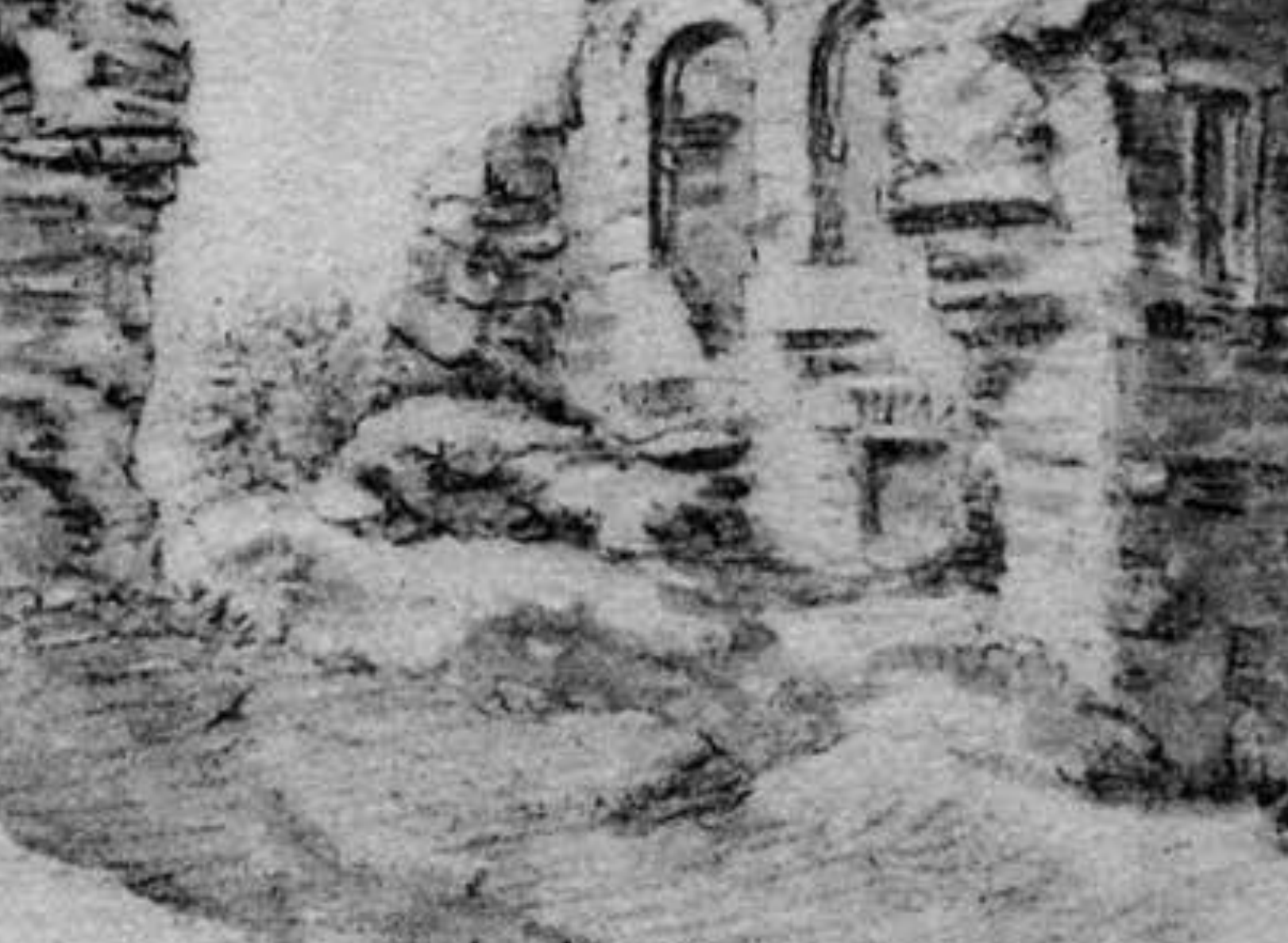
zas $+x$

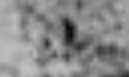

acosis? 


\section{Goethe ante la arquitectura}

Para una aproximación a los escritos de Goethe sobre arquitectura es necesario situarlos en el contexto de su obra y de su pensamiento. Su dedicación al dibujo, incluido el arquitectónico, discurre paralelo a sus lecturas de los tratados y a sus conversaciones con arquitectos y estudiosos. El contrapunto a ese intento por delimitar el entramado teórico lo representa la práctica de la construcción que tenía entre sus cometidos como gestor y responsable de las obras públicas en Weimar. Todas estas líneas se entrecruzan y emergen, de manera más o menos evidente, en su esfuerzo, finalmente abandonado, de establecer una teoría de la arquitectura con la redacción en 1795 del Baukunst. 
156. Goethe (1991), I: 346 A no ser que se indique lo contrario, de hora en adelante las citas a la versión española de las obras completas de Goethe provendrán de esta edición. Se prescinde, por tanto, de la fecha en las referencias al texto con el fin de aligerar la redacción. Las contracciones de las obras pueden encontrarse especificadas en la bibliografía de referencia.

\section{A. "Lo que no se comprende no se posee" 156}

Goethe estaba convencido de que el conocimiento humano tiene un mismo sustrato compartido por todos los intereses intelectuales específicos que se manifiestan en las respectivas parcelas del saber. No sólo piensa que "en este ingente universo todo guarda una eterna y segura relación, y una cosa engendra otra y es recíprocamente engendrada" (Part. Aut., III: 996), sino que la mente humana, en su forma de razonar, puede desentrañar esa realidad. En consecuencia, hay una ósmosis del pensamiento que se trasvasa de unos lugares a otros porque considera "que las actividades, en un sentido superior, no se deben mirar aisladamente, ya que por turno préstanse mutua ayuda" (Part. Aut., III: 951). El afán de descubrir esas relaciones entre las cosas es lo que orienta y estimula al estudioso. Escribe: "todo talento poderoso es un talento general, que por doquiera tiende la vista y ejercita su actividad acá o allá, donde le place." (Par. Aut., III: 973). Fruto de la imbricación de todo con todo, y la capacidad humana de encontrar esos nexos entre las más diversas realidades, surgía en su ánimo una positiva fecundación de materias dispares aparentemente alejadas y ajenas entre sí que, de este modo, entraban en sintonía mutua.

Sin embargo, veía que la marcha de la cultura discurría en el sentido contrario a sus convicciones y arremetió contra la separación drástica de los distintos territorios del saber origen de especialistas que se ignoran entre ellos. Durante su juventud había comprobado que

\footnotetext{
Tratábanse por separado todas las actividades: ciencia y arte, práctica de negocios, artesanía y demás cosas por el estilo, movíanse dentro de círculos totalmente cerrados. [...] Arte y Poesía apenas se rozaban, no habiendo que pensar en ninguna viva acción recíproca, y poesía y ciencia aparecían como los más sañudos adversarios. (Part. Aut., III: 979)
}

Frente a su defensa de un saber globalizador creía que el mero especialista que sólo se mueve en parcelas autónomas y acotadas es incapaz de abarcar y comprender la generalidad. El desinterés con que el mundo científico ignoraba sus trabajos, valorándole sólo como literato, le convenció de que el hombre moderno "al tratar las ciencias corre el peligro de dispersarse en la elaboración aislada de lo múltiple sabedero, de perderse en conocimientos incoherentes" (W., III: 1015).

Contrario a esa tendencia y consecuente con su pensamiento enciclopédico se preocupó por encontrar esas interdependencias entre el arte, la poesía y las diversas ramas de la ciencia. Desarrolló, simultáneamente, estudios en materias tan dispares como la botánica y la metamorfosis de las plantas, la anatomía comparada y el hueso intermaxilar, la cristalografía y el origen los volcanes, la meteorología y la forma de las nubes, (Fig. 1) la óptica y la teoría de los colores, además de su dedicación al dibujo y la arquitectura, y su atención a la pintura y la escultura. En definitiva, le atraía la realidad en casi todas aquellas manifestaciones que pudieran ser observadas buscando sus lazos ocultos. Abundando en su idea escribe: "nadie se allanaba a reconocer que entre ciencia y poesía pudiera haber lazo alguno. Olvidaban que la ciencia engendrárase en la poesía [...y...] pudieran ambas volver a encontrarse 


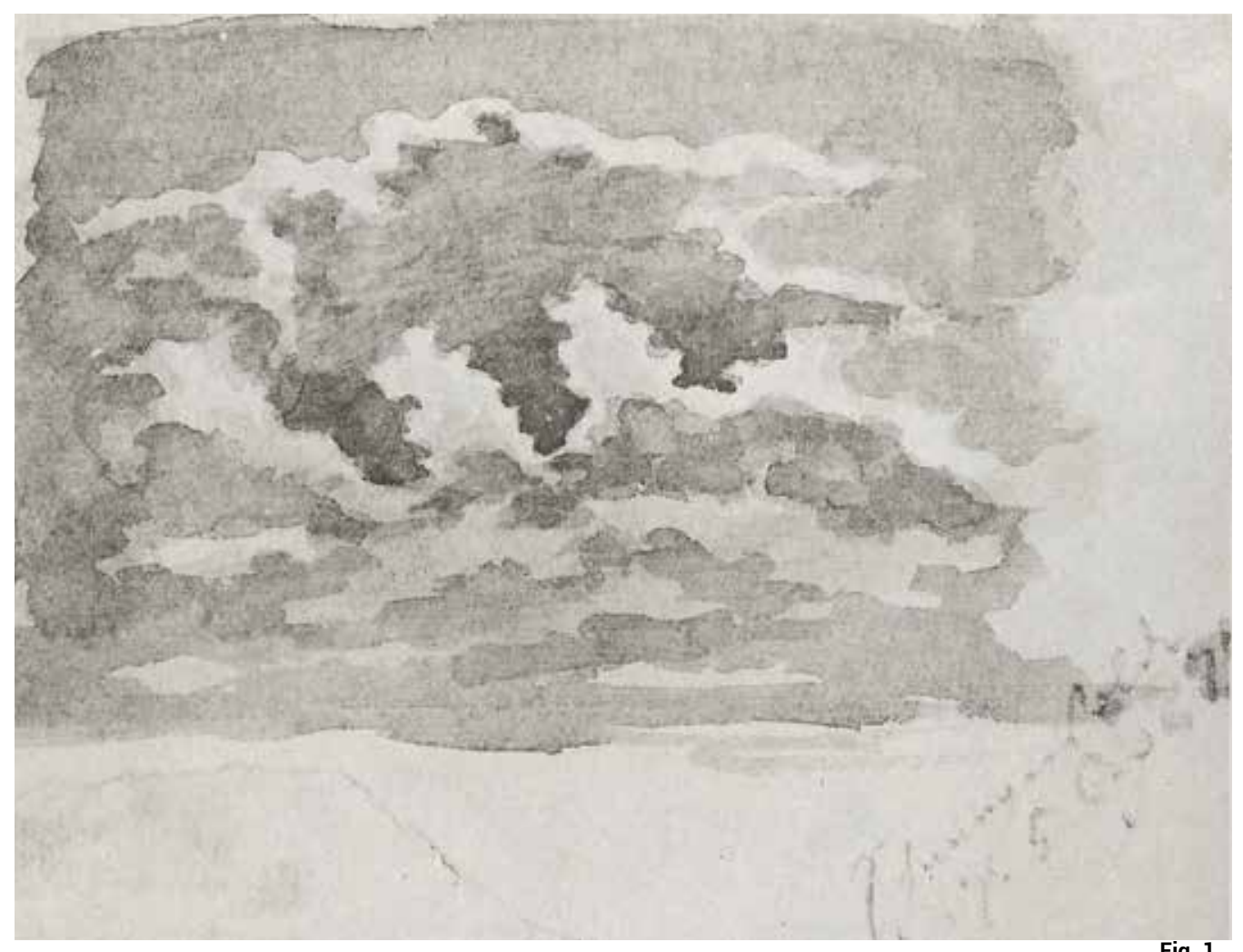

Fig. 1

cariñosamente para recíproco provecho y en plano superior." (Part. Aut., III: 974). Se trataba de unificar, con una misma matriz de pensamiento, conocimientos muy separados y distantes pero capaces de estimular, en cada uno de ellos, los avances, las indagaciones y las ideas procedentes de otros.

La aplicación de una misma forma de pensar no suponía, sin embargo, la elaboración de una única formulación general abstracta, filosófica o sistemática, susceptible de ser proyectada de la misma manera sobre cualquier situación, ${ }^{157}$ sino de ir extrayendo, a partir de los casos reales analizados, principios válidos capaces de fructificar en otras parcelas. Pero la multitud de líneas de interés en las que se dispersaba le producía una cierta inquietud. Comenta: "Poseía yo un método llamado a desarrollarse y envolverse, pero en modo alguno compilador y ordenador; no sabía qué hacerme con los acontecimientos en tropel, preocupándome más bien, ante todo, de su filiación." (Part. Aut., III: 910). Su trato con Schiller le aportó el contrapunto teórico que precisaba. Schiller consideraba que Goethe tenía el don de la observación y la capacidad por las particularidades yendo de los ejemplos singulares a los conceptos universales. Por el contrario, Schiller partía de las ideas buscando su manifestación concreta. En un encuentro entre ambos en Jena el
157. "Goethe no es un pensador sistemático; además, no tiene verdaderamente el gusto por el pensamiento abstracto" (Todorov, 1996: 10).

Fig. 1: Johann W. Goethe, Böengewölk [nubosidades], 5.4.1779 (115x151 mm. Lápiz, tinta china) en Femmel [1958] 1972, Vb: 223 
158. En ello insistirá en el jardín botánico de Palermo el 17 de abril de 1787: "A la vista de tantas nuevas y renovadas formas vegetales volvió a acometerme otra vez la antigua manía de si no podría yo descubrir entre aquel tropel de plantas la planta primitiva. ¡Porque tiene que haber una planta así! ¿Cómo, si no, podría yo reconocer que esta o la otra forma es una planta de no estar todas ellas plasmadas según un modelo?" (V. It., III: 1215)

159. En este mismo sentido, comentando la polémica entre Cuvier y Geoffroy de Saint-Hilaire sobre botánica, los define como: "dos modos distintos de pensar, que se encuentran en el género humano hartas veces separados y repartidos, de suerte que lo mismo en las ciencias que en todos los demás aspectos de la vida es raro hallarlos unidos, y estando separados hácese difícil reunirlos." (Part. Auto., III: 988-989). El primero consiste en ir "describiendo con toda exactitud lo que tiene delante [...pasando...] de la parte al todo que se presupone, aunque se le tenga por imposible de reconocer". El segundo, por el contrario, considera "el todo en el sentido íntimo y hállase convencido de que de él podría ir sacando poco a poco la parte" (Part. Aut., III: 988-989)

160. Foucault, comentando el planteamiento de Descartes, escribe: "no hay conocimien-
20.7.1794, tras exponerle Goethe sus trabajos sobre la metamorfosis de las plantas y su búsqueda de la Urpflanze, la planta arquetípica, escribe que Schiller:

movió la cabeza y dijo: «Eso no es una experiencia: eso es una idea!» [...] me dominé y repuse: «Celebro mucho tener ideas sin saberlo y hasta verlas con mis propios ojos» [...] Para que tuviera él una idea de lo que para mí era una experiencia, menester era que entre los dos hubiera algo intermedio, alguna referencia [...y más adelante apostilla...] Fácil es, pues, pensar que ni yo ni Schiller gozábamos de una madurez cumplida. (Part. Auto., III: 907-908 y 910)

El centro de gravedad del disenso estriba en la consideración de la Urpflanze como mera idea, en el caso Schiller, o dotada de un valor experiencial, en el caso de Goethe. Para Schiller se trata de una idea en tanto que concepto de la razón que no puede ser imaginado por ninguna representación. Goethe, en cambio, insiste en que esa idea es real, hasta el punto de que, como recoge en su Italienische Reise debería poder llegar a verla con sus propios ojos. ${ }^{158}$ La síntesis de ambas posturas, en principio opuestas, las convertía en complementarias. Para Goethe la Idea, el concepto y la experiencia entendida como observación de los fenómenos, se enlazan mediante la inteligencia y la razón. Escribe: "Concepto es la suma; Idea, el resultado de la experiencia; para obtener aquél requiérese inteligencia; para alcanzar esta, razón" Y añade a continuación: "Lo que se llama idea, [es] aquello que siempre se manifiesta como fenómeno y por ello se nos presenta como ley de todos ellos" (Mx. nº 1132, 1133, I: 445). En definitiva: "la observación debe tener por base una idea, un concepto, capaz de fomentar la experiencia y hasta facilitar hallazgos e invenciones" (Part. Aut., III: 979). Así, pues, la "idea" de Schiller y las "experiencias" de Goethe se conjugaban, finalmente, para alumbrar el modo en que abordaba sus investigaciones y que él mismo lo calificó como un "pensar objetivo" (Part. Aut., III: 851). ${ }^{159}$

Esta forma de razonar consistía en que, a partir de una intuición inicial, realizaba un análisis metódico de los casos conocidos a fin de aislar los rasgos comunes y las leyes que los rigen para poder, finalmente, definir una malla racional explicativa de los fenómenos. Un método que va de la intuición a la formulación de la teoría pasando por el análisis comparativo de las observaciones mediante un proceso donde "el análisis y la síntesis son dos actos vitales inseparables [ya que] no hay más remedio, quieras que no, que ir del todo al detalle y del detalle al todo" (Part. Aut. III: 992-993), superando de esta forma etapas sucesivas que van aproximándose y afinando el resultado.

La intuición inicial es el estímulo que desencadena la elaboración del conocimiento. Esa intuición es el instrumento que abre el análisis de las cosas comparándolas entre sí. ${ }^{160}$ Un análisis comparativo que consiste, precisamente, en organizar los fenómenos encontrando las relaciones y diferencias entre ellos de acuerdo con un determinado orden. Así lo entendía Goethe: "Ningún fenómeno se explica por sí; sólo muchos de ellos, contemplados conjuntamente y metódicamente ordenados, nos facilitan finalmente algo que pueda pasar por una teoría" (Mx. n 1227, I: 452).

Para Foucault esta postura corresponde a uno de los dos modos del pensamiento clásico paralelo al otro que pretende reducir la realidad a su formulación matemá- 
tica. ${ }^{161}$ El primero está basado en la búsqueda de un orden. El segundo en la comparación mensurable. Orden o medida son, pues, las dos vías por donde discurrió, a partir de ese momento, el pensamiento racional moderno. En este contexto los saberes empíricos buscan conformar una taxonomía como conjunto ordenado, siguiendo la senda abierta por Linneo. ${ }^{162}$ Goethe adoptó este modelo. Escribe: "Y así, yo, lo mismo que los demás contemporáneos de Linneo, dime cuenta de su panorama y de su fuerza, que lo arrollaba todo. Entreguéme a él y su teoría con plena confianza" (Par. Aut., III: 967).

Es necesario considerar la aproximación a cualquier estudio realizado por Goethe bajo esas premisas. Por un lado, la certeza de la unidad del universo y la cualidad de la mente humana que permiten el intercambio de sugerencias o nociones susceptibles de emigrar de unos campos a otros, abriendo nuevas perspectivas que se nutren y se enriquecen mutuamente. Por el otro, el procedimiento de investigación seguido por Goethe consistente en la búsqueda de un orden a partir de una intuición inicial, mediante el análisis comparado de los ejemplos observados, generando una estructura comprensible de la realidad. ${ }^{163}$ Estas dos coordenadas, la ósmosis de nociones de unas disciplinas a otras y la intuición que desencadena un proceso de análisis ordenado que lleve al enunciado de una teoría, encontraron un campo particularmente fértil en el cruce entre la estética, las artes plásticas y la arquitectura.

\section{B. "Este pequeño mundo del arte"}

Si bien para Goethe el conocimiento se despliega sobre todas las cosas, se divide, sin embargo, en dos grandes parcelas orientadas en sentidos complementarios y fines distintos: la ciencia y el arte. Escribe:

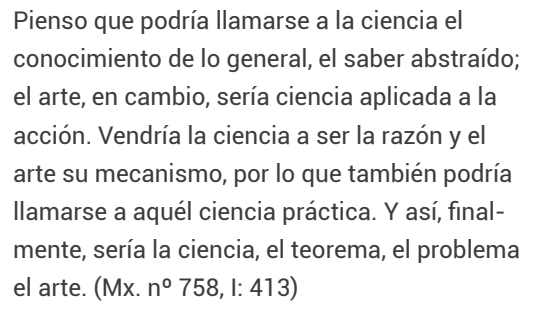

Desde el Renacimiento, las llamadas artes del disegno (pintura, escultura, arquitectura y grabado) habían ido confluyendo hasta conformar el sistema moderno de las artes (Kristeller, 1986) compartiendo unos mismos valores y criterios esenciales. El cruce de nociones de unas artes plásticas a otras, que venía avalado por esta tradición cultural, encontró en el talante intelectual de Goethe, proclive a esos trasvases y confluencias, un sustrato especialmente propicio.

Fue durante su viaje a Italia cuando a Goethe se le despertó un creciente interés por estudiar en profundidad y comprender las bases teóricas y las reglas que rigen las artes. El conocimiento de las obras, el estudio de los escritos y el trato con artistas le imprimió un giro radical en esa orientación que se intensificó la década posterior a su regreso. ${ }^{164}$

\section{Conocedor, diletante, artista}

Hasta entonces Goethe se había acercado a las artes plásticas con la curiosidad de una persona culta pero, tras su viaje, evolu- to verdadero más que por intuición" (2009: 59) y señala que, desde el siglo XVII: "el análisis va a alcanzar muy pronto el valor de método universal." (2009: 63).

161. Según Foucault: "Existen dos formas de comparación y sólo dos: la comparación de la medida y la del orden." (2009: 59). Y añade en relación con el orden: "comparar y ordenar no son sino una y la misma cosa: la comparación por orden es un acto simple que permite pasar de un término a otro y después a un tercero, etc. [...] Así, se establecen series en las que el primer término es de una naturaleza tal que puede tenerse por intuición aparte de cualquier otra; y en la que los otros términos son establecidos según diferencias crecientes."(2009: 60). 162. Según Foucault: "Y quizá la unidad remota pero insistente de una Taxinomia universalis aparece con toda claridad en Linneo, cuando proyecta volver a encontrar en todos los dominios concretos de la naturaleza o de la sociedad, las mismas distribuciones y el mismo orden." (2009: 82). 163. Por ejemplo, en el caso de la metamorfosis de las plantas la "intuición inicial" de que debía existir una planta original Goethe la empezó a vislumbrar en el botánico de Padua (Part. Aut., III: 968 969) revelándosele claramente en el botánico de Palermo en 1787 (V. It., III: 1215). Una 
intuición similar respecto a los huesos del cráneo la tuvo en Venecia en 1790. El propio Goethe las vincula ambas cuando escribe: "Sin punto de reposo fui persiguiendo la versatilidad de la Naturaleza en el reino vegetal, y en 1787, en Sicilia, tuve la suerte de adquirir, no sólo la intuición, sino también el concepto de la metamorfosis de las plantas. Cerca le andaba a ésta la metamorfosis del reino animal, y en 1790 hubo de revelárseme en Venecia el origen del cráneo, formado de huesos" (Part. Aut., III: 950). 164. Según Safranski: "De hecho Italia fue un paraíso para Goethe, no cuando estuvo allí, sino cuando después de su viaje regresó de nuevo." (2015: 299). El propio Goethe, en 1820 , se refiere a esos años como: "aquella época tan principal del postrer decenio del siglo pasado" (Part. Aut., III: 893).

165. „Ein Kunstwerck hingegen hat seine Vollkommenheit ausser sich, das "Beste" in der Idee des Künstlers, die er selten oder nie errreicht, die folgenden in gewissen angenommnen Gesetzen, welche zwar aus der Natur der Kunst und des Handwercks hergeleitet, aber doch nicht so leicht zu verstehen und zu entziffern sind als die Gesetze der lebendigen Natur." DKV II.4: 195-196 [Una obra de arte tiene, por otra parte, su perfección fuera de sí misma; tiene lo «mejor» en la idea del artista, la cual él rara vez o cionó desde la postura del mero aficionado que contempla las obras por placer, a la del auténtico aficionado que es capaz de apreciarlas porque puede desentrañar las normas sobre las que se basan sus cualidades específicas y rigen la labor del artista. Según Goethe

el auténtico aficionado [wahre Liebhaber] no sólo ve la verdad de la imitación, sino la excelencia de la selección y lo ingenioso de la composición: lo supraterrenal de este pequeño mundo del arte. Él siente que debe subir al nivel del artista para disfrutar de la obra. (Salmerón, 1999: 126)

Más aún, el conocimiento de las directrices, que el autor ha sabido trasladar a su obra, es lo que puede elevar "al Ilamado aficionado, el único auténtico público del artista, hasta el espíritu del artista" (Salmerón, 1999: 47). Por lo tanto, entendía que para el disfrute pleno del arte no era imprescindible ser un profesional. Bastaba con conocer sus principios entrando, en cierta manera, en la mente del creador. En una carta escribe a la Duquesa Louise desde Roma: "Una obra de arte tiene, por otra parte, su perfección fuera de sí misma; tiene lo «mejor» en la idea del artista". ${ }^{165}$ Un convencimiento que Goethe compartía con Winckelmann de quien había leído "ávida y devotamente" (Safranski, 2015: 559) sus escritos y tenía como referente cultural. ${ }^{166}$

Desde l'Abbé Batteux, a comienzos del s. XVIII, se consideraba que era, precisamente, el conocedor del arte [connaisseur] quien podía juzgar las obras incluso mejor que el propio artífice. ${ }^{167}$ Goethe comparte esta opinión, porque escribe: "Un artista que ha llevado a cabo trabajos estimables no siempre es capaz de dar luz sobre las propias o ajenas obras" (Mx. nº 1067, I: 438). Se abría así un hiato entre los intereses de los profesionales y los de los entendidos dando origen a la estética moderna. ${ }^{168} \mathrm{~A}$ partir de ese momento la reflexión sobre el arte se alejó de los anteriores escritos sobre las prácticas y técnicas destinados a establecer las pautas de su trabajo a los artistas. Y consecuentemente, los escritos teóricos se desgajaron de los manuales prácticos en dos ámbitos separados. Un planteamiento que establecía una clara diferencia entre el trabajo del autor, la contemplación del conocedor, la labor del crítico y la reflexión del filósofo. Goethe, con carácter general, no compartía totalmente esta postura ya que dice: "Teoría y experiencia hállase entre sí en pugna constante. Toda fusión de ellos en la reflexión es puro engaño; sólo mediante la acción puede reunirse" (Mx., $\left.n^{\circ} 1228, I: 452\right)$. Y con carácter general repite en otro lugar: "Teoría y práctica actúan siempre una sobre otra" (III: 583). Sin embargo, en relación con la experiencia en el arte distinguía claramente la práctica como actividad del artista de la experiencia estética del que lo contempla. 0 sea, entre la creación artística, la fruición del arte y la teoría estética. ${ }^{169}$

Dos conclusiones se desprenden de esta cuestión. La primera es que la reflexión teórica recaía en manos de estudiosos o críticos experimentados en el conocimiento de las obras pero no en su ejecución. La segunda, que los problemas técnicos sólo interesaban a los maestros en ejercicio cuyas preocupaciones suelen discurrir, generalmente, por cauces distintos y ajenos a cuestiones teóricas. Bajo este prisma se afianza una deriva negativa ya que las obras quedan, en gran medida, desplazadas a un papel secun- 
dario convirtiéndose en meras ilustraciones de las teorías, en ejemplos demostrativos.

Además de esa divergencia de intereses, entre el conocedor y el artista existe otra diferencia sustancial: las aptitudes naturales que el segundo posee y que no tiene el primero. El disfrute de las obras, que está al alcance de cualquiera, se va ampliando a medida que, al profundizar en su conocimiento, se van comprendiendo las normas que rigen las bases estéticas sobre las que se asienta el arte convirtiendo al mero aficionado en connaisseur. Un conocedor que puede devenir en diletante que practica esporádicamente alguna modalidad artística por placer o distracción. Pero, para llegar a ser un verdadero maestro es necesario que, junto con el aprendizaje de las reglas y el dominio de las habilidades, que hacen posible trasladar la invención a la obra, se conjugue el talento personal. La ignorancia de los métodos de ejecución o de los principios lastra tanto los juicios del aficionado como las realizaciones del diletante alejándoles del profesional. Y aunque el control de esos conocimientos y prácticas puedan serles de gran ayuda, dándoles autoridad, eso no basta ni los convierte en artistas. El verdadero creador, que, como profesional, domina los procedimientos y las reglas de su actividad, debe estar dotado, además, de un don natural. Goethe escribe: "En todas las artes hay cierto grado que puede alcanzarse con las disposiciones ingénitas, por así decirlo, exclusivamente. Pero al mismo tiempo es imposible rebasarlo como el arte no venga en nuestra ayuda" (Mx., $\mathrm{n}^{\circ} 1114$, I: 442). Es este don natural, las habilidades y el dominio de las normas las que le permiten al artista hacer sus "piezas de arte". Pero rebasarlas para que se convier- tan en "obras de arte" se precisa de un don especial. ${ }^{170}$

Goethe era muy consciente de sus limitaciones para el ejercicio de las artes plásticas por las que sentía una innegable vocación. ${ }^{171}$ Son muchos los comentarios al respecto diseminados por sus escritos. Por ejemplo, en 1799, escribía: "Como no podía llegar a ser artista hubiera caído en la desesperación si no hubiera estado destinado desde mi nacimiento a ser aficionado y coleccionista" (Salmerón, 1999: 143). Y, en otro lugar comenta:

Así, pues, cuando menos estaba yo dotado de naturales disposiciones para el arte plástico, con tanto más afán andaba yo a la husma de leyes y reglas, y hasta ponía más atención en la técnica de la pintura que en la de la poesía, que siempre tratamos de llenar, mediante la razón y la sagacidad, aquellos vacíos que la Naturaleza en nosotros dejara. (Part. Aut., III: 952)

En sus conversaciones con Eckermann le dice:

pienso en los años que necesité para darme cuenta de que mi inclinación a las artes plásticas era una falsa tendencia. [...] Yo, pese a todos mis afanes, no logré ser un gran artista plástico; pero como intenté hacer algo en todas las ramas de las bellas artes, llegué a poder darme cuenta del menor trazo y pormenor formal, o sea, a poder distinguir lo perfecto de lo imperfecto, lo consumado de lo deficiente. (Eck., III: 189).

Siempre sintió su mediocridad en su faceta artística y era consciente del esfuerzo y la dificultad que le exigía el ejercicio del dibujo, de lo magro de los resultados obtenidos y de lo alejados que se encontraban de las metas que buscaba. En 1821, con motivo de la edición por Schwerdeburth de unos dibujos nunca alcanza y sigue ciertas leyes aceptadas que, aunque derivadas de la naturaleza del arte y la artesanía, no son tan fáciles de entender y descifrar como las leyes de la naturaleza viviente.].

166. Hablando de la arquitectura, Winckelmann (1985, 265) escribe: "Todo el que haya estudiado algo de las cosas de la antigüedad y posea un mínimo de conocimientos de la materia, podrá juzgar lo que a continuación expongo sobre la arquitectura de los antiguos, como si fuera un arquitecto, sin tenerse que dedicar previamente a más profundos estudios."

167. Escribe: "el hecho de que la afinidad entre las distintas bellas artes sea más plausible al aficionado, que experimenta un tipo de goce afín que al artista propiamente dicho más preocupado por las metas y técnicas peculiares de su arte, resulta algo evidente de por sí". Citado por Kristeller (1986, 237). Goethe conocía las ideas de Batteux a quien remite irónicamente en la recesión sobre un escrito de Sulzer (1999: 43). 168. Según Kristeller: “El origen de la estética moderna en la crítica amateur nos explicaría en gran parte la razón por la que las obras de arte han sido analizadas hasta fecha reciente por los «estéticos» más bien desde el punto de vista del espectador, del lector y el oyente que del artista creador" (1986: 237-238). 
169. Marchán Fiz señala las diferencias surgidas en el siglo XVIII entre historia del arte, teoría del arte y estética, $y$, a su vez, entre la estética referida a las producciones frente a la recepción o consumo de las obras de arte, distinguiendo los términos "clásico" en estética, de "clasicismo" en las artes (2012: 13-16). Por su parte, Argán (2010), refiriéndose al siglo $X X$, distingue dos vertientes: "estética" y "artística".

Rosenkranz divide la estética "en tres clases especiales. La primera de ellas tiene que ver con la idea de lo bello, la segunda con el concepto de su producción, es decir con el arte, la tercera con el sistema de las artes, con la representación de la idea de lo bello por el arte en un medio determinado."

170. "No podrá negarse ciertamente que el genio, el talento artístico cultivado, puede de cualquier cosa hacerlo todo mediante la forma de tratarla, y doblegar la más recalcitrante materia.

Pero, bien miradas las cosas, prodúcese siempre entonces más bien una pieza de arte que no una obra de arte, la cual ha de descansar sobre un tema digno, para que después, finalmente, el modo de tratar este último con habilidad, desvelo y tanto tesón pueda mostrarnos tanto más afortunada y magnífica la dignidad de la materia" (III: 593). suyos, comenta: "podría preguntarme, no sin razón, si de ese reiterado esfuerzo y pertinaz afición no llegó a salir nada que satisficiera en el terreno artístico." (Par. Auto., III: 939). Una insuficiencia que intentó colmar con el ejercicio constante del dibujo y profundizando en el conocimiento de las normas. Así pues, tras asumir sus carencias y renunciar a convertirse en un artista consumado, adoptó el doble papel de experto conocedor y de dibujante diletante.

\section{Juicio, creación, genio}

A diferencia de sus escasas aptitudes plásticas Goethe sentía que, por el contrario, su talento poético fluía en su mente de manera espontánea y casi incontrolable. Y pensó que el conocimiento destilado del mundo del arte podía aplicarlo, también, a su producción literaria sirviéndole, en alguna medida, para encauzarla. Escribe:

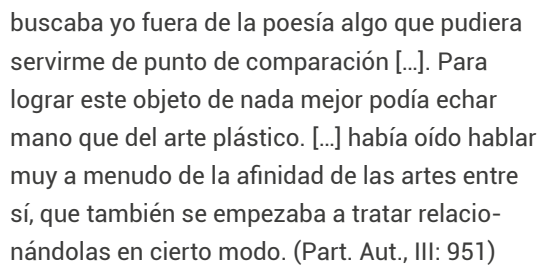
muy a menudo de la afinidad de las artes entre sí, que también se empezaba a tratar relacionándolas en cierto modo. (Part. Aut., III: 951)

Por consiguiente, la idea de la unidad de las artes, que se había asentado a lo largo del siglo XVIII, justificaba el empleo de las nociones estéticas extraídas del ámbito pictórico a su dedicación poética. Algo que expresamente reconoce al escribir "que poesía y arte plástico podían influir por veces una en otro" (Par. Aut., III: 952). Algo que ya había comprendido desde sus años de estudiante en Leipzig porque escribe:

\begin{abstract}
Los múltiples objetos que veía tratados por los artistas despertaban en mí el talento poético, y de igual modo que se hace un grabado para una poesía, hacía yo poesías para los grabados y dibujos [...] acostumbrándome de ese modo a considerar las artes mutuamente unidas. (III, 612)
\end{abstract}

Y refiriéndose a sí mismo repite con posterioridad: "Mi dibujar y estudiar, lejos de perjudicarle a mi capacidad poética, lo que hace es ayudarle; porque en el escribir debemos ser parcos y en el dibujar largos." (V. It., III: 1337).

Su convicción más general sobre las transferencias conceptuales entre disciplinas distintas encontraba una aplicación directa entre el mundo del arte y el de la literatura, extendiéndose, también, a la sensibilidad y los sentidos. ${ }^{172}$

$$
\text { La creación poética y el juicio }
$$
sobre el arte eran, para Goethe, dos facetas copartícipes y confluyentes hacia un mismo objetivo. El sustrato conceptual aportado por la reflexión se convertía en el tronco común del que surgían las distintas artes, cada una de ellas regida por sus propios principios y normas. El esfuerzo pertinaz, la indagación y la razón aportaban al conocedor los criterios de valor convenientes en el campo plástico. Un conocimiento de la teoría que no quedaba restringido a ser un fin en sí mismo, ni como un mero estímulo a su producción poética, sino que le servía, sobre todo, para la práctica del arte y su enseñanza. ${ }^{173}$

Las tres vertientes artísticas en las que se desplegaba la actividad de Goethe, escritor, dibujante y conocedor, se sustentaban y se reforzaban mutuamente. Mediante el estudio profundizaba en las bases teóricas y las normas generales. El ejercicio del dibujo 
suponía una práctica dirigida a comprender y resolver los problemas concretos que plantean las obras y dominar las normas aplicables en cada caso. Sin embargo, su capacidad poética surgía de una raíz distinta. Escribe: "A las artes y a las ciencias llégase mediante el pensar, y a la poesía, no, pues esta es inspiración; antes de moverse ya estaba difusa en el alma. No se le debería llamar arte ni ciencia, sino genio" (Mx. $\mathrm{n}^{\circ} 759$, I: 413). ${ }^{174}$ Hay en Goethe un paralelismo entre las ideas de inspiración en el campo del arte e intuición en las ramas científicas.

El genio, en su opinión, se sitúa fuera de las cuestiones teóricas o prácticas dominando y arrastrando al artista creador incluso más allá de su voluntad. El autor genial está dotado con un don natural que sobrevuela por encima de directrices y de habilidades. ${ }^{175}$ Conversando con Eckermann le dice: "Las leyes de la poesía y la pintura se pueden aprender hasta cierto punto, pero para ser un gran poeta o un gran pintor se necesita genio" (Eck., III: 262). Y en otra ocasión le aclara: "Pues el genio no es más que la fuerza productiva, engendrando hechos dignos de presentarse ante Dios y la Naturaleza que, por ende, son fecundos en consecuencias y de larga duración" (Eck., III: 337). Sólo el artista genial está capacitado para producir auténticas obras maestras. La ciencia y la investigación permiten conocer los vínculos que atan las distintas manifestaciones de la realidad, pero la obra de arte genial va más lejos porque la expresa directamente sin otra mediación. "Hay en el mundo mucha cosa bella; pero el genio es el llamado a descubrir las relaciones entre ellas y formar así obras de arte." (Mx. $\mathrm{n}^{\circ} 451, \mathrm{I}$ : 380).
Goethe, se sentía tocado por el genio para la literatura pero estaba, igualmente, persuadido de sus escasas dotes para la práctica de las artes plásticas y la arquitectura. Y, en consecuencia, dirigió sus esfuerzos hacia la teoría artística donde, según su opinión, la ausencia de la práctica profesional no era ningún impedimento para llegar a ser un conocedor autorizado. ${ }^{176}$

\section{Arte $\mathbf{y}$ arquitectura}

Si la teoría está en manos de entendidos ajenos a los problemas de la profesión, esto significa que todo tipo de especulaciones sobre los cimientos teóricos del arte quedan inmunes a cualquier influencia de las cuestiones técnicas cotidianas que interesan a los artistas. Esta constatación tiene efectos importantes en el contexto arquitectónico al desplazar de las discusiones teóricas los aspectos constructivos, que son, precisamente, los que atraen la atención de los arquitectos. De este modo, se debilitan los lazos entre la construcción como técnica y la arquitectura como arte, considerándose que cada una de ellas trata de materias susceptibles de abordarse de manera separada y autónoma. Y, por lo tanto, para poder ser una autoridad en la teoría arquitectónica no sería preciso ni conocer con precisión el comportamiento de los materiales ni dominar las técnicas constructivas. Escritos sobre la teoría arquitectónica, por un lado, y manuales de construcción, por otro, iniciaron en aquellos momentos su desarrollo independiente.

Pero lo cierto es que, a diferencia de otras disciplinas artísticas, la práctica arquitectónica no queda constreñida, exclusivamente, al dominio de las reglas y habilidades
171. En su juventud Goethe había aprendido en Leipzig grabado en cobre con Michael Stock y dibujo con Adam Friedrich Oeser, y pensó en dedicarse a la enseñanza de las bellas artes. Incluso, entre noviembre de 1781 y enero de 1782, se hizo cargo de la Academia de dibujo de Weimar donde dio clases de osteología (Safranski, 2015: 43,50 y 282).

172. Dice Goethe: "Veo con ojos que sienten, siento con manos que ven" (citado por Safranski, 2015: 330).

173. El 5.7.1787 escribía en Roma: "búllenme en la cabeza cien cosas nuevas, y el quid no está en pensar, sino en hacer" (V. It., III: 1283). Según Todorov "Si Goethe se compromete con empresas teóricas, y discursivas, lo hace con un único fin: ayudar a los artistas en sus prácticas" añadiendo: "no le interesa la teoría más que encarnada en la acción" y, comentando su participación en una revista de estética, con fecha 19 de octubre de 1784 Goethe le escribía a Schiller: "ante todo nos proponemos formar buenos artistas" (Todorov, 1996: 12 y 13). Esa voluntad didáctica se extendía, también, a sus escritos científicos como queda patente cuando dice: "Si mi intención se limitara a escribir para entendidos, bastaría con que expusiese en serie los ensayos, dejando al arbitrio de cada cual su ejecución y empleo teóricos; pero como deseo interesar a 
todo el mundo..." (Par. Aut.

III: 925).

174. Goethe encontraba esta inspiración genial en Winckelmann de quien dice: "Podría comparársele con Colón, que antes de descubrir el nuevo mundo ya lo llevaba en su imaginación." (Eck., III: 126) 175. Kant (2007: §46) escribe: "El genio es un talento de producir aquello para lo cual no puede darse regla determinada alguna, y no una capacidad de habilidad". 176. Pevsner (1983: 121) empieza su artículo "Goethe y la arquitectura" con esta cita suya de 1821: "Mi actitud ante la arquitectura ha sido meramente histórica, teórica y crítica."

177. Tal y como quedará enunciado con claridad en el Baukunst, para Goethe con el carácter ya se alcanza el estatus de obra de arte, siendo por tanto la forma adecuada una cualidad previa a su consideración como arte. A este respecto, Goethe (III: 593) diferencia entre "pieza de arte" y "obra de arte". que exige la composición formal de las obras. Por el contrario, requiere, como condición previa, su viabilidad material. Lo que significa, por una parte, la adecuación a las condiciones físicas impuestas por los materiales y, por otra, su correcta manipulación en la puesta en obra. Materiales y construcción son dos condiciones insoslayables, anteriores y necesarias, para que exista la arquitectura. Aún hay otro matiz que diferencia la arquitectura de otras actividades artísticas. El arquitecto ejerce el control técnico de las obras pero su ejecución efectiva no la tiene directamente encomendada, sino que está en manos de los maestros constructores. No necesita, por lo tanto, la habilidad manual que se presume en los demás artistas plásticos. En resumen, la construcción, con todas estas características señaladas, es el requisito imprescindible para que haya arquitectura, la cual no es, tampoco, el resultado directo de la actividad manual del arquitecto.

Además, los edificios no tienen una exclusiva finalidad artística sino que deben adecuarse a la vida y los hábitos de sus ocupantes. No son objetos de pura contemplación y disfrute, como las otras obras de arte, sino que, también, han de expresar convenientemente con su forma el fin al que se destinan de acuerdo con las expectativas de la sociedad que los levanta. Es decir, la obra de arquitectura debe ser adecuada a su uso, pero, sobre todo conveniente a las costumbres de la sociedad. Esa capacidad es lo que Goethe, siguiendo la teoría de tradición francesa, llama el carácter. Por lo tanto, la construcción y la manifestación de su carácter, conjuntamente, son las condiciones que se precisan para que a un edificio se le pueda considerar una "pieza de arte". ${ }^{177}$
En resumen, por una parte, en el contexto de la estética desde el Renacimiento, la arquitectura comparte con las artes plásticas un sustrato general que, en cada caso, se concreta en sus normas y valores específicos. Pero, por otra, y a diferencia de las otras artes, tiene unas premisas exclusivas y esenciales: en primer lugar, depende de las propiedades físicas de los materiales que emplea. Además, su práctica, está sometida no sólo a los principios artísticos propios sino, también, a las técnicas constructivas derivadas de su materialidad que, si bien el arquitecto debe conocer y proyectar, su puesta en obra es ajena a su destreza personal. Por último, las obras no tienen como finalidad única la contemplación sino que se extiende así mismo a su carácter.

Goethe, para quien la reflexión teórica es inseparable de la práctica, al estudiar la arquitectura no puede obviar su condición material sometida a las leyes físicas que acotan lo que es constructivamente factible, es decir, los problemas derivados de la práctica, ni tampoco a la manifestación de su carácter. En el Baukunst identifica tres fines, cada uno de los cuales, presupone y engloba al anterior: el fin inmediato [der nächste] vinculado con la materialidad como algo previo y necesario, aunque insuficiente, el fin superior [der höhere] relativo a los valores tanto culturales como estéticos, y el fin supremo [der höchste] que Goethe identifica con la invención poética y surge del genio creador. Sólo las obras de arte geniales alcanzan este nivel. ${ }^{178}$

\section{Texto y dibujo}

Aunque Goethe estaba persuadido de la posibilidad de trasladar los criterios de las artes 
plásticas al discurso sabía que no era algo fácil ni inmediato porque, como había señalado su admirado Lessing en su libro Laocoonte, pertenecen a esferas independientes en la medida que las primeras se plasman en imágenes espaciales y el segundo se rige por el discurrir del tiempo narrativo. Goethe escribe:

Difícil es, por no decir imposible, la transición de todo lo literario, incluso lo más sublime, que trata con la palabra y el lenguaje de la Poesía y la Retórica a las artes plásticas, pues hay entre unas y otras una sima inmensa, que sólo salvarse puede mediante una naturaleza especialmente indicada. (W., III: 1018)

Así pues, a pesar de esa separación casi infranqueable, admitía que el tránsito de unas a otras, aunque difícil, era viable. Más aún, imágenes y palabras podían complementarse entre sí aportando, cada una de ellas, los valores que son inexpresables en la otra. El dibujo era un instrumento especialmente útil para explicar con imágenes lo que las descripciones no pueden conseguir. Refiriéndose a sus estudios sobre el hueso intermaxilar apunta: "Pero no sólo con representaciones gráficas, sino también con descripciones de palabra, quisimos ilustrar el trabajo, ya que imagen y verbo compiten sin cesar en punto a precisar y difundir la natural historia." (Part. Auto., III: 984). Goethe encontraba que la confluencia de textos e imágenes completa y enriquece las ideas expuestas. La Máxima 188 se refiere a esta cuestión:

Palabra e imagen son términos correlativos que siempre andan buscándose [...]. Así de todo tiempo, lo que al oído se le dice o canta para adentro, tuvo que ofrecerse también a la contemplación de los ojos. [...] Si se expresara lo que no se pinta y se pintara lo que no se puede decir, estaría eso muy en su punto; pero sucede que muchas veces se yerra y se habla en vez de pintar. (Mx. nº 188, I: 352)

Pero el dibujo, practicado asiduamente por Goethe, no quedaba limitado a su papel de manifestación artística diletante, ni a su uso para la exposición de sus ideas como complemento de las descripciones, sino que era, también, un medio muy útil para la elaboración de conocimiento fijando las observaciones o resolviendo cuestiones conceptuales, morfológicas y compositivas. Los trabajos en materias tan diferentes como la anatomía, la botánica, el paisaje o las fortificaciones, canalizados a través del dibujo, le permitían profundizar en sus elementos, sus cualidades visuales o sus estructuras formales, así como esbozar en apuntes las escenas vistas o imaginadas, fijar las imágenes de los lugares y los edificios visitados, y analizar las muestras recogidas durante sus viajes. (Fig. 2) De alguna manera Goethe compartía la consideración del papel que el dibujo había tenido desde el Renacimiento como el lenguaje universal de todo tipo de artes, ciencias y técnicas, antes de su progresivo arrinconamiento por las matemáticas a la esfera artística, a partir del siglo XVII. Es, precisamente, con el dibujo como se inició, de una manera más provechosa, en sus estudios sobre arquitectura queriendo conocer sus principios y sus leyes.

El estudio de los tratados renacentistas de arquitectura había llevado a Goethe a la convicción de que las ilustraciones y los textos, tomados conjuntamente, eran esenciales para exponer, no sólo las soluciones constructivas, sino, especialmente, los aspectos teóricos y compositivos. ${ }^{179}$ Goethe
178. En efecto, ya hay arte de la arquitectura cuando se alcanza el fin superior, aunque no puede considerarse aun "obra maestra genial". Esta clasificación de los edificios recuerda la que estableció posteriormente Valèry: "les uns sont muets; les autres parlent; et d'autres enfin, qui sont les plus rares, chantent [...] Ceux édifices qui ne parlent ni ne chantent, ne méritent que le dédain; (...) Quant aux monuments qui se bornent à parler, s'ils parlent claire, je les estime. [...] mais plaçons au-dessus les édifices de l'art seul! [...] il y a un instant, qu'íls sembent chanter par eux-mêmes» («Unos son mudos; otros hablan; y otros, en fin, que son los más raros, cantan. [...] Estos edificios que no hablan ni cantan, solo merecen el desdén; [...] En cuanto a los monumentos que se limitan a hablar, si hablan claro, los estimo. [...] ¡Pero pongamos encima a los edificios sólo artísticos! [...] Hay un momento en que parecen cantar por sí solos" (2004: 20 y 23). 
Fig. 2: Johann W. Goethe, Pflanzenskizze [boceto de plantas], después de 1790 (81x170 mm. Sanguina). En Femmel, [1958], 1972, Vb: 98 179. Palladio, del que Goethe estudió con admiración su tratado y sus obras, reconocía la elocuencia del dibujo para exponer aspectos arquitectónicos por encima de las descripciones. Escribe: "se aprende mucho más en poco tiempo de los buenos ejemplos con el medir y el ver en una pequeña hoja los edificios enteros y todas sus partes, que con largas explicaciones" (Palladio, 1570, Lib. III, Proemio a i Lettori, 5).

180. El propio Winckelmann se lamentaba de esta carencia que coartaba su trabajo. En 1762 escribe: "Esta es la descripción más extensa que se puede dar de los restos antiguos de la ciudad de Paestum sin recurrir a grabados" (1985: 268). Y en otro lugar repite: "Pero me veo obligado a limitarme a investigaciones que no me exijan ningún grabado." (1985: 566). El barón Johann Hermann von Riedesel (1740-1785) había dedicado su guía ilustrada a Winckelmann y Goethe el 26.4.1787 en Agrigento habla de: "Riedesel, cuyo librito llevo en el seno cual breviario o talismán. [...] devoción fervorosa a un maestro que ilustra a Winckelmann" (V. It., III: 1222-1223).

181. Marchán Fiz comenta: "Hasta el enciclopédico y mensurado Goethe se siente

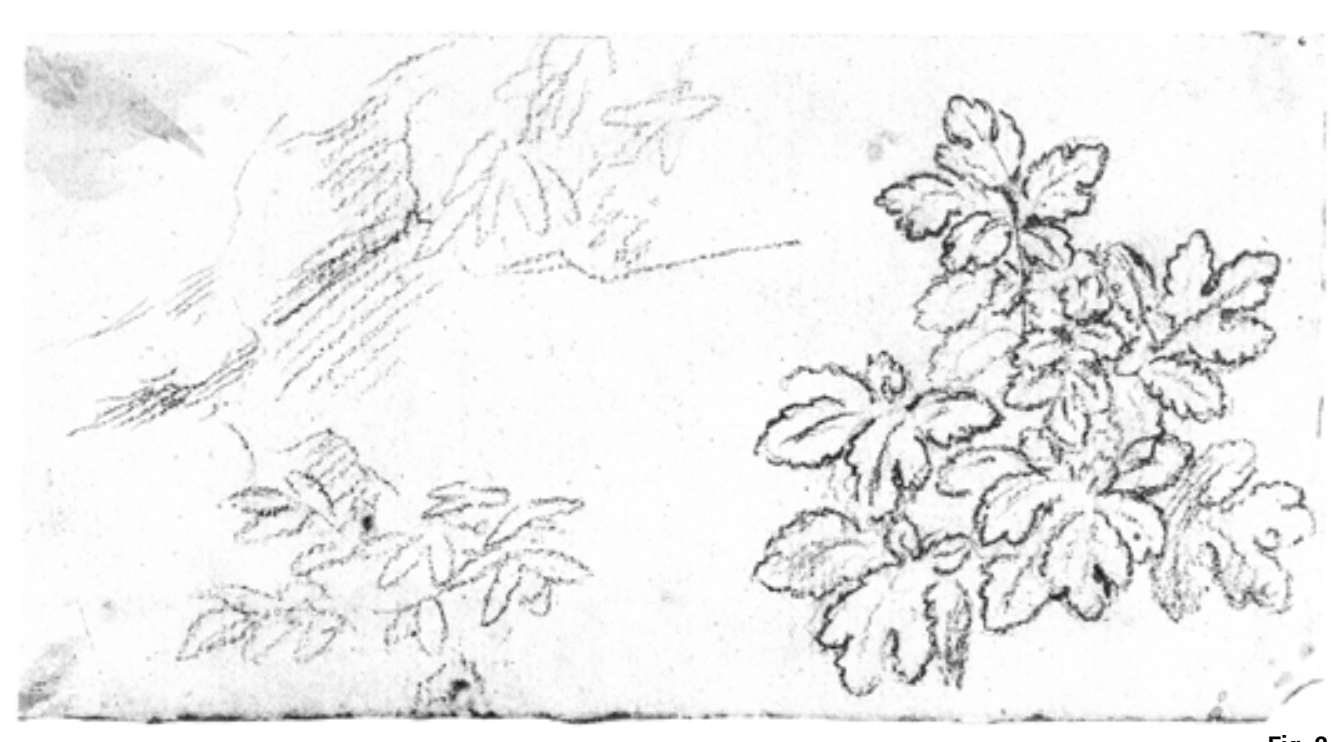

Fig. 2

se habría persuadido sobre la eficacia de esta forma de exposición combinada de dibujos y textos al comprobar la dificultad de explicar ejemplos y obras en los libros de arquitectura sin imágenes como el de Winckelmann Observaciones sobre la arquitectura de los antiguos, ${ }^{180}$ o en sus propios escritos sobre esta materia publicados con anterioridad. Así pues, cuando se propuso elaborar su estudio sobre la arquitectura decidió incorporar figuras en el Baukunst, disponiéndolas junto al discurso como algo imprescindible.

En resumen, para Goethe el dibujo tenía un triple cometido. Por una parte, como dibujante diletante, era un modo de canalizar su vocación plástica. ${ }^{181}$ En Nápoles escribe: "Cuando quiero escribir palabras, tengo siempre cuadros ante los ojos" (V. It., III: 1177). Por otra, le servía como medio para realizar sus estudios y trabajos en el campo científico y en distintas esferas artísticas como la escenografía o la arquitectura. ${ }^{182}$ Por último, cumplía una labor esencial en la exposición de sus teorías como contrapunto necesario a las descripciones y textos explicativos. ${ }^{183}$ Una síntesis de dibujos y textos que asumen un carácter didáctico al que, tal vez el Baukunst aspiraba como regeneración de un arte que, en su opinión estaba en decadencia. ${ }^{184} \mathrm{Un}$ análisis de sus aportaciones en este campo reclama, necesariamente, no sólo la consideración simultanea de textos y figuras, sino también, los croquis, esbozos y apuntes hechos coetáneamente sobre los mismos temas con los que mantienen una evidente relación temporal y conceptual. 


\section{C. "Arte otra naturaleza..."}

Kein Mensch will begreifen, daß die höchste und einzige Operation der Natur u. Kunst die Gestaltung sei.

Carta a Zelter, 30 de octubre $1808^{185}$

Una de las constantes de todo el pensamiento estético clásico es la teoría de la mímesis: el arte imita a la naturaleza. En su primitiva acepción entre los griegos la mímesis significaba "éste es aquél", es decir, alude a una transubstanciación donde alguien o algo se convierten en otra persona o cosa. ${ }^{186}$ Pero este concepto fue fluctuando con significados distintos en el transcurso del tiempo ${ }^{187}$ deviniendo, en el siglo XVIII, en imitación creadora [bildende Nachahmung] (Marchán, 2012: 88). Ya no se trataba de reproducir las formas de la naturaleza sino su capacidad formativa, su genio creador. ${ }^{188}$ De este modo, parcelas artísticas como la arquitectura, que habían tenido un encaje difícil en la mímesis figurativa clásica, encontraban ahora una nueva justificación sin tener que recurrir a representaciones naturalistas. ${ }^{189}$ Goethe escribe: "Arte, otra Naturaleza, misteriosa también, pero más inteligible, ya que brota del intelecto." (Mx. nº 1103, I: 441).

El arte ya no buscaba el parecido de la naturaleza ni imitaba sus formas, sino su estatus convirtiéndose en otra naturaleza hecha por el artista genial erigido en demiurgo. Según Moritz, exponiendo opiniones que eran fruto de su intercambio de ideas con Goethe, ${ }^{190}$ existe una correspondencia entre la "fuerza activa de la Naturaleza" y la "fuerza activa del genio" que la capta directamente y brota en la mente del artista como inspiración, antes de la ejecución efectiva de la obra tan inspirado al contemplar los templos griegos en el sur de Italia, que nos deja unos delicados dibujos de su percepción de los mismos en el paisaje, mostrando un especial esmero por situarlos y ambientarlos en su lugar geográfico." (2012: 126).

182. Véase a este respecto el papel del dibujo en el diseño de la arquitectura teatral y la escenografía en la obra de Goethe, en Rubio y Calduch (2016), y Calduch y Rubio (2017). 183. Durante su viaje a Italia, el 20.11.1786 escribe: "es muy digna de aplauso la idea de Tischbein de que poeta y pintor deberían de laborar de consuno, a fin de formar desde el principio una unidad. Resultarían, ciertamente, muy aminoradas las dificultades, empleando poemitas que fácilmente se pudieran abarcar con la mirada y repasar. [...] ni el arte poético ni el plástico, cada uno de por sí, serían bastantes a representarlos" (V. It., III: 1128). Finalmente, en 1821 Goethe recuperó esta idea y compuso unos poemas para acompañar algunos dibujos de Tischbein.

184. En Venecia el 8 de octubre de 1786 escribe: "El arte que preparaba a los antiguos su terreno y abovedaba a los cristianos su cielo de iglesia, desaparece ahora en cajitas y cintajos. Estos tiempos son mucho peores de lo que se piensa" (V. It., III: 1093). La vocación didáctica del arte, una idea madurada en colaboración con Schiller, se recoge en un apartado posterior de este texto.

185. “Nadie está preparado para concebir que el único y más elevado proceso tanto en la naturaleza como en el arte es la creación de formas." (Mx. n² 20.1, I: 197)

186. Véase Bozal (1997: 41-59). Este sentido permanece, en cierta medida, en el rito católico de la consagración, donde, para los creyentes, el pan y el vino, sin cambiar de forma aparente ni de constitución física, cambian de esencia y se convierten en la carne y la sangre de Cristo. 187. Según Marchán Fiz ya Platón "concebía la mímesis en cuanto composición de imágenes como una participación del mundo de las ideas [...]. Aun así, añade el matiz de que la mimesis puede ser reproductiva, como en la labor del artesano y del arquitecto, o ilusionista, como sucede en el escultor y el pintor." (2012: 40) y Aristóteles plantea: "la necesidad innata de imitar no ya las Ideas, sino los caracteres, es decir, la realidad natural y humana, incluidas las acciones y las pasiones. Igualmente, la imitación puede diferir respecto a los objetos o qué cosas imita, según los medios o artes con los que se lleva a cabo y según las diversas maneras y modos, es decir, cómo o cuáles sean los grados de la imitación." (2012: 40).

188. En sus años juveniles, según Safranski "al principio de la imitación contrapone Goethe el principio de la expresión creadora" (2015: 129). Marchán Fiz escribe: "se debilita el principio imitativo en beneficio de las poéticas aurorales del crear o formar [...] mientras que la imitación, si es que todavía es invocada, se transmuta en "formadora»." (2012: 88).

189. Basta pensar en las versiones clásicas de la mímesis poco convincentes utilizadas en arquitectura como la cabaña primitiva cuyo origen estaba en los árboles, las formas humanas de cariátides y atlantes persas, las proporciones del hombre vitruviano, los estípites antropomorfos o los capiteles y ornamentos con hojas y motivos vegetales.

190. Goethe intercala el texto de Moritz Sobre la imitación plástica de lo bello (Braunschweig, 1788) en sus Viajes Italianos (V. It., III: 1395-1400) justificando esta inclusión porque "EI folleto de Moritz había surgido como como fruto de nuestros diálogos, que Moritz luego aprovechara y moldeara a su manera [...y...] permite ver qué clase de ideas se abrían entonces delante de nosotros" (V. It., III: 1395). 
191. Marchán Fiz comenta que en aquella época: "lo natural empieza a tener otro sentido: la adecuación racional de las formas a sus fines y la conformación a los materiales." (2012: 184) 192. Según Safranski para Goethe "la «verdad de la naturaleza» se convierte también en la «verdad del arte» [...] lo cual se produce mediante el libre juego y la «imaginación». Así pues, la verdad del arte es la verdad de la naturaleza lúdicamente incrementada." (2015: 406) de arte. El genio plástico es "tan amplio como la Naturaleza misma" dice Moritz (V. It., III: 1395). Abundando en esta convicción, escribe Goethe: "Pero yo quiero demostrar que las artes conocidas de los hombres son idénticas a acontecimientos naturales" (Mx. $\mathrm{n}^{\circ}$ 626, I: 398). Una identidad esencial, por lo tanto, que no se deduce de la imitación directa, ni de la copia de modelos, ni se debe confundir con la sensibilidad o el gusto del autor.

\section{Naturaleza, arte, razón}

Esa resonancia entre la naturaleza y el mundo del arte, la "otra Naturaleza", es posible porque ambos son accesibles a la razón humana, porque son inteligibles. Las producciones artísticas son como los seres naturales, por lo que pueden ser comprendidas con las mismas ideas y los mismos criterios racionales empleados para estudiar esos fenómenos. Goethe dice:

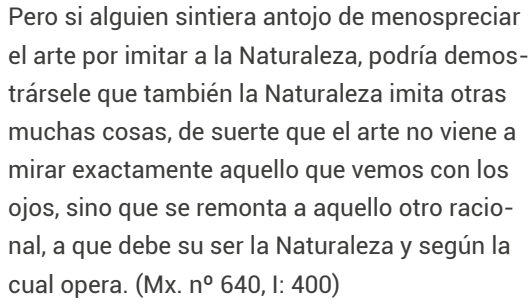

La naturaleza y el arte comparten la racionalidad ${ }^{191} \mathrm{y}$ ambos se apoyan en el mismo pensamiento objetivo: "Cuando los artistas hablan de la Naturaleza, siempre se sobreentiende la Idea, sin que de ello se percaten" dice Goethe (Mx. n 1069, I: 438). 0 sea, cuando el arte remite a la naturaleza, lo hace mediante el concepto ideal que de ella se forma en la mente del artista. La razón, que al enfrentarse con las cosas naturales busca con la ciencia descubrir su verdad, es la misma que confiere veracidad a las obras de arte en la medida que remiten a la propia naturaleza haciéndolas verosímiles. Goethe lo dice claramente: "La base de todo arte teatral, como de cualquier arte, es lo verdadero, lo conforme a la Naturaleza" (Mx. nº 736, I: 411). La "verdad artística" tiene su fundamento en la "verdad de la naturaleza" Ilegando, incluso, a superarla, defenderá Goethe en los Propyläen (Safranski, 2015: 404). ${ }^{192}$ Ambos, la naturaleza y el arte, despiertan, así mismo, idéntico afán de conocimiento: "Quien empieza a arrancarle sus secretos a la Naturaleza siente un ansia invencible de su más digno intérprete, el arte." (Mx. $\mathrm{n}^{\circ}$ 201, I: 353). El verdadero arte es un espejo elocuente que nos muestra, de manera comprensible, la naturaleza, no en su imagen aparente sino en su esencia más profunda. En este sentido, el arte nos aporta una idea de la naturaleza pero lo hace por una vía distinta, aunque complementaria, al conocimiento científico. La ciencia busca el sustrato teórico general que esconde la naturaleza, y el arte se orienta hacia su particularidad. El conocimiento artístico recorre el camino de lo particular de las obras a lo general de la idea. Pero los dos extremos están vinculados entre sí porque "lo general y lo particular coinciden; lo particular es lo general, que se presenta en otras condiciones" (Mx. n 569, I: 393). De este modo se cierra el círculo, dado que "aún lo más particular que ocurra muéstrase siempre cual imagen y semblanza de lo más general" (Mx. nº 571, I: 393).

Esta equiparación entre naturaleza y arte facilita el trasvase de contenidos de una esfera de pensamiento a otra siguiendo el flujo mental tan característico de Goethe. Ex- 
traer de las obras de arte las ideas estéticas que las sustentan es lo mismo que estudiar los ejemplos que encontramos en la naturaleza para descubrir las leyes que los gobiernan. Hablando de su propia experiencia comenta:

$Y$ de esta manera, casi sin advertirlo, vime metido en un campo extraño, pasando de la poesía al arte plástico y de éste a la investigación de la Naturaleza [...]. Pero habiéndome demorado harto tiempo en estas extrañas regiones, di, finalmente, con el feliz regreso al arte, merced a los colores fisiológicos y al efecto moral y estético de los mismos. (Par. Aut., III: 959).

Un vaivén entre el arte, la poesía y la naturaleza donde las ideas que la mente genera son el nexo que los une. ${ }^{193}$ Más aún, la belleza del arte encuentra en la naturaleza su referencia, la cual no se basa en apariencias o semejanzas visibles sino en "principios estables y constantes". ${ }^{194}$ Lo que asegura la verdad y la belleza de las obras artísticas ya no es la reproducción formal y mimética de los modelos naturales sino los fundamentos racionales del pensamiento que, siendo únicos, el hombre encuentra tanto en la naturaleza como en el arte. De alguna manera, las normas que se descubren en la naturaleza son tanto el sustrato metódico para el conocimiento estético, como la guía adecuada para el disfrute de la belleza. Por eso, las condiciones naturales a las que se han de ajustar las obras son el requisito que garantiza la validez de la mímesis en el arte, cualquiera que sea el modo en que se interprete esa noción.

En el Baukunst, siguiendo la pauta marcada por Winckelmann, Goethe buscó en las cualidades de los materiales, en la racionalidad constructiva y en la adecuación conveniente a los fines, o sea, en los aspectos debidos a su procedencia natural, y someti- dos a las leyes impuestas por su condición física y social, los cimientos racionales de la arquitectura sobre los que se sustenta su carácter artístico.

\section{Historia natural}

La forma directa de acometer el estudio de la naturaleza era, en aquella época, la ordenación comparativa y la clasificación de los seres según sus elementos más característicos, siguiendo lo que Foucault denomina un a priori histórico. ${ }^{195}$ La naturaleza tiene su propia historia: la formación de los volcanes y los procesos de petrificación, o la metamorfosis de las plantas, entre otras muchas cuestiones que interesaron de un modo especial a Goethe, revelan la historia del mundo. Muestran claramente la existencia de una historia natural que sigue abierta y en proceso, regida por unas leyes que pueden ser encontradas y enunciadas racionalmente.

Para Goethe toda investigación en este campo pretende determinar y aislar las transformaciones que se han ido produciendo en la naturaleza con el transcurso del tiempo para encontrar no sólo su origen ,sino, también, las causas que han generado esos cambios. O sea, buscar su filiación y, simultáneamente, alumbrar su estructura racional, a fin de establecer, por un lado, el inicio del proceso, por otro, el orden de las cosas y, por último, las bases que explican los cambios. 0 , como él dice, refiriéndose al objeto de la Historia Natural, "derivar los procesos naturales de fenómenos superiores" (Esbozo Teor. Col., I, 583). La historia así interpretada se desdobla en dos caras: la descripción de los fenómenos y la estructura teórica que descubre las conexiones que hay entre ellos.
193. Argán (2010: 36-37) señala que "el problema de la relación entre arte y realidad es equivalente al de la relación entre arte y naturaleza o, también, entro lo artificial y lo natural, en cuanto componentes, igualmente válidos de la realidad: se trata por tanto de un problema de dialéctica o de dinámica interna de lo real."

194. Marchán Fiz, citando a François Blondel, cuyo Curso de Arquitectura tenía Goethe en su biblioteca, escribe: "sostiene que existe una belleza natural derivada de las proporciones numéricas y geométricas [...] las proporciones son la causa de una belleza fundada en la naturaleza y se basan en "principios estables y constantes»" (2012: 68).

195. Foucault habla de "una especie de a priori histórico" y añade: "El a priori histórico que, en el siglo XVIII, fundamentó las investigaciones o los debates [...] es la existencia de una historia natural [...]. La historia natural de la época clásica [...] recubre una serie de operaciones complejas que introducen en un conjunto de representaciones la posibilidad de un orden constante." (2009: 158-159) 
196. Según Safranski para Goethe "una idea directiva es el pensamiento de la evolución, cuyo contenido es que también la naturaleza tiene historia" (2015: 281). Según Foucault en esta interpretación: "toda la continuidad de la naturaleza se aloja entre un prototipo, absolutamente arcaico, enterrado más profundamente que cualquier historia, y la complicación extrema de este modelo, tal como se puede observar" (2009: 155)

197. Refiriéndose a Goethe escribe Safranski: "Que la naturaleza tenga una historia significa también para él que ésta no ha terminado su propia obra en sí misma. La historia continua y continua también con el hombre."

(2015: 282), Según Marchán Fiz: "tal vez quien mejor capte semejante transición [desde la historia natural] hacia la historia sea Herder" (2012: 94). Y, conviene recordar, el vínculo intelectual y de amistad, tan profundo, que existía entre Goethe y Herder a quien le escribe desde Nápoles 817.5.1787): "pues somos tan afines en nuestras respectivas maneras de pensar cómo es posible serlo sin ser una misma persona, y en los puntos principales es donde más lo somos." (V. It., III: 1253).
Goethe lo explica: "Así las ciencias como las artes constan de una parte comunicable (real), aprendible, y de otra parte incomunicable (ideal), inaprendible" (Mx. $\mathrm{n}^{\circ} 1152, \mathrm{I}$ : 445). De este modo, "la Historia se convierte en Natural" (Foucault, 2009: 129) y el orden histórico se identifica con el orden natural como procedimiento para elaborar un conocimiento general.

Instaurar una historia natural, tal como entonces se interpretaba, no significaba situar a las cosas en una secuencia temporal construyendo un relato lineal de ejemplos que, simplemente, se van sucediendo unos a otros. Tampoco se regía por ninguna clase de evolucionismo de carácter progresivo donde los seres devienen de los anteriores por transformaciones enlazadas e interdependientes. Por el contrario, consistía en descubrir, mediante la comparación, las relaciones que vinculan entre sí todas las cosas que ahora existen simultáneamente, y ordenar los cambios y las divergencias que han ido creando una malla desde un estado original único hasta su diversidad y dispersión actuales. ${ }^{196}$ Todo lo que forma la realidad que ahora contemplamos y nos sorprende con su exuberante variedad es el resultado de una acumulación de ramificaciones cada vez más complejas producidas en varias etapas y diversas circunstancias a partir de un principio unitario. Y la historia natural nos muestra y explica, sintéticamente, como en un cuadro sinóptico o en un corte geológico, lo ocurrido.

Los estudios científicos sobre distintas parcelas de la naturaleza emprendidos por Goethe están teñidos por este enfoque histórico. Citando la Histoire Naturelle de Buffon escribe: "«Hay un arquetipo primitivo y original, cuyas huellas pueden rastrearse fá- cilmente hasta muy lejos», con las cuales palabras dejó sentada de una vez para siempre la máxima fundamental de la Historia natural comparada." (Part. Aut., III: 991). Su intuición sobre la planta arquetípica [Urpflanze] desencadenó su investigación sobre las leyes que explicasen racionalmente las metamorfosis de todas las demás plantas existentes. Sobre esta base Goethe quería construir, a la vez, la historia natural de la botánica y la morfología de las plantas.

La historia asume también el papel de charnela entre la naturaleza y el hombre ya que, como ser natural, es su manifestación más elevada. Historia natural e historia de la humanidad son dos disciplinas hermanadas que hacen plausible el intercambio de conocimientos entre sí. ${ }^{197}$ El proceso de complejidad creciente que muestra la historia natural se hace aún más evidente en las estructuras sociales que presenta la historia de la humanidad, desde la simplicidad de los pueblos primitivos a la intrincada realidad de las culturas y las naciones actuales. Así, para Goethe, era inevitable que se produjera el traspaso entre sus indagaciones de los fenómenos naturales a sus estudios sobre las producciones humanas en el arte o la arquitectura. La historia de la arquitectura, enfocada con los mismos criterios que sus trabajos de historia natural, fue el método que utilizó para llegar al planteamiento de su teoría arquitectónica. ${ }^{198}$ Este era el objetivo implícito del Baukunst.

\section{Historia del arte}

Cuanto más verdadera es una obra de arte, más próxima está a la naturaleza. Una cuestión que es esencial, no sólo en la reinterpretación de la teoría de la mímesis, 
sino también, en la valoración del arte griego antiguo tal como lo postuló Winckelmann ${ }^{199} \mathrm{y}$ adoptó Goethe: "El espíritu sensible para las creaciones poéticas y plásticas siéntese ante la antigüedad en el más gratamente ideal estado de naturaleza" (Mx. nº662, I: 403). Para ambos la excepcionalidad de Grecia estribaba en que lo bello, como sublimación de la propia naturaleza, encontró allí su concreción en la historia. Desde Winckelmann se aceptaba que la naturaleza y el arte convivían entre los antiguos griegos en tan íntima comunión que prácticamente se identificaban alcanzando, en aquella época, su nivel estético más elevado. El arte de la antigüedad, surgiendo de la naturaleza, iniciaba, así, su historia. ${ }^{200}$ Por eso Goethe le dice a Eckermann: "estudiaremos, ante todo, a los clásicos griegos y siempre a los griegos" (Eck., III: 311 ).

Los vínculos entre la naturaleza y el arte, por un lado, y entre la historia natural y la historia del arte, por el otro, eran objeto de debate en las distintas teorías estéticas de la época. ${ }^{201}$ Una tesis, asumida por Goethe quien, refiriéndose a los griegos escribe: "Tengo la sospecha de que procedieron precisamente según las leyes que sigue la Naturaleza y que yo voy rastreando." (V. It., III: 1148). ${ }^{202}$ Es lo que emprende, implícitamente, en el Baukunst, trasladando a la arquitectura el método que Winckelmann ya había utilizado en la historia del arte. ${ }^{203}$

Bajo la perspectiva de Winckelmann seguida por Goethe el arte echa sus raíces en la naturaleza y su historia arranca con los griegos que abrieron el camino. En consecuencia, había que encontrar el entramado estético subyacente, es decir, la Idea, a partir del análisis ordenado de los ejemplos históricos conocidos. ${ }^{204}$ No se trata, por tanto,
198. Pevsner defiende esta idea cuando escribe: "Así las ideas de Goethe de la vida vegetal, y sobre Gestaltung [morfología] y metamorfosis en general, son aplicadas aquí a la arquitectura." (1983: 130).

199. Assunto comenta: "el neoclasicismo bajó esta idea de lo bello desde el cielo platónico a la tierra de la historia configurando como relación entre naturaleza e historia lo que en el idealismo estético del XVII había sido una relación entre naturaleza e idea." (1990: 14). Y añade: "Y la novedad de Winckelmann, [...] consistirá en resaltar el carácter histórico de la Idea y de la naturaleza" (1990: 81).

200. Assunto, refiriéndose a los griegos antiguos y citando a Winckelmann, escribe: “«... hay que ser conscientes de que no basta la influencia del clima, sino también la de la educación y de la forma de gobierno». [...] estas afirmaciones de la Historia del Arte en la Antigüedad [...] clarifican y llevan adelante el paso de la Idea desde la naturaleza a la historia" (1990: 91). Y concluye: "Es el problema de la formación de la categoría estética como categoría histórica" (1990: 92)

201. Según Assunto: "la Naturaleza de Gessner coincide, en última instancia, con la Antigüedad de Winckelmann, y luego de Moritz [...] y a todas estas se accede a través de la historia; mejor aún: a través de la historia del arte tratada de modo sistemático [...]. Y si para Winckelmann la historia permitía recuperar la naturaleza a través de la antigüedad mediadora, para Gessner sucede lo contrario: es la historia -la historia del arte [...]- la que nos lleva ante la presencia de la antigüedad como fuente donde la historia brota de la naturaleza." (1990: 164). Y concluye: "la antigüedad siempre se presenta como mediadora entre la naturaleza y la historia" (1990: 173).

202. Algo así comunica por carta desde Roma el 28 de enero de 1787: "Supongo que ellos [los griegos] procedían según las mismas leyes que aplica la naturaleza, tras el rastro de las cuales yo me encuentro." (Teo. Nat., 75, nº 37).

203. Refiriéndose a los trabajos de Winckelmann Goethe subraya su "interés de poner a prueba el método ya por él introducido en la historia del Arte" (W., III: 1026). El objetivo de Winckelmann, según Assunto era "construir la Historia del Arte como sistema, es decir, conjugar la reflexión histórica del arte real con la reconstrucción teórica de las ideas estéticas y de su historia." (1990: 148) Y, en este sentido: "Naturaleza e historia tendían a unirse en la imagen de una antigüedad en la que la naturaleza se hacía historia, y a su vez la historia tenía su propia imagen y legitimación en la naturaleza." (1990: 149). 
204. Marchán Fiz menciona: "la ruptura doble que Winckelmann había provocado, pues si bien éste, por un lado, toma contacto con una presunta realidad histórica, la griega, por otro idealiza de tal manera, que la permuta en la encarnación de una naturaleza humana universal." (2012: 38).

205. Así se recoge en Eckermann (1827: 21.1 y 31.1). 206. Esta triple acepción la señala Marchán Fiz. Refiriéndose a la Historia del arte en la Antigüedad de Winckelmann escribe: "Desde esta doble orientación lo clásico se desdoblaba como una categoría histórica de época, y como un concepto normativo." (2012: 30) Y añade: "otra doble filiación inédita de lo clásico [...] por un lado, lo clásico es identificado con la Antigüedad clásica (das klassische Altertum), por otro, [...] se predica de las obras más elevadas o modélicas en su género: los llamados modelos actualizados por la estética ilustrada y el Neoclasicismo artístico." (2012: 35). de imitar la naturaleza directamente sino a través de los griegos. ${ }^{205}$ Goethe, señalando esta cuestión, dice:

No siendo posible poner largo tiempo la atención en las obras de arte sin descubrir que no sólo son de diversos artistas sino que también corresponden a épocas diversas, y que hay que plantear al mismo tiempo todas esas cuestiones de lugar, época y mérito individual, ocurrió que también Winckelmann hubo de intuir, con su exacto sentido, que en eso estriba el eje de todo conocimiento artístico. (W., III: 1020)

La historia como vía imprescindible para el conocimiento del arte debía ser completada con la experiencia y el conocimiento directo de las obras para poder enunciar un juicio. Dos vertientes que sólo conjuntamente pueden dar sus frutos. Estando en Roma escribe:

ante la enorme $y$, sin embargo, ruinosa riqueza de esta ciudad, vese uno obligado, a vista de cada objeto artístico, a preguntar de qué época data, Winckelmann nos exhorta apremiantemente a distinguir las épocas, reconocer los diversos estilos [...]. Necesítase una asidua práctica visual de muchos años, y hay que empezar por aprender para poder preguntar. [...] tampoco en este terreno es posible ningún juicio, sino cuando se le puede dar un desarrollo histórico. (V. It., III: 1148)

Es a los antiguos, por su contacto estrecho con la naturaleza, hacia donde hay que dirigir, inevitablemente, tanto el conocimiento en general, como el artístico en particular, porque fueron ellos los que asentaron firmemente las bases teóricas en todos los campos. Según Goethe:

Láncese una ojeada a cualquier arte o ciencia que se desee, y se verá que ya el sentido recto, exacto, habíale descubierto al observador antiguo [griegos] muchas cosas que debido a la subsiguiente barbarie [de romanos y bárbaros] quedaron convertidas en un misterio. (W., III: 1020)

El arte (y también la ciencia) de la antigüedad clásica como narración histórica, la teoría estética del clasicismo como sustrato conceptual, y la práctica artística, se entrecruzan y funden en una frágil síntesis. ${ }^{206}$ La teoría del arte, elaborada a partir del conocimiento histórico de los antiguos griegos, es, también, el trasfondo de donde extraer las normas que orientan la ejecución de las obras. Y, en consecuencia, los artistas no debían dirigir su mirada directamente a la naturaleza, como si la historia no hubiera existido, sino que tenían que hacerlo a través del filtro de los antiguos.

Pero no se trataba de sustituir la imitación simple de la naturaleza por la copia de modelos antiguos sino de aspirar al ideal clásico. Lo clásico, cuya idea obtenemos mediante el estudio de arte y la arquitectura de los antiguos griegos, alcanza, sin embargo, un valor atemporal que sobrevuela los avatares de la historia. Por eso, ser clásico no significaba copiar los ejemplos antiguos sino hacer como Rafael que, siéndolo, "jamás imita el estilo griego $y$, sin embargo, siente, piensa y actúa como un griego" (Salmerón, 1999: 174). 0 como Palladio cuyas obras son utilizadas por Goethe como modelos en el Baukunst. Se trata, en definitiva, de diferenciar "el estilo" de la "maniera". "El estilo se apoya en las bases más profundas del conocimiento de la esencia de las cosas, en la medida que la podemos reconocer en formas visibles y tangibles" (Salmerón, 1999: 69). La maniera, por el contrario, "tiene facilidad para agrupar 
apariencias superficiales" de modo que "es un término medio entre la imitación simple y el estilo" (Salmerón, 1999: 69-70). ${ }^{207}$

\section{Historia de la arquitectura}

El estudio de la historia de la arquitectura era, para la cultura del momento, una rama más de la historia del arte compartiendo sus mismos principios. Lo dicho del arte en general se aplicaba directamente a la arquitectura. Goethe siguió esas pautas en el Baukunst donde reconoce expresamente que lo dicho para la arquitectura era extensible a las demás artes, haciéndose eco de otros planteamientos similares entonces vigentes. La búsqueda del orden primigenio en arquitectura, identificado con el dórico griego primitivo, y la delimitación de las circunstancias que fueron generando el surgimiento de todos los demás órdenes, así como las variaciones formales debidas a causas constructivas o utilitarias, se fusionan en el Baukunst. El resultado es una síntesis donde Goethe, al apoyarse en la historia de la arquitectura de los antiguos, pretende definir y acotar el sustrato clásico arquitectónico.

Goethe entiende que se puede "encarar todo el arte como un ser vivo ( $\varepsilon \omega o v)$ que por fuerza ha de representar un imperceptible origen, un desarrollo lento, un instante brillante de plenitud y un gradual descenso, cual todo ser orgánico, sólo que en varios individuos" (W., III: 1020-1021). Incluso postula la metáfora inversa al comparar los organismos con la arquitectura cuando escribe:

¡Cuántas cosas importantes compónense de partes! Fijémonos en las obras de arquitectura: vense en ellas apiladas muchas cosas en forma regular e irregular. De ahí que el concepto atomístico nos resulte asequible y cómodo; y de ahí también que no nos asuste el aplicarlo incluso en los casos orgánicos" (Mx. n 725, I: 411)

Así pues, la historia natural, ahora enfocada hacia la vida de un organismo, le servía de referencia, nuevamente, para comprender la historia del arte en su conjunto y, por lo tanto, la de la arquitectura en particular.

Esta postura, cuyo cenit se produjo en los últimos lustros del siglo XVIII, precisamente cuando Goethe estaba ocupado en el Baukunst, encerraba ya el germen de su disolución. Porque la metáfora de la historia del arte como un ser vivo significa que al momento de máximo esplendor sólo puede seguirle la decadencia. ${ }^{208}$ Esto produjo una fisura, que empezó a emerger a principios del siglo XIX, entre el significado de la historia y el pensamiento estético. Historia y teoría del arte empezaron a discurrir por vías distintas. Finalmente, se consumó una separación, que fue definitiva, y la historia abandonaría su papel como fundamento para la teoría. ${ }^{209}$

En el pensamiento de Goethe sobre la arquitectura esta cuestión sufrió un deslizamiento que, en cierta medida, refleja ese devenir y que se hizo patente en su reflexión sobre las ruinas. Tras su regreso de Italia los vestigios antiguos tenían para él una doble y ambigua valoración: como estímulo estético y como fuente de conocimiento. "Siempre sentimos enojo cuando excavan alguna [ruina] medio sepultada, pues eso puede, a lo sumo, rendir algún provecho a la erudición, pero a costa de la fantasía." (III: 1019). Las ruinas tenían un atractivo estético como parte del paisaje donde se diluyen en la naturaleza despertando la reflexión sobre el
207. Esta noción de estilo de Goethe tiene afinidades con su idea del carácter. Sobre esta cuestión ver el correspondiente análisis posterior. 208. Winckelmann situó ya la decadencia de la arquitectura en tiempo de los romanos. Escribe: "y como los arquitectos vieron que no podían aventajar ni igualar a sus predecesores en belleza, trataron de suplir su falta por la riqueza y la profusión." (1985: 556). Y, el mismo Goethe escribe: "Ias antigüedades de Herculano nos muestran que, también en la época de los antiguos, todo terminó por desembocar en semejante manierismo" (1999: 273). 209. Marchán Fiz menciona los principales hitos de esta ruptura y concluye: "En este escenario historicista aparece la disolución (auflösung) no sólo del clasicismo, sino incluso de las tentativas de síntesis entre lo objetivo y lo subjetivo." (2012: 107). Y en este mismo sentido Assunto comenta: "La historia del arte, escribirá Herder ha de ser tratada sólo como historia, y no como sistema". (1990: 175). 
210. "las ruinas no basculan solamente entre la historia y la naturaleza, aunque sean producto de ambas, sino entre la historia y la estética" (Marchán, 2012: 141-142) 211. Por ejemplo: VIb, 89 : 1787/88: Templo junto a un acantilado; II, 159: abril/mayo 1787: Templo junto al mar. Fantasía; II, 99: 17.5.1787: Restos de columnas junto al mar. Paestum; III, 48: verano/ otoño 1787: Foro Romano; VIb, 65: 2.6.1787: Erupción del Vesubio sobre Pompeya; VIb, 66: 2.6.1787: Erupción del Vesubio sobre Pompeya; VIb 76: 1787: Paisaje inventado con ruinas de un templo, etc. Fig. 3: Johann W. Goethe, Kirchenruine auf den Petersberg bei Halle [Ruina de iglesia en Petersberg en Halle], 30.5.1778 (375x530 mm. Lápiz). En Femmel [1958], 1972, I: 198

Fig. 4: Johann W. Goethe, Säulentrümmer am Meer, Motiv von Paestum [Restos de columnas en el mar, motivo de Paestum], 1787 (225×305 mm. Lápiz). En Femmel [1958], 1972, II: 99

212. Entre otros: I, 63: hacia 1769: Paisaje con ruinas de Puerta de muralla antigua; I, 166: 1777: Escena de brujas. Ruinas de palacio con torre de escalera; I, 177: 1777: Torre entre siluetas de árboles; I, 198: 1778: Ruinas de la iglesia de Petersberg junto a Halle; I, 206: 1778/80 Caserío en ruinas (Hassenstein, Bohemia); I, 211: 1779: Ruinas de la iglesia de San paso del tiempo. (Fig. 3) En la estética de las ruinas se trenzan la historia, la naturaleza y la pervivencia mutilada de la obra de arte..$^{210}$ Son numerosos los dibujos de Goethe de esos años, muchos de ellos hechos en Italia, donde queda patente esta postura. ${ }^{211}$ Todavía en 1823 escribía: "Tiene toda ruina importante algo de venerable; presumimos, vemos en ella el conflicto entre una digna obra humana y el tiempo que nada respeta" (Part. Auto., III: 1002).

Sin embargo, para el estudio de la teoría clásica las ruinas antiguas eran la principal fuente de información. Y, para este fin, una ruina es sólo un despojo incompleto de la obra, escaso e insuficiente, que es necesario restituir. Vistos así, los restos de un edificio eran una limitación que había que superar para su cabal conocimiento. Goethe se hace eco de este problema quejándose: "Y así antójasele a uno raro el que, cuando tanto nos afanamos por formarnos una idea de la antigüedad, solo se nos ofrezcan ruinas, de las que tendríamos que inferir trabajosamente aquello de que aún no tenemos ninguna idea" (V. It., III: 1116). (Fig. 4)

Frente a esta doble postura ante las ruinas clásicas, los restos de edificios medievales y góticos tenían para él una consideración muy diferente que fue modificándose desde sus años juveniles a su vejez. El interés estético de su juventud, teñido de paisajismo romántico, quedó reflejado en los abundantes dibujos de torres, murallas, puertas de ciudades y construcciones medievales en estado ruinoso. ${ }^{212}$ En 1770, por influencia de Herder,

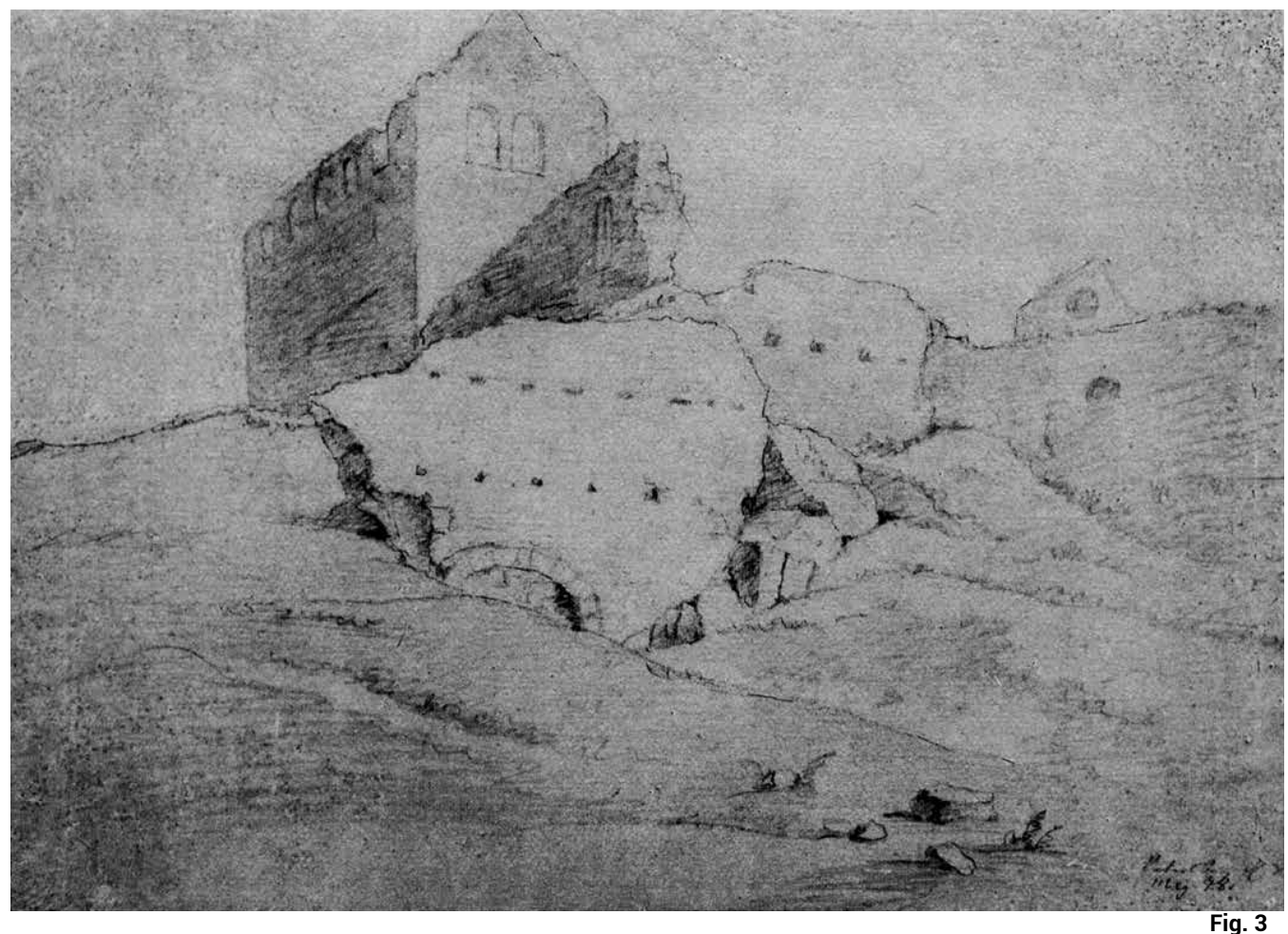




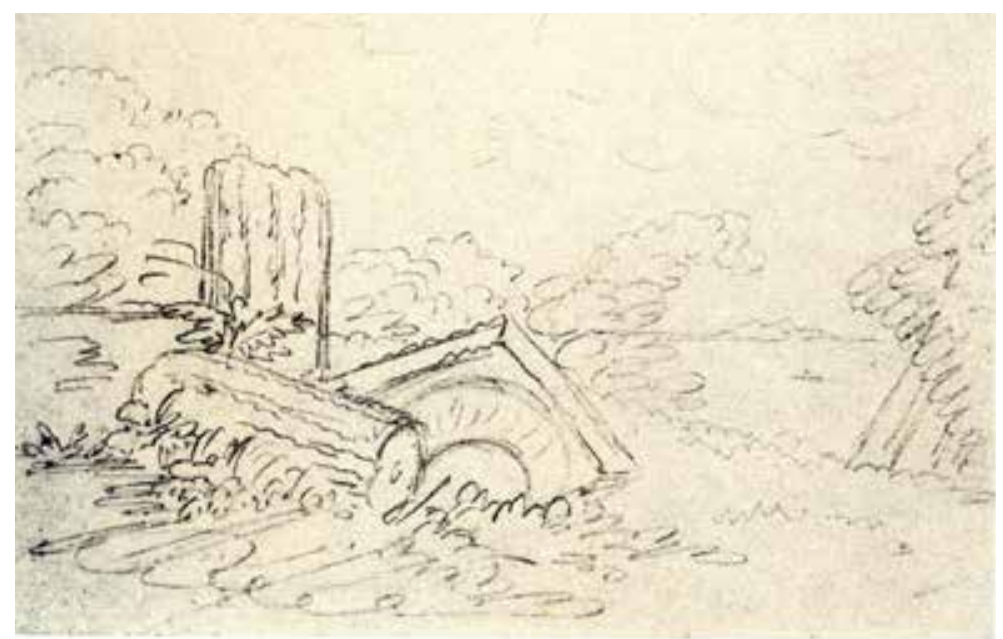

Fig. 4

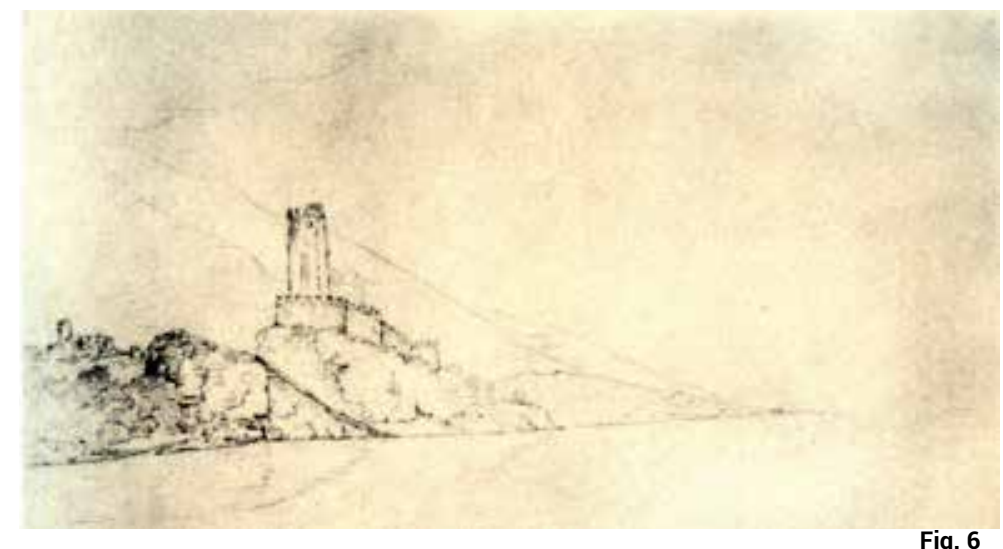

había visitado la catedral de Estrasburgo escribiendo unos apasionados artículos sobre su arquitectura (1772) y sobre su supuesto autor (1775). (Fig. 5) Todavía arrastraba esta actitud paisajística al viajar a Italia porque, nada más llegar el 13.9.1786, en Malcesine, escribe: "Aprovecharé lo mejor posible esta parada, sobre todo para dibujar el castillo, que se alza en la orilla del agua, y es un tema bellísimo. Hoy, al pasar por delante de él ya saqué un boceto." (V. It., III: 1054) ${ }^{213}$ y, ante la desconfianza de los vecinos que no encon-

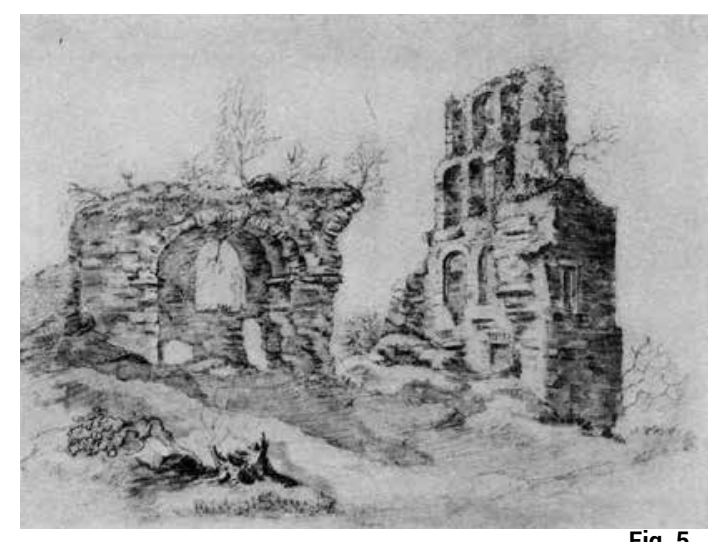

Fig. 5
Fig. 6

traban nada digno de aprecio en aquella torre medieval, Goethe les contestó "que no solo eran dignas de atención las antigüedades griegas y romanas, sino también las del medioevo" (V. It., III: 1056). (Fig. 6)

Pero el vuelco que supuso su viaje a Italia y su adscripción decidida y sin vacilación al clasicismo, le alejó de esas querencias juveniles por lo gótico. ${ }^{214}$ En Venecia, a los pocos días del anterior comentario, a la vista de los restos clásicos de una colección, escribe:
Nicolás en Kreuzburg; I, 214: 1779: Ruinas del palacio de Heidelberger; I, 215: 1779: Torre de fortificación agrietada, etc. Refiriéndose a esta época Goethe escribe: "no veía castillo ruinoso o muros que evocasen los tiempos remotos que no considerara yo objeto digno de dibujarse y no intentara en la medida de lo posible reproducirlo". (Goethe, III, 562)

Fig. 5: Johann W. Goethe, Krayenburg/Rhön, 9.4.1782 (316x423 mm. Carboncillo, sanguina y lavado a tinta). En: Femmel [1958], 1972 I: 259 213. Existen dos dibujos de este castillo: II, 16: 13.9.1786: Castillo de Malcesine; y II, 17: 14.9.1786: Apunte del castillo de Malcesine.

Fig. 6: Johann W. Goethe, Castell Malcesine am Gardasee [Castillo Malcesine en el lago de Garda], 1786 (186x309 mm. Lápiz) En: Femmel [1958], 1972 II: 16 
214. Una primera intuición de este giro Goethe la tuvo de regreso de su estancia en Estrasburgo visitando en Manheim la Sala de los Antiguos al contemplar las copias de esculturas clásicas y de un capitel del templo de Vesta en Roma. Escribe: "no negaré que en presencia de aquellas hojas de acanto, tan enormes como elegantes, empezó a

flaquear un tanto mi fe en la arquitectura nórdica. / Esta grande y precoz contem-

plación, que hizo sentir sus efectos a lo largo de toda mi vida, no tuvo, sin embargo,

grandes consecuencias para el tiempo que inmediatamente siguió." (III: 719).

215. En esos años Goethe empieza también a dibujar piezas arquitectónicas que evocan formas góticas o medievales como, por ejemplo, los proyectos del monumento para el jubileo de Lutero en noviembre de 1816 : Vla, 215: 14.11.1816: Alzado para un monumento a Lutero en su jubileo de 1817; y Vla, 216: nov. 1816: Monumento a Lutero. Planta y alzado; además de escenografías para representaciones teatrales, como Romeo y Julieta de Shakespeare IVb, 207: 28.2.1821: Baldaquino con sarcófago.

216. Pevsner cita un comentario sobre Goethe de Boisserée en su diario (1818) que habla "acerca de la «indignación y la aversión» del gran hombre respecto a

\author{
Esto es en verdad algo muy distinto de nuestros \\ santos, semejantes a mochuelos, hacinados \\ unos sobre otros encima de modillones, del \\ estilo gótico, algo muy distinto de nuestras \\ columnitas, que parecen pipas de fumar; de \\ nuestras buidas torrecillas y floridos carámba- \\ nos, de todo eso, gracias a Dios, estoy ya libre \\ para siempre. (V. It., III: 1093-1094)
}

Sin embargo, años después, en 1817, ante las ruinas de Paulinzella, un convento cisterciense del siglo XII abandonado en 1534, manifestaba una renacida curiosidad por los restos medievales. Tras comentar que nunca se había interesado por ellos porque "no estaba de moda el considerar aquellas ruinas eclesiásticas como principalísimas y respetabilísimas" (D. y A., IV: 187), decidió hacerles una visita "durante la cual podía contemplarse con todo espacio y holgura aquella antigua edificación" (D. y A., IV: 187). Esta renovada atracción por esos monumentos "que nos trasladaban a aquellos tiempos sombríos, en verdad, pero también honrosos e interesantes" (D. y An., IV: 157) respondía ahora a un fin fundamentalmente erudito. Algo completamente diferente a la valoración de los vestigios antiguos. Los edificios medievales le interesaban, sobre todo, por su valor histórico. ${ }^{215}$ Un renovado aprecio por el gótico que había sido estimulado en Goethe, unos años antes, por los hermanos Boisserée. Refiriéndose a ellos, en 1823 Goethe dice: "son acreedores a magna gratitud aquellos que nos pusieron en condiciones de sentir y reconocer valor y dignidad en el justo sentido, es decir, en el histórico" (Part. Auto., III, 1001). En 1814, había estudiado las obras de terminación de la Catedral de Colonia y, tras visitarlas, manifestaba una actitud oscilante entre la curiosidad y el rechazo. ${ }^{216}$ Escribe:

\begin{abstract}
Con ya predispuesto asombro hube de ver el doloroso monumento de lo inconcluso y, no obstante, pude captar con los ojos la medida de aquello que habría debido ser, aunque, sin embargo, aún permaneciera incomprensible para mí, hablando con estricto rigor. [...]. Respecto a la arquitectura, y en relación con mi viaje a Colonia, hablóse y discutióse de muchas cosas, teniendo a la vista planos y bocetos de antiguos edificios alemanes, flamencos y franceses, lo que poco a poco íbale a uno capacitando para sacar y asimilarse de entre una gran mole, hartas veces singular y confusa, lo puro y bello, que es lo que el humano espíritu busca, bajo cualquier forma que fuere. (D. y A., IV: 170-171)
\end{abstract}

Esta constatación, aparentemente contradictoria, de que es posible encontrar belleza en el gótico a pesar de su aspecto confuso, Goethe la justificaba en la existencia de la simetría y las proporciones que, para él, eran las bases de lo clásico en arquitectura. ${ }^{217}$ Lo gótico, por lo tanto, generaba una doble estimación: como documento histórico de una época pasada, por un lado, y como obra de arte en la medida que compartía con lo clásico determinados valores estéticos, por el otro.

En resumen, la arquitectura gótica, que en la catedral de Estrasburgo despertó en el joven Goethe "una impresión plena y grande" que le llenó el alma haciéndole sentir "el arrebatador impulso" de disfrutarla y conocerla (Salmerón, 1999: 36), y que, posteriormente, la había repudiado al compararla con los vestigios clásicos en Italia, era de nuevo apreciada por representar un destacable hito histórico y por contener algunos valores clásicos a pesar de su deforme ornamentación. En 1823, comentado sus estudios de edificios góticos, corroboraba esta postura diciendo: "Sólo que, según la índole del asunto, y, sobre 
todo, en razón de mi edad y posición, había de ser lo histórico lo más principal para mí en todo aquello" (Part. Auto., III: 1002).

La arquitectura egipcia, sin embargo, tenía para Goethe connotaciones distintas. Le cautivaban los obeliscos de Roma por sus jeroglíficos entonces incomprensibles y misteriosos ${ }^{218} \mathrm{y}$, especialmente, la pirámide de Cayo Cestio de la que se conservan siete dibujos suyos, copiándola o insertándola en paisajes inventados. ${ }^{219}$ (Fig. 7) A diferencia de lo gótico la moda egipcia (Pevsner y Lang, 1983) le seducía por su halo enigmático y su relación con los ritos secretos de la muerte.

Recuérdese que era masón. En septiembre de 1787 escribe:

He vuelto otra vez a las cosas egipcias. Estos días he estado varias veces a ver el obelisco que aún yace destrozado entre cascotes y ripia en un corral. [...] sus partes no estropeadas [...] son del más bello trabajo (en su estilo). He mandado sacar moldes de yeso de una esfinge de la punta y de las caras de esfinges, hombres y aves. Hay que poseer estas cosas inapreciables [...]. Lo mismo pienso hacer con las mejores cosas etruscas, etcétera. Ahora estoy modelando en barro esas cosas para asimilármelas bien. (V. It., III: 1302)
$\mathrm{Y}$, en otro momento, tras conocer a Louis Ferdinand Cassas, comenta con admiración sus dibujos entre los que cita "una pirámide restaurada según algunos documentos antiguos, conjeturas y presunciones". Y refiriéndose al dibujo de otra pirámide dice: "Representa este dibujo la idea arquitectural más grande que yo he visto en mi vida y no creo que se pueda ir más lejos" (V. It., III: 1308). En este caso, por lo tanto, la arquitectura egipcia, que sólo conocía de un modo muy parcial, le provocaba sentimientos sobre lo enigmático próximos a la estética de lo sublime. ${ }^{220}$

Todo esto señala una postura vacilante y contradictoria. Las ruinas clásicas eran los vestigios cuyo estudio podía conducir a la formulación de la teoría arquitectónica clásica como Idea situada fuera del devenir del tiempo. Por el contrario, los edificios y restos medievales o exóticos eran documentos que nos informan de la historia despertando otro tipo de sentimientos y reacciones. Lo clásico como sublimación de la antigüedad, se situaba, por lo tanto, en un plano distinto y superior a los otros estilos ya fueran anteriores, como el egipcio, o posteriores, como el gótico. Esta diferencia la subrayó

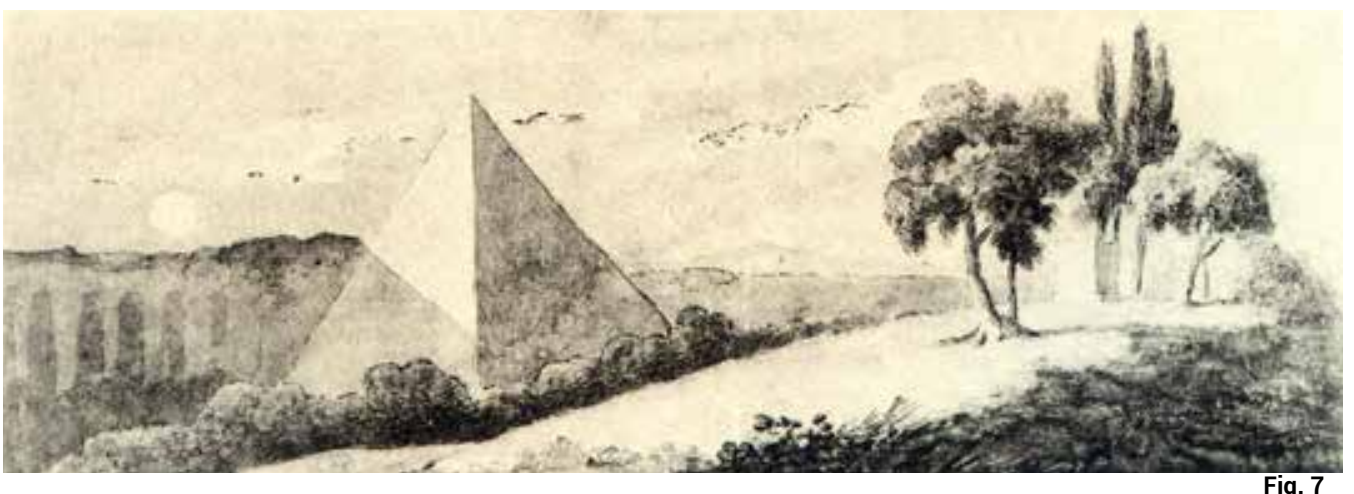

la arquitectura gótica" (1985: 128).

217. En el citado artículo de Goethe De la arquitectura alemana (1823) apoya su opinión en un párrafo del Cours d'Architecture de François Blondel en el que, entre otras cosas, se dice:

"Así contemplamos con delectación algunas masas de esos edificios góticos, cuya belleza parece engendrarse de la simetría y la proporción del todo con respecto a las partes y de las partes entre sí, y se hace notar en medio de la horrible ornamentación que los recubre y aún a pesar de ella" (Part. Auto., III: 1001). 218. Winckelmann refiriéndose a los egipcios escribe: "Sus pensamientos pasaban indiferentes ante lo natural, pero se entretenían con lo misterioso" (Winckelmann, 1967: 43). Goethe dibujó algunos de los obeliscos egipcios implantados en Roma como, por ejemplo, el situado ante el palacio de Letrán (III: 53, verano/otoño, 1787: Palacio de Letrán. Roma). En la carpeta de Actas del consejo para las obras oficiales en Weimar presidido por Goethe hay un dibujo donde se compara la altura de la torre del palacio con los obeliscos del Vaticano y de Letrán (Akten, GSA 30/117). La altura de estos y otros obeliscos y de la columna trajana están recogidos en Serlio, lib. III, fol. XXXIII anv. 219. Son II: 321, 11.8.1787: Paisaje con pirámide en una 
bahía; II: 332, 16.2.1788: Pirámide de Cestio; III: 14, enero/febrero 1787: Pirámide de Cestio, Roma; III, 49: verano/otoño 1787: Pirámide de Cestio y Porta di San Paolo, Roma; II: 331, invierno, 1787?: Paisaje con pirámide a medianoche; VIb: 210, 1788: Pirámide y restos de columnas junto al mar; Vlb: 211 , hacia 1787: Pirámide a orillas de un lago.

Fig. 7: Johann W. Goethe, Cestius-Pyramide im Vollmondlicht [Pirámide de Celso a la luz de la luna llena], antes del 16.2.1788 (136x380 mm. Lápiz, tinta a pluma y sepia. Lavado a tinta). En Femmel [1958], 1972 II: 332

220. La noción de lo sublime en Goethe se analiza en un apartado posterior.

221. Assunto tratando esta cuestión escribe: "Y en una historia del arte liberada de todo apriorismo, los Egipcios, los Etruscos, serían considerados en sí mismos y por sí mismos, por lo que hicieron en relación con lo que querían hacer" (1990: 175-176) y,

citando a Herder añade que:

"los Egipcios no trabajaron ni para los Griegos ni para nosotros" (1990: 176). 222. El 27.9.1786 en Padua, Goethe escribe: "Por fin he adquirido las obras de Palladio, cierto que no en su edición original, que vi en Vicenza, y que tiene sus láminas grabadas en madera, sino una copia exacta, mejor dicho, un facsímil en cobre, debido a un hombre excelen-
Goethe al decir: "Las antigüedades chinas, hindúes, egipcias, no pasan de ser curiosidades; están muy bien para ilustrarse acerca de ellas e ilustrar a los demás; pero para nuestra cultura moral y estética de poco habrán de aprovecharnos" (Mx. n 763, I: 414).

Goethe no llegó a dar el paso que, a lo largo del siglo XIX, se produjo en el historicismo y que ya había señalado Herder: la consideración de la arquitectura antigua en plano de igualdad con las otras corrientes y estilos, como una etapa histórica más. ${ }^{221} 0$ sea, la pérdida irreversible del papel normativo clásico en la arquitectura que había buscado Goethe, siguiendo a Winckelmann, en los restos de la antigüedad. Tal vez, en la vaga intuición de su incapacidad por dar ese salto que arrinconaba a la antigüedad a un papel puramente histórico, está una de las razones de que abandonase el Baukunst sin concluirlo.

\section{D. "Siendo arquitecto..."}

En 1786 durante su viaje a Italia, en Asís, Goethe se presentó como arquitecto justificándose ante unos vigilantes que sospecharon de su presencia en la ciudad. Escribe:

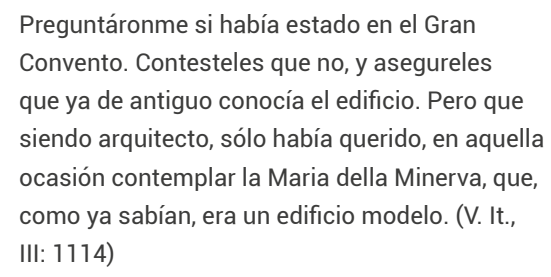

No fue la única vez durante ese viaje en que le ocurrió una confusión similar. Anteriormente, visitando una librería de Vicenza para adquirir el tratado palladiano, no corrigió el error de los presentes que "tomándome por arquitecto, aplaudiéronme el que me aplicase ante todo al estudio de este maestro, que para el uso y empleo era mucho más útil que el propio Vitruvio" (V. It, III: 1074). ${ }^{222}$ Sin duda, se sentía cómodo adoptando el papel de artista, ya fuera arquitecto, pintor e incluso escultor. ${ }^{223}$ Tal vez inconscientemente, al asumir de manera ficticia esas profesiones estaba dejando constancia de su vocación frustrada como artista plástico.

Pero la inclinación de Goethe por la arquitectura era anterior a este viaje. Se remontaba a sus años de estudiante y se englobada dentro de su afición por las bellas artes. $^{224}$ Él mismo calificó posteriormente su postura como un "lego entusiasmo" (Part. Auto., III: 1001) más propio de un simple aficionado consecuencia de su arrebato juvenil y de la ausencia de conocimiento más precisos. 
Italia fue el punto de inflexión en un doble sentido: por un lado, significó un giro radical decantándose sin ambigüedad por el clasicismo. Y por otro, pero íntimamente conectado con ese cambio, hizo que se orientara de una manera más sistemática e intensa al estudio de la arquitectura. Explicando esa transformación escribía en Roma el 20.12.1786:

Me parezco a un arquitecto que edificó una torre poniéndole malos cimientos, pero que a tiempo lo advirtió y mandó derribar de buen grado lo que ya levantara, y ahora trata de dilatar y ennoblecer sus planos y asegurar mejor los cimientos, holgándose por anticipado de la más cierta solidez de la futura obra. (V. It., III: 1136)

Y comentaba: "desde que puse el pie en Roma data para mí un segundo nacimiento, un verdadero renacer." (V. It., III: 1134). Durante ese viaje el estudio de los escritos sobre arquitectura junto con la visita a las ruinas de la antigüedad y a las obras renacentistas confluían en su aprendizaje complementándose entre sí e inclinando su gusto hacia lo clásico. Escribe:

\begin{abstract}
Pero cuando hemos echado un vistazo seguro, entonces ya podemos de buen grado leer y escuchar, pues esto va a unirse a la impresión viva; entonces ya podemos pensar y juzgar [...] ahora consagro mi atención a arquitectos, escultores y pintores y aprenderé también a orientarme en ese terreno. (V. It., III: 1139)
\end{abstract}

Según estas palabras Goethe se acercó al arte y a la arquitectura por tres vías simultáneas: en primer lugar, visitando las obras y los monumentos; en segundo lugar, familiarizándose con los escritos y tratados; por último, a través del trato con arquitectos, estudiosos, artistas y teóricos con los que intercambiaba ideas y opiniones. A esto hay que añadir el aprendizaje del dibujo arquitectónico durante su estancia en Roma. Por otro lado, tras su llegada a Weimar en 1775 , Goethe se había implicado en la práctica de la construcción al hacerse cargo de las obras oficiales por mandato del Gran Duque. ${ }^{225}$ Una doble faceta, por lo tanto, en su aproximación a la arquitectura: la profundización en su vertiente artística y la gestión de la práctica constructiva. Sin embargo, cada una de estas tenía un significado muy distinto para Goethe porque el arte de la arquitectura posee su propio ámbito autónomo que está más allá de la mera construcción, la cual sólo juega un papel como condición previa pero situada en un nivel inferior.

Ciertamente, para Goethe la teoría y la práctica del arte son inseparables, si bien para él no es en la construcción sino en la invención donde estriba la práctica artística de la arquitectura. Piensa que el arquitecto ejercita su arte cuando proyecta, y el proceso posterior llevado a cabo por los maestros que la construyen queda fuera de ese aspecto. En este sentido Goethe comparte la ruptura que se había producido en el Renacimiento al considerar que el arte de la arquitectura termina con el trazado del proyecto $y$, por lo tanto, la posterior realización material de la obra carece de relevancia para ese fin.

Los problemas cotidianos que, como responsable de las obras en Weimar, tenía que resolver, le servían para comprender el entramado sobre el que se apoya la arquitectura. Pero esas cuestiones apenas tenían importancia en su formulación de la teoría arquitectónica y sólo aparecen en los primeros apartados del Baukunst. Desde esta pers- te, Smith". (V. It., III: 1074). Se refiere a la reedición publicada entre 1770 y 1780 . 223. El 18.8.1787 en una carta a Charlotte von Stein desde Roma le dice: "Con el dibujo no me va bien, así que he optado por modelar, y esto parece que progresa. [...] Hay empezada una cabeza de Hércules; si sale bien, seguiremos adelante" (V. It., III: 1296-1297). Con intención de viajar de incógnito se presentaba a veces como el barón Von Müller, pintor alemán, se inscribió en Roma como Johann Philip Möller, comerciante de Leipzig y el 8.11.1786 escribe: "ahora me he transformado en el barón Rondanini" (V. It., III: 1124). EI 5.4.1777 en su diario, Goethe escribe que ha terminado en el jardín de su casa de campo de Weimar una escultura de piedra formada por una esfera sobre un cubo para conmemorar su encuentro con Charlotte von Stein y a la que llama el Altar de la Buena

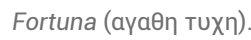

224. Siendo adolescente sus estudios de matemáticas le ayudaron a "poder trazar mis bocetos arquitectónicos con más precisión" (III: 498). En Leipzig practicó dibujo y pintura en la academia de arte de Adam Friedrich Oeser y grabado con Johann Michael Stock, leyó a Winckelmann (III: 609-621) y estudió algunos grabados de Palladio (Safranski, 2015: 305). De regreso en Frankfurt escribía a Oeser (noviembre 1768) que 
se ejercitaba en el dibujo y estudiaba arquitectura. 225. Fue nombrado por el gran duque Karl August en 1777: Presidente de la comisión de Arquitectura para la reconstrucción del castillo ducal; en 1779: Director de los departamentos de la Guerra, y de Puentes y Caminos; y finalmente, en 1782: Director de Hacienda (Cansinos, I:

93). Según Safranski “Desde 1779 , las funciones de Goethe abarcan la construcción de caminos, la desecación de zonas pantanosas, el cultivo del suelo, la mejora en la prevención de incendios, las minas en IImenau, la mejora de las condiciones de trabajo, la ayuda en el caso de inundaciones, la contención del gasto en la corte" (2015: 219). 226. Johann Heinrich Wilhelm Tischbein (1751-1829). En Roma Goethe se hospedó en su casa en la que convivían otros dos pintores alemanes, Johann Georg Schütz y Friedrich Bury (Safranski, 2015: 307).

227. Christoph Heinrich Kniep (1755-1825) le acompaño en sus visitas de Nápoles y Sicilia. Durante la travesía marítima Goethe escribe que: "me ha explicado el mecanismo de la acuarela, que ahora en Italia goza de mucha boga, así como el empleo de ciertos colores para producir determinadas tonalidades, en las que, de no conocer el secreto, haríamos una mezcolanza mortal" (V. It., III: 1191). pectiva, la empresa de Goethe se distancia de aquellos tratados renacentistas destinados a los profesionales en ejercicio a los que, en cierta manera, quería emular.

Por un lado, el Baukunst, confeccionado paralelamente con dibujos y textos, retoma la tradición de la tratadística que, en aquella época, había ya agotado su ciclo histórico. Pero por el otro, la reducción de su contenido a cuestiones conceptuales lo aleja de ese modelo. En cierta medida, el Baukunst se presenta como un pequeño tratado pero se desarrolla en una dirección distinta al ignorar las cuestiones constructivas de los casos estudiados. Está a caballo de dos intenciones opuestas: formalmente quiere recuperar una estructura tratadística ya caduca, pero su desarrollo asume la separación entre el arte y la técnica siguiendo al camino que había emprendido la cultura moderna. Hay un intento de síntesis muy problemática que difícilmente podía tener éxito y puede explicar, en parte, su abandono inconcluso.

\section{Dibujo arquitectónico}

Goethe, que había utilizado frecuentemente la arquitectura como tema de sus dibujos paisajísticos, era consciente que su representación arquitectónica debía ajustarse a unos sistemas y unas pautas precisos porque hay una diferencia sustancial entre dibujar imágenes arquitectónicas con fines artísticos y hacerlo para usos técnicos.

Durante su viaje a Italia, Goethe se hizo acompañar por pintores y dibujantes con los que compartía experiencias y prácticas. En algunas etapas le acompañaron Tischbein ${ }^{226}$ y Kniep, ${ }^{227}$ y conoció en Nápoles a Hackert. ${ }^{228}$ Con estas influencias realizó dibujos de panoramas y vistas con arquitecturas $^{229}$ siguiendo la tradición de los vedutisti a quienes menciona, como Piranesi (V. It., III: 1342), Clérisseau (V. It., III: 1149), Van Schwanevelts (V. It., III: 263 y 1342) o Van der Neer (V. It., III: 1266), entre otros.

Pero conseguir el dominio del dibujo arquitectónico, siguiendo la tradición asentada desde el Renacimiento, implicaba el conocimiento de la perspectiva y el aprendizaje de los sistemas gráficos específicos de esta materia. En el relato de su viaje son varias las ocasiones que Goethe alude a sus prácticas en perspectiva, ${ }^{230}$ aunque fue durante su estancia en Roma, en el verano de 1787, cuando se dedicó a ella más intensamente. Con ese objetivo asistió a unas clases sobre las que dice: "He aprendido mucho, sobre todo en perspectiva. Verschaffelt, hijo del director de Manheim ha meditado mucho sobre esta materia y me comunica sus obras de arte." (V. It., III: 1294). ${ }^{231}$

Esos ejercicios no tenían por objeto exclusivamente la representación de elementos arquitectónicos, sino que le servían, también, para sus apuntes paisajistas y para el dibujo de la figura humana porque el 27.7.1787 escribe: "He adelantado en la perspectiva y arquitectura, y también en la composición del paisaje. Ahora estamos liados con los seres vivos" (V. It., III: 1287). (Fig. 8) Sin embargo, era en el estudio de la arquitectura donde encontraba, prioritariamente, su aplicación. Simultaneaba la perspectiva con el estudio de la arquitectura que era lo que le ocupaba por esas mismas fechas, ya que el 5.7.1787, escribe: "he empezado a cultivar más seriamente la arquitectura, y todo se me hace sorprendentemente fácil (es decir, la 
idea, pues la práctica requiere toda la vida)." (V. It., III: 1282). Algunas perspectivas de Goethe de esos momentos son copias del tratado de Serlio ${ }^{232}$ aunque no son las únicas. Y aún hay otras láminas de ejercicios de perspectiva fechadas en los años sucesivos cuando trabajaba en el Baukunst. ${ }^{233}$

Pero fue Palladio y su tratado I quattro libri dell'architettura ${ }^{234}$ de donde extrajo algunos modelos para ilustrar el Baukunst, así como para otros dibujos contemporáneos que se pueden relacionar directamente con este trabajo. ${ }^{235}$ Respecto a la imagen gráfica de la arquitectura, el rasgo más relevante del tratado de Palladio es que nunca utiliza la perspectiva para representar los edificios. ${ }^{236}$ Ya Alberti había escrito que la perspectiva era útil para el pintor pero inadecuada para el arquitecto porque deforma ángulos, produce traslapos y distorsiona las figuras, por lo que no nos permite hacer mediciones con precisión ni conocer las dimensiones verdaderas de la obra. ${ }^{237}$ Palladio y Antonio da Sangallo fueron los dos primeros arquitectos renacentistas que siguieron esta pauta de

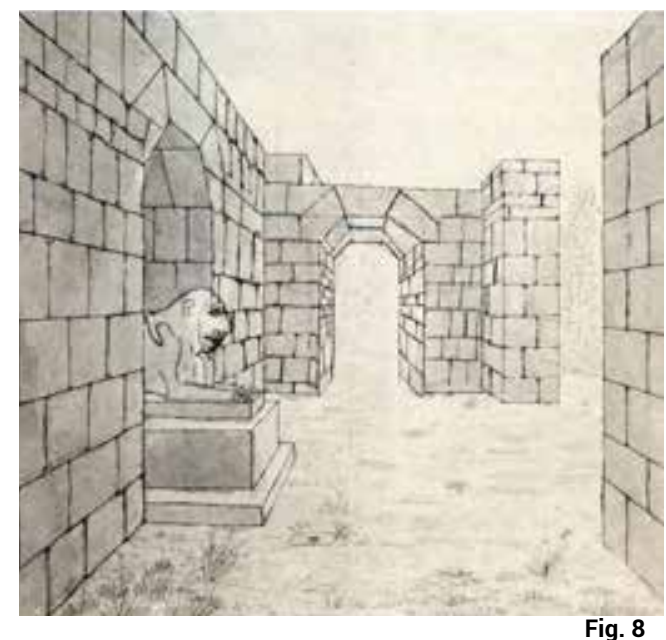

228. Jacob Philipp Hackert (1737-1807). El 15.3.1787 en Caserta escribe que Hackert: "Con su habitual y rotunda franqueza díjome: «Usted tiene disposiciones, pero no puede sacar partido de ellas. Quédese conmigo dieciocho meses y producirá algo que le llenará de alegría a usted y a los demás" ¿No es este un tema sobre el que a todos los aficionados se les debería estar predicando eternamente?" (V. It., III, 1175)

229. Por ejemplo: IVa: 2: hacia 1790: Palacio y lago; IVa: 8: hacia 1790: Explosión del Vesubio; IVa: 9: hacia 1790: Templo dórico junto a la costa; IVa, 42: 1787: Paisaje con la tumba de Cecilia Metella. Roma; IVa: 139: hacia 1790: Palacio Berg. Adršpach. Chequia; IVa: 140: 1790: Palacio Berg Fantasía; IVb: 187: Escena con templo, puente y complejo palacial.

230. El 20.1.1787 escribe: "Debo decir ahora que por las noches estudiamos también la perspectiva" (V. It., III: 1145). Y todavía el 7.12.1787 comenta en una carta: "Esta semana he estado dedicado al dibujo, pues la poesía no se me daba [...] la perspectiva nos ocupa las noches" (V. It., III: 1336)

231. Aludiendo a este mismo curso dice en otro lugar: "Inauguró Verschaffelt un curso de Perspectiva, y allí nos reuníamos por las tardes numerosa concurrencia, que escuchaba sus lecciones y en seguida las llevaba a la práctica. Lo mejor de todo aquello era que aprendíamos allí lo preciso, pero no demasiado." (V. It., III: 1301). Maximilian von Verschaffelt (1754-1818), era pintor y arquitecto

Fig. 8: Johann W. Goethe, Perspektivzeichnung [Dibujo de perspectiva], hacia 1795 (230x246 mm. Lápiz, tinta a pluma, lavado a sepia). En Femmel [1958] 1972, IVb: 133 232. Por ejemplo III: 118, Escaleras (copia de Serlio libro II, 19 anv.); III: 105, verano 1787: Portal rústico (copia de Serlio libro IV, 9 anv.); Vla: 157, 19.1.1797: Gradas del Coliseo (copia de Serlio libro III, 79); Vla: 142, verano 1787: Plinto y basa de columna (hecho a partir de Serlio, Lib. II fol 4, aunque podría, también, ser copia de otros libros de perspectiva como el de Andrea del Pozzo, Perspectiva pictorum et architectorum, 1693-1698, fig. XX). Incluso utiliza en algún caso el grafismo del tratado de Serlio, por ejemplo, en la representación de la cubierta en el dibujo IVb: 101, hacia 1795: Fachada renacentista.

233. Por ejemplo: III: 110, julio 1787: Perspectiva frontal; III: 111, julio 1787: Puntos de fuga en perspectiva; III: 112, julio 1787: Sistema de puntos de fuga en perspectiva; III: 113, julio 1787: Elemento arquitectónico en planta, alzado y perspectiva; III: 115, julio 1787/enero 1788: Perspectiva frontal; III: 116, agosto 1787: Edificios en perspectiva; III: 117, julio 1787/enero 1788; Calle en perspectiva; IVb: 133, hacia 1795: Dibujo en perspectiva; Va: 114, Sombras.

234. No hay constancia de que utilizara, también, los dibujos palladianos del Vitruvio de Daniele Barbaro (1556 y 1567).

235. Por ejemplo: III: 66 rev., verano/otoño 1787: Fachada de una villa; III: 102, verano/otoño 1787: Estudios de detalles de cornisas y dos capiteles jónicos; IVB: 108, verano 1787: Detalle del alzado de una loggia; IVb: 111, hacia 1795: Detalles arquitectónicos de ventanas, basa de columna, cornisa y lesena de muro y dos capiteles corintios; IVb: 113, hacia 1795: Fachada de un pabellón de jardín; IVb: 128, 1797/1801: Alzado y perspectivas de un pabellón.

236. Para un análisis en profundidad de los dibujos de Palladio, véase Calduch (2017).

237. Leon Baptista Alberti, De re ædificatoria (1485). escribe: "Entre el designo del pintor y del architecto ay esta differencia que aquel procura mostrar los resaltos dela tabla con sombras, lineas y angulos desmenuzados, y el architecto menospreciando las sombras pone los resaltos alli donde la descripción y planta del fundamento, y enseña los espacios y figuras de cada frente y lados en otra parte con lineas constantes y verdaderos angulos, como quien quiere que sus cosas no sean imaginadas con vistas aparentes, sino notadas con ciertas y firmes medidas". Cita de la traducción al castellano de Francisco Loçano (1977, Lib. II, cap. I, 34-35). 
238. Por ejemplo III: 42 , 18.8.1787: Plaza del Capitolio. Roma; III, 48: verano/ otoño 1787: Foro Romano; III, 66: verano/otoño 1787: Casa de campo con pórtico de columnas; III: 73, verano/otoño 1787: Palacio con puerta de muralla; III: 114, julio 1787: Villa a la luz de la luna; IVa: 254, 18.9.1792: Grand Pré (Campaña de Francia); IVa: 255, 18.9.1792: Palacio Grand Pré (Campaña de Francia); IVb: 135, 15/16.10.1792: Murallas de Luxemburgo; IVb: 200, 1793?: Tumba antigua en un paisaje; IVb: 250, 1793?: Escena teatral; IVb: 251, 1793?: Escena teatral; IVb: 253, Ruinas; Vla: 126, hacia 1790: Decorado para "Eginhard"; VIb: 194, 16/19.10.1972: Vista de las murallas de Luxemburgo. 239. Es posible que Goethe conociera la sistematización del dibujo arquitectónico que estaba realizando en aquellos momentos Gaspard Monge con la geometría descriptiva. 240. En comparación con su extensa producción gráfica tiene pocos dibujos de plantas completas de edificios.

En los años en que trabajaba en el Baukunst suelen estar relacionadas con las obras en Weimar que supervisaba, como por ejemplo: IVb: 91, posterior a 1793: Planta ideal de la casa de Goethe en Weimar; IVb: 121, 1795: Alzado parcial de la fachada al jardín de la casa de Goethe en Weimar; IVb: 121 rev.: 1795: Alzado y perfil del zócalo de una manera más sistemática. Aunque Goethe seguía dibujando edificios en perspectiva en sus paisajes así como en escenas urbanas y en decoraciones teatrales, ${ }^{238} \sin$ embargo, en el Baukunst nunca la emplea, evidenciando que era plenamente consciente del tipo de representación que reclama un trabajo de carácter teórico. ${ }^{239}$ Los dibujos arquitectónicos de Goethe en el Baukunst están hechos a mano alzada y ajustados al sistema diédrico: plantas parciales, alzados, secciones y detalles. De este modo, estas imágenes ponen de manifiesto su finalidad técnica y descriptiva.

Hay, sin embargo, una cuestión significativa que señalar. A diferencia de los tratados, incluido el de Palladio, en el Baukunst no aparece ninguna planta general de los ejemplos que menciona. ${ }^{240}$ Entre los conservados de esos años existe un ejemplo singular por su excepcionalidad: IVb: 131 rev.: Planta de templo antiguo díptero, esquema de sección, dos capiteles de columna dórica y dos cabezas de santo. (Fig. 9) Está hecho hacia 1790 y representa, entre otras figuras, la planta incompleta de un templo díptero in antis. A pesar de todo, el dibujo no parece querer representar una planta canónica ya que, en contra de todo establecido desde Vitruvio, es cuadrada de $8 \times 8$ columnas aunque no todas se representan: en un frente sólo se dibujan siete, cinco en el otro y falta un lateral completo. Lo más destacable es la articulación del muro de la cella con semicolumnas. Winckelmann, en relación con el templo de

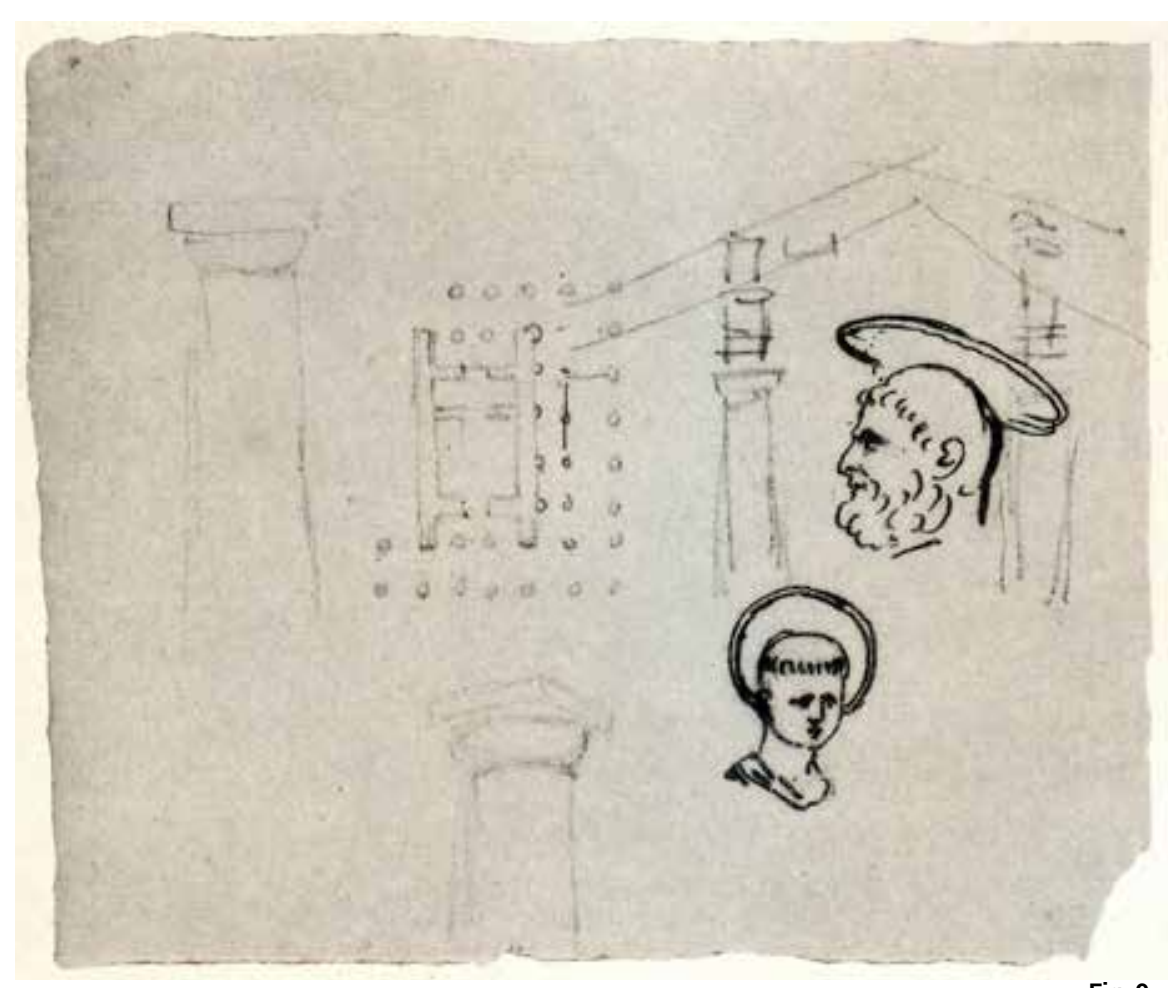


Júpiter Olímpico (Zeus) de Agrigento, comenta esta solución y concluye: "este templo tenía en la parte exterior columnas semicirculares, y en el interior estaba decorado con pilastras" (1985: 571). Goethe no sólo conocía el texto de Winckelmann, sino que había visitado estas ruinas sobre las que escribe: "Todo elemento plástico ha desaparecido en ese baturrillo, salvo un enorme triglifo, y un fragmento de una media columna correspondiente al mismo" (V. It., III: 1222). Esto es lo único que pudo contemplar y, en su comentario, no hace ninguna alusión a su posible planta. Poco después, hablando sobre un pequeño edificio junto a la muralla, en el mismo Agrigento, dice: "También allí muéstrense las medias columnas bellamente ligadas a los sillares del muro y fundidas con ellos, lo que resulta gratísimo a la vista." (V. It., III: 1223). El análisis de la articulación del muro y la columna es, pues, la cuestión que le interesaba y de la que trata en este croquis, aunque lo haga dibujando una planta parcial. ${ }^{241}$

Tampoco son frecuentes en esas fechas dibujos de Goethe con aspectos constructivos y, cuando los incluye en el Baukunst, le sirven para ilustrar los tipos de aparejos de los muros en los párrafos iniciales. De nuevo el dibujo anteriormente mencionado (IVb: 131 rev.), nos resulta elocuente en este aspecto. Junto al esquema de planta mencionado y unas cabezas de santos, hay un apunte apenas esbozado de la sección de una cubierta apoyada sobre columnas con sus respectivos entablamentos realzados, y dos dibujos (un alzado y una perspectiva) del capitel y parte del fuste de una columna dórica. Parece que lo que intenta dilucidar en este caso es la cuestión del apoyo de una cubierta inclinada a dos aguas sobre las columnas y el entablamento. Está claro que este apunte se relaciona con la planta parcial y con las columnas dibujadas. El hecho de que los faldones continúen mucho más allá de los apoyos, indica que no se trata de las columnas perimetrales exteriores sino de la fila intermedia y, más probablemente, de las semicolumnas del muro de la cella. ${ }^{242}$ Por lo que es fácil deducir que este dibujo no es tanto un apunte constructivo sino una cuestión de articulación. Tampoco hay otros dibujos de esos años que muestren la preocupación de Goethe por cuestiones constructivas. ${ }^{243}$

A diferencia de la ausencia de plantas generales y de soluciones constructivas, se conocen varios dibujos de detalles arquitectónicos hechos durante el viaje italiano y en los años posteriores, cuando trabajaba en el Baukunst, representando basas, capiteles, columnas, cornisas, molduras, entablamentos, recercados de huecos y otros elementos. ${ }^{244}$ Algunos están delineados y muchos han sido copiados de los tratados de Scamozzi, Serlio, Vignola, Galiani, Palladio, etc. ${ }^{245}$ Igualmente son abundantes los estudios de fachadas o parte de ellas, con un claro aire palladiano, tanto relacionadas con el Baukunst como con otros proyectos y obras en los que estaba inmerso. ${ }^{247}$

Se pueden extraer algunas conclusiones de esta manera de representar técnicamente la arquitectura ligada y paralela a la redacción del Baukunst. La imagen de la arquitectura es la principal cuestión que le interesa, y se concreta en los alzados y los detalles formales sin tener que incluir ni las plantas, donde se solventa la organización de los espacios, ni las soluciones constructivas que hacen factible la materialización de las formas. Esto significa que la definición visual la fachada al jardín de la casa de Goethe en Weimar; Vla: 160 rs.: 1797: Planta de un pabellón para una vivienda en Jena (¿para Schiller?).

Fig. 9: Johann W. Goethe. Tempelgrundriss, Doppel-Antentempel... [Planta de templo, doble templo in antis...], hacia 1795 (174×210 mm. Lápiz, tinta a pluma) En Femmel [1958] 1972, IVb: 131 rs. 241. Sobre esta cuestión de las semicolumnas Winckelmann alude también a la casa de campo de Mecenas en Tívoli: "las columnas, medio sujetas en el muro, están hechas lo mismo que todo el edificio: de piedra tallada en forma de cuña." (1762: 541) y menciona el templo de la Fortuna Viril en Roma (571) recogido igualmente por Palladio (lib. IV, p. 49) quien incluye, además, el templo de la Concordia en Roma (ib. IV, p. 125) y la Maison Carrée en Nimes (lib. IV, p. 112). También Serlio dibuja esta solución (lib. III, fol. XX rev.). Goethe conocía todos estos tratados, aunque ninguno de esos ejemplos es díptero. 242. Una solución semejante la dibuja Palladio en su tratado en la sección del Panteón por el pórtico (lib. IV, p. 77). 243. El dibujo ya mencionado Vla: 157 (19.1.1797) recoge el detalle constructivo del encaje de las gradas del Panteón, aunque se trata de una copia de Serlio (lib. III, folio XXXIIII rev.). Hay también la sección constructiva y los apoyos de una bóveda recogida en las 
Actas del consejo sobre la reconstrucción del palacio de Weimar presidido por Goethe, pero el croquis está firmado por Steiner (Akten, GSA 27/71). Se trata, posiblemente, del maestro de obras Steiner o de su hijo de Carl Friedrich Christian Steiner, arquitecto de Weimar (17741840) que redactó los planos del palacio de Weimar (1807) cuando era director de la comisión de reconstrucción Goethe.

244. Por ejemplo II: 177 rev.: abril/mayo 1787: Detalle de entablamento dórico; III: 96 rev., 10.1787: Apuntes de cornisas, basas y columnas dóricas; III: 101, 1787: Capitel coríntio; IVb: 106, 1806?: Centros geométricos para dibujar una voluta y detalles de cenefas con motivos vegetales; IVb: 118, hacia 1795: perfil de cornisa con ovas; IVb: 204, hacia 1795: Croquis de capitel corintio y cornisa.

245. Por ejemplo: Scamozzi, III: 93: Fachada y detalles de órdens; IVb: 107, hacia 1795: Detalle de recercado de ventana, panel superior y cornisa; IVb: 109, hacia 1795: Diferentes recercados de ventanas; Serlio: III: 104, verano 1787: Portal rústico; IVb: 110, hacia 1795: Detalles de recercados de ventana, articulación de lesenas y hornacina, y capitel con arranque de columna; 110 rev., hacia 1795: Detalles de articulación de huecos en vertical en fachadas ; IVb: 112, hacia 1795: Fachadas de pabellón de jardín y capiteles dórico, jónico y corintio; IVb: 115, 1791/1795: Pabellón de jardín y portal; Vignola: IVb: 119, 1797: Entablamento jónico; Vla: 146, verano 1787: Molduras; Galiani: III: 94, 10.10.1786: Transformación de entablamento dórico de madera a piedra (de la Tavola IV, fig. 1); Vla: 134, Aparejo de muro (de la Tavola III); Palladio: Vla: 135, 1786: Detalles de perfiles de cornisas y basas de columnas; Vla: 158, 1795/97: Perfil de pedestal y basa de columna.

246. Por ejemplo: IVb: 95, 1790/1795: Fachada de templo; IVb: 98, hacia 1795: Dos fachadas y esquema de planta; 98 rev., hacia 1795: Fachada de edificio urbano; IVb: 99, 1795: Fachada de edificio urbano, perfil y detalles de zócalo; IVb: 99 rev., 1795: Cuatro fachadas urbanas y detalles; IVb: 100, hacia 1795: Fachada de edificio urbano; IVb: 101, hacia 1795: Fachada de edificio urbano; IVb: 102, hacia 1975: Fachada de edificio urbano; IVb: 103, hacia 1795: Fachada de edificio urbano; IVb: 104, hacia 1795: Zócalo dórico; IVb: 105, hacia 1795: Perfil de cornisa; IVb: 108, 1795: Recercados dóricos de huecos; IVb: 120, 1800?: Articulación de orden jónico con columnas pareadas; IVb: 203, hacia 1795: Fachada de templete; Vla: 150, 1791/17996: Alzado de un pabellón clasicista en un parque; Vla: 159, 1798: Croquis de fachada de palacio.

247. Assunto comenta que Goethe miraba "con el ojo de literato, el cual en la arquitectura buscaba armoniosidad y magnificencia de imágenes" (en Chastel, 1990: 32) y lo contrapone al enfoque de los críticos de arquitectura como Lodoli, Milizia o Algarotti.

248. Winckelmann sólo menciona el color en los apartados: 62: Dorados y 67: El decorado de las habitaciones, donde dice: "El espacio, tanto de encima como de debajo de la cornisa, estaba dividido en compartimentos o paneles que eran más altos que anchos [...] encuadrados por filetes de distintos colores. Había otros más pequeños, redondos o cuadrados, en los que se pintaba una figura o un paisaje. [...] los compartimentos de arriba eran más anchos que largos, y en ellos se pintaban también paisajes, marinas o temas parecidos." (1985: 562). También Palladio defendía el color blanco para los templos al escribir: "Entre todos los colores ninguno es el que más conviene a los Templos que la blancura, puesto que la pureza del color y de la vida es sumamente grata a DIOS" (1570, Lib. IV, cap. II, p. 7).

249. El dibujo Vla: 205, hacia 1795 , es un esbozo arquitectónico tal vez procedente de una pintura pompeyana.

250. „die Gebäude selbst am Platze sähe, um nicht allein ihre architektonischen, sondern auch ihre optischen Verhältnisse kennen zu lernen“ (Ewald, 1999: 27). El 15 de enero de 1797, y los problemas compositivos son el núcleo central sobre el que se levanta su teoría arquitectónica. $Y$, en consecuencia, entiende que en la resolución de estas cuestiones y en su progresiva complejidad consiste la labor creativa del arquitecto y donde se manifiesta su aportación artística y su impulso genial.

\section{Monumentos, ruinas}

Por el tipo de dibujos que Goethe realizaba en esas fechas se podría concluir que el arte de la arquitectura se concretaba para él en su definición formal y visual. ${ }^{247}$ Resulta sorprendente que en esa idea formal de la arquitectura Goethe no considere el color, a pesar de la gran importancia que daba a su Teoría de los colores en la que estaba interesado en esos momentos. Tal vez, siguiendo la estela de Winckelmann, entendía la arquitectura clásica como blanca o del color de la piedra. ${ }^{248}$ Eso se desprende del comentario que hace sobre la restauración del templo de la Concordia en Agrigento cuando, el 25.4.1787 escribe:
No me lamentaré porque el reciente laudable propósito de conservar ese monumento haya sido llevado a la práctica de un modo falto de buen gusto, supliendo las fallas con yeso de una deslumbrante blancura, con lo que este monumento resulta, en cierto modo, estropeado para la vista: ¡tan fácil como habría sido darle al yeso el color denegrido de la piedra!" (V. It., III: 1221).

En su opinión la decoración con colores vivos y pinturas de la arquitectura antigua quedaba reducida a las obras residenciales. Al visitar los restos de Pompeya y Herculano, comenta: "Son las casas pequeñas y angostas, pero todas por dentro primorosamente pintadas." (V. It., III: 1173). ${ }^{249}$ Los estudios 
sobre el colorido en la arquitectura antigua, que empezaban a ser conocidos, son silenciados por Goethe.

Comprender la arquitectura era, sobre todo, verla, captando su estructura compositiva llegando hasta los detalles. Pero esa percepción no podía ser la del mero aficionado, sino culta, segura, dirigida por la idea de quien conoce las normas y tiene experiencia directa de los edificios. Se trata de "ver el edificio en el lugar, para conocer no sólo sus condiciones arquitectónicas sino también ópticas", dice Goethe. ${ }^{250}$ El viaje a Italia le sirvió para acumular esas vivencias a medida que visitaba las obras y monumentos llegando, finalmente, a la conclusión, que, a pesar de todo, la imagen visual no agota el disfrute de la arquitectura.

Tres grandes experiencias marcaron la formación de Goethe en su conocimiento directo de las obras: la lección de Palladio al visitar sus edificios en Vicenza y Venecia; los vestigios romanos de Verona y Asís, pero, sobre todo, de Roma; y la arquitectura griega descubierta en Paestum y Sicilia. Cada uno de estos hitos le abría un abanico de cuestiones. Palladio era la confirmación de la vigencia y evolución del clasicismo porque "fue el primero en educarse en la escuela de los antiguos para después restaurarlos" (V. It., III: 1082). Las ruinas y monumentos romanos le pusieron en contacto con el vasto panorama de la antigüedad y el Renacimiento, así como con la gran escala y magnificencia de aquellas fábricas. Los restos griegos supusieron, en primer lugar, un cierto desconcierto ante sus proporciones y formas para, inmediatamente, confirmarle en el convencimiento de que ahí había que buscar el origen del clasicismo. ${ }^{251}$
En el libro que cuenta su viaje Goethe cita a Palladio veinte veces y en el Baukunst repite algunas opiniones vertidas anteriormente. De entre sus obras habla del teatro Olímpico, de la Basílica, de la Loggia del Capitano, de la conocida como Casa de Palladio y de la villa Rotonda en Vicenza, y, en Venecia, del convento della Carità, de las iglesias del Redentore, de San Francesco della Vigna y de San Giorgio y, en otro lugar, menciona el proyecto del puente de Rialto para valorarlo por encima del construido. Además, hizo un apunte de la fachada de $\mathrm{Ca}$ Diavolo (Palazzo Porto Breganze) en Vicenza (III: 2, 19/25.09.1786). Ante la vista de estas obras desgrana diferentes reflexiones que van desde la admiración a la reserva crítica. Del convento de la Carità comenta:

\begin{abstract}
El plano, de excelente diseño, lo mismo en conjunto que en sus distintas partes, causóme infinito placer y me esperaba encontrar con una maravilla; pero jay! que apenas si se ha realizado su décima parte, aunque esta parte sea digna también de su divino genio [...] Pienso que no he visto nada más elevado y completo, y creo que no me equivoco. (V. It., III: 1082) ${ }^{252}$

Y más adelante repite:

El pabellón de la Carità debe ser para nosotros de tanto más valor porque el artista tuvo allí la mano libre y pudo seguir sin limitaciones los dictados de su genio. Si el monasterio estuviera terminado no habría acaso hoy en todo el mundo obra de arquitectura más perfecta. (V. It., III: 1089)
\end{abstract}

El estado inacabado de la obra le generaba un juicio similar al producido por la visión de las ruinas antiguas en la medida que, en ambos casos, era necesario un esfuerzo el médico de Jena Schleusner pregunta a Goethe qué ejemplares recomendaría para una biblioteca de arquitectura. Goethe contesta mandando el 22 de febrero de 1797 y opina sobre diferentes autores y cuestiones relativas a la arquitectura. Esta carta no se reproduce en la edición de DKV que ha servido de referencia para este trabajo, por ello se recurre a la trans cripción revisada en Ewald (1999: 26-30)

251. Refiriéndose a Goethe escribe Pevsner: "La Antigüedad significaba para él -por encima de todo- las ruinas de Roma y los templos griegos de Paestum y Sicilia. E Italia significaba Palladio" (1968: 124)

252. En la carta al médico Schleusner dice que: "el monasterio de la Carità de Venecia, que [Palladio] quería llevar a cabo según el modelo de un edificio antiguo tal y como nos lo describe Vitruvio, y que a tenor de los planos se habría convertido en uno de los edificios más notables del nuevo mundo." [das Kloster della Carita in Venedig gehört, welches er nach dem Muster eines antiken Gebäudes, wie uns die Beschreibung davon durch Vitruv überliefert ist aufführen wollte, und das dem Risse und dem fertig gewordenen Theile nach, gewiß eines der merkwürdigsten Gebäude der neuen Welt geworden wäre.] (Ewald, 1999: 28). 
253. En un escrito a Charlotte von Stein le dice: "La Basílica es, y sigue siendo, una obra espléndida, ni se la puede imaginar quien no la ha visto al natural; e infinitamente bellas son las cuatro columnas del Capitanio. Entre estos edificios la Plaza no es más ancha de cuarenta pasos, de lo que esos [edificios] ganan en magnificencia". (Assunto, en Chastel, 1990: 32).

254. El mismo Goethe experimentó la dificultad de casar las necesidades modernas en modelos antiguos cuando, junto con Coudray proyectó la reconstrucción del teatro de Weimar tras su incendio en 1825. Tuvo que desechar una solución inicial inspirada en el teatro de Palladio (IVb: 130; Vla: 175) para ajustarse a las necesidades de las representaciones modernas. Aunque, finalmente, tras ser rechazadas hasta tres propuestas, el nuevo teatro fue construido por Carl Friedrich Chistian Steiner (Eck., III: 288-289). mental para intuir la arquitectura que podría ser pero ha quedado incompleta o mutilada.

Las diferencias entre lo ejecutado con respecto a la idea mostrada en las páginas del tratado palladiano le llevan a comprender las dificultades con las que se encuentra la arquitectura para alcanzar la perfección. Por un lado, está la inconveniencia del lugar: "No puede expresarse el aspecto que muestra la basílica de Palladio, contigua a un edificio antiguo, salteado de ventanas desiguales, con traza de castillo, que seguramente el arquitecto habría pensado eliminar junto con la torre". (V. It., III: 1070). ${ }^{253}$ Por otro, lamenta la ignorancia y la indiferencia de la gente ante el valor de esos monumentos siendo ésta la principal causa de su lastimoso estado. Escribe:

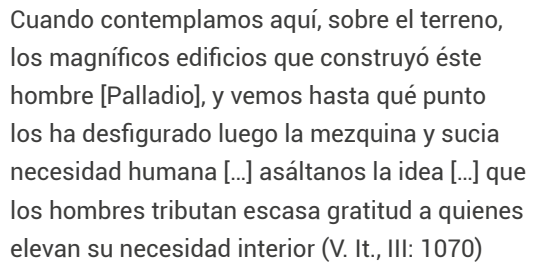

Los cambios introducidos por las necesidades que debe satisfacer la arquitectura conducen a soluciones que, para ser factibles, se tienen que alejar de los modelos ideales. En el intento de superar esta tensión, haciendo compatible lo apropiado según los principios arquitectónicos con lo conveniente de acuerdo con los usos y costumbres, se originan desajustes y resultados insatisfactorios que Goethe detectaba en las iglesias venecianas. En su opinión, Palladio:

Llevaba a mal, según infiero del suave giro de su libro, el que los templos cristianos se

\begin{abstract}
siguiesen edificando con arreglo a la forma de las antiguas basílicas, por lo que buscaba aproximar sus edificios sagrados a la forma de los antiguos templos, de donde se derivaron ciertos yerros, que solo en II Redentore combatió con acierto pero que en San Jorge saltan con exceso a la vista. (V. It., III: 1083)
\end{abstract}

Sin embargo, ante esta comprobación, Goethe se muestra comprensivo porque dice: "Siguen ajustándose todavía las iglesias cristianas a la forma de basílica, aunque quizá le conviniera más al culto la del templo." (V. It., III: 1108). De la Rotonda alaba su emplazamiento pero critica su incomodidad. Escribe: "Su interior puede habitarse, pero no puede llamársele habitable. El salón es de las más bellas proporciones, así como los aposentos; pero apenas bastarían para las necesidades del veraneo de una familia distinguida" (V. It., III: 1071). Elogia los cuatro pórticos de columnas jónicas en las fachadas "cada una de las cuales podría satisfacer como perspectiva de un templete" (V. It., III: 1071). Estos juicios establecen, de hecho, una jerarquía que antepone la belleza a la comodidad. En todo caso, ajustar los tipos antiguos a las necesidades modernas es el reto que ahora se le presenta al arquitecto. Esa era la gran aportación de Palladio, y Goethe encontraba en el teatro Olímpico el ejemplo más elocuente: "es un teatro antiguo, realizado en pequeño y de una belleza indecible" (V. It., III: 1069). ${ }^{254}$

El 19.10.1786 Goethe escribe: "ocurre con el arte igual que con la vida: que cuanto más nos adentramos en ella, más ancha se vuelve. [...] pero para gozar realmente de esas obras son menester ciencia y juicio, cosas que a mí me faltan, y que sólo poco a poco es posible adquirir." (V. It., III: 1105). Así, 
poco a poco, Goethe se iba percatando de los escollos que jalonan la ejecución de las obras e introducen interferencias que las alejan de los ideales a los que tienden. Y, tras constatarlo, su juicio negativo inicial por los desajustes encontrados se convirtió en alabanza al esfuerzo del arquitecto por superar esas dificultades.

En las obras ejecutadas por Palladio, sobre todo en las iglesias, he encontrado muchas cosas dignas de censura, codeándose con lo más exquisito. Pero cuando ahora recapacito para mi capote hasta qué punto tendría yo razón contra hombre tan extraordinario, paréceme cual si estuviera junto a mí y me dijese: «Esto y esto hícelo en contra de mi voluntad; pero lo hice porque solo así atendidas las circunstancias, podía aproximarme a mi más alta idea» Paréceme también, cuando en ello pienso y retepienso, que al considerar la altura y amplitud de una iglesia ya existente, de una casa antigua a la que hubiera que ponerle fachada, solo tenía en cuenta: «¿Cómo les darás la forma más grande a esos espacios? En los detalles tendrás, atendida la necesidad, que cambiar algo o hacer una chapuza, alguna torpeza se deslizará acá o allá; pero eso no importa, con tal que el conjunto muestre un alto estilo y para ti sea una alegría el trabajar»

Y así llevó también la visión más grande que en el alma guardaba, incluso allí donde no se acomodaba del todo, donde en los pormenores no tenía más remedio que fragmentarse y mutilarse. (V. It., III: 1089)

Entre el tipo ideal y las condiciones impuestas por la realidad, el arquitecto debe encontrar el punto de equilibrio que haga posible la obra. Una cierta aceptación y pragmatismo son el camino adecuado, porque la idea siempre es totalmente inalcanzable, pero eso no justifica nunca la renuncia a intentarlo. En 1795 decía: “Cuanto menos favorezcan a la arquitectura la situación y las circunstancias externas, más se tiene que estar atento a lo que sucede. Un arte despreciado o descuidado del que no siempre se puede prescindir, se venga cruelmente cuando irrumpe la necesidad." ${ }^{255}$ Así resume Goethe el aprendizaje extraído del descubrimiento de Palladio: "Solo deploro lo atrasado que estoy en estos conocimientos, aunque ya adelantaré, pues, cuando menos, conozco el camino. Palladio hámelo abierto para eso y para todo arte y vida." (V. It., III: 1093).

Las obras de Palladio le aportaron dos importantes enseñanzas. En primer lugar, que la arquitectura clásica era un ciclo abierto y vigente. En este sentido, para ilustrar su teoría, Goethe utilizó en el Baukunst ejemplos palladianos como un eslabón que retoma y continúa las cuestiones que plantearon los griegos. Y, en segundo lugar, que el contexto de la construcción exige un pragmatismo que haga viable la arquitectura pero que, por eso mismo, aleja a los edificios del universo ideal del arte. La arquitectura como arte y la construcción discurren por caminos distintos: la primera se emplaza en su universo ideal y autónomo; la segunda se atiene a los contratiempos de la vida. ${ }^{256}$

Su primer contacto con restos romanos lo tuvo en la Arena de Verona de la que le interesó la funcionalidad de su forma de cráter donde el público mismo es el ornato (Viaje, III, 1061). Al visitar el templo de Minerva en Asís exclama: "he aquí que se alza ante mis ojos la obra más encomiable, el primer monumento íntegro de la antigüedad que me echo a la cara" (V. It., III: 113). Admira así mismo su fachada, y comprende a Vitruvio y Palladio sobre la importancia del emplazamiento de los edificios públicos. Pero
255. Über die verschiedenen Zweige der hiesigen Tätigkeit [Acerca de las diversas ramas de las actividades locales] (DKV 18.1, 386-397). Extracto de la conferencia para la Weimarer Freitagsgesellschaft. 256. Safranski escribe: "Tras su regreso de Italia la idea de la autonomía del arte alcanzó una gran importancia para Goethe" (2015: 336) y más adelante añade: "Desde la perspectiva actual el arte es un círculo cerrado en sí mismo con sentido, que por eso mismo no sirve para ningún otro fin." (2015: 337). Y concluye: "En la poesía todo es posible, también lo imposible; por el contrario, en la política y en los demás negocios de la vida se trata del arte de lo posible." (2015: 338) 
257. Sobre esta cuestión véase: Ghisetti Giavarina, Adriano, 2006-2007 "Palladio e le antichità dell'Umbria" en: Annali di architettura. Rivista del Centro Internazionale di Studi di Architettura Andrea Palladio di Vicenza n 18-19.

258. Posiblemente este comentario sobre templo de Asís y su relación con Palmira la extrajo de Winckelmann quien comete el mismo error que Palladio cuando escribe: "el único edificio conocido en Italia en el que cada columna tiene su estilóbato propio es un antiguo templo que hay en Asís, en la Umbria. Esta particularidad se ve en otros edificios de Palmira y en un templo representado en el antiguo mosaico de Palestrina". (1762: 546). El comentario de Goethe se encuentra casi literalmente en Guattani, autor al que nombra en el Baukunst (1795): “Il Palladio, ed altro più moderno autore che lo seguitò, non avendo veduto questo Tempio, gli diedero piedistalli alti quanto è largo l'intercolunnio, profilanti ciascuno sotto le colonne; cosa di magro effetto, ma no nuova com'egli pretende, osservandosi ciò praticato in due edificii di Palmira, e in un tempio del mosaico di Palestrina." [Palladio, y otro autor más moderno que le ha seguido [seguramente se refiere a Winckelmann], no habiendo visto este Templo, le pusieron pedestales tan altos como ancho es el intercolumnio, perfilados cada uno bajo las columnas, cosa de mal efecto, pero no nueva como pretenden, observándose eso mismo en dos edificios de Palmira, y un templo del mosaico de Palestrina] (Guattani, Giuseppe Antonio, Monumenti antichi inediti overo notizie sulle antichità e belle arti di Roma per... (Roma, 1786-1789, p. XXI).

259. Desde su niñez y por influencia de su padre que había estado en Italia y del que conocía los relatos y su diario del viaje, Goethe se había hecho una imagen de Roma a través de los grabados que había traído de Falda, Spechi y el flamenco Gomar Wouters conservados en su casa de Frankfurt. Escribe: "Dentro de la casa atraía preferentemente mis miradas una serie de vistas de Roma [...] Allí veía yo diariamente la Piazza del Popolo. El Coliseo, la plaza de San Pedro, la Basílica del mismo nombre, por dentro y por fuera, el castillo de Sant'Angelo y otros muchos edificios. Estas figuras quedábanse muy grabadas en mi imaginación" (III: 438).

Fig. 10: Johann W. Goethe, Ruinen auf dem Palatin in Rom [Ruinas en el Palatino en Roma], verano/otoño 1787 (138x228 mm. Lápiz, pincel con sepia). En Femmel [1958] 1972, III: 38 260. "Die Geschichte der Peterskirche interessiert mich mehr als jemals, es ist wiklich eine kleine Weltgesichte" Goethe (1998, DKV II.4 (31): 132) y ss. Serlio (lib. III, fol. 16 anv., rev.). 261. "Besonders finden sich einige von Bramante, die sehr merkwürdig sind." En la carta a Schleusner (Ewald, 1999: 29).

262. Toda la última parte del libro de Winckelmann (1762) está dedicada al análisis de los templos de Agrigento. Escribe: “Mi intención [es] reunir algunas observaciones sobre la arquitectura dórica de los tiempos más antiguos, porque ni Vitruvio ni los que han escrito sobre esta materia posteriormente, nos dicen nada del antiguo estilo de este orden arquitectónico." (1985: 566). Es, en su opinión, el punto original de la evolución histórica de la arquitectura clásica. Una idea que Goethe retomó.

263. En relación con esta cuestión Winckelmann refiriéndose a Paestum escribe: "Es de notar en el templo pequeño la particularidad de que la tercera de las columnas del pórtico descansa en la tercera grada, y que las otras dos tienen bajo el fuste un tambor, además del plinto o basa, que también es redonda. Así pues, sabemos que desde los tiempos más remotos se veían columnas dóricas con basa, cosa que no había sido observada hasta hoy." (1985: 267). 264. Schiller dice a Wilhelm von Humboldt en una carta (5/9.11.1795), en la que alude a conversaciones con Goethe en el contexto de la redacción del Baukunst, que: „Göthe verlangt von einem schönen Gebäude, daß es nicht bloß auf das Auge berechnet sei, sondern auch einem Menschen, der mit verbundenen Augen hindurchgeführt würde, noch empfindbar sein und sobre todo, descubre la dificultad que entraña la restitución de la forma de la arquitectura antigua a partir de los levantamientos de los restos existentes. En este caso, al encontrarse semienterrado el basamento del edificio, el propio Palladio cometió errores de interpretación en la restitución dibujada en su tratado ${ }^{257}$ que Goethe detectó. Escribe:

Palladio, en quien tenía yo confianza ciega, da, es cierto, la imagen de este templo, pero no es posible que lo hubiera visto con sus propios ojos, ya que pone pedestales encima de las superficies, con lo que las columnas resultan desmedidamente altas, engendrándose de ahí un feo monstruo palmiriano, siendo así que en realidad ofrece a la vista un aspecto sereno, simpático, que por igual satisface a los ojos y al intelecto. (V. It., III: 1113-1114)

Un comentario que repite en el Baukunst. ${ }^{258} \mathrm{La}$ anastilosis a partir de los restos conduce, a su vez, a reconstrucciones erróneas que Goethe cree descubrir en el llamado templete de Clitumno conocido entonces como San Crocedisso del que dice: "no me parece vestigio de un templo que allí antaño hubiera, sino que han descubierto y amañado con columnas, pilares y vigas de una manera no estúpida, sino loca" (V. It., III, 1116). Aunque, al utilizar este ejemplo en el Baukunst parece asumir su antigüedad.

De nuevo se admira ante la vista del acueducto de Spoleto y, a pesar que tenía un escaso conocimiento directo de la arquitectura romana en aquellos momentos, escribe: "Es esta ya la tercera obra de los antiguos que veo, y siempre el mismo gran sentido. Una segunda Naturaleza que atiende a fines burgueses: tal es su arquitectura, y a ella responden anfiteatro, templo y acueducto." (V. It., III: 1116). 
Pero la experiencia más relevante ante los monumentos y las ruinas la tuvo en Roma. Nada más llegar escribe: "todo es como yo me lo imaginaba y todo nuevo [...] Sólo en Roma puede uno prepararse para Roma" (V. It., III: 1119). El contraste entre la ciudad concebida a partir de los grabados, y la realidad con la que se topó debió producirle una fuerte impresión. ${ }^{259}$ Allí “Encuéntrense huellas, de una magnificencia y una destrucción que sobrepasan nuestras ideas" (V. It., III: 1122). Ante el Coliseo el 15.11.1786 escribe: “'Cuando se ve eso, todo lo demás antójase mezquino, pues es tan grande que no cabe su imagen en el alma" (V. It., III: 1125). Todas estas vivencias le llevan a concluir: "De todo esto, nada en verdad, puede comunicarse." (V. It., III: 1125). El panorama del Foro visto con los ojos de Claudio de Lorena, el perfil urbano coronado con la cúpula de San Pedro del Vaticano, la plaza del Campidoglio y las ruinas del Palatino o del Ponte Roto son algunas de las imágenes más relevantes que recoge en sus dibujos queriendo transmitir esa grandeza inexpresable. (Fig. 10)

Durante su segunda estancia en Roma, en septiembre de 1787 escribe:

\begin{abstract}
no podíamos menos de considerar a Roma, como un quodlibet, pero único en su clase; pues también en este sentido reúne este lugar las mayores ventajas. No hizo aquí el acaso resaltar nada, limitándose a destruir; cuanto aún se tiene en pie es magnífico; cuanto yace ruinoso, respetable; lo informe de las ruinas delata primitiva regularidad; que de nuevo se manifiesta en nuevas y grandes formas de iglesias y palacios. (V. It., III: 1309)
\end{abstract}

Posteriormente, en 1795, cuando redactaba el Baukunst, mostró un interés especial por la construcción de San Pedro del
Vaticano, del que conocía los proyectos de Bramante y Peruzzi publicados por Serlio, por considerarlo "verdaderamente una pequeña historia del mundo". ${ }^{260} Y$ dos años después mencionaba a varios arquitectos como Brunelleschi, Alberti, Miguel Ángel, II Cronaca y Vignola, pero, de un modo especial, a Bramante del que destaca alguna de sus obras romanas al juzgarlas "muy excepcionales". 261 Sin embargo, y en relación con la idea de arquitectura que estaba madurando, no fue hasta el descubrimiento de los restos griegos cuando pudo compararlas con la arquitectura romana antigua y avanzar algunas hipótesis de interpretación. En una carta a Herder el 27.10.1787 tras su estancia en Sicilia y Paestum le dice: "Encuentro especialmente bella la época griega, que en la romana echo de menos algo de corporeidad." (V. It., III: 1320).

La visión de la arquitectura doméstica romana en Pompeya le dejó perplejo "por su angostura y pequeñez" (V. It., III: 1169) y el encuentro con los templos de Paestum le ihm gefallen müsse." [Goethe quiere de un edificio bello que no sólo pueda apreciarse con los ojos, sino que también un hombre con los ojos vendados pudiese hacérselo perceptible y disfrutarlo.] Goethe (1998, DKV II.4 (31): 129). 265. La palabra que atribuye Eckermann a Goethe traducida por Cansinos como "música petrificada" es "erstarrte Musik" [música solidificada] que es un término que había utilizado Schelling en su escrito Philosophie der Kunst (1809). Sin embargo, en sus escritos Goethe no emplea este calificativo sino otro distinto. En su diario (7.4.1828) escribe "stumme Musik" [música silenciosa] y en Sprüche in Prosa (1827), refiriéndose posiblemente a Schelling dice: "Ein edler Philosoph sprach von der Baukunst als einer erstarrten Musik und mußte dagegen

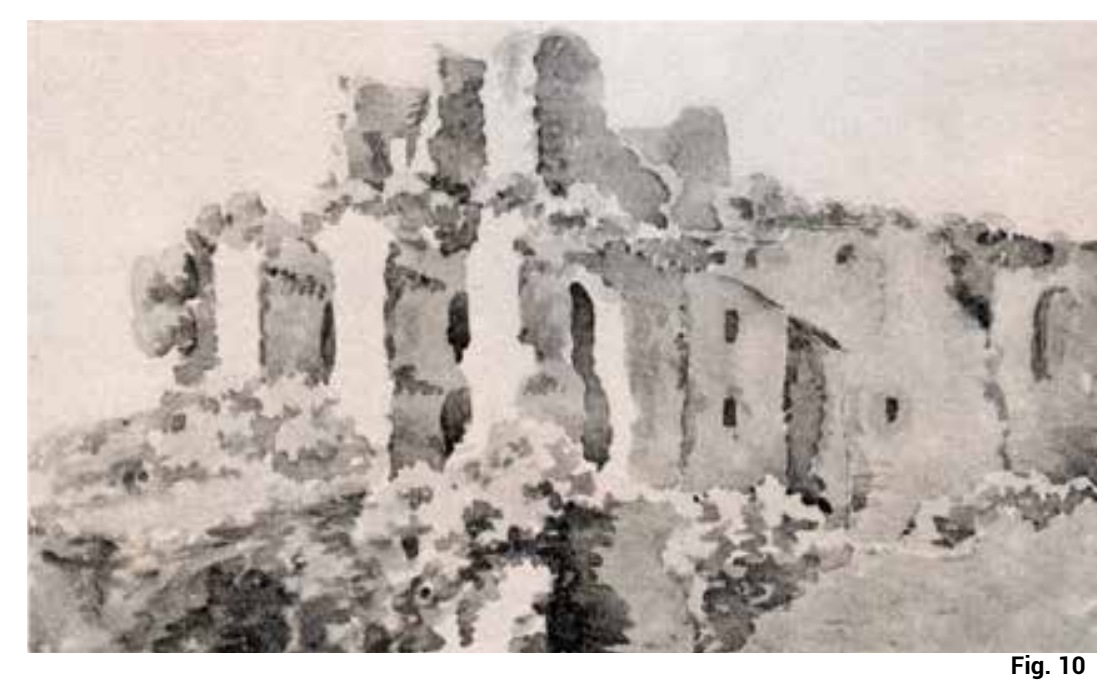


manches Kopfschütteln gewahr werden. Wir glauben diesen schönen Gedanken nicht besser nochmals einzuführen, als wenn wir die Architektur eine verstummte Tonkunst nennen." (1907: 234) [Un sabio filósofo hablaba de la arquitectura como una música solidificada, lo que tuvo que producirle numerosos dolores de

cabeza. No creemos que esta bella idea pueda ser mejor presentada si llamamos a la arquitectura un arte musical silencioso.] Esta cualificación como "música silenciosa" parece más coherente con el contenido del Baukunst. Paul Valéry retomó esta vinculación entre música y arquitectura en Eupalinos ou l'Architecte. Dialogue des morts (1921) poniendo en boca de Sócrates: “Cette imagination me conduit très facilment à mettre d'un côté, la Musique et l'Architecture; et de l'autre, les autres arts" [Esta imaginación me lleva fácilmente a poner en un lado la Música y la Arquitectura, y en el otro las demás artes.] (2004: 31). Una idea que ya había expuesto en su breve escrito La paradoxe sur l'Architecte (1891): "Pues sutiles analogías unen la irreal y fugitiva edificación de los sonidos, al arte sólido, por quien formas imaginarias se inmovilizan al sol en pórfido." (2004: 107)

266. Esta es la interpretación que da Pevsner (1983, nota 22, p. 425): “Pero esta misma causaron un desconcierto del que intentó distanciarse de inmediato. Escribe:

$$
\begin{aligned}
& \text { la primera impresión sólo podía ser de asombro. } \\
& \text { Hallábame en un mundo enteramente extraño } \\
& \text { [...]. Hoy nuestros ojos, y por ellos todo nuestro } \\
& \text { ser íntimo, tiran y resueltamente optan por una } \\
& \text { arquitectura más esbelta, de suerte que aque- } \\
& \text { llas masas de columnas, tan apretadas, chatas, } \\
& \text { cónicas, antójasenos pesadas y hasta terribles. } \\
& \text { Yo, sin embargo, me repuse en seguida, recordé } \\
& \text { la historia del arte, evoqué los tiempos cuyo es- } \\
& \text { píritu encontraba adecuada aquella arquitectu- } \\
& \text { ra, representéme el severo estilo de la plástica, y } \\
& \text { en menos de una hora ya me sentí familiarizado } \\
& \text { con aquello y hasta di gracias al numen que } \\
& \text { me había deparado la contemplación con mis } \\
& \text { propios ojos de aquellos restos tan bien conser- } \\
& \text { vados." (V. It., Ill: 1184) }
\end{aligned}
$$

Las enseñanzas de Winckelmann

le llevaron a superar la primera reacción debida al gusto vigente, para intentar recrear en su mente el momento del nacimiento del clasicismo con su primitivismo espontáneo, rotundo y sin concesiones. La contemplación de esa epifanía petrificada en Paestum debió tener, para Goethe, el valor de una intuición. El orden dórico griego es el que inaugura su teoría arquitectónica recogida en el Baukunst. Lo anterior aún no era arquitectura. Lo posterior era el desarrollo, cada vez más complejo, de las cuestiones ya planteadas allí. En adelante, frente a cada tema analizado siempre volvía a este origen.

Las ruinas de Agrigento no sólo le confirmaron en esa idea, sino que le permitieron establecer un primer análisis comparativo con los templos de Paestum rastreando su historia. ${ }^{262}$ Del templo de la Concordia dice: "su esbelta arquitectura aproxímale ya a nuestra escala de lo bello y grato, y se halla respecto a lo de Pesto en la misma relación que las figuras de los dioses respecto a las de los titanes." (V. It., III: 1221). Esta visión cronológica le habilitaba para establecer juicios de valor. En una carta a Herder desde Nápoles, al regreso de Sicilia, le dice: “EI templo del centro [Poseidón] es también, a mi juicio, preferible a todo cuanto aún se ve en Sicilia" (V. It., III: 1253).

La descripción de las ruinas y su abandono, las intervenciones realizadas para su conservación, el tipo de piedra y su deterioro debido a la intemperie y el tiempo transcurrido, o el intento de descubrir entre los escombros las trazas originales, son las pautas que canalizan sus visitas con una clara voluntad sistemática. En el estado inacabado del templo de Segesta intuía aspectos constructivos y compositivos de su ejecución. Un dibujo de este templo hecho el 20.4.1787 (Vla: 140) plantea varias hipótesis que retomó posteriormente en el Baukunst. ${ }^{263}$ Este enfoque que centraba su mirada a los restos con cierto afán de inspección, demuestra una creciente seguridad que le capacitaba para "pensar y juzgar", y un principio de sistematización teórica.

Pero la visión de las obras, frente a su simple conocimiento en grabados o textos, le hizo comprender que las representaciones de la arquitectura no pueden sustituir la vivencia directa. Goethe apunta en el Baukunst que el recorrido, que involucra a todos nuestros sentidos, es la verdadera fruición de la arquitectura. Y aunque alguno de ellos, como la vista, nos sea eventualmente negado, las sensaciones recibidas por los otros se combinan y lo suplen para conformar su imagen mental. Es algo similar, en el ámbito de la sensibilidad, a lo que Goethe defendía respecto a la mente cuyas ideas 
pasan de unas disciplinas a otras abriendo nuevas perspectivas de conocimiento. ${ }^{264} \mathrm{En}$ este sentido Goethe comparó la arquitectura con la música: "la arquitectura es algo así como música petrificada. Y realmente algo de verdad hay en ello. La emoción que la arquitectura suscita en nosotros linda con la que nos produce la música" (Eck., III: 170). ${ }^{265}$ Siguiendo esta misma línea de pensamiento en el Baukunst Goethe asimila la sensación estética que produce la arquitectura con la de la danza. Con esta formulación parece que está anticipando la teoría de la Einfühlung (empatía) que surgió en la estética alemana casi un siglo después en los trabajos de Vischer, Lipps y Smarchow. ${ }^{266}$ Por lo tanto, entre la creación de la arquitectura y su fruición Goethe está marcando diferencias. La composición está sometida a normas y se concreta en la forma visual proporcionada y característica. Pero su disfrute requiere recorrerla y vivirla. Hay en estas ideas una cierta manifestación de la estética de la recepción como contrapunto a la estética de la creación.

\section{Tratados, escritos}

Como el mismo Goethe decía, la "impresión viva" y el "vistazo seguro a las obras" le capacitaban para "leer" los escritos y "escuchar" la opinión de los expertos afinando su sentido del gusto. Su interés por el estudio de la arquitectura se pone de manifiesto en la abundancia de textos y autores que cita en sus escritos, en su correspondencia y en los libros que tenía en su biblioteca. ${ }^{267}$ En su viaje a Italia y en la década posterior menciona a muchos arquitectos o utiliza las láminas de sus tratados, como las de Serlio de quien co- pia perspectivas, o las de las obras palladianas dibujadas por Ottavio Bertotti Scamozzi. Utilizó en su viaje la guía de Johann Jakob Volkmann ${ }^{268}$ y en Sicilia el libro de Johann Hermann von Riedesel. ${ }^{269}$ Se encuentran, también, referencias directas o implícitas de los tratados de Vignola, Vincenzo Scamozzi, François Blondel, Giuseppe Galli Bibiena, Antonio Labacco y Jacques François Blondel. ${ }^{270}$

En Weimar, cuando en 1795 estaba elaborando el Baukunst, consultó diferentes tratadistas como Serlio, Scamozzi o Labacco. Sobre estos autores, el 16.11.1795, le dice a Meyer:

De Antonio Labacco le adjunto un anexo. Si puede encontrar la obra de este hombre, ya sea al completo o ciertas láminas, tómelo en consideración, puesto que difícilmente puede encontrarse algo mejor trabajado y mejor grabado. [...] En Serlio he encontrado también trazados de diversas extrañas ruinas, que no se darían en ningún otro lugar. También he ojeado a Scamozzi, una obra excelente sin igual. ${ }^{271}$

Y poco después lo repite: "Serlio era para mí un fenómeno por derecho propio. En las partes relevantes y duraderas de la arquitectura y, por así decirlo, en sus inicios más tempranos es excelente." $272 \mathrm{Y}$ de la obra de Scamozzi dice: "es la más completa, más sólida y excelente para estudiar la arquitectura solo con una obra. A un amante del arte le bastaría. Aquello que le falta, lo puede reemplazar una buena cabeza." ${ }^{273}$

Así mismo, durante esos años dedicados al Baukunst menciona a otros escritores, dibujantes y teóricos del arte como Antonio Lafreri, Giovanni Paolo Lomazzo, Giovanni Pietro Bellori, Antonio Bosio ${ }^{274} y$, en los años posteriores, amplió su biblioteca con otros insistencia en la experiencia estética directa en arte y arquitectura movió a Goethe, por otra parte, a establecer en passant [...] un principio de crítica arquitectónica, restablecida por Schmarsow y su escuela a partir de 1892 en adelante, y que todavía hoy es válido: el de que la arquitectura es un arte al que apreciar no sólo con nuestros ojos, sino también con nuestro sentido del movimiento a través del espacio."

267. Ruppert (1958) aporta cincuenta entradas entre libros y colecciones de láminas.

268. Cuando parte de Weimar, Goethe lleva en su equipaje el libro de Johann Jakob Volkmann, Historich-Kritische Nachrichten von Italien (1770-71) (tres volúmenes) y el Genera plantarum (1737) de Linneo. Posteriormente compró Geschichte der Kunst des Altertums (1764) de Johann Joachim Winckelmann (obra que ya había estudiado en profundidad), la versión más reciente del Palladio (1770-1780) y el Vitruvio de Galiani. Estas cinco obras le acompañarán durante el viaje. Es significativo que este conjunto de obras constituya lo que posteriormente llamará "los tres grandes reinos": la sociedad, la naturaleza y el arte, como así lo aclara Goethe en "Fortuna del manuscrito", publicada en WA II-6: 132: "Moviéndome en estas regiones de acá para allá tratando de 
perfeccionar mis conocimientos, me propuse poner por escrito lo que me parecía haber visto más claramente, y así me puse a sistematizar el recuerdo, a ordenar la experiencia y a fijar el instante. Al mismo tiempo escribí un ensayo sobre arte, manera y estilo, otro para explicar la metamorfosis de las plantas, y El carnaval romano. Todos ellos muestran lo que por entonces se agitaba en mi interior, y qué posición había tomado frente a estos tres grandes reinos. El intento de explicar la metamorfosis de las plantas, es decir, de reconducir a un principio general simple la multiplicidad de los fenómenos particulares del espléndido jardín del mundo, fue el primero en quedar terminado." (Teoría de la naturaleza, 76). De hecho, Goethe publicó durante esos años tres ensayos sobre estos tres reinos: Einfache Nachahmung der Natur, Manier, Stil (1789) sobre arte, Versuch, die Metamorphose der Pflanzen zu erklären (1790) sobre naturaleza y El carnaval romano (1789) sobre sociedad. Sorprende, en este sentido, que no mencione explícitamente la arquitectura, habiendo publicado en 1788 su ensayo Baukunst en Auszüge aus einem Reise-Journal.

269. Johann Hermann von Riedesel, Reise durch Sizilien und Großgriechenlan (Zúrich, 1771). 270. En su biblioteca tenía los tratados: Bibiana, Giuseppe Galli, Architettura e prospettive (1740); Blondel, François, Cours d'Architecture enseigné Dans l'Academie Royale d'architecture, (1675-1683); Blondel, Jacques François, Cours d'Architecture ou Traité de la décoration, distribution \& construction des bâtiments (1771-1777); Davilier, Augustine Charles; Cours d'Architecture qui comprend les ordres de Vignole. Avec des commentaires... (1730). 271. „Von Antonio Labacco lege ich eine Nachricht bei. Wenn Sie das Werk dieses Mannes, entweder ganz oder in einzelnen Abdrücken, finden können, so nehmen Sie es ja mit, denn es findet sich leicht etwas besser gearbeitet und gestochen. [...] / Im Serlio habe ich auch die Risse verschiedener merkwürdiger Ruinen gefunden, die sonst nicht überall vorkommen; auch habe ich den Scamozzi durchlaufen, ein fürtreffliches Werk, das Wohl wenige seines gleichen hat." Goethe (1998, DKV II.4 (31): 131-132).

272. En una carta a Meyer de entre el 30 de diciembre de 1795 y el 3 de enero de 1796: „Serlio war mir ein eignes Phänomen, in den ernsthaften und soliden Teile der Baukunst und gleichsam in ihren ersten Anfängen ist er fürtrefflich." Goethe (1998, DKV II.4 (31): 152).

273. "Scamozzi's Werk ist das vollständigste, solideste und trefflichste, das die Architektur aufzuweisen hat, dieses Werk alleine genugsam durchzustudieren, würde einen Freund der Kunst schon genug weit bringen. Das wenige, was ihm an der Methode fehlen möchte, weiß ein guter Kopf leicht zu ersetzen." (Carta a Schleuner, en Ewald, 29). Se está refieriendo a L'idea della architettura universale. Venet. 1615, 2 Tom. Edición también en Ámsterdam 1661 y versión alemana en Ámsterdam 1665

274. En concreto cita: Antonio Lafreri, Speculum romanæ magnificentiæ (1575); Giovanni Paolo Lomazzo, Trattato dell'arte della Pittura, Scultura ed Architettura, (1585); Piertro Bellori, Admiranda Romæ antiquæ vestigia, (1693); Antonio Bosio, Roma sotterranea (1632).

275. Entre los libros de su biblioteca sobre estas cuestiones se pueden destacar, entre otros: Boisserée, Sulpice, Ansichten,Risse und einzelne Theile des Doms von Köln (1821-23); CanceIlieri, Francesco, Sagrestia Vaticana eretta dal regnante Pontefice Pio sesto e descritta (1784); Durand, Jean Nicholas Louis, Grundlinien der bürgerlichen Baukunst (1806); Hittorff, Jakob Ignaz, Karl Ludwig Wilhelm Zanth, Architecture moderne de la Sicile ou Recouil des plus beaux monuments religieux et des édifices publics particuliés, Paris; Laugier, Marc Antoine, Des Abts Lauguier aeue Anmerkungen über die Baukunst. Nebst e. zwiefachen Anh. als: des Herrn (Julien David) le Roi Geschichte der Einrichtung und Gestalt der crhistlichen Kirchen von... (1768); Montenari, Giovanni, Del Teatro Olimpico di Andrea Palladio in Vicenza (1733) (citado en: V. It., III: 1069). libros de arquitectura y ediciones de láminas con planos de edificios y teatros. ${ }^{275}$

Pero, sin duda, los dos arquitectos tratadistas más relevantes en los que se apoyó Goethe para su teoría fueron Vitruvio y Palladio. Del tratado palladiano compró la edición de Smith (1770-1780) y del Vitruvio la de Galiani que era la más reciente entonces publicada. El 12.10.1786 escribe: "Como Palladio todo lo refiere a Vitruvio, me he procurado también la edición de Galiani; solo que este infolio pesa en mi equipaje como su estudio en mi cerebro." (V. It., III: 1100). ${ }^{276}$ Y añade:

Palladio, con sus palabras y obras, con su manera de pensar y crear, me ha acercado a mí más el Vitruvio y me ha servido con él de intérprete mejor de como pudiera hacerlo su traducción italiana. No es tan fácil de leer Vitruvio, y el libro está ya de por sí oscuramente escrito y exige un estudio crítico. Pero, a pesar de ello, léolo a saltos, y me deja mucha digna impresión. Mejor sería decir que lo leo cual un breviario, más por devoción que por enseñanza. (V. It., III: 1100).

De este párrafo se desprenden algunas cuestiones significativas para entender el Baukunst. El texto de Vitruvio era poco útil para el conocimiento de la arquitectura, exigía una lectura crítica y, para comprenderlo realmente, había que filtrarlo con la interpretación hecha por Palladio. Winckelmann (1762) cita con frecuencia a Vitruvio, algunas veces para criticarlo, comparando sus afirmaciones con la realidad de las ruinas existentes. Goethe en el Baukunst incluso duda de la interpretación gráfica que Galiani hace del templo dórico según Vitruvio. Por otra parte, estas críticas, así como la oscuridad de su texto, eran afirmaciones recurrentes y habituales desde 
la recuperación del manuscrito en el siglo XV. Con estos antecedentes parece lógica la reserva que Goethe, como seguidor de Winckelmann, hace sobre la utilidad del escritor latino para analizar la arquitectura clásica. Vitruvio, para él, merece respeto pero no era ni fácil de comprender ni útil para el conocimiento.

Su actitud hacia Palladio era muy distinta. Aunque lo considera "probablemente el mejor", dice de su tratado que "sus medidas y dibujos de los edificios antiguos no son siempre correctos"277 pensando, posiblemente en el templo de Asís. Comenta:

\begin{abstract}
Cada vez comprendo mejor cómo pensaba y cómo trabajaba [Palladio], según voy leyendo sus obras, y por ellas veo cómo trataba a los antiguos, porque dice pocas palabras, pero todas ellas son de peso. El cuarto libro, que representa los antiguos templos, es una verdadera iniciación a la contemplación juiciosa de las reliquias antiguas. (V. It., III: 1089-1090).
\end{abstract}

Y a Meyer, el 16 de noviembre de 1795 , le dice en una carta:

$$
\begin{aligned}
& \text { Palladio, además de sus trabajos sobre la } \\
& \text { arquitectura, ha proporcionado trabajos sobre } \\
& \text { la antigüedad romana que no se nos deben } \\
& \text { escapar; puesto que es muy interesante por una } \\
& \text { parte aquello que se encontró entonces, cuyas } \\
& \text { pistas hoy han desaparecido por completo, } \\
& \text { por otra sus restauraciones y comentarios son } \\
& \text { siempre importantes. }{ }^{278}
\end{aligned}
$$

Goethe está dejando claro que, en su opinión, el eslabón más reciente que ha seguido el clasicismo en arquitectura es Palladio, por eso los problemas originados en la arquitectura griega que explica en el Baukunst encuentran en Palladio su continuidad natural y, en su tratado, su exposición más clara. La historia de la arquitectura clásica seguía abierta y Palladio representaba el nexo que enlazaba el presente con la antigüedad. Un ejemplo elocuente era, precisamente, la adaptación contemporánea de la articulación de la columna y el muro:

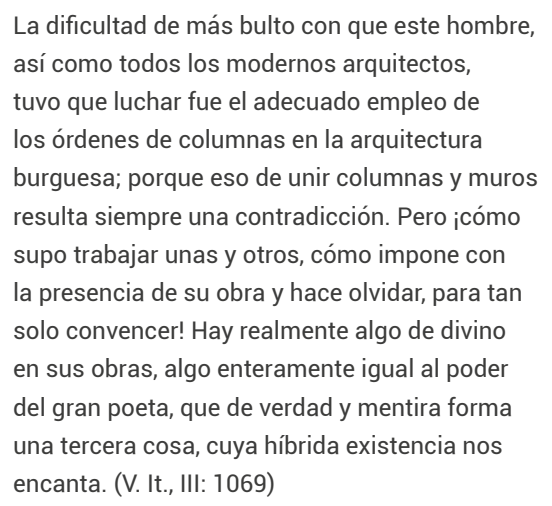

La articulación de columnas y muros le sirve a Goethe para subrayar la aportación del Divino Palladio ${ }^{279}$ descubriendo en él la genialidad de un gran artista capaz de elevarse al fin supremo [der höchste] del arte de la arquitectura.

Así, pues, Goethe avanzaba en la comprensión de la arquitectura paralelamente en varios frentes: con la visión de las obras, con los dibujos o grabados que las representan y con la consulta de tratados y escritos teóricos. Si los primeros, sobre todo el de $\mathrm{Pa}$ lladio, conjugan imágenes y textos siendo por eso especialmente útiles, sin embargo, tanto los libros de arqueología, como los de historia y los de teoría de la arquitectura de su época solían carecer de ilustraciones. Cuando Goethe leía estos volúmenes sin figuras, para imaginar sus descripciones, los compaginaba con los dibujos disponibles. Para este fin las láminas de las publicaciones más antiguas de los siglos XVI y XVII le aportaban muchos datos sobre las ruinas que, en su tiempo, habían ya desaparecido. Escribe:
276. Galiani (1758), aunque este tratado no está en la relación de libros de su biblioteca.

277. „Palladio ist geistreich und gratiös und wohl in schicklicher Anwendung architektonischer Fiktionen der erste [...]. Seine Ausmessungen und Zeichnungen antiker Gebäude sind nicht immer richtig." (Carta a Schleuner, en Ewald, 28-29). [Palladio es ingenioso y delicado y probablemente el mejor en aplicaciones de las ficciones a la arquitectura [...]. Sus medidas y dibujos de los edificios antiguos no son siempre correctos.]. Precisamente, las láminas redibujadas por Scamozzi de las obras de Palladio tenían como objeto restituir en los planos las dimensiones reales de los edificios construidos. 278. „Auch hat Palladio, außer seinem Werk über die Architektur, das wir besitzen, noch römische Altertümer herausgegeben, die uns nicht entgehen dürfen, denn teils ist es sehr interessant, was die Menschen noch damals fanden, dessen Spuren jetzt völlig verschwunden sind, teiIs sind auch ihre Restaurationen und Bemerkungen immer wichtig." Goethe (1998, DKV II.4 (31): 131).

279. La frase original dice: "Es ist wirklich etwas Göttliches in seinen Anlagen". Y Assunto comenta: "la inicial mayúscula [Göttliches], indicando una promocional sustantivación del adjetivo 
'göttlich', 'divino', sirve para hacerle comprender al lector que este vocablo no figuraba allí por recurso retórico [...] sino que intenta significar la creatividad del artífice humano en cuanto cooperador de la omnipresente divinidad" (en Castel ed., 1990, 35).

Resulta significativo que esa sustantivación del calificativo "Divino" está en el texto pu-

blicado pero no en las notas y cartas redactadas durante el viaje, lo que supone una rectificación adoptada de manera consciente por Goethe.

280. Son, por el orden de exposición en la carta: Stiegliz, Geschichte der Baukunst der Alten, Leipzig, 1792; Julien-David Le Roy, The ruins of Pestum or Posidonia. London 1767; Stuart y Revett, The antiqvities of Athens, Londres, 1762; Jean Houel, Voyage pittoresque des isles de Sicilie, de Malte et de Lipari, Paris, 1784; Giovanni Gherardo De Rossi (et al.),

Journées pittoresques des édifices de Rome ancienne, Roma; Giambattista Nolli,

Plano de Roma, 1748; Giovanni Battista Piranesi, Della magnificenza e d'Architettura de'Romani, Verona, 1761; Antonio Labacco, Appartenente all'Architettura, nel qual si figurano alcune notabili antiquità di Roma, Roma, 1558; Antoine Desgodez, Les édifices antiques de Rome dessinés et mesurés, Paris, 1682; August Rode, Vitruvius, Dessau; Sebstiano Serlio, Tutte l'opere d'Architettura
Estos libros y colecciones de láminas [...] resultaban especialmente valiosos, cuando se los podía ver en buenas reproducciones, pues nos ponían ante los ojos aquel tiempo remoto en que la antigüedad era mirada con severidad y respeto y estampados sus vestigios con sólido carácter [pudiendo] advertir con toda claridad las transformaciones que introdujeron los dos siglos siguientes y reconstituir, pese a importantes obstáculos, lo destruido y suplir lo postergado. (V. It., III: 1333)

A principios de 1797, cuando Goethe hacía más de un año que había definitivamente abandonado inacabado su trabajo sobre el Baukunst, recibió una carta del médico de Jena Schleusner pidiéndole recomendación de los libros que deberían formar una biblioteca de arquitectura. En una larga contestación fechada el 22.02.1797 Goethe le ofrece una extensa lista de libros "que nos ponga en contacto con la historia de la arquitectura". ${ }^{280}$ Esta relación se podría considerar la síntesis de los textos más relevantes sobre la arquitectura para Goethe en ese momento, esto es, en el contexto de la cancelación del proyecto de redacción del Baukunst y sus intensas conversaciones con Schiller que desembocarán en 1799 en, una vez más, un intento frustrado de sistematización de su visión sobre la arquitectura y el resto de artes (Über den Dilettantismus).

Junto con la consulta de los tratados y estampas, el pensamiento estético y arquitectónico de Goethe quedó marcado desde su juventud por la lectura de determinados autores de la generación anterior a los que, sin llegar a conocerlos personalmente, se sentía vinculado. Especialmente Kant, Lessing y Winckelmann, ${ }^{281}$ aunque menciona a otros como Sulzer o Mengs. ${ }^{282}$
A Kant lo consideraba el filósofo más importante de la cultura alemana de la época (Eck., III: 129). Comparte su concepto del genio y la idea del arte como libre, autónomo y desinteresado y, en consecuencia, el papel singular que tiene la arquitectura entre las artes, en la medida que está sujeta a un fin propio, la utilidad, ajeno a la imitación de formas naturales. ${ }^{283}$ La conveniencia del edificio a sus demandas sociales y culturales, como condición previa para que la arquitectura pueda alcanzar la categoría de arte, es una idea que, procedente de la cultura francesa, asumió Goethe siguiendo en esta cuestión a Kant y reflejándola en el Baukunst. Muchas otras sugerencias de la Critica del Juicio se pueden encontrar dispersas entre las reflexiones estéticas de Goethe incidiendo en el enunciado de su teoría arquitectónica. ${ }^{284}$ Durante su estancia en Leipzig Goethe evitó encontrarse con Lessing ${ }^{285}$ por el que sentía una gran admiración. En el Baukunst, sin embargo, se aleja de la tesis defendida en el Laocoonte sobre la separación entre las artes del espacio y las del tiempo, y sostiene que, en el disfrute de la arquitectura, considerada como un arte del espacio, las sensaciones recibidas a lo largo del recorrido que consume tiempo, forman parte esencial de la vivencia. ${ }^{286}$

Pero fueron las ideas de Johann Joachim Winckelmann las que marcaron de un modo especial la interpretación de Goethe del clasicismo y su entusiasmo por el arte y la arquitectura griegos. ${ }^{287}$ Siendo estudiante fue Adam Friedrich Oeser, director de la Academia de Leipzig, quien introdujo a Goethe en el pensamiento de Winckelmann y le dejó sus obras. En Roma, el 1.12.1786, compró "la Historia del Arte de Winckelmann traducida por 
Fea" (V. It., III: 1134) que acababa de publicarse en italiano y que utilizó como provechosa guía en sus visitas. Unos días después el 13.12.1786 comenta: “Esta mañana cayeron en mis manos las cartas de Winckelmann, escritas desde Italia" (V. It., III: 1135) que habían sido publicadas en Dresde (1777-1780). ${ }^{288}$

El contenido del Baukunst de Goethe es, en gran medida, deudor del escrito de Winckelmann Anmerkungen über die Baukunst der Alten, 1762 [Observaciones sobre la arquitectura de los antiguos]. Sin embargo, años después, el 26.2.1827 refiriéndose a Winckelmann y comparándolo con Meyer dice:

Más de una vez se le ve andar a tientas; solo que sus tanteos siempre conducen a algo. [...] Leyéndolo no aprendemos nada pero ganamos mucho. Meyer ha ido más allá y ha elevado a la cumbre los conocimientos artísticos. Su historia del arte es una obra de un valor eterno. (Eck., III: 126) ${ }^{289}$

Parece que él mismo está proyectando en Meyer su propio afán por retomar y superar a Winckelmann siguiendo su ejemplo: "Desde su tumba nos corrobora el soplo de su fuerza y despierta en nuestras almas el vivísimo impulso de continuar sin descanso, con fervor y amor, lo que él iniciara" (W., III, 1030). Ambos, Goethe y Meyer, eran íntimos amigos, se sentían herederos de Winckelmann, y estaban convencidos que eran ellos quienes podían seguir desarrollando las ideas del maestro, incluso superarle, para llevarlas a un estadio más elevado y definitivo. Es posible interpretar así el intento de Goethe por establecer una teoría arquitectónica en el Baukunst a partir de las propuestas de Winckelmann, como había ocurrido, en opinión de e prospetion, Venecia, 1619; Andrea Palladio, I quattro libri dell'Architettura, Venecia, 1570; Vincenzo Scamozzi, L'idea dell'architettura universale, Venecia, 1615 (edic. alemana: 1665); Leo Battista Alberti, De re aedificatoria, Paris, 1512; Jacopo Barozzi da Vignola, Regola delli cinque ordini d'architettura, Roma, 1562; Weinlich, Briefe über Rom, Dresde, 1782/1784; François Blondel, Cours d'Architecture, Paris, 1675; Abbé Laugier, Anmerkungen über die Baukunst, Leipzig, 1768.

281. El día 12.05.1825 le decía Goethe a Eckermann: “Para mí por ejemplo fue de gran importancia el que Lessing, Winckelmann y Kant fuesen de más edad que yo, e influyesen en mí; los dos primeros en mi juventud, y el último en mi edad madura." (Eck., III: 86). Y comenta: "Goethe confiesa agradecido lo que les debe a Lessing, Winckelmann, Kant y Schiller, los hermanos Humboldt y los Schlegel" (Eck., III: 339)

282. De Johann Georg Sulzer, en concreto de su Allgemeine Theorie der schönen Wissenschaften und Künste [Teoría general de las ciencias y las bellas artes] (1771-74) el 15.11.1786 escribe: "no podemos estar enteramente de acuerdo con esta obra" (V. It., III: 1127). En 1772 del libro Gedanken über den Ursprung der Wissenschaften und schönen Künste [Las bellas artes en su origen, su verdadera naturaleza y su mejor aplicación] (1762) había hecho una reseña crítica titulada Recesión de las Bellas Artes de Sulzer (Salmerón, 1999: 43-49). También cita: "la nueva edición de las obras de Mengs, libro que ahora me resulta infinitamente interesante, pues poseo el sentido plástico que por fuerza ha de preceder a su lectura, si se aspira a entender debidamente siquiera un renglón. [...] También sus Fragmentos sobre la belleza que algunos encuentran tan oscuros, déboles yo felices esclarecimientos." (V. It., III, 1389-1390). 283. Kant escribe en la Critica del Juicio que la arquitectura: "es el arte de exponer conceptos de cosas que sólo por el arte son posibles, y cuya forma tiene como fundamento de determinación, no la naturaleza, sino un fin arbitrario" y en ella: "un cierto uso del objeto, del arte es lo principal, y a él, como condición, subordínanse las ideas estéticas [...] lo esencial de un edificio lo constituye la acomodación del producto para un cierto uso" (2007: §51).

284. Por ejemplo: las diferencias entre adorno y ornato (Kant, 2007: §14), el concepto de la plástica (que incluye la arquitectura y la escultura frente a la pintura) que expresa las ideas en la intuición sensible mediante la verdad sensible de figuras en el espacio cognoscibles por la vista y el tacto (2007: §51), etc

285. Por "momentánea majadería" (III, 620) Goethe rehuyó encontrarse con Lessing en Leipzig en 1768 lamentándose de no tener ninguna otra ocasión de tratarlo directamente. 286. Lessing escribe: "la pintura, para imitar la realidad, se sirve de medios o signos completamente distintos de aquéllos de los que se sirve la poesía -a saber, aquélla, de figuras y colores distribuidos en el espacio; ésta, de sonidos articulados que van sucediéndose a lo largo del tiempo" (1990: 107).

287. Tampoco pudo conocer en persona Winckelmann. Escribe que durante su estancia en Leipzig mientras esperaban entusiasmados su visita "como un rayo en un despejado cielo, vino a caer entre nosotros la noticia de la muerte de Winckelmann" (III: 621).

288. En 1805 promovió una publicación en homenaje suyo titulada Winckelmann y su siglo donde dice que en él "la verdad, exactitud, probidad y honradez eran la base de todo su ser" (W., III, 1026).

289. Se trata de: Geschichte der bildenden Künste bei den Griechen. El 28.11.1823 Eckermann escribe: "Goethe parece muy agradablemente entretenido con la lectura de la Historia del Arte, de Meyer, que acaba de ver la luz" (Eck., III: 274). 
290. Winckelmann en la conclusión de sus observaciones de los templos de Agrigento escribe: "queda abierto a otro el camino para que deduzca observaciones y reglas generales sobre el arte arquitectónico de los antiguos."

(1764: 573). Es como si tanto Goethe como Meyer hubieran asumido como algo personal este reto.
Goethe, con la publicación de Meyer sobre la historia del arte. ${ }^{290}$

\section{Escritores, arquitectos}

Refiriéndose a Winckelmann escribe Goethe:

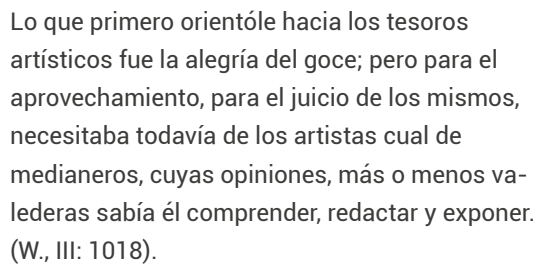

Eso significaba para Goethe que la percepción directa de las obras y el aprendizaje, a través de los libros, quedaban incompletos sin el intercambio mediador, directo y enriquecedor de las conversaciones, la correspondencia y las pláticas con artistas y entendidos que le permitían contrastar sus ideas y opiniones. La imposibilidad de debatir con los autores de los escritos y tratados era necesario compensarla y potenciarla con la charla viva y espontánea con especialistas y estudiosos contemporáneos. Así pues, a la par que las lecturas de los textos, el trato con artistas, arquitectos, historiadores, arqueólogos y especialistas completaron su cultura en el ámbito arquitectónico. Goethe fomentaba esos diálogos y buscaba la compañía de los que compartían con él su interés por el arte y la antigüedad. De estas enseñanzas comenta: "Gustan los artistas de ilustrarme, pues comprendo pronto las cosas." (V. It., III: 1152).

El arqueólogo Aloys Hirt le sirvió de cicerone en las visitas a las ruinas de Roma. Goethe consideraba la arqueología como unos estudios que tratan "de lo mejor que el mundo ha producido [y, en consecuencia] alcanzan sus conocimientos tal plenitud, tal seguridad en sus juicios y tal consistencia en su gusto, que dentro de su propia esfera parecen tan formados como para mover a admiración y aún a maravilla." (W., III: 1026). Y hablando de Hirt dice:

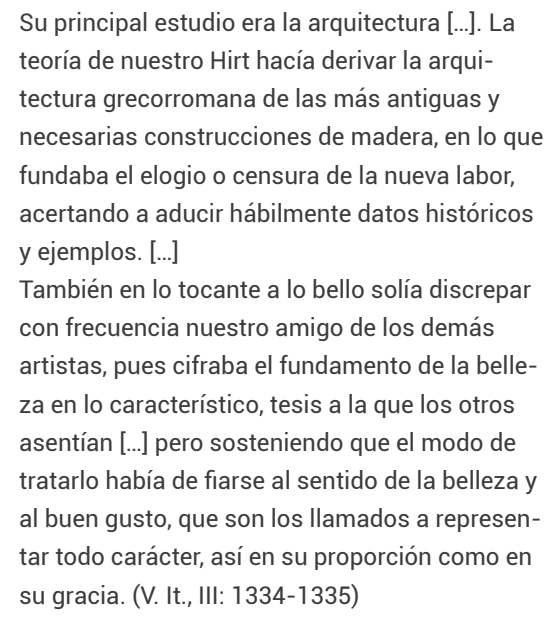

La tesis del origen de la arquitectura en las construcciones en madera, habitual en aquella época que el propio Winckelmann repite (1762: 540), la recogió Goethe en el Baukunst. Incluso estando en Italia copió un dibujo (III: 94, 10.10.1786: Transformación de entablamento dórico de madera a piedra) del Vitruvio de Galiani (tavola IV, fig. 3) representando ese paso de la arquitectura de madera a la de piedra queriendo demostrarlo visualmente.

Aunque en 1817 Goethe decía que con Hirt "nunca lograra coincidir respecto a los principios" (D. y a., IV: 189), sin embargo, algunas ideas, expuestas en la anterior cita son relevantes en la teoría del Baukunst. En concreto, el concepto del carácter y su relación con la proporción. En 1809 Goethe menciona su interés por Hirt y parece recordar su, ya entonces, abandonado trabajo y el 
estímulo que supuso el arqueólogo para su propia iniciativa. Escribe:

\footnotetext{
La obra de Hirt sobre arquitectura requirió nuevamente nuestra atención e interés en esa rama de conocimientos obligándonos luego su autor a retrotraernos a los tiempos antiguos con las restauraciones del templo de Diana en Éfeso y del de Salomón. A la historia y la contemplación de las ruinas viose obligada a unirse la imaginación; interesámonos vivamente en todo aquello y nos sentimos movidos a acometer ensayos semejantes. (D. y a., IV: 151) (291 $^{2}$
}

Durante su estancia en Roma mantenía reuniones y charlas sobre arte con Karl Philipp Moritz. Escribe: "Moritz estudia ahora las antigüedades y piensa humanizarlas y limpiarlas de toda la polilla libresca y polvo escolar para uso de los jóvenes y de cuantos piensan. Tiene una manera muy feliz y muy justa de ver las cosas" (V. It., III: 1295). Goethe mismo reconoció esta dependencia al incluir posteriormente un texto de Moritz en su relato del viaje, y las ideas procedentes de sus encuentros quedaron incorporadas a su pensamiento estético. Posteriormente, en 1820 escribía: "Del arte y de sus requisitos teóricos hablara yo mucho en Roma con Moritz; y todavía anda por ahí un pequeño impreso que atestigua de nuestra fructífera oscuridad de aquella época." (Part. Auto., III: 891).

También en Roma había conocido a Johann Heinrich Meyer entablando con él una profunda y duradera amistad. Refiriéndose a sus primeros encuentros escribe el día 15.12.1787: "Seguía él tranquilamente el camino abierto por Winckelmann y Mengs" y añade: "Él ha sido el primero en abrirme los ojos para el detalle y las peculiaridades de las formas aisladas e iniciádome en el verdade- ro oficio" (V. It., III: 1338). En la publicación de los Viajes italianos intercaló párrafos de un artículo suyo (V. It., III: 1333-1334). Desde 1795 Meyer era profesor en Weimar y Consejero Áulico en el Instituto de esta ciudad, teniendo una importante influencia sobre Goethe en cuya casa estuvo viviendo un tiempo. Junto con Schiller fueron sus dos principales interlocutores en esa época, con quienes contrastaba sus opiniones sobre arte y arquitectura, colaborando con ellos en trabajos y publicaciones. ${ }^{292}$ Dejando constancia de este vínculo en 1811 comenta: “Meyer laboraba sin descanso en la Historia del arte, y las investigaciones a que ello le obligaba dábanos abundante materia para instructivas pláticas" (D. y a., IV: 157).

En los temas de historia del arte y la arquitectura Meyer era, en cierta medida, el alter ego de Goethe, su amigo y su interlocutor, con el que compartía los criterios y valores, teniéndolo como "asesor artístico" (Safranski, 2015: 401). En 1810 Goethe lo recordaba: "Un amigo, Enrique Meyer, a quien ya en Roma debiera más de una enseñanza, no dejó, a su regreso de allá, de colaborar conmigo en la consecución de la finalidad adoptada, que a él también le interesaba vivamente." (Part. Auto., III: 959). Y, refiriéndose a la obra de Meyer sobre la "historia del colorido", comenta que la divide en dos partes: "la antigua, que puede llamarse hipotética, porque sin ejemplos bastantes tenía que inferirse antes de la naturaleza del hombre y del arte que de la experiencia, y la moderna, que se basa en documentos que todo el mundo puede examinar y juzgar" (Part. Auto., III: 959). La hipótesis de Meyer basando la historia de la pintura antigua en la naturaleza del hombre, debido a la carencia de suficiente información, parece
291. Ese mismo año 1809 Hirt había publicado Die Baukunst nach den Grundsätzen der Alten, que Goethe tenía en su biblioteca y sobre el que versa este comentario. 292. En 1797 programaron juntos un viaje a Italia, que finalmente sólo realizó Meyer, y pensaron en redactar conjuntamente una obra sobre la cultura italiana (Safranski, 391). Eckermann relata que durante los años 1820, se reunían frecuentemente Meyer y el arquitecto Coudray con Goethe en su casa (Eck., III: 191, 269 y 273). 
293. "Sie können wohl denken, daß ich ihn bei dieser Idee, die so sehr mit unsern ästhetischen Begriffen zusammenstimmt, festgehalten", Goethe: DKV 1998, II.4 (31), p. 128

294. Louis François Cassas, Voyage pittoresque de la Syrie, de la Phénicie, de la Palestine, et de la Basse Egypte (1799-1800).

295. Winckelmann cita las obras de Le Roy (1759) sobre los templos griegos, de Stuart y Revett sobre las ruinas griegas (1750), de Dawkins y Bovery sobre Palmira completada y publicada posteriormente junto con Wood y refiriéndose a la obra inacabada de Norden sobre las ruinas egipcias concluye: "Una obra análoga sobre los edificios de Tebas y de otros lugares de Egipto es la que nos hacía falta." (1985: 269). Goethe comenta que Winckelmann "Soñaba con un viaje a Egipto" (III: 1014) un referente directo al planteamiento de Goethe en el Baukunst sobre la arquitectura griega primitiva de la que apenas conocía por experiencia los restos de Paestum y Sicilia.

Schiller, a quien Goethe admiraba profundamente y con quien compartía sus ideas y proyectos, era el otro interlocutor que le servía para verificar su teoría arquitectónica. Una confianza que era correspondida. En una carta de Schiller a Wilhelm von Humboldt (5/9.11.1795), tras exponer las principales cuestiones desarrolladas por Goethe en el Baukunst concluye: "Como podrá imaginarse, le he apoyado en esta idea, tan cercana a nuestros conceptos estéticos". ${ }^{293}$

El contrapunto a los debates teóricos con escritores e historiadores eran las aportaciones de arquitectos profesionales sobre aspectos específicos de la práctica que le ilustraban en cuestiones disciplinares. En su viaje a Italia aprendió perspectiva con Maximilian von Verschaffelt y se refiere con cierta admiración a Louis François Cassas. Resulta llamativo el entusiasmo con el que habla de los dibujos que Cassas había hecho en su viaje por Palmira y Egipto, y que publicó posteriormente. ${ }^{294}$ En septiembre de 1787 escribe:

Un arquitecto francés llamado Cassas, acaba de regresar de su viaje a Oriente; allí midió los más principales de los monumentos antiguos, sobre todo los aún no editados, así como también dibujó las regiones que allí son de ver, restaurando gráficamente antiguos pasajes derruidos y destrozados, y presentando parte de sus dibujos, de gran precisión y gusto, trazados a punta de pluma y animados con colores a la aguada. (V. It., III: 1307)

Y añade: "Las cosas de Cassas son extraordinariamente bellas." (V. It., III: 1305), concluyendo: “Dibujando y pintando con el mismo buen gusto de Cassas, habría suscitado dondequiera entusiasmo." (V. It., III: 1308). Winckelmann se había lamentado que no existiesen buenas representaciones de las ruinas de Egipto comparables a las que ya se conocían de las antigüedades griegas ${ }^{295}$ y es posible que el comentario de Goethe estuviera en parte motivado por considerar que el trabajo de Cassas venía a completar esta carencia.

Durante su visita a Italia Goethe conoció también en Roma al arquitecto de Hamburgo Johann August Arens a quien, posteriormente, Ilamó para trabajar en el palacio de Weimar y en la construcción de la Römische Haus cuando él era el director de la comisión responsable de las obras oficiales. En ambos trabajos, que coincidieron con la redacción del Baukunst, Goethe participó de una manera activa. Así, pues, las obras en las que se veía implicado eran un referente fundamental donde Goethe podía, en cierto sentido, contrastar con los arquitectos los problemas de ejecución y ensayar las ideas sobre la teoría arquitectónica que estaba elaborando.

\section{Proyectos, obras}

Más allá del interés de Goethe por la teoría y el arte de la arquitectura, desde su juventud estaba interesado por las cuestiones constructivas y distributivas de los edificios, especialmente las casas. Refiriéndose a esa etapa y hablando de la vivienda que su padre había reformado en Frankfurt escribe: "Así, por ejemplo, habíame yo formado una idea general de la arquitectura, instalación y ornato de las casas" (III, 636). En sus escritos 
biográficos, al describir la visita a la casa de su amiga Federica en Sessenheim, comenta con satisfacción el levantamiento y proyecto para la reforma de la casa que le propuso a su padre:

entreguéle el boceto, lo que le alegró mucho; consulté con él lo que al hacer aquel trabajo se me había ocurrido, y el hombre no cabía en sí de puro contento, elogiando, sobre todo, lo primoroso del dibujo, pues se ha de hacer cuenta que yo había ejercido mucho el lápiz desde chico, y aquella vez me había esmerado de un modo especial (III: 694)

Sin embargo, estas fueron sólo aproximaciones circunstanciales sin continuidad. Fue tras su llegada a Weimar donde esta vocación se consolidó.

Se pueden diferenciar en dos grandes apartados las obras en las que se vio inmerso Goethe los años posteriores a su regreso de Italia, coincidiendo con su empuje por definir las bases de la arquitectura. Por un lado, los trabajos oficiales que, como responsable, estaban bajo su dirección. Y, por el otro, algunas iniciativas que emprendió para la reforma de su casa en la ciudad. En el primer caso no sólo tenía bajo su mando a los arquitectos y técnicos que proyectaban y ejecutaban las obras sino que, él mismo, se implicó en cuestiones proyectuales. En el segundo, actuó como un verdadero arquitecto proyectando y dirigiendo las obras. La realización de estos proyectos, coincidiendo con las fechas de la elaboración del Baukunst, significaban un elemento comparativo para su teoría arquitectónica dado que, para él, la teoría y la práctica del arte son inseparables.

El palacio de Weimar sufrió un importante incendio el 6.5.1774. Desde 1777 la Comisión para la Reconstrucción del Palacio estaba bajo la dirección de Goethe. En 1789 Llamó a Johann August Arens (1757-1806) que había conocido en Roma, quien entre 1789-1792 trabajó en el proyecto diseñando los planos generales y la Falkengallerie, sucediéndole el arquitecto Steiner. Sobre estas intervenciones Goethe decía en 1795:

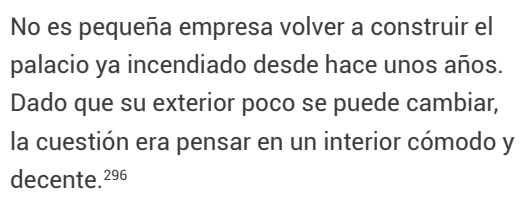

Entre los años 1798 y 1800 el responsable fue Nikolaus Freidrich von Thouret (1767-1845), arquitecto de Stuttgart. Pero las obras cogieron nuevo impulso a partir de 1800 bajo la dirección del arquitecto Heinrich Gentz (1766-1811) quien proyectó la escalera imperial que conduce a la puerta del parque del IIm. En 1803 Goethe escribe:

$$
\begin{aligned}
& \text { La reedificación del palacio de Weimar, que } \\
& \text { durante largos años llevárase despacio y que } \\
& \text { luego recibió más impulso, hizo que afluyeran } \\
& \text { allá arquitectos de talento, y sucedió lo que } \\
& \text { siempre ha ocurrido y ocurrirá: que en viendo } \\
& \text { edificar entran ganas de hacerlo (D. y a., IV: 69). }
\end{aligned}
$$

Hay, pues, una confirmación de que, durante esos años, Goethe experimentó un impulso en su vocación por la arquitectura como reflejo de su responsabilidad en la gestión de las obras y que se reflejó en la redacción del Baukunst.

La implicación de Goethe en todas estas intervenciones no se redujo sólo a su papel como director de la comisión, sino que se extendía, también, a los aspectos de diseño. Refiriéndose a estos trabajos le dijo a Eckermann el 12.02.1829:
296. „Es ist kein geringes Unternehmen, das vor mehrern Jahren abgebrannte Schloß wieder herzustellen. Da an seinem Äußern wenig verändert werden kann, so war es der Sache gemäß, auf eine innere bequeme und anständige Einteilung zu denken." Über die verschiedenen Zweige der hiesigen Tätigkeit [Acerca de las diversas ramas de las actividades locales] (DKV I.18, 389). Se trata de un extracto de la conferencia para la Weimarer Freitagsgesellschaft celebrada en la segunda mitad de noviembre de 1795. 
297. En un dibujo (I, 265 ¿1783?) aparece en un lateral una imagen parcial del Schloss terminado cuando aún se encontraba en ruinas por lo que parece una idea del edificio tal como la imaginaba Goethe.

298. IVb: 121, 1792-1800:

Planta general de parcelas en torno a un patio y alzado parcial; IVb: 121 rev., 1792-1800: Planta general de dos pabellones en torno a un patio $y$ alzado con muro y puerta de cerramiento; IVb: 123, hacia 1800: Planta esquemática general de pabellones en torno al patio.

299. IVb: 116, hacia 1795: Portón y cancelas clásicas en el muro del patio; IVb: 117, hacia 1795: Puerta del muro de cerramiento; IVb:

124, hacia 1800: Esquema en planta y muro de cerramiento del patio con portón. 300. IVb: 122, hacia 1800: Planta parcial y esquema de fachada.

Fig. 11: Johann W. Goethe, Grundisse und Aufrisse [Planta y alzado], hacia 1800 (205x347 mm. Lápiz, pluma con sepia). En Femmel [1958] 1972, IVb: 121

Fig. 12: Johann W. Goethe, Gartenarchitektur [Arquitectura de jardín], hacia 1795 (114x191 mm. Lápiz, tinta con pluma) en Femmel [1958] 1972, IVb: 116

Fig. 13: Johann W. Goethe Torbau [Construcción de acceso], hacia 1800 (205×347 mm. Lápiz, tinta con pluma)
Italia me dio una idea verdadera de lo severo y lo grandioso, aunque no una habilidad concreta. Lo que más contribuyó a mis progresos en ese sentido fue la edificación del palacio de Weimar, pues me vi precisado a colaborar en esa obra, y se dio más de una vez el caso de tener que dibujar una cornisa. Y diz [sic] que hasta cierto punto aventajaba a los del oficio, pues los ganaba en inventiva. (III: 162) ${ }^{297}$

Algo que se evidencia por la cantidad de apuntes sobre estas cuestiones que realizó en esos años. Hay distintos dibujos que van desde aspectos urbanos como las parcelaciones, edificios afectados y ordenación general de pabellones en torno a una explanada, ${ }^{298}$ al diseño del portón y el muro de acceso al patio central de armas, ${ }^{299}$ pasando por distintos esquemas de fachada ${ }^{300} \mathrm{y}$ por imágenes de la escalera imperial. (Figs. 11, 12 y 13)

La otra iniciativa cortesana realizada en los mismos años cuando trabajaba en el Baukunst fue la construcción en el parque del IIm de la llamada Römische Haus [Casa romana] construida por Arens (1792-1797). ${ }^{301}$ En 1795 se tenía que reformar la parte posterior del edificio por problemas de grietas debidas al deslizamiento en la pendiente del terreno y Goethe dibujó diferentes alternativas para la esa fachada, ${ }^{302}$ realizó distintos alzados de pabellón de jardín relacionados con este tipo de casa de recreo ${ }^{303}$ y dibujó una planta general de situación con los parterres del entorno. ${ }^{304}$ (Fig. 14)

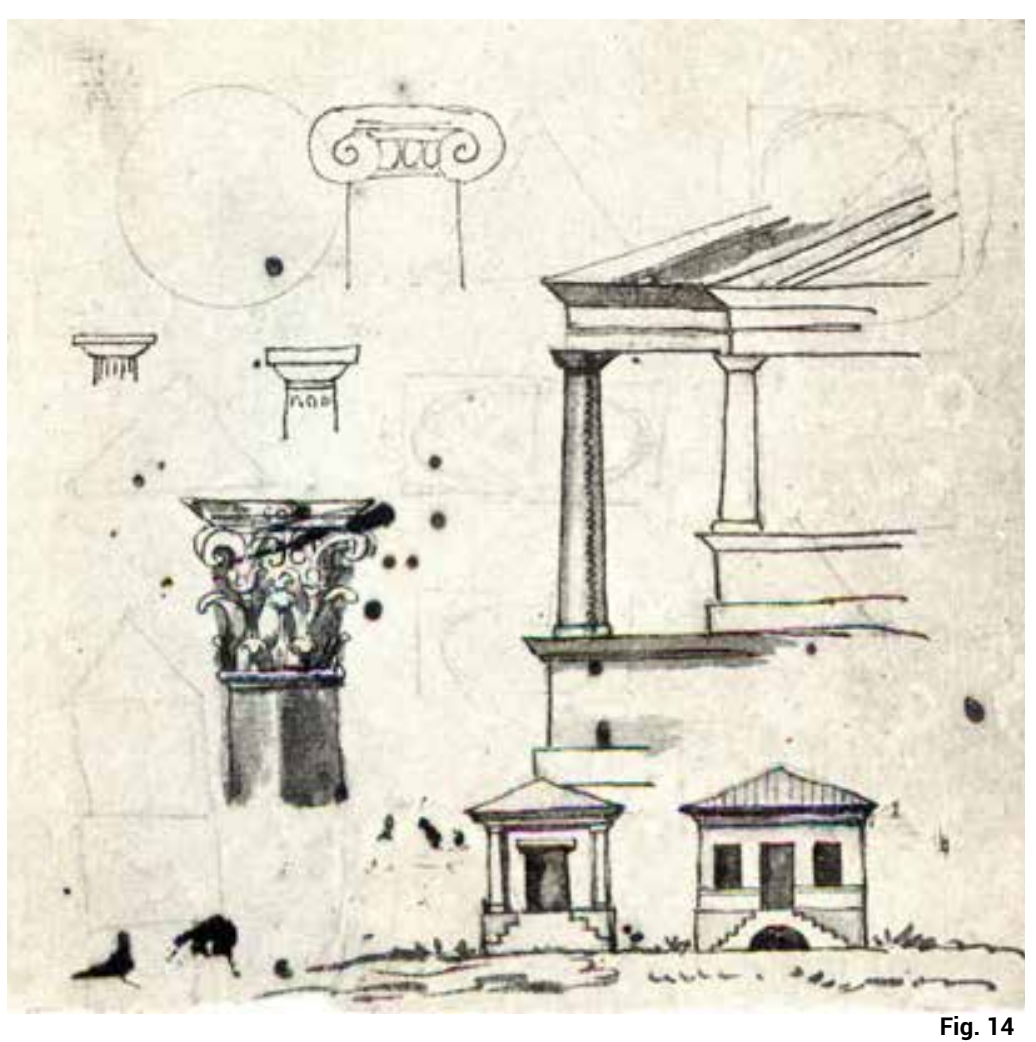




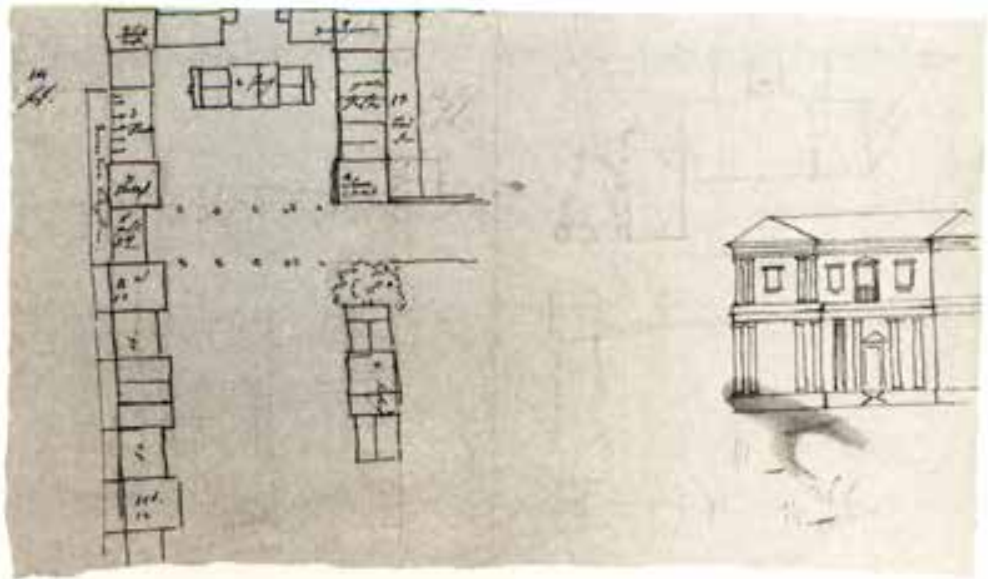

Fig. 11

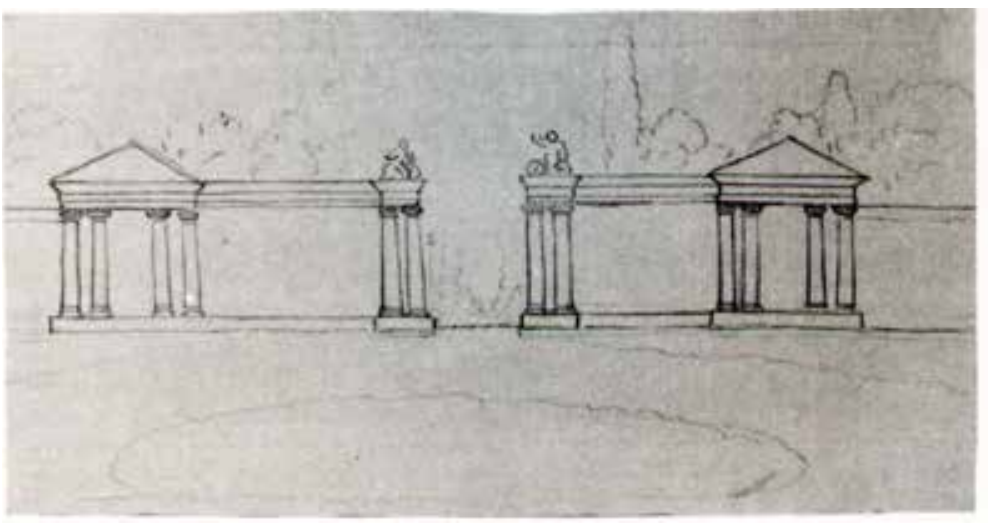

Fig. 12

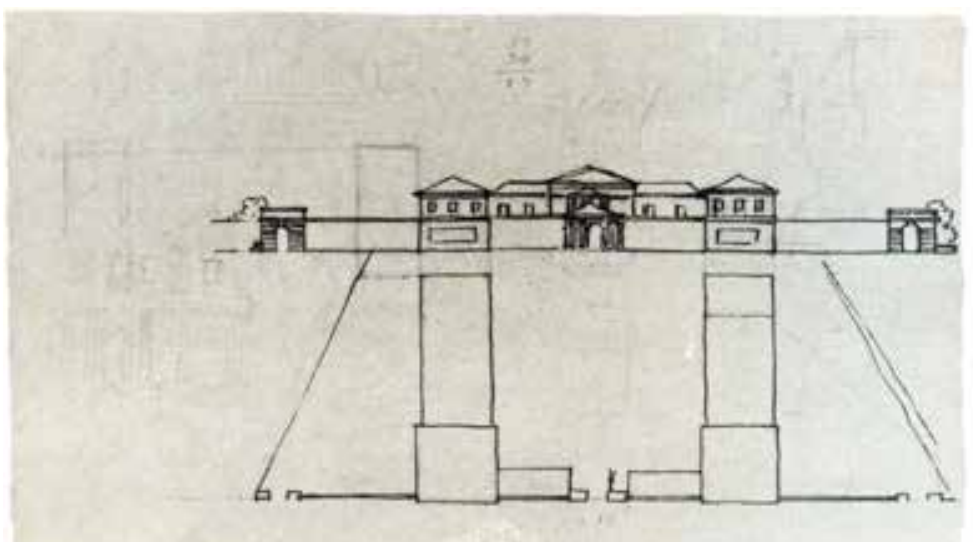

en Femmel [1958] 1972, IVb:

$121 \mathrm{rs}$.

301. Arens había dibujado un plano para una Casa de Campo (1788) que pudo ser un referente para esta obra. 302. IVb: 97, 1792-1795: Dos estudios de la fachada trasera y tres alternativas de la pieza posterior de la planta. Parece que también se le pidió consejo al arquitecto Gilly durante su visita a Weimar. 303. IVb: 112, hacia 1795 : Fachadas de pabellones de jardín y capitel dórico; IVb: 113, hacia 1795: Alzado de un pabellón de jardín; IVb: 114, hacia 1795: Alzado de un pabellón de jardín; IVb: 115, 1791/1795: Alzado de un pabellón de jardín y un portal. 304. Vla: 151, 1793: Jardín y planta de la Römische Haus. Fig. 14: Johann W. Goethe, Zwei Fassaden von Gartenpavillons, Kapitelle [Dos fachadas de pabellón de jardín, capiteles], hacia 1795 (139x136 mm. Lápiz, tinta con pluma, lavado a tinta), en Femmel [1958] 1972, IVb: 112 
305. 1797: boceto de proyecto para el teatro de Lauchstädt (Ewald, 1999, fig 60.1); IVb: 251, ¿después de 1793?: Perspectiva teatral (a partir de Piranesi).

Fig. 15: Johann W. Goethe, Theaterprospekt [Perspectiva teatral], ¿después de 1793? (240x267 mm. Lápiz, pluma con sepia), en Femmel [1958] 1972 IVb: 251
Una tercera conexión con la arquitectura oficial fue su responsabilidad al frente del teatro de Weimar desde su llegada a la ciudad hasta 1817. Coincidiendo con la última década del siglo XVIII y en relación con las obras y proyectos teatrales, Goethe intervino (con Friedrich Beuther) en las mejoras funcionales y estéticas del teatro de Weimar proyectadas por Thouret (1798-1800) (D. y a., IV: 69), y obtuvo de Friedrich Gilly durante su estancia en Weimar un croquis para su reforma (28.08.1798) (Ewald ,1999, fig. 58). En Lauchstädt, residencia estival de la corte desde 1793, alentó la construcción de un nuevo teatro cuyo proyecto inicial (del arquitecto Steiner, 1797) fue revisado posteriormente en 1801 por los arquitectos Gentz y Martin Friedrich Rabe (1765-1856) (Diarios, IV, 69), siendo el responsable de las obras el propio Goethe (1802-1803). También de estas actividades existen dibujos arquitectónicos y de escenografías ${ }^{305}$ de Goethe confirmando que su dedicación no quedaba reducida a la administración de las obras ya que, como director de los montajes teatrales, participaba personalmente en cuestiones proyectuales y de diseño. (Fig. 15)

Pero su actividad arquitectónica no se reducía a sus cargos oficiales, sino que tenía también una vertiente privada: su propia vivienda. En 1792 Goethe se había trasladado a una vivienda en la ciudad de Weimar situada en la Frauenplan desde la casa del guardabosques en el parque del IIm, que le había

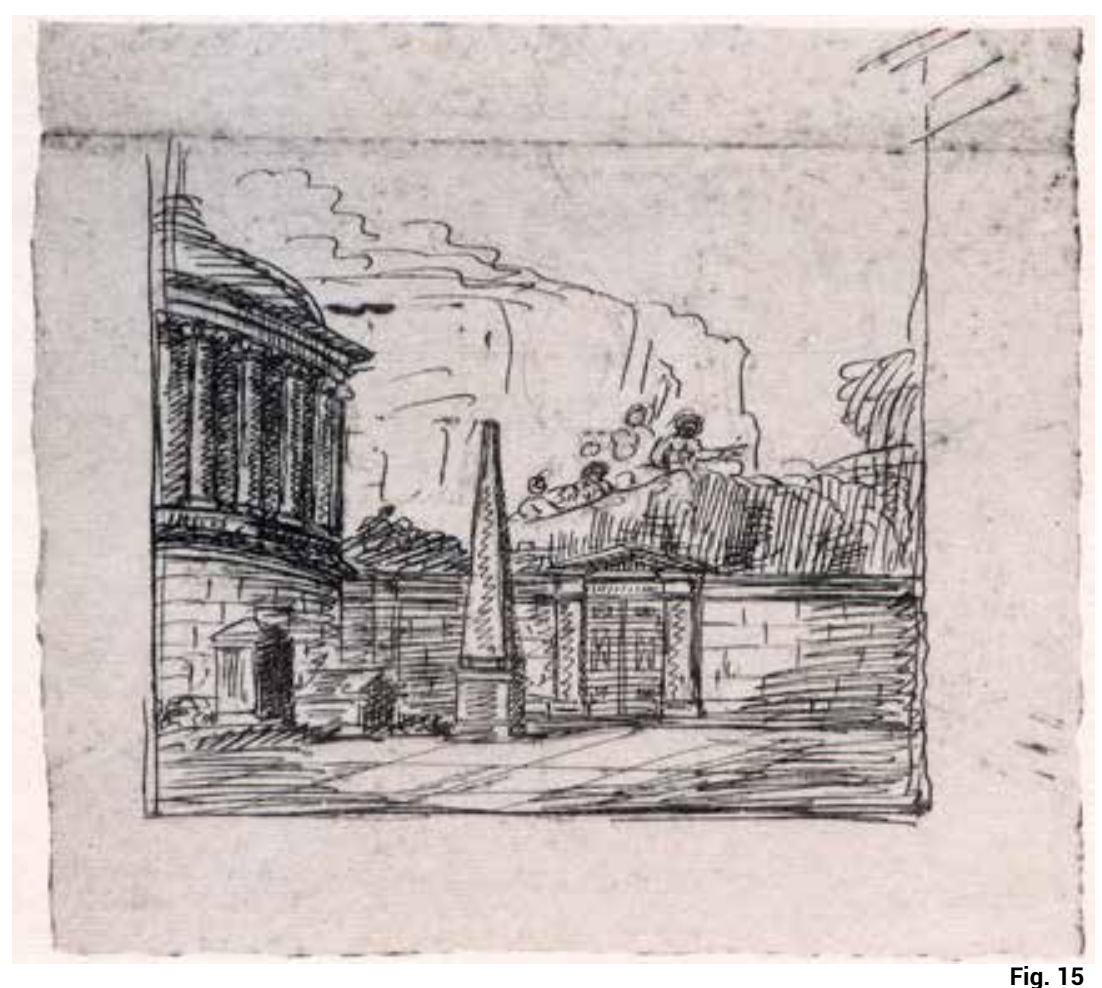


regalado el Gran Duque en abril de 1776 a los pocos meses de su llegada a la ciudad. A esta vivienda rural le adosó en su fachada este un pequeño cuerpo con terraza ahora inexistente que aparece en alguno de sus dibujos (VIb, 26: 1777?: Casa y jardín de Goethe en Weimar). Tras su viaje a Italia realizó una serie de reformas en su casa urbana instalándose definitivamente en junio de 1792 (Safranski, 2015: 613 y 615). ${ }^{306}$ Existen unos dibujos de Goethe referidos a las reformas en este edificio que nos lo muestran como autor y proyectista de las reformas de su propia casa. Son, pues, los ejemplos más paradigmáticos de la actividad de Goethe como arquitecto.

Hay un pequeño croquis de distribución en planta (IVb: 9 rev.) de un lateral del edificio y un dibujo (IVb: 91, 1795: Planta ideal de la casa de Goethe en Weimar) (Fig. 16) que contiene una planta general de la vivienda con un alzado al jardín y esquemas de secciones parciales. La fachada posterior se articula simétricamente con dos alas laterales y un pórtico central con columnas. Este elemento central lo repite en otros dibujos: un alzado completo (IVb: 92, 1795?: Fachada al
306. El plano de la casa de Goethe en la Frauenplan firmado por J. F. Steiner anterior a la reforma está fechado hacia 1792 (Ewald, 1999: 112).

Fig. 16: Johann W. Goethe, Idealgrundriß zu Goethes Wohnhaus (I. Obergeschoß) [Planta ideal de la casa de Goethe (primer piso)], posterior a $1792(215 \times 341$ mm. Lápiz, tinta a pluma), en Femmel [1958] 1972, IVb: 91

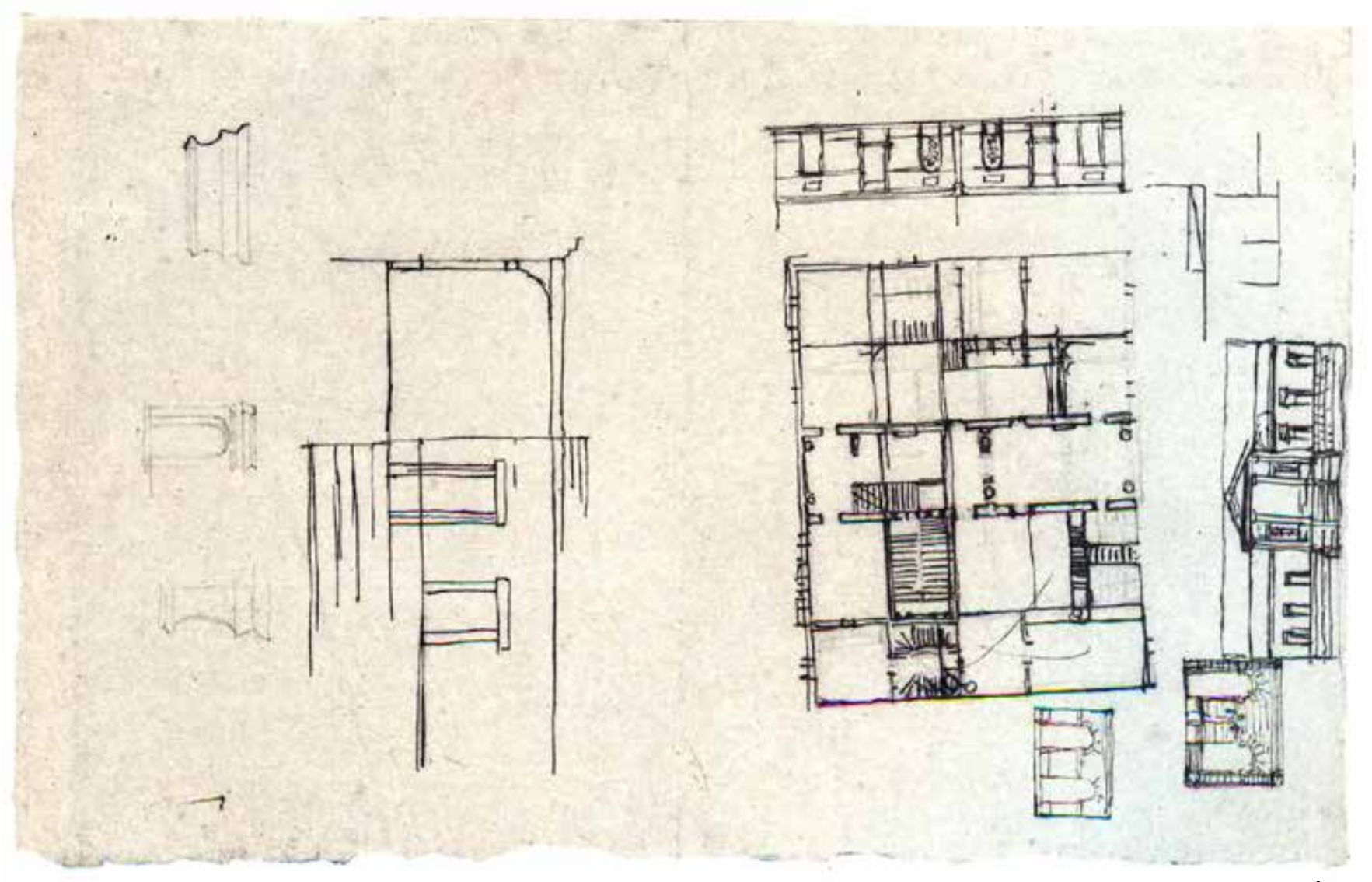


307. En la realidad el primer tramo está desplazado del cuerpo principal y es paralelo a los otros dos tal como se aprecia en el plano de K. F. Zelter (1814) (Ewald, 1999 122).

308. En la imagen hay dibujada una esvástica similar a las del dibujo IVb: 83

309. En la actualidad en este descansillo hay dos puertas iguales una que conecta con la escalera de servicio de caracol y otra que da a un pequeño gabinete en el poché entre los muros de ambas escaleras.

310. Algo que manifestó desde su juventud. Intervino también, como director, en la compleja escalera imperial del palacio de Weimar de salida al parque del IIm diseñada por Heinrich Gentz (1800) de la que se conserva un dibujo de Goethe, Vla:

163, 1801?: Perspectiva del tramo superior de la escalera imperial del palacio. Véase para más detalle Calduch y Rubio, 2018

311. Palladio había representado varias escaleras circulares y elípticas tanto con núcleo ciego como abierto (lib. I, pp. 63,63) y las escaleras circulares dobles cruzadas de Chambord (lib. I, p. 65) entre otras. Además de la del convento de la Carità (lib. II, p. 30) proyectó otras muchas tanto en modelos imaginados, como en la casa de los griegos (lib. II, p. 44) o en la basílica antigua (lib. III, p. 39), como en sus obras de jardín y detalle del zócalo de la casa de Goethe); el estudio del cuerpo central en alzado y sección (IVb: 91 rs., 1795?: Fachada y sección del cuerpo central del frente al jardín); una planta parcial del pórtico desplazando la escalera a un lateral (IVb: 92 rev., 1795?: Planta parcial de un pórtico con columnas y escalera lateral); y una sección por la escalera principal (IVb: 93, s. f. boceto arquitectónico para la reconstrucción de la casa de Goethe). Sin entrar en un análisis de estos dibujos, cabe resaltar que Goethe está barajando distintas alternativas de la fachada de salida al jardín situado a diferente cota que el pavimento interior, lo que origina un semisótano y una escalinata. Todos ellos rezuman un evidente aire palladiano tanto en la composición como en los elementos arquitectónicos utilizados y en la ornamentación interior.

En la planta general (IVb: 91) la escalera principal está formada por un primer tramo que enlaza perpendicularmente con otros dos de tramos rectos encajados entre muros y que conduce a la planta noble. ${ }^{307}$ Una solución distinta a la dibujada en el plano de Steiner (1792). De esta pieza, con fecha 7.6.1792, el mismo mes en que se había trasladado a esa vivienda, hay tres perspectivas: dos en sentido descendente desde el rellano superior (IVb: 78, Perspectiva parcial desde el rellano superior del núcleo de escalera principal de la casa de Goethe; IVb: 79 , Perspectiva desde el rellano superior del núcleo de la escalera principal de la casa de Goethe) y otra hacia arriba desde el rellano intermedio (IVb: 77, perspectiva desde el reIlano intermedio del núcleo de la escalera de la casa de Goethe). Hay también un conjunto de dibujos de ornamentos de grecas entrelazadas y esvásticas, fechados ese mismo día
7.6.1792 (IVb: 83, voluta rectilínea y esvásticas entrelazadas; IVb: 85, Cenefas de volutas rectilíneas y motivos vegetales; IVb: 89 , Malla de esvásticas entrelazadas), lo que indica claramente que están relacionados con la decoración interior de las cornisas y cenefas de los muros, tanto de ese núcleo de escalera como de otras estancias.

Antes del 6 junio de 1792 (IVb: 82, Planta de la escalera de caracol de la casa de Goethe en Weimar) ${ }^{308}$ había dibujado una escalera de planta elíptica encajada entre muros con tres descansillos que sirven a tres niveles intermedios, tal como existe en la actualidad, conectando espacios privados de la casa con la escalera principal a través de una puerta en el nivel intermedio. ${ }^{309} \mathrm{El} \mathrm{mismo}$ día vuelve a dibujar en planta, a mano alzada y delineada, esta escalera tres veces, en dos pequeñas láminas: la IVb: 81 y IVb: 80 .

Todos estos dibujos evidencian que el Goethe arquitecto estaba particularmente interesado en el diseño de escaleras. ${ }^{310}$ Sobre la del convento della Carità en Venecia de Palladio había escrito que era "la escalera de caracol más bella del mundo [...] cuán bella sea puede inferirse del hecho de que el propio Palladio la dé por buena." (V. It., III: 1082). Además de ésta Palladio dibujó en su tratado otras muchas escaleras de caracol tanto circulares como elípticas, ${ }^{311}$ algunas construidas, que Goethe pudo conocer. Y en estas obras hechas por Goethe en su propia casa hay una clara intención de emularlo.

Sin embargo, Goethe era consciente de sus limitaciones como arquitecto cuyo trabajo había ensayado con estos proyectos. Ya en sus años juveniles criticó la espaciosa escalera que había construido su padre en Frankfurt (III: 636) ${ }^{312}$ y en su vejez se lamen- 
taba de las construidas por él mismo en su vivienda. Le dice a Eckermann: "Yo, por ejemplo, traje de Italia el gusto por las grandes y bellas escaleras y por efecto de ello estropeé esta casa pues sus habitaciones resultan ahora más chicas." (Ec., III: 210).

De estas experiencias Goethe debió percatarse de que la arquitectura es la obra construida, y su práctica profesional, como él mismo escribió "requiere toda la vida". Y, siendo consecuente, sus trabajos arquitectónicos posteriores, los abordó siempre en colaboración con arquitectos profesionales con algunos de los cuales, como Clemens Wenzeslaus Coudray (1775-1845), mantuvo una intensa relación en las últimas décadas de su vida e incluso redactó, en 1825 tras el incendio de teatro de Weimar, varios proyectos para su reconstrucción.

La responsabilidad en las obras oficiales, la colaboración con los arquitectos de Weimar y sus contactos con otros además de los mencionados que también lo visitaron como Ludwig Friedrich Catel, ${ }^{313}$ Johann Jakob Friedrich Weinbrenner ${ }^{314}$ o Karl Friedrich Schinkel, ${ }^{315}$ continuó mucho después de que abandonara el borrador inacabado del Baukunst. Lo que pone en evidencia que si el intento de elaborar un texto teórico sobre la arquitectura se abortó eso no significó que la vinculación de Goethe con la arquitectura quedara interrumpida.

Es en este contexto de la actividad teórica y gráfica sobre la arquitectura y su implicación como responsable, gestor, colaborador y proyectista en diferentes trabajos de construcción donde hay que encuadrar los ensayos, artículos y manuscritos de Goethe de entre los que destaca de manera singular el texto ilustrado incompleto e inédito de 1795 Baukunst. palacios (lib. II, p. 6, 13...) y villas (lib. II, p. 52, 53...). 312. Hizo un dibujo de esta escalera: I, 56: Escalera de la casa de Goethe en Frankfurt (1768/1770).

313. En 1802, Catel le envió a Goethe su Vorschläge zur Verbesserung der Schauspielhäuser (1802).

314. Goethe recibió en 1809 su ensayo Über Theater in architectonischer Hinsicht (1809) y en 1815 visitó su Karlsruher Hoftheater (1804). En su biblioteca tenía también los libros: Bemerhungen des Baumeisters zur Kritik eines Miniatur-Mahlers über baukünstlerische Gegenstände (1817); Ideen zu einem teutschen National-Denkmal des eutscheidende Sieges bey Leipzig mit Grund- $u$. Aufressen (1814) y Über die wesentlichen Theile der Säulen-Ordenungen und die jetzige Bauart der Italiäner, Franzosen und Deutschen (1809).

315. En agosto 1820 visitó a Goethe, intercambiando ideas sobre la arquitectura teatral. En su biblioteca Goethe tenía el libro: Sammlung architectonisher Entwürfe von Schinkel, enthaltend theils Werke, welche ausgeführt sind, theils Gegenstände, deren Ausführungbeabsichtigt wurde (1821-1826). 
gevey $2 x 6$
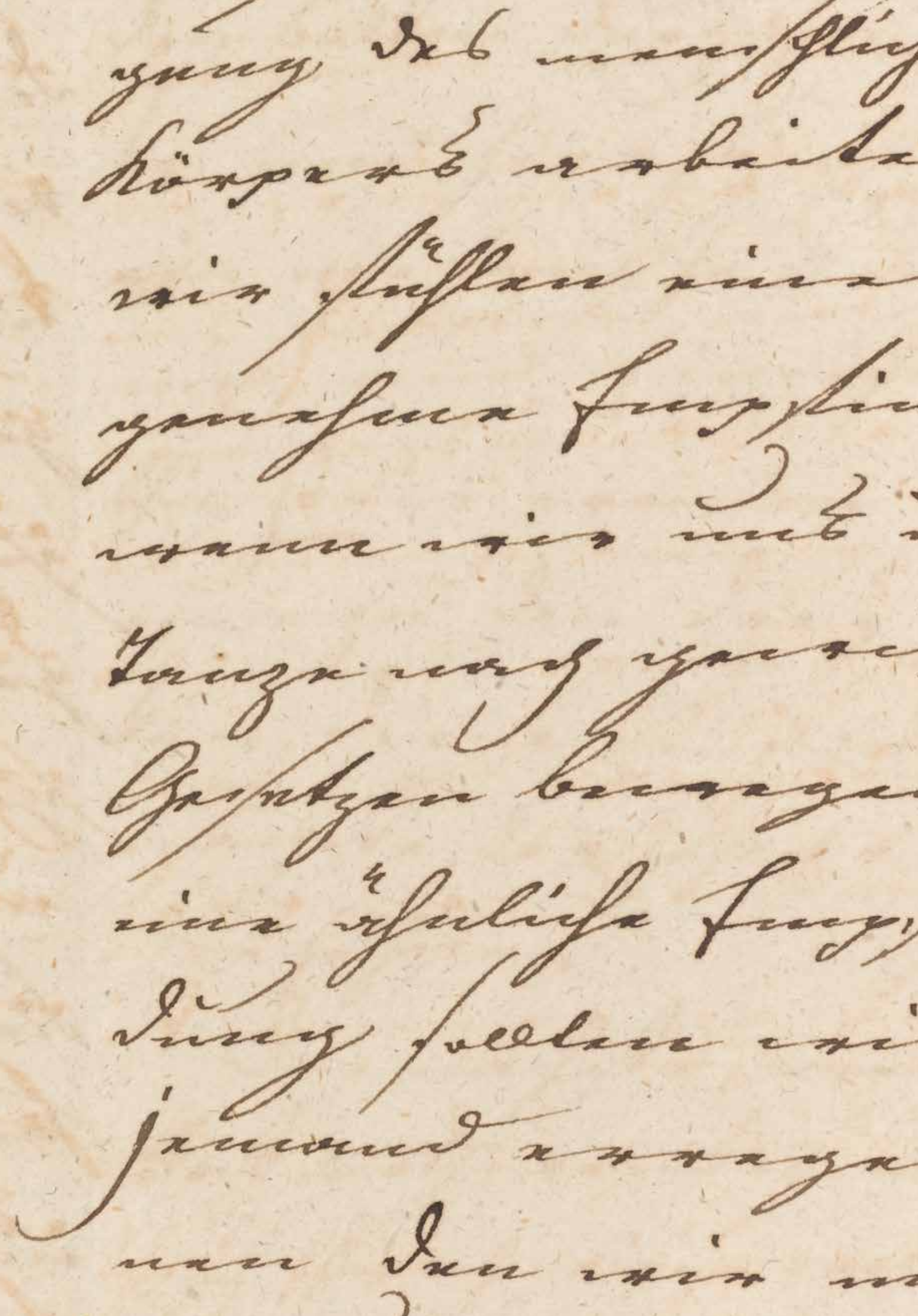


\section{Hacia una teoría de la arquitectura}

Goethe escribió en repetidas ocasiones sobre arquitectura. Publicó en vida un buen número de ensayos, reseñas y prólogos centrados en esta disciplina. ${ }^{316}$ Registró variadas referencias en poesías, diarios y cartas, cuentos y novelas, en los que la arquitectura, la ciudad o el paisajismo jugaban un papel relevante. ${ }^{317}$ En conjunto, todos estos textos constituyen un amplio corpus del que difícilmente se puede extraer un discurso unitario que los articule orgánicamente, máxime si a ellos se suman aquellos múltiples escritos en los que la arquitectura no se despliega explícitamente como una cuestión central pero cuyo contenido sí presenta claves relevantes para entender la aproximación de Goethe a la arquitectura. ${ }^{318}$ Pese a ello no han faltado los intentos de sistematizar su producción estética en general, 
316. Además de los cuatro textos pertenecientes a las series "Von deutscher Baukunst" y "Baukunst", escritos más célebres de su producción centrada en la arquitectura, conviene tener presente: Über die verschiedenen Zweige der hiesigen Tätigkeit (1795), Die zum Studium der Baukunst erforderlichen Werke (1797), Zur Geschichte der Peterskirche (1797), Eröffnung des Weimarischen Theaters (1798), Zur Kunst und Baukunst des Mittelalters (1799), Schemen über den Dilettantismus (1799), Winckelmann und sein Jahrhundert (1805) [Winckelmann y su siglo], Aus einer Reise am Rhein, Main und Neckar (1816), Herstellung des Straßburger Münsters (1817), Altdeutsche Baukunst (1817), Kölner Domriß durch Moller (1819), Kirchen, Paläste und Klöster in Italien (1821), Ansichten, Risse und einzelne Teile des Doms zu Köln (1823), Wilhelm Tischbeins Idyllen (1822) [Los idilios de Wilhelm Tischbein], Tempel zu Puzzoul (1823), Schloß Marienburg (1823), Boissereesches großes Domwerk (1824), Pentazonium Vimariense (1828), Südöstliche Ecke des Jupitertempels von Girgent (1828), Architecture moderne de la Sicile (1828), Architecture antique de la Sicile (1828), Der Oppenheimer Dom (1828), Fassaden zu Stadtund Landhäusern (1828), Die schönsten Ornamente und sin diferenciar de manera específica la arquitectura. Las más de las veces se ha tratado de dividir su producción en tres etapas, con el fin de periodizarla en fases que presuntamente mantuvieran un posicionamiento coherente. $^{319}$

En el caso de la arquitectura, por añadidura, refuerza esta predisposición hacia la sistematización el hecho de destacar por encima de toda su producción cuatro textos que se prestan cronológicamente a una periodización: Von Deutscher Baukunst (1772), Baukunst (1788), Arquitectura [Baukunst] (1795) y Von Deutscher Baukunst (1823). En la más extendida interpretación se aprecia claramente la división en función de su proximidad o alejamiento a la tradición del clasicismo centroeuropeo. Así, el primero de sus textos viene a ser situado habitualmente bajo el influjo del Sturm und Drang, los dos textos homónimos inevitablemente contextualizados en el marco de su "experiencia iniciática en el clasicismo", el conocido viaje en Italia (1786-1788), y, finalmente, el texto de vejez donde su acalorado debate sobre la arquitectura alemana de juventud es desplazado hacia el ambiguo terreno de la moderación. ${ }^{320}$

No obstante, sería equívoco identificar en la producción de Goethe, especialmente en el terreno de la estética de la arquitectura, una progresión homogénea desde sus obras de juventud hasta su vejez. En primer lugar, huelga recordar que Goethe era reacio a todo sistema totalizador, especialmente en lo tocante al arte. A diferencia de contemporáneos suyos de gran impacto en la historia de la estética, como puedan ser Kant, Schiller, Schelling o Hegel, Goethe no pretendió nunca establecer un sistema estético (Todorov, 1996: 9). En su producción, llevada a menudo al socaire de los acontecimientos y, muchas veces, de forma fragmentaria, ${ }^{321}$ puede encontrarse posicionamientos divergentes e incluso contradictorios. Su aproximación al arte era en efecto refractaria al espíritu de síntesis que predominaba en su época. Y ello se debía fundamentalmente a dos razones. En primer lugar, porque el arte para Goethe era irreductible a la teoría, tal y como paradigmáticamente enunciaba sin eludir la polémica en su correspondencia con Schiller. ${ }^{322}$ Pero, además, era una máxima aplicable a toda actividad humana para Goethe la imposibilidad de separar lo concreto de lo abstracto, el pensamiento de la acción. ${ }^{323}$ Fuente innegable de conflictos con sus contemporáneos alemanes, Goethe rehuía el impulso imperante hacia la abstracción. En el terreno del arte estaba de hecho mucho más interesado en la práctica que en la teoría, ${ }^{324}$ por más que haya que insistir aquí en el inevitable entrelazamiento de ambas.

No es por lo tanto objeto de este texto establecer una articulación de su obra en un todo orgánico, ni situar en una presunta periodización la producción de Goethe en el contexto de la estética de la arquitectura. En lo que sigue se propone abordar en su singularidad el texto Baukunst (1795), quizás el proyecto más ambicioso de Goethe en lo tocante a la teoría de la arquitectura. Se trata de un manuscrito inédito en el que sintetiza su propuesta de teoría de la arquitectura, notablemente condicionado por su admiración a Palladio. Fue iniciado en 1795, años después de su regreso de Italia, y, pocos meses después, Goethe dejó el texto sin terminar. Se esboza el contexto que dio lugar a este breve trabajo y aportan una serie de aclaraciones con el fin de, a continuación, poder interpretar 
con mayores garantías la reproducción facsímil del legajo. La documentación se completa con una transcripción y una traducción, de manera que se ofrece al lector variadas maneras de abordar este trabajo de Goethe. En un segundo apartado se comentan (y se transcriben y traducen, llegado el caso) varios textos complementarios, antes y después de su viaje a Italia, claro punto de inflexión en lo que a su concepción de la arquitectura en general se refiere $y$, más concretamente, como podrá ponerse de manifiesto en las conclusiones, en lo que atañe a la cuestión de la autonomía de la arquitectura. En concreto, destacan la serie sobre la arquitectura alemana, el Baukunst de 1788 (que completaría, junto con el Baukunst de 1795, la segunda serie) y un texto inconcluso clave, Über den Dilettantismus, redactado en coautoría con Schiller y Meyer. merkwürdigsten Gemälde aus Pompeji, Herculanum und Stabiae (1830). Nótese que todas fueron producciones posteriores al Baukunst (1795), evidenciándose así un marcado punto de inflexión en su interés por la arquitectura.

317. De entre ellos destacan por su importancia y rotundidad las menciones en Der Chinese in Rom (1796), Xenien [über Architektur] (1797), Dichtung und Wahrheit (1811-1813 y 1831) [Poesía y verdad], Kampagne in Frankreich (1822) [Campaña en Francia], Italienische Reise (1816-1817 y 1829) [Viajes italianos], Tag- und Jahreshefte (1830) [Diarios y anales] y Biographischen Einzelheiten (1836-1837) [Particularidades autobiográficas]. Por otra parte, las referencias dispersas a la arquitectura y las obras públicas son muy frecuentes en sus Conversaciones con Eckermann.

318. Baste recordar a este respecto: Reise der Söhne Megaprazons [Viajes de los hijos de Magaprazon] (1792), Märchen (1795), el ciclo de Wilhelm Meister (1796 y 1829), Achilleis (1799), Die Wahlverwandtschaften [Las afinidades electivas] (1809), Des Epimenides Erwachen [El despertar de Epiménides] (1815) y Faust. Der Tragödie zweiter Teil [Fausto] (1832), por ejemplo.

319. Esta división a tres ha cobrado las más diversas versiones: romanticismo, clasicismo y vejez; Sturm und Drang, barroco y clasicismo; romántico, clásico y moderno... Coinciden en establecer en Goethe una progresión encaminada hacia una suerte de síntesis armónica al final de su vida, resultado dialéctico de las tensiones de su juventud y mediana edad. Esta interpretación se repite cuando se trata de la arquitectura.

320. Esto se muestra con Ilamativa claridad en Goethe (1994).

321. Dice Rafael Cansinos al referirse a la redacción de los Viajes italianos y, en concreto, la "Segunda estada en Roma": al examinar los diarios y cartas de Goethe, vemos "el modo peculiar de Goethe, tocante a la redacción de sus obras, su aversión a seguir ordenadamente ningún plan, prefiriendo empezar por donde le placía y seguir según su vena del momento, dejando para más adelante la tarea de colmar los blancos que iba dejando provisionalmente en las cuartillas." (Viaj. It., III: 1037-1038)

322. Véase, por ejemplo, las cartas del 16-05-1798 y 27-07-1799.

323. "Lo más grande sería comprender que todo lo facticio es de suyo teoría. El azul del cielo nos está revelando ya la ley fundamental de la cromática. No se busque nada por detrás de los fenómenos, que ellos mismos son ya doctrina." (Max. n5 575, I: 394).

324. Como defiende Todorov: "Si Goethe s'engage dans des entreprises théoriques et discursives, il le fait avec un seul but: aider les artistes dans leur pratique" (1996: 12-13). Véase para más detalle los puntos "Juicio, creación, genio" y "Conocedor, diletante, artista."

325. Este arranque de frase se encuentra en una carta dirigida a Meyer el 16 de noviembre de 1795 que cabría interpretar en el contexto de la elaboración del Baukunst, tal y como se argumentará más adelante.

Este capítulo procede en gran medida de los apartados "Baukunst. El arte de construir" y de "Anexos al Baukunst (1795)" de la publicación J. Calduch y A. Rubio-Garrido (2019), Baukunst. Goethe ante la arquitectura. Madrid: Cátedra (en imprenta). Unas primeras aproximaciones a esta interpretación del Baukunst (1795) pueden encontrarse en J. Calduch y A. Rubio-Garrido, "Baukunst. Goethe's Notes for a Treatise on Architecture", en E. Castaño Perea y E. Echeverría Valiente (ed.), Architectural Draughtsmanship. From Analog to Digital Narratives. Springer, 2018, pp. 1205-1220; y A. Rubio-Garrido y J. Calduch, “Baukunst. El pensamiento arquitectónico de Goethe", en Quintana. 2017, nº 15, pp. 255-267. 326. "La arquitectura resurge de la tumba como un antiguo espíritu, me muestra sus enseñanzas como las reglas de una lengua muerta". 
327. Veinte años después, un Goethe ya anciano reconoce "dos de mis [sus] defectos capitales": "Consiste uno de ellos en no poder aprender el oficio de alguna cosa que quisiera o debiera cultivar. De lo que dimana el que, dotado de tantas aptitudes naturales, haya aprovechado tan poco. Así como también el que, impelido por la fuerza del espíritu hacia las cosas, salieran bien o salieran mal, a la ventura, o luego de ponerme a hacer una cosa bien, $y$ tras mucho pensarlo, me entrase miedo y no pudiese darle cima. El otro defecto, estrechamente unido a aquél, cífrase en que nunca pude dedicar a un trabajo o asunto todo el tiempo que para ello se requería. Gozando de la dicha de poder pensar y combinar muchas cosas en poco tiempo, hácese aburrida e insoportable la gradual ejecución de un plan." (20 de julio 1787, segunda estada en Roma) (Viaj. It., III: 1285).

328. Así lo recuerda Cansinos en su introducción "Biogra-

fía de Goethe" a las Obras completas.

329. El primero de noviembre de 1795 , Goethe confiesa sentirse arrastrado a profundizar sobre sus conocimientos en arquitectura "Durch äussere Veranlaßung", en Goethe: DKV 1998, II.4 (31), p. 125 [Por un motivo externo]. 330. En la carta, del 16 de noviembre de 1795, dice literalmente: "Durch einen äußern Anlaß bin ich bewogen wor-

\section{A. "Ya veo la posibilidad ante mí..." ${ }^{325}$}

$$
\begin{aligned}
& \text { Die Baukunst steigt wie ein alter Geist aus dem } \\
& \text { Grabe hervor, sie heißt mich ihre Lehren wie die } \\
& \text { Regeln einer ausgestorbenen Sprache studieren } \\
& \text { Italienische Reise }
\end{aligned}
$$

Dos cuestiones han contribuido en construir una suerte de aura de misterio en torno al Baukunst de 1795.

En primer lugar, cabría aludir a una cuestión obvia: es un borrador que quedó inconcluso. Esto podría parecer, en principio, motivo suficiente para las delicias de los especialistas exegéticos de la obra de Goethe, máxime cuando no se conocen razones determinantes que puedan justificarlo. Pero lo cierto es que es perfectamente compatible con su peculiar talante. Reconocido por él mismo, combinaba una arrebatada necesidad por adentrarse en territorios desconocidos con una falta de empeño en profundizar en esas nuevas áreas de conocimiento. ${ }^{327}$ A esto se añade su método de trabajo. Es frecuente encontrar entre sus escritos tentativas abortadas, anotaciones deshilvanadas o múltiples revisiones de una misma obra. ${ }^{328}$ Luego, que el escrito quedase inconcluso, no implica por fuerza que Goethe decidiera en algún momento no terminarlo.

Por otra parte, no hay alusiones explícitas en los diarios de Goethe o en las cartas de la época que puedan afirmar con seguridad cuáles fueron sus motivaciones. Las conjeturas a este respecto son múltiples. Es incuestionable el hecho que, durante y tras el viaje a Italia, Goethe intensificara notablemente sus indagaciones en esta disciplina. Una motivación obvia, pues, podría ser la de aclarar su posicionamiento respecto de la arquitectura a la luz de sus investigaciones, contactos y experiencias en el país transalpino. No obstante, el testimonio directo de Goethe, en cartas a Schiller ${ }^{329}$ y a Meyer, ${ }^{330}$ apunta a causas ajenas para justificar su empresa, esto es, motivaciones fundadas en presiones externas o en razones instrumentales. Esto ha llevado a diversos especialistas a conjeturar al menos tres explicaciones, no por ello excluyentes.

Coinciden muchos en señalar la preparación del tercer viaje a Italia como la motivación principal, ${ }^{331}$ hipótesis que vendría corroborada por ciertos comentarios de Schiller. ${ }^{332}$ En línea con esta suposición, tanto la versión inconclusa del Baukunst como sus esbozos previos se clasificaron entre los Italiänischen Collectaneen. ${ }^{333}$ Luego, este escrito debería enmarcarse en el intento abortado de elaborar un exhaustivo documento sobre el arte, la naturaleza y la cultura en Italia emprendido junto a Meyer, material preparatorio para su tercera incursión transalpina. ${ }^{334}$ No en vano, como se verá a continuación, todos los ejemplos mencionados vienen referidos a obras italianas de la Antigüedad o el Renacimiento. ${ }^{335}$

La labor de documentación y análisis plasmada fragmentariamente en el Baukunst podría, asimismo, estar relacionada con su implicación práctica en las obras de la corte de Weimar. En tanto que supervisor de los grandes proyectos en Weimar, durante el otoño de 1795, Goethe siguió con atención las reformas del Palacio Ducal y la construcción de la Römische Haus. De ello ha quedado constancia en numerosos documentos, escritos administrativos, dibujos y cartas. En este sentido, Goethe podría haber emprendido la redacción con el fin de profundizar en sus 
propias convicciones con vistas a desempeñar su actividad profesional con mayores garantías. ${ }^{336}$ Ciertos especialistas han planteado incluso la posibilidad de que Goethe preparase el Baukunst para presentarlo a la Weimarer Freitagsgesellschaft ${ }^{337}$ y forzar así la asunción de ciertas modificaciones en la Römische Haus que venía reclamando infructuosamente. ${ }^{338}$

\section{Aclaraciones previas}

Si no es fácil consensuar una teoría que dé cuenta del carácter inconcluso de la obra y de su motivación inicial, sí hay indicios suficientes para poder reconstruir con bastante verosimilitud el proceso de gestación del texto. La redacción del Baukunst se dilató a lo largo de varios meses y consta al menos de tres etapas claramente demarcadas.

La primera concluye el 29 de octubre de 1795, tal y como quedó consignado por el propio Goethe en el original. En esa fecha, Goethe cierra un borrador del texto. Consta, por una parte, de un breve texto en el que se exponen por primera vez las tesis que quedarán posteriormente desarrolladas en el Baukunst; y, por otra parte, de un esquema de contenidos claramente posterior al texto introductorio. No se pueden fechar con seguridad los primeros escritos del borrador.

A partir de entonces, Goethe regresó a este esquema inicial repetidamente. Tres días después, como se ha señalado anteriormente, el primero de noviembre, informó a Schiller sobre sus indagaciones en el terreno de la arquitectura. ${ }^{339} \mathrm{Al}$ día siguiente, el 2 de noviembre consta en el registro de préstamo de la Herzoglichen Bibliotek de Weimar la salida de los dos primeros volúmenes de Briefe den über die Baukunst Betrachtungen anzustellen und habe versucht mir die Grundsätze zu entwickeln nach welchen ihre Werke beurteilt werden können.", en Goethe: DKV 1998, II.4 (31), p. 131 [Por una motivación externa, he sido empujado a especular sobre la arquitectura y he intentado desarrollar los principios con arreglo a los cuales sus obras puedan ser juzgadas.] 331. Goethe visitó Venecia en compañía de la Gran Duquesa entre el 13 de marzo y el 20 de junio de 1790, su segundo viaje a Italia. Entre enero 1795 y verano 1796, Goethe prepara un tercer viaje a Italia junto a Meyer, como así se lo recuerda por ejemplo en la carta del 16 de noviembre de 1795 (Goethe: DKV 1998, II.4 (31), p. 131.5). Véase Kühnlenz (1959), von Einem (1972); Bisky (2000)

332. Así se lo indica por carta a Wilhelm von Humboldt el 9 de noviembre de 1795. Según Schiller, Goethe por aquel entonces pensaba emprender su segundo viaje a Italia en agosto de 1796. Goethe: DKV 1998, II.4 (31), p. 128

333. El 25 de octubre de 1795, Goethe escribe a Schiller: "In diesen letzten zerstreuten Tagen habe ich meine Italiänischen Collectaneen vorgenommen und zu ordnen angefangen und mit viel Freude gesehen: daß, mit einiger Beharrlichkeit, ein wundersames Werck wird zusammengestellt werden können." Goethe: DKV 1998, II.4 (31), p. 121 [En estos últimos dispersos días, me he dedicado y comenzado a organizar mis Italiänischen Collectaneen, y he visto con gran alegría que con cierta perseverancia se puede armar un maravilloso trabajo.] Pese a que inicialmente el Baukunst se archivase con arreglo a estos indicios en los Italiänischen Collectaneen, esta clasificación se ha mostrado, no obstante, equivocada. Véase para más detalle el apartado "Borrador del Baukunst".

334. El 16 de noviembre de 1795, Goethe escribe a Meyer: "Ich sehe schon die Möglichkeit vor mir einer Darstellung der physikalischen Lage, im allgemeinen und besondern, des Bodens und der Kultur, von der ältesten bis zur neuesten Zeit, und des Menschen in seinem nächsten Verhältnisse zu diesen Naturumgebungen.", Goethe: DKV 1998, II.4 (31), p. 131 [Ya veo la posibilidad ante mí de dar una representación del aspecto físico, en general y particular, el suelo y la cultura, de la más antigua a la más reciente época, y la gente en sus sucesivas relaciones con estos entornos naturales.]

335. Aunque no hay que olvidar que Goethe sólo conocía algunas obras griegas en suelo italiano. Winckelmann, que le sirve de referencia, analiza de un modo especial las obras clásicas griegas existentes en Italia si bien también cita otros ejemplos a partir de textos.

336. En Goethe: DKV 1998, II.4 (31), p. 834 se señala que "el motivo externo" que le lleva a profundizar en la arquitectura es su intervención en la rehabilitación y reforma del Palacio Ducal. Así lo apunta igualmente Ewald (1999: 22).

337. En otoño de 1795, Goethe prepara la conferencia Über die verschiedenen Zweige der hiesigen Tätigkeit para la Weimarer Freitagsgesellschaft. No está claro si llegó a pronunciarla, pero sí consta que su contenido fue comentado. En esta, Goethe aludía en un sentido crítico a la Römische Haus. Pero ello no es óbice para que, en un momento dado de su argumentación, aluda a ella en un sentido muy cercano al que luego de manera más abstracta será desarrollado en el Baukunst: “Das Gartenhaus Durchl. des Herzogs kann man das erste Gebäude nennen das im Ganzen in dem reinern Sinne der Architektur aufgeführt wird, und es würde belehrend sein sowohl über die Risse als über die Ausführung Betrachtungen anzustellen.", Goethe (1998), DKV, I.18: 390 [La casa de campo del Duque puede nombrarse como el primer edificio que se formula en su totalidad en el sentido más puro de la arquitectura, y sería instructivo considerar tanto los planos como la ejecución.] Véase para más detalle Susanne Müller-Wolff (2007), Ein Landschaftsgarten im Ilmtal: die Geschichte des herzoglichen Parks in Weimar. Colonia-Weimar: Böhlau Verlag, p. 305 y ss. 
338. Esta es la hipótesis defendida en Büchsenschuß (2009).

339. "Durch äussere Veranlaßung habe ich in der Baukunst mich wieder umgesehen und habe einiges bey dieser Gelegenheit zusammengestellt, das Urteil über solche Kunstwercke zu erleichtern und zu fixiren.", en Goethe: DKV 1998, II.4 (31), p. 125 [Por un motivo externo, he vuelto a examinar la arquitectura y he reunido algunas cosas en esta ocasión para facilitar y fijar el juicio sobre tales obras de arte.]

340. Schiller informará a Wilhelm von Humboldt por carta el 9 de noviembre de 1795 de una prolongada discusión sobre la arquitectura con Goethe. Goethe: DKV 1998, II.4 (31), pp. 128-129. Varios indicios respaldan la idea, por otra parte compartida unánimemente por los especialistas, de que Schiller está haciendo referencia a la redacción del Baukunst (1795). En primer lugar, esta anécdota coincide con el periodo de mayor intensidad en la redacción de este texto. De hecho, como se tendrá ocasión de comentar, son evidentes los rastros de la intervención de Schiller cuando se compara el primer borrador del 25 de octubre de 1795 (esto es, poco antes de el encuentro al que Schiller se refiere) y la versión final del Baukunst. En segundo lugar, la referencia de Schiller a sus trabajos preparatorios para über Rom de Weinlig, Allgemeines Künstlerlexikon de Fueßli y el libro de Antonio Labacco Appartenente a l'Architettura. Dos días después, el 4 de noviembre tomó en préstamo Tutte l'Opere d'Architettura de Serlio y una traducción parcial al alemán de Idea della Architettura de Scamozzi (von Keudell, 1931). De todo ello se puede claramente deducir la intensa implicación de Goethe en este proyecto a lo largo de esas semanas. Hasta el 5 de noviembre escribe Goethe una primera versión del texto, que comentó con Schiller en ocasión de la celebración de su cumpleaños en Jena. ${ }^{340} \mathrm{~A}$ su regreso, Goethe describe a Meyer el 16 de noviembre la buena impresión que le ha causado a Schiller esa primera versión y le conmina a discutirlo con él. ${ }^{341}$

Durante las siguientes semanas redactó la última versión del Baukunst (1795). Entre el 30 de diciembre de 1795 y el 3 de enero de 1796 escribe a Meyer que ha seguido consultando los "viejos libros de arquitectura" (DKV 1998, II.4 (31), 152). Entre el 22 y el 25 de enero refiere de nuevo a Meyer su trabajo sobre la arquitectura en tono irónico y da a entender que renuncia a la conclusión del tratado (DKV 1998, II.4 (31), 162). Finalmente, en algún momento del otoño de 1796, Goethe quizás se replanteó la posibilidad de retomar el trabajo. ${ }^{342}$ Pero no consta que el borrador del Baukunst de principios de año fuera alterado.

Pese a las incógnitas antes aludidas, se pueden intuir las partes de las que constaba el proyecto de Goethe para el Baukunst. Ello se desprende de la constancia documental, por una parte, pero de forma mucho más concluyente por referencias de terceros a su proyecto. Es elocuente a este respecto la carta enviada por Schiller a Wilhelm von Humboldt el 9 de noviembre de 1795:

\footnotetext{
Goethe está aquí desde el 5 y aun se queda aquí estos días para celebrar mi cumpleaños [el 10 de noviembre]. Nos sentamos juntos desde la tarde a las 5 hasta las 12 e incluso $1, y$ charlamos. Acerca de la arquitectura, que atiende ahora en preparación de su viaje a Italia, ha dicho muchas cosas interesantes a las que me he podido consagrar. Conoce su sólido proceder, siempre recibiendo la ley del objeto y deduciendo sus reglas de la naturaleza de la cosa. De igual manera lo intenta aquí, y toma todas las normas que aquí se dan de los tres conceptos originales: la base, la columna (pared, muro y similares) y la cubierta. ${ }^{343}$
}

Siguiendo el testimonio de Schiller y de acuerdo con el manuscrito, el documento constaría, pues, de una introducción a su aproximación teórica, "Baukunst" [Arquitectura] (de la página 3 a la página 13), en la que enuncia una teoría de la arquitectura, el primero de los tres apartados "Basen ganzer Gebäude" [Basamentos de los edificios en su conjunto] (de la página 15 a la 20) y partes fragmentarias del segundo apartado relativo a las columnas (tabla de órdenes de la página 23 y los dos párrafos de la página 25). Según esta hipótesis, el tercero de los apartados, aquel que alude según Schiller a la cubierta, habría quedado sin siquiera esquematizar o se habría perdido el rastro de su planteamiento. Estos tres apartados vendrían a ser el despliegue desde el objeto arquitectónico de la formulación teórica presentada en la introducción "Baukunst" que, a su vez, permitirían aclarar lo enunciado desde la teoría. Fiel a su proceder morfológico, Goethe dispone una progresión en la arquitectura basada en observaciones empíricas que se apoya en una representación de la arquitectura. ${ }^{344}$ En 
este sentido, los dibujos que acompañan las partes del desarrollo han de entenderse como instrumentos de investigación a modo de representaciones de las formas que Goethe extrae de la observación concreta del fenómeno arquitectónico, como se ha podido desarrollar en el apartado "Texto y dibujo".

Adicionalmente, al final de la introducción Goethe indica que, una vez se hayan expuesto cada una de las partes que componen la arquitectura, "cabrá expresar con mayor precisión y comprender mejor lo hasta aquí dicho." (1795: 13). Con ello Goethe explicita, por una parte, que el desarrollo concreto de cada una de las partes de la arquitectura permite comprender mejor la exposición teórica de la introducción "Arquitectura", y sugiere, por otra, que estaría contemplando la posibilidad de incluir a continuación un apartado adicional en el que presumiblemente sintetizaría la exposición teórica y las observaciones de las tres partes de la arquitectura. En este supuesto, el tratado se ajustaría al esquema de un ensayo: introducción, desarrollo y conclusión.

Al abrir su exposición, Goethe advierte al lector que se refiere "exclusivamente a la arquitectura", incluso en el caso en el que lo que propone pueda ser "común a todas las artes", tal y como apunta literalmente. ${ }^{345}$ Así, en la línea de las reflexiones modernas en torno a la estética del gusto, Goethe asume que toda teoría de las artes ha de "establecer en cada una de las artes qué es digno de alabanza o de reproche" con arreglo a "una norma para nuestros juicios" (1795: 3). ${ }^{346}$ Combina así una aproximación que atiende a las propiedades del hecho arquitectónico con el reconocimiento, explícitamente kantiano, de que abordar estéticamente la arquitectura un nuevo viaje a Italia es perfectamente compatible con la posible motivación inicial para escribir el Baukunst. Por último, las referencias concretas al contenido de las discusiones entre ambos coinciden con el material que Goethe ya tenía preparado en el borrador del 25 de octubre de 1795. En este mismo volumen, Wilhelm von Humboldt publica "Vorerinnerung über Schiller und den Gang seiner Geistentwicklung", en donde incluye la mencionada carta de Schiller. Se trata del primer documento público en el que se exponen las ideas centrales de la inconclusa obra.

341. Literalmente "meinen ersten Entwurf“ [mi primer ensayo], en Goethe: DKV 1998, II.4 (31), p. 131

342. Al retomar sus apuntes del abortado tercer viaje a Italia, consciente del material, escribe a Schiller el 26 de octubre 1796: "Zu einer absichtlichen Komposition umgearbeitet würden solche Aktenstücke wohl einigen Wert erlangen, aber so in ihrer lieben Natur sind sie gar zu naiv." Goethe: DKV 1998, II.4 (31), p. 255. [Estos documentos solo adquirirían algún valor si fueran reelaborados y rehechos en una composición guiada por una intención, pero así como están, en su frescura, son demasiado ingenuos].

343. "Göthe ist sei dem 5ten hier und bleibt diese Tage noch hier, um meinen Geburtstag mit zu begehen. Wir sitzen von Abend um 5 Uhr bis Nachts 12 auch 1 Uhr beisammen, und schwatzen. Über Baukunst die er jetzt zur Vorbereitung auf seine Italienische Reise treibt hat er manches Interessante gesagt, was ich mir habe zueignen können. Sie kennen seine solide Manier, immer von dem Objekt das Gesetz zu empfangen, und aus der Natur der Sache heraus ihre Regeln abzuleiten. So versucht er es auch hier, und aus den drei ursprünglichen Begriffen, der Base, der Säule (Wand, Mauer und dergleichen) und dem Dach nimmt er alle Bestimmungen her, die hier vorkommen." Goethe: DKV 1998, II.4 (31), p. 128

La distinción entre tres partes constitutivas de la arquitectura es una teoría ampliamente difundida en el clasicismo. Pero, además, refuerza la posibilidad de que Schiller esté aludiendo a la división del desarrollo del Baukunst el hecho de que, en el ensayo homónimo anterior de 1788 , Goethe ya desarrollase dos de las tres partes: el entablamento del templo clásico dórico (de manera específica los triglifos y metopas) y la columna, precisamente aquellas menos desarrolladas en 1795

344. Recuérdese que en 1795 Goethe ya había trabajado en profundidad sobre su teoría de la metamorfosis de las plantas. En 1789-1790, Goethe publica Versuch die Metamorphose der Pflanzen zu erklären, en la que sintetiza el reconocimiento de un orden natural que regiría la diversidad empírica de la naturaleza. En este texto dice: "El Ensayo para explicar la metamorfosis de las plantas, es decir, los diversísimos extraños fenómenos del espléndido jardín del mundo, refiriéndolos a un sencillo principio general, quedó terminado por aquella época [hacia 1790]" (III: 972).

345. Durante el Renacimiento, las artes estaban hermanadas en el dibujo, pero se consideran disciplinas diferentes. Posteriormente, los debates, los tratados, etc. -incluidos los de la Academie francesa- se centraron en señalar el parentesco, pero no hay una unidad teórica. La unidad de las artes plásticas tal como la interpreta la cultura moderna se establece en el XVIII -véase Kristeller (1986)-. El posicionamiento de Goethe a este respecto es, por tanto, un tanto ambiguo. Oscila entre heredar la unidad de las artes de la teoría moderna y asumir la multiplicidad renacentista al señalar la singularidad de la arquitectura.

346. En el original, Goethe usa deliberadamente la fórmula kantiana: "eine Norm für unsere Urteil" (1795: 3). A esto se refiere Schiller en su carta a Humboldt con el intento de Goethe de establecer una cierta objetividad en el juicio sobre la arquitectura. 
347. "Lo que en la representación de un objeto es meramente subjetivo, es decir, lo que constituye su relación con el sujeto y no con el objeto, es la cualidad estética de la misma." (Kant, 2007: VII). La arquitectura, en este sentido, constituye un caso singular. En la medida en que para alcanzar el estatus de obra de arte para Kant es requisito la exclusión de toda finalidad y concepto en el objeto, y siendo la arquitectura una práctica fundamentalmente orientada a la satisfacción de las necesidades sociales, difícilmente puede presentarse como desinteresada o sin concepto en su fundamento.

Pero al mismo tiempo, no puede negarse a la arquitectura características propias de las artes. el hecho que las referencias a la arquitectura en la obra de Kant sean tan escasas bien puede interpretarse como un síntoma de su "incómoda" condición. Para salvar este escollo, Kant establece una distinción crucial entre la belleza de los objetos con arreglo a su necesaria o no orientación a fines: la belleza libre (pulcritudo vaga) para aquellos objetos no condicionados a fin a alguno y la belleza adherente (pulchritudo adhaerens) para aquellos que estén condicionados a un fin particular. La belleza de un edificio, así como la humana o la de un caballo, "presupone un concepto de fin que determina lo que deba ser la cosa; por tanto, un concepto de su supone desplegar una crítica del juicio del gusto. ${ }^{347}$ Esta duplicidad será relevante a la hora de clasificar los diferentes fines de la arquitectura.

\section{Las tres categorías de la arquitectura}

En su introducción, Goethe aprovecha la enunciación de su teoría sobre la arquitectura para señalar los límites de ciertas aproximaciones que han jugado un papel central en la historia de la teoría de la arquitectura. Desde su formulación sintética, en la que señala que "La arquitectura presupone un material que puede ser aplicado gradualmente para tres fines" (1795: 3), su teoría arquitectónica entabla progresivamente un diálogo con conceptos o constelación de conceptos como el material, la proporción, el carácter, la utilidad... con el objetivo de medir respecto de sus contemporáneos la capacidad aclarativa de su teoría. Adicionalmente, contrasta cada una de las fases de esta progresión por medio de los fines con ejemplos de la historia de la arquitectura (1795: 8-9). En concreto, estos tres fines, que estructurarán por otra parte su exposición teórica, consisten en: el fin inmediato (vinculado a los etruscos), el fin superior (vinculado a la antigüedad griega) y el fin supremo (vinculado a Palladio). ${ }^{348}$

Queda claro, pues, que el desarrollo de la teoría propuesta por Goethe parte, en primer lugar, de una condición previa de la arquitectura para después desplegar una terna de fines, a modo de grados de desarrollo jerarquizados, con arreglo a los cuales la arquitectura puede ser juzgada. No obstante, tanto la terna como la condición previa se entrelazan en la progresión de la arquitectura hasta sus cuotas más altas de sofistica- ción, de suerte que conviene entender estos cuatro hitos como partícipes dinámicos de un movimiento ascendente. ${ }^{349}$ Por ello resulta más aclarativo exponer los polos de tensión que fuerzan a la arquitectura, al arquitecto $y$ al espectador a abordar la siguiente fase. En última instancia, cada una de ellas podrá entenderse como el resultado dialéctico de la acumulación de categorías estéticas y no tanto un estado inequívocamente reconocible en la arquitectura concreta. Así, en lo que sigue, se articulará la explicación de la condición previa y los fines en la arquitectura a partir de tres categorías puente. En primer lugar, la forma adecuada como resultado de la tensión introducida en la condición previa por la pulsión hacia el fin inmediato. En segundo lugar, la idea de arquetipo como destino de la transición del fin inmediato al superior. En tercer lugar, la verosimilitud como síntesis del fin superior y el supremo.

\section{Primera categoría: la forma adecuada. Del} material a la satisfacción de la función Goethe profundizó en el significado del material para las artes plásticas en Italia, como así se desprende de la temprana enunciación de sus propiedades en "Zur Theorie der bildenden Künste" ["Teoría de las artes plásticas"] (1788). ${ }^{350}$ En el contexto de su redacción, un mes después de su regreso a Weimar, escribe a Heyne en una carta del 24 de julio de 1788 :

\footnotetext{
Si estuviera dispuesto a trasladar algo al papel, sería por el momento cosas muy sencillas. Por ejemplo, en qué medida la materia de la cual está formada la obra determina al artista sensato crearla así y no de otra manera. Así los diferentes tipos de piedra dan suficiente información sobre la arquitectura: cualquier cambio en el material y la técnica da otra de-
} 
terminación y restricción a la obra de arte. Los antiguos eran, entre todos, por lo que he podido constatar, igualmente en esto indeciblemente sabios y me he sumergido frecuentemente con gran interés en estas consideraciones. ${ }^{351}$

La "materia de la cual está formada la obra", esto es, convertida en material de construcción, apunta fundamentalmente a los requerimientos físico-mecánicos de las diferentes materias primas de la arquitectura. Se refiere, por tanto, a la resistencia, la durabilidad, el comportamiento mecánico de la madera, de la piedra... Recae en el material un postulado negativo, según el cual se desprende una cierta forma ajustada a sus propiedades sin más intervención que una habilidosa disposición de sus elementos. Basta para ello la artesanía, esto es, un cierto grado de pericia y de conocimiento del material y sus propiedades.

Se sirve en este contexto de diferentes ejemplos de cada caso para ilustrar su propuesta de interpretación. Así, se puede emplear la piedra o la madera con arreglo a sus prestaciones inmediatas: la piedra proporciona un buen comportamiento a compresión y, por lo tanto, puede asumir y transmitir cargas axiales, en tanto que las tracciones pueden ser absorbidas por la madera, proporcionando por tanto la posibilidad de asumir cargas excéntricas y librar luces de gran amplitud. Gracias a la técnica, alcanzado por tanto un grado superior de conocimiento, se está en disposición de forzar las propiedades inmediatas de los materiales y lograr así, por ejemplo, que la piedra pueda proporcionar espacios abovedados o la madera aumente su luz de carga máxima con ingenios como la cercha. ${ }^{352}$ perfección: así pues, es belleza adherente" (Kant, 2007: §16). La arquitectura según Kant, pues, es un arte, aunque uno no puro.

Por otra parte, la diferenciación entre una estética de la producción con una de la recepción sintoniza con las teorías de Karl Phillipp Moritz de Sobre la imitación plástica de lo bello. 348. Ciertos autores han señalado que esta triada recuerda a aquella establecida por Vitruvio. En este sentido, la firmitas podría entenderse como el fin inmediato de la arquitectura, la utilitas como el elevado y, por último, la venustas como el superior. Véase Gage (1980: 199), Salmerón (1999: 77), Bisky (2000: 72) y Forssman (2000: 7-25)

Como se tendrá ocasión de mostrar en lo que sigue, este paralelismo anularía una de las aportaciones más significativas del Baukunst (1795): la incorporación de la apercepción sensible en el seno de las teorías arquitectónicas objetivistas, en un intento de superar la polarización introducida por la Querelle des Anciens et des Modernes a finales del siglo XVII.

349. De hecho, al final de su borrador del 25 de octubre, Goethe no distingue entre la condición previa y los tres fines. Los considera las cuatro condiciones principales de la arquitectura, en tanto que normas objetivas según las cuales debe juzgarse la arquitectura construida. Deja claro, por tanto, en esta primera aproximación la concepción progresiva entre el material y los tres fines que, posteriormente, corregirá en favor de la claridad. En efecto, en tanto que condición previa, el material no puede ser considerado un elemento de juicio.

350. Publicado en Teutschen Merkur en octubre 1788, a su inmediato regreso de Italia. Este texto está transcrito y traducido en el anexo "Baukunst (1788)" de la presente publicación. Goethe señala la limitación material de las formas en el arte y sitúa la maestría artística en la restricción a las necesidades y posibilidades del material, y su agotamiento. Por tanto, se entiende ya el material como una resistencia frente al despliegue absoluto del arte. De hecho, en su viaje a Italia, Goethe mostró interés en la manera de trabajar el material. En Los viajes italianos recoge comentarios sobre el convento de la Carità de Palladio, el pavimento en el Palacio Pisani, el trabajo murario en la tumba de Metela o las torres boloñesas. Asimismo, en Sicilia se interesa por los materiales empleados en las construcciones (toma muestras de mármol, por ejemplo, lo que enlaza con su interés por la mineralogía). En Mesina realiza comentarios sobre la estática de los edificios en el contexto del terremoto que asoló poco antes de su visita esta localidad.

351. „Wenn ich geneigt wäre etwas auf das Papier zu bringen; so wären es vorerst sehr einfache Sachen. Z.B. inwiefern die Materie, woraus gebildet worden, den klugen Künstler bestimmt, das Werk so und nicht anders zu bilden. So geben die verschiedenen Steinarten gar artige Aufschlüße über Baukunst, jede Veränderung des Materials und des Mechanismus, giebt dem Kunstwercke eine andere Bestimmung und Beschränkung. Die Alten waren, nach allem, was ich bemercken konnte, auch besonders hierin unaussprechlich klug und ich habe mich oft mit großem Interesse in diese Betrachtung vertieft." (DKV 1991, II-3: 415)

Goethe está fundamentalmente interesado a su regreso de Italia, en lo que a la arquitectura se refiere, en profundizar en el concepto de material como determinación previa a la acción del artista, que condiciona de alguna manera la forma final de la arquitectura. De hecho, en el mismo apartado en el que publica "Baukunst", "Zur Theorie der bildenden Künste" ["Teoría de las artes plásticas"], introduce un segundo apartado que lo complementa: "Material der bildenden Kunst" [Material de las artes plásticas], explicitando por tanto su interés en la cuestión. En este sentido, las cuestiones que surgen con el cambio de material de la madera a la piedra manteniendo las formas en el templo primitivo da origen a su interpretación de la mímesis. 352. En 1795, Goethe realizó al menos dos dibujos de cerchas que ponen de manifiesto su interés por estas técnicas (Vla: 165; Vla: 166). 
353. Después de describir las construcciones más primitivas, ligadas a satisfacer la necesidad inmediata de cobijo, "origen primitivo de edificar", Vitruvio traza una progresión hacia el arte de la arquitectura muy cercana a lo planteado por Goethe: "como con el diario trabajo los hombres fueron haciendo sus manos más ágiles en la práctica de edificar, y perfeccionando y ejercitando su ingenio, unido a la habilidad, llegaron con la costumbre al conocimiento de las artes"(1980: 37).

354. En el texto anterior de 1788 el fin inmediato se vincula a los egipcios Desde finales del siglo XV se relacionaban los etruscos con los egipcios (Pevsner, 1983:

188), pero hacia 1760 , a partir del libro del Conde Caylus, Recueil d'antiquités egyptiens, étrusques, grecques et romaines (1752) el arte egipcio: "ya no era considerado meramente como una fase inicial del arte griego clásico, sino como arte por derecho propio. [...] En este aspecto la comprensión del egipcio y el dórico griego forman un paralelo." (Pevsner, 1983:

200). Este giro y el escaso

conocimiento de Goethe de la arquitectura egipcia de la que sólo tenía experiencia de los obeliscos de Roma y la versión de la pirámide del mausoleo de Cestio así como de las imágenes recogidas en dibujos y láminas (de Cassas entre otros), pueden explicar el que en el texto del
Este dominio sobre el material está relacionado con la progresión de los fines de la arquitectura. El primero de los fines de la arquitectura, el inmediato [der nächste], atiende a lo meramente necesario cuando se limita a cumplir con las exigencias del material, o a lo útil cuando con la asistencia de la técnica permite disponer de un mayor número de soluciones posibles. En este sentido, conviene recordar, también de su viaje a Italia, una de las primeras experiencias de esta superación de la condición previa de la arquitectura por medio del impulso hacia la satisfacción de una funcionalidad: la Arena de Verona.

$$
\begin{aligned}
& \text { Cuando algo digno de verse ocurre en tierra lla- } \\
& \text { na y todo el mundo echa a correr, los que están } \\
& \text { más atrás hacen todo lo posible por empinarse } \\
& \text { sobre los de delante, encarámase en bancos, } \\
& \text { acarrean toneles, montan en coches, tienden } \\
& \text { cables acá y acullá, trepan a alguna colina cer- } \\
& \text { cana y rápidamente fórmase un cráter. } \\
& \text { Cuando el espectáculo desarróllase más a } \\
& \text { menudo en el mismo sitio, constrúyense ligeros } \\
& \text { andamios para las personas que pueden pagar, } \\
& \text { y el resto de la masa se las arregla como puede. } \\
& \text { Pues satisfacer la general necesidad es aquí } \\
& \text { el deber del arquitecto. El cual prepara con los } \\
& \text { recursos del arte un cráter así, lo más sencillo } \\
& \text { posible, para que le sirva de ornato el pueblo } \\
& \text { mismo. (Viaj. It., III: 1060-1061) }
\end{aligned}
$$

Esta progresión de la conformación del graderío en Verona está relacionada, por otra parte, con el primer capítulo del segundo libro de Vitruvio en el que presenta la leyenda del origen de la arquitectura: desde la mímesis con el entorno (copiar madrigueras de animales) o desarrollar elementos técnicos más ingeniosos, hasta la aparición de la simetría y las proporciones. ${ }^{353}$

En este sentido, la artesanía es el vínculo entre el control sobre el material y la forma que adquiere con arreglo a fines, esto es, la forma adecuada. Dado que un edificio puramente funcional exige únicamente un conocimiento artesanal, la mecánica es el prerrequisito básico para elevar la arquitectura a la satisfacción del fin inmediato. Para alcanzar, en lo siguiente, el fin superior se requiere de un artista versado en las propiedades de los materiales y las técnicas de construcción, de manera que es capaz de utilizar el material de las más diversas formas, incluso en contra de sus propiedades inmediatas. La superación de la resistencia del material para conseguir nuevas formas es una condición previa para el despliegue del fin elevado y el superior.

Los etruscos serían, siguiendo este razonamiento, un pueblo que sólo alcanzaron a plasmar en sus construcciones el fin inmediato. ${ }^{354}$ Sus edificios estaban dominados por el material y sus propiedades intrínsecas, lo que condiciona en definitiva las formas arquitectónicas de las que disponían. Esto implica para Goethe que, en rigor, sus obras no puedan considerarse arte. Esboza para ilustrarlo una esquemática historia del desarrollo de la fábrica desde el muro ciclópeo (opus incertum) al aparejo de sillares regulares (del opus pseudisodomum al opus isodomum) con el apoyo de una serie de cuatro dibujos. ${ }^{355}$

En definitiva, Goethe concibe el material no solo ya como un conjunto de cualidades físico-mecánicas, sino fundamentalmente en su interacción con la función concreta de la arquitectura. El arquitecto ha de conocer las propiedades de los materiales empleados para poder usarlos ajustados a sus propiedades, lo que implica que toda fase ulterior deberá, por tanto, partir de la forma adecuada. ${ }^{356}$ 
Segunda categoría: la idea de arquetipo. De la función al carácter

Pero, para que la arquitectura pueda ser considerada como arte, junto con la funcionalidad y una forma adecuada, Goethe advierte que han de incorporarse a la arquitectura "Ios elementos armoniosos para los sentidos" (1795: 5), esto es en definitiva un cierto tipo la belleza que apunta explícitamente hacia la satisfacción "para los sentidos". He aquí, ya, un primer elemento de la progresión de la arquitectura hacia el cumplimiento del fin superior [der höhere] en el que conviene detenerse.

Goethe denuncia que se le haya dado demasiada importancia al sentido visual en la arquitectura y reivindica que la arquitectura se convierta en un arte centrado en "el movimiento mecánico del cuerpo humano" (1795: 6) ${ }^{357}$ En rigor, además de una explícita jerarquización de los sentidos, al apelar al movimiento en la arquitectura Goethe está incorporando la dimensión temporal remitida, además, a la corporalidad (Bisky, 2000: 72 y ss.). ${ }^{358}$ Para ilustrarlo Goethe recurre a una analogía en extremo esclarecedora, en la que una persona "con los ojos vendados" guiada por un edificio pudiese sentir un placer equivalente a "cuando nos movemos en la danza conforme a ciertas reglas" (1795: 6). La "sensación placentera" que ha de proporcionar una arquitectura armoniosa depende ciertamente de reglas, aquellas en este caso similares a las que rigen en la danza. Y si algo las caracteriza, pues, es el hecho de que el espectador deba ser capaz de sentir esa armonía sin la concurrencia accidental del sentido de la vista. ${ }^{359}$

La naturaleza de estas reglas ocupa lo que sigue. Pero cabe insistir de nuevo en el marco que proporciona este singular planteamiento. Solo por medio del movimiento puede el bailarín o el espectador hacerse cargo de la armonía sensible de la danza o el edificio. Esta desconfianza hacia la vista potenciando por tanto el sentido del movimiento establece una relación particular entre el espectador y la arquitectura. La sensación placentera se da cuando se discurre a través de la arquitectura construida en la medida en que la persona y el edificio entren en armonía, como un cuerpo en danza. La mera visualización de la arquitectura, no proporciona, por tanto, acceso al nivel del fin superior. $Y$, dado que se parte de una condición previa y de una forma adecuada a su función, solo usando la arquitectura se puede percibir esa característica armonía. ${ }^{360}$ Han de participar otros sentidos que, por cierto, determinen las condiciones para juzgar el arte.

Este novedoso criterio de valoración en la progresión de la arquitectura, otorga para Goethe un papel central a "la difícil y complicada doctrina de las proporciones", entendida esta como un elemento instrumental en la medida en "que hace posible el carácter del edificio y sus diversas partes" (1795: 6-7). ${ }^{361}$ La forma armónica para los sentidos ha de entenderse, pues, como el resultado de una cierta intervención de la doctrina de las proporciones en una forma ajustada al fin inmediato de la arquitectura con arreglo a sus condiciones previas que, en última instancia, dotará de carácter al edificio. Esta insistencia en remarcar la naturaleza instrumental de la doctrina de las proporciones viene motivada por su rotunda denuncia de la supeditación del edificio a su métrica, algo que identifica en "la arquitectura más reciente [neuere]". ${ }^{362}$ Tan es así que Goethe va más allá y anuncia que
Baukunst (1795) sustituya como antecedente la arquitectura egipcia por la etrusca de la que tenía conocimiento directo como recoge en algún dibujo hecho durante su viaje a Italia y que repite en el Baukunst (1795).

355. Goethe conocía estas técnicas por sus lecturas de Vitruvio (Libro II, capítulo VIII) y Palladio (Lib. I, cap. IX, pp. 11-14 de I Quattro Libri..., 1570).

356. Esta fase está relacionada con el concepto de distributio en Vitruvio: "La distribución consiste en el debido y mejor uso posible de los materiales y de los terrenos" (1980: 15).

357. Al anteponer el sentido del movimiento al visual en la arquitectura, Goethe se adelanta en gran medida a las teorías más recientes contrarias al oculocentrismo. Kruft señala, no obstante, el precedente de Le Camus de Mézières (1782: 287), aunque lo cierto es que no hay constancia documental de que Goethe fuese un gran conocedor de su obra (Einem, 1972: 104).

358. En este sentido se distancia de Lessing 359. En el borrador del Baukunst, esta persona guiada es ciega. Como bien apunta Calduch (2017: 100113), este "ir a ciegas" en contraposición al ser ciego potencia la concurrencia de la memoria y los estímulos sensoriales alternativos de manera que proporcionan una 
"comprensión del lugar en el que estamos como sustitución de la visión óptica".

360. Es sintomático de esta cuestión el interés que Goethe manifestó a lo largo de toda su vida por las escaleras. En efecto, se trata este de un elemento arquitectónico en el que el entrecruzamiento del uso y la espacialidad es notable. Véase para más detalle Calduch y Rubio, 2018.

361. Al vincular explícitamente el carácter de un edificio a la doctrina de las proporciones, Goethe introduce lo que, más adelante, se explicitará: la revisión de la doctrina de la proporción en tanto que ratios de medidas, esto es, en tanto que composición. Respecto a esta, Goethe comenta el 20.6.1820 a Eckermann que es "una palabra ruin que les debemos a los franceses y que hemos de procurar sacudirnos lo antes posible. ¿Cómo puede decir nadie que Mozart, por ejemplo, compuso su Don Juan? ¡Composición! Como si se tratase de una torta o un bizcocho que se hacen con huevos batidos, harina y azúcar. Pero en ese caso se trata de una creación espiritual, cuyas partes, lo mismo que el todo, emanan de un espíritu como fundidas en una pieza, impregnadas del soplo de una vida, durante la cual el artista no ensayaba, ni descomponía, ni laboraba a su capricho, sino que estaba dominado del espíritu demoníaco de su genio y tenía que hacer lo que éste le ordenaba." (Eck., III: 378-379). "el carácter no se deja expresar propiamente por la medida". Al advertir que "en las mediciones de edificios reales vemos qué difícil es reducir sus partes a relaciones numéricas" (1795: 10-11) se pone en evidencia la limitada aplicación de la doctrina de las proporciones en un sentido no solo estrictamente numérico, sino también reductivamente visual. La crítica a la preponderancia numérica en la doctrina de las proporciones completa, por tanto, su reivindicación de superación del imperio de lo visual en la arquitectura a la luz del carácter.

La introducción en este punto del concepto de "carácter" resulta especialmente significativa, en especial si se tiene en cuenta que en su primer Baukunst (1788) no está presente. ${ }^{363}$ Por otra parte, no es tampoco de extrañar en la medida en que en su más inmediato entorno, Hirt, Stieglitz o Sulzer ya habían tratado en 1795 la teoría del carácter. De este último Goethe conocía su obra Allgemeine Theorie der schönen Künste probablemente desde su estancia en Roma. ${ }^{364}$ En ella define el carácter como el "Hauptteil der Kunst" [parte principal del arte] (1994, I: 454), concediéndole por tanto un papel mucho más relevante que al que Goethe está apelando. ${ }^{365}$ En la entrada "Gebäud" [edificio] puede leerse igualmente una mención explícita:

Incluso se pueden resumir estos y otros comentarios relevantes en la regla general de que cada edificio debe afirmar su carácter y mostrar su finalidad tanto en sus partes esenciales como en las contingentes, pero al mismo tiempo ha de verse bien a su manera y debe incluir en todas partes buenas condiciones, gusto, firmeza y diligencia diaria. ${ }^{366}$

La semejanza respecto de la propuesta de Goethe es notable en la medida en que Sulzer vincula el carácter con la finalidad de la arquitectura, pese a que en este pasaje dicho vínculo quede reducido a un nexo copulativo, en tanto que Goethe propone una progresión condicionada. Para Sulzer, el carácter y la finalidad del edificio son condiciones que han de coexistir en tanto que para Goethe es solo a partir de la forma adecuada, con la introducción de criterios de belleza, como puede darse lugar al carácter. Quizás más relevante sea la introducción de las condiciones culturales y materiales en la ecuación de Sulzer, lo que lo aproximaría al concepto de decoro en Vitruvio, para el cual supone "el aspecto correcto de la obra, que resulta de la perfecta adecuación del edificio" con arreglo a las costumbres y el emplazamiento (1980: 14). En este sentido, Goethe se aleja de Sulzer en la medida en que asume la funcionalidad como prerrequisito del carácter, al tiempo que se acerca por medio de la exigencia previa de la forma adecuada.

Por otra parte, parece inevitable que, bien sea por el recurso a las fuentes directas, bien por medio de otras influencias, Goethe se viera apelado por el concepto de carácter de la teoría arquitectónica francesa. ${ }^{367}$ Jacques-François Blondel, del que Goethe tenía su publicación más relevante en su biblioteca, Cours d'Architecture ou Traité de la décoration, distribution \& construction des bâtiments, es clave al respecto:

\footnotetext{
Puesto que todas las diferentes especies de producciones que dependen de la arquitectura deben llevar la impronta del destino particular de cada edificio, todos deben tener un carácter que determine su forma general y que anuncie el edificio por lo que es. ${ }^{368}$
} 
En este sentido, cada edificio debe tener su carácter ajustado a la finalidad del edificio: los templos han de ser decentes, los edificios públicos grandiosos, los monumentos conmemorativos suntuosos.. (1771-1777, I: 390) Para Blondel, el carácter del edificio es, en definitiva, la expresión de su función. Consiste en poder reconocer la finalidad de un edificio con solo verlo. La imagen muestra el uso del edificio sin necesidad de estar usándolo. Goethe, en cambio, lo vincula a la forma proporcionada, esto es, algo que va más allá de su uso, pese a que su funcionalidad esté garantizada. Son las proporciones (sensiblemente captadas) las que dan el "carácter" al edificio, no el uso (captado, también por el sentido de la vista). En el caso de Blondel, el carácter sería el "uso intuido por la vista" y, en el de Goethe, "las proporciones vistas y sentidas". De alguna manera esto significa y confirma que para Goethe "el carácter" no tiene una componente "exclusivamente" visual (como se podría deducir de las teorías francesas y Blondel), y que la "funcionalidad" no es algo "visual" sino que incluye la actividad, el recorrido: sólo recorriendo el edificio podemos captar su "carácter" en relación con su "utilidad". ${ }^{369}$

Nótese cuán delicada es esta operación. Por una parte, Goethe está apelando a la tradición del carácter con el fin de poder introducir un cierto sentido de la proporción que garantice la incorporación de criterios de belleza al edificio pero que, al tiempo, trascienda su concepción como mera métrica o visualidad. Por otra parte, no asume la desvinculación del carácter a la función del edificio (Sulzer) ni su reducción a la expresión de una función (Blondel). Goethe estaría, en este sentido, aludiendo a un sentido mucho más
362. Goethe denuncia aquí la influencia de la tratadística en la arquitectura en la medida en que pudiera colaborar en la preponderancia de la métrica frente al carácter de un edificio. De manera explícita, ello ya fue objeto de duras críticas en Von Deutscher Baukunst (1772), en este caso centradas en la tratadística francesa y, muy especialmente, en la "composición". Recuérdese, las alusiones directas a textos de M. A. Laugier. En esta ocasión, podría interpretarse que Goethe amplía la crítica a los orígenes renacentistas de la tratadística. De hecho, ya Vitruvio admite que las medidas que aporta son sólo orientativas y, en cada caso, la obra se debería ajustar a las condiciones que le afectan. Daniele Barbaro, al comentar el Cap. Il del libro IV, Sobre medidas y proporciones de los edificios privados de Vitruvio, escribe: "aquello que Vitr. ha dicho antes, y muy claramente dice en este lugar, o sea, que no siempre se deben observar las mismas reglas, y simetrías, porque la naturaleza del lugar requiere a veces otra razón de medidas de las que hemos propuesto, y la necesidad se ve obligada a darlas o quitarlas" (Barbaro, 1567: 283)

363. No obstante, el concepto de carácter aparece ya en Von Deutscher Baukunst (1772), en tanto que mecanismo por medio del cual la sensibilidad dota de unidad a la multiplicidad de las manifestaciones concretas del arte. Goethe llega incluso a atribuirle carácter a las "formas más arbitrarias" y a aquellas que "no guardan proporción entre sus partes" a condición de que se atengan a la condición exigida de verdad. Pese a ello, afirma que el arte que aúna con mayor verosimilitud carácter y verdad es el gótico: “Este arte característico es pues el único verdadero. Cuando actúe con una sensación interna, única, propia e independiente, y se mantenga despreocupado e inconsciente de todo lo extraño, ya nazca de la aspereza salvaje o de la refinada sensibilidad, es pleno y está vivo." (Goethe, 1999: 38). En este contexto, el carácter es un atributo plástico previo a la belleza. Por añadidura, y a diferencia de lo planteado en el Baukunst (1795), en Von Deutscher Baukunst el carácter no viene condicionado por la funcionalidad o la materialidad. Por otra parte, en el borrador del 29 de octubre de 1795 Goethe ya emplea el concepto de carácter, aunque con un significado mucho menos preciso que en la versión definitiva del Baukunst.

364. Según Büchsenschuß, Goethe leyó este artículo en Roma durante su visita a Phillip Hackert (2009: 207)

365. Más adelante, Goethe señalará la ficción en la arquitectura como «la cuestión central» de la arquitectura (1795: 11). Sulzer se alinea con Marie-Joseph Peyre cuando alude al "papel crucial del carácter" (Szambien, 1993: 242).

366. "Man kann überhaupt diese und andre hieher gehörige Anmerkungen in die allgemeine Regel zusammenfassen, daß jedes Gebäude, sowohl in seinen wesentlichen, als zufälligen Theilen, seinen Charakter behaupten und seinen Zweck anzeigen, zugleich aber in seiner Art gut in die Augen fallen, und überall gute Verhältnisse, Geschmack, Festigkeit und angewandten Fleiß an den Tag legen müsse." (Sulzer, 1994, II: 313).

367. Así lo defiende Kruft (1982: 287), aunque reconozca que no se puede especificar con precisión la fuente.

368. Cours, tomo II, cap.: "Del carácter que convendría dar a cada género de edificios" pp. 229-232.

369. En 1788, Quatremère de Quincy introdujo una distinción "entre el carácter de la idea expresada y el carácter de un género de edificio" (Szambien, 1993: 247). El carácter tendría, por lo tanto, una doble interpretación y Goethe, en la medida que considera que excede la mera expresión visual de la funcionalidad, parece apuntar a ese doble sentido. 
370. Palladio retoma el criterio de decoro vitruviano en tanto que "conveniencia" (Libro II, Cap. Primo: "Del decoro, o convenienza, che si deue osservar nelle fabriche private"). Ello recuerda, de hecho, a la afirmación de Goethe: Ios griegos prestaron más atención en los templos dóricos a la idea que a una similitud o igualdad externa concreta. 371. De hecho, en la anterior cita de Sulzer, los criterios de belleza no parecen desprenderse de la satisfacción del carácter en el edificio, alejándose por tanto del academicismo francés.

Para Blondel, la convenance se alcanza en un edificio cuando se «a remarqué que sa disposition extérieure et les principales parties de sa décoration sont absolument relatives à l'objet qui a donné lieu à ériger l'édifice» (1771-1777, I: 389). Según la teoría francesa, lo adecuado es una categoría inferior a la conveniencia [convenance] en la medida en que la segunda incorpora ya un criterio propio de belleza. En efecto, Cordemoy y, sobre todo, Blondel (cuyo tratado Goethe tenía en su biblioteca) equipara la convenance con la belleza de la arquitectura y la relaciona con la disposición de las formas, el estilo, la decoración y el carácter, y todo ello vinculado con el uso y la utilidad del edificio. Por lo tanto, para Blondel hay una jerarquía que lleva de la adecuación al fin (uso) a la convenance. cercano al empleado por Palladio por medio del concepto de conveniencia. ${ }^{370} \mathrm{~A}$ diferencia de la "adecuación", que marca la síntesis entre la materialidad y la función, la "conveniencia" introduce el criterio de belleza. ${ }^{371} \mathrm{En}$ este sentido, la propuesta de Goethe sobre el carácter del edificio como síntesis de la forma adecuada y la belleza se aproxima al concepto de "conveniencia" y se aleja del significado blondeliano del "carácter", inevitablemente relacionado con el estilo. ${ }^{372}$ Goethe va más allá de esta interpretación.

Para ilustrarlo, Goethe trae a colación la arquitectura, específicamente de templos, en los griegos antiguos. Centraron sus esfuerzos en desarrollar una "misma idea", gracias a la cual "ejercitaron y refinaron su sensibilidad", permitiéndoles que, pese a que se puedan reconocer los diferentes tipos de edificios, prevalezca un sentido de la multiplicidad en las obras concretas. Así, "todos los templos dóricos de Sicilia y Magna Grecia fueron erigidos con arreglo a una idea y, sin embargo, son muy diferentes entre sí." (1795: 10). Los griegos no determinaron unas medidas, sino que construyeron con arreglo a una idea. Dado que no se vieron constreñidos por rigideces métricas, pudieron dar lugar a una arquitectura reconocible en su unidad al tiempo que respetuosa de la diferencia. Con ello, tal y como se apunta más adelante en el tratado, Goethe está aludiendo a una experiencia empírica: el hecho de poder reconocer en todos los templos griegos de la Antigüedad un templo griego como tal. Independientemente de su localización, tamaño, advocación, estilo... los templos griegos, en su diversidad, conforman una unidad.

Es una idea la que permite dotar de belleza a un edificio, en aplicación de la doctrina de las proporciones, pero sin supeditarse al imperio de la medida ni a la preponderancia de lo visual. Es la idea, por tanto, la que para Goethe proporciona el carácter necesario al edificio para la consecución del fin superior. Desde el punto de vista estético, el carácter de un edificio como síntesis de la forma adecuada y la belleza remite inevitablemente a la propuesta de Kant en Crítica del Juicio sobre las "ideas estéticas" ${ }^{373}$ y, lo que es quizás más relevante en este punto, sitúa la incorporación de este concepto en el contexto de las discusiones con Schiller llevadas a cabo durante la redacción del Baukunst (1795). A la influencia de Schiller, en efecto, se le puede atribuir la nueva composición de los conceptos en la primera parte del ensayo, así como la introducción del concepto de "idea" para definir mejor la relación entre función, carácter y teoría de la proporción. ${ }^{374}$ Sobre ello Schiller da cuenta en la carta que envía a Humboldt y a la que ya se ha hecho referencia con anterioridad. Prosigue así:

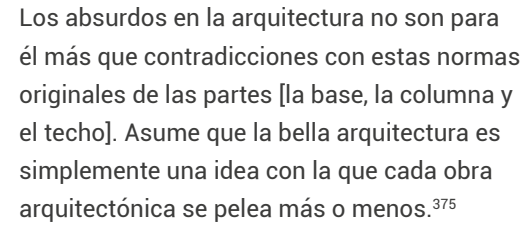

Para determinar cuándo se convierte en obra de arte, Schiller considera que la bella arquitectura existe solo como idea y que la real siempre intenta acercarse a esta infructuosamente. ${ }^{376}$ Dado que la arquitectura debe satisfacer una función, incluso si el arquitecto trabaja como el poeta para el "hombre ideal", solo puede aproximarse parcialmente a la idea. ${ }^{377}$ Para Schiller, la idea se construye a partir de la abstracción de las necesidades 
y es irrealizable. En cambio, Goethe quiere derivar las leyes de la arquitectura directamente del objeto arquitectónico. Se parte de la realidad y se persigue la idea que en ella está contenida. Al igual que durante la anécdota recogida en el apartado "Lo que no se comprende no se posee", la tensión entre la concepción de la Urpflanze como idea (en el caso de Schiller) o como realidad (en el de Goethe) se saldaba con su consideración como arquetipo -al que toda planta remite y con arreglo al cual se da cuenta de la multiplicidad de sus manifestaciones concretas,- 378 la idea en la arquitectura constituye a fin de cuentas un arquetipo con arreglo al cual toda arquitectura que satisfaga el fin superior ha de remitirse. La concreción del carácter es para Goethe la idea de un tipo arquitectónico particular, siendo el templo clásico el ejemplo más ilustrativo.

Siguiendo este paralelismo con sus teorías de la morfología, la primera etapa de la metamorfosis del edificio se manifiesta en la transición desde el fin puramente funcional al fin superior del carácter o la armonía sensitiva, y se da superando las capacidades artesanales y las necesidades del usuario. La arquitectura, para que pueda ser considerada un arte, tiene que satisfacer su unidad formal interna fruto de la síntesis adecuada de los materiales y la función. Pero no basta. Es necesario mejorar la forma con arreglo al fin superior de manera que se manifieste en él la idea que se desprende de la aplicación de un carácter no supeditado ni a lo visual, ni a la métrica. Luego, si el fin inmediato da lugar a la forma útil, el fin superior proporciona la forma devenida idea, esto es, el símbolo estético de la necesidad.
De alguna manera es una evolución desde la teoría de Perrault: lo que para este son los tres fines de la arquitectura (reinterpretando a Vitruvio) para Blondel se ha convertido en una jerarquía. En cierta medida esto recuerda la idea de Goethe, aunque empleando términos diferentes. El concepto de Blondel de convenance estaría, en este sentido, cercano a lo que Goethe persigue al sintetizar con la consecución del fin superior en su particular relación con el concepto de carácter, es decir, una fase posterior a la que corresponde a la forma adecuada. 372. Szambien: "Para Blondel, el carácter sigue estando próximo a lo que hoy se designa con el nombre de «estilo»." (1993: 239). "Desde Blondel, la cualidad de producir carácter continúa estando asociada al genio. Y he aquí que se sitúa más allá de las reglas." (1993: 250).

373. La naturaleza del contenido en la obra de arte, conceptual pero sin que medie concepto ni en su juicio ni en su producción, corresponde a lo que Kant define como la "idea estética" (2007: §49). Para ilustrar su propuesta hace mención a la sublimidad, la majestuosidad, referencias a lo invisible (el reino de los bienaventurados, el infierno, la eternidad) o abstractas (la muerte, la envidia). En el caso de la arquitectura, la expresión de "ideas estéticas", en tanto que representaciones de la imaginación que dan pie al libre juego de las facultades, ha de partir de su orientación a un fin objetivo. Sobre la manera en que ello puede llevarse a cabo, no obstante, Kant apenas adelanta nada, pero es de suponer que una iglesia, dado que sirve para el recogimiento espiritual, ha de transmitir la necesaria sobriedad y humildad que corresponde a la religión (evidentemente cristiana protestante), alineándose en cierta medida con el concepto de carácter de Blondel. Así, podría deducirse que un palacio mostrará arquitectónicamente el poder y riqueza de su habitante, que una fortaleza transmitirá una clara representación de su solidez y de su amenazante presencia, que un palacio de justicia inspirará rigor y contundencia... Véase para más detalle Rubio-Garrido (2015: 198-217). 374. Sobre la influencia de Schiller en Goethe véase Horn-Oncken (1967, cap. 1). 375. „Die Absurditäten in der Baukunst sind ihm nichts als Widersprüche mit diesen ursprünglichen Bestimmungen der Teile. Von der schönen Architektur nimmt er an, daß sie nur Idee sei, mit der jedes einzelne Architekturwerk mehr oder weniger streite." (DKV 1998, II.4 (31), 128).

376. El siguiente comentario de Goethe sobre Palladio: “Y así llevó también la visión más grande que en el alma guardaba, incluso allí donde no se acomodaba del todo, donde en los pormenores no tenía más remedio que fragmentarse y mutilarse." (V. It., III: 1089), refleja esta idea.

377. Es esta una discusión que, desde entonces, quedará irresoluta. Precisamente en la diferencia entre necesidad / utilidad y entre adecuación / conveniencia estaría el obstáculo insalvable para Schiller, compartido por toda la arquitectura idealista, desde Ledoux a Mies. 378. La intención de Goethe al desarrollar la teoría de la metamorfosis no es la de encontrar el origen de la evolución de las plantas, en un sentido por ejemplo darwiniano. Señala en cambio una forma específica de conformidad a leyes. En su acepción germana, pues, el prefijo Ur- de Urpflanze no adquiere un significado cronológico, sino más bien procesual o, si se prefiere, genealógico. Las traducciones más extendidas al castellano, "planta originaria" o "planta primitiva", inducen por tanto a error. En su lugar sería más preciso hablar de "planta arquetípica" (Rubio-Garrido, 2018: 127-151). 
379. En este sentido, cabría revisar el paralelismo con la triada vitruviana antes aludido. La condición previa se aproximaría, por tanto, a la firmitas, el fin inmediato a la utilitas y el fin superior a la venustas

380. En este punto, por tanto, Goethe está maneja simultáneamente al modo kantiano la teoría de la creación (el genio) y la de la recepción (e "espíritu cultivado", en tanto que "aficionado culto" que disfruta de la arquitectura) La fase anterior, en cambio, atendía significativamente a una estética del objeto arquitectónico, en la línea de la tradición tratadística clasicista.

381. Véase el apartado "Juicio, creación, genio». En otros términos, es a lo que Eckermann se refiere cuando recoge la siguiente afırmación de Goethe: "Las leyes de la poesía y la pintura se pueden aprender hasta cierto punto, pero para ser un gran poeta o un gran pintor se necesita genio" (Eck., III, 262)

382. Véase el apartado «Arte otra naturaleza...».
Tercera categoría: la verosimilitud. Del carácter a la ficción

Hasta el momento se ha planteado una condición previa de la arquitectura y dos fines. Cada uno de los pasos de una a otra etapa de este progresivo ascenso de la arquitectura hacia el fin supremo está condicionado por la satisfacción de una síntesis dialéctica de los polos de las etapas en tensión. Del entrelazamiento del material y la función se puede dar pie a la forma interna de la arquitectura (categoría de la adecuación) por medio del conocimiento artesano experto. Se ha satisfecho en este punto el fin inmediato de la arquitectura. De la superación dialéctica de la forma adecuada y la armonía sensitiva se alcanza la forma característica (categoría del tipo arquitectónico) gracias a la intervención, en este caso, de un artista, para lo cual el conocimiento técnico ya no basta, porque implica, también, la sensibilidad del espectador. Se ha satisfecho en este punto el fin superior de la arquitectura, que ya puede ser considerada como arte. ${ }^{379}$

Dos movimientos simultáneos y aparentemente divergentes pueden localizarse en esta progresión. Por una parte, la progresión de la arquitectura hasta el fin superior se llevaba a cabo profundizando en las cualidades que son propias a la arquitectura, bien por medio de la forma adecuada a la materia y la función, bien por medio de la forma característica ajustada a una idea arquetípica. Por otra, el progresivo ascenso hacia el fin superior se aleja progresivamente del objeto, de manera que, desde los condicionantes objetivos de la forma adecuada, se pasa a la concurrencia de los sentidos del espectador y ciertas reglas condicionadas por estos.
En el caso del fin supremo [der höchste] se abunda en ambas dinámicas. Se requiere la concurrencia del genio artístico y del entendido, "espíritu y sensibilidad tanto en su uso como en su valoración." (1795: 12). El caso del fin supremo supone pasar de la armonía sensitiva a la esfera espiritual, ahondando por tanto en el alejamiento del objeto y aproximarse a una estética de la recepción al introducir lo que Goethe denomina "la parte poética de la arquitectura". Esta es la que "se propone la sobre-satisfacción de los sentidos" y alimenta la esfera espiritual del espectador, en este caso "un espíritu cultivado" (1795: 7). ${ }^{380}$

Una vez dominadas las fases anteriores, habiendo pues incorporado a la forma arquitectónica cada una de ellas, algo que solo puede realizar un genio (aquel que "ha dominado las demás exigencias"), del carácter en la arquitectura se puede pasar a la ficción. Este salto, a diferencia de los anteriores, se realiza en la arquitectura incorporando de la poesía elementos que son ajenos a la arquitectura por medio de la imitación porque, para Goethe, aunque la arquitectura no es un arte imitativo tampoco puede renunciar a ella en su más alto grado (1795: 7). El recurso al genio enfatiza la tesis de Goethe de su capacidad de trascender las reglas. ${ }^{381}$

El problema de la mímesis, recurrente en todo el clasicismo, es retomado por Goethe en un sentido kantiano. Lo que "imita" el arte no sería la figura de la naturaleza, sino el "genio de la naturaleza". ${ }^{382}$ De ahí que Goethe no la reduzca al sentido visual. Pero, por otra parte, en relación con la arquitectura regresa a una interpretación más habitual, es decir, a la apariencia: la piedra que imita la madera. Esta era una teoría muy frecuente en la época 
y Goethe la conocía por Winckelmann, Hirt y Galiani. Siguiendo a Winckelmann, Goethe defiende que no se trata de "imitar" la naturaleza directamente sino emular aquello que realizaron los griegos cuando, tomando como referencia la construcción en madera, construyeron en piedra (1795: 8). ${ }^{383}$ De ello da cuenta, por otra parte, en un dibujo realizado durante su viaje a Italia y copiado del Vitruvio de Galiani, donde representa la relación del entablamento primitivo en madera y su transformación en piedra. (Fig. 17)

Luego, no son meramente formas sensitivas las que se originan por medio de la imitación, sino que, para provocar el deleite espiritual propio del fin supremo, el genio ha de transferirlas de manera tal que, sin violen- tar la forma adecuada ni el tipo arquitectónico, la haga "llegar a ser variada y rica". A lo que añade Goethe, reforzando la ambigüedad de todo este crucial pasaje: "tan difícil es sentir aquí para el artista si está haciendo lo conveniente, como para el entendido juzgar si se ha hecho lo conveniente." (1795: 8). En una esclarecedora carta a Charlotte von Stein, en ocasión de su visita al teatro Olímpico de Palladio el 19 de septiembre de 1786, puede quizás encontrarse una clave para barruntar una posible interpretación:

\section{Die größe Schwürigkeit ist immer die Säule- nordnungen in der bürgerlichen Baukunst zu brauchen. Säulen und Mauer zu verbinden, ist ohne Unschicklichkeit beynahe unmöglich, davon mündlich mehr. Aber wie er [Palladio] das durcheinander gearbeitet hat, wie er durch}

383. Así se recoge en Eckermann (1827: 21.1 y 31.1).

Fig. 17. Johann W. Goethe, Dach- und Gebälkkonstruktion des dorischen Tempels nach Vitruv [Construcción de cubierta y vigas del témplo dórico según Vitruvio], sept./ oct. $1786(205 \times 286 \mathrm{~mm}$. Lápiz, tinta con pluma), en Femmel [1958] 1972, III: 94 
384. "La mayor dificultad es siempre utilizar los órdenes de las columnas en la arquitectura civil. Unir columnas y muros es casi imposible sin deshonestidad, de palabra más. Pero la manera en que [Palladio] lo ha solucionado, la manera en que con la presencia de su obra impresiona y hace olvidar que son monstruos. Hay realmente algo de divino en sus obras, el verdadero poder del gran poeta, del que puede crear a partir de la verdad y la falsedad un tercer término que nos hechiza." Véase el apartado "Dibujo arquitectónico", en el que se recoge un comentario similar de Winckelmann sobre la articulación entre el muro y la columna a propósito de las ruinas de Agrigento.

385. "Hay realmente algo de Divino en sus obras, algo enteramente igual al poder del gran poeta, que de verdad y mentira forma una tercera cosa, cuya híbrida existencia nos encanta." (V. It., III: 1069) Respecto al calificativo "Divino" [göttliches] Assunto hace un comentario muy sugerente (ver nota anterior), en este caso solo aplicable a la versión de los Viajes italianos, dado que en la carta a von Stein "göttliches" aparece escrito en minúscula. Cansinos, por otra parte, tampoco recoge esta variación en su traducción.

386. Así queda sugerido, más adelante, cuando comenta: "Se [Palladio] ha movido en esta profesión con plena die Gegenwart seiner Wercke imponirt und vergessen macht daß es Ungeheuer sind. Es ist würcklich etwas göttliches in seinen Anlagen, völlig die Force des großen Dichters der aus Wahrheit und Lüge ein drittes bildet das uns bezaubert. (1991, II-3: 63) $)^{384}$

Algo igualmente recogido el 19 de septiembre 1789 en Italienische Reise:

Es ist wirklich etwas Göttliches in seinen [Palladio] Anlagen, völlig wie die Force des großen Dichters, der aus Wahrheit und Lüge ein Drittes bildet, dessen erborgtes Dasein uns bezaubert. ${ }^{385}$

El recurso a la imitación en el fin superior de la arquitectura implica, por tanto, una operación de alto riesgo en la medida en que se introduce "una falsedad". ${ }^{386}$ En términos generales, la "unión de pilastras y muros" da lugar a un monstruo (en el sentido de algo contra-natura, visto como una redundancia bajo la óptica de la racionalidad constructiva y estructural) en la medida en que violenta el proceso de sofisticación al que alude Goethe. No es propio de un edificio, sino fruto de la transposición de características de un edificio a otro. Solo un genio como Palladio puede conseguir, no ya que dejen de ser monstruos estos edificios contra-natura, sino que no lo parezcan. ${ }^{387}$ De igual manera, construir en piedra con la forma conveniente a la madera produce una monstruosidad, tal fue el caso del templo griego. La ficción a la se refiere Goethe es una alteración del rango de verdad en el arte que la arquitectura debe incorporar en su "más alto grado" por medio de la introducción de la falsedad, dando lugar a una tercera instancia, la instancia poética, única posibilidad de estimular espiritualmente al entendido. Puede, por tanto, no ser todo ver- dad lo que en esa arquitectura que satisface el fin superior se represente a condición de que "parezca verdadero y real" (1999: 121). En "Sobre verdad y verosimilitud en las obras de arte" (1798), en efecto, se alude a este proceso que incorpora la ficción por medio de la mímesis: una introducción de la falsedad que, junto con la verdad inherente al arte, da lugar al concepto poético de verosimilitud al introducir un sentido transcendente o sagrado. ${ }^{388}$ De ahí que, en su contextualización histórica por medio de Palladio, Goethe sintetice este postulado como "una ficción doble y una imitación duplicada" (1795: 12). A la primera ficción operada por la imitación mimética (por medio de la genialidad del arquitecto) le sigue una segunda que traslada el resultado a otro contexto que no le es propio por medio de la verosimilitud (gracias al espectador entendido). Es decir, se trata de una mímesis duplicada no sólo de la apariencia sino también de la esencia; y, a su vez, se trata de una ficción doble porque a su semejanza formal el genio es capaz de infundirle, más allá de las reglas, un vínculo que la trasciende y que puede ser captada por el espectador entendido.

La verosimilitud está igualmente relacionada con la capacidad creativa de la metamorfosis. Así lo refleja en Nápoles, el 17 de mayo, a su regreso del viaje de Sicilia en relación con las plantas:

\footnotetext{
La planta primitiva ha de ser la criatura más extraordinaria del mundo, y la Naturaleza misma me la habrá de envidiar. Con este modelo y su clave correspondiente podrán idearse luego plantas y más plantas hasta lo infinito, que no tendrán más remedio que ser consecuentes entre sí, es decir, que aunque no existiesen podrían, cuando menos, existir, no siendo meras
} 
sombras y vislumbres poéticas o pictóricas, sino que, por el contrario, han de poseer verdad y necesidad íntimas. Idéntica ley podrá aplicarse también a todo cuanto vive. (V. It., III: 1254)

La posibilidad de la existencia de la Urpflanze, así como el producto de la doble ficción, basan su verosimilitud en la apariencia de naturalidad. Goethe estaría estableciendo, en este sentido y una vez más, un nuevo vínculo en el ámbito de la ficción en la arquitectura con la mímesis de la naturaleza. El genio, al remitirse al arquetipo proporcionado por la naturaleza, está imitando el poder creativo de la naturaleza, dotando por tanto a la nueva creación de vida propia. Tal como él mismo dice, el arte es otra naturaleza que actúa como tal.

La arquitectura parte del reconocimiento de una condición inicial, su materialidad, y una pulsión hacia la satisfacción del fin inmediato, su funcionalidad. Basta un artesano para conseguir una forma que le sea adecuada a ambas, alcanzando así el fin inmediato de la arquitectura. Basándose en esta constatación y guiado por una idea de tipo arquitectónico, el arquitecto, al aumentar su dominio sobre el material y la función, puede dar lugar a la forma característica, incorporando diversidad y belleza (armonía sensitiva) al edificio. Se ha alcanzado en este punto el fin superior de la arquitectura. En este caso, la percepción de su virtud estética por parte del receptor culto no es visual, sino que se da con la participación de todos los sentidos en el movimiento a través del espacio.

El último de los niveles al que puede alcanzar la arquitectura, aquel que atiende al fin supremo, supone superar el rango sensible gracias a la concurrencia del genio en la creación y el entendido en el disfrute, y alcanzar lo espiritual. La "doctrina de la ficción" es necesaria para no reducir la arquitectura a prosa, esto es, a una aplicación experta que no estimule espiritualmente (1795: 12-13). ${ }^{389}$ Con arreglo al principio poético de la verosimilitud, el arquitecto tocado por el genio añade al edificio, ya bello y de perfecta forma, elementos que no le son propios. El arquitecto genial ha de ejercer en tanto que poeta, lo que de alguna manera remite al comienzo del tratado y señala una suerte de convergencia de todas las artes en el fin supremo: aquello "común a todas las artes" (1795: 3).

\section{Las tres partes de la arquitectura}

Cada parte de la arquitectura puede estar sujeta a su vez a una crítica semejante a la presentada teóricamente respecto del ideal total de arquitectura en la introducción del "Baukunst". Las partes, pues, participan en el todo asumiendo las mismas claves, una tensión entre la inherencia de su forma y función, con la trascendencia del criterio superior de belleza y el supremo de expresión poética. Al tiempo, esta formulación teórica debe interpretarse a la luz de los ejemplos que le siguen en la segunda parte del tratado, de suerte que no puede ser entendido lo uno sin lo otro. Por ello, en lo que sigue, se vinculará cada una de las finalidades de la arquitectura y sus categorías al ejemplo o ejemplos correspondientes, siguiendo la secuencia establecida por Goethe desde los casos más primitivos hasta los más sofisticados.

Tal y como se ha mencionado ya, el estado actual del manuscrito por sí mismo permite deducir que la primera de las partes de la arquitectura, el basamento, está prácticamente acabada. No es el caso de las libertad y cuando sobrepasa sus límites siempre se le perdona, sin embargo, lo que se le reprocha." (1795: 12) 387. La cuestión de la articulación de columna y muro es un problema constante en la teoría clásica. Es sorprendente, en este sentido, que Goethe no se apoye en Winckelmann cuando comenta el templo de Júpiter (Zeus) Olímpico de Agrigento y aporta, además, otros ejemplos romanos (1985: 570), o en Palladio que en su tratado incluye el ejemplo del templo de la Fortuna Viril entre otros. 388. En este sentido conviene recordar que para Aristóteles la poesía expresa una verdad superior a la verdad histórica porque se refiere a aspectos que exceden la mera relación de los hechos (Aristóteles, Poética; 1451 a-b). 389. Esta acusación a aquellos que "convierten todo en prosa" podría venir referida a un notable episodio biográfico de Goethe. Después de años trabajando en su Ifigenia en Táuride, durante su viaje a Italia Goethe finalizó su versión versificada final. El público anhelaba la naturalidad de la prosa anterior y lamentaron que Goethe presentara entonces "más que una heroína, una santa". Véase Cansinos (Goethe, 1991: 1564-1565). 
390. Con el término "Base" Goethe quiere hacer extensible su teoría del tipo arquitectónico referido inicialmente al crepidoma de los templos griegos antiguos a otros ámbitos de la composición arquitectónica: la basa, el plinto, el dado, el estereóbato o el pedestal son, en este sentido, potencialmente incluibles en esta parte de la arquitectura. Palladio, una de sus referencias fundamentales, para expresar una idea semejante sobre la parte inferior de un edificio utiliza el término "basamento" [basamento] cuando se refiere al edificio $(\mathrm{I}, \mathrm{XII}, 15)$ y "Ia parte más baja" [parte piu bassa] diferenciándola de la "basa" [basa] de la columna. Por ello, y por evidenciar la conveniencia de emplear términos arquitectónicos, se ha decidido traducir "Base" por "basamento".

391. Este mismo ejemplo lo aporta Winckelmann que, al hablar de las gradas de los templos de Paestum dice: "Tienen tres palmos romanos de altura por dos palmos y tres cuartos de anchura, de manera que son bastante incómodas para subir por ellas, cosa que no se puede hacer sino con gran dificultad" y, a continuación, generaliza esta opinión a todo tipo de gradas: “Las gradas que rodean el templo de Júpiter Olímpico de Agrigento tienen también esta altura, y las del templo de Teseo, en Atenas, no parece que fueran más bajas. [...] Estas gradas alrededor de los templos eran difíciles de subir" (1985: 552).

392. Escribe en la entrada del 25 de octubre de sus Viajes...: "Los pies de las columnas y las planchas que llevan debajo parecen descansar sobre pedestales, pero sólo lo parecen, [pues los pedestales son en realidad zócalos cortados], y en cada uno de esos cortes suben cinco peldaños por entre las columnas. [...] No es posible precisar el número de peldaños que aún quedarán por debajo [del actual pavimento], pues, salvo unos pocos, todos los demás están soterrados y enlosados." (V. It., III, 1113-1114). Entre corchetes se resalta aquello modificado de la traducción de Rafael Cansinos.

393. Esta interpretación se aleja de la propuesta por Palladio (1570, IV: 103-105) al que Goethe critica (GSA 25/XLV,6), p. 17). Además del tratado palladiano nombrado, según Ugo, Goethe conocía bien el texto, Le fabbriche e i disegni di Andrea Palladio raccolti ed illustrati da Ottavio Bertotti Scamozzi, con la traducción francesa, Vicenza, F. Modena, 1176-1784, en cuatro volúmenes." Y se está refiriendo, así mismo, al libro mencionado de Guattani al que parafrasea (Goethe, 1994: 60, nota 33).

394. Se trata del Templo de Diana. El número del capítulo está equivocado en el tratado de Palladio. En realidad, tal y como cita Goethe, la numeración correcta es el XXIX y no el XIX que figura en el tratado.

395. En relación con el templo de Asís y el templete de Clitumno véase: A. Ghisetti Giavarina, "Palladio e le antichità dell'Umbria", Annali di architettura. Rivista del Centro Internazionale di Studi di Architettura Andrea Palladio di Vicenza, 2006-2007.

Fig. 18. Andrea Palladio, Templo de Clitumno (1570, IV: 100)

Fig. 19. Johann W. Goethe, (sin título), 1795 (folio: 342x211 mm., dibujo: 102×50 mm. Lápiz, tinta con pluma, lavado a sepia), en Femmel [1958] 1972, Vla: 155

Fig. 20. Johann W. Goethe, Tempelfassade [Fachada de templo], hacia 1792 (188x143 mm. Lápiz, tinta con pluma, lavado a sepia), en Femmel [1958] 1972, IVb: 95 dos restantes. En los casos de la columna y la cubierta apenas si se puede barruntar las ideas generales que debieron guiarlas gracias a los escritos previos y preparatorios.

\section{El basamento 390}

El interés de Goethe por los basamentos, desarrollado en el primer apartado de la segunda parte del Baukunst "Basamentos de los edificios en su conjunto", había sido ya explicitado durante su viaje a Italia. En concreto, durante su visita a Segesta en Sicilia, Goethe realizó un dibujo en su cuaderno (Vla: 140) y describió su perplejidad al no poder determinar si las columnas del templo tuvieron o no zócalo (1991, III: 1217). En el caso desarroIlado por Goethe por medio de dos dibujos en el Baukunst (1795: 15), la funcionalidad del acceso al interior del templo condujo al desarrollo de peldaños continuos por todo su perímetro. Pero, al proporcionarlos según las dimensiones totales del edificio, buscando la belleza y aplicando la doctrina de la proporción, adquirían una altura impracticable, lo que obligó, en consecuencia, a añadir escalones intermedios en el frente principal. ${ }^{391}$

Este ejemplo demuestra para Goethe cómo la armonía de los sentidos en la proporción de un edificio está siempre unida a su originaria funcionalidad y, por tanto, no depende de añadidos ornamentales. Por otra parte, a eso responde la aparición de la moldura en voladizo de los peldaños en época de Augusto. Según Goethe, este ejemplo anticipa el podio romano in antis al jerarquizar los lados del crepidoma, potenciando el frontal y eliminando los laterales. Se consolida, así, por exigencias funcionales un nuevo tipo arquitectónico que conlleva, a su vez, nuevos desajustes que han de ser resueltos y que tiene 
como horizonte la aparición de "las columnas sobre pedestales totalmente independientes" (1795: 17).

Con arreglo a su planteamiento progresivo, el fin supremo sigue al superior. Así como la belleza sensible se desarrolla a partir de la funcionalidad, desde el fin superior surgirá el fin supremo a través de pasos morfológicos intermedios. En este sentido, el caso del templo de Asís, que Goethe estudió en su primer viaje a Italia con gran entusiasmo, es sólo un ejemplo transicional en apariencia. ${ }^{392}$ Por necesidad, puesto que no se dispone de apenas espacio para su desarroIlo, la escalera penetra más allá de la línea de columnas. El efecto es así semejante al de las columnas sobre pedestales, cuando en realidad "descansan sobre el suelo del vestíbulo, que tan sólo está interrumpido por la escalera" (1795: 17). ${ }^{393}$ Se dan, en cambio, ejemplos en los que los pedestales aparecen aislados aun cuando no hay escaleras, es decir, cuando no están sometidos a la necesidad (contrariamente al caso de Asís). Esta es la clave de la ficción poética. Para ilustrarlo, Goethe hace mención de dos casos recogidos en los Quattro libri dell'architettura. Si en el "Otro templo de Nimes" -como lo llama PaIladio-394 los pedestales son el resultado de la prolongación de la basa de la columna, en el Templete que recuerda al de Clitumno, por el contrario, están los "basamentos divididos" (1795: 17). De este último edificio, Goethe incluye en su tratado una reproducción parcial. ${ }^{395}$ (Figs. 18, 19 y 20)

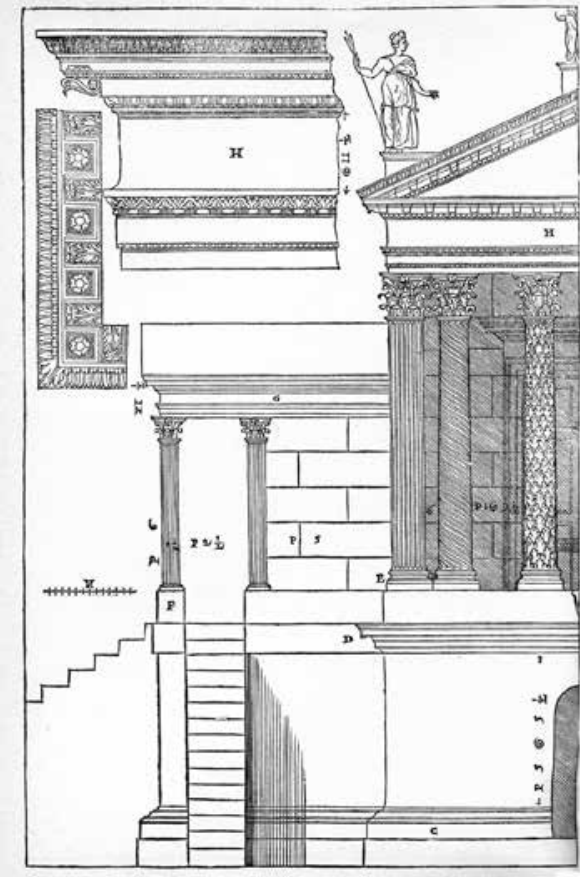

Fig. 18

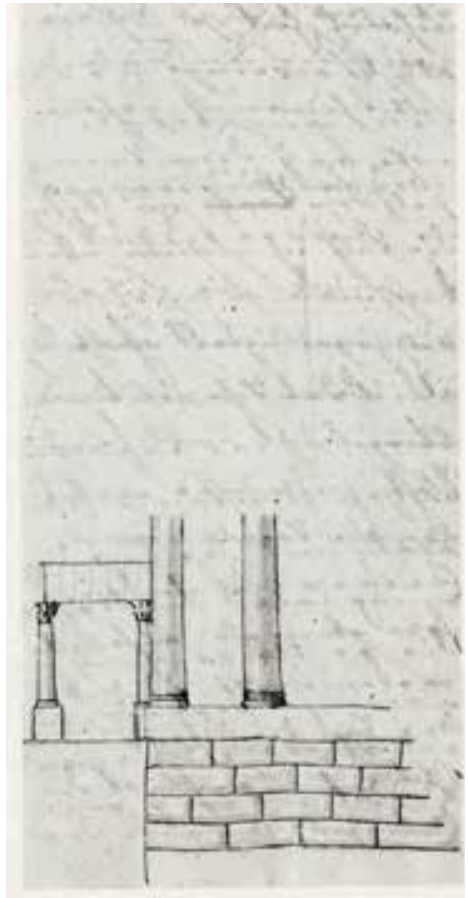

Fig. 19

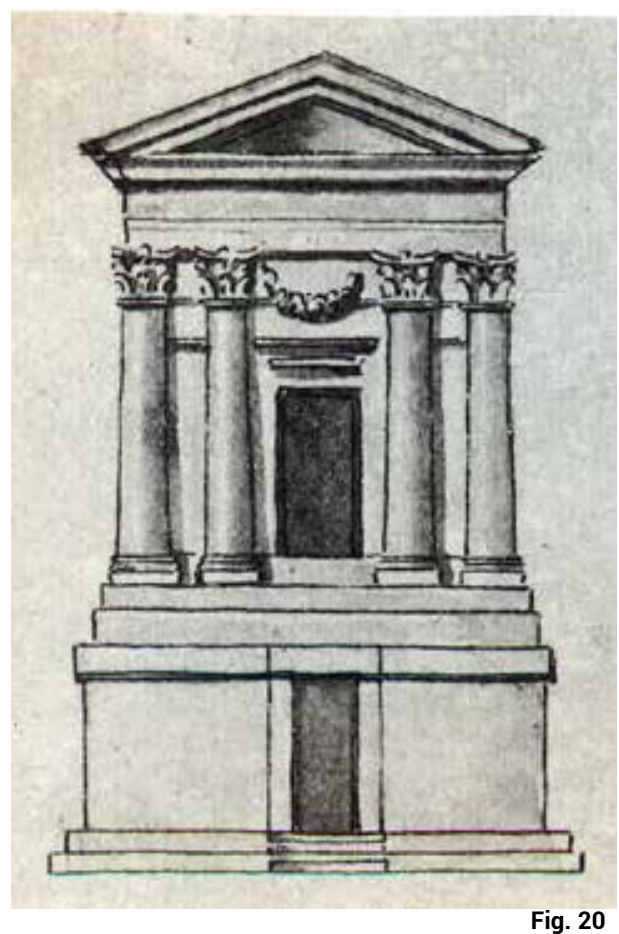


396. También sobre el templo de Clitumno (según Kruft, 1982), Goethe realizó otro dibujo unos años antes (IVb: 95). Le interesaba, en este caso, la posibilidad de que el basamento del templo se quebrase por la inclusión de un acceso. Nótese el detalle del peldañeado. Esto podría señalar que, en 1792, Goethe no había establecido aun la progresión del basamento tal y como la redactó en 1795 , lo que concordaría con el hecho de no haber sido tratada esta parte de la arquitectura en su escrito Baukunst de 1788.

Por otra parte, ha sido

señalada la cercanía de este dibujo a la fachada de la Römische Haus de Weimar, lo que corroboraría que este tipo de disquisiciones teóricas estaban íntimamente vinculadas a motivaciones prácticas

Fig. 21. Johann W. Goethe, (sin título), 1795 (folio: 342×211 mm., dibujo: 60×105 $\mathrm{mm}$. Lápiz, tinta con pluma, lavado a sepia), en Femmel [1958] 1972, Vla: 155 rs. 397. En los edificios urbanos, incluso en aquellos donde tuvo libertad, Palladio solo llegó a concebir el pedestal como basamento dividido. Es el caso, por ejemplo, del palacio Valmarana (Palladio, 1570, II, 17). Durante su estancia en Vicenza, Goethe dibujó la parte de la fachada existente del palacio Porto-Breganze de Palladio (III: 2), aunque con un zócalo continuo cuando, en realidad,

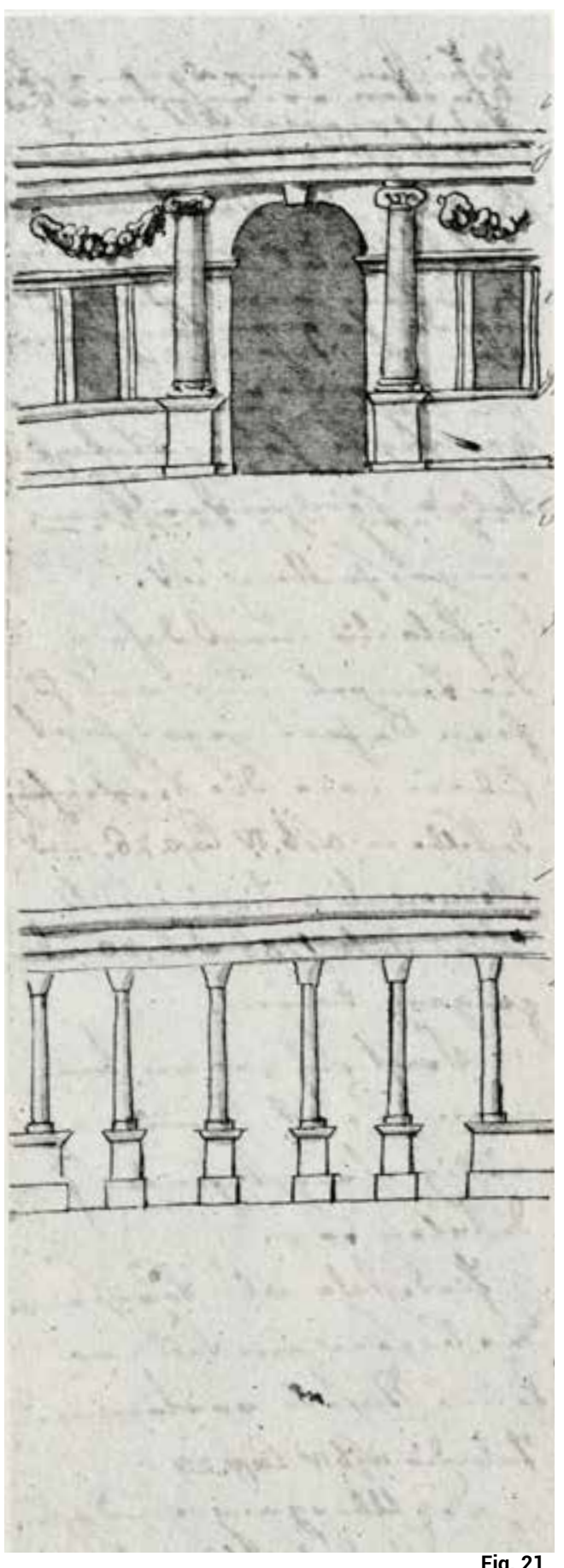

El punto de partida hacia la consecución del fin supremo en esta parte de la arquitectura lo constituye el zócalo continuo. Por medio de la metamorfosis del basamento, se tiende a un tipo de pedestal independiente con las basas divididas. ${ }^{396}$ Tras estas diversas fases transicionales en época clásica, fue Palladio quien pudo potenciar el carácter de sus construcciones y aumentar la diversificación de las soluciones, alcanzando así su forma más evolucionada. Aunque Goethe reconoce, en este sentido, que Palladio apenas superó la concepción de los pedestales como proyecciones de las bases en la mayoría de sus edificios (tal y como recoge en el primero de los siguientes dibujos). No obstante, hay un ejemplo de pedestal independiente para Goethe, aunque sólo sea "como prolongación ideal del basamento" (1795: 18). (Fig. 21)

No en vano, la segunda imagen representa la columnata de una villa - posiblemente la Villa Thiene (Palladio, 1570, II: 64)-,

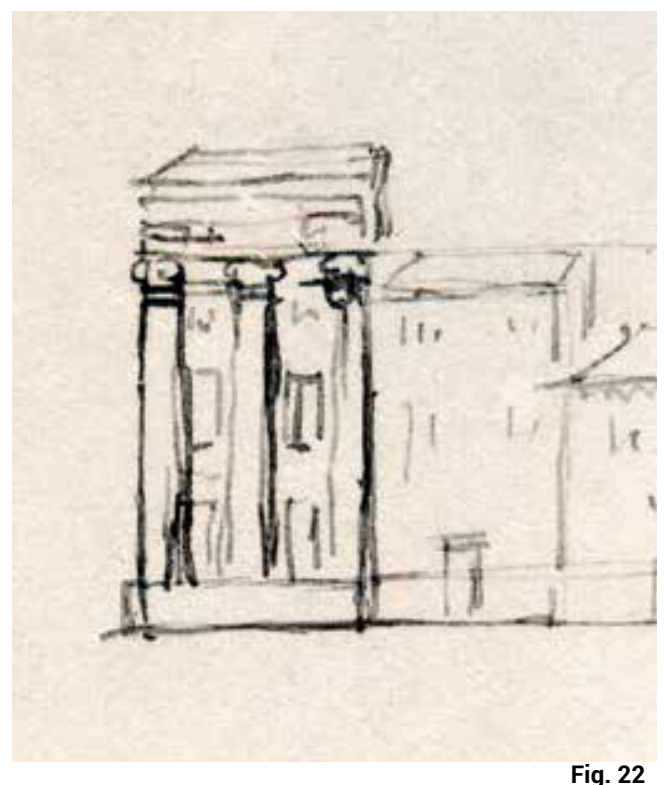


donde "tuvo mayor libertad" en comparación a sus edificios urbanos. ${ }^{397}$ (Fig. 22) Goethe señala la continuidad de la horizontalidad del basamento originario a un lado y otro de la columnata (1795: 19). El arquitecto deja de lado las exigencias de la necesidad y se eleva a un estatus de libertad que puede alumbrar la "ficción poética" en la arquitectura, aspiración última de este arte al trasladar elementos propios de los templos a la arquitectura civil. ${ }^{398}$ En este ámbito, Goethe destaca la figura de Palladio, quien "se ha movido en esta profesión con plena libertad" (1795: 12). Así como el artesano cumple con el fin inmediato de la utilidad y es necesario un artista para hacer de un edificio una obra de arte para los sentidos, se requiere un genio para que esta alcance valores poéticos y pueda aplicar, sin dar lugar a una monstruosidad, la exigida imitación en el grado más elevado del desarrollo de la arquitectura.
Por último, en una serie de cinco dibujos, para los que ya no llegó a redactar el correspondiente texto aclarativo, Goethe parece establecer una recapitulación de sus deducciones para la parte del basamento.

Goethe dedicó durante 1795 mucha atención a este tipo de fachada como lo demuestra una serie de dibujos fechados durante el periodo de redacción del Baukunst (IVb: 98; IVb: 98R; IVb: 99; IVb: 99 r; IVb: 100, IVb: 101, IVb: 102, IVb: 103). (Figs. 23 y 24) En ellos es evidente el interés de Goethe por mostrar la evolución de estas fachadas burguesas por medio de las sucesivas perforaciones de lo que, en origen, él identifica con el estilóbato de un templo y que, tras la operación metamórfica, constituye propiamente la planta baja del edificio. ${ }^{399}$ En uno de ellos (IVb: 99 r.), una serie de tres fachadas semejantes atiende a la transición desde el renacimiento italiano al clasicismo, por lo que los pedestales están resaltados (la fase de transición para Goethe)

Fig. 22: Johann W. Goethe, "Ca' del Diavolo" (Palazzo Porto Breganze, Vicenza), sept./oct. 1786 (116x98 mm. Tinta con pluma), en Femmel [1958] 1972, III: 2

398. Recuérdese, en este contexto, que para Schiller la belleza se presenta como la representación sensible de la moralidad: "Analogía de una apariencia con la forma de la voluntad pura o de la libertad es belleza (en su acepción más amplia). / Belleza no es otra cosa que libertad en la apariencia." (1990: 21).

Fig. 23: Johann W. Goethe, Fassaden [Fachadas], 1795 (191×228 mm. Lápiz, tinta), en Femmel [1958] 1972, IVb: 99 r.

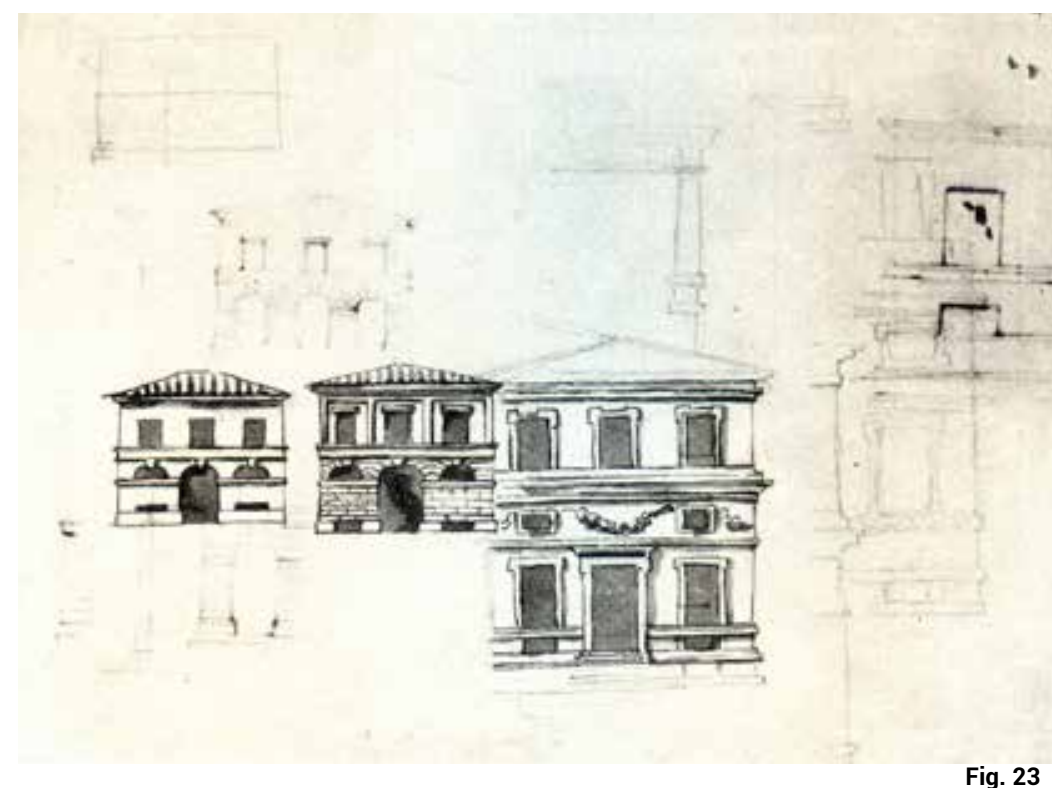

Fig. 23

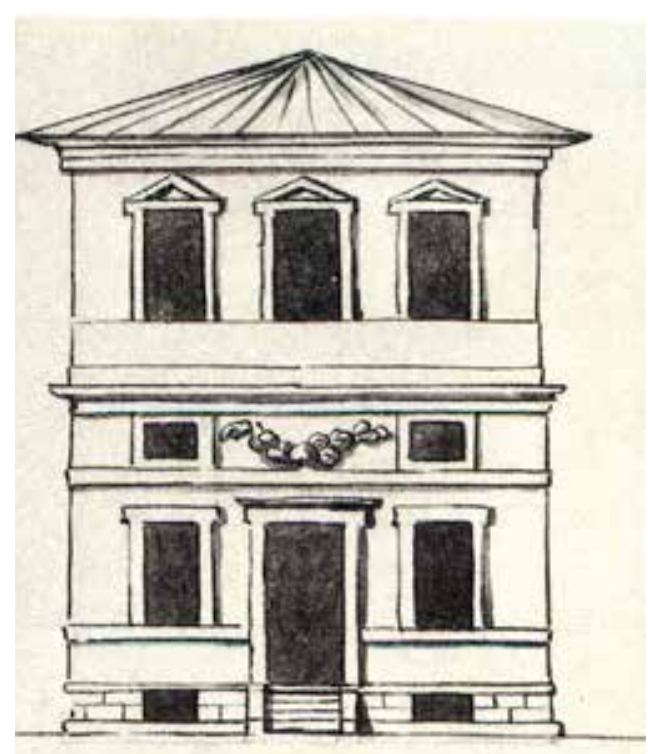

Fig. 24 
Fig. 24: Johann W. Goethe, Renaissanceistische Fassade [Fachada renacentista], 1795 (228x192 mm. Lápiz, tinta con pluma), en Femmel [1958] 1972, IVb 101

399. Hay que señalar que en todos estos esquemas no aparecen ni pilastras ni semicolumnas, con la excepción de una fachada del dibujo IVb: 99 rs. y el IVb: 103 en los que hay pilastras en el piso superior. 400. Se trata en muchos casos de ejemplos extraídos de los tratados que manejaba: Vignola, Palladio, Serlio, Scamozzi, etc. Vitruvio, tras la explicación de los órdenes, dedica un capítulo a las proporciones de las puertas de los templos diferenciando entre dóricas, jónicas y corintias (lib. IV, cap. VI). La ornamentación de los recercados de los huecos, puertas y ventanas, era un tema recurrente en los tratados y, posiblemente, Goethe tenía previsto abordar esta cuestión.

Fig. 25: Johann W. Goethe, Fensterrahmen in dorischer und Compositordnung [Recercados de ventana en orden dórico y compuesto], 1795 (227×191 mm. Lápiz, tinta con pluma, lavado a sepia), en Femmel [1958] 1972, IVb 108

Fig. 26: Johann W. Goethe, Türrahmen [Recercados de puerta], 1795 (88x101 mm. Lápiz), en Femmel [1958] 1972, IVb 107

Fig. 27: Johann W. Goethe, Fensterrahmen in der Compositordnung [Recercados de ventana en orden compuesto], 1795 (227x191 mm. Lápiz,
Goethe parece estar señalando una progresión morfológica histórica.

En el caso de otros dibujos, Goethe ensaya adaptaciones de recercados con arreglo a los órdenes (IVb: 107; IVb: 108; IVb: 109; IVb: 110). ${ }^{400}$ (Figs. 25, 26 y 27) De nuevo, varios dibujos de ese periodo remiten al mismo motivo (IVb 97/103 como parte de una fachada, IVb: 104, como elemento singularizado: zócalo de una vivienda con arreglo al orden dórico). Incluso uno de ellos establece explícitamente sus proporciones (IVb: 105).

Todos ellos son ejemplos para Goethe de la multiplicidad de maneras de abordar la metamorfosis del basamento. Con esta serie de cinco dibujos, Goethe parece querer mostrar, en este caso solo gráficamente puesto que falta el texto que debería acompañarlos, la progresión desde los ejemplos más primitivos de estilóbatos perforados por las escaleras de acceso a la transposición de elementos arquitectónicos propios de los templos a los edificios civiles en forma de zócalos o balaustradas por medio del mecanismo de la imitación.

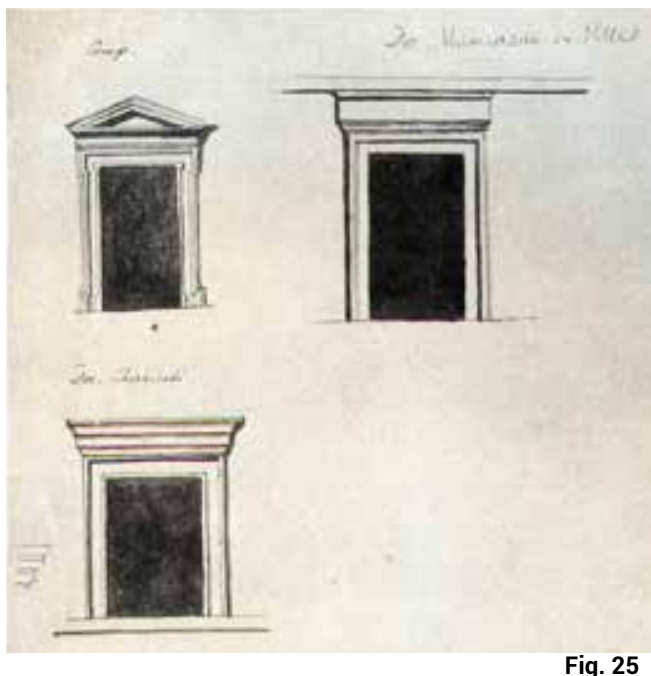

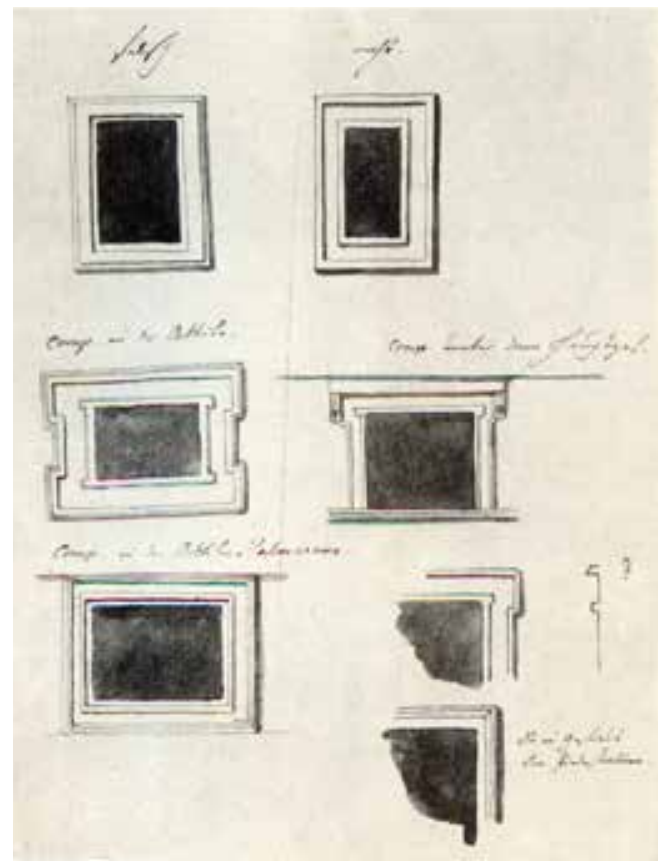

Fig. 27

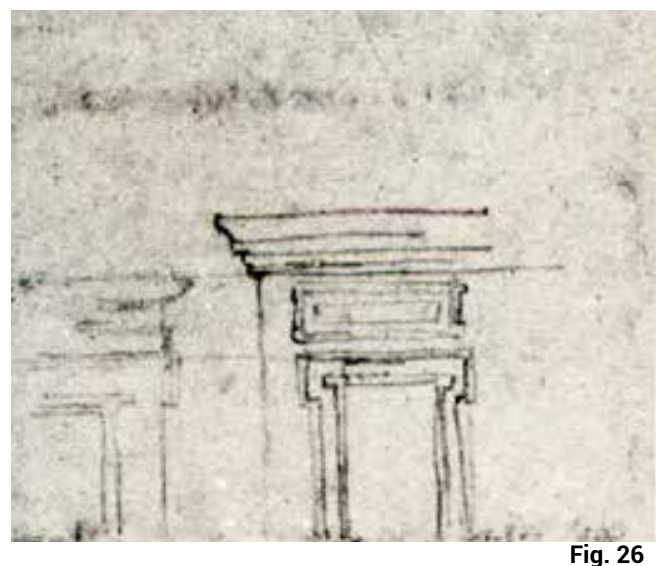


El hecho de que no terminase la redacción de este apartado podría interpretarse como un indicio de las dificultades a las que tuvo que hacer frente. En efecto, la progresión hacia el basamento independiente parece conducirle a su disolución en las fachadas burguesas clasicistas. Quizás, en cambio, la idealización de esta progresión quedase plasmada en un dibujo, fechado entre 1795 y 1797, en el que Goethe representa un perfil de pedestal y la basa de una columna con excepcional detalle. (Fig. 28) Bien podría entenderse como un singular ejemplo del basamento finalmente independiente. ${ }^{401}$

\section{La columna}

A continuación del último dibujo referente a los basamentos de los edificios, tras tres pá-

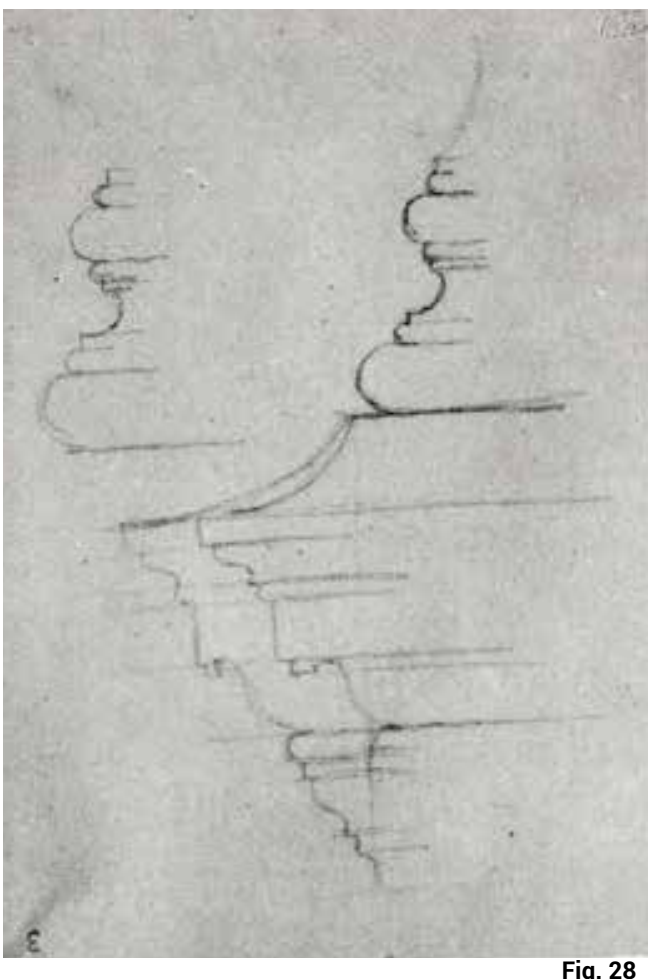

ginas en blanco, en la página 23 del Baukunst se recoge una tabla de órdenes de columnas clasificados en función de cada una de sus divisiones: los capiteles, los fustes ["columnas"] ${ }^{402}$ y las basas ["basamentos"]. ${ }^{403}$ Dos párrafos completan toda la documentación que fue recogida en el Baukunst respecto de esta segunda parte de la arquitectura. Es de suponer que el hueco dejado libre responde a la íntima convicción de Goethe de no cerrar el Baukunst, al menos en el manuscrito que había trabajado hasta entonces. Presumiblemente, esta segunda parte de la arquitectura, así como la tercera, hubiera seguido un desarrollo similar a la primera y, por tanto, cabría esperar un texto corrido y dibujos.

En la tabla de órdenes establece una gradación cronológica ${ }^{404}$ por medio de cada uno de los estilos: el toscano, el dórico, el jónico, el corintio y el compuesto, distinguiendo entre órdenes antiguos y nuevos. ${ }^{405}$ Esta clasificación, responde a un análisis muy extendido ya desde el Vitruvio según el cual la aparición de los órdenes respondía a un impulso hacia la estilización de sus formas. Goethe justifica de esa manera la aparición del jónico en su Baukunst de 1788, ${ }^{406}$ en la medida en que "el ojo buscase siempre algo más esbelto y el espíritu creyese experimentar de este modo mayor grandeza y libertad". El jónico aparece motivado, pues, por la tendencia en la arquitectura a la esbeltez. ${ }^{407}$ Las generaciones posteriores siguieron encontrando en la esbeltez motivo de agrado $y$, de ahí, que el estilo siempre se desarrollase en esa dirección y diese lugar posteriormente al corintio y al compuesto, aunque Goethe no mencione explícitamente este desarrollo. En sus dibujos Goethe suele representar por separado las partes de la columna, capiteles, tinta con pluma, lavado a sepia), en Femmel [1958] 1972, IVb 109

Fig. 28. Johann W. Goethe, Piedestal- und Säulenbasisprofile [Perfiles de pedestal y basa], 1795/1797 (208x220 mm. Lápiz), en Femmel [1958] 1972, Vla: 158. Este dibujo está girado $180^{\circ}$ respecto de su versión publicada para que el perfil se visualice en su correcta posición.

401. No es casualidad que dicho perfil recuerde los dibujos del tratado de Palladio (en concreto el pedestal corintio: lib. I, cap. XVII p. 43) y el de las semicolumnas interiores de la iglesia de San Giorgio Maggiore en Venecia.

402. Goethe escribe "Säulen", término que se traduce habitualmente por columnas, para referirse a la división central de la columna, aquella situada entre el capitel y la basa. Técnicamente se trata del fuste de la columna y la referencia al éntasis así lo corrobora. Por otra parte, esta mención explícita al éntasis contradice la tesis de Winckelmann cuando escribe: "Las columnas iban disminuyendo en la parte superior, imitando en esto a los troncos de los árboles, y el abombamiento, que Vitruvio Ilama éntasis, sobre el cual se extiende mucho, no se ve en ninguna de las columnas de los grandes edificios; pero sí en algunos pequeños, de tiempos más remotos. Hay que añadir que este abombamiento no añade ninguna gracia a las columnas." (1980: 541). 
403. Goethe escribe en este punto "Basen", término igualmente utilizado para referirse a la parte de la arquitectura precedente. En este caso, en cambio, es evidente que Goethe se está refiriendo específicamente a los elementos que constituyen una columna, en este caso, la basa de la columna. Una vez más, esta falta de precisión en el empleo de los términos nos alerta sobre ciertas carencias en la formación técnica de Goethe. En este punto queda claro, por otra parte, una significativa diferenciación de la división en partes de la arquitectura operada por Goethe respecto de aquella propuesta por Palladio y los tratadistas. Estos últimos vinculaban el estilóbato a la columna, en tanto que Goethe, como se ha podido mencionar con anterioridad, lo incluye claramente en la parte del basamento del edificio.

404. Goethe no habla específicamente de establecer una cronología, pero puede deducirse que su intención era señalar una progresión temporal atendiendo a la división de estilos que propone, dividiendo entre arcaico y nuevo, y por el cierre de la tabla con el estilo "compuesto más reciente". 405. Vitruvio (lib. IV, cap. I) sólo menciona tres órdenes (dórico, jónico y corintio) aunque en un capítulo posterior (Lib. IV, cap. VII) habla del templo toscano dejando abierta la posibilidad de que se considerara un cuarto orden. En consecuencia, Alberti menciona cuatro: dórico, jónico, corintio y toscano. Rafael en su Memoria a León X cita cinco: dórico, jónico, corintio, toscano y ático (Ray, 1974: 369). El listado que se convirtió en definitivo lo recogió Serlio al identificar el cuarto nivel del anfiteatro de Vespasiano como el orden compuesto (que Winckelmann llama romano), estableciendo así la clasificación canónica de todos los tratadistas posteriores como Palladio (lib. I, cap. XII): toscano, dórico, jónico, corintio y compuesto, que es también la utilizada por Goethe. Por otra parte, Goethe no distingue historiográficamente entre órdenes griegos y romanos. Esto resulta especialmente significativo a la luz de su cambio de opinión sobre el dórico arcaico de Paestum antes y después de su visita a Sicilia. De un inicial rechazo, principalmente motivado por estar acostumbrado a las formas romanas, pasa posteriormente a reconocer su valor. Véase para más detalle el apartado «Monumentos, ruinas».

406. Por las evidentes correspondencias entre las versiones del Baukunst de 1788 y 1795 cabe deducir que, en lo que a las columnas se refiere, las tesis manejadas por Goethe apenas variaron. 407. De nuevo, referencia explícita a Vitruvio, capítulo 1, libro IV.

Fig. 29: Johann W. Goethe, Toskanische Ordnung nach A. Palladio QL 19/20 [Orden toscano según Palladio QL 19/20], 5.10.1786 (206x143 mm. Lápiz, tinta con pluma), en Femmel [1958] 1972, Vla: 131

408. Este punto Goethe lo ilustra en el Baukunst (1788) con el uso en Egipto del granito y la imposición, por sus cualidades, de una cierta forma más estilizada a la que se da en la Grecia arcaica. 409. Se trata de un templo tetrástilo, con un profundo pronaos que se sitúa sobre un alto pódium. Dórico con basa cuadrada. Actual Cori, provincia de Latina, región de Lazio. No consta que Goethe lo visitase.

Winckelmann al comentar la evolución histórica del dórico se refiere al templo de Cora en el punto "30. Otra posible forma del orden dórico": "Las columnas dóricas de este edificio, cuyo diámetro al pie de la columna tiene tres palmos y un cuarto, y en la parte alta del fuste es de dos palmos y ocho pulgadas, tienen siete palmos de altura, sin contar la base ni el capitel, y la altura total es de veintisiete palmos y diez pulgadas." (1985: 543) y lo considera como una cuarta etapa en la evolución del dórico (1985: 544)

410. La utilización que hace Goethe del término en plural (órdenes) y aunque no lo menciona explícitamente parece referirse a un problema relevante en la teoría clásica renacentista: la superposición de los órdenes en un edificio de varias plantas. La composición canónica la estableció Alberti en el patio del palacio Venezia en Roma al tomar como referencia la secuencia del Coliseo. A partir de ese momento se consideró que la superposición correcta es: dórico o toscano, jónico, fustes y basas (IVb: 111 y IVb: 112) alguno de los cuales se podría pensar que están elaborados para su inclusión en el manuscrito. (Fig. 29)

Esta tendencia a la estilización es un impulso inherente en la arquitectura, que viene condicionado por las sucesivas formas adecuadas a los materiales empleados. ${ }^{408}$ Es, de hecho, históricamente constatable la tendencia a la estilización, no solo en el paso de un orden a otro, sino también en el seno de cada orden. Ello se muestra paradigmáticamente para Goethe en el caso del dórico, como así lo prueba el templo de Cora, ejemplo aludido tanto en el Baukunst (1788) como en la tabla de órdenes del Baukunst (1795), ${ }^{409}$ donde, de hecho, el templo de Cora corresponde al "dórico nuevo", de lo que puede deducirse que la distinción entre antiguo y nuevo atiende fundamentalmente a estadios de transición hacia la estilización y

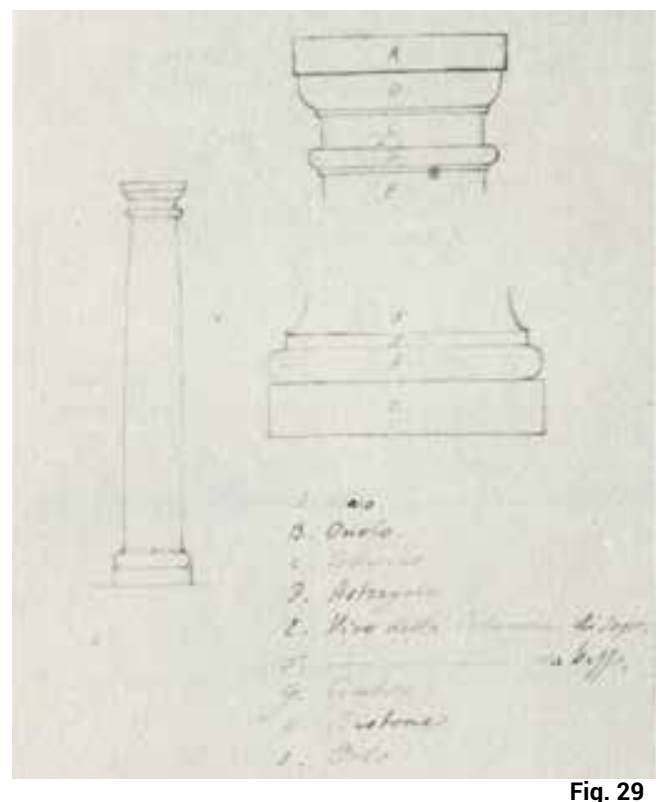


quizás, también, a la existencia de basa en la columna.

A esta progresión histórica, bajo el impulso de la esbeltez, cabe añadir un elemento clave en el contexto del análisis de los órdenes de columnas, cuestión que interesó a Goethe ya desde su visita a Vicenza. Al teatro Olímpico de Palladio se remite a la hora de señalar la importancia del "adecuado empleo de los órdenes de columnas" (1963, III: 42). ${ }^{410}$ A la luz de los apuntes dejados por Goethe en el Baukunst (1795), este adecuado empleo de los órdenes podría señalar una doble articu-

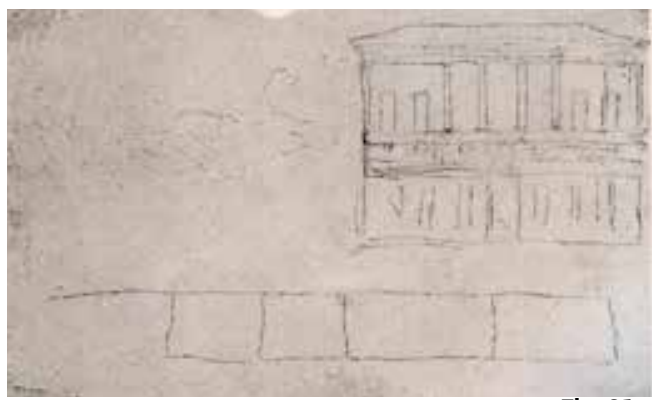

Fig. 31

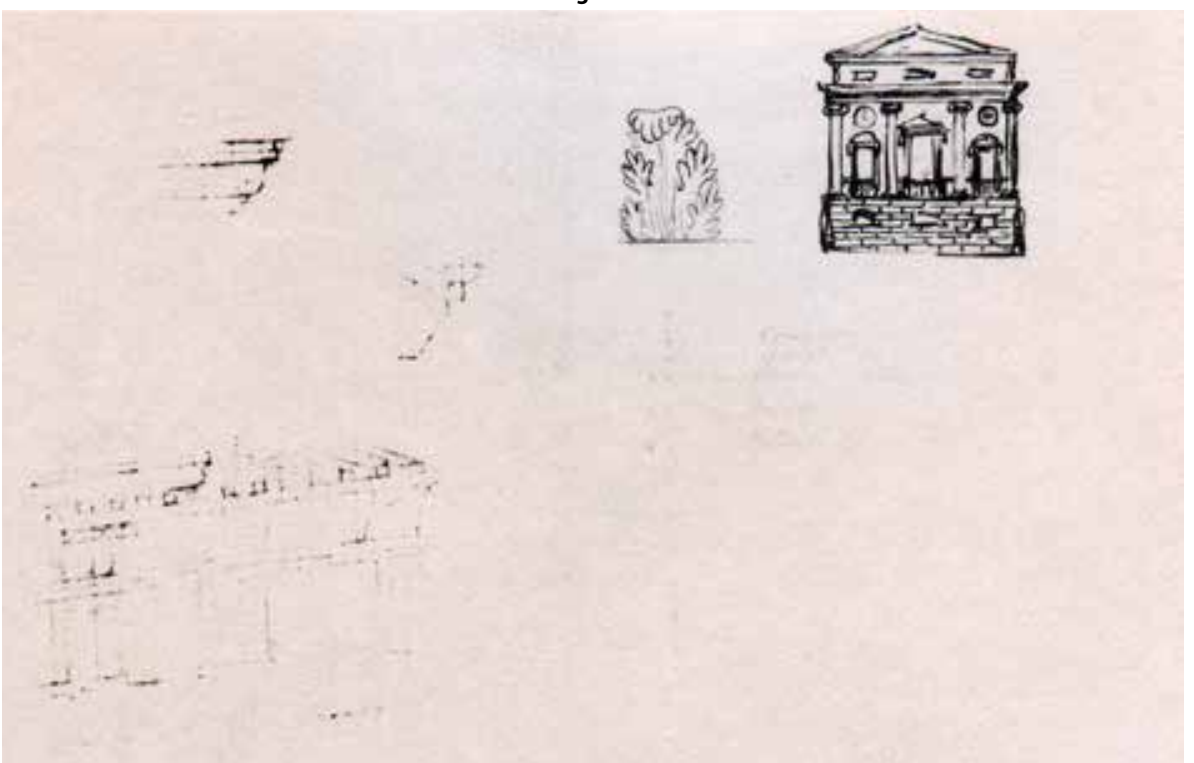

lación del orden con el edificio. ${ }^{411}$ En el dibujo inferior apenas esbozado a lápiz de la página 19 del Baukunst (1795) antes mencionada se representa la fachada de un edificio de dos plantas articuladas con un solo orden gigante jónico. La sucesión de los dos dibujos de esta página parece plantear implícitamente un argumento lógico que se desarrolla desde el templo sobre un alto podio al edificio de dos plantas y sirve de charnela entre el apartado del basamento al de la columna. El paso siguiente al que tal vez alude el dibujo del zócalo perforado con una ventana del folio siguiente (página 20) correspondería al podio convertido en planta baja y, en consecuencia, el orden se desplegaría en el piso superior. Y siguiendo esta misma lógica la fase posterior consistiría en añadir un ático abriendo huecos en el friso, una solución que sería coherente con las metopas huecas que comenta en el Baukunst (1788). En los dibujos que Goethe realiza paralelamente a su trabajo corintio y compuesto. En su teatro Olimpico Palladio se ajustó al modelo vitruviano que él mismo había dibujado para la edición del Vitruvio de Bárbaro (1567, libro V, pp. 253-254): columnas corintias en el piso inferior, y compuestas en el superior.

411. El traslado de la superposición de los órdenes a la composición de la

fachada de un edificio de varias plantas, además de la cuestión debatida por Goethe de la articulación del muro con las columnas, tuvo diferentes soluciones. 0 bien se consideraba un solo orden en la planta superior y se tomaba la planta baja como el basamento (como el proyecto de Bramante en la llamada Casa de Rafael), o bien se desarrollaban las plantas en el muro posterior unificando toda la altura con un solo orden gigante (como la propuesta de Miguel Ángel en el palacio de los Conservadores del Campidoglio de Roma), o bien se seguía una superposición de órdenes haciéndolos coincidir con las distintas plantas. Palladio realizó obras de los tres tipos: un solo orden sobre basamento rústico (p. e. el Palazzo Thiene), un orden gigante abarcando toda la fachada ( $p$. e., el Palazzo Porto Breganze dibujado por Goethe en III, 2, $19 / 25.09 .1786$ ) y ordenes superpuestos (p. e., el Palazzo Barbarano). A juicio de Goethe, las soluciones adoptadas por Palladio fueron las más 
adecuadas en su trasposición a la arquitectura civil, tal y como se ha referido en referencia al teatro Olimpico en la carta a von Stein (19 de septiembre de 1786) y recoge en sus Viajes.

Fig. 30: Johann W. Goethe, (sin título), sept./oct. 1786 (205x286 mm. Lápiz, tinta con pluma), en Femmel [1958] 1972, III: 94 rs.

Fig. 31: Johann W. Goethe Fassade der Gartenseite [Fachada al jardín], verano/ otoño 1787 (139x229 mm. Lápiz), en Femmel [1958] 1972, III: 66 rs

412. Se refiere al pasaje de Vitruvio en el que justifica el paso al jónico porque el dórico "siempre resultará defectuoso en alguna parte" (1980: 93). Al relacionar las principales diferencias entre el dórico y el jónico Goethe no menciona, sin embargo, la inclusión de los dentículos. Winckelmann refiriéndose al orden dórico escribe: "Las características del orden dórico son, además, el tener triglifos en la parte central o más ancha del entablamento, parte llamada friso; gotas en el arquitrabe y dentículos en

la parte inferior de la cornisa." (1985: 541-542).

413. Este entrelazamiento del orden característico materializado fundamentalmente en las columnas con el resto de elementos del edificio se manifiesta en la articulación de las columnas con los muros, en la medida en que las "semi-columnas en el muro en el texto aparecen todas estas alternativas. (Fig. 30 y 31 )

Por otra parte, emplear adecuadamente el orden supone ajustarse a sus reglas, desarrolladas por medio de sucesivas variaciones morfológicas que, en el caso paradigmático del dórico derivan del origen de la construcción en madera (Goethe, 1795: 8). Se trataría en este caso de la imitación más directa, propia del fin inmediato. En el Baukunst (1788), de hecho, alude citando a Vitruvio (Capítulo 3, Libro IV, "Del orden dórico") al paso siguiente dado por el arquitecto Hermógenes. Según Goethe para Vitruvio la introducción del jónico es consecuencia del impulso hacia la esbeltez, y por coherencia con el resto de elementos del edificio, en concreto, el capitel y el friso:

\section{El orden jónico se diferenció pronto del dórico, no sólo por medio de la altura más proporciona- da de la columna, por un capitel más decorado, sino principalmente prque los triglifos fueron eliminados del friso, evitando las siempre inevi- tables discontinuidades en su introducción. ${ }^{412}$}

Su teoría de la trasposición de las formas de una materia a otra es, pues, aplicable en la aparición del dórico pero, a continuación, es la exigencia de coherencia entre las partes de la arquitectura, como los frisos, la que empuja la aparición del jónico. Sin embargo, Goethe duda de esta justificación para apuntar a una cuestión que refuerza sus tesis sobre la importancia del material como condición previa. Dice: "yo, en cambio, prefiero con creces pensar que, al ver los bellos bloques de mármol frente a él, este hombre prefirió destinarlos a una construcción más complaciente y encantadora, en la medida en que la materia no dificultaba la ejecución".
En este contexto podría iluminarse la nota, un tanto críptica, que aparece deshilvanada en el primero de los párrafos: "Para los materiales encontrados, por ejemplo columnas, encontrar la arquitectura restante" (1795: 25). Se trataría, por tanto, una vez caracterizadas las columnas con arreglo a sus órdenes, de establecer correspondencias con el resto de elementos que constituyen el edificio, en este caso el templo clásico: el basamento, el entablamento, la cornisa, el frontón... Esta correspondencia, advierte Goethe, entraña un cierto riesgo, "sobre todo si al mismo tiempo se daba también la necesidad de la casa." (1795: 25) 413 $^{13}$ en vano se trata de la segunda imitación, aquella a la que Goethe apela para alcanzar el fin supremo en la arquitectura introduciendo la parte poética, según la cual se estaría trasladando a la arquitectura doméstica características que son propias de la arquitectura sagrada. ${ }^{414}$ Esta operación, como se ha podido señalar, solo puede dar lugar a una arquitectura que no se reduzca a su monstruosidad si es emprendida por un genio. Con ello, además, Goethe sigue la tradición tratadística: el origen de la arquitectura estaría indiscutiblemente ligado al templo. Sobre esta tesis ya se posicionó explícitamente en el Baukunst (1788):

\footnotetext{
Los templos dóricos del orden más antiguo [...] nos llevan a pensar con naturalidad que no fue una cabaña de madera aquella que en primer lugar constituyó aquel remoto caso.
}

A diferencia de lo que plantea Vitruvio, del que destaca despectivamente "el cuento de la cabaña". ${ }^{415}$ En consecuencia, para Goethe el origen de la arquitectura no se localiza en la casa, sino en el templo. Precisamente en este trasvase del templo a la casa 
consistiría la dificultad que Goethe comenta, porque se estarían utilizando formas sacralizadas procedentes de la mímesis a fines civiles. Una contradicción constructiva (el muro y la columna) y una ficción monstruosa (la mímesis sagrada destinada a fines burgueses) que precisaban de una ficción genial para salir airosa. De aquí su admiración por las soluciones palladianas.

En los manuscritos y borradores del Baukunst, a excepción de la breve cita vista anteriormente relativa a la mayor decoración del capitel jónico respecto al dórico, se detecta un silencio sobre la parte que remata la columna, es decir, el capitel. ${ }^{416}$ Con todo se puede intuir alguna de sus ideas a partir de los dibujos de capiteles que realizaba en la época en que estaba trabajando en este texto. En efecto, a la vista de sus dibujos se comprueba que su interés no se reduce a la representación de soluciones canónicas, sino que le atraen también capiteles de formas y ornamentos singulares. ${ }^{417}$ En todo caso resulta sorprendente que no trate sobre la singularidad de los capiteles dóricos de los templos griegos con sus pronunciados equinos que podrían interpretarse, siguiendo su mismo razonamiento sobre la evolución hacia un mayor refinamiento, como una solución primitiva y potente respecto a la mayor elegancia de los capiteles romanos posteriores. ${ }^{418}$ (Fig. 32)

\section{La cubierta ${ }^{419}$}

De este apartado no constan desarrollos explícitos. Solo la referencia de Schiller a von Humboldt permite rescatar el cierre de las tres partes de la arquitectura. Ciertos dibujos, no obstante, así como las menciones de dos de los referentes de Goethe para la redacción provienen de las columnatas" (1795: 25). Winckelmann comenta esta cuestión al hablar de las columnas encastradas en el muro: "Según expresión de Diodoro de Sicilia, las columnas del templo de Júpiter Olímpico eran redondas por la parte exterior y cuadradas por la interior [...]. Por «cuadradas en la parte interior» puede entenderse que estas columnas estaban talladas en el muro de forma cuadrada. [...]. Pero yo creo que lo que Diodoro de Sicilia ha querido decir no es eso, sino que este templo tenía en la parte exterior columnas semicirculares, y en el interior estaba decorado con pilastras." (1985: 570). Un ejemplo de trabazón de columnas y muros lo comenta Goethe en Agrigento el 26.04.1788: "En el amplio espacio que se extiende entre las murallas y el mar vense aún los restos de un pequeño templo, que se ha conservado cual cristiana capilla. También allí muéstrense las medias columnas bellamente ligadas a los sillares del muro y fundidas con ellos, lo que resulta gratísimo a la vista." (III, 1223).

414. Es precisamente en este contexto como se entiende la admiración de Goethe por Palladio que supo plantear estas cuestiones en la arquitectura civil.

415. Recuérdese en Von Deutscher Baukunst (1772): "nuestros bellos espíritus, Ilamados filósofos, siguen componiendo hasta día de hoy, a partir de cuentos protoplásticos, los principios y la historia del arte." (1999: 34)

416. Winckelmann describe los capiteles, volutas, etc. como hilo conductor para tratar la particularidad de los diferentes órdenes. Tal vez Goethe tenía un plan similar en el Baukunst, como se desprende de la tabla de los órdenes que incluye.

417. Por ejemplo, los capiteles del Renacimiento alemán en el dibujo IVb: 134. En el dibujo IVb: 204 parece insinuar una banda continua de la misma anchura del capitel corintio que recuerda los ornamentos dibujados por Palladio en una de las salas corintias (Lib. II, cap. IX, p. 40)

418. Sobre este tipo de capitel Winckelmann escribe: “El capitel consta simplemente de un gran equino liso y muy alargado, en el lugar en que en los tiempos posteriores las columnas dóricas tenían las llamadas ovas, y en esta parte descansa inmediatamente el ábaco, también llamado trapecio, que tiene más resalte sobre el equino que en los tiempos más antiguos de Grecia." (1985: 541)

Fig. 32: Johann W. Goethe, Kapitell der dorischen Ordnung [Capitel de orden dórico], 1787 (101x142 mm. Lápiz), en Femmel [1958] 1972, III: 42 rs.

419. El término utilizado por Schiller en su carta a Wilhelm v. Humboldt es "Dach", técnicamente traducible por "cubierta". Asumiendo que Schiller transmite el término utilizado por Goethe, y dadas las referencias utilizadas por Goethe durante la redacción del Baukunst, cabe suponer que por "Dach" Goethe se está refiriendo al remate frontal de un edificio clásico y todos sus elementos. Esto incluye, como es común a Winckelmann, Palladio y Vitruvio, el entablamento (formado por el arquitrabe, el friso y la cornisa), el frontón y sus ornamentos.

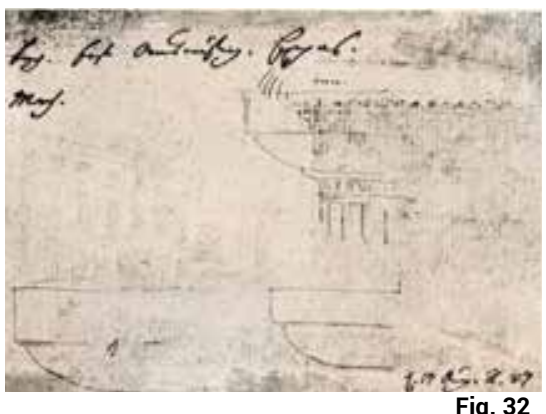


Fig. 33: Johann W. Goethe, Gebälk dorische Ordnung; Steilküste mit Segler [Entablamento de orden dórico; Costa escarpada con marineros], entre mediados de abril y mitad de mayo de 1787 (232x174 mm. Lápiz), en Femmel [1958] 1972,

II: 177 rs. Este dibujo está girado $180^{\circ}$ respecto de su versión publicada para que el entablamento se visualice en su correcta posición.

Fig. 34: Johann W. Goethe, Umgestaltungsentwurf zur Gartenseite von Goethes Wohnhaus in Weimar [Proyecto de remodelación del lado hacia el jardín de la casa de Goethe en Weimar], 1795/1802 (163×201 mm. Tinta con pluma), en Femmel [1958] 1972, IVb: 92

420. Escribe: "El coronamiento triangular se llamaba en griego aetos (áદтóc) o bien aetoma (áعтó $\mu$ a), y forzosamente debían tenerlo los edificios y los templos antiguos, cuya techumbre, con el tejado, formaba un triángulo" (1985: 548), por lo tanto diferencia entre el frontón y la cubierta.

421. Vitruvio y los tratadistas posteriores tratan la cubierta como parte de la construcción y no dentro de las características formales de los órdenes que es el asunto que a Goethe le interesaba. 422. Conviene recordar que, en las ruinas griegas visitadas por Goethe, las cubiertas ya no existían y en aquellos edificios que las tenían eran del Baukunst (1795) pueden permitir avanzar algunas hipótesis sobre su desarrollo.

Hay varios dibujos de Goethe tanto anteriores como de esos años en los que trata los perfiles de cornisas (IVb: 106 y 118), o de entablamentos (IVb, 119), así como fachadas y pórticos con frontones (IVb: 92, $95,103,112$ y 127, Vla: 157). (Figs. 33 y 34) Incluso en un esquema aborda la solución de la estructura y los faldones de la cubierta de un pabellón en $L$ a dos aguas (Vla: 165). Existe un único ejemplo donde, junto con otros dibujos, se incluye un croquis de sección incorporando la columna, su entablamento y la estructura de cubierta (IVb: 131 rs.).

En relación con esta parte de los edificios, Winckelmann diferencia entre las "bóvedas" como forma de cubrir las estancias, la "techumbre" que alude a la cubierta sus pendientes y gárgolas, y el "coronamiento" que se refiere a los tímpanos y frontones incluyendo sus ornamentos, esculturas, acróteras y cornisas (1985: 533 y 548-549). ${ }^{420}$ Por su parte Palladio, siguiendo a Vitruvio, incluye los entablamentos con sus cornisas en la descripción de los órdenes y comenta las coberturas, faldones y gárgolas en el cap. XXIX del libro I (1570, I: 67). ${ }^{421}$ Frente a esta sistematización

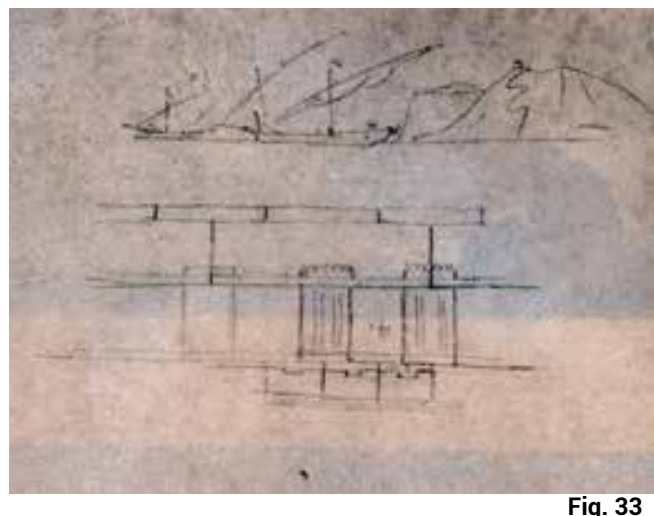

clara, hay una cierta ambigüedad en el tratamiento dado por Goethe a esta parte. Parece que para él la tercera parte de la arquitectura, aquel remate horizontal paradigmáticamente desarrollado en los templos clásicos, incluiría el entablamento (formado por el arquitrabe, el friso y la cornisa) y, en cierta medida, el frontón, dejando al margen las cuestiones específicas de la cubierta como remate constructivo del edificio. ${ }^{422}$

Sobre el entablamento ya adelanta algo en el Baukunst (1788) centrándose en el friso dórico formado por triglifos y metopas y su paso al jónico. Los glifos en las cabezas de la viga que constituían el entramado de cubierta, muescas producto de la falta de habilidad de los constructores de los primeros templos y de la preponderancia de la satisfacción de una necesidad inmediata, dieron lugar en su petrificación a los triglifos. ${ }^{423}$ Los espacios libres entre las vigas, dejados abiertos por no estar siquiera "revestidos", proporcionaron un espacio vacante dedicado a albergar los "cráneos de los animales sacrificados" y dio lugar en su versión petrificada a las metopas, cierre del entrevigado en fachada. ${ }^{424}$ Ambos elementos descansaban en la viga maestra, matriz del arquitrabe. ${ }^{425}$

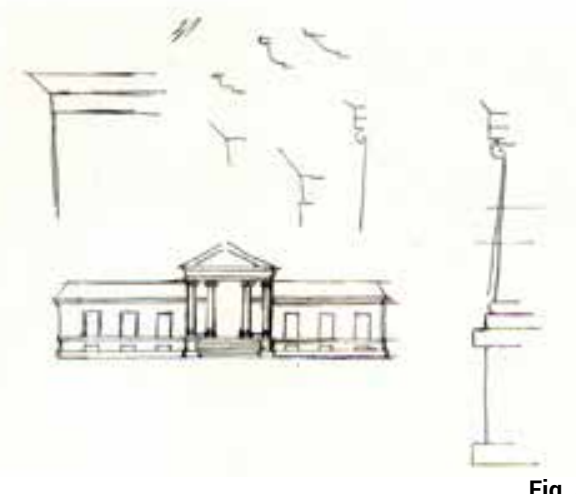

Fig. 34 
En relación con la cornisa como remate superior es muy escasa la información existente sobre la idea de Goethe. No incluye ningún comentario en los diferentes textos sobre el Baukunst, ni es posible extraer suficiente información a partir de los dibujos conocidos de esos años (IVb: 118). Tampoco comenta ni se conocen dibujos donde aparezcan los mútulos con sus gotas bajo la cornisa dórica (geison) ${ }^{426}$ ni los mascarones de desagüe. ${ }^{427} \mathrm{Sin}$ embargo, dada su convicción sobre el origen del templo en la mímesis del antecedente de madera no es descartable que pensara aludir a estas cuestiones.

En la serie de dibujos de fachadas completas de Goethe a la que ya se ha hecho mención como progresión del basamento hacia el zócalo de los edificios civiles, queda patente un especial interés en definir la articulación del cuerpo con la cubierta con forma triangular que en el dibujo (IVb: 101) ${ }^{428}$ evoca un frontón, así como la representación de verdaderos frontones como remate de fachada (IVb: 103). (Fig. 35) Las cornisas cobran especial protagonismo a este respecto e incluso copió de Serlio (lib. III, cap. IV, folio 10 rs.) el encuentro en el frontón entre la cornisa horizontal y la inclinada (Vla: 157, 19.01.1797). (Fig. 36)

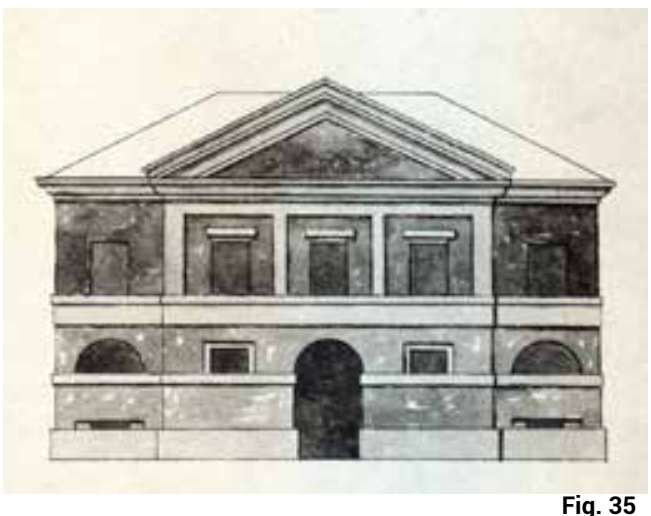

intervenciones posteriores, como en la capilla junto a la muralla de Agrigento o el templo de Vesta en Roma.

423. Sin embargo, no menciona las gotas que sobresalen en su parte inferior sobre el arquitrabe y que, de acuerdo con la teoría del templo originario de madera, corresponderían a las cuñas para fijar la viga en su posición y evitar su deslizamiento.

424. Remite Goethe al Ifigenia entre los tauros de Eurípides "de forma que era posible colocar en su interior los cráneos de los animales sacrificados" En el prólogo de la tragedia, frente a la fachada del templo de Artemis en la Táurica, Orestes pregunta a Pílades: "Ves cráneos colgados de la misma cornisa?", a lo que este responde: "Sí, con exvotos de extranjeros muertos". Véase Eurípides (1995), Ifigenia entre los tauros, Madrid: Gredos, p. 9. Winckelmann alude a esta misma cuestión, aunque su comentario es algo diferente porque al referirse a los adornos de las metopas ya ciegas escribe: "Cuando después se cerraron esos espacios, quedando las superficies denominadas metopas, se pensó también en adornarlas, y tales adornos de las metopas debieron su origen a los escudos con que se decoraba el friso [que] se colgaban de las metopas." (1985: 560). En realidad, ambos tipos de ornamentos, bucráneos y discos, se solían alternar en las metopas como en Palladio (lib. I, cap. XV, p. 23, 24). 425. En el dibujo IVb 119 se representan las tres partes del arquitrabe jónico con sus filetes intermedios ornamentados.

426. Según Vitruvio (V., lib. IV, cap. II) correspondían a las tablas de madera de la cobertura original. De ahí su alineación en vertical con los triglifos. La desaparición de éstos en el friso jónico implicaba una solución constructiva de la cobertura diferente dando origen a la aparición de los dentículos. En consecuencia, la existencia de un orden dórico denticular (como en el teatro Marcello en Roma) había sido expresamente rechazada por Vitruvio (Lib. IV, cap. II) porque significaba una incongruencia constructiva en relación con el modelo de madera original, aunque fue aceptado por algunos tratadistas como Serlio (libro IV, lám. XXII). Sin embargo, en el dibujo de Galiani copiado por Goethe (III, 94, 10.10.1786) (Fig. 17) sobre la transformación del entablamento de madera en piedra sí se representan estos dentículos. 427. Según Winckelmann, "La cornisa del entablamento estaba en general adornada con mascarones de forma de cabeza de leones a distancias determinadas, que servían para el desagüe de las lluvias" (1985: 561).

428. El grafismo utilizado en este dibujo para representar la cubierta de líneas que confluyen en la limatesa es similar al que Serlio usa en algún dibujo como las láminas de fachadas del Libro IV.

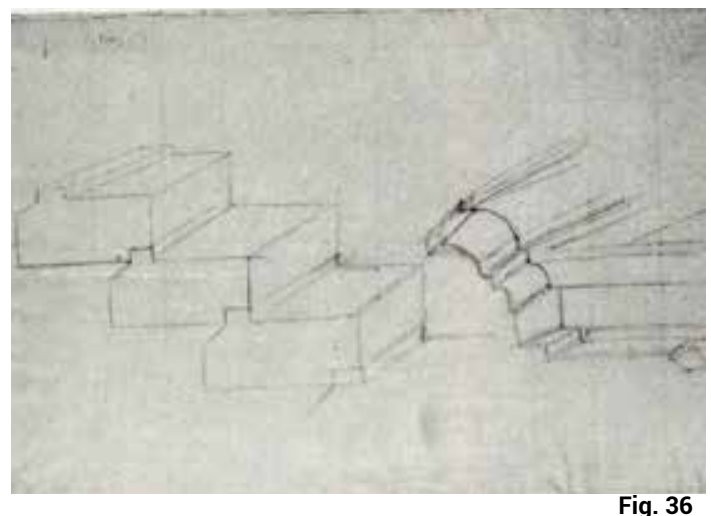

Fig. 35: Johann W. Goethe, Fassade eines Klassizistischen Gebäudes [Fachada de un edificio clasicista], hacia 1795, (138x235 mm. Tiralíneas, tinta, sepia), en Femmel [1958] 1972, IVb: 103

Fig. 36: Johann W. Goethe, Serlio-Studien (Lib. III, folio 79 y 60) [Estudios de Serlio], segunda mitad de los 1790 (210x345 mm. Lápiz), en Femmel [1958] 1972, Vla: 157 
429. En el registro actual del Goethe- und Schiller-Archiv, consta con la entrada: "Manuskript und Notizen mit der alten Aufschrift, Über Baukunst. 1795'" [Manuscrito y notas con la vieja inscripción, Sobre la Arquitectura. 1795]. La signatura completa es: GSA 25/W 3606.

430. En Weimar, previo a la normalización métrica, el Fuß [pie] equivalía a $281,98 \mathrm{~mm}$. Luego el formato $342 \times 211$ correspondería a $14,5 \times 9$ pulgadas. El folio utilizado por Goethe para el legajo coincidiría con el formato normalizado Propatria plegado en dos, de uso relativamente frecuente en Weimar en aquel periodo.

\section{El Baukunst (1795)}

El documento es una carpeta de quince folios plegados en su mitad, escritos y dibujados, en su caso, por ambas caras. ${ }^{429}$ A excepción de las dos últimas páginas, el resto respetan el mismo formato: $342 \times 211 \mathrm{~mm} .{ }^{430}$ En cada una, el texto ocupa en vertical la mitad derecha, dejando en blanco para los dibujos la parte vertical izquierda. Tanto el escrito como los dibujos están hechos a tinta, aunque algunos de ellos parecen esbozados a lápiz previamente. Esto es constatable principalmente en aquellos que dejó sin repasar a tinta. Algunas figuras están sombreadas a la aguada. Hay en total diecisiete dibujos todos ellos ajustados a las convenciones gráficas del sistema diédrico, al igual que en los dibujos arquitectónicos preparatorios que se le conocen. No se aprecia en ningún caso el uso de instrumental de apoyo: compás, regla, etc.

En el documento hay columnas de texto interrumpidas, quedan páginas en blanco intercaladas y algunos dibujos están apenas insinuados, lo que pone en evidencia que, por una parte, es un trabajo inacabado y que, por otra, tenía presumiblemente una extensión y estructura ya concebida al quedar en blanco las partes que, estando previstas y acotadas, no fueron finalmente redactadas o dibujadas. En este sentido, puede identificarse un primer bloque en apariencia desarrollado parcialmente hasta la página 20 , seguido de una serie de folios dejados en blanco con la interposición de una tabla de órdenes en la página 23 y dos párrafos de texto corrido en la página 25. Este primer bloque, por su parte, fue desarrollado desigualmente. En su última versión consta de un cuerpo de texto corrido combinado con dibujos en el que se distinguen dos partes o capítulos separados por un folio en blanco (página 14): "Baukunst" [Arquitectura] (de la página 3 a la página 13) y "Basen ganzer Gebäude" [Basamentos de los edificios en su conjunto] (de la página 15 a la 20). En la primera, Goethe propone una aproximación teórica a la arquitectura con un despliegue conceptual que, en la segunda parte, quedará ilustrado con diferentes ejemplos de la historia de la arquitectura. Así como la primera, atendiendo a la manera en la que ocupa el espacio del legajo, parece estar concluida en su formulación escrita, la segunda sólo ha llegado fragmentariamente como pone en evidencia el hecho de que el texto esté interrumpido en la página 19 y los dibujos a lápiz inacabados. En ambos casos han quedado espacios libres para nuevos dibujos, lo que no implica necesariamente que esa fuera la intención de Goethe. Sólo en la segunda parte, dadas las referencias escritas, puede aventurarse con bastante verosimilitud que faltan dibujos.

El Baukunst se editó por primera vez en la Weimarer Ausgabe [WA], tomo 47, pp. 67-76, 1896. En esta versión se recoge el manuscrito de Goethe hasta la página 19 y sin dibujos, dando pie así a una versión parcial del Baukunst que se ha consolidado a lo largo de las sucesivas ediciones de la que ha sido objeto este texto. El mismo tomo de la WA incluye asimismo los dos últimos párrafos de la página 25 del manuscrito en la p. 330, como parte de los paralipómenos del "Schema über Baukunst". La tabla con los órdenes de la página 23 -no incluida deliberadamente en la WA- se publicó por primera vez en la Frankfurter Ausgabe, tomo I: 18, pp. 378-379, como parte de los paralipómenos del "Schema über Baukunst". 
Para la trascripción al alemán de la presente edición se han respetado los criterios filológicos de la edición de Johann Wolfgang Goethe (1998), Sämtliche Werke. Briefe, Tagebücher und Gespräche. Band 18, Ästhetische Schriften 1771-1805, Friedmar Apel (ed.), Frankfurt am Main: Deutscher Klassiker Verlag. El Baukunst se encuentra en pp. 367-374 y se incluyen los dibujos entre el texto corrido, a diferencia de su localización paralela al texto en el manuscrito. Los dos párrafos de la página 25 del manuscrito y la tabla con los órdenes de la página 23 forman parte de los paralipómenos del "Baukunst", pp. 378-379. En esta transcripción se han significado, distinguiéndolos del cuerpo de texto, los añadidos o modificaciones reconocibles en el manuscrito.

Respecto de las traducciones, fue determinante para los lectores de habla no germana la traducción al inglés "Palladio. Architecture (1795)", en Goethe on Art, Ed. John Gage, Londres, Scolar Press, 1980, pp. 196-200. Es evidente que ha supuesto para traducciones posteriores en otras lenguas una referencia de primer orden. A esta le han seguido, por nombrar las más cercanas al lector en español, la traducción al italiano de Renata Gambino, "Architettura", en J. W. von Goethe (1994), Baukunst: del Gotico al Classico negli scritti sull'Architettura. Ed. Vittorio Ugo. Palermo: Medina, pp. 49-58 y al español de Miguel Salmerón (1999), "Arquitectura. 1795", en J. W. von Goethe, Escritos de arte, Miguel Salmerón (trad., intr. y n.). Madrid: Síntesis, pp. 73-77. En todas ellas se repite la reproducción parcial del tratado hasta la página 19 del legajo, haciéndose eco de la edición más frecuente en las diversas obras completas de Goethe en lengua alemana. La edición italiana reproduce íntegramente entre el texto corrido los dibujos que acompañan el Baukunst (1795). ${ }^{431}$ Estas tres traducciones han supuesto, por otra parte, una referencia de gran ayuda a la hora de emprender la presente traducción y el resultado es, en parte, deudor de ellas.

Dos motivaciones iniciales han sido las impulsoras de la presente traducción. En primer lugar, el intento de proporcionar para los lectores en español una versión completa del Baukunst (1795) de Goethe que incluya el texto al completo, paralelamente al facsímil del original e incluyendo sus dibujos. En segundo lugar, se ha considerado de especial importancia dotar de claridad la traducción del lenguaje técnico empleado por Goethe en su manuscrito tomando como referencia la tratadística y la terminología arquitectónica que consultó con asiduidad durante la redacción. En este sentido, se ha prestado especial atención a la reproducción de los errores terminológicos en los que Goethe incurrió en su texto.

Si toda traducción es una interpretación del texto original, en el caso presente, siendo este un texto inédito que alberga incluso pasajes de cierta oscuridad, se ha optado por la máxima fidelidad al manuscrito de Goethe siempre que no comprometiera la inteligibilidad en español. Esto ha llevado, por momentos, a tomarse ciertas licencias sintácticas y léxicas en aras de proporcionar un texto accesible al lector no familiarizado con el alemán. En todo caso, la transcripción en su lengua original que se incorpora pretende ayudar al lector a solventar estas cuestiones.
431. Una reproducción en la p. 52 de la Tabla del alzado lateral del 'Tempio ch'e' sotto Trevi" (Tabla IV) de I Quattro Libri dell'Architettura di Andrea Palladio, Libro IV, cap. XXV de la edición de Venecia del 1570 completa el material gráfico de esta versión. 
432

\section{Baukunst ${ }^{433}$}

1795'.
Arquitectura $^{434}$

1795.

432. En el original aparecen sucesivas anotaciones que corresponden a las signaturas con arreglo a las cuales se han clasificado sus manuscritos en diferentes periodos.

433. Friedrich Theodor David Kräuter completó entre 1822 y 1823 el título original "Baukunst", resultando el encabezamiento: "Über Baukunst, veranlaßt durch den Schloßbau. 1795" [Acerca de la arquitectura, motivado por la construcción del palacio. 1795"], según la Münchner Ausgabe (1998), 4.2, Wirkungen der Französischen revolution 1791-1797, p. 954. La diferencia caligráfica y de tinta es evidente a simple vista. Las anotaciones añadidas fueron posteriormente tachadas, a excepción del "Über".

434. El alemán moderno dispone de dos sustantivos equivalentes a "arquitectura", uno de raíz germana y otro de raíz griega. El primero, "Baukunst", es el que Goethe elige para encabezar su trabajo. Es una composición formada por los sustantivos "Bau" y "Kunst", "construcción" y "arte" respectivamente, de manera que literalmente podría traducirse por "arte de la construcción". En época de Goethe, "Baukunst" era, de hecho, la manera culta de referirse a la arquitectura, especialmente en un ámbito académico. El segundo, "Architektur", es utilizado a lo largo del texto en varias ocasiones y en contextos diferentes, sin que pueda establecerse un criterio claro en su empleo.

En la actualidad el término "Baukunst" ha caído en desuso pese a que su raíz permanezca muy viva en palabras derivadas de uso corriente, notablemente aquellas relacionadas con la construcción. En cualquier caso, es "Architektur" la indiscutida manera de apelar a la arquitectura como disciplina. Esta duplicidad en los términos, con la carga etimológica que ambos aportan, ha dado lugar durante la segunda mitad del siglo XX a diversos intentos de rescate de la raíz germana. Con considerables diferencias, ilustrarían esta cuestión la apelación de Heidegger en "Bauen Wohnen Denken" ["Construir, habitar, pensar"] (1951) o aquella de Mies van der Rohe cuando decía en 1958: "Preferimos decir «Bauen» (construir) que «Architektur» (arquitectura); y los mejores resultados pertenecen al campo de la «Baukunst» (arte de construir)" (Neumeyer, 1995: 515) 
$144^{4} 7,(1=1) \times 50$

1, N.

\section{2ienal}

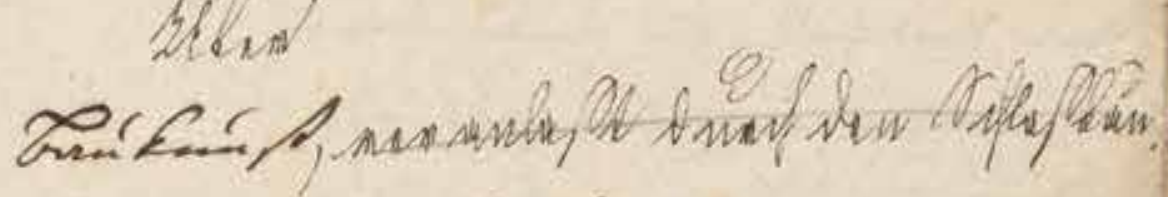

$$
1795 \text { '. }
$$




\section{Baukunst}

In jeder Kunst ist schwerer als man glaubt zu bestimmen, was lobens- oder tadelnswert sei; um einigermaßen eine Norm für unsere Urteile über Baukunst zu finden, mache ich folgende Deduktion, und bemerke nur vorläufig, daß einiges, was ich sagen werde, allen Künsten gemein ist; um aber nicht in Zweifel zu geraten, spreche ich davon bloß vorzüglich auf die Baukunst.

Die Baukunst setzt ein Material voraus, welches zu dreierlei Zwecken stufenweise angewendet werden kann.

Der Baukünstler lernt die Eigenschaften des Materials kennen und läßt sich entweder von den Eigenschaften gebieten, z. B. daß der Stein bloß vertikal trägt und ge-

\section{Arquitectura}

Es más difícil de lo que se cree establecer en cada una de las artes qué es digno de alabanza o de reproche. Para encontrar en cierta medida una norma para nuestros juicios sobre la arquitectura hago la siguiente deducción y señalo provisionalmente que algo de lo que diré es común a todas las artes. Pero para evitar confusión me referiré exclusivamente a la arquitectura. ${ }^{435}$

La arquitectura presupone un material que puede ser aplicado gradualmente para tres fines. ${ }^{436}$

El arquitecto traba conocimiento de las propiedades del material y, o bien se deja condicionar por estas, como, por ejemplo, que la piedra sostiene y es sostenida sólo

435. La idea de que todas las artes comparten un sustrato estético común era generalmente asumida. Sin embargo, la teoría de cada una de ellas es diferente en función de sus condiciones y el material específico que utiliza. Ya Lessing en su Laocoonte (1766) distinguía entre las artes poéticas que se sirven de la palabra y las artes visuales que se manifiestan en las imágenes. No es posible, por lo tanto, utilizar unos mismos criterios de evaluación para todas, sino que se hace necesario encontrar los correspondientes a cada una de ellas en particular. Goethe está dejando claro desde la primera frase que su interés no es enunciar una estética general sino una teoría específica de la arquitectura, sin que eso suponga que sus conclusiones no puedan fecundar, también, otras esferas artísticas. El paso de lo particular a lo general y la ósmosis entre unos conocimientos y otros eran unas de sus convicciones más arraigadas.

436. Vitruvio dedica el libro I de su tratado a los materiales y formas de utilización y, en el cap. III se refiere a que los edificios "deben construirse con atención a la firmeza, utilidad y hermosura". No usa el término "fines" aunque desde la tradición académica se ha interpretado que esas tres cualidades son los objetivos que debe alcanzar la arquitectura (Vitruvio, lib. I, cap. III). También Palladio trata en el libro I de "la preparación de la materia, y preparada, cómo y en qué forma se deben colocar en la obra" (Lib. I, Proemio à i Lettori, p. 6) pero no menciona ni fines ni objetivos. Winckelmann habla así mismo en el capítulo $1^{\circ}$ de la sección primera de su escrito (1762) sobre "Materiales y arte de edificar". Estos textos eran los que más directamente tenía Goethe como referencia. Al empezar con ese planteamiento asume una postura canónica pero, a diferencia de ellos, introduce el término "fines" dando un giro importante porque su desarrollo posterior no corresponde a lo señalado por Vitruvio que, entre todo ellos, sería el más afín a este respecto.

437. La página 2 ha sido dejada en blanco para respetar la maquetación. Los comienzos de capítulo se localizan invariablemente en página impar. 


\section{bistinust.}

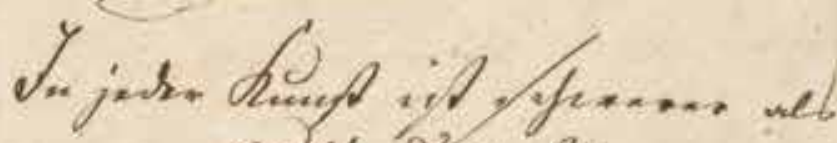

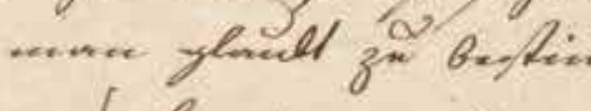

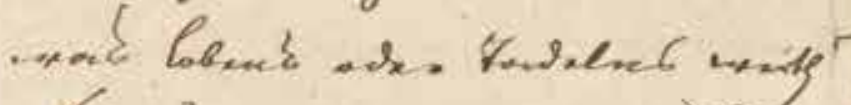

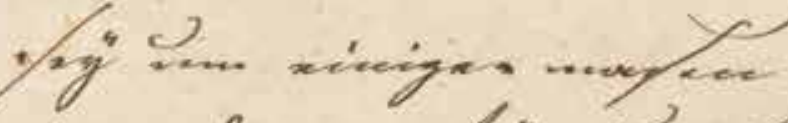
and howe tis?

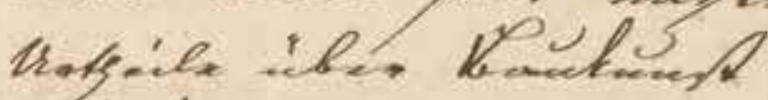

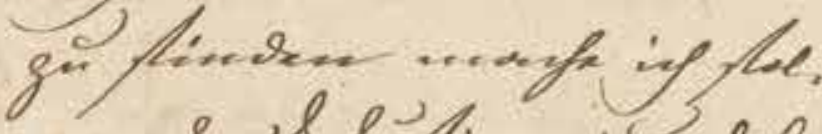

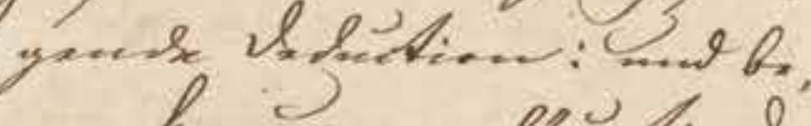

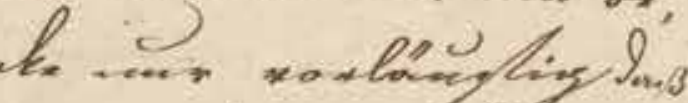
miniyat, .... if if sisy ...

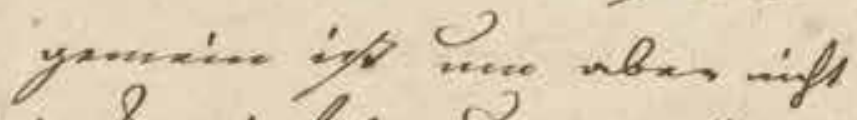
ing forithe go ynatgen 1rafe if lun... Bead raringly math si kne, hinusts.

$$
\text { Q.) pish. }
$$

mate sine wornos and

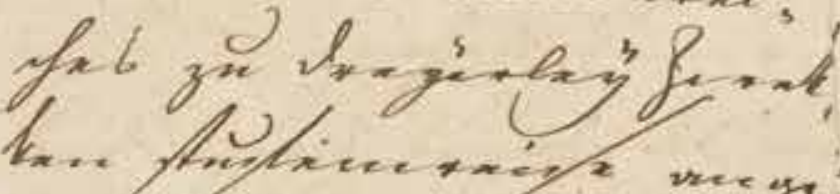
nnest ment

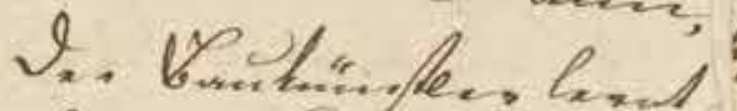

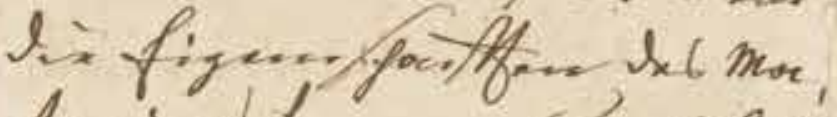
la aineb ta............. glass

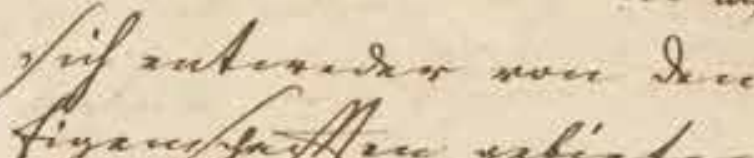

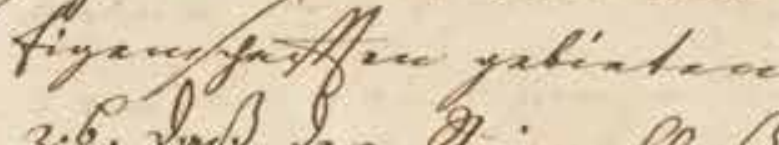

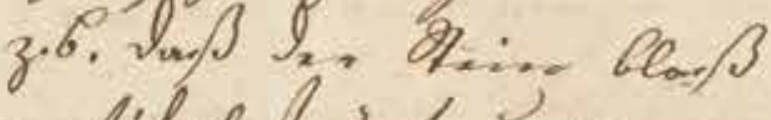
vertilul tringt none yas" 
A.y.......... rew n.

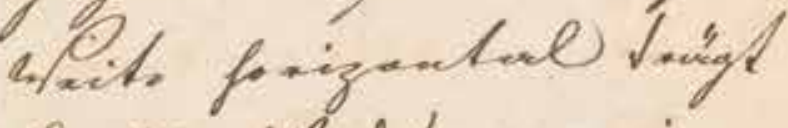

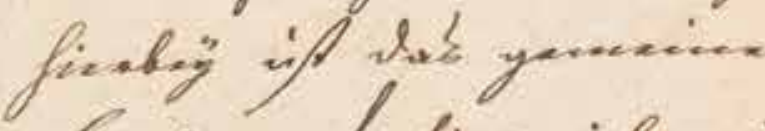
ofwe...t finc.ifen

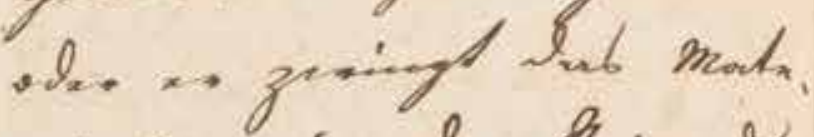
ind nis be k. \& \& Opr...ible, by ben w...... l.. buel. k?

l 2 fin he nofixys if ffe ofte manning hand,

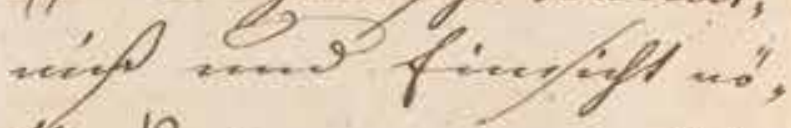
fig 2 in ......... d

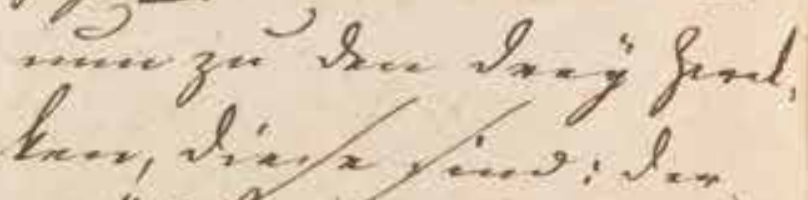

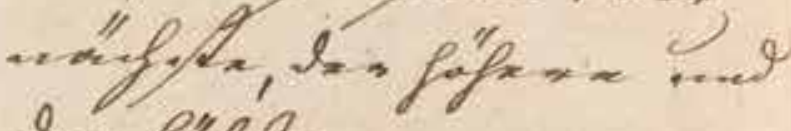
sn-figpto.

$$
\text { s.x miffe, }
$$

len

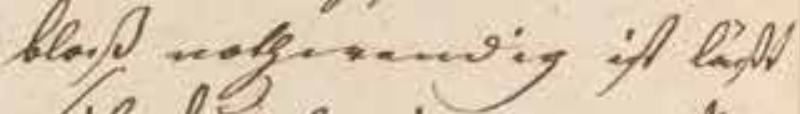
iff ling x.... ng ha,

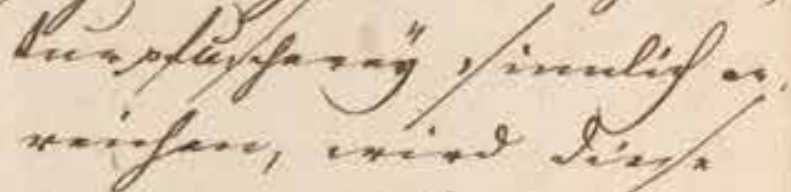

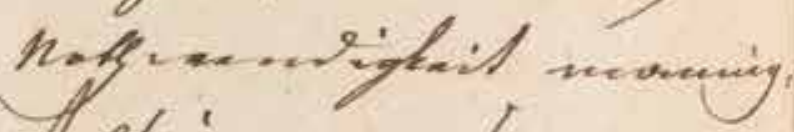

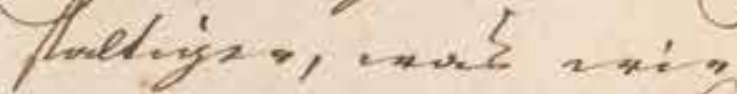
mifley ......... I. y

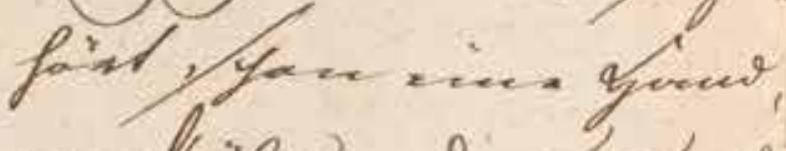

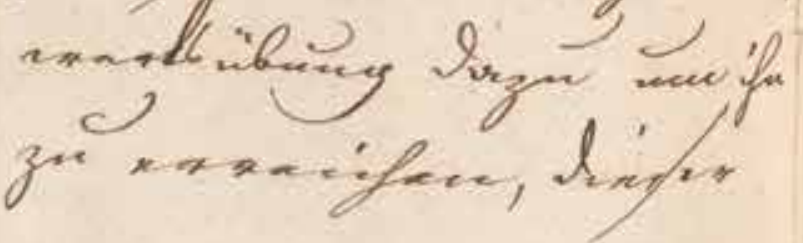


tragen wird, das Holz hingegen auf eine große Weite horizontal trägt -hierbei ist das gemeine Handwerk hinreichend- oder er zwingt das Material wie den Stein durch Gewölbe, durch Klammern, den Balken durch Hangwerke, und hierzu ist schon mechanische Kenntnis und Einsicht nötig.

Wir werden uns nun zu den drei Zwecken, diese sind: der nächste, der höhere und der höchste.

Der nächste, wenn er bloß notwendig ist, läßt sich durch eine rohe Naturpfuscherei sinnlich erreichen; wird diese Notwendigkeit mannigfaltiger, was wir nützlich nennen, so gehört schon eine Handwerksübung dazu, um ihn zu erreichen; dieser verticalmente mientras que la madera sostiene horizontalmente a lo largo de una gran amplitud, o bien fuerza al material con la bóveda o los anclajes en el caso de la piedra, o con las cerchas en el de las vigas. Para lo primero basta el oficio común, para lo segundo ya es necesario conocimiento técnico y pericia. ${ }^{438}$

Trataremos ahora los tres fines, que son: el inmediato, el superior y el supremo. ${ }^{439}$ El inmediato, cuando es meramente necesario, puede alcanzarse sensiblemente mediante un tosco remiendo de la naturale$z^{2} .{ }^{40} \mathrm{Si}$ esta necesidad se vuelve más variada, lo que llamamos útil, para alcanzarlo se requiere entonces práctica en el oficio. ${ }^{441}$ Este

438. A diferencia de los tratados renacentistas, Goethe no desarrolla la parte correspondiente a los materiales ni a la construcción alejándose, por lo tanto, de esa tradición. Éste es casi el único párrafo donde Goethe menciona cuestiones constructivas y lo hace, además, de un modo muy general y elemental. Las características físicas y mecánicas de los materiales se imponen como inevitables, pero con su conocimiento técnico y perspicacia puede el constructor encontrar soluciones que superen esas limitaciones como en los ejemplos que utiliza. Resulta evidente que Goethe considera estos aspectos necesarios pero ajenos al enunciado de una teoría del arte de la arquitectura. El atrevimiento estructural del gótico que tanto le había impresionado en Estrasburgo queda ahora eliminado del ámbito artístico. Así pues, la firmitas de Vitruvio que trata de estas cuestiones es una condición necesaria pero no forma parte de la teoría arquitectónica que postula ya que es un asunto previo a los fines que desarrolla a continuación.

439. De las posibles traducciones de esta terna de fines, se ha optado por aquella que, por una parte, resulte más natural para el hispanohablante y, por otra, respete la continuidad léxica entre "höhere" y "höchste". Este criterio coincide con el empleado en italiano por Renata Gambino (Goethe, 1994: 49).

440. Con esta frase sobre la forma elemental de alcanzar el fin inmediato [der nächste], Goethe parece aludir al origen de las primeras construcciones de los hombres primitivos que imitaban las madrigueras de los animales tal como lo narra Vitruvio (Lib. II, cap. 1 "Del principio de los edificios").

441. Vitruvio (lib. II, cap. 1) explica el progreso en las construcciones "destinadas al gusto y comodidades de la vida humana, con el auxilio de las artes" (Ortiz y Sanz, 1997: 30). Así, pues, Goethe está siguiéndolo para explicar el origen de la construcción como técnica (ars). 
nächste Zweck und dessen Beurteilung ist dem mehr of oder weniger gebildeten Menschenverstand überlassen, das Notwendige mit Bequemlichkeit vollbringen zu können.

Soll aber das Baugeschäft den Namen einer Kunst verdienen, so muß es neben dem Notwendigen und Nützlichen auch sinnlich-harmonische Gegenstände hervorbringen. Dieses Sinnlich-Harmonische ist in jeder Kunst von eigner Art und bedingt; es kann nur innerhalb seiner Bedingung beurteilt werden. Diese Bedingungen entspringen aus dem Material, aus dem Zweck und aus der Natur des Sinns, für welchen das Ganze harmonisch sein soll. fin inmediato y su valoración se confían al sentido común, más o menos cultivado, para así llevar a cabo lo necesario con comodidad. ${ }^{442}$

Pero, si la ocupación constructiva ha de merecer el nombre de arte, debe engendrar junto con lo necesario y lo útil también elementos armoniosos para los sentidos. ${ }^{443}$ Esta armonía sensitiva ${ }^{444}$ es diferente y está condicionada según el tipo de arte; sólo puede ser valorada en el seno de sus propias condiciones. Estas condiciones surgen del material, el fin y la naturaleza del sentido, para el cual el todo debe ser armonioso. ${ }^{445}$

442. Alberti había reformulado los requisitos vitruvianos convirtiéndolos en necessitas, commoditas y voluptas, cambiando su significado. La estabilidad y resistencia de la obra (necesitas) y el uso satisfactorio del ocupante (commoditas) se consiguen con la buena construcción racionalmente resuelta de acuerdo con los conocimientos técnicos y científicos. 0 como Goethe dice, "llevar a cabo lo necesario con comodidad", lo que parece incluir los dos aspectos de la necesitas y la commoditas. Estos objetivos están al alcance del entendimiento humano cultivado y de la experiencia en la práctica. Esto mismo lo recoge en la máxima 759: "A las artes y a las ciencias llégase mediante el pensar". En esto consiste el fin inmediato [der nächste]. Goethe conocía el tratado de Alberti que recomendó a Schleusner en 1797, y le menciona en sus cartas y notas entre otros arquitectos

443. El paso de la construcción al arte de la arquitectura significa incorporar al edificio la belleza interpretada como lo armonioso para los sentidos. La palabra latina utilizada por Alberti (voluptas) se refiere a esa armonía que proporciona placer sensible. No basta la construcción racional. Por encima de esa construcción que satisface la necesidad y la comodidad se encuentra el arte de la arquitectura que ha de poseer, además, una armonía capaz de captarse por los sentidos.

444. La armonía sensitiva es, precisamente, la belleza física percibida sensiblemente, y por lo tanto, es de naturaleza distinta según el sentido humano que la percibe. En consecuencia, cada arte será diferente según el órgano sensitivo al que se dirige.

445. Goethe retoma de nuevo lo que ya había anticipado "provisionalmente" al principio del escrito y que ahora ha quedado argumentado. A diferencia de un sustrato estético general no existe una teoría general del arte porque cada uno de ellos depende de tres variables: las limitaciones que le impone el material con el que está hecho, el fin al que se destina (el uso en el caso de la arquitectura) y el modo en que se disfruta, es decir, la manera en que se concreta su percepción armónica según el sentido humano específico que estimula. Esta última es la cuestión más relevante que Goethe aborda inmediatamente después. Es, precisamente, en el modo en que se capta y disfruta la arquitectura, que es propio y exclusivo de este arte, lo que trata Goethe de desentrañar. 



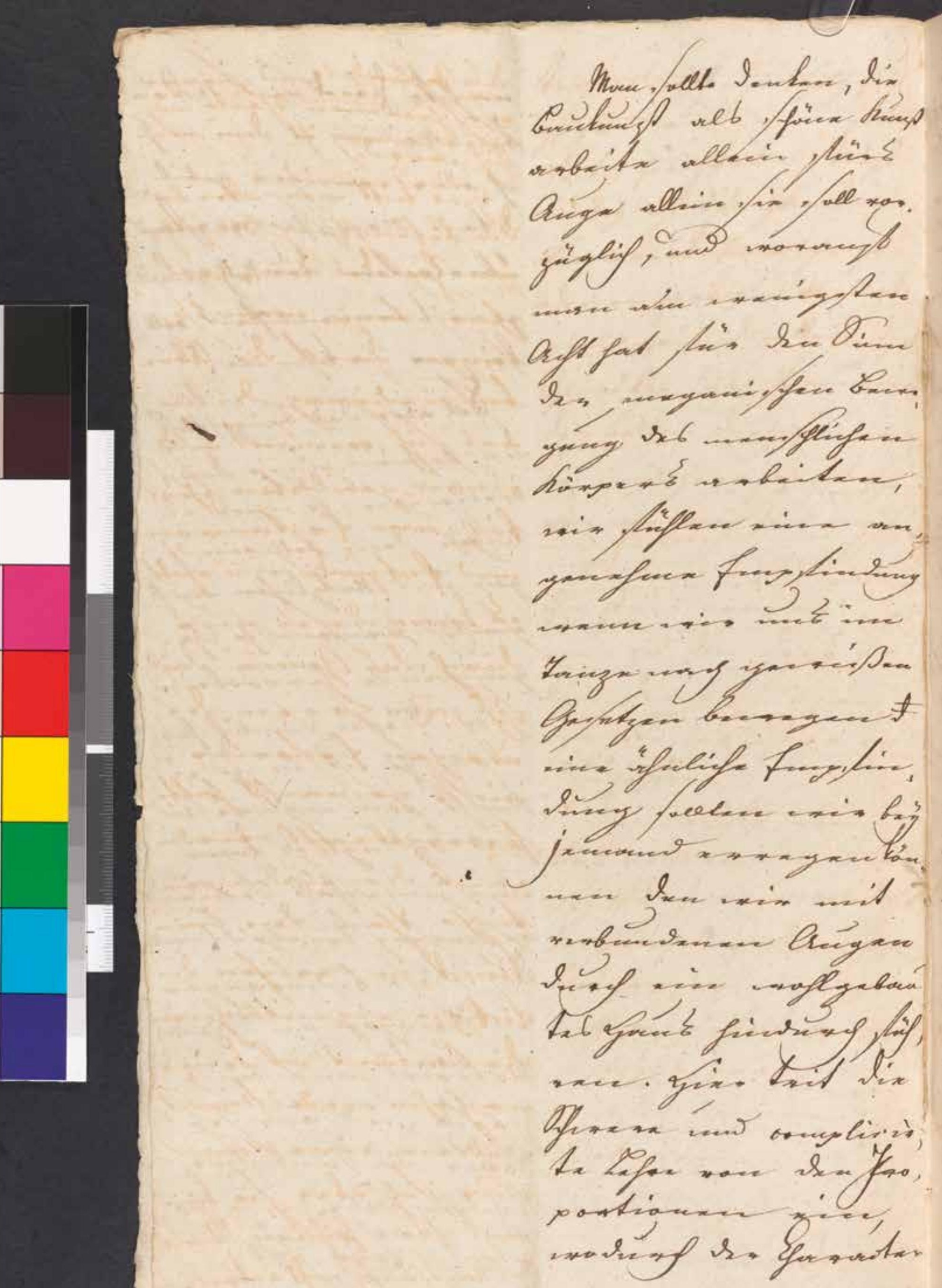


Man sollte denken, die Baukunst als schöne Kunst arbeite allein für's Auge; allein sie soll vorzüglich, und worauf man am wenigsten Acht hat, für den Sinn der mechanischen Bewegung des menschlichen Körpers arbeiten; wir fühlen eine angenehme Empfindung, wenn wir uns im Tanze nach gewissen Gesetzen bewegen; eine ähnliche Empfindung sollten wir bei jemand erregen können, den wir mit verbundenen Augen durch ein wohlgebautes Haus hindurch führen. Hier tritt die schwere und komplizierte Lehre von den Proportionen ein, wodurch der Charakter
Se podría pensar que, en tanto que arte bello, la arquitectura trabaja sólo para el ojo, pero debe trabajar preferentemente, y se presta poca atención a ello, para el sentido del movimiento mecánico del cuerpo humano. ${ }^{446}$ Experimentamos una sensación placentera cuando nos movemos en la danza conforme a ciertas reglas. Tendríamos que ser capaces de producir una sensación similar en alguien a quien guiáramos con los ojos vendados a través de una casa bien construida. ${ }^{447}$ Aquí interviene la difícil y complicada doctrina de las proporciones, ${ }^{448}$ que hace posible el carácter

446. Con esta apreciación Goethe está refiriéndose a una de sus aportaciones más relevantes. Plantea que el sentido humano que estimula la arquitectura no es la vista sino "preferentemente" el movimiento en el que confluyen y se sintetizan todas las percepciones sensibles de un modo háptico.

447. El arte del movimiento humano sujeto a reglas es la danza. La arquitectura como arte, que también estimula ese mismo movimiento, debería disfrutarse de manera similar. Por lo tanto, si anulásemos temporalmente el sentido de la vista se potenciarían todos los otros sentidos. Es entonces, al desplazarnos por ella, cuando se puede apreciar la arquitectura como arte al quedar en evidencia de forma sintética sus relaciones armónicas globales.

448. La cuestión de las proporciones trae a colación un asunto que se debatía en la Academia francesa desde el siglo XVII. Frente a la idea del clasicismo ligada a las formas cuyas medidas responden a leyes proporcionales se empezaron a analizar experimentalmente la resistencia y rotura de piezas con distintas dimensiones y diferentes materiales como la madera o el metal. A principios del siglo XVIII se estudiaba sistemáticamente las deformaciones de vigas de distintas clases de madera según cargas, luces y escuadrías, y se elaboraron tablas completas y precisas con los resultados (Collins, 1998: 191). Es decir, se abordaba de un modo científico experimental el comportamiento a solicitaciones de tracción, compresión y flexión de los materiales habituales de construcción a partir de sus dimensiones: longitud y sección. La conclusión es que las medidas adecuadas de los elementos arquitectónicos sometidos a esfuerzos como las columnas o las vigas dependen del material y se establecen con ensayos sistemáticos y no mediante criterios formales de proporciones. Cuando Goethe vinculaba en su Baukunst (1788) la evolución de los órdenes a la mayor esbeltez debido al uso de piedras más resistentes como el granito parece que se está haciendo eco de estos conocimientos de los que tenía constancia puesto que en su biblioteca tenía el libro de Johann Christian Huth Allgemeiner und gründlicher unterricht zu Bau-Anschlägen... de 1777 (primera parte: principios y teoremas y su aplicación en el cálculo de todos los materiales de construcción y los gastos de construcción) comprado en Weimar el 26.9.1778 (Ruppert, 1958: 344-345). Años después Friedrich Weinbrenner, conocido por Goethe, en su libro Architektonisches Lehrbuch (1819) señalaba "que la proporción depende del uso y del material. De este modo, las proporciones de un orden cuando el material empleado es la madera, no será la misma que cuando es la piedra o el hierro", y observó "que el malestar que experimentamos cuando vemos proporciones incompatibles con las cualidades del material, desaparece si la superficie está pintada y no podemos identificar el material empleado. Es necesario, entonces, conocer el material [...] en nuestra apreciación de las proporciones." (De Zurko, 1958: 181). Es decir, la proporción o desproporción de un elemento arquitectónico no es el resultado de leyes formales o métricas sino del material y se capta directamente con la vista. Esta parece ser la idea de Goethe manifestada mucho tiempo antes en ese escrito. 


\author{
des Gebäudes und seiner verschiedenen Teile \\ möglich wird. \\ Hier tritt nun aber bald die Betra-
} chtung des höchsten Zweckes ein, welcher, wenn man so sagen darf, die Überbefriedigung des Sinnes sich vornimmt und einen gebildeten Geist bis zum Erstaunen und Entzücken erhebt; es kann dieses nur durch das Genie, das sich zum Herrn der übrigen Erfordernisse gemacht hätte, hervorgebracht werden; es ist dieses der poetische Teil der Baukunst, in welchem die Fiktion eigentlich wirkt. Die Baukunst ist keine nachahmende Kunst, sondern eine Kunst für sich, aber sie kann auf ihrer höchsten Stufe der Nachahmung nicht entbehren; del edificio y sus diversas partes. ${ }^{449}$

Aquí interviene en seguida la consideración del fin supremo, el cual, si se permite decirlo así, se propone la sobre-satisfacción de los sentidos y eleva a un espíritu cultivado hasta el asombro y el deleite. ${ }^{450}$ Esto tan sólo puede producirse por medio de aquel genio que ha dominado las demás exigencias. ${ }^{451}$ Esta es la parte poética de la arquitectura en la que opera propiamente la ficción. ${ }^{452} \mathrm{La}$ arquitectura no es un arte imitativo, sino un arte para sí, pero no puede renunciar a la imitación en su más alto grado. ${ }^{453}$

449. Goethe, al relacionar las proporciones con el carácter, parece apuntar a la posterior teoría de la Einfühlung según la cual las formas que percibimos son capaces de transmitirnos sensaciones cenestésicas como equilibrio, inestabilidad, tensión, peso, resistencia, esfuerzo, agobio... Según Lipps "las poderosas columnas transmiten en nosotros estímulos energéticos, y la anchura o estrechez de las proporciones espaciales controla la respiración" (citado por Arnheim, 1978: 167). Goethe está formulando una idea similar al considerar que las proporciones se captan sensitiva e intuitivamente y es así como percibimos el carácter del edificio y de cada una de sus partes.

450. Goethe considera distintos niveles de calidad en las obras de arte. Dice que la mayoría son "piezas de arte" en las que se alcanzaría el "fin superior", pero las diferencia claramente de las "obras de arte" que corresponderían a las obras maestras excepcionales que llegan al "fin supremo" sobrepasando la mera satisfacción sensible de los sentidos para despertar la "sobre-satisfacción" de "un espíritu cultivado", o sea, el placer estético en su más alto grado.

451. Según Kant el genio lleva al artista hábil que domina las reglas a sobrepasarlas (2007: §46). Esta idea es compartida por Goethe. Superar el fin superior para llegar al supremo sólo se puede conseguir si el genio lleva al artista a desbordar "las demás exigencias" ya dominadas.

452. En este punto Goethe se topa con la dificultad de acotar conceptualmente en qué consiste esa "sobre-satisfacción" correspondiente al fin supremo en el caso de la arquitectura. Si con el fin superior ya se satisfacen las condiciones de la arquitectura como arte, superarlo implica llegar a un nivel por encima de sus fines utilitarios, convenientes y sensibles. Retomando su idea de la ósmosis entre las artes Goethe plantea la ficción poética como el camino a seguir, siendo consciente que ese hiato sólo puede salvarse "mediante una naturaleza especialmente indicada" (W., III, 1018). Es decir, con la ayuda del genio. Delimitar en qué consiste esa ficción poética en el caso de la arquitectura es, pues, su siguiente objetivo. 453. La idea de la imitación aplicada a la arquitectura por las teorías clásicas (desde la imitación formal de estípites, cariátides, acantos, bucráneos y otros seres naturales a la tesis sobre las proporciones humanas de los órdenes, la cabaña primitiva emulando la protección de los árboles o la relación con el círculo y el cuadrado del hombre vitruviano) eran claramente insuficientes o forzadas. Goethe lo plantea abiertamente: la arquitectura no imita a ningún otro ser natural distinto. Posteriormente en la arquitectura moderna la máquina y la abstracción fueron las vías por donde se orientó su condición no imitativa. Sin embargo, para el clasicismo de Goethe en la medida que la arquitectura es un arte, la imitación forma parte de su esencia artística y "no puede renunciar a ella". Pero no se trata de una imitación directa. Es, precisamente el genio, capaz de sobrepasar todas las limitaciones, el que puede encontrar un sentido imitativo mediante la ficción poética para alcanzar ese nivel más alto del fin supremo. Convertir la arquitectura como obra de arte en una obra genial consiste, para Goethe, en encontrar mediante la ficción poética la imitación en su grado más elevado desbordando su universo propio. El texto se desarrolla a continuación en esta dirección. 
\& 6 gabivease 6 in

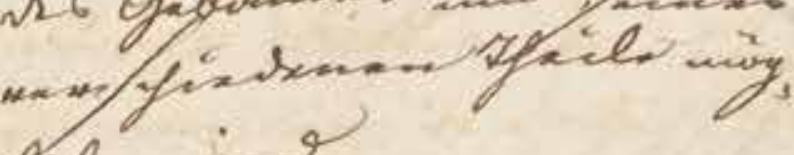
lif mins.

giin taifl wes

l. $P$ mens veban boves

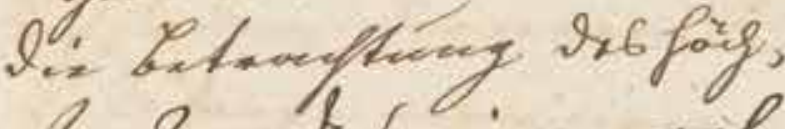
shergentat nin, wal, for maner mave ofo. frogen laxt li: Gbas buflaiariong Sor Piv.

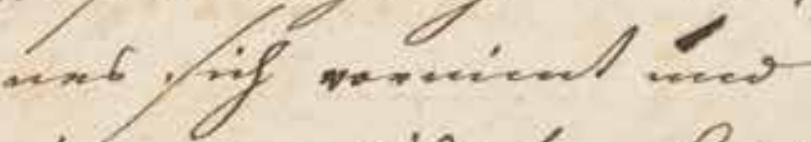
an... yabilsture lfill bir z ne... of $x$ tow ines fotzicita nofess - S Luene te: at nes.

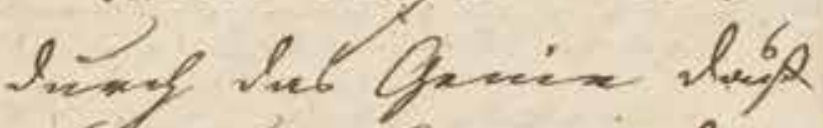
if gine zaind ibxige.. falara., $\therefore$ D. yen...ng forth forth

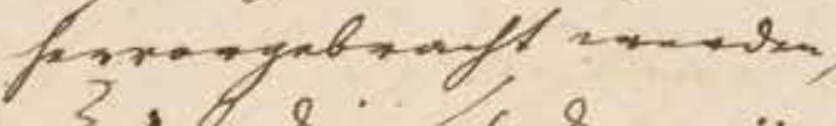

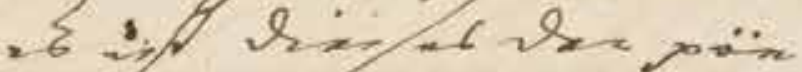
Lifye Hfill \&. Evin, trouftin walex in Sittia.. vigactlief nind

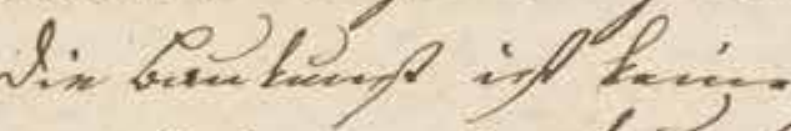
noyfoforase have,

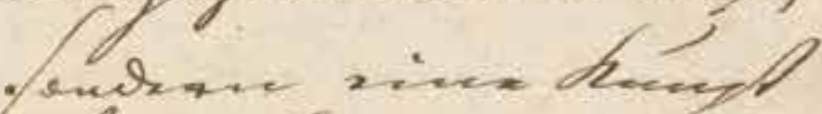
fir fin ubes fir ha

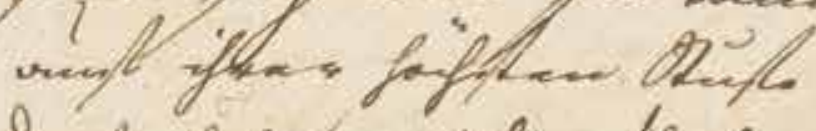

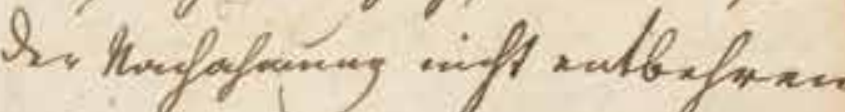




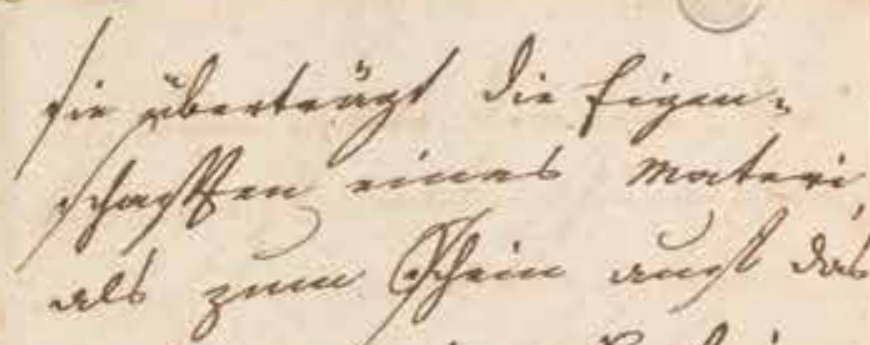

$$
\begin{aligned}
& \text { makn win go. biy }
\end{aligned}
$$

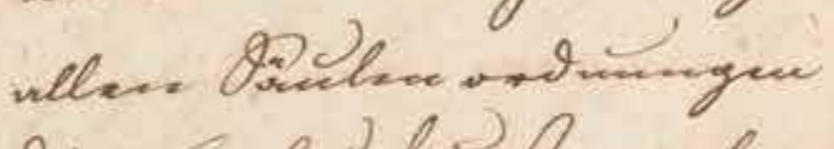

$$
\begin{aligned}
& \text { is yoegbaukines nufge. } \\
& \text { Is figmenfforfter and }
\end{aligned}
$$

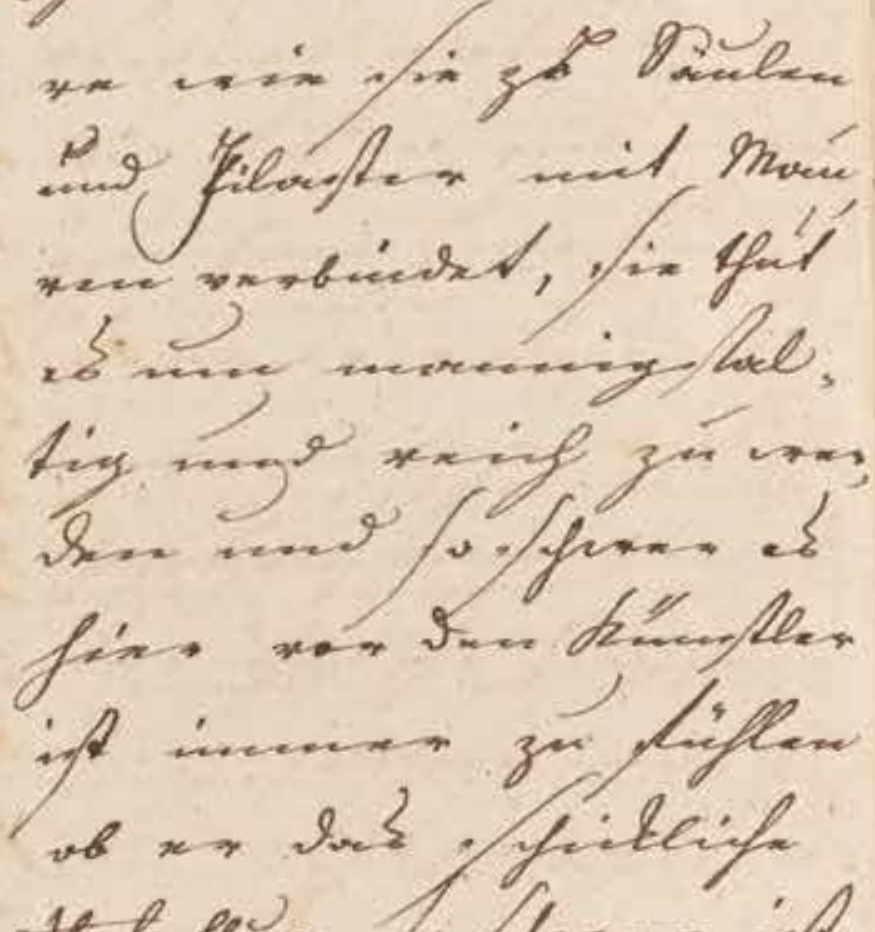

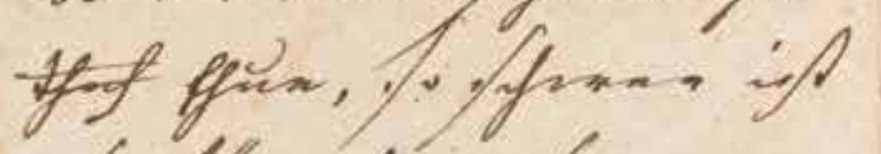

$$
\begin{aligned}
& \text { bf Lit s.e dh...... }
\end{aligned}
$$

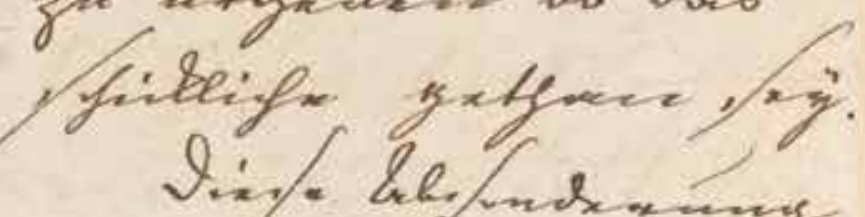

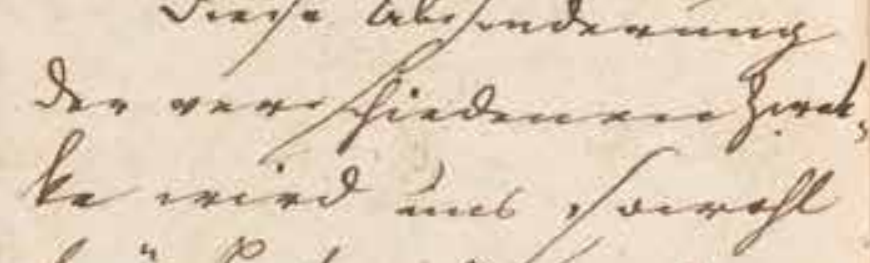

$$
\begin{aligned}
& \text { bay bitaopung s. }
\end{aligned}
$$


sie überträgt die Eigenschaften eines $\mathrm{Ma}$ terials zum Schein auf das andere, wie z. B. bei allen Säulenordnungen die Holzbaukunst nachgeahmt ist; sie überträgt die Eigenschaften eines Gebäudes auf's andere, wie sie z. B. Säulen und Pilaster mit Mauren verbindet; sie tut es, um mannigfaltig und reich zu werden, und so schwer es hier vor den Künstler ist immer zu fühlen, ob er das Schickliche tet tue, so schwer ist es für den Kenner zu urteilen, ob das Schickliche getan sei.

Diese Absonderung der verschiedenen Zwecke wird uns sowohl bei Betrachtung der verschiedenen Gebäude
En apariencia transfiere las características de un material a otro, como por ejemplo ocurre en la manera en que todos los órdenes de columnas imitan la construcción en madera; 454 transfiere las características de un edificio a otro, como por ejemplo en la manera en que une columnas y pilastras con muros. ${ }^{455} \mathrm{Lo}$ hace para llegar a ser variada y rica, y tan difícil es sentir aquí para el artista si está haciendo lo conveniente, como para el entendido juzgar si se ha hecho lo conveniente. ${ }^{456}$ Esta subdivisión de los diferentes fines nos resultará muy útil tanto al examinar

454. Puesto que la arquitectura no imita ningún otro ser, la mímesis se convierte en autorreferencial: la arquitectura mimetiza la construcción hecha con materiales distintos. La teoría más extendida sobre el origen de las formas clásicas de los órdenes que se enuncia ya en el texto de Vitruvio era que los templos de piedra imitaban el templo primitivo de madera repitiendo los elementos y modos de ensamblaje de la carpintería de armar original. Goethe se hace eco de esta interpretación e incluso la representó en un dibujo realizado en Italia copiado del Vitruvio de Galiani (tavola IV, fig. 3), que compró durante su viaje (Fig. 17). En todo caso es la mímesis la que convierte en arte lo que previamente era sólo construcción. En esta transformación, el papel esencial lo asume la noción primitiva de la mímesis que tenía la cultura griega mediante la cual la esencia sagrada del templo original se transfiere al nuevo.

455. La articulación de una columnata con un muro era un problema debatido por el clasismo. En realidad, se trata de una redundancia estructural consistente en la superposición de dos sistemas portantes diferentes: la fábrica y el pórtico. Probablemente la construcción de muros reforzados con machones para mejorar su estabilidad fuese el origen de esta solución. La cara interior del muro del tempo de Júpiter Olímpico (Zeus) en Agrigento, tal como lo describe Winckelmann (1985: 571) parece aludir a ese tipo de refuerzos convertidos en "pilastras" como señala Goethe. Por el contrario, la descripción de la cara exterior de ese mismo ejemplo mediante la inserción de "columnas" en el muro refleja más fielmente esa mezcla estructural. Winckelmann describiendo esta solución en la quinta de Mecenas en Tívolo escribe: "las columnas medio sujetas en el muro están hechas lo mismo que todo el edificio: de piedra tallada en forma de cuña." (1985: 541) Sin embargo, Goethe y, en gran medida el clasicismo, no lo enfocaban como una cuestión estructural sino como una contradicción meramente formal.

456. Considerada la cuestión de la articulación de columnas y fábrica como un problema exclusivamente formal los criterios de evaluación sobre su corrección resultan difíciles de establecer como apunta Goethe porque los aspectos constructivos de estabilidad o abombamiento, por ejemplo, que podrían servir para valorar si la solución es o no adecuada, no se tienen en cuenta. Goethe que veía esta mezcla como "monstruosa" sin embargo alaba el caso de un pequeño templo convertido en capilla en Agrigento. Al obviar los aspectos estructurales la evaluación queda limitada, por ejemplo, a pensar en cómo dimensionar los intercolumnios para que no sean ni demasiado anchos ni demasiado estrechos. En el primer supuesto darían una imagen débil de la columnata y en el segundo el muro quedaría visualmente troceado. Por eso entiende que la resolución correcta de esta articulación es una prueba de la capacidad del arquitecto. 
sehr zu statten kommen, als auch in der Geschichte der Baukunst zum Leitfaden dienen.

So lange man nur den nächsten Zweck vor Augen hatte und sich von dem Material mehr beherrschen ließ, als daß man es beherrschte, war an keine Kunst zu denken, und es ist die Frage, ob die Etrurier in diesem Sinne ehemals Baukunst gehabt haben; so lange man große Steine, wie man sie findet, in allem Gestalten und Richtungen zusammen fügt, kann noch nicht einmal der Zufall den Handwerker auf Symmetrie hinweisen; er wird erst eine Weile viereckte Steine in horizontaler Lage übereinander gemauert haben, bis es ihm einfällt, los diferentes edificios, como también para orientarnos en la historia de la arquitectura. ${ }^{457}$ Mientras sólo se contemplaba el fin inmediato y el material dominaba, en vez de ser dominado, no se pudo pensar en ningún arte. Y la pregunta sería si, en este sentido, los etruscos tuvieron alguna vez arquitectura. ${ }^{458}$ Mientras se ensamblaron grandes piedras, tal y como se encontraban, en todas las formas y direcciones, ni siquiera la casualidad pudo conducir al artesano a la simetría. ${ }^{459}$ Primero tuvo que disponer, unas sobre otras, piedras cuadrangulares en posición horizontal durante algún tiempo, hasta que se le ocurrió 460

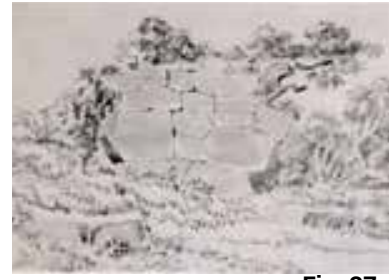

Fig. 37

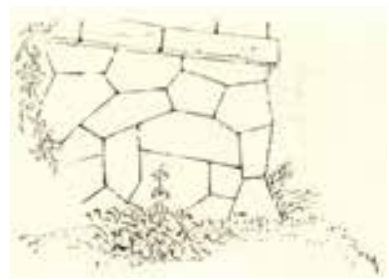

Fig. 38
457. Planteados los fines como los parámetros de estudio (siguiendo así el sistema de Linneo y el modelo de la historia natural que él mismo había adoptado para la morfología de las plantas), Goethe trata de aplicarlo a la historia de la arquitectura.

458. Al referirse a los etruscos está rechazando las obras egipcias como antecedentes del clasicismo, tal vez por influencia de Herder, como había dado a entender en otras reflexiones anteriores. Vitruvio (Lib. IV cap. VII) da las proporciones de los "templos a la toscana" pero en el siglo XVIII ya se sabía que el pueblo primitivo que ocupó la Toscana eran los etruscos. En consecuencia, el debate estaba en si considerar el toscano como una interpretación torpe del dórico hecha por los etruscos o si, realmente, constituía un orden diferente previo como lo habían tomado todos los tratadistas. Goethe pensaba que el primer orden era el dórico y, en consecuencia, duda de que los etruscos llegaran a tener construcciones dignas de ser consideradas arquitectura, a pesar de lo señalado por Vitruvio y los autores posteriores.

459. El dibujo del opus incertum que Goethe incluye para explicar gráficamente lo descrito por el texto está rehecho a partir del dibujo Zyklopenmauerwerk fechado en 24.02.1787 (Fig. 37). Es de suponer que se trata de los restos de muros que tuvo ocasión de ver camino a Nápoles, entre Fondi y Sessa, última estación de postas antes de llegar a la ciudad. Así se refiere en la correspondiente entrada de sus Viajes...: "Algunos muros de antiguos edificios, de una labor en forma de red, hubieron de causar nuestro asombro" (III: 1158). Hay un segundo dibujo (Fig. 38) del verano de 1787 que remite al mismo motivo. El dibujo de Palladio de este tipo de muro (Lib. I, p. 12) representa parcialmente un paño de fábrica reforzada en las esquinas con sillares rústicos. Goethe al dibujar sólo un trozo de muro en ruinas no es capaz de valorar el papel de refuerzo de estos sillares de esquina y, en consecuencia, no alcanza a entender el resultado trabado del conjunto, por lo que deduce el aparejo resultante como una cuestión de azar debido al amontonamiento más o menos ordenado de las piedras. Fig. 37: Johann W. Goethe, Zyklopenmauerwerk [Fábrica de muro ciclópeo], 24.02.1787 (149x210 mm. Lápiz, lavado a sepia), en Femmel [1958] 1972, III: 25

Fig. 38: Johann W. Goethe, Zyklopenmauerwerk [Fábrica de muro ciclópeo], verano de 1787 (119x193 mm. Lápiz, tinta con pluma), en Femmel [1958] 1972, III: 99

460. Pies de imágenes en lápiz en el original: opus incertum [Muro irregular de piedra con mortero] / opus pseudoisodomum [Muro de piedra con aparejo de diferente altura]. 
If géflatten La Lilltara lian..... D. he.

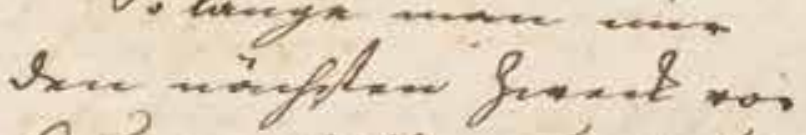
Angine full anoty w... s... mata time me beforfon bis, nes ing and ac ace,

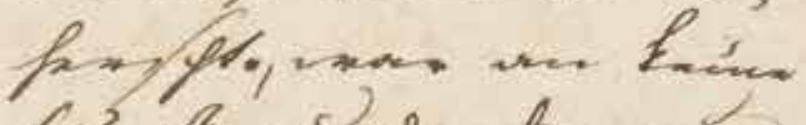

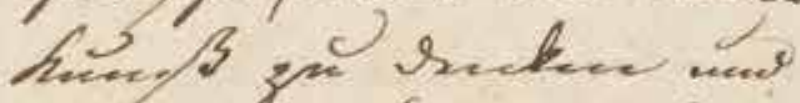
is is Is: Amy of 1: fincine. in 2 -i... . fe. 10. Arand bave.

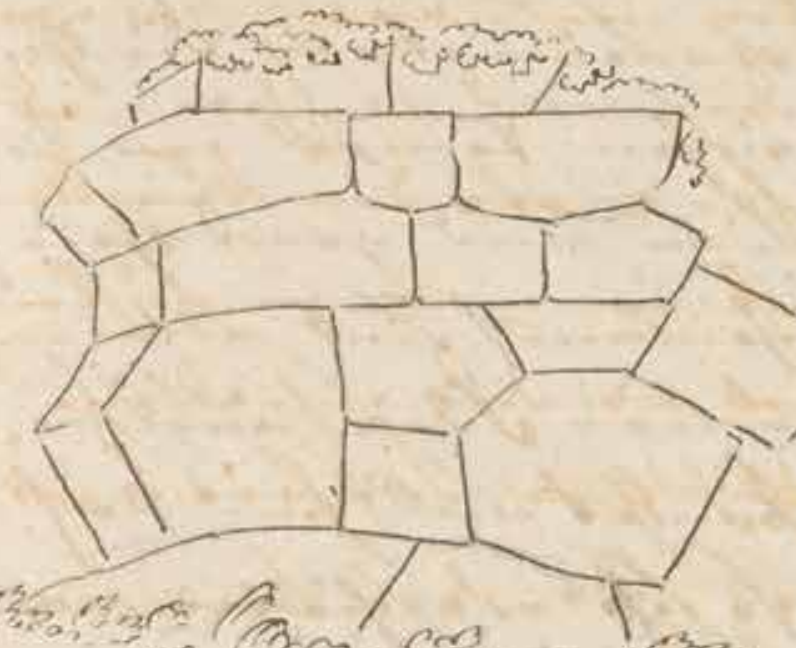
Lin.p ypust fene on

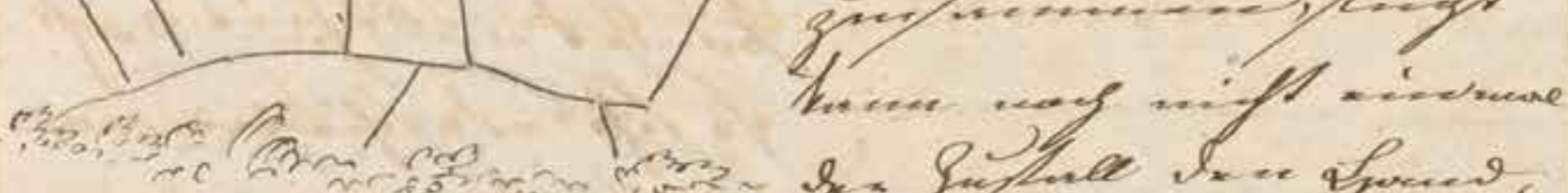

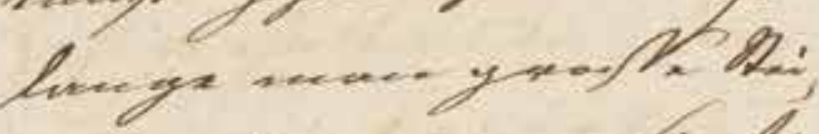

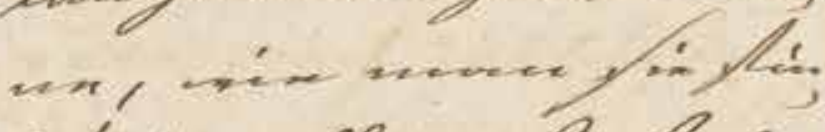
it $\therefore$ old... Ex fue, An......., diff gin. (........... tis

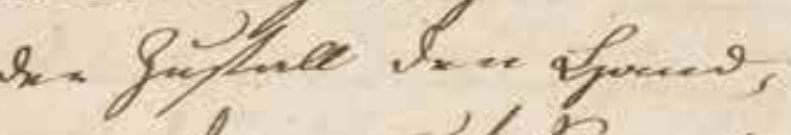

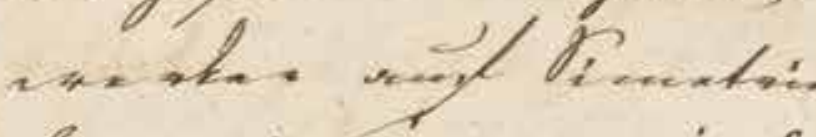
fim......... .....ing

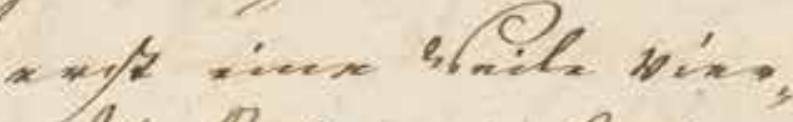
4. D..... in forizon,

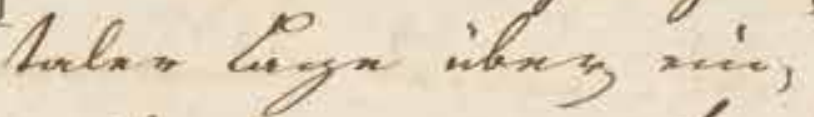

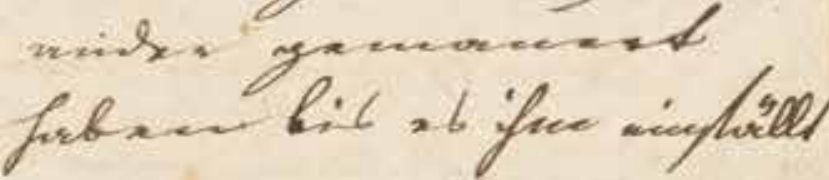




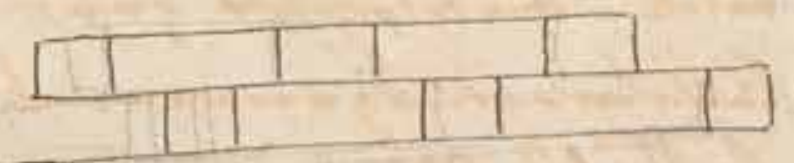

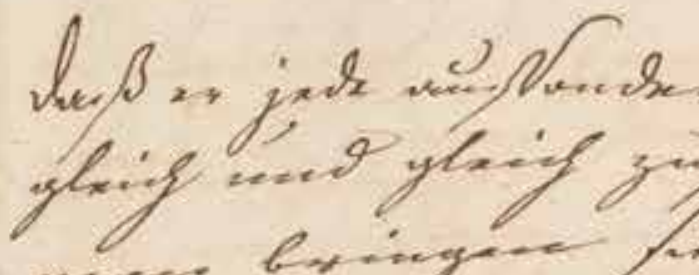

hirg log.t. on: .nges bafen... Jace...

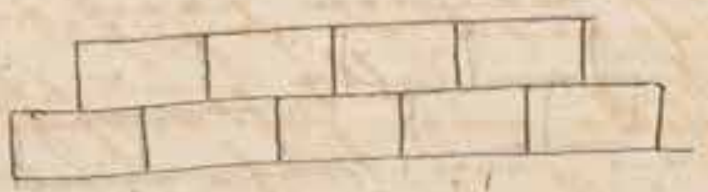

bightraffung s $q_{2}$ fift se withes int. s... Gringene fiff now, lus at if boryil nom

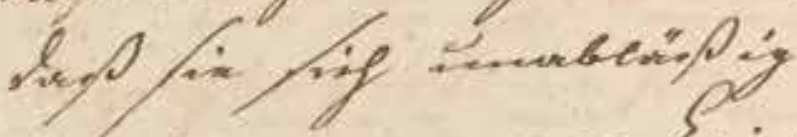
$\therefore$ …........ .

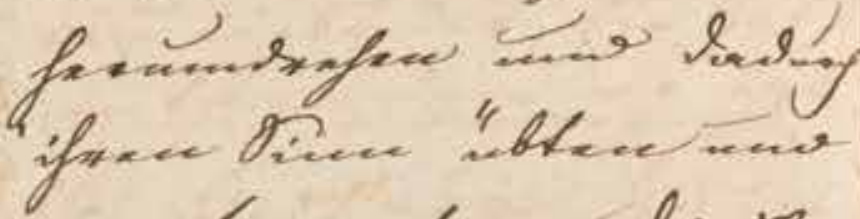
wontlinesta... linge,

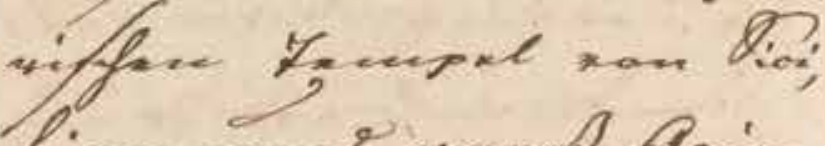
lin.....e yangs gais, Apubures ang ween ay ine. Fen wintage bund not fimesof

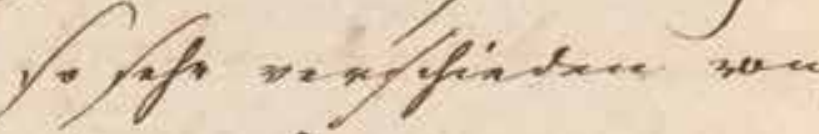
inaneser.

foffuint net.

$\therefore$ m lanfor...

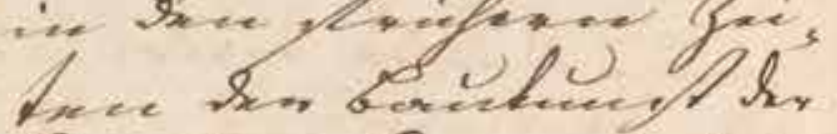

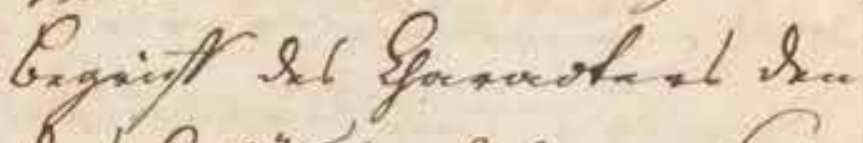
rub grains fobere vel

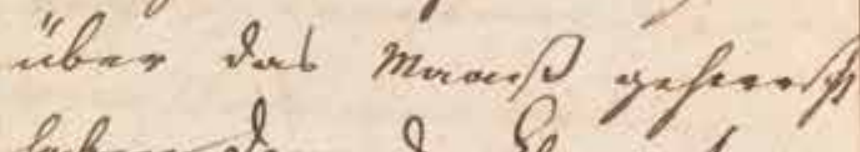
foben \&.... h. Egrasta. 
daß er jene aussondern, gleich und gleich zusammen bringen, sie symmetrisch legen oder wohl gar zu einerlei Maß behauen sollen.

Bei Betrachtung der Geschichte der Baukunst unter den Griechen sieht man, daß es ihr Vorteil war, daß sie sich unablässig in einem engen Kreise herumdrehten und dadurch ihren Sinn übten und verfeinerten; die dorischen Tempel von Sicilien und Großgriechenland sind alle nach einer Idee aufgebauet und sind doch so sehr verschieden von einander.

Es scheint als wenn in den frühern Zeiten der Baukunst der Begriff des Charakters, den das Gebäude haben soll, über das Maß geherrscht habe; denn der Charakter que debía seleccionarlas, juntar las iguales, colocarlas simétricamente o incluso tallarlas con arreglo a una misma medida. ${ }^{461}$

Examinando la historia de la arquitectura de los griegos se hace patente que su ventaja fue que le dieron vueltas sin cesar a lo mismo, con lo que ejercitaron y refinaron su sensibilidad. Todos los templos dóricos de Sicilia y la Magna Grecia fueron erigidos con arreglo a una idea $y$, sin embargo, son muy diferentes entre sí. ${ }^{462}$

Parece como si en los primeros tiempos de la arquitectura el concepto de carácter que debe tener un edificio hubiese dominado al de medida, pues el carácter 463

461. Tres son los dibujos con los que Goethe ilustra este párrafo, uno en la página anterior y dos en esta. El primero representa tres hiladas de sillares cada una de ellas de altura diferente (pseudoisodomo) y dispuestos al azar a soga y tizón. El aparente desorden de la disposición no es consecuencia de la falta de control formal como da a entender Goethe sino de la necesidad de trabar la fábrica con algunos sillares a tizón. El segundo dibujo es de dos hiladas de la misma altura con sillares en cada una alternando a soga y tizón recordando el aparejo flamenco. En este caso la mejor simetría que Goethe señala es la consecuencia del aparejo no un intencionado o prioritario objetivo formal. El tercero es de dos hiladas iguales con sillares del mismo tamaño formando el aparejo isodomo aparentemente a soga que Goethe parece considerar el mejor en la búsqueda de la simetría. En definitiva, los tres dibujos de muros utilizados para ilustrar este párrafo permiten comprender el modo en que Goethe interpretaba los aparejos de los muros como una cuestión puramente formal: la igualdad de la talla de los sillares y la disposición siguiendo una ordenación simétrica y no como consecuencia del aparejo y traba constructiva más apropiada en cada caso a partir del tipo de sillares utilizados.

462. En estas frases se detecta en Goethe un rechazo a los caprichos y fantasías que caracterizaban la arquitectura barroca y rococó, por un lado, así como una crítica de la copia puramente repetitiva de modelos por otro. Frente a las invenciones formales se trata de afinar la sensibilidad siendo fieles a una misma idea con un trabajo puntual y minucioso en los problemas específicos que caracterizan el arte de la arquitectura. Y los ejemplos griegos demuestran que, en este cometido, es posible crear nuevos eslabones que marquen su devenir y variedad superando la simple copia. Son dos aspectos complementarios. La arquitectura griega es esencial en este doble sentido y reconstruir su historia es la mejor manera de alumbrar una teoría de la arquitectura porque ambas, teoría e historia, tienen su origen y se funden entre los griegos. Sin duda, la influencia de Winckelmann y la voluntad de seguir su camino está presente en esta convicción. 463. Pies de imágenes en lápiz en el original: opus isodomum [Muro de piedra con aparejo de altura regular]. 
läßt sich eigentlich durch Maß nicht ausdrucken und wir sehen bei Ausmessungen wirklicher Gebäude, wie schwer es sei ihre Teile auf Zahlverhältnisse zu reduzieren; es war gewiß kein Vorteil für die neuere Baukunst, als man anfing, anstatt auf den Charakter aufmerksam zu machen, die Zahlverhältnisse zu lehren, nach welchen die verschiedenen Ordnungen aufgestellt werden sollen.

Am meisten aber ist man in dem Hauptpunkte zurückgeblieben, man hat das Eigentliche der Fiktion, das Schickliche der Nachahmung selten verstanden, da man es doch am nötigsten brauchte, indem man das, was sonst no se deja expresar propiamente por la medida, y en las mediciones de edificios reales vemos qué difícil es reducir sus partes a relaciones numéricas. ${ }^{464}$ No representó ciertamente ninguna ventaja para la arquitectura más reciente que, en lugar de atender al carácter, se empezasen a hacer manifiestas las relaciones numéricas con arreglo a las cuales debían erigirse los diferentes órdenes. ${ }^{465}$

Pero la mayoría de las veces no se alcanzó la cuestión principal, rara vez se entendió lo que era propio de la ficción y la conveniencia de la imitación, pese a que se necesitaban más que nunca, por lo que se transfirieron a

464. Galileo ya había demostrado en su mecánica (Discorsi e dimostrazioni matematiche intorno a due nuove scienze) que lo monstruoso en la naturaleza es mantener las proporciones cuando se aumentan las medidas. En ese supuesto o bien se cambia de materia para mantener las proporciones formales o bien se modifica la forma si se quiere conservar la misma materia. O sea, un cambio en las medidas implica un reajuste proporcional. Aunque Vitruvio aporta relaciones proporcionales de los elementos de los distintos órdenes, sin embargo, las mediciones hechas en los restos arqueológicos ponían de manifiesto que ni coincidían con lo escrito por Vitruvio ni existía una identidad proporcional entre diferentes edificios pertenecientes a un mismo orden. De las tablas de resistencias de distintos materiales según secciones y longitudes sometidos a solicitaciones y cargas que reflejaban los experimentos realizados tampoco era posible extraer leyes proporcionales que vinculasen entre sí los distintos casos con medidas variables. En consecuencia, no se pueden establecer de forma general normas proporcionales porque en cada ejemplo dependen del material y las dimensiones, y cambian si se modifican las medidas. Así pues, las proporciones son un asunto de dimensiones no de medidas, de relaciones dimensionales no métricas. Proporciones y medidas son variables independientes entre sí. La proporción nos remite a dimensiones relativas de cada edificio y éstas cambian si los tamaños (y la materia) varían. Esta es la conclusión que recoge Goethe. 465. Vitruvio define el término procedente de la retórica de la euritmia (Lib. I, cap. II) como la apariencia conveniente que se obtiene de las relaciones entre los diferentes miembros del edificio según las relaciones proporcionales entre sus dimensiones. Pero esas proporciones son específicas para cada edificio. Con esa proporción se expresa la euritmia que, siguiendo la teoría francesa, Goethe llama el carácter. En resumen, el carácter de un edificio es la manifestación de sus propias relaciones proporcionales independientemente de sus medidas. Cuando la teoría clásica buscó establecer relaciones proporcionales de forma general empezó a comparar los distintos órdenes en función de sus medidas. Las láminas con la comparación de formas, medidas y alturas de los cinco órdenes, que inauguró Serlio (Li. IV, fol. 3 anv.), son la manifestación de este interés. Goethe consideraba esta deriva como negativa. 


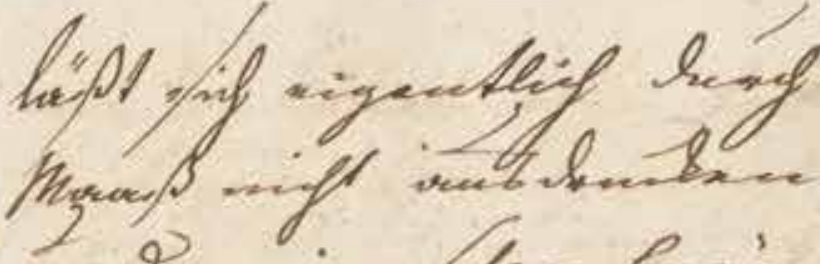
uno nin Mfen by Qú: D. lifes Gabinge win

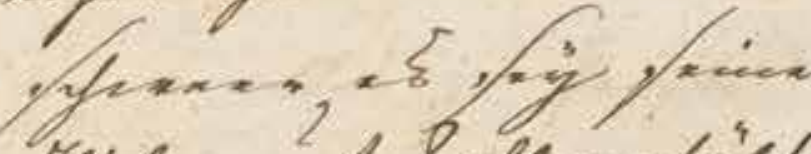

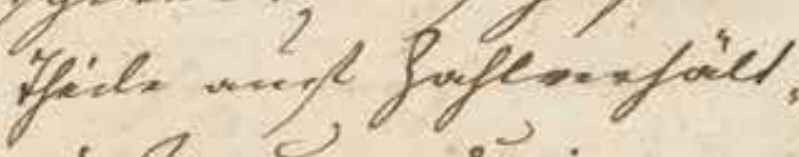
nips. y x x. to nnes yeerisp haic Anelgil tis si wa. traichu of aeb

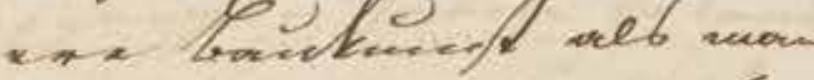
malling me fatl mét

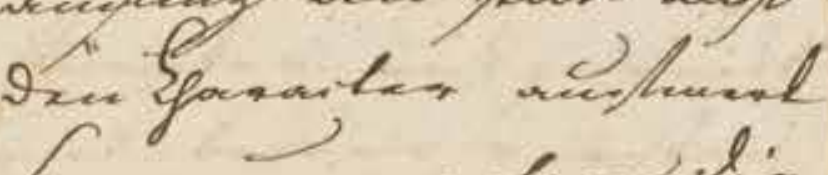
fum gn noxpere $l_{\text {in }}$

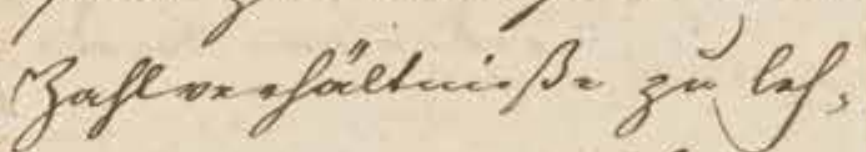

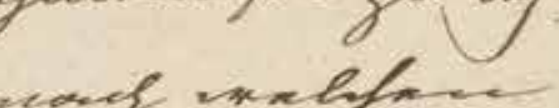
in sox-f finsuren

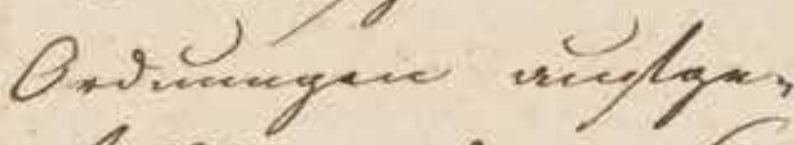
faeer n...er... veen

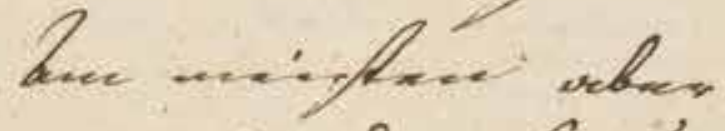

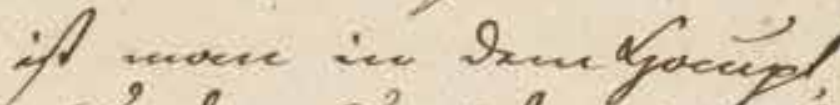
pruete zin icist yablia bes, manc lat is S fingulleife a. didtion, 96 oyiklige s. Marfofinungy fetur

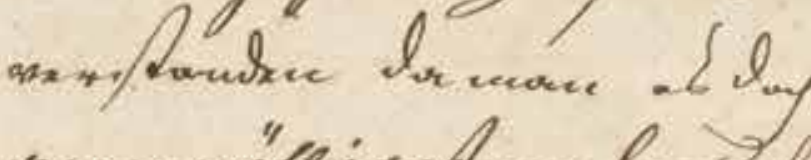

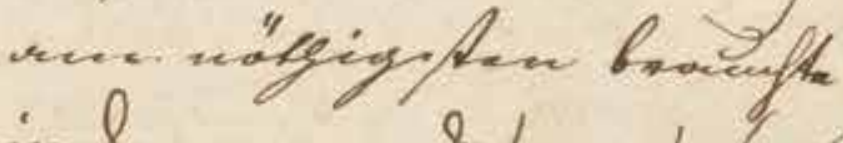

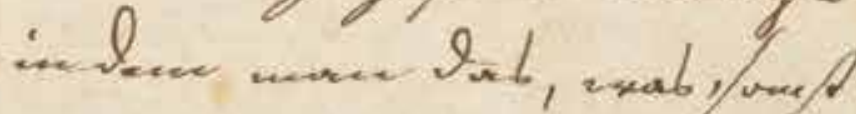


d) Hemple mo ifted,

lifex Gabin's s.o werys,

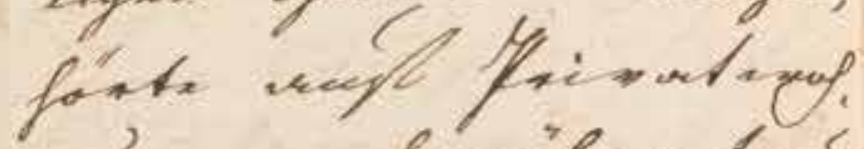

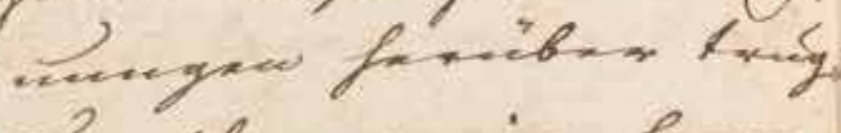

c... fow $\therefore \therefore f_{x \rightarrow}$,

lifes burtofer ger yo.

b.

Mare bare. Inge.. Inp

$\therefore$ h. ........ g.t

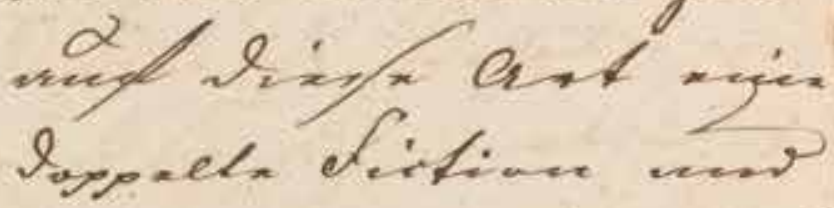

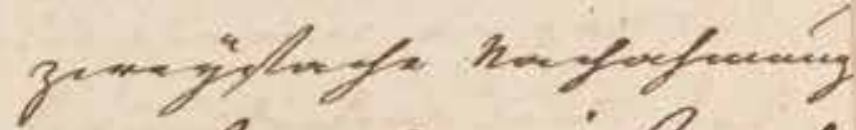

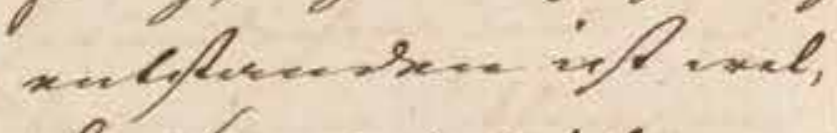

fa a. oxe big if...

a........ny nel beys.

burffilung gail ....

Pi... \#thares.s.

Ifix \& inn foot wis,

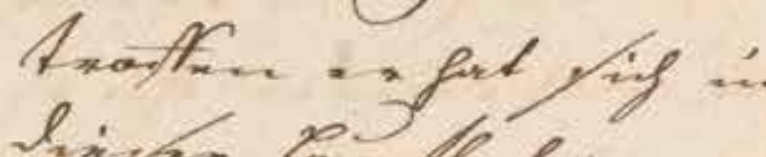

hinar candbefor vew

$\therefore f_{x}=g_{x} \ldots$,

gav Iba nf foitt I/"

in.....n conel

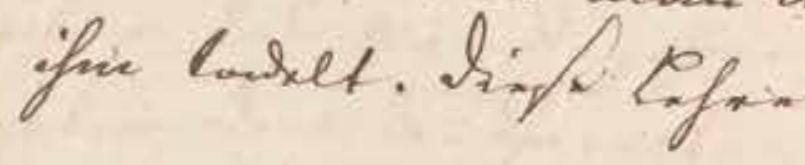


nur Tempeln und öffentlichen Gebäuden angehörte, auf Privatwohnungen herüber trug, um ihnen ein herrliches Ansehn zu geben. Man kann sagen, daß in der neuern Zeit auf diese Art eine doppelte Fiktion und zweifache Nachahmung entstanden ist, welche sowohl bei ihrer Anwendung als bei der Beurteilung Geist und Sinn erfordern. Hierinne hat niemand den Palladio übertroffen, er hat sich in dieser Laufbahn am freiesten bewegt, und wenn er ihre Grenzen überschritt, so verzeiht man ihm doch immer, was man an ihm tadelt. Diese Lehre las viviendas particulares, para así darles un aspecto majestuoso, lo que en un primer momento sólo correspondía a templos y edificios públicos. ${ }^{466}$

Se puede decir que, en la actualidad, ha surgido así una ficción doble y una imitación duplicada que requieren espíritu y sensibilidad tanto en su aplicación como en su valoración. ${ }^{467}$

En este punto nadie ha superado a Palladio. Se ha movido en esta profesión con plena libertad y cuando sobrepasa sus límites siempre se le perdona, sin embargo, lo que se le reprocha. ${ }^{468}$ Esta doctrina

466. El interés del clasicismo por cuestiones de medidas entre órdenes desvió la atención de lo principal que, para Goethe, es la ficción poética y la mímesis correspondiente en cada situación para alcanzar el fin supremo. En consecuencia, para el reto al que se enfrentaba la historia de la arquitectura en el tránsito del templo a la casa lo principal era encontrar la ficción mimética adecuada a ese problema.

467. Ficción doble que supone pasar de la construcción en madera a la arquitectura en los templos y edificios públicos y, de estos a la arquitectura doméstica. Y imitación duplicada: la casa que imita al templo que, a su vez, imita al templo original y, en consecuencia, que transfiere la esencia sagrada del templo primigenio a la casa burguesa. Un doble salto que sólo está al alcance del arquitecto genial y del espíritu elevado capaz del disfrute estético.

468. Para Goethe la genialidad de Palladio consiste en la libertad con la que actuó, siendo capaz de encontrar esa doble ficción mimética. Una capacidad que le empujaba a superar los requisitos y condiciones más allá de los límites convencionales. Por lo tanto, estos excesos siempre son perdonables porque nacen de la necesidad de superación para alcanzar el fin supremo de la arquitectura. 
von der Fiktion, von ihren geistigen Gesetzen ist nötig, um gewissen Puristen zu begegnen, die auch in der Baukunst gern alles zu Prosa machen möchten.

Wenn wir die verschiedenen Teile der Baukunst einzeln werden durchgegangen haben, so kann das bisher Gesagte bestimmter ausgedruckt und besser verstanden werden. de la ficción y de sus leyes espirituales es necesaria para hacer frente a ciertos puristas a los que, también en la arquitectura, les gusta convertir todo en prosa. ${ }^{469}$

Cuando hayamos recorrido separadamente las diferentes partes de la arquitectura, cabrá expresar con mayor precisión y comprender mejor lo hasta aquí dicho. ${ }^{470}$

469. Entre sus máximas, Goethe escribe: "En todas las artes hay cierto grado que puede alcanzarse con las disposiciones ingénitas, por así decirlo, exclusivamente. Pero al mismo tiempo es imposible rebasarlo como el arte no venga en nuestra ayuda" (Mx. $\mathrm{n}^{\circ} 1114, \mathrm{I}$ : 442). El respeto escrupuloso a las normas y cauces por donde discurre la arquitectura, es la pauta a la que se atienen los puristas. Pero en estos casos el resultado sólo será una arquitectura que nunca se elevará a la ficción poética que conduce a las cumbres más elevadas del arte. Prosa, simples "piezas de arte" y no poesía que son las auténticas "obras de arte".

470. En este punto Goethe cierra, tal vez provisionalmente, la exposición general de su teoría. Pero es consciente que sólo mediante el estudio detallado de la evolución morfológica de los elementos esenciales de la arquitectura los conceptos expuestos podrán comprenderse de manera más clara. Parece insinuar también una recapitulación general al final del recorrido propuesto. De ser así el texto se estructuraría en tres partes: tesis que corresponde a lo escrito hasta aquí, demostración mediante el estudio de los casos y síntesis final que ratificaría la teoría. Dado que el manuscrito quedó inacabado ésta es sólo una suposición. 


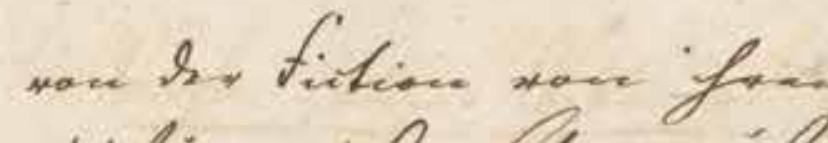
yiiflige... Agrlat... is waing mu, yneithe fi xipa.. gre bugrge

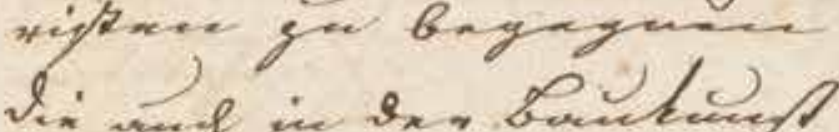
in ning in $a_{x \rightarrow b}$ buckent

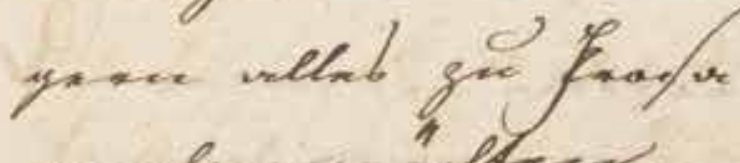

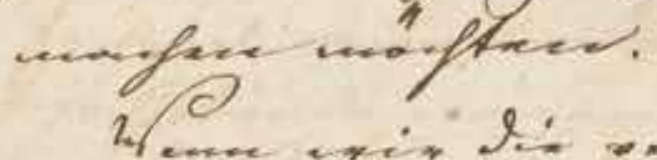

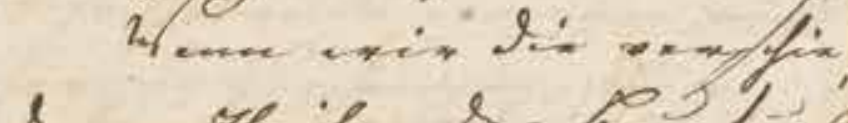

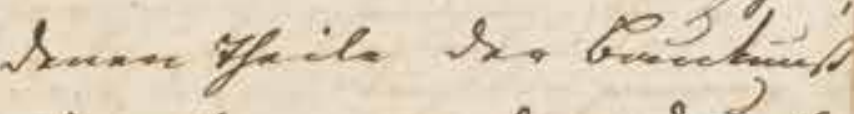
xingle waxher In yegangen forber

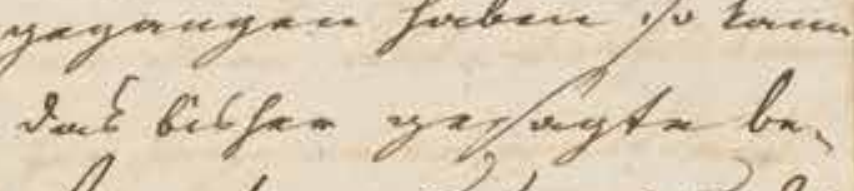
finmatar nut tyas os

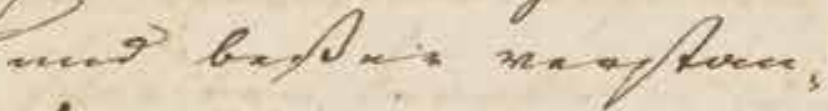
bere ......... 
Basen ganzer Gebäude woraus in der Folge die Zocken und Postamente entstehen. ${ }^{471}$

1. Die Basen der ältesten Tempel waren Stufen, diese Gebäude waren rings herum zugängig. Nur daß diese Stufen proportionierlich zum Gebäude in den ältern Zeiten z So $^{472}$ hoch waren, daß der Mensch sie nicht erschreiten konnte; es wurden also an der Vorderseite der Tempel diese hohen Absätze nochmals durch kleinere Stufen durchschnitten. ${ }^{473}$

Bei andern Tempeln waren die Stufen ringsum von dem Maße, daß man hinaufsteigen konnte.

\section{Der Auftritt der Stufen hatte einen} scharfen Winkel, die vorspringenden Glieder an denselben kommen erst zu Augusts Zeiten
Basamentos de los edificios en su conjunto, ${ }^{474}$ de donde surgen sucesivamente los zócalos y los pedestales.

1. Los basamentos de los templos más antiguos eran escalones; estos edificios eran accesibles por todo su perímetro. Sólo que, en las épocas más remotas, estos escalones, proporcionados respecto al edificio, eran tan altos que el hombre no podía subir por ellos. De ahí que en el frente del templo se dividiesen a su vez estos altos tramos por medio de escalones más pequeños.

En otros templos, el tamaño de los escalones en su perímetro permitía subirlos. ${ }^{475}$

La contrahuella tenía un ángulo agudo. Su parte saliente apareció por vez primera en época de Augusto. ${ }^{476}$

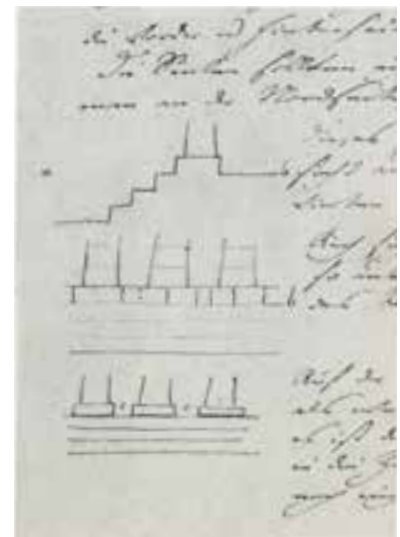

Fig. 39

471. Son palabras de uso más corriente, respectivamente, "Sockel" y "Piedestal" (que empleará más adelante en el texto), ambos términos genéricos que no aportan precisión técnica a los elementos arquitectónicos a los que Goethe se está refiriendo. Esto podría estar motivado por su voluntad de señalar una evolución morfológica entre ellos como da a entender la frase.

472. El "so" [tan] ha sido añadido posteriormente, matizando el posicionamiento inicial según el cual los escalones eran demasiado [zu] altos. No se trata, por tanto, de que los escalones sean en absoluto demasiado altos, sino que son lo suficientemente altos como para impedir subir por ellos. Lo son en relación a su utilidad. De nuevo aquí se ve la importancia para Goethe de condicionar la morfología de la arquitectura a su uso y, más específicamente, a la posibilidad de ser recorrida.

473. En el margen, al comienzo del párrafo, Goethe escribió "1.", indicando por tanto su intención (no desarrollada) de considerar dentro de este capítulo diferentes apartados. Esta idea vendría reforzada por no tener sangrado este primer párrafo del primer apartado.

474. Aunque los tratados clásicos empiezan refiriéndose al terreno y a la cimentación, Goethe obvia estas cuestiones seguramente por considerarlas aspectos puramente constructivos. En su novela Die Wahlverwandtschaften (Las afinidades electivas, 1808-1809) se demora en el rito de la colocación de la primera piedra en un edificio y pone en boca del maestro albañil: "Tres cosas -empezó- se han de observar en un edificio: que se alce en el lugar adecuado, que tenga buenos cimientos y que esté bien hecho." (II: 1241). La resolución de los basamentos de los templos era un aspecto que ya le había interesado en su visita a Segesta en Sicilia. En relación con esta cuestión Goethe, realizó un dibujo en su cuaderno (Fig. 39), que acompañó con abundantes notas (DKV, II-3: 287-289). Escribió en su Viajes...: “Hasta qué punto habían de tener zócalo las columnas resulta difícil de precisarlo ni darlo a entender con claridad sin un diseño. Tan pronto parece que las columnas se alzasen sobre la cuarta grada, debiendo entonces haber otra que descendiese hacia el interior del templo, tan pronto aparece dividida la grada superior, pareciendo como si las columnas tuvieran basamento, o vuelven a estar colmados estos espacios intermedios, encontrándonos entonces en el primer caso." (III: 1217). En su cuaderno de notas, se extiende La existencia de columnas dóricas con basa "en los tiempos más remotos" ya la había señalado Winckelmann (1985: 525).

Fig. 39: Johann W. Goethe, Tempel zu Segesta [Templo de Segesta], 20.4.1787 (240x192 mm. Tinta con pluma), en Femmel [1958] 1972, Vla: 140

475. Esta misma argumentación se encuentra en Winckelmann (1985: 553) que aporta ejemplos.

476. Goethe se refiere aquí al vuelo o bocel del peldaño, es decir, el alargamiento por la parte delantera de la huella del peldaño más allá de la tabica, una solución habitual para camuflar la junta cuando se trata de piezas distintas. Cuando 


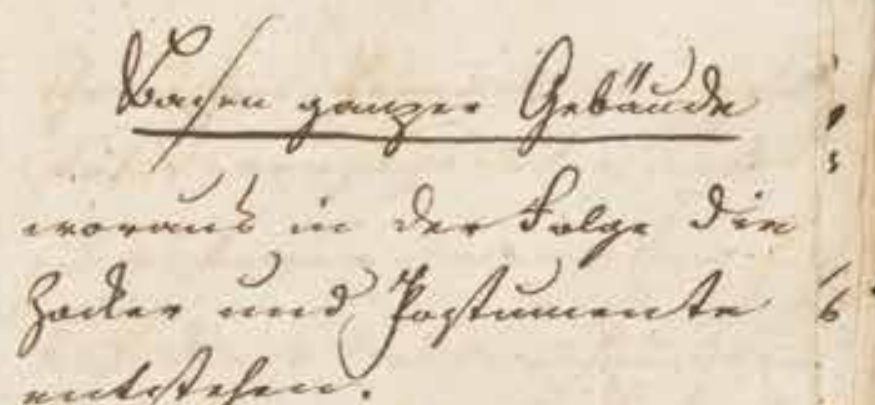
$x=02 y, y=0$.

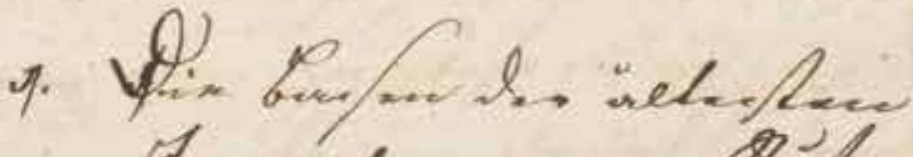

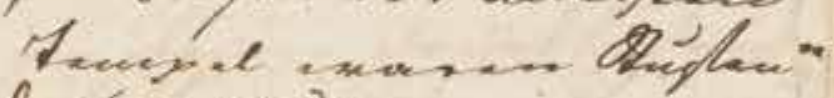

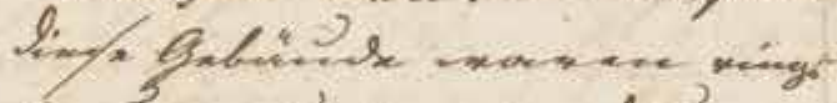

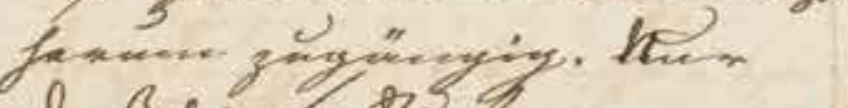

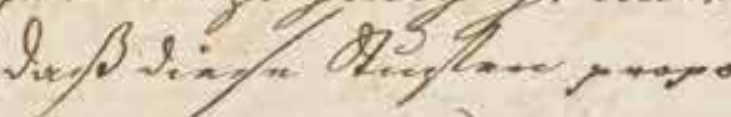
Lin.xlif zane Pabiris $\therefore$ see velumfoikn

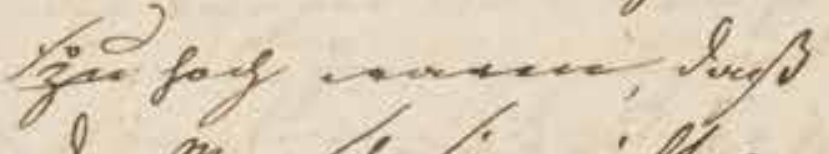

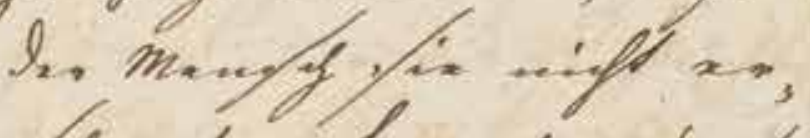

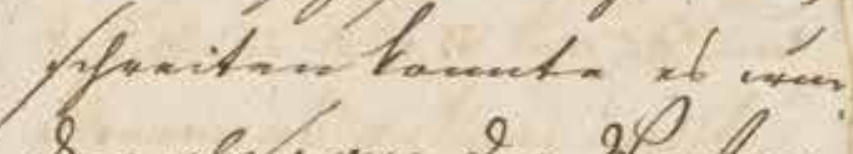

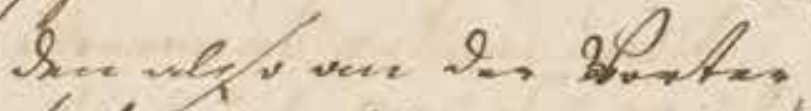

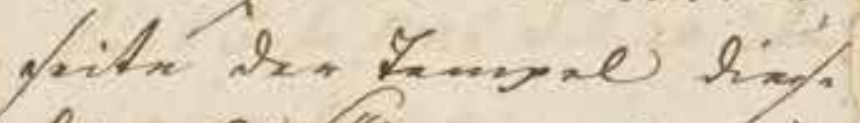

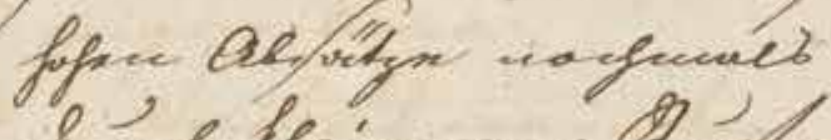

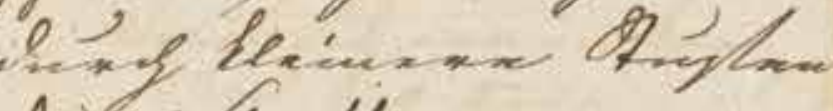
bexelfyeithac.

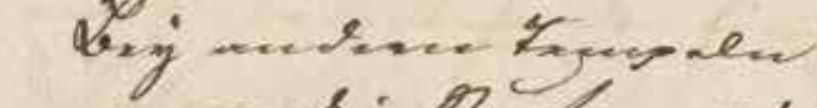

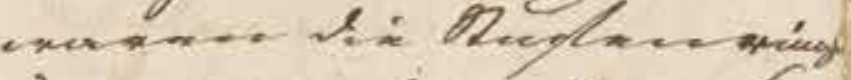

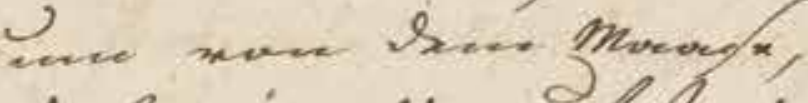

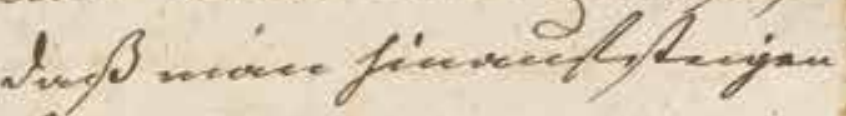
tacentix.

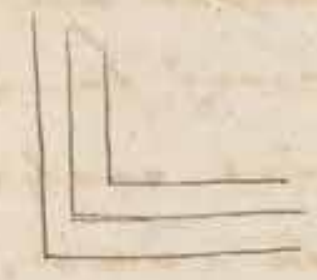

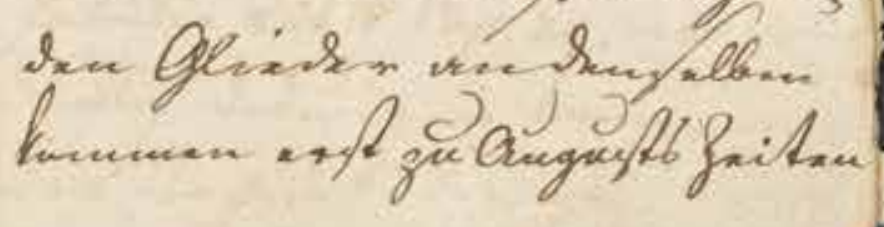



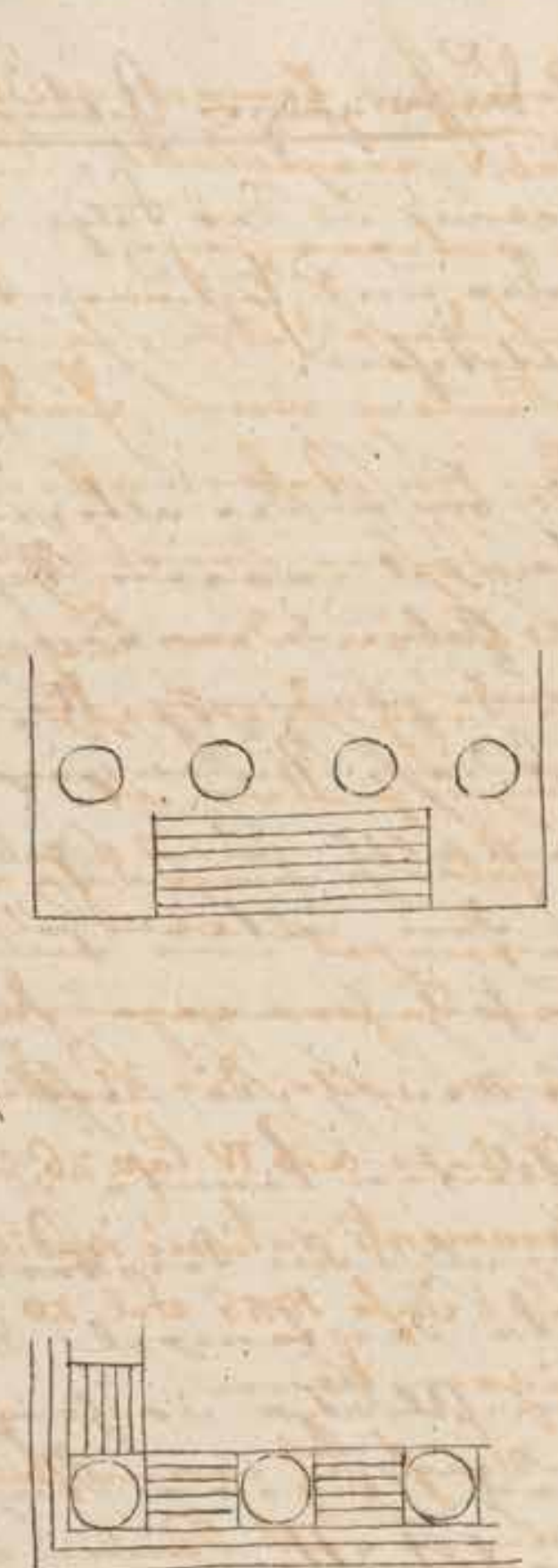

now. Inxe Iti Yanegal $1 / v$

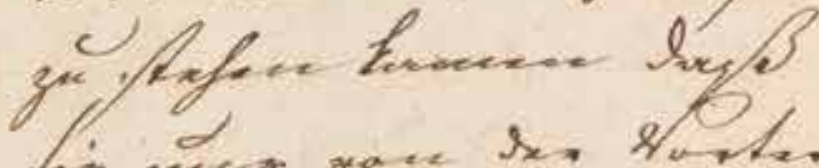

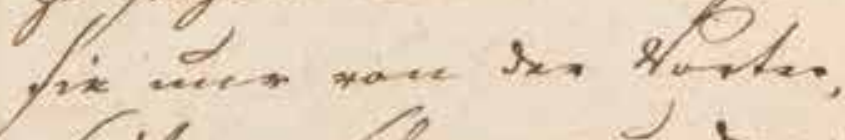

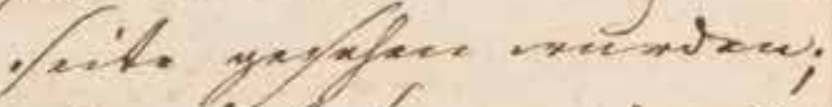

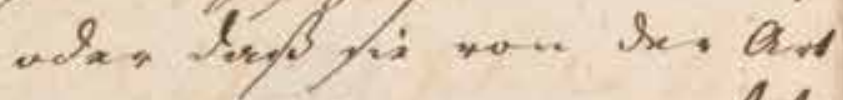

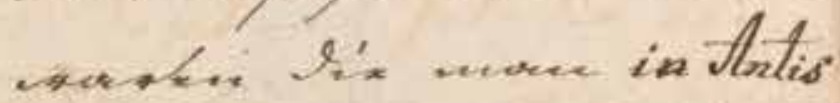

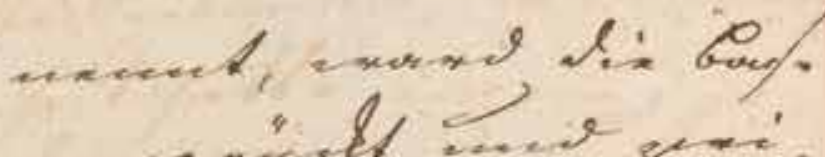

maxye wast wenter get,

10000

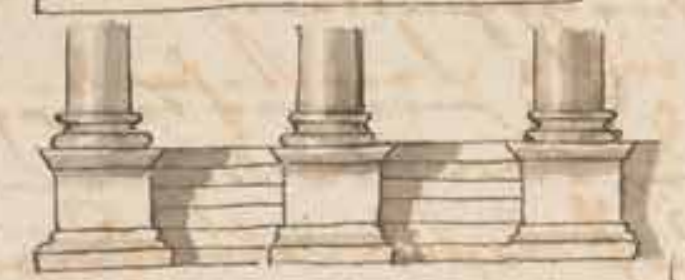

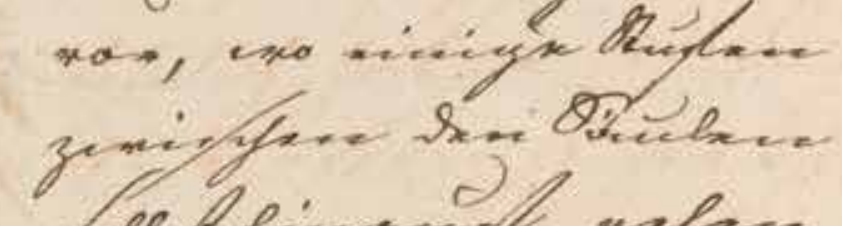
Inls fiveneyl yaface,

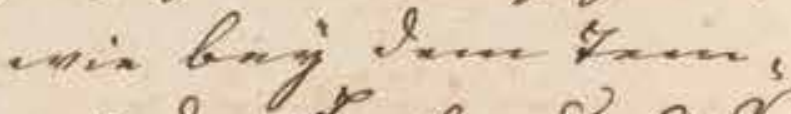

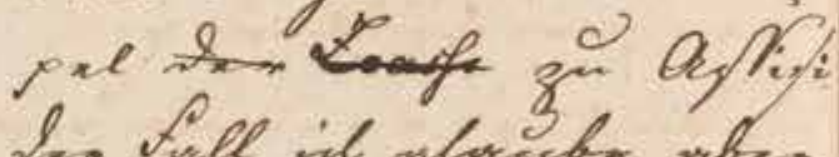
s. thel if ylusen wh. lup ...... nl .... máb nogy...... lifaed yotyen,

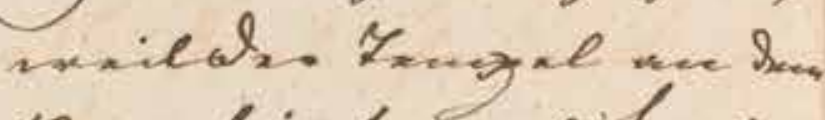
ry ligh noth

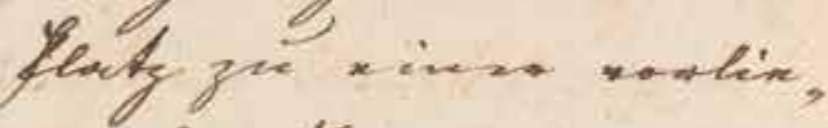

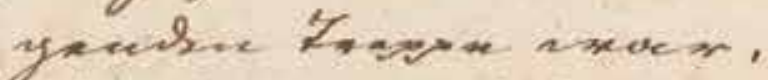

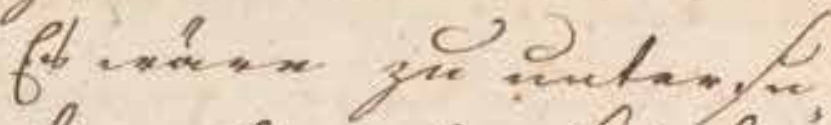

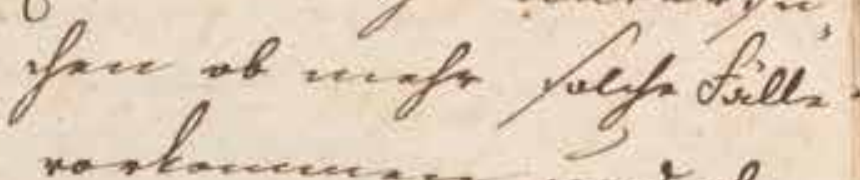

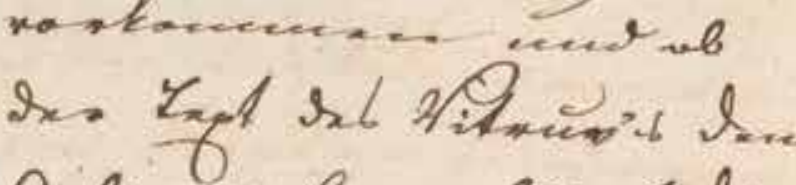

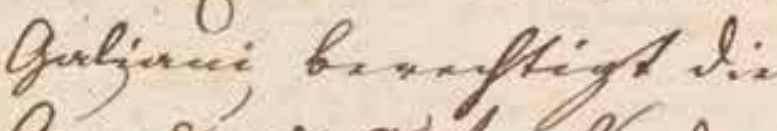

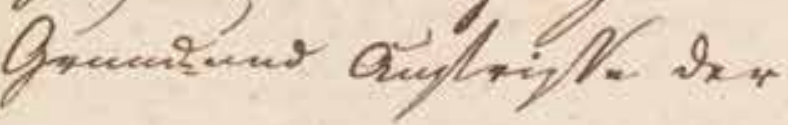


vor. Wenn die Tempel so zu stehen kamen, daß sie nur von der Vorderseite gesehen wurden; oder daß sie von der Art waren die man in antis ${ }^{478}$ nennt, ward die Base vorgerückt, und zwischen derselben ging die Treppe hinauf.

Es kommt auch ein Fall vor, wo einige Stufen zwischen den Säulen selbst hinauf gehen, wie bei dem Tempel den Zeushs ${ }^{479} z u$ Assisi der Fall; ich glaube aber, daß man er nur aus Notwendigkeit getan, weil der Tempel an dem Berg liegt und kein Platz zu einer vorliegenden Treppe war. Es wäre zu untersuchen, ob mehr solche Fälle vorkommen und ob der Text des Vitruvs den Galiani berechtigt die Grund- und Aufrisse der
Cuando los templos se emplazaban de tal manera que sólo se podían ver de frente o eran del tipo llamado in antis, ${ }^{480}$ el basamento se adelantaba y la escalera discurría por el centro.

Se da también un caso en el que algunos escalones remontan entre las columnas, como ocurre en el templo de Asís. Creo no obstante que se hizo sólo por necesidad, puesto que el templo está situado en las proximidades de la montaña y no había espacio para una escalera frontal. ${ }^{481}$ Habría que investigar si se dan más casos semejantes y si el texto de Vitruvio autoriza a Galiani a trazar la planta y el alzado del

Winckelmann habla de esta cuestión alude también a que no pueden ser muy antiguas, aunque no menciona el momento de su posible aparición (1985: 553), por lo que es posible que la información de que surgieron en la época de Augusto le fue dada por Meyer.

477. La página 14 se ha dejado en blanco en el manuscrito para adecuarse al cambio de capítulo.

478. En el manuscrito, "in Antis" está escrito con otra caligrafía y remite al recurso actual de las cursivas, como así ocurre en otras referencias a libros. En la trascripción utilizada no se ha interpretado así. Por otra parte, "in" parece corregir algo anterior.

479. La advocación del templo a Zeus fue tachada posteriormente. Se trata de la actual Santa Maria sopra Minerva, cuyo origen se remonta al 30 a.C., templo dedicado probablemente a Hércules.

480. El templo in antis es el primer tipo que menciona Vitruvio (lib. III, cap. I) dando a entender que es el más simple o primitivo. Palladio menciona tres tipos in antis, próstilo y anfipróstilo y comenta: "De los dos primeros aspectos de Templos en nuestros días no queda ningún vestigio" (lib. IV, cap. III: De gli aspetti de i Tempii, p. 7).

481. El templo de Minerva en Asís supuso un hito en su viaje a Italia al tratarse del primer edificio romano completo que veía. De este edificio comenta "que todavía no se ha sacado un buen diseño ni grabado en cobre." (III: 1114). 


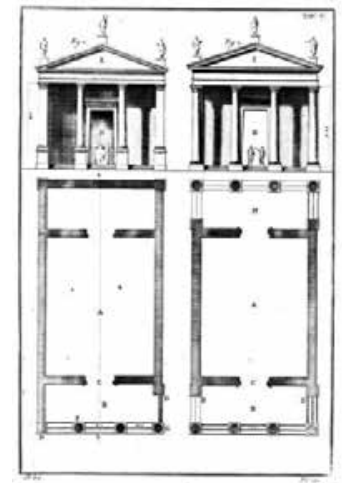

Fig. 40

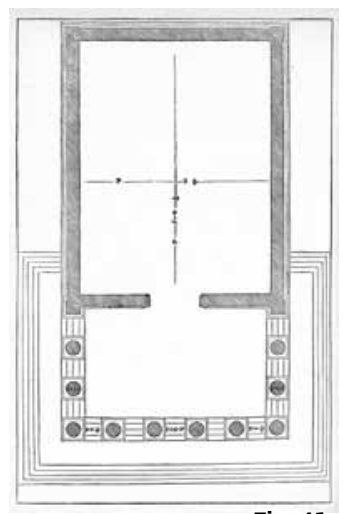

Fig. 41

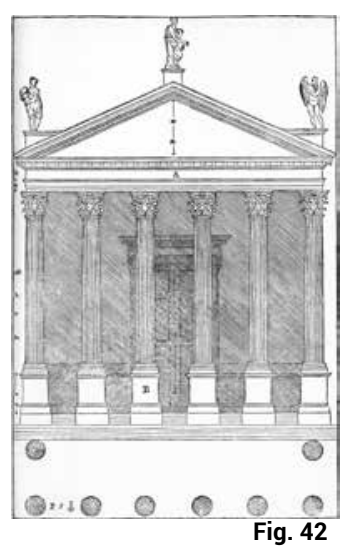

dorischen Tempel, wie sie Tab. $V$ vorgestellt sind, zu entwerfen.

Auf diese Weise scheinen die Säulen auf Piedestalen zu stehen, allein sie stehen wirklich auf dem Boden der Vorhalle, der durch die Treppe nur eingeschnitten ist. Palladio muß daher die Tempel nur aus Hörensagen gezeichnet haben, wie die Vergleichung desselben Lib. IV Cap. 26, und Monumenti antiqui inediti für's Jahr 1786 Fol. 20 überzeugen kann.

Fragt sich, wann kommen zuerst Säulen auf völlig freistehenden Piedestalen vor.

Piedestale als Vorsprünge der Basen im Fall, wo keine Stufen vorkommen, Palladio Lib. IV Cap. 29.

Der Übergang sind offenbar durchschnittene Basen, Palladio Lib. IV Cap. 25, wo man deutlich deduzieren kann, wie der Architekt, der ohne dies templo dórico, tal y como son representados en la Tab. V. ${ }^{482}$

De esta manera las columnas parecen descansar sobre pedestales, cuando en realidad descansan sobre el suelo del vestíbulo ${ }^{483}$ con la particularidad de estar interrumpido por la escalera.

Por tanto, Palladio debe haber dibujado el templo sólo de oídas, como evidencia la comparación del Lib. IV Cap. 26. del mismo y los Monumenti antiqui inediti del año 1786, Fol. 20.484

Cabe preguntarse cuándo aparecen por vez primera las columnas sobre pedestales totalmente independientes.

Pedestales como proyecciones de los basamentos donde no se encuentra ningún escalón, Palladio Lib. IV Cap. 29.485

Los basamentos divididos son evidentemente la transición, Palladio Lib. IV Cap. $25,{ }^{486}$ de donde se puede claramente deducir cómo el arquitecto, sin ser

482. La edición bilingüe latín italiano del tratado de Vitruvio hecha por Galliani, L'architettura di M. Vitruvio Pollione colla trad. italiana e comento del Marchese Berardo Galiani, Napoli 1758, fue adquirida por Goethe el 9 de octubre de 1786 en Venecia (Ruppert, 1958, n01461). (Fig. 40)

Fig. 40: Galliani, L'architettura di M. Vitruvio Pollione colla trad. italiana e comento del Marchese Berardo Galiani, Nápoles 1758 (tavola V, imagen 4)

483. Por vestíbulo, Goethe alude al pronaos del templo.

484. La crítica de Goethe sigue al libro de Giuseppe Antonio Guattani, I monumenti antichi inediti ovvero Notizie sulle anctichità e belli arti di Roma per l'Anno MDCCLXXXVI. Se trata de unos escritos que se publicaban periódicamente y Goethe lo tuvo en posesión los años 1784, 1785 y 1786 (Ruppert, 1958, n²095). Winckelmann (1985: 546) también es criticado por Guattani porque comete el mismo error que Palladio. (Figs. 41 y 42)

Fig. 41: Andrea Palladio: Planta del templo de Minerva en Asís (1570, IV:104)

Fig. 42: Andrea Palladio, Alzado del templo de Minerva en Asís (1570, IV:105)

485. Alude al Templo de Diana de Nimes, reproducido por Palladio con el nombre de "Otro templo de Nimes" con la numeración equivocada (XIX en lugar de XXIX).

486. Se trata del Templo de Clitumno que en la relación de su viaje a Italia Goethe menciona como San Crocedisso aunque se trata de la iglesia del Salvador. En ese texto hace una descripción muy negativa. Escribe: "San Crocedisso, una admirable capilla junto al camino, no me parece vestigio de un templo que allí antaño hubiera, sino que han descubierto y amañado con columnas, pilares y vigas de una manera no estúpida, sino loca. No se presta a la descripción, pero anda por ahí grabado en cobre." (III: 116). Sin embargo, ahora lo considera un ejemplo a tener en cuenta para comprender la transición del pedestal. 
Yoniffer rangel.nich gin nuter...the.

h'/ s.

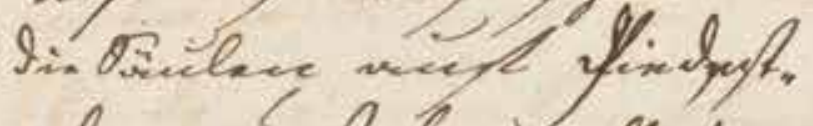
ahe gre fife on ullein.

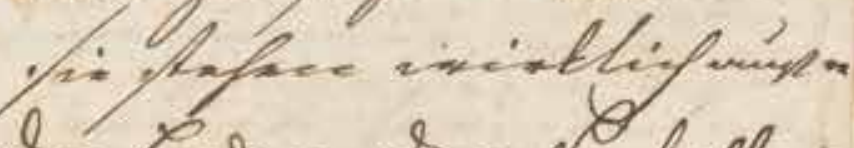

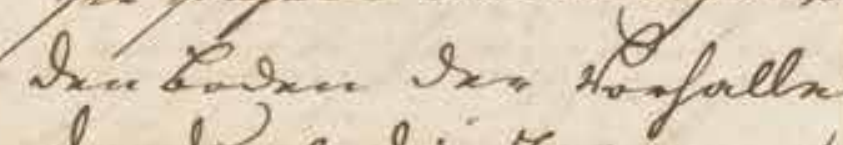

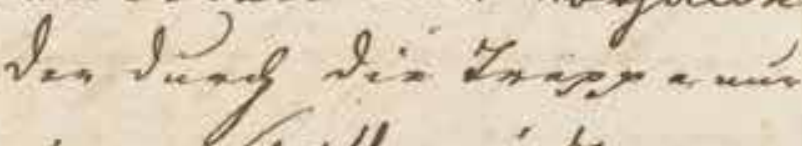
cinguf fillew is.

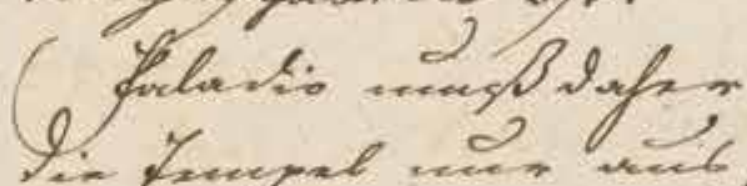
far. oufere yasifual feran win sin plogliffy

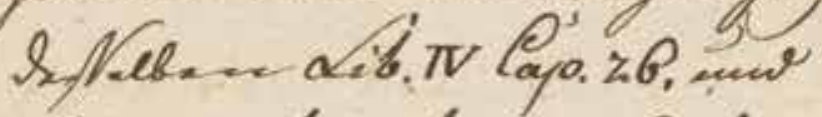
Monumenti antigué inediti

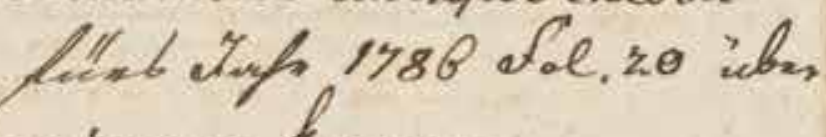
grigar have.

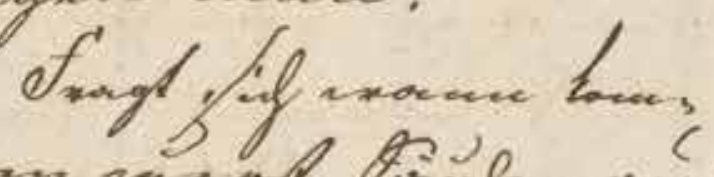

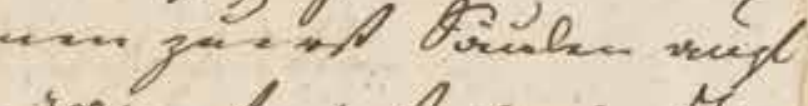

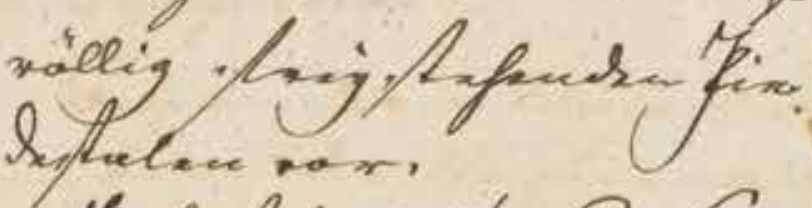
Fubluma ald so D costonge inl.

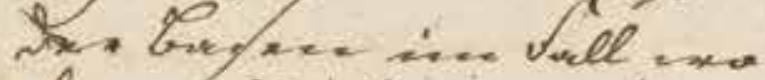

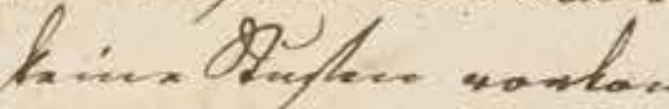

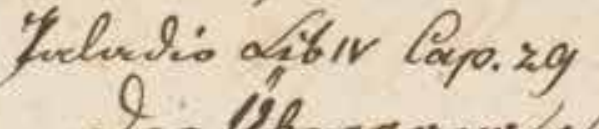
In lib nung ineathe bum linff pritteun bingom Yobatio Litw layo. is, no

\begin{tabular}{|l|l|}
1 & 1 \\
1 & 1
\end{tabular}

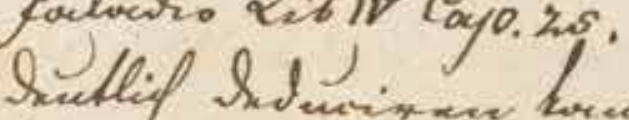

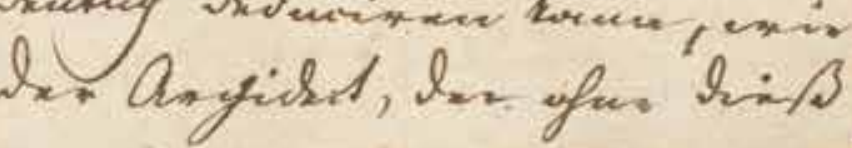




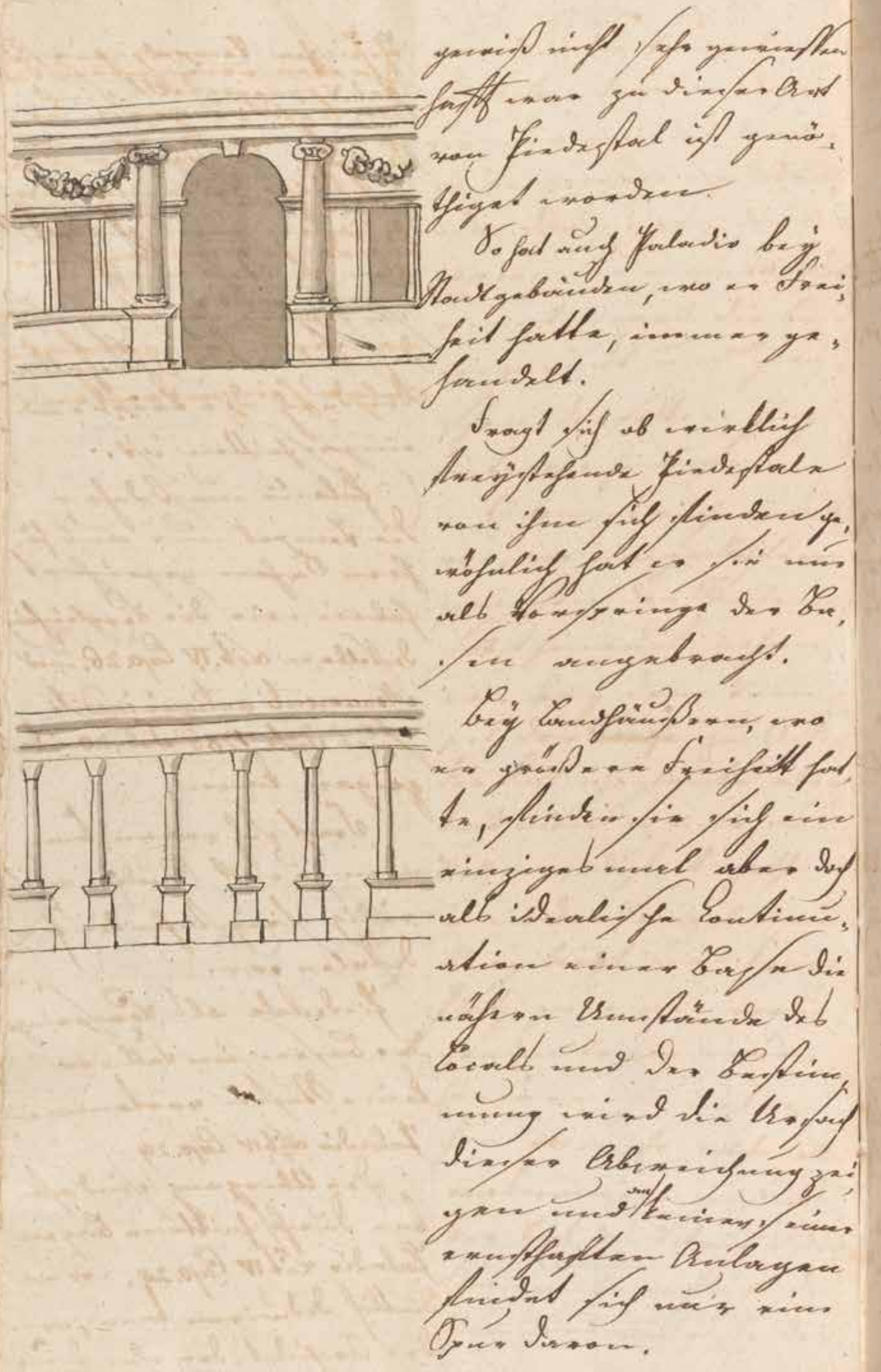


gewiß nicht sehr gewissenhaft war, zu dieser Art von Piedestal ist genötiget worden.

So hat auch Palladio bei Stadtgebäuden, wo er Freiheit hatte, immer gehandelt.

Fragt sich ob wirklich freistehende Piedestale von ihm sich finden; gewöhnlich hat er sie nur als Vorsprünge der Basen angebracht.

Bei Landhäusern, wo er größere Freiheit hatte, finden sie sich ein einziges Mal, aber doch als idealische Kontinuation einer Base. Die nähern Umstände des Lokals und der Bestimmung wird die Ursache dieser Abweichung zeigen, und $a n^{487}$ keiner seiner ernsthaften Anlagen findet sich nur eine Spur davon. muy concienzudo, se vio obligado a servirse de este tipo de pedestal.

Así ha actuado siempre también Palladio en los edificios urbanos, allí donde tuvo libertad. ${ }^{488}$

Cabe preguntarse si en él se pueden encontrar realmente pedestales independientes; normalmente los usó sólo como proyecciones de los basamentos.

En las villas, donde tuvo mayor libertad, hay un único caso de ello, aunque siempre como prolongación ideal del basamento. ${ }^{489}$ Las circunstancias detalladas del local y su disposición mostrarán la causa de esta desviación, y en ninguna de sus construcciones más serias se encuentra un sólo rastro de ello. ${ }^{490}$

487. "an" añadido posteriormente, sin más trascendencia probablemente que un cambio de verbo a posteriori.

488. La generalización que hace ("siempre") sobre la libertad de actuación de Palladio no parece justificada por la realidad de sus palacios urbanos, pero es un argumento que Goethe utiliza para reforzar su discurso y justificar su tesis. Es, en efecto, difícil determinar en qué casos tuvo esa libertad, tal y como se pone de manifiesto a continuación. 489. Posiblemente se refiere a la Villa Thiene (Palladio, 1570, II: 64). Tal vez Goethe considera que tuvo mayor libertad en las villas por tratarse de edificios privados y exentos.

490. Parece que el razonamiento de Goethe es el siguiente: Palladio era consciente del atrevimiento que suponía el troceamiento de los basamentos convertidos en pedestales de las columnas. Algo que no podía plantear en las obras públicas más representativas y sólo se atrevió a hacerlo en los casos de palacios y villas donde dispuso de libertad de acción por parte de los comitentes al tratarse de edificios privados. 
In oben erwähnten Fällen ließ er gern in der Höhe des Säulenfußes einen Zockel um das Gebäude herumlaufen, um immer auf eine gewisse horizontale Folge hinzudeuten.
En los casos arriba mencionados, le gustaba disponer a la altura de la basa ${ }^{491}$ un zócalo rodeando el edificio para acentuar un cierto efecto horizontal.

492
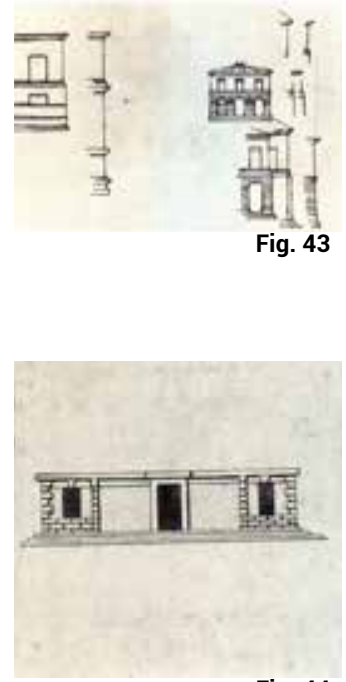

Fig. 44
491. Posiblemente se está refiriendo a aquellos casos mencionados anteriormente donde no pudo desarrollar su idea de pedestales independientes con total libertad. En ellos planteó una solución de compromiso mediante un zócalo que hacía el papel del basamento del edificio.

492. Esta página incluye cuatro dibujos que parecen apuntar a la evolución desde basamento del templo al edificio doméstico convirtiéndose en la planta baja como zócalo. (Figs. 43 y 44) El primero de ellos es un pórtico de columnas con una escalera frontal que penetra en el estilóbato de lo que parece ser un templo del tipo in antis. Este dibujo se asemeja al alzado del ejemplo que esgrime Goethe al comienzo para ilustrar el paso de un basamento continuo a su primera interrupción (1795: 16). El segundo corresponde a un pedestal y columna sin basa, presumiblemente del orden dórico. Este ejemplo supondría, por tanto, la alusión a una fase en la que el basamento se muestra ya dividido, pero en tanto que prolongación ideal de la basa de la columna. El tercer boceto remite a un alzado de fachada con columnas frontales sobre un zócalo continuo, sólo interrumpido por la puerta de acceso. Este ejemplo es significativo porque supone la conexión entre el apartado en el que Goethe trata el basamento y el posterior de la columna y recuerda, de nuevo, modelos palladianos. El cuarto dibujo remite, asimismo, a un tema al que Goethe regresó reiteradamente durante ese periodo. Representa un hueco recercado en el que una balaustrada proporciona una cierta continuidad del zócalo que la flanquea.

Fig. 43: Johann W. Goethe, Fassade... [Fachada...], hacia 1795 (191x228 mm. Lápiz, tinta), en Femmel [1958] 1972, IVb: 99 Fig. 44: Johann W. Goethe, Dorische Ordnung [Orden dórico], hacia 1795 (181x114 mm. Lápiz, tinta con pluma y pincel), en Femmel [1958] 1972, IVb: 104

493. Aquí acaba el texto corrido. Es de suponer que el capítulo sobre los basamentos quedó inacabado, dado que los dibujos continúan incluso hasta la página siguiente. El hecho de no haber sido terminado podría ser la causa de no constar nuevos apartados, más allá del primero anotado en la página 15. 


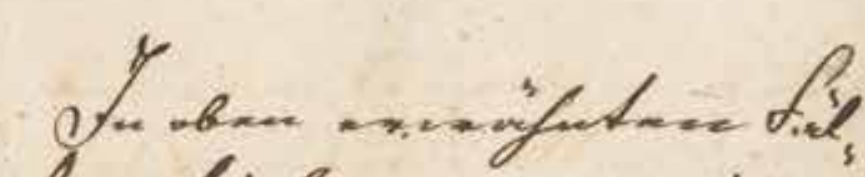

$$
\begin{aligned}
& \text { hum limp...... in }
\end{aligned}
$$

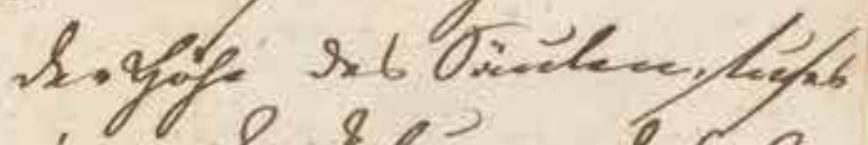

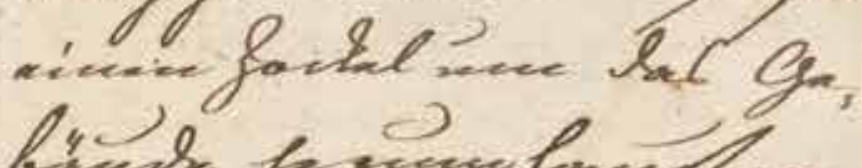

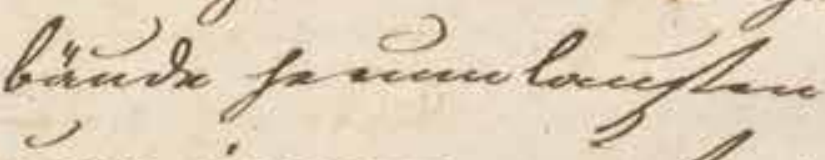

$$
\begin{aligned}
& \text { yourifte forizontula } \\
& \text { dolya fingubother. }
\end{aligned}
$$



494. No hay texto en el original. Esta página solo incluye un dibujo de un zócalo perfilado con abertura para ventana. Se trata una cuestión que atrajo la atención de Goethe (Fig. 45) y recuerda la lámina que desarrolla la fachada del Palazzo Chiericatti de Palladio en I Quattro libri (lib. II, cap. III, p. 7) que Goethe conocía, donde aparece una ventana sin recercado en el basamento, aunque en la construcción real no existe. (Fig. 46)

Fig. 45: Johann W. Goethe, Proportionen eines Gebäudesockels [Proporciones de un zócalo de edificio], hacia 1795 (99x94 mm. Lápiz, tinta con pluma), en Femmel [1958] 1972, IVb: 105

Fig. 46: Andrea Palladio, Palazzo Chiericatti (1570, II: 6,7)
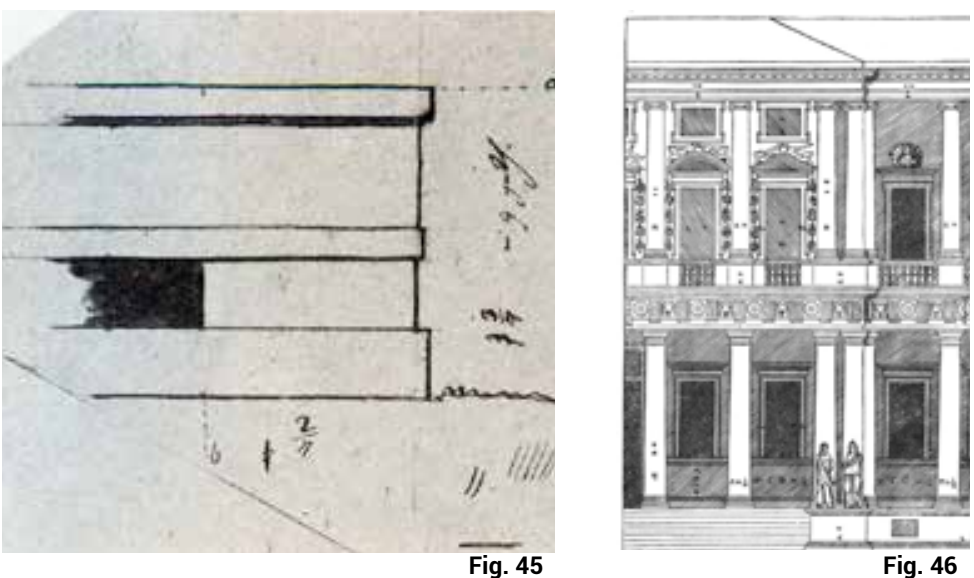


\section{Kapitäle}

Toskanisches // Alt Dorisches // Neu Dorisches // Alt Jonisches // Neu Jonisches // Alt Korinthisches // Neu Korinthisches // Zusammengesetztes // Sonst verziertes.

\section{Säulen}

Toskanische // Entasis / Dorisch // Ausbauchung / Jonische // Korinthische // Komposita // Abweichende.

\section{Basen}

Alt Dorische bisweilen niedrige / Untersätze // Neu Dorische. Tempel zu Cora // Alt Jonische, aus Würfeln / und Zocken // Neu Jonische ${ }^{495}$ // Attische Base. // Korinthische // Zusammengesetzte // Neueste zusammengesetzte.

\section{Capiteles $^{496}$}

Toscano // Dórico arcaico // Dórico nuevo // Jónico arcaico // Jónico nuevo // Corintio arcaico // Corintio nuevo // Compuesto ${ }^{497}$ // En caso contrario decorado. ${ }^{498}$

$$
\text { Columnas }{ }^{499}
$$

Toscana // Éntasis / Dórica // Abombamiento ${ }^{500}$ / Jónica // Corintia // Compuesta // Irregular. ${ }^{501}$

\section{Basamentos $^{502}$}

Dórico arcaico a veces bajos / plintos ${ }^{503}$ // Dórico nuevo. Templo de Cora ${ }^{504}$ // Jónico arcaico, en dados / y zócalos ${ }^{505}$ // Jónico nuevo // Basa ática. ${ }^{506}$ // Corintia // Compuesta // Compuesta más reciente. ${ }^{507}$

495. Este punto no fue transcrito en los Paralipomena de la DKV sin justificación alguna.

496. A diferencia de la estructura general del Baukunst prevista de acuerdo con la secuencia constructiva desde el basamento a la cubierta pasando por el sistema portante de columnas es Ilamativo que Goethe plantee la exposición de este apartado siguiendo el sentido inverso a la lógica constructiva de basa, fuste y capitel, tal como hicieron los tratadistas, y vaya de la parte superior a la inferior sin que exista ninguna razón aparente que lo justifique.

497. El hecho de que Goethe no diferencie en los órdenes toscano y compuesto entre antiguo y nuevo pone en evidencia que aceptaba, en relación con el primero, que sólo era una posible interpretación torpe del dórico y, respecto al segundo, que era una aportación de la teoría renacentista. Frente a los que consideraban el compuesto como un orden distinto otros pensaban que se trataba de una variante del orden corintio. Winckelmann describe el orden "compuesto romano" diciendo "que no consiste más que en una columna con un capitel corintio, al que se han añadido las volutas propias del orden jónico." (1985: 546).

498. Goethe conocía la sustitución de las volutas y acantos en los capiteles jónicos y corintios por otros elementos porque Palladio en su tratado recoge ejemplos con ramas de olivo como en el Panteón (Lib. IV, p. 73) y en el templo de Marte Vengador (Lib. IV, p.15) donde, además, dibuja caballos alados en vez de volutas quizás como símbolos de Pegaso (Lib. IV, p. 22). También Winckelmann aporta ejemplos de capiteles con ornamentaciones singulares (1985: 545-546). La clasificación de Goethe situándolo en un apartado distinto tal vez sea debido a que quería explicar las soluciones ortodoxas de los capiteles diferenciándolas de las desviaciones decorativas.

499. En la tratadística la columna incluye la basa, el fuste y el capitel que Goethe ha separado en apartados diferentes. Ya se ha aclarado que con el nombre de columna se está refiriendo, en realidad, a los fustes. En ningún momento Goethe muestra interés ni menciona las estrías de los fustes que existen en todos los ejemplos antiguos que pudo conocer. Tal vez fuera por la influencia de Palladio que, en sus propias obras, hace siempre columnas de fuste liso y nunca utilizó columnas estriadas. Winckelmann ya menciona las estrías de los templos más antiguos (1985: 541) diferenciando las dóricas de las jónicas y corintias (1985: 567) así como los fustes dóricos con el tercio inferior sin estrías (1985: 544) e incluso las estrías en espiral (1985: 557) que fueron el antecedente de las columnas salomónicas. 

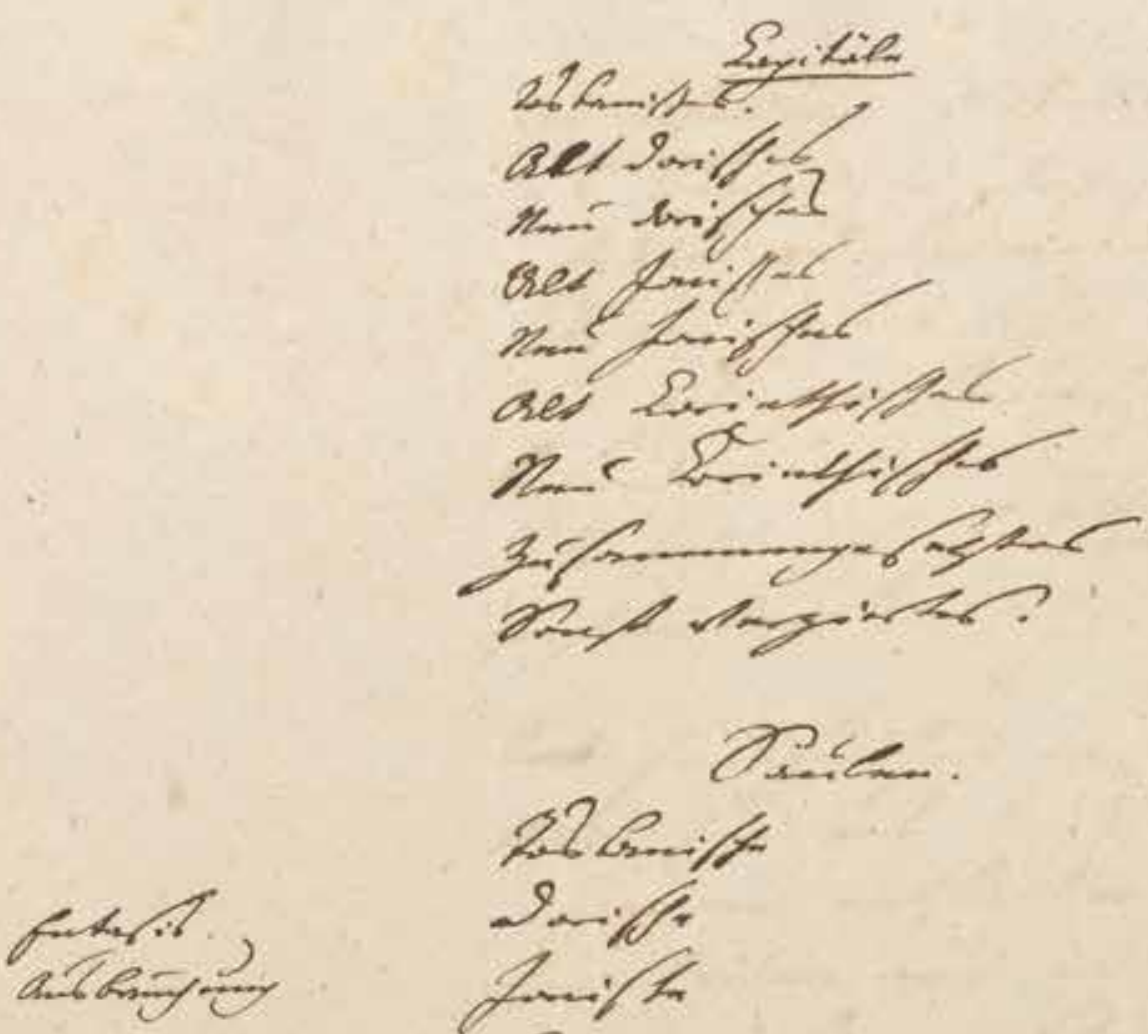

$$
22 \mathrm{~b} \text { Dith }
$$$$
\text { rant/ }
$$$$
2+1 / 4
$$$$
\text { Sinfefte }
$$$$
\text { s. of ik }
$$

$$
\text { restyos. }
$$

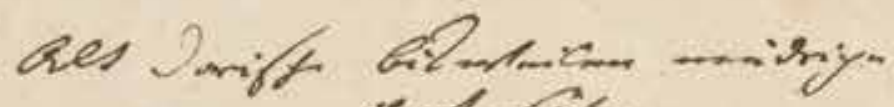

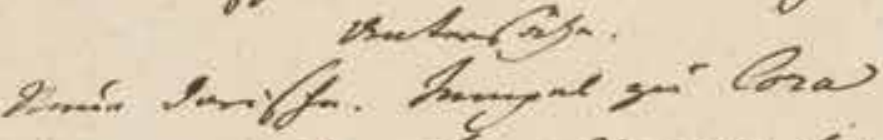
aet founte aty sanise

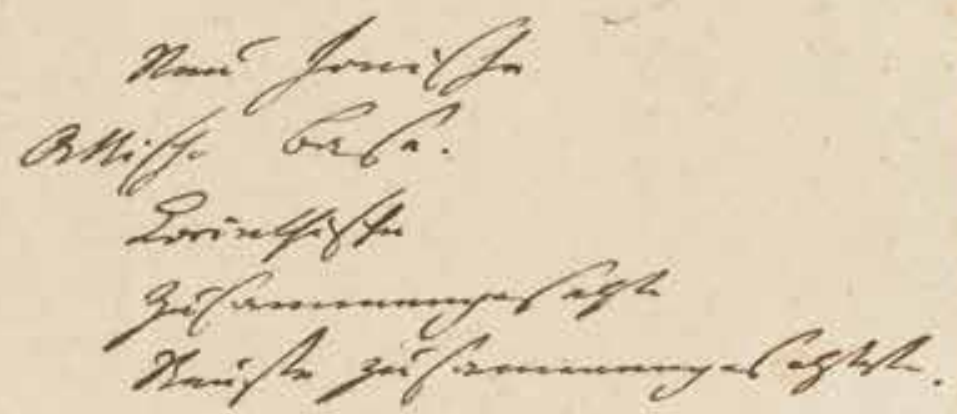


500. Winckelmann distingue entre la disminución de la sección de la columna con la altura a imitación de los troncos de los árboles del "éntasis" que identifica con el "abombamiento" y que critica (1985: 541). Sin embargo, Goethe los separa en dos apartados diferentes y los sitúa de manera que parecen referirse de forma general a todos los órdenes. Es posible que pretendiera tratar como éntasis la disminución de sección del fuste asimilándolo al tronco de los árboles.

501. Siguiendo una pauta coherente con el aparatado de los capiteles, Goethe incluye aquí una clasificación diferente para las columnas irregulares, tal vez pensando en las de sección ovalada que describe Winckelmann (1985: 547).

502. El tercer elemento de la columna al que aquí hace mención Goethe es la basa y no el término genérico de "basamento" (que emplea de hecho para nombrar la parte anterior de la arquitectura, añadiendo aun más confusión). La basa es el elemento de articulación entre dos piezas relevantes del edificio: el crepidoma que corresponde al basamento y la columna como sistema portante. Está compuesta de varios elementos y molduras que varían de unos órdenes a otros. La exclusión del toscano en esta relación confirma la convicción de Goethe de que no era propiamente arquitectura, cuyo origen incuestionable para él es el dórico.

503. En el orden dórico arcaico como lo denomina Goethe la existencia de basas era algo excepcional y sólo se encuentra en algunos raros ejemplos como los que menciona Winckelmann (1985: 535) si bien se recoge habitualmente en los tratados como en el de Palladio (Lib. I, cap. XV, p. 23). El fuste dórico apoyando directamente sobre el basamento es el reflejo más inmediato de la mímesis del tronco de madera levantado directamente sobre el pavimento del templo original. El elemento de arranque de la basa es el plinto. Winckelmann al referirse a los templos de Agrigento escribe: "tienen bajo el fuste un tambor, además del plinto o basa, que también es redonda" (1985: 525) dando a entender que en ese caso la basa ha quedado reducida al plinto y es posible que Goethe se esté refiriendo a esos casos. La forma redonda del plinto en el ejemplo de Winckelmann es muy excepcional porque lo habitual es que sean cuadrangulares. Puesto que el plinto es el único elemento de la basa de forma cuadrangular se podría interpretar como algo más vinculado al apoyo en el basamento que a la propia columna. Goethe cuando visitó el templo de Segesta consideró que el plinto es el vestigio de una fase intermedia en la evolución de la arquitectura. Correspondería a la mímesis del tronco de madera (cilíndrico) sobre el basamento pétreo rebajado entre las columnas para facilitar el paso entre ellas. Éste sería el origen de la forma cuadrangular de la articulación entre el basamento del edificio y la columna origen de las basas.

504. Winckelmann alude al Templo de Cora de la Campania romana que Winckelmann identifica como una cuarta etapa en la evolución del dórico. Escribe: "Estas columnas descansan en una base que no se encuentra en otras antiguas columnas dóricas, y se parece mucho al capitel toscano" (1985: 543) es decir, los elementos de la basa dórica son similares a los del capitel toscano: el plinto de planta cuadrada correspondería al ábaco y el toro de la basa es semejante al óvolo, el equino o el cuarto bocel del capitel. En esta etapa de la evolución del dórico la basa de la columna está ya definitivamente establecida.

505. La existencia de dados bajo los plintos de las columnas y su evolución como pedestales emergentes de los zócalos o independientes Goethe lo consideraba como una fase evolutiva de la arquitectura. Quizás por esto, aunque los tratadistas incorporaban pedestales en la sistematización de todos los órdenes, sin embargo Goethe excluye el dórico y sólo los menciona a partir del jónico.

506. Palladio al describir la basa jónica aporta las molduras dadas por Vitruvio pero añade que en lugar de esa solución "en muchos edificios antiguos se ven basas áticas y a mí me gustan" dando a continuación sus medidas (Palladio, lib. I, cap. XVI, p. 31). La principal diferencia con la basa jónica está en la eliminación de los astrágalos quedando entre los dos toros una sola escocia.

507. Puesto que Vitruvio no incluye el orden compuesto tampoco da ningún tipo de basa. Palladio al describir el orden compuesto dice: "La basa de la columna se puede hacer ática, como en el corintio, y se puede hacer también compuesta de la ática y la jónica" (Lib. I, cap. XVIII, p. 47). Aunque resulta difícil intuir qué pretendía Goethe con su diferencia en dos apartados tal vez iba en el sentido señalado por Palladio. 

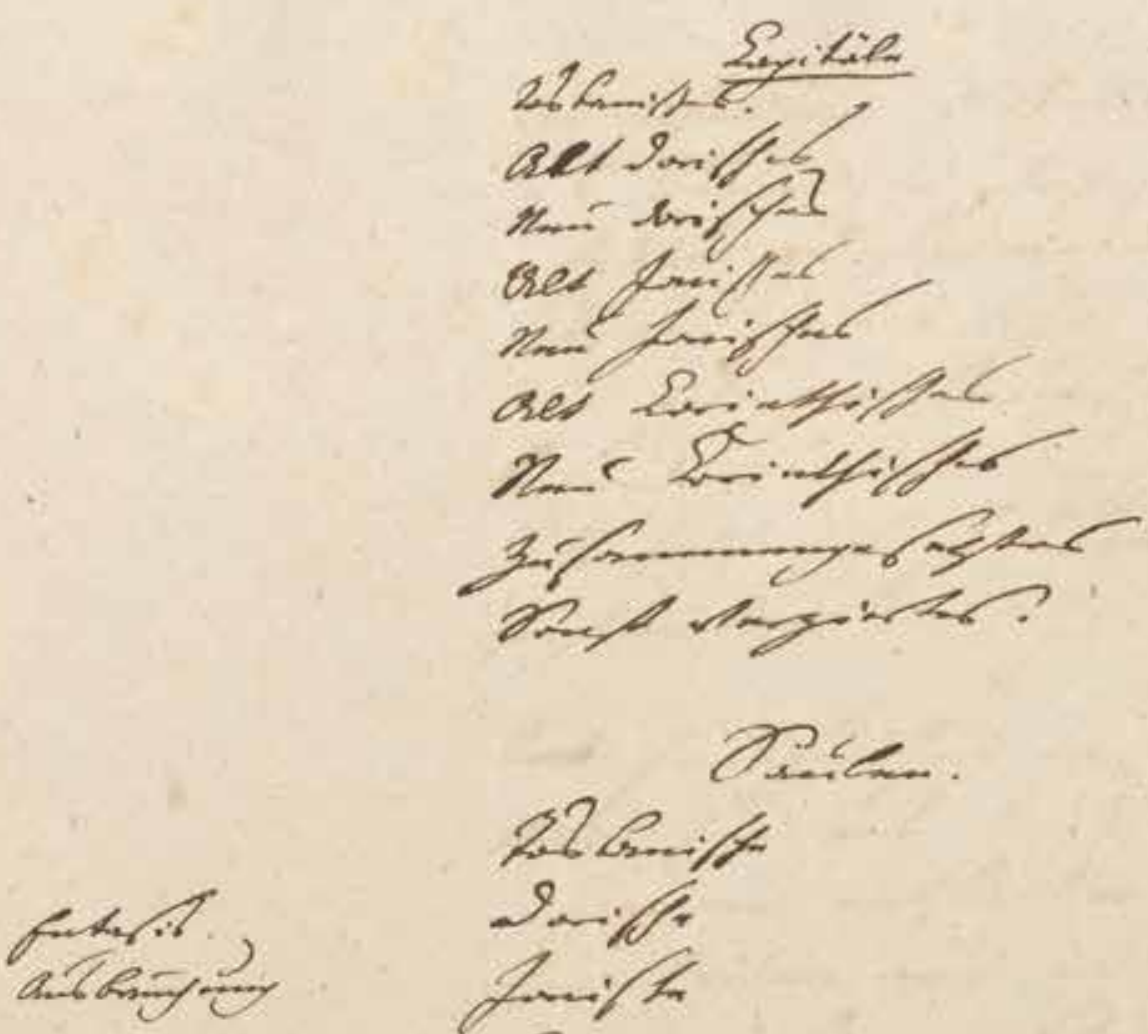

$$
22 \mathrm{~b} \text { Dith }
$$$$
\text { rant/ }
$$$$
2+1 / 4
$$$$
\text { Sinfefte }
$$$$
\text { s. of ik }
$$

$$
\text { restyos. }
$$

aes Jift aldect wis.y.

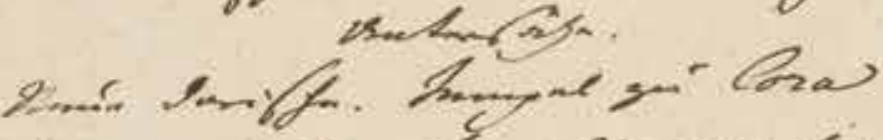
aet founte aty sanise

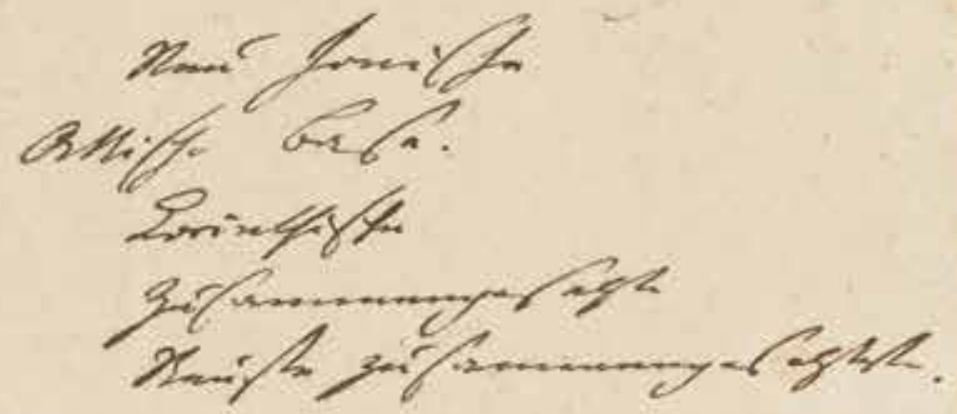


Zu gefundenen Materialien z. B. Säulen, die übrige Architektur zu finden. Dieses hat bei neuern sehr viel Abweichungen verursacht, besonders wenn auch das Bedürfnis des Hauses zugleich gegeben war.

Halbsäulen an der Mauer sind aus den Säulengängen entstanden die von weiten auch an der Mauer zu liegen scheinen.
Para los materiales encontrados, por ejemplo columnas, encontrar la arquitectura restante. ${ }^{508}$ Esto ha causado en la más reciente una gran cantidad de desviaciones, ${ }^{509}$ sobre todo si al mismo tiempo se daba también la necesidad de la casa. ${ }^{510}$ $=$

Las semicolumnas en la pared surgen de las columnatas, que parecen desde lejos estar apoyadas también en el muro. ${ }^{511}$

508. Goethe parece referirse al problema de comprender los edificios completos a partir de los restos parciales de las ruinas. Una teoría de la arquitectura deducida sistemáticamente siguiendo el modelo de la morfología de las plantas debería aportar el conocimiento suficiente para deducir de un elemento, por ejemplo, las columnas, la totalidad del organismo correspondiente, es decir, el edificio. Ese método es el que había seguido Palladio al restituir en su tratado (Lib. IV) los edificios antiguos a partir de los restos conservados.

509. Las diferencias entre las distintas versiones de la restitución de los vestigios antiguos entre los tratadistas es lo que implica la necesidad de contar con un método preciso y sistemático como el que Goethe busca para evitar interpretaciones distintas y errores.

510. Cuando Vitruvio aborda la arquitectura doméstica lo hace prioritariamente en su aspecto funcional y distributivo y, por lo tanto, en la idea de Goethe, no aborda la cuestión del fin supremo consistente en trasladar la ficción poética del templo a la residencia. Los dibujos de Palladio que ilustran la domus romana (1570, lib. II, cap. VII p. 34) incluyen un vestíbulo o pórtico columnado en el acceso, del que Vitruvio no habla, y que sería la manifestación más conspicua del planteamiento de Goethe conscientemente planteado por Palladio. Encontrar el paso entre la arquitectura del templo a la arquitectura doméstica es, para Goethe, el problema más complejo en su intento de establecer una teoría de la arquitectura completa y unitaria. Precisamente, en una serie de dibujos de 1795 (IVb: 98, IVb: 98R, IVb: 99, IVb: 99R y más claramente el IVb: 103)

(Fig. 35) Goethe ensaya fachadas y perfiles de viviendas, aunque sin incluir en ningún caso columnas. Son intentos de traslado de los órdenes a las viviendas privadas modernas. De alguna manera, esto podría llevar a pensar que la necesidad de la casa compromete el empleo de las columnas como recurso compositivo, en gran medida por su incompatibilidad funcional con las exigencias de habitabilidad burguesas. A este respeto, puede encontrarse en su correspondencia referencias a, por ejemplo, la recomendación de cerrar las logias para adaptarlas al clima del norte o la dificultad de respetar el gusto elevado asumiendo la preferencia de los del norte por las viviendas con muchas ventanas y grandes estancias (agosto de 1797)

511. La visión lejana es la que más se aproxima a la representación del alzado en diédrico donde el punto de vista se sitúa en el infinito. Esta postura, a diferencia de otros tratadistas, había sido adoptada de manera rigurosa por Palladio en su tratado dando origen a articulaciones arquitectónicas muy diferentes a partir de una misma imagen planimétrica: pórtico de columnas, muros articulados con semicolumnas o pilastras, etc. y que son un rasgo característico de su arquitectura. Goethe parece aludir a esta cuestión y este sistema gráfico es, precisamente, el que utiliza Goethe en los dibujos con los que ilustra el Baukunst. Esta última nota del manuscrito parece justificar su convicción de que, para la elaboración de una teoría arquitectónica, los dibujos que la explican deben ajustarse a las convenciones del sistema ortogonal por ser el que, desde Alberti, se consideraba propio del arquitecto y que Gaspard Monge con la geometría descriptiva estaba sistematizando de una manera precisa en aquellos mismos años.

512. En el legajo original, las páginas 26-30 están en blanco. Las páginas 29 y 30 (anverso y reverso del mismo folio) no mantienen el mismo formato que el resto y están reducidas en su anchura de los $171 \mathrm{~mm}$ a $50 \mathrm{~mm}$. 


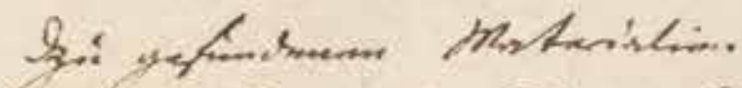

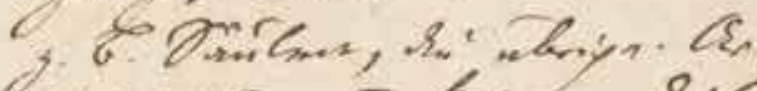

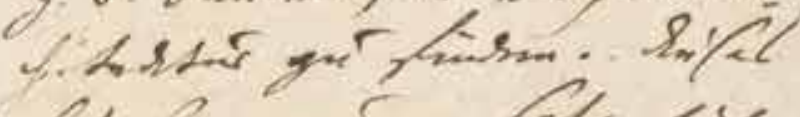
fist an neniver fife tese

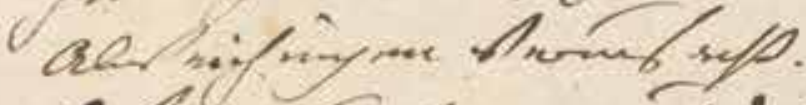

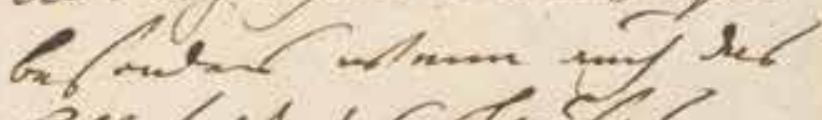
veriafwis he forefob

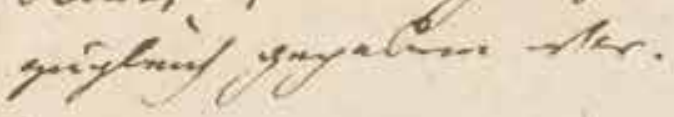

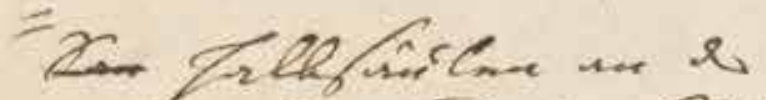

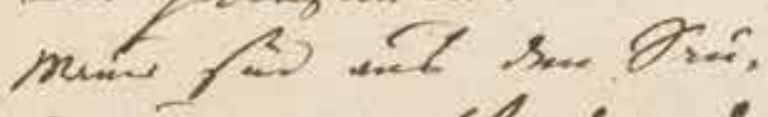

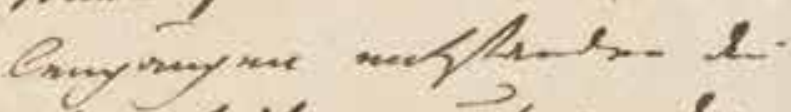

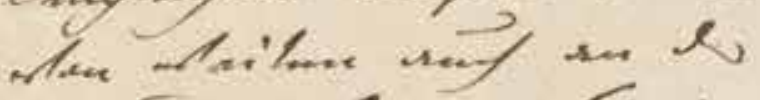
num zi tisymer foriemes 
513. En el Goethe- und SchiIler- Archiv, este documento tiene la signatura GSA 25/W 2637

514. Según la WA I 47 (p

327) ha quedado probado, no obstante, que originariamente este estudio previo no pertenecía a este fascículo, puesto que en su registro detallado no constan los dos folios en cuestión.

515. Quizás la diferencia más evidente sea que en el esquema Goethe ya distingue entre el material y los tres fines. No habla de las cuatro condiciones de la arquitectura, como así ocurre en el borrador, sino que ya adelanta la clasificación del Baukunst (1795).

\section{Borrador del Baukunst (1795)}

Existe un estudio previo del Baukunst (1795), titulado "Baukunst". ${ }^{513}$ Está incluido en un voluminoso fascículo de 99 folios cuyo fin era la preparación del segundo viaje a Italia. ${ }^{514} \mathrm{Se}$ trata de un manuscrito escrito con precipitación, en el que se pueden identificar a simple vista dos partes claramente diferenciadas: un texto corrido que coincide a grandes rasgos, a veces incluso literalmente, con pasajes del Baukunst (1795), seguido de un esquema fechado el 29 de octubre de 1795. Por las diferencias constatables entre ambos se puede deducir que la fecha corresponde exclusivamente al esquema, trazado con posterioridad al texto corrido del que no se dispone por otra parte una fecha de redacción precisa. ${ }^{515}$

El apartado "1 Baukunst" se publica por primera vez (versión en la que se basa la FA) en la WA I 47 (1896), pp. 327-329, en tanto que "2 <Schema über Baukunst>" en la MA 4.2. (1986), pp. 956-958. Con anterioridad habían sido publicados solo parcialmente. Para la presente transcripción se han respetado los criterios filológicos de la edición de Johann Wolfgang Goethe (1998), Sämtliche Werke. Briefe, Tagebücher und Gespräche. Band 18, Ästhetische Schriften 1771-1805, "Paralipomena", Friedmar Apel (ed.). Frankfurt am Main: Deutscher Klassiker Verlag, pp. 375-376; última edición y más completa de la obra de Goethe. El "2 <Schema über Baukunst>" se reproduce respetando la paginación, de ahí que no se haya seguido el esquema en dos columnas bilingüe. 
1

BAUKUNST

In jeder Kunst ist schwerer als man glaubt zu sagen, was lobens- oder tadelnswert sei. Um einigermaßen eine Norm zu unseren Urteilen über Baukunst zu finden, mache ich folgende Deduktion. Die Baukunst setzt a) ein Material voraus b) dessen zweckmäßige Anwendung kann auch noch durch das einfache Handwerk geschehen, wenn der Zweck bloß nützlich, sogar durch die rohste Naturpfuscherei, wenn er bloß notwendig ist. Soll sie aber Kunst werden, so muß c) der Zweck neben dem notwendigen und nützlichen auch das sinnlich Harmonische sein. d) Dieses ist in jeder Kunst von eigner Art und bedingt; es kann nur innerhalb seiner Bedingungen beurteilt werden. e) Diese Bedingungen entspringen aus dem Material, aus dem Zweck und aus der Natur des Sinnes, für welchen das ganze harmonisch sein soll. Man sollte denken, die Baukunst arbeite allein für's Auge; allein sie arbeitet vorzüglich, und woran am wenigsten gedacht wird, für den einen Sinn der mechanischen Bewegung, der
1

ARQUITECTURA

Es más difícil de lo que se cree decir en cada una de las artes qué es digno de alabanza o de reproche. Para encontrar en cierta medida una norma para nuestros juicios sobre arquitectura hago la siguiente deducción. ${ }^{516} \mathrm{La}$ arquitectura presupone a) un material b) cuya aplicación apropiada puede realizarse incluso por medio de la sencilla artesanía cuando el fin es meramente útil, incluso mediante el más tosco remiendo de la naturaleza cuando es meramente necesario. Si, en cambio, ha de considerarse arte, $c$ ) el fin debe ser, junto a lo necesario y lo útil, también armonioso para los sentidos. ${ }^{517} d$ ) Ello [lo armonioso para los sentidos] es diferente y depende en cada arte; sólo puede ser valorado desde sus propias condiciones. ${ }^{518}$ e) Estas condiciones surgen del material, el fin y la naturaleza del sentido, para el cual el todo debe ser armonioso. ${ }^{519}$ Se podría pensar que la arquitectura trabaja sólo para el ojo, pero trabaja preferentemente, y se piensa poco en ello, para el sentido del movimiento mecánico, que no puede conse-

516. Es significativo que en esta primera versión Goethe no aluda a la posibilidad de extrapolar las conclusiones que derivan del caso concreto de la arquitectura al conjunto de las artes y puede deberse en gran medida a la intervención posterior de Schiller. Ello quedará posteriormente sistematizado en su texto conjunto Über den Dilettantismus.

517. Esta clasificación recuerda el comienzo del libro de Winckelmann que, al referirse al "Plan de la obra", escribe: "En ellas trataré de las dos partes de la arquitectura, es decir, de la construcción propiamente dicha o parte material de los edificios en general, y de los adornos que sirven para embellecerlos." (1985: 529). La misma diferencia entre construcción y arquitectura se encuentra apuntada en el texto anterior Baukunst de 1788.

518. Esta misma idea la expone Goethe en relación con la ópera en 1798. "Si la ópera es buena, da lugar a un pequeño mundo propio, en el que todo acontece según unas leyes fijas, que debe ser juzgado por sus propias leyes y requiere ser sentido según sus características" (1999: 124).

519. Con el desarrollo posterior de esta idea, Goethe parece aludir al concepto clásico albertiano procedente de la retórica y reelaborado por la teoría francesa de la concinnitas que supone armonía, belleza, elegancia, etc. 
unter keinen andern gebracht werden kann. Der Körper wie wir im Tanzen sehen, fühlt eine angenehme Empfindung, wenn er im Tanze sich nach gewissen Gesetzen bewegt. Diese Empfindung sollte ein Blinder haben der durch ein wohlgebautes Haus geführt würde. Die Gesetze der Baukunst sollen aus diesen drei Bedingungen vorzüglich herzuleiten sein. Ich sage vorzüglich, weil in den bildenden Künsten auch mitunter f) etwas vorkommt, dessen Ursprung man anderswo suchen muß, etwas Fremdes oder fremd scheinendes, das tadelnswert oder lobenswert sein kann. Es ist eigentlich der poetische Teil, die Fiktion, wodurch ein Gebäude wirklich ein Kunstwerk wird. Dieser poetische Teil bezieht sich auf die Nachahmung; denn die Baukunst ist keine nachahmende, sondern eine Kunst für sich; sie ruft aber die Nachahmung zu Hülfe, um mannigfaltig zu werden; sie belebt fremde guirse por ningún otro. ${ }^{520}$ Como vemos en la danza, el cuerpo experimenta una sensación placentera cuando se mueve conforme a ciertas reglas. ${ }^{521}$ Un ciego ${ }^{522}$ guiado a través de una casa bien construida debería tener esta sensación. Las leyes de la arquitectura deben derivar principalmente de estas tres condiciones. Digo principalmente porque en las artes plásticas a veces f) ocurre algo, cuyo origen ha de buscarse en otra parte, algo ajeno o de apariencia ajena, que puede ser digno de alabanza o de reproche. Se trata precisamente de la parte poética, la ficción, a través de la cual un edificio puede devenir realmente una obra de arte. ${ }^{523}$ Esta parte poética hace referencia a la imitación; ya que la arquitectura no es imitativa ${ }^{524}$ sino un arte para sí, pero reclama la ayuda de la imitación para ser variada. Estimula cuerpos ajenos para aparecer rica y gloriosa. Luego, cuatro con-

520. La alusión a "ningún otro" [keinen andern] puede estar referida a "ningún otro arte", es decir, que solo la arquitectura puede proporcionar armonía por medio del movimiento mecánico, o a "nadie más", en la medida en que se entiende que al trasladar lo armonioso al sentido del movimiento, la experiencia individual cobra protagonismo y enfatiza el carácter autopropulsor o autorreferencial de la percepción.

Por otra parte, respecto de la versión final, aquí elude elocuentemente la referencia a la "doctrina de las proporciones" y su relación con las reglas que pueden proporcionar placer en el movimiento a través del espacio. Es evidente, en este sentido, que Goethe identificaba aquí un punto débil de su planteamiento.

521. Con esta idea Goethe pretende liberar la arquitectura de su dependencia exclusiva al aspecto visual.

522. Un ciego carece de memoria visual y, por lo tanto, queriendo dar protagonismo a las sensaciones no visuales está anulando las procedentes de la vista. El cambio que posteriormente introdujo en el texto sustituyendo la persona ciega por la que lleva los ojos vendados es significativo porque parece encaminada a corregir esta limitación.

523. El material, la utilidad y la armonía sensitiva global son "principalmente" las tres condiciones a las que, "a veces" se le añade la ficción poética. Una ficción que procede de otra parte, lo que nos recuerda que la fluencia y ósmosis entre las artes poéticas y plásticas es una de las ideas más arraigadas en el pensamiento de Goethe. A diferencia de lo que establece en la versión definitiva, en este caso Goethe localiza la consideración de la arquitectura como arte en la medida en que incorpore la ficción, lo que posteriormente sintetizará en el fin supremo. En la versión definitiva, en cambio, con la satisfacción del fin superior la arquitectura ya puede ser considerada arte. En el contexto del reconocimiento de la autonomía de la arquitectura, este matiz es de crucial importancia en la medida en que, en la versión definitiva, la arquitectura puede ser arte por sí misma, en tanto que en esta versión ha de recurrir a medios que le son ajenos.

524. Esta paradoja de la imitación en una arquitectura que no es imitativa es una de las cuestiones más problemáticas de la teoría de Goethe, se vincula con la teoría del carácter y parece reforzar la diferencia entre la mera construcción y la obra de arte. La construcción que resuelve los problemas del material y el uso no es imitativa. En consecuencia, para alcanzar 
Körper, um reich und herrlich zu erscheinen. Also vier Hauptbedingungen 1) die Eigenschaft des Materials, 2) die Vorschrift des nächsten Zweckes 3) die Anforderung des Sinnes, deren Befriedigung der hohe Zweck ist 4) das gehörige (sichtliche) der Fiktion wodurch die Über-Anforderung des Sinns, das Erstaunen, das Entzücken erreicht wird. ad 1) Läßt sich mechanisch erlernen a) entweder wir folgen ihr, wir tun was sie uns anweist, daß der Stein bloß vertikal trägt und getragen wird, das Holz auch horizontal auf gewisse Weise b) oder wir zwingen sie, wie den Stein durch Gewölbe, durch Klammern, den Balken durch Hangwerke.

ad 2) Ist dem Verstand unterworfen und läßt sich durch den mehr oder weniger gebildeten Menschenverstand beurteilen. Das Urteil wird schwerer diciones principales 1) la característica del material, 2) el precepto del fin inmediato 3) la exigencia de lo sensible, cuya satisfacción es el fin superior 4) la [exigencia] correspondiente (evidente) de la ficción, mediante la cual se alcanza la sobre-exigencia del sentido, el asombro, el encanto. ${ }^{525}$

ad 1$)^{526}$ Se puede [la característica del material] aprender mecánicamente a) ya sea la seguimos, hacemos lo que nos encomienda, que la piedra sostiene y es sostenida sólo verticalmente, en cierta manera la madera también en horizontal b) o bien la forzamos, como a la piedra con la bóveda, con anclajes, las vigas con las cerchas. ${ }^{527}$

ad 2) Se somete [el precepto del fin inmediato] al entendimiento y permite ser juzgado por el entendimiento humano más o menos instruido. ${ }^{528} \mathrm{El}$

su condición de obra de arte que estimula la sensibilidad la arquitectura debe buscar la mímesis en apariencias ajenas y así consigue ser variada, rica y gloriosa. En esta frase Goethe está utilizando el concepto de imitación en su significado habitual que corresponde a la verdad externa o la apariencia. Según Salmerón Goethe contrapone “La «verdad interna» o la «forma interna» de la obra de arte frente a la «verdad externa» de la pura imitación, es decir, la «verdad artística» frente a la «verdad natural»" (1999: 127). En definitiva, como escribe Winckelmann, se trata de enfatizar la diferencia entre la construcción "como parte material de los edificios" y los "adornos que sirven para embellecerlos" (1985: 529).

525. Aparecen aquí los cuatro estadios que reformulará en el texto posterior reduciéndolos a tres con una condición previa. Cada uno ellos presupone el nivel anterior. Las características del material imponen sus condiciones a la mera construcción correctamente ejecutada de acuerdo con sus usos; una obra que se convierte en arte cuando satisface, además, la belleza sensible y no sólo la visual. Por encima aún está la obra que alcanza el máximo nivel, cuando mediante la ficción alcanza el sobre-requisito sensible. Se refleja de este modo la idea de Goethe sobre el genio capaz de conducir al artista a realizar obras maestras. Esto ocurre cuando el artista "emprendiendo el vuelo al que le lleva el genio, le confiere a su obra toda su perfección" (1999: 124).

526. "ad", preposición latina, se emplea como equivalente a "zu punkte", es decir, "al punto".

527. Un enunciado que recuerda las tesis de Perrault sobre las limitaciones de los materiales debido a sus condiciones físicas resistentes y la racionalidad constructiva capaz de superarlas. Winckelmann atribuye esta cualidad de superación en el caso de la construcción de bóvedas de la antigüedad al hormigón romano. Escribe: "Parece ser que la puzolana no se ha encontrado en Grecia, como observa Vitruvio, y precisamente por la falta de esta tierra los griegos no han podido conseguir dar a sus bóvedas la ligereza que consiguieron los romanos." (1985: 532). Resulta sorprendente que Goethe no mencione este material de construcción lo que hace pensar en sus limitados conocimientos de construcción. 528. Goethe consideraba que cualquier persona podía disfrutar del arte como aficionado pero debía tener un cierto nivel de cultura para apreciarlo adecuadamente (Salmerón, 1999: 126). La racionalidad postulada por Perrault comprende tanto 
je näher das Gebäude an 3) rückt. Ob ein Wohnhaus bequem, ob ein Palast geräumig und prächtig, ob ein Tempel würdig sei, sieht jeder.

3) Hier tritt die schwere und komplizierte Lehre vom Ebenmaß, woraus der Charakter des Gebäudes entspringt, ein.

4) Hier tritt die ganze Lehre von der Nachahmung (z. B. der Holzbaukunst durch Stein, woher sich die Säulenordnungen schreiben) und des feinern $\mathrm{Ge}$ brauchs des Materials, die Erhöhung des Zweckes und der gefühltesten Proportionen ihrer Annäherung und juicio se complica cuanto más cerca el edificio 3) se encuentre. ${ }^{529}$ Todo el mundo ve si una casa es cómoda, un palacio espacioso y grandioso, un templo digno. ${ }^{530}$

3) Aquí [en la exigencia de lo sensible] interviene la difícil y complicada doctrina de la simetría, ${ }^{531}$ de donde proviene el carácter del edificio. ${ }^{532}$

4) Aquí [en la exigencia correspondiente de la ficción] interviene toda la doctrina de la imitación ${ }^{533}$ (por ejemplo, de la arquitectura de madera mediante la piedra, donde se inscriben los órdenes de columnas) y el más fino

la firmitas como la utilitas y ambas constituyen la belleza objetiva susceptible de ser comprendida por todos. Una idea similar sobre la accesibilidad de la arquitectura a cualquiera con un cierto nivel cultural la formula Winckelmann cuando escribe: "Todo el que haya estudiado algo de las cosas de la Antigüedad y posea un mínimo de conocimientos en la materia, podrá juzgar de lo que a continuación expongo sobre la arquitectura de los antiguos, como si fuera un arquitecto, sin tenerse que dedicar previamente a más profundos estudios." (1985: 523)

529. Esta proximidad del edificio no parece referirse a distancia física sino a su comprensión y conocimiento por el observador instruido: a mayor conocimiento el juicio es más complejo.

530. Estas cualidades del uso de los edificios que todos pueden "ver" es lo que Blondel consideraba el carácter.

531. Se confirma que para Goethe el "sentido" como valor que sintetiza la percepción sensible se vincula con la concinnitas albertiana y la simetría vitruviana. Para Blondel las formas "producen en su reunión un no sé qué [je ne sais quoi] que hace brillar admirablemente la forma de la belleza y que nosotros llamamos concinnitatem en latín, y en francés, armonía simetría, gracia, gentileza y correspondencia." (Szambien, 1993: 90) El que Goethe emplee la palabra simetría en lugar de concinnitas puede deberse a que, para la teoría francesa, no tienen una total correspondencia como explica Szambien: "la simetría no recubre exactamente la concinnitas de Alberti, la armonía. Puede corresponder a ella cuando los autores adoptan la tesis de la existencia de una armonía universal. [...] La concinnitas, traducción latina de la symmetria griega, no es, pues, la simple armonía." (1993: 82).

532. Aunque Goethe hace alusión explícita al "carácter del edificio" en el sentido de Blondel antes comentado parece hacerse eco de otra interpretación dada en 1788 por Quatremère de Quincy que introdujo "una distinción entre los caracteres de la arquitectura histórica y los de la arquitectura contemporánea, entre el carácter de la idea expresada y el carácter de un género de edificio" (Szambien, 1993: 247). Este concepto tiene, en consecuencia, una interpretación que va más allá de la expresión del uso. Por otro lado, Peyre: "Reconoce igualmente el papel crucial del carácter, sin embargo, sólo el genio preside su puesta en práctica." (Szambien, 1993: 242). Así pues, esta interpretación del carácter se enlaza con la teoría del genio susceptible de convertir una obra de arte en obra maestra mediante el "sobre-requisito" de la ficción poética según Goethe.

533. Según Szambien: “A través de la producción del carácter, el concepto de imitación, convertido en analógico, puede ser salvaguardado." (1993: 225). Para Quatremère de Quincy que tomó la idea de la influencia del clima en la arquitectura griega de Winckelmann: "Si el carácter esencial depende de la historia de la arquitectura, el carácter relativo está ligado a la práctica arquitectónica y, en consecuencia, a la imitación. Es "sinónimo de propiedad y de conveniencia»" (Szambien, 


\author{
Kontraste, -welches die schwerste \\ ist, weil sie alle die andern zusamm- \\ enfaßt, ihnen das geistige hinzutut \\ und bloß durchs schickliche beurteilt \\ werden kann. \\ Diese vier Bedingungen müssen wir \\ nie aus den Augen lassen, sie bald einzeln \\ bald zusammen betrachten und anwenden. \\ Ich gebe einige Beispiele, wie uns diese \\ Normen durch die Geschichte der Baukunst \\ hindurch führen können.
}

uso del material, la elevación del fin y de las más sentidas proporciones $^{534}$ de su enfoque y contrastes -la cual [la elevación] es la más difícil puesto que resume todas las demás, introduce en ellas lo espiritual y sólo puede ser juzgada por medio de la conveniencia. ${ }^{535}$

No debemos nunca perder de vista estas cuatro condiciones, que se verán pronto individualmente, pronto en conjunto y se aplicarán. ${ }^{536}$ Doy ciertos ejemplos de cómo estas normas nos pueden orientar a través de la historia de la arquitectura. ${ }^{537}$

1993: 249). Y Szambien comenta: "Se espera, en efecto, que el carácter permita justificar razonablemente el principio de imitación de la naturaleza, más allá de la imitación de las proporciones del cuerpo humano y de la cabaña primitiva." (1993: 234). Y concluye: "La imitación constituye el lazo entre la historia y la práctica" (1993: 253). Boullée, discípulo de Blondel formuló estas consideraciones de un modo sintético: “El arquitecto se inspira en los caracteres de la naturaleza para dotar a sus producciones de un carácter que despierta en el espectador las mismas sensaciones que despertaría la naturaleza." (1993: 258). Según Szambien, "La teoría de los caracteres [...] prepara, en medida no desdeñable, la estética de la Einfühlung" (1993: 264), una conclusión que Pevsner (1983: 121-131) atribuye, también, al pensamiento arquitectónico de Goethe.

534. Szambien pone en evidencia la relación de la teoría de las proporciones con el concepto de simetría en la teoría francesa. Escribe: "La simetría antigua queda así definida como la identidad de las proporciones en dos o más objetos de dimensiones diferentes" (1993: 88).

535. El concepto de conveniencia (convenance) en la teoría francesa alude a aquello que es adecuado, como la solución óptima a sus demandas y, además, es decoroso, es decir, que satisface las expectativas sociales y culturales que le corresponde en relación con su destino y con los valores aceptados. En este sentido, según Szambien, Perrault: "resuelve definitivamente el problema, al menos en lo que concierne a la euritmia, la proporción y la symmetria. [... las tres, según P.] no hablan [...] más que de la conveniencia, de la correspondencia y de la proporción de las partes con el todo" (1993: 87). Y Diderot: "Todo el arte está comprendido bajo estas tres palabras: solidez o seguridad, conveniencia y simetría" (Szambien, 1993: 192). Tres requisitos en cierta medida paralelos a los fines que enuncia Goethe al que añade la ficción poética que, a veces, conduce al genio a realizar obras maestras.

536. El nächste se divide en un fin necesario y uno útil, el höhere como "Anforderung des SInnes" y el höchste como "das "Gehörige [...] der Fiktion". Las cuatro condiciones (material y los tres fines) se consideran al final del texto como las normas objetivas según las cuales debe juzgarse la arquitectura construida. Al final del texto, pues, la materialidad y la orientación a fines vuelven a coexistir, pese a que al principio estuvieran entrelazadas. Esto será eliminado en la última versión, en la que solo se seguirá el despliegue de fines, siendo el material la condición previa.

537. Parece que en el apartado posterior no desarrollado Goethe pretendía explicar con los distintos ejemplos enumerados la teoría apuntada anteriormente tal como se puede intuir en el esquema siguiente. El hecho de que en el texto de Baukunst posterior incorporase dibujos para reforzar las explicaciones y comentarios sería el modo en que, finalmente, consideró como la manera más adecuada de exponer esta parte. 
$<$ SCHEMA ÜBER BAUKUNST>

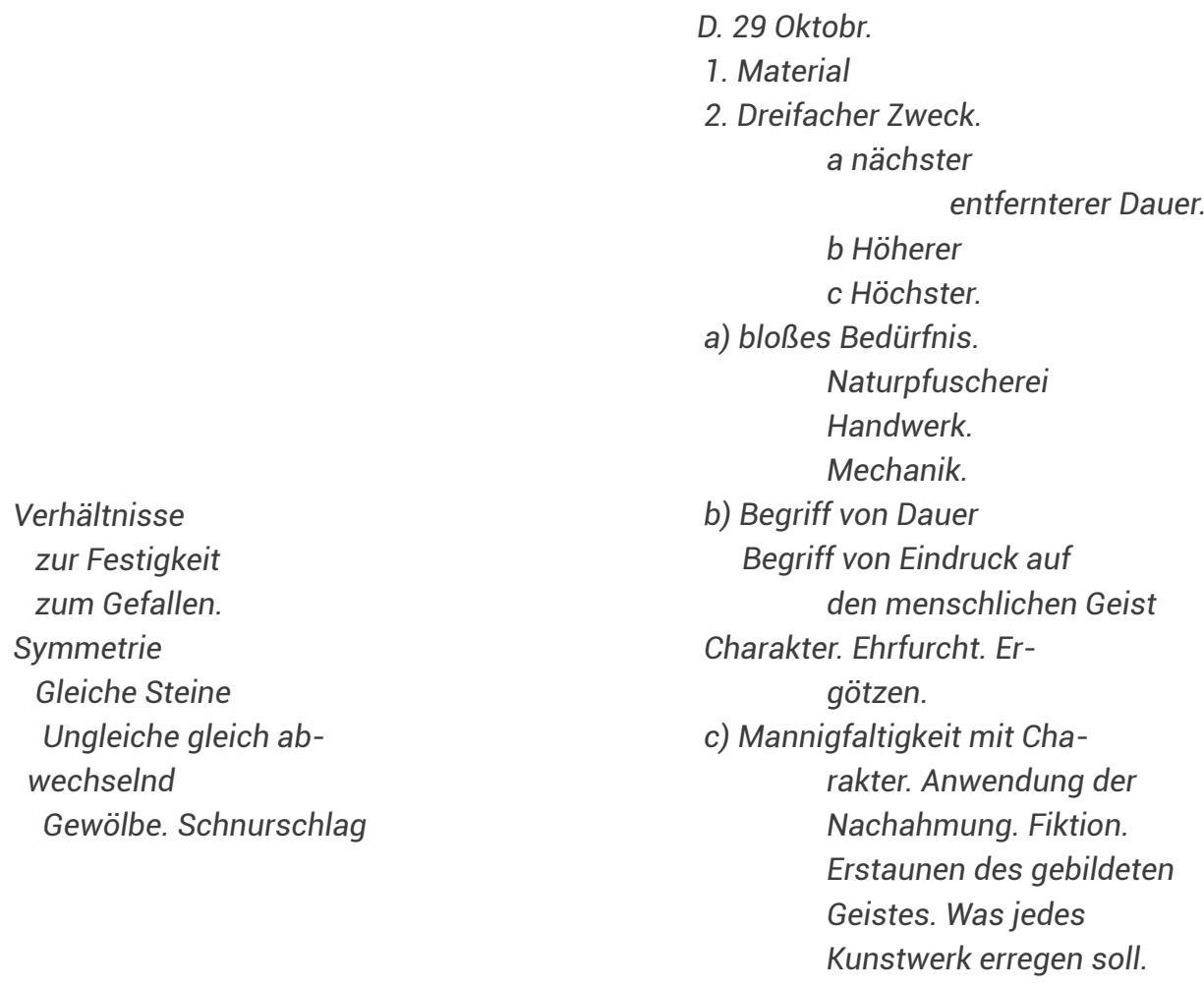

538. La separación del esquema en dos columnas verticales parece indicar un desarrollo argumental paralelo: en la parte derecha se presenta un despliegue teórico que va progresando, mientras que en la parte izquierda se indican aspectos concretos o ejemplos relacionados con esa parte de la teoría. En este sentido es posible deducir que hay una sintonía entre ambas columnas.

539. En la enumeración de la derecha, Goethe ya distingue el material de los tres fines tal como recogió en el texto posterior. No habla de las cuatro condiciones de la arquitectura, sino que anuncia la teoría que quedará plasmada en la versión definitiva. Los apartados siguientes tienen como objetivo describir las características de cada uno de esos fines. Desde este borrador, Goethe ya tenía en mente la importancia del material: una dependencia de la progresión de los fines de la arquitectura respecto de la manera más o menos sofisticada de tratar con el material.

540. Goethe divide el primer fin, al que le atribuye la característica de "bloße Bedürfnis" en dos: el "nächste" y el "entferntere", a lo que añade el concepto de "Naturpfuscherei-Handwerk-Mechanik". Ambos remiten a la técnica más directa de la artesanía como etapa de perfeccionamiento en la aplicación racional de las necesidades impuestas por la naturaleza de los materiales. 


\section{Relaciones}

con la solidez

con el agrado.

Simetría

Misma piedra

Diferente igual al-

ternativamente

Bóvedas. Tiralíneas

F. 29 oct.

1. Materia| ${ }^{539}$

2. Triple fin.

a inmediato

periodo más remoto.

b superior

c supremo.

a) pura necesidad. 540

Remiendo de la naturaleza

Artesanía.

Mecánica.

b) Concepto de duración ${ }^{541}$

Concepto impresión en

el espíritu humano

Carácter. Veneración. De-

leite.

c) Variación con ca-

rácter. ${ }^{542}$ Aplicación de

la imitación. Ficción.

Asombro del espíritu

instruido. Lo que cualquier obra de arte debe suscitar.

541. En cuanto al segundo, el fin superior señala "Begriff von Dauer-Begriff von Eindruck auf den menschlichen Geist-Charakter". En este sentido, el material técnicamente manipulado, cobra protagonismo como charnela entre la funcionalidad (el primer fin) y el carácter al ser capaz de producir distintas reacciones espirituales que responden, paralelamente en la columna de la izquierda, a los objetivos conseguidos que se enumeran en el apartado de la derecha. Así el agrado es la reacción al trabajo bien hecho y sólido. A su vez, el carácter se consigue por distintos medios. Bien con la simetría, una cualidad formal captada por los sentidos que ya no depende de condiciones técnicas, o bien con la habilidad ya sea inventando soluciones alternativas como las bóvedas, o perfeccionando la ejecución con herramientas más precisas (así se podría interpretar el término "tiralíneas").

542. Cuando confluye la variación con el carácter se alcanza el estadio de la obra de arte que provoca el más alto placer a quien está instruido. Goethe señala dos condiciones para que esto se produzca: la mímesis como cualidad del arte clásico y la ficción. Ambos temas son los que desarrolló posteriormente en el texto inacabado del Baukunst. 
Gemeines Erstaunten zu erregen. Menge der Säulen

\section{Absonderung des Heiligen vom gemeinen durch Mauern von Alters her.}

Verfall

Begriff von Eindruck ohne Sinn für Charakter Sinn für Pracht und Größe. Gegenwart aller Mannigfaltigkeit.

Daraus wird Zierrat als Zierrat

Verlust des Gefühls des schicklichen.

Mangel an Fiktion Zuflucht zum Gegensatz zum Sonderbaren zum Unschicklichen.

\section{Andere Idee als im Norden.}
und nicht
etwa ne-
gativ nein!
Inwendig
war und ist
die Welt.

543. A partir de este apartado seguir el hilo argumental resulta algo confuso. Parece vincular el sentido de decadencia a la provocación de meras impresiones superficiales que no responden al carácter tal como hacen las obras que sólo buscan el asombro popular como la acumulación injustificada de columnas que se menciona en la izquierda, por ejemplo, en las fachadas de iglesias barrocas. En este mismo sentido se podría interpretar la simple acumulación de variaciones que son el origen de la decoración "como decoración". Esta frase parece referida a la ornamentación (tal como la define Vitruvio) interpretada como la indiscriminada superposición de adornos, algo muy diferente de la noción albertiana de decoro que se refiere a las formas y elementos adecuados al tema y a las expectativas sociales y culturales. Se está apuntando así lo que en el texto posterior, siguiendo a la teoría francesa, se menciona como "lo necesario convenientemente". En definitiva, “la decoración como decoración" y la "pérdida del sentimiento de lo decoroso" parecen apuntar a las diferencias analizadas por la teoría francesa entre aquellos ornamentos que le son propios y convenientes a la obra frente a los que son meros adornos añadidos destinados a impresionar al público no preparado. La falta de ficción y los contrastes extraños (que también recuerdan implícitamente los excesos barrocos y rococós) son otros tantos procedimientos para provocar lo "indecoroso" entendido como lo inconveniente. Todo este apartado sobre la decadencia desapareció en el texto posterior. 544. A partir de este punto la parte de la izquierda no tiene correspondencia con la de la derecha que ha quedado vacía. En este enunciado se intuye un tema que adquirió protagonismo en el texto posterior: el problema de la doble ficción poética en el paso de la arquitectura sagrada del templo a la arquitectura civil y privada ejemplificado en la incorporación de los órdenes en la arquitectura doméstica y que se manifiesta de un modo elocuente en la articulación de las columnatas y las fábricas. La columnata como símbolo de la arquitectura sagrada y el muro como manifestación de la arquitectura civil son los dos elementos que se funden de modo problemático y que Goethe se proponía analizar en los ejemplos siguientes: el templo de Marte y la villa Giulia. 


\section{Provocar asombro po- pular. Conjunto de columnas}

\section{Separación de lo sagrado respecto de lo popular a través de muros en la antigüedad. ${ }^{544}$}

Decadencia ${ }^{543}$

Concepto de impresión sin sentido para el carácter Sentido de esplendor y grandeza. Presencia de todas las variaciones.

\section{De ello proviene la decoración} como decoración

Pérdida del sentimiento de lo decoroso.

Falta de ficción

Refugio para lo contrario para lo extraño para lo indecoroso.

\begin{tabular}{l|l} 
Tempio di Marte ${ }^{545}$ & $\begin{array}{l}\text { y no } \\
\text { algo ne- } \\
\text { gativo, no! } \\
\text { Muros del convento } \\
\text { Papa Julia }\end{array}$ \\
Interior \\
fue y es \\
el mundo.
\end{tabular}

Otra idea respecto al norte. ${ }^{547}$

545. Según la FA I, 18, p. 1201 esta referencia alude al Templo de Marte Ultor de Roma, en el Foro Augusto. Un templo períptero sine postico, de orden corintio, octástilo sobre un alto podio ante el que se extiende un gran patio cerrado perimetralmente que dibujó Palladio en detalle en I quattro libri dell'architettura, (1570. libro IV, cap. VII "Tempio di Marte Vendicatore" pp. 24-28). De esta obra parece interesar a Goethe especialmente el cerramiento del gran patio que antecede al templo formado exteriormente por un muro ciego y en su cara interior por una columnata anexa al muro sobre un zócalo continuo. Así pues, el muro exterior volcado al espacio público protege el interior sagrado que representa la columnata. 546. Según la FA I, 18, pp. 1201-1202, se trata de la Villa Giulia para el Papa Julio III en Roma a mediados del XVI. Construida a partir de los planos de Vignola, intervinieron asimismo Vasari, Miguel Ángel y Ammanati. El edificio vierte al jardín posterior rodeándolo lateralmente con dos alas de trazado curvo, y desde la explanada central se desciende a un ninfeo situado en una cota inferior. Posiblemente Goethe se refiere a las dos alas formadas por un muro perimetral y una columnata al jardín en forma de logia. Dos cuestiones diferencian este ejemplo del patio del templo de Marte anterior: entre el muro y la columnata existe un espacio habitable y, en este caso, se trata de un edificio civil y privado y no sagrado. Es, pues, un eslabón que ilustraría el tránsito de la ficción entre lo sagrado y lo profano. Por eso Goethe manifiesta una valoración positiva. Algunas de las barchesse de las villas palladianas que Goethe conocía (como la villa Badoer), representan una solución similar y es posible que el protagonismo de Palladio en el texto posterior signifique que para él la solución a esta cuestión la había resuelto de un modo más coherente y definitivo este arquitecto, incluso en las fachadas de los palacios urbanos.

547. Con esta frase parece que Goethe está pensando en que los ejemplos de obras aportados no son directamente aplicables a los países con clima distinto y es necesario encontrar una idea apropiada a esa situación. Conviene recordar que, según Winckelmann, el clima tenía una influencia esencial en el arte y la arquitectura griegos. 
548. WA II-6: 131. [De Italia, el reino de la forma, me encontré devuelto de nuevo a la informe Alemania]

549. Ya durante su primera estancia en Roma, piensa publicar sus reflexiones con Christian Gottlob Heyne en Gotinga a su regreso. Así se lo sugiere él mismo el 13 de enero de 1787 al ofrecerse como "un fiel observador in situ" ["einen treuen Beobachter am Orte"]. DKV 1991, II-3: 219 550. „wenn ich wiederkomme gleich ein Exemplar in das ich hinein korrigieren und das Ganze in Ordnung bringen könnte." DKV, 1991, II-3: 122. Nada más regresar a Weimar, en efecto, Goethe reclamó a

Charlotte von Stein las cartas y las porciones del Diario de viaje, tal y como así le confiesa esta a su hijo en una carta del 6 de julio de 1808 (Intr. V. It., III: 1036)

551. Se utilizará en lo que sigue "Sobre la arquitectura alemana (1772)", en Goethe, Escritos de arte, Salmerón (trad.), pp. 31-40. Llegado el caso, cuando se estime pertinente, se indicarán ciertos cambios en esta traducción. 552. Los exegetas más acreditados no han logrado consensuar su periodo de gestación. Por citar solo los más destacados, Pevsner (1971: 118) y Forssmann (2000: 7) defienden 17701771. Kruft (1982: 282) en cambio, iniciado a principios de 1771 en Sessenheim y terminado en 1772 en Frankfurt o Wetzlar.

\section{B. "He empezado a cultivar más se- riamente la arquitectura..."}

\author{
Aus Italien dem formreichen war ich in das ges- \\ taltlose Deutschland zurückgewiesen ${ }^{548}$
}

A lo largo de su primer viaje por Italia, el interés de Goethe por la arquitectura se incrementó notablemente. Goethe tomó abundantes notas en general y, muy particularmente, en relación con la arquitectura. Así se lo transmitió explícitamente a Charlotte von Stein el 23 de agosto de 1787 durante su segunda estancia en Roma:

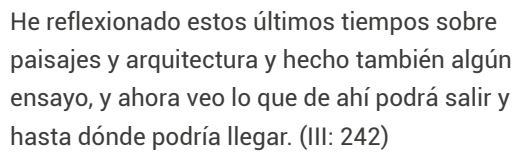

He reflexionado estos últimos tiempos sobre paisajes y arquitectura y hecho también algún ensayo, y ahora veo lo que de ahí podrá salir y hasta dónde podría llegar. (III: 242)

Ya en el transcurso del mismo, Goethe consideró incluso la posibilidad de publicar un relato de viaje al antiguo estilo (emulando predecesores que él mismo tuvo muy presentes tanto en la preparación como en su transcurso), en el que incluyese sus reflexiones e impresiones suscitadas en su periplo por el país transalpino. ${ }^{549}$ De hecho, durante los últimos días de su estancia en Venecia, esto es, muy al principio de su viaje, junto con las cuatro primeras partes de su Diario de viaje, envía a Charlotte von Stein una carta el 14 de octubre de 1786 en la que le comunica su intención de, a su regreso, utilizar el material a ella dirigido para posteriormente reelaborarlo con miras a "formar un todo ordenado". 550

De aquellas reflexiones y el conjunto de material que fue recopilando durante los casi dos años de duración de su viaje a Italia cabe recuperar un giro apreciable en su manera de concebir la arquitectura. Este se materializa, primero, en un breve ensayo titulado "Baukunst" de 1788 y, posteriormente y tal y como ya se ha puesto de manifiesto, el Baukunst de 1795. Para apreciarlo, conviene atender a otros textos que, antes y después de su viaje, muestran a las claras un largo proceso de maduración en el que asoman, por momentos de manera velada, otras veces explícitamente, cuestiones que en el Baukunst de 1795 quedarán plasmadas. De entre ellos, además del Baukunst de 1788, son de destacado interés la serie sobre la arquitectura alemana y un ensayo elaborado con Schiller sobre el diletantismo. En lo que sigue se propone un breve recorrido por las claves estéticas de estos textos en su relación con el Baukunst (1795) con el fin, en última instancia, de entresacar claves que permitan aproximar una propuesta de Goethe en lo que a la autonomía de la arquitectura se refiere en el periodo posterior a su viaje a Italia hasta 1795.

\section{Serie sobre la arquitectura alemana}

Si en el Baukunst (1795) ha quedado evidenciado el carácter lábil e inclasificable de su autor con respecto a las convenciones historiográficas, no lo es menos en la conocida serie Von Deutscher Baukunst, que arranca con el ensayo de juventud de 1772, que se completa con la breve Tercera peregrinación a la tumba de Erwin de 1775 y se cierra con el ensayo de vejez de 1823.

Von Deutscher Baukunst (1772) El ensayo Von Deutscher Baukunst, "Sobre la arquitectura alemana", 51 es del primer texto escrito por Goethe en prosa, un controver- 
tido punto de partida de su relación con la arquitectura.

Favorecido sin duda por su formato, este ensayo entrevera múltiples enigmas e indefiniciones, partiendo incluso de su datación. Escrita entre Sessenheim, Estrasburgo, Frankfurt y -probablemente- Wetzlar durante su periodo de estudiante de derecho, las hipótesis varían en un amplio abanico de fechas entre 1770 y $1772 .{ }^{552}$ Lo cierto es que la única constancia de su elaboración es una carta del 21.09.1771, donde describe a su compañero de estudios Johann Gottfried Röderer la catedral de Estrasburgo como la "größten Meisterwerks der deutschen Baukunst" [la mayor obra maestra de la arquitectura alemana] y adelanta su teoría sobre la genialidad del maestro de obra: si se quiere construir la casa de Dios, debe alzarse como Dios por encima de las cosas (2004: 367). Citará como ejemplos a Erwin y a Bramante. ${ }^{553} \mathrm{El}$ hecho de que pidiese por esas fechas a Johann Daniel Salzmann una copia de los planos de las catedrales más importantes es un claro indicio de su creciente interés por estas construcciones (2004: 379).

El texto fue impreso por primera vez como folleto anónimo en noviembre 1772 (con fecha 1773) en la imprenta de Johann Conrad Deinet en Frankfurt. Pese a las malas críticas recibidas, que Goethe recibirá con enojo (2004: 437 y ss.), el texto se volvió a editar en 1773 para la compilación de Herder Von deutscher Art und Kunst, en Allgemeinem Magazin für die bürgerliche Baukunst de Gottfried Huth en 1789 y, finalmente, reeditada por el propio Goethe en Über Kunst und Altertum (1824, IV: 3).

Se trata de un texto breve, a mitad camino entre el manifiesto y el himno, entre el ensayo y la prosa poética, en el que se entrecruzan reflexiones, estados de ánimo, crítica a las teorías arquitectónicas contemporáneas y opiniones deliberadamente injustificadas. ${ }^{554}$ No puede determinarse con claridad si se trata propiamente de una propuesta teórica, habida cuenta de su oscuro y subjetivista posicionamiento. Pero no puede negarse su valor teórico. No es propiamente una prosa poética, pero encierra momentos de belleza poética. Los más destacados exégetas, de hecho, no son capaces de determinar cuál ha sido la intencionalidad de este texto ni a qué formato cabe adscribirlo. ${ }^{555}$ Tan es así que cada una de las cinco partes - señaladas con un salto de línea- que componen este texto atiende a motivaciones y estructuras diferenciadas.

La primera parte establece las condiciones en las que se encuentra el narrador, Goethe, frente a su profesada admiración por el artífice de la catedral de Estrasburgo, Erwin von Steinbach. ${ }^{556}$ Goethe se dirige en primera persona a Erwin diluyendo así los límites entre la ficción y lo real. La muerte preside la narración, dando respuesta al encabezamiento del ensayo, ${ }^{557}$ y se entrelaza con hechos reales. Goethe alude a la búsqueda de la lápida de Erwin como motivación inicial de su visita, apuntando así un hecho contrastado, ${ }^{558}$ y dando pie, en un plano poetizante, al ensalzamiento y reivindicación de su recuerdo. Una ausencia real da pie a los lamentos y sentidas promesas de restitución de la honorabilidad de Erwin. Desde el comienzo del ensayo Goethe ensalza, pues, el gótico ejemplificado en la catedral de Estrasburgo, el "monumento [...] más magnífico posible" (1999: 31) y la genialidad de Erwin, un "hombre perfecto" (1999: 32): "A muy pocos les ha sido dado concebir
553. La vehemente defensa de la arquitectura gótica en este ensayo contrasta con el interés mostrado por Goethe en años anteriores por la arquitectura clásica, tal y como se tendrá ocasión de desarrollar a continuación. 554. En ello insiste Keller (1974: 7).

555. Para Bisky, por ejemplo, se trata claramente de un tratado teórico, aunque no sean aclarados los puntos esenciales (2000: 38 y 43) Koch reconoce a su vez un contenido teórico de considerable valor, junto con un innegable valor poético (1984: 237 y ss.).

556. En realidad, Erwin fue solo uno de los maestros de obra implicados en la construcción de la Catedral de Estrasburgo, que se dilató 250 años. Solo proyectó la fachada oeste, aunque se le atribuya toda la obra. 557. En el original "D. M Ervini a Steinbach". D. M. por Divis Manibus: inscripción latina equivalente a "las almas de los difuntos"

558. En ocasión de las obras en época de Goethe, la lápida de Erwin fue enterrada. No será reencontrada hasta la intervención en 1816 de Sulpiz Boisserée y el arquitecto $\mathrm{Da}$ niel Engelhardt en la esquina noroeste de la catedral. 559. La alusión a los árboles y la mención al "bosque en el que reverdecen los nombres de mis personas queridas" es una velada referencia a un episodio biográfico. Por 
aquel entonces, Goethe clavó una tabla en los bosques de Sessenheim donde figuraban los nombres de sus amigos y el suyo.

560. En el primer párrafo, Goethe cita a un italiano ("Es para un gusto mezquino"), en tanto que las dos siguientes pertenecen al abate M. A. Laugier. "¡Niñerías!" puede estar relacionado con el

pasaje en el que Laugier describe los ornamentos góticos como "bisarrement configurés \& puérilement entasés", (1753: 4) y la acusación de Goethe por su tendencia clasicista ("meterse en su lata à la Grecque") puede venir referida a múltiples pasajes, como podría ser: "L'Architecture doit ce qu'elle a de plus parfait aux Grecs, nation privilegiée" (1753: 3-4). 561. Que Goethe estuviera versado en ellas es aun hoy una tesis polémica.

Para Liess (1985: 41 y ss.), la fuerza del ensayo estriba precisamente en la radicalidad y la falta de apoyo científico. En el otro extremo, Kruft defiende que Goethe tenía conocimientos profundos de la teoría arquitectónica francesa,

en especial sobre François Blondel y Jean-Louis de Cordemoys. No hay constancia documental de ello.

562. Esta vertiente anti-ilustrada del texto es la que, posteriormente, recuperaría la revisión fenomenológica. Véase Christian Norberg-Schulz (1979). Más adelante, será si cabe más en su alma un concepto babélico, pleno, grande y necesariamente bello hasta sus partes más diminutas, como si se tratara de árboles creados por Dios." (1999: 31-32). ${ }^{559}$

En la segunda parte, Goethe increpa a un ficticio interlocutor personificado, primero, en el academicismo italiano y, después, en el francés, más concretamente en el abate $\mathrm{M}$. A. Laugier. ${ }^{560}$ Con la excusa de este diálogo, Goethe polemiza sobre las cuestiones más controvertidas de su tiempo: la belleza sensual o racional, el origen de la arquitectura y la desintegración de los órdenes arquitectónicos. ${ }^{561}$ En cualquiera de estos temas, su argumentación reposa en una sistemática polarización entre la defensa de la arquitectura gótica alemana frente a los improperios vertidos por "extranjeros".

Así, destacará la libertad de expresión alemana, imbuida de "genio", frente a las ataduras de "los antiguos". Ensalza el carácter sensitivo del gótico frente a la tendencia racionalizadora de lo extranjero (buscando así, por tanto, la polarización entre subjetivismo y racionalismo, esto es, entre empirismo inglés y universalismo francés):

\section{Si hubieras sentido en lugar de medido, si el espíritu de las medidas que contemplaste se hubiera apoderado de ti, si no te hubieras limi- tado a copiar porque ellos lo hicieron y es bello, hubieras llevado a cabo tus planes de manera necesaria y verdadera y de ellos hubiera mana- do una belleza viva que se habría apoderado de tu obra. (1999: 33)}

Es interesante hacer notar en este pasaje cómo Goethe ya vincula la teoría de las proporciones a una limitación en la manera de entender la arquitectura. En este caso, no obstante, no se ha llegado al nivel de conceptualización posterior, y la alternativa se reduce a oponer proporciones/racionalismo a espíritu/sensualismo. La crítica en este contexto a la imitación clasicista es reveladora. Frente a aquellos que aun sustentan el imperativo de autoridad, y por tanto se sitúan en la tradición de la imitatio, Goethe propone ya un sentido activo de la creación aludiendo al vitalismo de la belleza gótica. No en vano, esta propuesta recae una y otra vez, en la reivindicación del genio constructivo. Se apunta ya, aunque sea de manera larvaria, al par kantiano referido a la naturaleza y al genio artístico. En este caso, no obstante, se añade el retraimiento a lo necesario y verdadero, en íntima relación con un sentido tectónico de la arquitectura. ${ }^{562}$

En lo que respecta a la discusión sobre el origen de la arquitectura, Goethe hace una explícita referencia al mito de la cabaña tal y como lo reinterpreta Laugier de Vitruvio: 563

\footnotetext{
Yo te preguntaría a ti, erudito francés de nuevo cuño y filosofizante, ¿qué valor puede entrañar para nosotros que el primer ser humano que tuvo que ser ingenioso por necesidad hincara en el suelo cuatro troncos, los uniera mediante cuatro travesaños y los cubriera por arriba con ramas y musgo? (1999: 34$)^{564}$
}

Esta parodia del origen está íntimamente relacionada con la crítica de la defensa de la columna como elemento fundante de la arquitectura clásica. Goethe refuta la oposición de Laugier a la semi-columna recurriendo a evidencias históricas: "Incluso los modernos completaban las columnas internas con muros." (1999: 35) [die Neuern sogar antiker Tempel Intercolumnia mit Mauerwerk ausstopften]. ${ }^{565}$ Antes bien, para Goethe, tal y como defendió Alberti en su De Re Aedificatoria ${ }^{566}$ contradiciendo a Vitruvio, el origen de 
la vivienda se encuentra en el muro y no en la columna. ${ }^{567}$

En la tercera parte, se escenifica el encuentro con el genio de la catedral [Genius des Münsters], que le permitió superar su inicial cercanía al clasicismo. ${ }^{568}$ En este pasaje se eleva la loa a la catedral de Estrasburgo a defensa de lo gótico como arquitectura alemana. La relación de Goethe con el gótico fue cambiante a lo largo de su vida. Desde muy pronto, Goethe vinculó la excelencia arquitectónica a la arquitectura antigua. En ello influyó notablemente los grabados de Piranesi. De hecho, es significativo que hasta los años 70 Goethe no mostrase ningún interés por el gótico, hasta el punto de que no mostró ningún recelo frente a la remodelación de la vivienda gótica familiar ni prestase atención a la catedral de Fráncfort. Al gótico en sí, que él reconoce como diseño [Bauart] alemán (irónicamente ya los teóricos de la arquitectura del Renacimiento, contra los cuales polemiza entre otros, ya se refirieron al gótico como el diseño alemán) y que motiva desde el inicio el ensayo, Goethe le ha dedicado poco esfuerzo, en contra de lo que pretende trasladar en su ensayo. A excepción de la catedral de Estrasburgo, ${ }^{569}$ se interesó poco durante su juventud por otras construcciones góticas, ${ }^{570}$ pese a que cerca de su residencia tuviese la catedral de Mainz o la de Colonia (que visitó por primera vez en 1774 en un viaje al Rin). En el Korpus se encuentran de hecho pocos ejemplos de dibujos de edificios góticos con anterioridad al ensayo. ${ }^{571}$ De una manera un tanto confusa, se entrelazan en esta parte referencias a lo sublime, ${ }^{572}$ la relación clasicista entre las partes y el todo, ${ }^{573}$ y la imitación de la naturaleza. ${ }^{574}$ contundente al presentar a Erwin como contraejemplo de la ceguera de Laugier, dado que aporta variedad a las construcciones desde el sentimiento de pertenencia cultural: "Nadie bajará a Erwin del escalón al que él ha subido. Aquí está su obra, id hacia ella y reconoced el profundo sentimiento de verdad y belleza de las proporciones brotando de una fuerte y áspera alma alemana" (1999: 39)

563. En "De la vida de los hombres primitivos y de los principios de la Humanidad, así como del origen de los edificios y de sus progresos" (Vitruvio, 1980: 35-36)

564. El pasaje en cuestión es: «Quelques branches abbatues dans la forêt son les matériaux propres à son dessein. II en chosit quatre des plus fortes qu'il éleve perpendiculairemente, $\&$ qu'il dispose en querré. Au-dessus il en met quatre autres en traves; \& sur celles-ci il en éleve qui s'inclinent, \& qui se réunissent en pointe de deux côtés. Cetter espèce de toit est couvert de feuilles assez serrées pour que ni le soleil, ni la pluie ne puissent y pénétrer; \& voilà I'homme logé.» (Laugier, 1753: 12).

565. En concreto, Goethe ridiculiza la semi-columna en tanto que evidencia más clara de la falsedad de la teoría de Laugier: “¡Ay del mísero que ha adosado su delgado talle a los bastos muros!" (1999: 34). Laugier, en el artículo I "De la Colonne" establece como segunda regla: "La Colomne doit être isolée, pour exprimer plus naturellement son origine \& sa destination." (1753: 16). El primer defecto que destaca es cuando en lugar de disponerla aislada, "ont les tient engagées dans un mur. Il est certain que la colonne perd infiniment de sa grace" (1753: 17)

566. Para Alberti, la columna es el esqueleto (ossa, libro III) constructivo y un primarium ornamentum (libro VI) de la arquitectura.

567. "Nuestras casas no se erigen a partir de cuatro columnas en cuatro esquinas, sino a partir de cuatro muros en cuatro lados" (1999: 35)

568. En una clara referencia a Sulzer, se distancia de la concepción enciclopedista al aludir a su entrada del gótico, "como si se tratara de un artículo de diccionario" (1999: 35). Para Sulzer por gótico ha de entenderse un gusto bárbaro, aunque el significado exacto de la expresión se especifica raramente [entrada Gothisch: "Man bedienet sich dieses Beyworts in den schönen Künsten vielfältig, um dadurch einen barbarischen Geschmak anzudeuten; wiewol der Sinn des Ausdruks selten genau bestimmt wird.", (Sulzer, 1771: 489)]. Goethe: "Con no menor imprudencia que el pueblo que llama bárbaro al resto del mundo, yo llamaba gótico a todo aquello que no concordaba con mi sistema" (1999: 35).

569. Ya el primer día de sus estudios en Estrasburgo (¿4.4.1770?) visitará la catedral. Subió a la terraza de la torre en varias ocasiones para superar su miedo a las alturas. Poco después ya la consideraría la "größten Meisterwerks der deutschen Baukunt", como le dijo a Röderer el 21.9.1771. En tres ocasiones más visitará la catedral: en mayo y julio 1775 y en septiembre 1779. La describe en total cuatro veces. Sus impresiones del 13.7.1775 están descritas en Dritte Wallfahrt... tal y como se apuntará más adelante.

570. En Leipzig, el Adam Friedrich Oeser, amigo de Winckelmann, colaboró en distanciarlo aun más del gótico, durante su periodo de estudiante (1765-1768). Se trataba de un clasicista convencido, férreo defensor de la belleza absoluta de la Antigüedad, a quien Goethe consideraba, junto con Shakespeare y Wieland, sus "verdaderos" maestros. No fue, de hecho, hasta el encuentro con Herder cuando contagiado por su entusiasmo descubre en 1770 la belleza y la regla del gótico.

571. Véase, por ejemplo, los tres dibujos: I: 57, I: 58 y I: 59 . En ellos, en cualquier caso, se vislumbra mucho más claramente un interés pintoresquista por las construcciones góticas, más que por las cualidades propias de su arquitectura. 
572. Goethe relata cómo se siente sobrecogido por "una impresión plena y grande", que "quería degustarla y disfrutarla, porque procedía de miles de particularidades armónicas, pero de ninguna manera podía conocerla ni explicarla." (1999: 36)

573. "Hasta la más minúscula nervadura todo es forma y todo tiene como fin la totalidad." (1999: 37)

574. "con qué alegría pude extender mis brazos hacia ella al ver las grandes dimensiones convertidas en innumerables pequeñas partes como en las obras de la eterna naturaleza." (1999: 37)

575. Así dice: "el entendido alemán en arte, al dictado de sus envidiosos vecinos [los franceses], no aprecie su superioridad y minusvalore tu obra atribuyéndole el incomprendido concepto de 'gótica"' (1999: 37), u "Os quieren hacer creer que las bellas artes han nacido de la propensión que debemos tener a embellecer las cosas que nos rodean." (1999: 38). Se tratan de referencias a la entrada "Künste; Schöne Künste" (Sulzer, 1771: 609625).

576. "arte fue mucho antes plástico que bello y se hizo un arte verdadero y grande, a menudo más verdadero y más grande que el bello." (1999: 37)

577. "esto es arquitectura alemana, nuestra arquitectura" (1999: 37) [das ist
La cuarta y quinta parte generalizan la experiencia descrita de la catedral por medio, en concreto, de la introducción del concepto de lo característico y la importancia de la totalidad. En este contexto, en el que entabla una velada discusión con Sulzer, ${ }^{575}$ emplaza los valores propios del Sturm und Drang: juventud y belleza, contra "lo terso e irrelevante" del clasicismo; una crítica al criterio de belleza, frente al de verdad y grande$\mathrm{za} ;{ }^{576}$ el sentido de pertenencia cultural... ${ }^{577}$

Se ha destacado a lo largo de sus múltiples interpretaciones como un sentido testimonio de la corriente Sturm und Drang, ${ }^{578}$ a la que Goethe contribuyó activamente con obras paradigmáticas como Die Leiden des jungen Werthers (1774). La cercanía de este texto a los posicionamientos estéticos de este colectivo es efectivamente en muchos casos explícita y da buena cuenta de un momento muy concreto de la relación de Goethe con la arquitectura. Ello se concreta en cuestiones como la defensa del gótico como estilo nacional, el ensalzamiento de la vitalidad romántica y, en general, la crítica al academicismo. No obstante, al igual que tan inclasificable y variable colectivo, este ensayo contiene abundantes matices que llevan incluso a identificar rasgos clasicistas propios de etapas posteriores. ${ }^{579}$ Goethe es en efecto en su conjunto y sus partes difícilmente clasificable y se resiste a ser periodizado, estando sus producciones y sus estudios íntimamente relacionados con un decurso vital nada lineal.

Si algo testimonia con claridad este ensayo de juventud es la conmoción estética en la que se hallaba inmersa la cultura germana del último cuarto de siglo XVIII. La influencia de sus contemporáneos germanos es evidente (Sulzer y Winckelmann), pero no lo es menos el influjo clasicista francés, aunque de una manera harto personal. Es sintomático que aplique al gótico criterios que Winckelmann y sus antecesores habían empleado precisamente para defender la necesidad de aprender de la Antigüedad. En términos generales, puede leerse como un intento de resistencia a la llegada de la ilustración francesa, en la línea de los postulados de Herder. Así, frente a la construcción ilustrada del porvenir (especialmente político) a partir del sujeto como entidad aislada, como "mónada independiente e irreductible", se trataría de centrar su reclamo político y cultural en el pueblo, unidad orgánica, suma de lo diverso en lo unitario. De ahí la importancia de la "scala naturae" a nivel social: el pueblo evoluciona con arreglo a leyes propias, en las que el clima, la historia, la geografía su identidad juegan papeles fundamentales. Se avista así el conflicto entre cultura y civilización característico del siguiente siglo.

En relación con el Baukunst (1795), cabría destacar que ciertas claves de su estructura ya asoman en este temprano ensayo. Llama la atención, por ejemplo, cómo en la tercera parte ya se entrevé su teoría de las tres categorías en la arquitectura:

\footnotetext{
El arte fue mucho antes plástico que bello y se hizo un arte verdadero y grande, a menudo más verdadero y más grande que el bello. Pues en el hombre hay una naturaleza plástica que se manifiesta cuando su existencia ha quedado asegurada. Tan pronto como no tiene nada de lo que preocuparse, nada por lo que temer, el semidiós, poderoso en su descanso, busca materia para exhalar sobre ella su espíritu. (1999: 38)
} 
Frente a la belleza, Goethe defiende la autenticidad, el "arte característico", "el único verdadero". De ahí que corra en paralelo a esto la elevación de la identidad alemana en el gótico como valor estético, expresión genuina de una cultura, de un "alma". Contra ello se erigiría el marco normativo clasicista en la medida en que limita la expresión sin encasillamientos $y$, por tanto, la emergencia de un arte verdadero, esto es, propio. A diferencia de su propuesta en el Baukunst, aquí lo característico tiene un estatus epistemológico, se entiende como verdad en el arte y no acaba de desprenderse de su dependencia con lo sagrado. ${ }^{580}$ Goethe no renuncia en realidad a su teoría del carácter imbuido por el genio que se manifiesta ya en la catedral gótica de Erwin von Steinbach.

Es sintomático, por otra parte, que pese al tema tratado Goethe apenas desarrolle descripción alguna del edificio. ${ }^{581}$ Lo cierto es que, a diferencia de lo que hará después de Italia, Goethe no presta atención alguna a la arquitectura como elemento construido. Es más, parece traslucirse una cierta desconfianza hacia la técnica en la medida en que vendría asociada a criterios ajenos a la tradición germana. En este sentido, sería precisamente la ausencia de una descripción arquitectónica detallada la prueba de la fuerza poética que Goethe afirma haber descubierto en la catedral, y por la que expresó su admiración en el edificio y en la arquitectura alemana (Osterkamp, 2001: 145-161).

La crítica de las proporciones, tan vehemente en este texto, pasará después de Italia a ser crítica de las meras proporciones. Goethe alienta en este texto de juventud el sentido de lo genial, la sensación personal e inconmensurable que anuncia lo sublime en el arte. No es tanto la medida lo relevante (lo es en tanto que "grandeza"), sino el hecho de medir lo que imposibilita un acceso sensible a la intensidad poética de la arquitectura. Lo que en este texto supone un enfrentamiento radical entre el racionalismo y el sensualismo, posteriormente pasará a ser una versión atemperada del racionalismo, paradigmáticamente plasmada en el Baukunst (1795).

\section{Tercera peregrinación a la tumba de Erwin (1775) ${ }^{582}$}

Durante su primer viaje a Suiza (mayo-julio 1775), planeado desde 1774, Goethe aprovechó la ocasión para visitar una vez más la catedral de Estrasburgo (24-26 de mayo 1775). Esta visita le impulsó presumiblemente a repensar su ensayo Von Deutscher Baukunst ${ }^{583}$ y mantenerlo presente durante su visita al país helvético. A su regreso, el 13 de julio, Goethe visitará la torre sur de la catedral.

Concibe este himno al modo de un devocionario de peregrinación [Wallfahrtsbüchlein] inspirado por su visita a la Abadía de Maria Einsiedeln el 15 de junio, monasterio benedictino medieval en el cantón de Schwyz que le causó una profunda impresión. ${ }^{584} \mathrm{En}$ este breve texto describe en tres estaciones su ascenso a la torre sur una mañana soleada. Cada una de estas etapas, a modo del calvario que descubrió en Einsiedeln, corresponden respectivamente a las dos galerías y la plataforma de la torre. El título de este ensayo es deudor del recuerdo de la Abadía, centro de peregrinación de Santiago de Compostela, confirmando el carácter religioso que ya en su primer ensayo le atribuía a la visita de la catedral. deutsche Baukunst, unsre Baukunst].

578. Sin ir más lejos, Salmerón incluye este ensayo entre los "escritos de la primera época", la del Sturm und Drang (1771-1786). 579. Así lo defiende acertadamente Kruft, para quien el ensayo es "una extraña combinación de una aproximación gótica y clásica" (1982: 282). 580. Un cierto tono beato atraviesa todo el ensayo. Pueden localizarse numerosas referencias a la Biblia: “Está lleno de animales puros e impuros" (1999: 33), referencia

a Hechos de los apóstoles, 10 ("San Pedro recibe del Cielo un mantel en el que viajan animales, puros: cuadrúpedos, e impuros: reptiles."). Referencia al culto sensualista a la naturaleza. Referencia al Salmo 139, 9: "alas de la aurora" (1999: 39); Salmo 17, 12: "como el león de las montañas" (1999: 39).

581. La única referencia concreta al edificio es: "¿Ves cómo sobre la entrada [...] que las rodeaban" (1999: 36-37). 582. Se publica por primera vez en Louis-Sébastian Mercier, Neuer Versuch über dis Schauspielkunst. Aus dem Französischen [de Heinrich Leopold Wagner]. Mit einem Anhang aus Goehtes Brieftasche, Leipzig, 1776, pp. 483508. Puede consultarse la traducción en Goethe (1999: 61-63). Años más tarde en Dichtung und Wahrheit (II, 9; III, 12) volverá a mencionar a Erwin. 
583. Véase Goethe: DB Band 10, 2004, Briefe, Tagebücher, Gespräche p. 779 y ss. 584. Anota en su diario el 18 de junio que ha dibujado la capilla. Esta será su única referencia arquitectónica. En Dichtung und Wahrheit, veinte años después, la describe como "Kirschlein in der Kirche".

585. En lo que sigue se utilizará preferentemente la traducción de Cansinos "De la arquitectura alemana" (II: 2024-2027), título por otra parte juzgado más acertado que "Sobre la arquitectura

alemana".

586. El 27 de marzo revisa la primera versión que será poco después publicada. Así se lo indica a Boisserée en una carta del 10 de abril de 1823.

587. Quizás fuese su visita a la catedral de Magdeburgo en 1805 el primer indicio de este giro.

588. Goethe llegó incluso a implicarse políticamente en la vida social, en contra de sus más profundas convicciones, e intervino para frenar una publicación contra Napoleón: "avíneme a infringir la ley que a mí mismo me había impuesto de no meterme en asuntos políticos" (D. y A., III: 581).

589. En 1809, interés por la "prehistoria nórdica y romántica en general" (D. y A., III: 598). Traducción de Los nibelungos.

590. Además de sus estudios sobre Winckelmann ha de
Gran parte de los comentaristas, de hecho, no han visto una aportación sustantiva a la discusión sobre la arquitectura alemana en este texto. Ha sido mayormente interpretado como una mera confirmación de su conocido ensayo o, a lo sumo, como una aclaración. Es cierto que Goethe no aporta nada sustantivo respecto a aquel. Es más, se refiere explícitamente en este texto, que tiene el carácter de expiatorio ("Quiero escribir porque me hace bien, y siempre que he escrito le hice bien a otros", 1999: 62), a su anterior ensayo para reafirmarse en sus convicciones de entonces si cabe con mayor rotundidad: "Que sea mi destino como el tuyo, torre que apuntas al cielo, y como el tuyo, vasto mundo de Dios. Los extranjeros de todas las naciones se quedan boquiabiertos ante nosotros y nos archivan en sus diminutas mentes." (1999: 62-63)

No obstante, es relevante este texto por un giro que, con el tiempo y especialmente tras el estudio de la tratadística clásica y las teorías estéticas kantianas, cobrará más y más importancia: la relación del arte con la naturaleza. Tal y como lo evoca en la "Oración", el contacto con la naturaleza durante su ascenso a los Alpes (las cataratas de Schaffhaussen, el paso de San Gotthard y el lago de Zúrich) ha operado en él una cierta potenciación de su sensibilidad estética: "Siento, gracias a Dios, que me sigue conmoviendo, como me conmovió en su momento, lo grande. $Y$ joh maravilla! Me emociona de manera más singular y exclusiva que antes." (1999: 61) Desde entonces en adelante, la contemplación de la naturaleza será considerada como estímulo del poder creador en el genio del artista. Este texto ha de entenderse, pues, como una confirmación, sí, pero tam- bién como una apelación a los "artistas creativos y conocedores llenos de sensibilidad" con el fin de protegerlos contra "la insípida e inagotable mediocridad" (1999: 63).

\section{Von Deutscher Baukunst (1823) y la serie en su conjunto}

Cincuenta años después de su escrito de juventud Von Deutscher Baukunst (1772), Goethe publica un escrito homónimo en Arte y Antigüedad, tomo IV, número $2 .{ }^{585}$ Listo ya desde marzo de $1823,{ }^{586}$ este texto es la culminación de un renovado interés por el gótico acusado desde comienzos del siglo XIX. ${ }^{587}$ Hasta entonces, más allá de su primer ensayo de 1772, Goethe no prestó atención alguna al gótico. Es más, tal y como se ha podido mostrar anteriormente, el interés del joven Goethe en la catedral de Estrasburgo estuvo entonces condicionado por una explícita instrumentalización que restaba relevancia a la construcción concreta.

Los primeros años del siglo XIX fueron años convulsos para Goethe y motivaron cambios sustantivos en sus objetos de atención. La inesperada muerte de Schiller coincidió con un regreso a sus estudios sobre la arquitectura -prácticamente ausentes desde su intento fallido de terminar el Baukunst (1795) - que se concretan en su prólogo sobre Winckelmann (1805), "aquel hombre magnífico, largo tiempo echado de menos" (D. y A., III: 551). A nivel político es igualmente un periodo agitado debido principalmente a las guerras napoleónicas. ${ }^{588}$ Este contexto biográfico, por prescindible que deba reconocerse a la hora de valorar críticamente sus textos, afectó notablemente la gestación de Von Deutscher Baukunst (1823), ensayo en el que se entrecruzan valoraciones, citas y men- 
ciones a experiencias concretas y condicionó en gran medida su predisposición a orientar su atención hacia cuestiones por largo tiempo aparcadas. El tono de esta predisposición quedó claramente plasmado en ocasión de la visita, poco después de la muerte de Schiller, a la catedral abandonada en la hospedería de Gleim (1805):

Tienen tales edificios algo de particularmente atractivo, hácenos evocar sólidos, aunque sombríos estados, y como no pocas veces gustamos de envolvernos en las penumbras del pasado, sentimos una grata impresión cuando una limitación sugestiva nos traspasa de cierto escalofrío, que obra física y moralmente sobre nuestro sentimiento, nuestra fantasía y nuestro ánimo, suscitando así en nosotros un estado de espíritu moral, poético y religioso. (D. y A., III: 569-570)

Desde entonces Goethe se ocupa crecientemente en el estudio de la historia germana, ${ }^{589}$ unido a un renovado interés por la arquitectura (aun con una acusada preferencia por la Antigüedad). ${ }^{590}$ Fue sin duda la influencia de los hermanos Boisserée, especialmente Sulpiz, la que desencadenaría en Goethe una renovada atención por el gótico, tal y como Goethe reconoce al comienzo de su ensayo. ${ }^{591}$ Tras años dedicados a su proyecto de puesta en valor del arte alemán antiguo, Sulpiz Boisserée elabora unos grabados de la catedral con los que pretende atraer a las personalidades de la cultura alemana más destacada. Consigue contactar finalmente con Goethe en 1810 a través de su común amistad Karl Friedrich von Reinhard. Así lo relata:

Gustoso evoqué yo los sentimientos de aquellos años, en que la catedral referida impusiérase a mi admiración, inspirándome manifestaciones de peregrino entusiasmo, que, no obstante, me brotaba de lo más profundo. Volvió ahora a estimularse el estudio de aquella antigua singular arquitectura, y los weimarianos amigos del arte tomaron en simpática consideración aquel principal objeto. (D. y A., III: 604)

Goethe acepta recibir a Boisserée en mayo de 1811 y escuchar sus explicaciones sobre los planos de la catedral de Colonia. Esta visita, y la serie de dibujos sobre los que pudieron discutir, llevó a Goethe, en sus propios términos, a saltar muchos siglos y pasar de sus renovados estudios sobre la Antigüedad a centrar su atención en la arquitectura gótica. ${ }^{592}$ Eso, unido al descubrimiento de un dibujo original, motivó un giro en su manera de abordar las edificaciones góticas, en las que "habríamos de ver y comprobar cómodamente el comienzo del género de arquitectura que esta vez considerábamos, su apogeo y, por último, su decadencia" (II: 2026), como destaca en Von Deutscher Baukunst (1823). Cuatro años después visitó la catedral de Colonia:

Debería hacer ahora mención de la antigua arquitectura germánica, cuya noción íbaseme más dilatando y depurando. Una excursión a Colonia [...]. Con el ya predispuesto asombro hube de ver el doloroso monumento de lo inconcluso y, no obstante, pude captar con los ojos la medida de aquello que había debido ser, aunque, sin embargo, aún permanecía incomprensible para mí, hablando con estricto rigor. [...]

Respecto a la arquitectura, y en relación con m viaje a Colonia, hablóse y discutióse de muchas cosas, teniendo a la vista planas y bocetos de antiguos edificios alemanes, flamencos y franceses, lo que poco a poco íbale a uno capacitando para sacar y asimilarse de entre una gran mole, hartas veces singular y confusa, lo puro y bello, que es lo que el humano espíritu mencionarse el impacto de la publicación en 1804 de Die Baukunst nach den Grundsätzen der Alten de Aloys Hirt (con quien coincidió en Roma). A esta última obra se dedicó con intensidad. En 1809 destacaría cómo le predispuso hacia la contemplación de la ruina (como lo inacabado y decadente): "a la historia y la contemplación de las ruinas vióse obligada a unirse la imaginación; interesámonos vivamente en todo aquello y nos sentimos movidos a acometer ensayos semejantes." (D. y A., III: 601). Esta predisposición anuncia la manera en la que recuperará su ensayo de juventud. 591. Von Deutscher Baukunst (1823) comienza con el rótulo "La labor de los hermanos Boisserée". El explícito agradecimiento a los hermanos regresa en el texto en tres ocasiones.

592. "Muchos siglos, en cambio, hubimos de saltarnos cuando el doctor Sulpicio Boisserée vino a vernos trayendo una considerable serie de dibujos y cobres e hizo derivar nuestra atención hacia la Edad Media. Deteníamonos de buen grado, pues teníamos ante los ojos una bien pensada serie de monumentos coincidentes, que nos trasladaban a aquellos tiempos sombríos, en verdad, pero también honrosos e interesantes." (D. y A., III: 606). 593. Motivadas fundamentalmente por las obras de Moller y Boisserée: "A la arquitectura 
paleogermánica, al contraste de su carácter mediante la apreciación de su sentido, al concepto del tiempo en que se produjera, hubieron de conducirme dos obras principales. Los monumentos arquitectónicos de Alemania, de Moller, cuyo primer cuaderno, ya terminado, teníalo a la vista. [...] publicose también el primer cuaderno de la obra de Boisserée sobre la catedral" (D. y A., III: 665)

594. „Das tüchtigste, grossartigste Werk, das vielleicht je mit folgerechtem Kunstverstand auf Erden gegriindet worden." (WA 49.2: 187). 595. En 1821: “Tocante a arquitectura, sólo trabajé en ella realmente en los respectos histórico, teórico y crítico." (D. y A., III: 662).

596. “No hay arte patriótico ni ciencia patriótica. Ambos pertenecen, como todo lo elevado y bueno, al mundo todo, y solo mediante la general libre colaboración de todos los que viven en una misma época, habida cuenta de lo que nos queda y conocemos del pasado, es como podemos progresar." (P. y V., $n^{\circ}$ 690, II: 1660 y 1675-1679). 597. "Die Kunst, welche das Strassburger Münster, den Dom zu Köln und andere Meisterstücke hervorbrachten, ist herrlich und erhaben, aber sie war das Resultat ihrer Zeit [...] Wir können diese Werke bewundern und nachahmen, aber nicht schaffen; weil die äusseren Verhältnisse, unter welchen jene Kunst busca, bajo cualquier forma que fuere. Los dos primeros pliegos de Möller [Denkmäler der deutschen Baukunst, 1815], que por aquellos días se publicaron prestámonos a ese fin la ayuda apetecida. Anexo a la parte técnica venía un antiguo ejemplar impreso de El gremio de canteros, testimonio notable de la gran importancia del mismo. Por él podíase ver claramente cómo aquí coinciden artesanía y arte. (D. y A., III: 618)

Desde entonces la producción de Goethe recoge alguna de estas inquietudes. ${ }^{593}$ En 1817 publica Herstellung des Straßburger Münsters (WA 49.2: 168-178) y Alt deutsche Baukunst. En 1819 Kölner Domriß durch Moller (WA 49.2: 178-181). En 1822 -apenas un año antes de Sobre la arquitectura alemana-, Ansichten, Risse und einzelne Teile des Doms zu Köln (WA 49.2: 182-188), en la que se refiere a la catedral de Colonia como "la más sólida y espléndida obra que nunca se emprendió en la Tierra con una correcta comprensión de las necesidades del arte". ${ }^{594}$

De todo ello conviene ahora rescatar al menos dos ideas a partir de las cuales ha de entenderse Von Deutscher Baukunst (1823). En primer lugar, destaca entre sus apreciaciones biográficas y sus anotaciones la prevalencia del enfoque teórico. ${ }^{595}$ Atrás quedan ya sus inquietudes constructivas o sus indagaciones sobre el comportamiento del material concreto y su disposición en el edificio. En segundo lugar, y en coherencia, convergen desde esta órbita arte y artesanía en la medida en que este primero adquiere paulatinamente (algo ya anunciado en Über den Dilettantismus) un carácter antropológico. En este sentido, el gótico puede suscitar interés en la medida en que supone una "correcta comprensión de las necesidades del arte" (en el sentido de los fines inmediatos del
Baukunst de 1795, que es desde donde parten los condicionantes sociales e históricos).

De ahí que Von Deutscher Baukunst

(1823) arranque con el reconocimiento del origen alemán del gótico pero en un sentido ya muy alejado al del patriotismo de su ensayo de juventud. ${ }^{596}$ En línea con lo que Moller planteó en su Denkmäler der deutschen Baukunst (así se lo transmitió en una carta a Goethe del 24 de octubre de 1815) el gótico adquiere un valor historiográfico y no tanto de modelo para el presente. ${ }^{597}$ Con la mirada del historiador, el gótico es síntesis de un momento histórico, testimonio de un pasado. Recuérdese, por el contrario, cómo en el Baukunst (1788) Goethe enuncia quizás la crítica al gótico más dura que jamás publicara en ocasión de su visita la catedral de Milán en 22-28 de mayo 1788. Después de su encuentro con la arquitectura clásica no pudo recibir ya del gótico ningún estímulo en la medida en que estaba inmerso en el proyecto clasicista de reconstruir una evolución de la arquitectura hacia sus más elevadas materializaciones. Escribe a Carl August el 23 de mayo de 1788 que la catedral de Milán se le presenta como "einganzes Marmorgebirg in die abgeschmacktesten Formen gezwungen" ["toda una montaña de mármol en las formas más absurdas"] (DB, 10: 4330). En cambio, en sus afirmaciones en Von Deutscher Baukunst (1823) reconoce que "Mi estancia en Italia no pudo reavivar aquellos sentimientos [el entusiasmo provocado por la catedral de Estrasburgo y plasmado en Von Deutscher Baukunst. 1772], además ello se vio aun más dificultado pues las recientes modificaciones de la catedral de Milán me impidieron reconocer su antiguo carácter [aquellas emprendidas por Pellegrino Pellegrini en el siglo XVII], y 
así viví durante muchos años alejado de este tipo de arte si no totalmente ajeno al mismo." (1999: 309).

En este contexto ha de interpretarse la revisión del Von Deutscher Baukunst (1772). Su homónimo ensayo de 1823 se abre con la larga cita tomada en una libre traducción de los Cours d'Architecture [cinquième partie, libre V, chapitres XVI-XVII] de Blondel. He aquí su tesis principal: "contemplamos con delectación algunas masas de esos edificios góticos, cuya belleza parece engendrarse de la simetría y proporción del todo con respecto a las partes y de las partes entre sí y se hace notar en medio de la horrible ornamentación que los recubre y aun a pesar de ella." (II: 2025). En ella señala que la proporción en tanto que composición- es independiente del estilo del edificio. No hay distinción a este respecto entre el gótico y la arquitectura de la antigüedad, entrando en explícita colisión con aquello planteado en 1772. Así lo justifica Goethe a continuación:

\section{A propósito de esto debemos recordar aquellos años moceriles en que la catedral de Estras- burgo hizo tanta impresión en nuestro ánimo, que no nos hartábamos de expresar nuestro lego entusiasmo. Precisamente entramos allí, sin saberlo, eso que el arquitecto francés, tras mediciones e investigaciones asiduas, confiesa y sostiene: que no a todos ha de pedírseles se den cuenta cabal de la impresión que les asalta. (II: 2025)}

Más allá de veladas autojustificaciones se hace patente su renuncia a juzgar toda obra arquitectónica bajo los logros de la arquitectura griega. Más allá de las disputas de estilo, Goethe interpreta -por medio del reconocimiento hacia el gótico- cada estilo como expresión de diferentes culturas, religiones y épocas, primando el enfoque histórico a la hora de aproximarse a la arquitectura. De ahí su interés por lo inconcluso y la ruina:

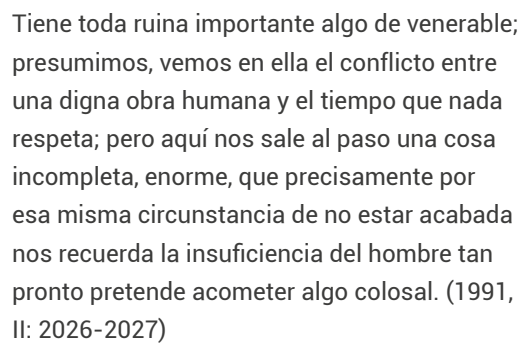

Se acusa una cierta relativización

de los criterios objetivos de juicio. Si, por una parte, su manera de ver el gótico sigue siendo el de un clasicista (Kruft, 1990, I:257), la incorporación del reconocimiento del valor intemporal de toda obra artística con independencia de su estilo abre la puerta a trascender las valoraciones estéticas enunciadas en sus obras precedentes. Prima un sentido de la pertenencia a una cultura y a la religiosidad, tal y como enunciará sintéticamente en Máximas y Reflexiones: "Antike Tempel concentrieren den Gott im Menschen; des Mittelalters Kirchen streben nach dem Gott in der Höhe." [El templo antiguo concentra a Dios en el ser humano; la iglesia medieval tiende hacia Dios en las alturas] (WA 48: 214). De hecho, no puede encontrarse en su producción una explícita renuncia a su admiración por los griegos. Podría decirse incluso que, a partir de la muerte de Schiller, se acentuó su interés por los griegos, por sus lecturas de la filosofía presocrática, por ejemplo, que algunos autores han relacionado con su producción de la teoría de los colores y de la luz y otros temas científicos (Bapp, 1921). entstand, in keiner Hinsicht mehr diesselben sind" [El arte que ha creado las catedrales de Estrasburgo y Colonia, como otras obras maestras, es maravilloso y sublime, mas fue el resultado de su época [...] Podemos admirar e imitar estas obras, pero no las podemos crear porque las circunstancias bajo las que se desarrolló este arte han cambiado profundamente]. Citado en Kruft (1990: 761). 
598. Der Teutsche Merkur fue una revista de literatura y de recensiones publicada por Christoph Martin Wieland [poeta, escritor y traductor] desde 1773 hasta 1789. Constituyó un privilegiado vehículo de difusión en Alemania de la ilustración francesa y, al tiempo, entre sus objetivos estaba consolidar un gusto nacional. Goethe publicó 17 artículos y reseñas desde 1776, hasta su cierre.
En suma, Von Deutscher Baukunst (1823) supone en sí mismo un cierto distanciamiento del clasicismo, pero no tanto como cuestionamiento de sus fundamentos sino como intento de incorporarlos a una visión más amplia de la producción arquitectónica universal. Si su ensayo de 1772 plasmaba con vehemencia la aproximación de un diletante a la arquitectura que asume los postulados generales de la crítica del arte en su sentido historiográfico, en 1823, pese a sus intentos en el Baukunst (1795) de aproximarse al saber técnico, sella definitivamente su renuncia a poder considerarse un verdadero conocedor de la arquitectura en toda su complejidad. Deja atrás las investigaciones que se sucedieron desde su viaje a Italia que giraban en torno a un concepto de material como determinación previa a la acción del artista, que condiciona de alguna manera la forma final de la arquitectura y que, posteriormente, se plasmarían en el Baukunst (1795) en la teoría de los tres fines. Lo necesario en la arquitectura se desvincula, pues, de cuestiones materiales (muy ligadas a las técnicas constructivas concretas) y aquello que inicialmente podría considerarse la motivación inicial (como en la Arena de Verona) pasa a ser lo necesario en la arquitectura: un cierto sentido de lo social ligado a lo histórico.

Al tiempo, quizás la aportación más relevante en el contexto de la discusión respecto de la autonomía de la arquitectura sea el hecho de que Goethe reconozca en ella la capacidad fundante de cultura. Su valor, en este sentido, estribaría más en el impacto epocal que produce, antes que en cuestiones meramente formales $y$, en este sentido, converge y se distancia del ensayo de 1772. Si en su juventud vio en el gótico la posibili- dad de ensalzar una cultura ancestral que se veía amenazada por usurpadores extranjeros, en su revisión de 1823 se apoya en un sentido universalista de la cultura para rescatar el valor histórico del estilo gótico.

\section{Baukunst (1788)}

En una carta de finales de agosto de 1788 , Goethe pide a Wieland, editor de la revista Der Teutsche Merkur, que reconsidere su oferta de publicar su diario de viaje. En contrapartida, Goethe le ofrece la posibilidad de publicar fragmentos de su viaje. Perdido entre cartas, abrumado por los múltiples apuntes en diarios y notas, Goethe trabaja durante ese verano para ordenar sus recuerdos, experiencias y anhelos (II-3: 422).

Apenas dos meses después, en octubre de 1788, una serie de relatos breves aparecen en la revista Der Teutsche Merkur ${ }^{598}$ con el título "Auszüge aus einem Reise-Journal" [Extractos de un diario de viaje]. Se trata de una compilación de diez textos con enfoques muy diversos, en el que Goethe combina descripciones en apariencia anecdóticas con formulaciones teóricas, a modo de ensayos breves, producto de sus experiencias italianas. Es, por otra parte, el primer testimonio público de Goethe sobre su viaje a Italia (hasta la fecha, cuestión llevada con notable discreción) y será posteriormente recogido, en algunos casos casi sin cambios (apartado 4, por ejemplo), en sus Viajes italianos.

De entre estos diez textos, Goethe incluye uno que, bajo el título de "Zur Theorie der bildenden Künste" ["Teoría de las artes plásticas"], incluye un subapartado dedicado monográficamente a la arquitectura. Lo titula "Baukunst" y se trata de su segundo trabajo 
teórico sobre esta disciplina, después de la arrebatada obra de juventud Von Deutscher Baukunst (1772). Sobre qué llevó a Goethe a redactarlo, ciertos especialistas defienden una motivación práctica (poder optar a los posibles encargos en Weimar) (Ewald, 1999: 20) o teórica (aclararse respecto de sus experiencias en Italia y, muy especialmente, respecto de la arquitectura de la Antigüedad) (Beyer, 2001: 17). Bisky defiende que se trata de un compendio de textos ajenos (200: 70 y ss.).

\section{"Extractos de un diario de viaje": naturaleza,} arte y cultura

Se inicia esta compilación con la descripción de una visita al Monte Pellegrino en Palermo y el santuario de Santa Rosalía, patrona de la ciudad. Lleva por título "1. Rosaliens Heiligtum" [Santuario de Rosalía]. Goethe se extiende inicialmente en descripciones pormenorizadas del ascenso al monte, a través de su zigzagueante sendero entre acantilados, y del interior del santuario. Se detiene con especial delectación en transmitir las emociones vividas al contemplar la estatua de la santa. Pese a no ser reconocida por Goethe como una obra artística de gran valor, destaca su capacidad para transmitir la "ilusión de su vida interna"599 y destaca la relación entre la arquitectura y la naturaleza (Rubio, 2018). El segundo capítulo, "2. Zur Theorie der bildenden Künste" [Teoría de las artes plásticas] incluye dos subapartados que han de entenderse en conjunto. El primero, "Baukunst", es aquel que más atención merece. El segundo, "Material der bildenden Kunst" [Material de las artes plásticas], ahonda en el primero ampliando sus deducciones a otras manifestaciones artísticas. Es significativo que no recuperase estas reflexiones en sus Viajes italianos, a diferencia de la mayoría de capítulos aquí recogidos. A continuación, en tono distendido, Goethe apunta ciertos comentarios al horario italiano en el tercer capítulo ("3. Stundenmass der Italiener"). Ilustra, después, lo característico y la diferencia en la forma de vivir y de pensar (en el sentido de Herder) ${ }^{600}$ con tres artículos: "4. Frauenrollen auf dem römischen Theater durch Männer gespielt" [Papeles de mujer interpretados por hombres en el teatro romano], una visita a Nápoles en el quinto artículo ("5. Neapel" [Nápoles]) y, por último, "6. Plinius Natur geschichte" [La historia natural de Plinio]. En el séptimo capítulo, Goethe regresa al ensayo con "7. Einfache Nachahmung der Natur, Manier, Styl" [Simple imitación de la naturaleza, maniera, estilo], ${ }^{601}$ pudiéndose considerar como el balance estético de sus experiencias artísticas en Italia. En el octavo capítulo, "8. Von Arabesken", Goethe destaca cómo, en la visita a Pompeya y al Palacio Real en Portici de Nápoles, entendió el significado que tuvo la pintura ornamental en los Antiguos, en tanto que la decoración en Villa Bagheria en Palermo puso a prueba la representación de la belleza para Goethe en este arte (que se remonta, en su opinión, a la Domus Aurea de Nero, y retoman Rafael de Perugino, Lippi o Pinturicchio). Le resulta difícilmente compatible con su idea de claridad. Continua, así, con una analogía con los arabescos y las formas fantásticas que puede uno encontrar en la escarcha que aparece en invierno en las ventanas, "flores de hielo" les llama.

La aparente heterogeneidad de estos textos viene a atarse de alguna manera por medio de un hilo conductor. En última instancia, quiso Goethe validar con tan diferentes
599. Se escuda, de hecho, en una cita de Voyage Pitoresque de la Sicile [se debe referir al Voyage pittoresque ou Description des royaumes de Naples et de Sicile de Jan-Claude Richard de SaintNon editado en 1781-1786] para justificarse: "la Statue est de bronze doré, avec les mains et la tete en marbre blanc, mais si parfaitement sculptée et dans une position si naturelle, que l'on serait tenté de la croire vivante." 600. Así lo interpreta Friedmar Apel en DKV-1138. 601. Traducido por Salmerón "Simple imitación de la naturaleza, maniera, estilo", erróneamente fechado en febrero de 1789 (1999: 67-71). 
602. Recuérdese en Von Deutscher Baukunst (1772): "nuestros bellos espíritus, llamados filósofos, siguen componiendo hasta día de hoy, a partir de cuentos protoplásticos, los principios y la historia del arte." (1999: 34).

603. Ello se hace mucho más evidente en el segundo apartado de este capítulo, en la medida en que le da nombre: "Material de las artes plásticas".

604. „Wenn ich geneigt wäre etwas auf das Papier zu bringen; so wären es vorerst sehr einfache Sachen. Z.B. inwiefern die Materie, woraus gebildet worden, den klugen Künstler bestimmt, das Werk so und nicht anders zu bilden. So geben die verschiedenen Steinarten gar artige Aufschlüße über Baukunst, jede Veränderung des Materials und des Mechanismus, giebt dem Kunstwercke eine andere Bestimmung und Beschränkung. Die Alten waren, nach allem, was ich bemercken konnte, auch besonders hierin unaussprechlich klug und ich habe mich oft mit großem Interesse in diese Betrachtung vertieft." (1991, II-3: 415)

605. Remite Goethe al Ifigenia entre los tauros de Eurípides "de forma que era posible colocar en su interior los cráneos de los animales sacrificados", comentario tomado de Winckelmann. En el prólogo de la tragedia, frente a la fachada del templo fenómenos y tan diferentes descripciones el principio formativo [Bildungsprinzip] contenido en la naturaleza, o en el arte, o en la cultura. Así ha de entenderse con la introducción en el noveno capítulo "9. Naturlehre" [la lección de la naturaleza] de canciones populares italianas y su respuesta en " 10 . Naturlehre Antwort".

\section{El contenido del Baukunst (1788)}

El ensayo plantea desde su comienzo lo que parece ser la motivación inicial: la discusión sobre el origen de la arquitectura.

\section{Los templos dóricos del orden más antiguo [...] nos llevan a pensar con naturalidad que no fue una cabaña de madera aquella que en primer lugar constituyó aquel remoto caso. (1788: 1)}

\section{A diferencia de lo que plantea}

Vitruvio, del que destaca despectivamente "el cuento de la cabaña", 602 el origen de la arquitectura no cabe localizarse para Goethe en la casa, sino en el templo. Emprende así una búsqueda de los principios fundadores de la arquitectura dórica en los templos de la antigüedad, tal y como los conoció en su viaje por el sur de Italia. Esta motivación, no obstante, se muestra rápidamente en su carácter instrumental. En realidad, el interés de Goethe se decanta por una cuestión mucho más ligada con sus investigaciones sobre la convergencia de arte, naturaleza y cultura. En concreto, en el caso de la arquitectura, y de una manera sintomática (tal y como anunciará al comienzo del Baukunst (1795)), su foco se va a centrar en la interacción entre material y forma. ${ }^{603}$ Así se lo trasmite a Heyne en una carta del 24 de julio de 1788, un mes después de su regreso a Weimar:

\begin{abstract}
Si estuviera dispuesto a trasladar algo al papel, sería por el momento cosas muy sencillas. Por ejemplo, en qué medida la materia de la cual está formada la obra determina al artista sensato crearla así y no de otra manera. Así los diferentes tipos de piedra dan suficiente información sobre la arquitectura: cualquier cambio en el material y la técnica da otra determinación y restricción a la obra de arte. Los antiguos eran, entre todos, por lo que he podido constatar, igualmente en esto indeciblemente sabios y me he sumergido frecuentemente con gran interés en estas consideraciones. ${ }^{604}$
\end{abstract}

Goethe está fundamentalmente interesado, en lo que a la arquitectura se refiere, en profundizar en el concepto de material como determinación previa a la acción del artista, que condiciona de alguna manera la forma final de la arquitectura. A la luz de la arquitectura de la antigüedad, sus reflexiones parecen conducir a la concreción de las normas que rigen esta restricción. Tan es así, que, a partir del tercer párrafo del texto, la cuestión antes aludida sobre el origen de la arquitectura y presentada como la motivación principal de la argumentación se desdibuja de una manera rotunda:

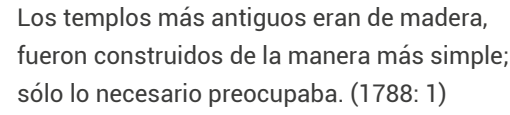

Las técnicas constructivas derivadas del uso de la madera como material, unido al hecho de haberse realizado para atender meramente a la necesidad inmediata, dio lugar por tanto a una serie de elementos que, posteriormente cristalizaron:

Esta forma del templo, enteramente sólida, sencilla y tosca, era empero sagrada a los ojos del pueblo y, así, en cuanto se comenzó a construir 
en piedra se imitó en el templo dórico tan bien como se pudo. (1788: 1)

Por tanto, las muescas en las cabezas de la viga que constituían el entramado de cubierta, producto de la falta de habilidad de estos primitivos constructores y de la preponderancia de la satisfacción de una necesidad inmediata, dieron lugar en su petrificación a los triglifos. Los espacios libres entre las vigas, dejados abiertos por no estar siquiera "revestidos", proporcionó un espacio vacante dedicado a albergar los "cráneos de los animales sacrificados y dio lugar en su versión petrificada a las metopas, cierre del entrevigado en fachada. ${ }^{605}$ Ambos elementos descansaban en la viga maestra, matriz del arquitrabe.

Esta explicación del entablamento del templo clásico en su conjunto se completa igualmente por el de la columna. Asoman en este sentido dos de las tres partes de la arquitectura que posteriormente desarrollará en su proyecto inconcluso del Baukunst 1795 y será precisamente el elemento al que concede menos importancia en este texto el único que desarrolló en su práctica totalidad siete años después, esto es, el basamento. En el desarrollo histórico de las columnas, desde su materialización en troncos recios a su sofisticado despiece en piedra (a diferencia de la arquitectura egipcia que sí disponía de "las piedras más sólidas"), Goethe identifica una segunda motivación. La necesidad está en el origen de las proporciones del dórico arcaico: no teniendo buena piedra a disposición, tuvieron que hacerlas "muy robustas" y "apuntadas".

Así, la forma reconocible en los templos griegos arcaicos, tal y como pudo comprobar en su viaje al sur de Italia, debe ser atribuida al uso, por una parte, de la madera como material constructivo ${ }^{606} \mathrm{y}$, por otra, a la necesidad. Se prefiguran aquí los dos elementos de partida que en el borrador del Baukunst llamará condicionantes y que, posteriormente, pasarán a ser la condición previa (material) y el fin inmediato.

Al hilo de esta discusión, Goethe aborda cuestiones que apuntan, en algunos casos muy tangencialmente, hacia el posterior desarrollo en el Baukunst (1795). La divergencia en algunas cuestiones centrales podría incluso llegar a justificar el que este texto, el Baukunst (1788), no volviera a publicarse después de 1789.

\section{Imitación y carácter}

El origen que Goethe atribuye a la construcción en madera se trata, pues, de un origen esencialmente formal. Lo relevante no es tanto que pueda localizarse un momento histórico de comienzo, sino que puede trazarse una cierta continuidad desde entonces. No en vano era este un tema ampliamente discutido en la teoría arquitectónica del momento. Su principal difusor fue Aloys Hirt, en contra de teóricos como Lodoli o Christian Traugott Weinlig de mediados del XVIII. Lo que sí puede considerarse una aportación de Goethe-quizás, el pasaje más interesante del ensayo- es la defensa del origen de la imitación del material en las costumbres de la gente. El papel central de la utilidad en el desarrollo de la forma de un edificio podría ser un corolario de esta tesis (esto quedará claramente formulado en el Baukunst de 1795). ${ }^{607}$ En el segundo capítulo del libro IV "De los ornamentos de las columnas y de su origen", Vitruvio también defiende el prece- de Ártemis en la Táurica, Orestes pregunta a Pílades: "Ves cráneos colgados de la misma cornisa?", a lo que este responde: "Sí, con exvotos de extranjeros muertos" (Eurípides, 1995: 9).

606. Esta teoría estaba muy extendida en su época y Goethe la toma de Hirt cuando comenta: "La teoría de nuestro Hirt hacía derivar la arquitectura grecorromana de las más antiguas y necesarias construcciones de madera" (III: 1335), de Winckelmann que escribe: “En los siglos más remotos, las columnas eran de madera" (1989: 540) y de Galiani (1758, tavola IV, figura III: Struttura di tetti, cpa. 2 lib. IV).

607. A partir del Renacimiento, las teorías del origen de la arquitectura y la evolución de la arquitectura dórica se fusionan (Germann, 1987: 102 y ss., y 216). Para Goethe, el más notable defensor de estas teorías será Laugier, contra cuya teoría de la cabaña ya polemizó en Sobre arquitectura alemana (1772). Goethe apunta a este respecto las conocidas correcciones introducidas por Winckelmann en su estudio sobre los templos de Agrigento (Cometa, 1993) 
608. "Sollte ich über das was ich an alter und neuer Kunst bemerkt, ein allgemeines Glaubenbekenntniß hersetzen, so würde ich sagen: daß man zwar nicht genug Ehrfurcht für das, was uns von alter und neuerer Zeit übrig ist, empfinden kann, daß aber ein ganzes Leben dazu gehört diese Ehrfurcht recht zu bedingen, den Werth eines jeden Kunstwercks in seiner Art zu erkennen und davon, als einem Menschenwercke, weder zu viel zu verlangen, noch auch wieder sich allzuleicht befriedigen zu lassen." (1991, II-3: 415) dente de la arquitectura de madera, aunque la vincula estrictamente a los ornamentos:

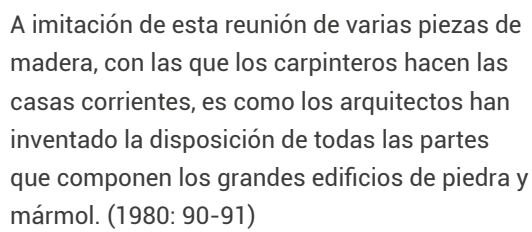
madera, con las que los carpinteros hacen las casas corrientes, es como los arquitectos han inventado la disposición de todas las partes que componen los grandes edificios de piedra y mármol. (1980: 90-91)

Desde su estancia en Vicenza y Venecia, Goethe ya estudió Vitruvio y Paladio con el fin de establecer planteamientos estéticos propios para la arquitectura. Ya en su ensayo sobre la Catedral de Estrasburgo, Goethe intentaba atribuir un fenómeno originario [Urphänomen] a la forma de la arquitectura, un régimen de necesidad en sus proporciones. Partiendo de Anmerkungen über die Baukunst der Alten (Winckelmann, 1762) y Reise durch Sizilien und Großgriechenland (Riedesel, 1771), Goethe esperaba que su contacto con la arquitectura más antigua fuera mucho más concluyente. Fue no obstante más extraña y confusa de lo que esperaba. Lo antiguo no hablaba inmediatamente. Requirió un esfuerzo considerable gestionar sus impresiones (véase influencia del arqueólogo Aloys Ludwig Hirt). En la carta a Heyne redactada durante el breve lapso de tiempo que separó su llegada a Weimar (junio 1788) y la publicación del "Baukunst" en octubre de 1788, Goethe confiesa las dificultades que ha tenido que afrontar:

\footnotetext{
Si tuviera que establecer una creencia general sobre lo que me di cuenta del arte antiguo y nuevo, diría así: a pesar de que no se pueda percibir el suficiente respeto por lo que los tiempos antiguos y nuevos nos han dejado, una vida entera es necesaria para encauzar ese respeto
}

reconociendo el trabajo en cada obra de arte en su estilo. ${ }^{608}$

En este ensayo queda evidenciada la dificultad de establecer lo que posteriormente concretará con el concepto de carácter en la arquitectura antigua. En su viaje a Italia, Goethe hace numerosas referencias al carácter de diversos edificios en relación con su función y belleza, entre las que destacan aquellas referidas a los edificios de Palladio, Porta Supa y el teatro de Taormina y Verona, la universidad de Padua, el acueducto de Spoleto, las villas en Frascati, el palacio de Caserta o el convento en Monte Pellegrino. Los templos sicilianos y Paestum fueron en este sentido una crucial experiencia. Precisamente Goethe toma el templo dórico como un ejemplo del progreso de la idea y no como forma de proporciones concretas. Probablemente, en este sentido, Goethe estaba muy influido por la extrañeza inicial que le provocó la arquitectura dórica arcaica, en contraposición al dórico romano. De ahí que quizás viese en el tipo de edifico lo característico, revelándose al espectador en la armonía de la función y la belleza.

En este ensayo quiere evidenciar la manera en que el conocimiento creciente del material afecta a la forma de la construcción con arreglo a fines. Los primeros templos tenían como única motivación la necesidad y, por tanto, tenían formas simples; bastaba simple artesanía para ello. La voluntad de trascender la temporalidad llevó a nuevos materiales, al uso de la piedra. Las diferentes características de las piedras empleadas llevaron a diferentes formas, una vez que habiendo precipitado la forma originaria propia de la madera como elemento cultural se quiso mantener. El descubrimiento 
del mármol y la mejora del dominio sobre el material permitió avanzar hacia la esbeltez de las columnas, entendiendo que cada material tiene una forma inherente. Tanto el templo de madera como el dórico o dórico arcaico mantienen una idea, un tipo arquitectónico, condicionada por la función del edificio $y$, aunque la materialidad y la proporción varíen, es reconocible para el espectador como una constante. El contraejemplo a todo ello sería, pues, el gótico.

\section{Trascripción y traducción}

Para la transcripción se han respetado los criterios filológicos de la edición de Johann Wolfgang Goethe (1998), Sämtliche Werke. Briefe, Tagebücher und Gespräche. Band 18, Ästhetische Schriften 1771-1805, Friedmar Apel (ed.), Frankfurt am Main: Deutscher Klassiker Verlag, pp. 202-206; última edición y más completa de la obra de Goethe. El subapartado "Baukunst" está traducido al italiano por Renata Gambino, con el título de "Architettura 1788" en J. Wolfgang Goethe (1994), Baukunst, Palermo: Medina, pp. 4347. 


\section{ZUR THEORIE DER BILDENDEN KÜNSTE}

\section{Baukunst}

Es war sehr leicht zu sehen, daß die Steinbaukunst der Alten, inso fern sie Säulenordnungen gebrauchten, von der Holzbaukunst ihr Muster genommen habe. Vitruv bringt bei dieser Gelegenheit das Märchen von der Hütte zu Markte, das nun auch von so vielen Theoristen angenommen und geheiliget worden ist: allein ich bin überzeugt, daß man die Ursachen viel näher zu suchen habe.

Die Dorischen Tempel der ältesten Ordnung, wie sie in Großgriechenland und Sicilien bis auf den heutigen Tag noch zu sehen sind, und welche Vitruv nicht kannte, bringen uns auf den natürlichen Gedanken: daß nicht eine hölzerne Hütte zuerst den sehr entfernten Anlaß gegeben habe.

\section{TEORÍA DE LAS ARTES PLÁSTICAS}

\section{Arquitectura}

Saltó a la vista que la arquitectura de piedra de los antiguos, en la medida en que utilizaron los órdenes de columnas, tomaron como patrón la arquitectura de madera. ${ }^{609}$ En este contexto, Vitruvio alude al cuento de la cabaña, que ya ha sido aceptado y consagrado por muchos teóricos. ${ }^{610}$ No obstante, estoy convencido de que hay que buscar el origen en época mucho más reciente.

Los templos dóricos del orden más antiguo, tal y como pueden verse aún hoy en la Magna Grecia y Sicilia, ${ }^{611}$ y que Vitruvio no conocía, nos llevan a pensar con naturalidad que no fue una cabaña de madera aquella que en primer lugar constituyó aquel remoto caso. ${ }^{612}$

609. Que la forma de los templos griegos proviniese de las técnicas constructivas en madera era una teoría muy extendida en aquella época. Goethe dice tomarla de Alois Ludwig Hirt cuando comenta: "La teoría de nuestro Hirt hacía derivar la arquitectura grecorromana de las más antiguas y necesarias construcciones de madera" (III: 1335). También Winckelmann se expresa en términos semejantes: "En los siglos más remotos, las columnas eran de madera" (1985: 540).

610. Vitruvio plantea esta historia de la cabaña como edificio primigenio en el capítulo primero del Libro II y fue asumida ya desde el Renacimiento. En lo que respecta a Goethe, cabría recordar su temprano rechazo a estas teorías del origen en Von Deutscher Baukunst (1772), referido en este caso a la interpretación de Laugier: "nuestros bellos espíritus, llamados filósofos, siguen componiendo hasta día de hoy, a partir de cuentos protoplásticos, los principios y la historia del arte." (1999: 34). Su teoría del Urphänomen, de hecho, viene a corregir esta tendencia mitificante y entiende el fenómeno fundador, más que como origen, como modelo.

611. Un comentario similar se encuentra en Winckelmann cuando escribe que los edificios de Paestum "son, sin duda alguna, los más antiguos monumentos que tenemos de la arquitectura griega y los mejor conservados, juntamente con el templo de Girgenti o Agrigento en Sicilia, y el Panteón de Roma" (1985: 266).

612. El origen de la arquitectura (que no de la construcción) en el templo era aceptado de forma general. Sólo Palladio asigna el origen a las casas, siguiendo a Gian Giorgio Trissino. Con este comentario parece que Goethe adopta una posición equidistante que pretende compatibilizar las diferentes teorías del origen. La construcción que es previa, necesaria y anterior a la arquitectura tendría su origen en la cabaña vitruviana. Pero la arquitectura como arte tiene su origen mucho después, en el templo dórico antiguo que Vitruvio no conocía. Atribuye el origen de la arquitectura a los templos, si bien sería posterior al origen de la construcción que estaría en la cabaña vitruviana. La diferencia entre construcción (previa) y arquitectura es una idea relevante en su pensamiento arquitectónico. 
Die ältesten Tempel waren von Holz, sie waren auf die simpelste Weise aufgebaut, man hatte nur für das Notwendigste gesorgt. Die Säulen trugen den Hauptbalken, dieser wieder die Köpfe der Balken, welche von innen heraus lagen, und das Gesims ruhte oben drüber. Die sichtbaren Balkenköpfe waren, wie es der Zimmermann nicht lassen kann, ein wenig ausgekerbt, übrigens aber der Raum zwischen denselben, die sogenannten Metopen, nicht einmal verschlagen, so daß man die Schädel der Opfertiere hineinlegen, daß Pylades, in der Iphigenie auf Tauris des Euripides, hindurch zu kriechen den Vorschlag tun konnte. Diese ganz solide, einfache und rohe Gestalt der Tempel war jedoch dem Auge des Volks heilig, und da man anfing von Stein zu bauen, ahmte man sie so gut man konnte im Dorischen Tempel nach.
Los templos más antiguos ${ }^{613}$ eran de madera, fueron construidos de la manera más simple; sólo lo más necesario preocupaba. Las columnas sostenían el arquitrabe, y este a su vez las cabezas de las vigas, tendidas desde el interior hacia el exterior, y la cornisa descansaba sobre la parte superior. ${ }^{614}$ Las cabezas de viga visibles, algo de lo que no puede prescindir el carpintero, estaban ligeramente muescadas. ${ }^{615}$ Por lo demás, el espacio entre ellas, las así llamadas metopas, ni siquiera estaba revestido, de forma que era posible colocar en su interior los cráneos de los animales sacrificados, siendo capaz Pílades, en el Ifigenia en Táuride de Eurípides, ${ }^{616}$ de anticiparse en esta propuesta. Esta forma del templo, enteramente sólida, sencilla y tosca, era empero sagrada a los ojos del pueblo y, así, en cuanto se comenzó a construir en piedra se imitó617 en el templo dórico tan bien como se pudo.

613. Winckelmann remitiéndose a Le Roy habla de tres épocas del dórico (1985: 543) añadiendo una cuarta que correspondería al templo de Cora (1985: 544). En el texto definitivo del Baukunst (1795), Goethe sólo diferencia entre "antiguos" y "modernos" en los que parece incluir, también, a los renacentistas como Palladio.

614. En esta frase recoge, en parte, el comentario de Winckelmann que, al hablar de los triglifos, escribe: "Los triglifos están en el lugar en que sobresalen las vigas del techo interior de los edificios, las cuales descansaban también sobre otra viga de madera, que era la que se apoyaba directamente en las columnas." (1985: 542).

615. Goethe se refiere aquí a los triglifos con sus estrías. Winckelmann al mencionar su origen escribe: "Vitruvio dice que, como motivo ornamental, se clavaban los triglifos en la parte saliente de las vigas; pero esto no es más que una simple suposición suya, pues en su época ya no subsistía ninguno de estos templos [antiguos], y no da ninguna otra explicación a esta clase de adornos. Parece ser que se hacían algunos entalles en el extremo de las vigas para evitar que se abriesen." (1985: 542). La referencia de Goethe al trabajo del carpintero en la cabeza de las vigas de madera parece aludir a ese comentario.

616. Goethe utiliza aquí el título de su drama homónimo publicado en 1787 que proviene de la errónea traducción latina de la obra de Eurípides.

617. El uso del término "imitó" en relación con lo sagrado del templo es relevante porque el concepto de mímesis en los ritos griegos primitivos es "éste es aquel" (Bozal, 1996: 41-74). Es decir, algo o alguien como el sacerdote, aunque conserve su figura y materia, sufre una transubstanciación y se convierte en otra cosa. En este sentido y aplicado a este caso imitar significaría, por lo tanto, dotar al nuevo templo de la esencia sagrada del templo original. Parece que Goethe quiere decir que al intentar la mayor apariencia formal aunque fuese tosca era el modo más idóneo para conseguir la mímesis sagrada pretendida. 
Es ist sehr wahrscheinlich, daß man bei hölzernen Tempeln auch die stärksten Stämme zu Säulen genommen habe, weil man sie, wie es scheint, ohne eigentliche Verbindung der Zimmerkunst, dem Hauptbalken nur gerad untersetzte. Als man diese Säulen in Stein nachzuahmen anfing, wollte man für die Ewigkeit bauen; man hatte aber nicht jederzeit die festesten Steine zur Hand; man mußte die Säulen aus Stükken zusammensetzen, um ihnen die gehörige Höhe zu geben; man machte sie also sehr stark in Verhältnis zur Höhe, und ließ sie spitzer zugehen, um die Gewalt ihres Tragens zu vermehren.

Die Tempel von Pestum, Segeste, Selimunt, Girgent sind alle von Kalkstein, der mehr oder weniger sich der Tuffsteinart nähert, die in Italien Travertin genannt wird; ja die Tempel von Girgent sind alle von dem losesten Muschel-Kalkstein, der sich denken läßt. Sie waren auch deshalb von der Witterung so leicht anzugreifen, und ohne eine andere feindliche Gewalt zu zerstören.

Man erlaube mir eine Stelle des Vitruv hierher zu deuten, wo er erzählt: daß Hermogenes, ein Architekt, da er zu Erbauung eines Dorischen Tempels den Marmor bei-
Es muy probable que en los templos de madera también se tomasen los troncos más fuertes para las columnas, puesto que, como parece, estas no estaban más que plantadas sin ensamblajes de carpintería bajo el arquitrabe. Cuando se empezaron a imitar en piedra estas columnas se quería construir para la eternidad, pero no siempre se tenía a mano las piedras más firmes. Se tuvo que montar las columnas a trozos para darles la altura adecuada, ${ }^{618}$ haciéndolas por tanto muy robustas en relación con la altura y apuntadas para aumentar su capacidad portante.

Los templos de Paestum, Segesta, Selinunte, Agrigento son todos de piedra caliza, más o menos cercana a la piedra de tipo toba llamada en Italia travertino. ${ }^{619}$ Precisamente los templos de Agrigento son todos de la piedra caliza conchífera más floja que uno pueda imaginar. Por ello las condiciones climáticas los atacaban tan fácilmente $e^{620} y$, sin la intervención de otra fuerza adversa, acababan destruidos por los elementos. ${ }^{621}$

Permitidme en este punto que aluda a un pasaje de Vitruvio en el que cuenta cómo Hermógenes, un arquitecto, después de haber reunido el mármol necesario para la erección

618. Según Winckelmann: "Cuando las columnas eran muy grandes, los griegos las hacían de varios bloques de distintos tamaños, trabajados a la vez" (1985: 541).

619. En Winckelmann se lee: "La primera clase de piedras utilizadas para la construcción de edificios públicos, tanto en Grecia como en Roma, fue una especie de toba [...]. / Hay toba de dos clases. Una se forma de humedad lapidífica [...]. Y esta toba, conocida con el nombre de travertino, se encuentra cerca de Tívoli. / La segunda [...] es conocida en Italia bajo el nombre de tufo, y en Francia, tuf. Y Vitruvio le da el nombre de piedra roja." (1985: 530)

620. En su viaje a Italia, el 25.04.1787 en Agrigento Goethe escribe: "las ruinas del templo de Juno deterióranse cada vez más de año en año, debido a que el aire y la intemperie se van comiendo la piedra más suelta." (III: 1221).

621. Vitruvio, Capítulo 3, Libro IV, “Del orden dórico". En el Capítulo 2, Libro II "De las especies de Templos" se refiere también a Hermógenes y su protagonismo en la invención del templo. Winckelmann discute la atribución de este templo y las columnas cuyo fuste era de una sola pieza, según Winckelmann, a Scopas, escultor del tiempo de Fidias y autor del templo de Palas en Tegea, por considerar que es un error debido a una mala traducción de Plinio (1985: 544) 
sammengehabt, seine Gedanken geändert, und daraus einen lonischen gebaut habe.

Vitruv gibt zwar zur Ursache an: daß dieser Baumeister, sowohl als andre, mit der Einleitung der Triglyphen nicht einig werden können: allein es gefällt mir mehr zu glauben, daß dieser Mann, als er die schönen Blöcke Marmor vor sich gesehen, solche lieber zu einem gefälligern und reizendern Gebäude bestimmt habe, indem ihn die Materie an der Ausführung nicht hinderte. Auch hat man die Dorische Ordnung selbst immer schlanker gemacht, so daß zuletzt der Tempel des Herkules zu Kora, acht Diameter in der Säulenlänge enthält.

Ich möchte durch das, was ich sage, es nicht gerne mit denjenigen verderben, welche für die Form der altdorischen Tempel sehr eingenommen sind. Ich gestehe selbst, daß sie ein majestätisches, ja einige ein reizendes Ansehen haben: allein es ist in der menschlichen Natur, immer weiter, ja über ihr Ziel fortzuschreiten; und so war es auch natürlich, daß in dem Verhältnis der Säulendicke zur Höhe, das Auge immer das Schlankere suchte, und der Geist mehr Hoheit und Freiheit dadurch ‘zu〉 empfinden glaubte. de un templo dórico, cambió de opinión y construyó uno jónico.

A decir verdad, Vitruvio indica la causa de ello: aquel maestro de obras, como también otros, no podía estar de acuerdo con la introducción de los triglifos. Yo, en cambio, prefiero con creces pensar que, al ver los bellos bloques de mármol frente a él, este hombre prefirió destinarlos a una construcción más complaciente y encantadora, en la medida en que la materia no dificultaba la ejecución. ${ }^{622}$ De hecho, el orden dórico mismo se ha hecho más y más esbelto, hasta el punto que finalmente el templo de Hércules en Cora $^{623}$ consta de ocho diámetros en la longitud de la columna.

No querría con lo que digo contrariar a aquellos que están muy impresionados con la forma del templo dórico arcaico. Yo mismo confieso que tienen un aspecto majestuoso, incluso algunos encantador. Sólo que está en la naturaleza humana seguir adelante avanzando en su propio objetivo; y así fue también natural que, en la relación entre el espesor y la altura de la columna, ${ }^{624}$ el ojo buscase siempre algo más esbelto y el espíritu creyese experimentar de este modo mayor grandeza y libertad.

622. Goethe parece insinuar una evolución del dórico al jónico por la voluntad de acoplar coherentemente la materia y la ejecución, lo que anticipa la idea del "fin inmediato" y la búsqueda de la forma adecuada que desarrolló posteriormente en el Baukunst de 1795.

623. La mención de este templo es importante porque tiene columnas dóricas con basa, una cuestión que centró el interés de Goethe en el Baukunst (1795). Refiriéndose al dibujo de Rafael sobre este templo Winckelmann escribe: "Las columnas dóricas de este edificio, cuyo diámetro al pie de la columna tiene tres palmos y un cuarto, y en la parte alta del fuste dos palmos y ocho pulgadas, tienen seis palmos de altura, sin contar la base ni el capitel, y la altura total es de veintisiete palmos y diez pulgadas. Dichas columnas tienen estrías reforzadas, que comienzan en el tercio de la altura, y el tercio inferior quedaba de esta manera libre y sin estrías. / Estas columnas descansan en una base que no se encuentra en otras antiguas columnas dóricas, y se parece mucho al capitel toscano [... porque...] Rafael lo ha tomado por un edificio de orden toscano" (1985: 543).

624. Winckelmann atribuye la evolución de las épocas del dórico a la esbeltez y proporciones de las columnas (1985: 544) 
Besonders, da man von so mannigfaltigem schönem Marmor, sehr große Säulen aus Einem Stücke fertigen konnte, und zuletzt noch der Urvater alles Gesteins, der alte Granit, aus Egypten herüber nach Asien und Europa gebracht ward, und seine großen und schönen Massen zu jedem ungeheuren Gebrauche darbot. So viel ich weiß sind noch immer die größten Säulen von Granit.

Die lonische Ordnung unterschied sich bald von der Dorischen, nicht allein durch die mehrere verhältnismäßige Säulen-Höhe, durch ein verzierteres Kapitäl, sondern auch vorzüglich dadurch, daß man die Triglyphen aus dem Friese ließ, und die immer unvermeidlichen Brüche in der Einleitung derselben vermied. Auch würden nach meinem Begriff die Triglyphen niemals in die Steinbaukunst gekommen sein, wenn die ersten nachgeahmten Holztempel nicht so gar roh gewesen, die Metopen verwahrt und zugeschlossen, und der Fries etwa abgetüncht worden wäre. Allein ich gestehe es selbst, daß solche Ausbildungen für jene Zeiten nicht waren, und daß
Sobre todo cuando se pudo realizar columnas muy altas de un solo bloque de tan variado y bello mármol, y finalmente fue traída desde Egipto a Asia y Europa incluso la madre de todas las rocas, el antiguo granito, y ofreció así grandes y bellas masas para cualquier enorme uso. Por lo que yo sé, las columnas más grandes aún siguen siendo de granito. ${ }^{625}$

El orden jónico se diferenció pronto del dórico, no sólo por medio de la altura más proporcionada de la columna, por un capitel más decorado, sino principalmente porque los triglifos fueron eliminados del friso, evitando las siempre inevitables discontinuidades en su introducción. ${ }^{626}$ En efecto, según mi criterio, los triglifos nunca habrían llegado a la arquitectura de piedra si el primer templo de madera imitado no hubiese sido tan tosco, si las metopas hubiesen estado protegidas y recubiertas, ${ }^{627}$ y los frisos algo encalados. ${ }^{628}$ Aunque yo mismo confieso que tales perfeccionamientos no eran propios de esos tiempos y que es totalmente natural para una

625. Según Winckelmann las mayores columnas de la antigüedad eran las del templo de Júpiter Olimpico en Atenas de Domiciano, acabadas en Roma (1985: 541).

626. Se refiere al pasaje de Vitruvio en el que justifica el paso al jónico porque el dórico "siempre resultará defectuoso en alguna parte" (1980: 93). El principal problema que presentan los triglifos está en los extremos, donde o bien se colocan a eje de la columna (de acuerdo con la transmisión de las cargas) pero queda media metopa en la esquina, o bien se coloca en la esquina evitando este problema pero se desplaza del eje estructural de la columna. La primera es, precisamente, la solución ortodoxa. En la traducción del Vitruvio de Bárbaro (lib. IV, p. 175) se dibujan cuatro soluciones de distribución de columnas y frisos siempre con medias metopas en las esquinas. Parece que en este párrafo Goethe se está refiriendo a este problema y, de alguna manera, apunta a la evolución de la arquitectura en relación con la columna, el capitel y el entablamento de modo similar a la evolución del basamento que analiza en el Baukunst (1795).

627. Winckelmann escribe: "Según el sentido más verosímil [...] las metopas de los templos más antiguos de las que Eurípides nos da aquí una idea, eran, sin duda alguna, abiertas" (1985: 542) y comenta el pasaje de Eurípides sobre Orestes y Pilades que entran en el templo de Diana entre los triglifos "en la parte que quedaba abierta" debatiendo esta cuestión con Guillermo Canter y con Barnes y compartiendo la opinión del padre Brumoi.

628. El friso dórico lo componen los triglifos y las metopas. Refiriéndose a éstas Winckelmann escribe: "El intervalo que quedaba entre dos extremos de vigas y sus triglifos, espacio denominado metopa, estaba revestido de obra de albañilería, 
es dem rohen Handwerk ganz natürlich ist, Gebäude nur wie einen Holzstoß übereinander zu legen.

Daß nun ein solches Gebäude, durch die Andacht der Völker geheiligt, zum Muster ward, wornach ein anderes, von einer ganz andern Materie, aufgeführt wurde, ist ein Schicksal, welches unser Menschengeschlecht in hundert andern Fällen erfahren mußte, die ihm weit näher lagen, und weit schlimmer auf dasselbe wirkten als Metopen und Triglyphen.

Ich überspringe viele Jahrhunderte und suche ein ähnliches Beispiel auf, indem ich den größten Teil sogenannter Gotischer Baukunst aus den Holzschnitzwerken zu erklären suche, womit man in den ältesten Zeiten Heiligenschränkchen, Altäre und Kapellen auszuzieren pflegte; welche man nachher, als die Macht und der Reichtum der Kirche wuchsen, mit allen ihren Schnörkeln, Stäben und Leisten, an die Außenstein der nordischen Mauern anheftete, und Giebel und formenlose Türme damit zu zieren glaubte. tosca artesanía disponer edificios como mera superposición de una pila de madera. ${ }^{629}$

Ahora bien, que tal construcción, santificada por la devoción de los pueblos, se convirtiese en un modelo según el cual se ejecutó otra desde una materia completamente diferente es una fatalidad que nuestro género humano tuvo que experimentar en cientos de ocasiones, mucho más cercanas, y que influyeron de por sí de forma más perniciosa que las metopas y los triglifos. ${ }^{630}$ Hago un salto de muchos siglos y busco un ejemplo similar, tratando de explicar el origen de la mayor parte de las tallas de madera de la asíllamada arquitectura gótica, usadas para ornamentar en las épocas más remotas pequeños relicarios, altares y capillas. A continuación, una vez el poder y la riqueza de la Iglesia hubieron crecido se los añadieron con todos sus arabescos, molduras y listeles a la piedra exterior de los muros nórdicos, y se creyó ornar con ellos gabletes y torres informes. ${ }^{631}$

como lo observa el arquitecto romano [Vitruvio]; mas parece ser que en los tiempos más antiguos estaba vacío" (1985: 542). El comentario de Goethe parece referirse al acabado del revestimiento de la albañilería. Goethe copió del Vitruvio de Galiani (tavola IV, figura 5) el dibujo de un entablamento con dos triglifos de madera y su conversión en piedra y dos metopas, una de ellas abierta (III: 94, 10.10.1786).

629. De nuevo aquí Goethe alude a una artesanía tosca como la fase de la construcción (lo que luego llamó el fin inmediato) necesaria y previa a la arquitectura.

630. La referencia a la imitación del primer templo santificado con su artesanía tosca de madera y sus consecuencias al trasladar estas características a un templo de piedra inciden de nuevo en la idea de la mímesis anteriormente comentada. Goethe se lamenta de que esa solución se hubiera conservado en todos los ejemplos posteriores.

631. Goethe aplica al gótico el mismo proceso del paso de la madera a la construcción en piedra y explica que, en este caso y a diferencia del templo clásico que copia un modelo constructivo, lo que se mimetizó fueron las tallas ornamentales de pequeños objetos religiosos. Durante su viaje a Italia en Venecia el 8.10.1786, al comparar la arquitectura clásica con el gótico, hace una crítica en términos parecidos. Escribe: "Esto es en verdad algo muy distinto de nuestros santos, semejantes a mochuelos, hacinados unos sobre otros encima de modillones, del estilo gótico, algo muy distinto de nuestras columnitas, que parecen pipas de fumar; de nuestras buidas torrecillas y floridos carámbanos" (V. it., III: 1093-1094). 
Leider suchten alle Nordische Kirchenverzierer ihre Größe nur in der multiplizierten Kleinheit. Wenige verstanden diesen kleinlichen Formen unter sich ein Verhältnis zu geben; und dadurch wurden solche Ungeheuer wie der Dom zu Mailand, wo man einen ganzen Marmorberg mit ungeheuren Kosten versetzt, und in die elendesten Formen gezwungen hat, ja noch täglich die armen Steine quält, um ein Werk fortzusetzen das nie geendigt werden kann, weil der erfindungslose Unsinn, der es eingab, auch die Gewalt hatte einen gleichsam unendlichen Plan zu bezeichnen.

\section{Material der bildenden Kunst}

Kein Kunstwerk ist unbedingt, wenn es auch der größte und geübteste Künstler verfertiget: er mag sich noch so sehr zum Herrn der Materie machen, in welcher er arbeitet, so kann er doch ihre Natur nicht verändern. Er kann also nur in einem gewissen Sinne und unter einer gewissen Bedingung das hervorbringen, was er im Sinne hat, und es wird derjenige Künstler in seiner Art immer der trefflichste sein, dessen Erfindungs und Einbildungskraft sich gleichsam unmittelbar mit der Materie verbindet in welcher er zu arbeiten hat. Dieses ist einer der großen Vorzüge der alten Kunst;
Por desgracia, todos los decoradores nórdicos de iglesias buscaron únicamente su grandeza multiplicando aquellas menudencias. Pocos supieron relacionar entre sí estas pequeñas formas. De ahí que semejantes enormidades como la catedral de Milán, donde, con enormes costes, se ha transportado una montaña entera de mármol que ha sido forzada en las formas más miserables, y aun hoy tortura a diario las pobres piedras para proseguir un trabajo que nunca puede ser concluido, ${ }^{632}$ porque el absurdo sin inventiva que lo inspiró tuvo asimismo el poder de establecer un plan en cierto modo infinito.

\section{Material de las artes plásticas}

Ninguna obra de arte es absoluta, incluso aquella elaborada por el artista más grande y con mayor experiencia. ${ }^{633}$ Desea dominar la materia en la que trabaja, pero no puede cambiar su naturaleza. Puede entonces traer a la luz aquello que tiene en mente tan sólo en un cierto sentido y bajo una cierta condición, y aquel artista cuya inventiva e imaginación conecten simultáneamente con la materia en la que está trabajando será siempre el más excelente. Esta es una de las grandes virtudes del arte antiguo; y cómo las personas sólo pueden ser llamadas sensatas y felices cuan-

632. Entre el 22 y 28 de mayo de 1788, Goethe visita la catedral de Milán. Describe su impresión a Carl August en una carta del 23 de mayo de 1788: "ein ganzes Marmorgebirg in die abgeschmacktesten Formen gezwungen [...]. Die armen Steine werden noch täglich gequält" ["toda una montaña de mármol en las formas más absurdas [...]. Las pobres piedras todavía están siendo torturadas a diario"] (1991, II.3: 407). Sobre ello regresará críticamente en Von Deutscher Baukunst (1823): “Mi estancia en Italia no pudo reavivar aquellos sentimientos [el entusiasmo provocado por la catedral de Estrasburgo y plasmado en Von Deutscher Baukunst (1772)], además ello se vio aun más dificultado pues las recientes modificaciones de la catedral de Milán me impidieron reconocer su antiguo carácter [aquellas emprendidas por Pellegrino Pellegrini en el siglo XVII], y así viví durante muchos años alejado de este tipo de arte si no totalmente ajeno al mismo." (1999: 309) 633. La imposibilidad de alcanzar la perfección ideal en el arte es particularmente relevante en el caso de la arquitectura, como refleja Goethe en sus comentarios sobre Palladio (V. It., III: 1089). Ya Alberti justificaba la necesidad de la ornamentación en la arquitectura para disimular los defectos y potenciar las virtudes porque ninguna obra humana puede alcanzar la belleza perfecta. 
und wie Menschen nur dann klug und glücklich genannt werden können, wenn sie in der Beschränkung ihrer Natur und Umstände mit der möglichsten Freiheit leben: so verdienen auch jene Künstler unsere große Verehrung, welche nicht mehr machen wollten, als die Materie innen erlaubte, und doch eben dadurch so viel machten, daß wir mit einer angestrengten und ausgebildeten Geisteskraft ihr Verdienst kaum zu erkennen vermögen. Wir wollen gelegentlich Beispiele ausführen, wie die Menschen durch das Material zur Kunst geführt und in ihr selbst weiter geleitet worden sind. Für diesmal ein sehr einfaches.

Es scheint mir sehr wahrscheinlich daß die Egyptier zu der Aufrichtung so vieler Obelisken durch die Form des Granits selbst sind gebracht worden. Ich habe bei einem sehr genauen Studio der sehr mannigfaltigen Formen, in welchen der Granit sich findet, eine do viven en la limitación de su naturaleza con la mayor libertad posible. De esta manera se merece, pues, nuestra gran admiración aquel artista que no quiera hacer más que lo que la materia le permita, $y$ aun con ello tanto haga que apenas podamos reconocer su esfuerzo con forzado y entrenado vigor mental. ${ }^{334}$

Queremos mencionar de paso ejemplos de cómo las personas han sido dirigidas por el material en el arte y lo han remitido a ellas mismas. Por esta vez, uno muy senciIlo. ${ }^{635}$

Para mí, resulta muy probable que la forma del propio granito ${ }^{636}$ llevase a los egipcios ${ }^{637}$ a la erección de tantos obelis$\cos .^{638}$ He constatado un consenso general en un estudio muy preciso de las muy variadas formas en las que se puede encontrar el granito: que los paralelepípedos en el que uno lo encuentra a menudo se dividen de nuevo en diagonal, por lo que forman inmediatamente

634. Aunque está hablando del arte en general parece evidente que piensa en la arquitectura, donde estas constricciones de la materia más claramente dejan su impronta en la invención del arquitecto. Superar esas limitaciones y hacerlo, además, sin que apenas se perciba el esfuerzo es parte del "fin inmediato" que posteriormente estableció en el Baukunst. 635. La manera en que el material incide en la arquitectura es el primer nivel hacia el arte que, en el texto posterior, lo tratará no sólo con la descripción de ejemplos sino también con dibujos.

636. Anteriormente en este mismo escrito Goethe ha comentado que el granito llevado a Grecia y Roma supuso poder levantar grandes edificios. En definitiva, la materia como condición previa a la arquitectura y su empleo en Egipto como antecedente de la obra clásica. Este interés, rayano al entusiasmo mitificante en Italia, por la cultura y el arte egipcio decayó, no obstante, a lo largo de los años.

637. El interés de Goethe por la cultura egipcia posiblemente estaba influenciado por su condición de masón. Según Pevsner Goethe conocía el libro de Cornelius de Pauw, Recherches Philosophiques sur les Egyptien et les Chinois, 1773 (1983, nota 29, p. 432). Por otra parte, se consideraba que las tradiciones de la francmasonería "se remontaban al oficio y el arte de la albañilería propios de Egipto" e incluso se "cita como origen de este oficio Egipto" (1983: 202). Desde el siglo XVII "los egipcios se cuentan entre los antecesores bárbaros de la civilización griega" (1983: 198). El vínculo entre la arquitectura clásica y Egipto aparece de forma tangencial en Vitruvio cuando habla de "Las estancias corintias, y de cuatro columnas, y aquellas Ilamadas egipcias..." (lib. VI, cap. V, p. 292) donde relaciona las salas egipcias con las basílicas y explica que en ellas las columnas están articuladas dentro del muro, un problema que atrajo, de manera particular, a Goethe. Palladio se refiere también a las salas egipcias en términos similares (Lib. II, cap. X, pp. 40-41). En 1785 Quatremère de Quincy había presentado un ensayo en la Academie des Inscriptions et Belles Lettres que "es un análisis de la arquitectura egipcia y una comparación con la de Grecia." (Pevsner, 1983: 201). En este contexto resulta evidente que Goethe buscara el origen de la arquitectura en Egipto. 
meist allgemeine Übereinstimmung bemerkt: daß die Parallekepsipeden, in welchen man ihn antrifft, öfters wieder diagonal geteilt sind, wodurch sogleich zwei rohe Obelisken entstehen. Wahrscheinlich kommt diese Naturerscheinung in Ober-Egypten, im Syenitischen Gebürge, kolossalisch vor, und wie man, eine merkwürdige Stätte zu bezeichnen, irgend einen ansehnlichen Stein aufrichtete, so hat man dort zu öffentlichen Monumenten die größten, vielleicht selbst in dortigen Gebürgen seltenen, Granit-Keile ausgesucht und hervorgezogen. Es gehörte noch immer Arbeit genug dazu, um ihnen eine regelmäßige Form zu geben, sie Hieroglyphen mit solcher Sorgfalt hinein zu arbeiten, und das Ganze zu glätten; aber doch nicht soviel, als wenn die ganze Gestalt, ohne einigen Anlaß der Natur, aus einer ungeheuern Felsmasse hätte heraus gehauen werden sollen. dos toscos obeliscos. Probablemente este fenómeno se produjera a gran escala en el Alto Egipto, en las montañas sieníticas. ${ }^{639} \mathrm{Y}$, como para denotar un lugar extraño se erigió una hermosa piedra, así se escogieron y extrajeron para los monumentos públicos las más grandes cuñas de granito, siendo estas poco frecuentes incluso en las montañas de la zona. Quedaba todavía mucho trabajo para darles una forma regular, trabajar en ellos jeroglíficos con cuidado tamaño y pulir el conjunto, pero no tanto como si toda la talla tuviera que ser cortada a partir de una enorme masa de roca sin concurrencia alguna de la naturaleza. ${ }^{640}$

638. Con seguridad Goethe debía conocer el texto de Herder, Alteste Urkunde des Menschengeschlechtes (1774), en el que se lee: "De acuerdo con la leyenda, los primeros templos egipcios, como en las colinas y bosques de todas las naciones, carecían de imágenes y estatuas: es decir, se adoraban las piedras. ¿Y por qué solo piedras? y en casi cualquier modalidad se adoraron piedras en el mundo primigenio? Entonces comenzaron los procesos de ensayo y error, 'Debéis representar estatuas que representen la tierra' -y les digo que no deberían representar más que lo que eran, piedras, memoriales, los primeros monumentos del mundo. [...] // Cuando el hombre salió de la cueva al exterior y añadió arte para crear un edificio, un edificio duradero ¿qué podía hacerse uniendo piedra y forma sino pirámide y obelisco? Cuadrado, esfera y punto relacionado de la manera más simple y más perdurable, ¿qué otra cosa podía ser?" [Nach der Sage waren auch die ersten Aegyptertempel, wie die heiligen Höhen und Haine aller Nationen, ohne Götterbilder und Statuen: es heißt, man verehrte Steine. Und warum man nun eben Steine? und fast allwegen in der Urwelt Steine verehrt? Da fangen die Systeme von Errathungen und Muthmassungen an, „Sie sollten Statuen vorstellen, die Erde vorstellen“ -und ich sage, sie sollen nichts vorstellen, als was sie waren, Steine, Denkmale, die ersten Denkmale der Welt. [...] // Als man nun in freie Luft kam, und sich die Kunst zufügte; zum Gebäude, zu ewigem Gebäude, was konnte aus Stein und Figur anders werden, als Pyramide und Obelisk? Viereck, Runde und Spitze auf die simpelste, ewigste Art verbunden, was konnt anders werden?" (I: 262-263). Durante su visita a Roma Goethe se interesó por la pirámide de Cestio de la que hizo varios dibujos, algunos inspirados en Piranesi (por ejemplo, la imagen III: 14 de enero/febrero de 1787 recuerda la lámina de $\mathrm{n}^{\circ} 24$ de Varie Vedute, Roma, 1745 , pp. 74), y los obeliscos egipcios de la ciudad (p. e., III: 53, Plaza de Letrán, verano/otoño 1787). Comentando los dibujos de Cassas en septiembre de 1787 escribe: "Los magníficos monumentos egipcios nos recordaban el poderoso obelisco que, plantado en el campo de Marte por Augusto, servía de horario solar" (III: 1309). En algunas de sus escenografías incluye también obeliscos (p.e., IVb 251 rs. 1793?) 
Ich will nicht zur Befestigung meines Arguments die Art angeben, wie die Hieroglyphen eingegraben sind; daß nämlich erst eine Vertiefung in den Stein gehauen ist, in welcher die Figur dann erst erhaben steht. Man könnte dieses noch aus einigen andern Ursachen erklären; ich könnte es aber auch für mich anführen und behaupten: daß man die meisten Seiten der Steine schon so ziemlich eben gefunden, dergestalt daß es viel vorteilhafter gewesen, die Figuren gleichsam zu inkassieren, als solche erhaben vorzusteIlen, und die ganze Oberfläche des Steins um soviel zu vertiefen.
No quiero alegar en refuerzo de mi argumento la manera en que los jeroglíficos están grabados; esto es, que primero se esculpe una depresión en la piedra, en la que sólo entonces se realza la figura. ${ }^{641}$ Esto se podría explicar de hecho por otras causas. Pero puedo, no obstante, personalmente aducir y sostener que la mayoría de lados de la piedra eran encontrados ya prácticamente planos, de tal manera que resultaba mucho más ventajoso encajar las figuras, ${ }^{642}$ por así decirlo, que imaginar semejante saliente y profundizar tanto en toda la superficie de la piedra.

639. Syene es la actual Assuan, en la orilla este del Nilo. Al sur se encuentra la cantera de granito de la antigüedad egipcia. 640. Con este comentario parece indicar que la forma de los obeliscos es consecuencia de cómo se encuentra y extrae la piedra en la cantera. Es decir, la forma está condicionada o limitada por la propia naturaleza.

641. Estando en Roma el 3 de septiembre de 1787 Goethe escribe: "He vuelto otra vez a las cosas egipcias. Estos días he estado varias veces a ver el obelisco que aún yace destrozado entre cascotes y ripia en un corral. [...] He mandado sacar moldes de yeso de una esfinge de la punta y de las caras de esfinges, hombres y aves. Hay que poseer estas cosas inapreciables [...]. Lo mismo pienso hacer con las mejores cosas etruscas, etcétera. Ahora estoy modelando en barro esas cosas para asimilármelas bien." (III: 1302). Posiblemente en el curso de esos trabajos y en el proceso de su asimilación se interesaría por su labra y extraería las conclusiones que aquí recoge.

642. Puede interpretarse "inkassieren" como "situar en un marco en relieve" o "meter dentro de una caja". Probablemente Goethe se está refiriendo a los cartuchos egipcios de los obeliscos cuyo relieve se obtiene de rebajar el fondo del marco que los encuadran sin tener que hacerlo de toda superficie de la cara de la piedra. 
643. "Wer fühlte wohl je in einem barbarischen Gebäude, in den düstern Gängen einer gotischen Kirche, eines Schlosses jener Zeit sein Gemüt zu einer freien, tätigen Heiterkeit gestimmt." (BA, 19: 308).

\section{Über den Dilettantismus (1799)}

En abril de 1799, Goethe intervino en la publicación de Meyer Über Lehranstalten zugunsten der bildenden Künste, antes de publicarla en Propyläen. De los comentarios que entonces Goethe le trasladó, conviene rescatar al menos uno de ellos:

Quien, en un edificio bárbaro, en los sombríos pasillos de una iglesia gótica, en un castillo de esa época, ha sentido alguna vez su mente sintonizada con una alegría libre y activa. ${ }^{643}$

En este contexto, un mes después, abordarán juntos con Schiller la redacción de un esquema sobre el diletantismo en las artes. Dado que Goethe había practicado personalmente la arquitectura desde claves diletantes y que era de entre los tres aquel mejor informado en materia de arquitectura, la mayoría de los comentarios referidos a esta disciplina pueden atribuírsele. Incluso diríase que este escrito tiene el carácter de una autoevaluación de su actividad como arquitecto diletante. Así recuerda aquella gestación:

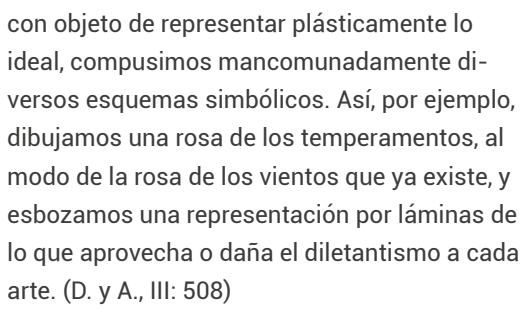

Existe una versión reducida previa fechada el 19 de mayo de 1799 y otra, más desarrollada, del 21 de mayo. A continuación se recogen los extractos de estos esquemas que atañen a la arquitectura. Para la transcripción se han respetado los criterios filológicos de la edición de Johann Wolfgang Goethe (1998), Sämtliche Werke. Briefe, Tagebücher und Gespräche. Band 18, Ästhetische Schriften 1771-1805, Friedmar Apel (ed.), Frankfurt am Main: Deutscher Klassiker Verlag, pp. 739786; última edición y más completa de la obra de Goethe. 
Hauptgesetz: Dilettantism ist unschuldiger, ja er wirkt bildend in solchen Künsten wo das Subjektive für sich allein schon viel bedeutet.

\section{Fach: Architektur}

Nutzen fürs Subjekt: Richtung nach mathematischen Formen, die ins Ästhetische übergehen.

Schaden fürs Subjekt: Nicht Übergang zum Schönen und vollständig gesetzlichen, welches doch bei dieser Kunst unerläßlich ist. Nicht so beim Tanz.

Nutzen fürs Ganze: Findet nur in rohen Verhältnissen statt.

Schaden fürs Ganze: Nicht nützlich und nicht schön. Perennierende Unform und Verderbnis des Geschmacks

Alte Zeit in Deutschland: Keine Liebhaberei. Handwerk.

Neue Zeit in Deutschland: Reisen nach Italien und Frankreich und besonders Gartenliebhaberei haben diesen Dilettantism sehr befördert.

Ausland: In Italien herrscht noch das charakteristische und ist mehr Beziehung auf Kunst. Polnischer Tanz eine anständige Promenade einer vornehmen Gesellschaft. Fandango und sarmatischer Tanz mechanischer künstlich und sinnlich.
Tesis principal: El diletantismo es inocente, de hecho, tiene un efecto educativo en las artes en las que lo subjetivo ya significa mucho para sí mismo. ${ }^{644}$

\section{Disciplina: Arquitectura}

Beneficio para el sujeto: Dirección hacia formas matemáticas que se convierten en estéticas. ${ }^{645}$

Perjuicio para el sujeto: Sin transición a lo bello y ajustado a normas, lo cual es indispensable en este arte. No así en el baile. ${ }^{646}$ Beneficio para todos: Solo se lleva a cabo en condiciones toscas. ${ }^{647}$

Perjuicio para todos: No es útil ni agradable. Perenne deformidad y corrupción del gusto ${ }^{648}$ Épocas remotas en Alemania: Ninguna afición. Artesanía.

Épocas recientes en Alemania: Los viajes a Italia y Francia, y especialmente la afición a los jardines, han promovido mucho este diletantismo. ${ }^{649}$ Extranjero: En Italia todavía existe lo característico y está más relacionado con el arte. La danza polaca es un paso decente de una sociedad distinguida. El fandango y la danza sarcástica mecánica artificial y sensitiva.

Jena, el 19 de mayo de 1799

Jena den 19 Mai 99

644. La arquitectura, el dibujo y la poesía épica y dramática son, en el contexto de este escrito, las disciplinas en las que lo subjetivo menos importa, de manera que el artista y el diletante guardan poco en común.

645. Pese a que las matemáticas son esenciales en la arquitectura, Goethe nunca mostró un interés especial hacia ellas en concreto. Es más, las "matemáticas [...] se convierten en estéticas" en la teoría de las proporciones en tanto que medidas, algo que Goethe siguiendo a Winckelmann rechazaba.

646. En su juventud, el propio Goethe admite que el estudio de la geometría (que es una parte de las matemáticas) le ayudó a dibujar mejor la arquitectura. En la medida que la perspectiva es un método geométrico sistemático es, también, un modo de relacionar arquitectura y matemáticas. 


\section{BAUKUNST}

Nutzen fürs Subjekt:

Architektur bringt aus einfachen Elementen (senkrechten, waagrechten Linien etc) und ohne organische Bedingungen ein schönes Gebild hervor.

Statt des organischen hat sie die Konstruktionsunterlage.

Sie weckt die freie Produktionskraft. Sie führt am schnellsten und unmittelbarsten von der Materie zur Form, vom Stoff zur Erscheinung und entspricht dadurch der höchsten Anlage im Menschen.

Sie erweckt und entwikkelt den Sinn fürs Erhabene, zu dem sie sich überhaupt mehr neigt als zum Schönen.

Sie führt Ordnung und Maß ein, und lehrt auch im Nützlichen und Notdürftigen nach einem schönen Schein und einer gewissen Freiheit streben.

\section{ARQUITECTURA}

Beneficio para el sujeto:

La arquitectura crea una estructura bella a partir de elementos sencillos (líneas verticales, horizontales, etc.) y sin condiciones orgánicas. ${ }^{650}$

En lugar de lo orgánico tiene el fundamento constructivo. ${ }^{651}$

Despierta el poder de producción libre. ${ }^{652}$ Conduce lo más rápida y lo más inmediatamente de la materia a la forma, de la materia a la apariencia, y por lo tanto corresponde al supremo talento en el hombre. ${ }^{653}$

Despierta y desarrolla el sentido de lo sublime, a lo que se inclina más que a la belleza. ${ }^{654}$ Introduce orden y medida, y también educa en lo útil y necesario a luchar por una apariencia bella y cierta libertad. ${ }^{655}$

647. La admiración por Palladio se refuerza, precisamente, por su dura lucha por conseguir los resultados perseguidos (V. It., III: 1089). Probablemente, su trato diario como gestor de las obras oficiales de Weimar también fueron una referencia sobre esta idea de la "crudeza" de la arquitectura. En este contexto, el fracaso de su proyecto de teatro es otra referencia fundamental.

648. Son frecuentes los comentarios de Goethe respecto a la ignorancia de los usuarios de la arquitectura (por ejemplo, V. It. III: 1070).

649. El propio Goethe cultivó y comentó la "moda del paisajismo inglés" en sus novelas, como es singularmente el caso en Las afinidades electivas.

650. La sencillez formal hace a la arquitectura fácilmente "accesible" en su condición más inmediata. En este sentido ayu da a "aprender" valores estéticos de manera más fácil y directa que las formas más "complejas" (orgánicas) de otras artes como la pintura, etc. Recuérdese, por otra parte, la tesis kantiana sobre la mímesis, que no es figurativa sino que parte del genio, aquel que sigue la regla de la naturaleza y la incorpora a la forma estética (2007: 233).

651. La necesidad, tal y como ya formulara Goethe en el Baukunst de 1788, está en el origen de la arquitectura. Una necesidad estrechamente vinculada a los materiales empleados y su utilidad.

652. Precisamente el arquitecto diletante, por el desconocimiento de las claves técnicas que concurren en la arquitectura, goza de una mayor libertad a la hora de abordar la creación artística que un arquitecto experto porque ese desconocimiento le lleva a centrar su atención en cuestiones ornamentales y superficiales.

653. La libertad con la que actúa el arquitecto diletante (fruto de su "ignorancia") estimula la invención.

654. Al igual que el arquitecto diletante dispone de mayor libertad creativa, su desconocimeinto de las claves técnicas y constructivas le llevan a poder aspirar a lo sublime, antes que a lo bello. De ahí su mayor predisposición a la mímesis orgánica o su tendencia hacia el sobredimensionamiento. 
Schaden fürs Subjekt:

Wegen ihrer scheinbaren Unbedingtheit scheint sie leichter als sie ist, und man läßt sich leichter dazu verführen.

Wegen der großen Schwierigkeiten in der Architektur den Charakter zu treffen, darin mannigfaltig und schön zu sein, wird der Dilettant, der dies nicht erreichen kann, immer nach Verhältnis seines Zeitalters entweder ins Magere und Überladene oder ins Plumpe und Leere verfallen. Ein Architekturwerk aber das nur durch die Schönheit Existenz hat, ist völlig null, wenn es diese verfehlt.

Wegen ihrer idealen Natur führt sie leichter als eine andere Kunst zum phantastischen, welches hier gerade am schädlichsten ist. Weil sich nur die wenigsten zu einer freien Bildung nach bloßen Schönheitsgesetzen erheben können, so verfällt der Baudilettant leicht auf sentimentalische und allegorische Baukunst und sucht den Charakter, den er in der Schönheit nicht zu finden weiß, auf diesem Wege hinein zu legen.
Perjuicio para el sujeto:

Debido a su aparente falta de condicionantes parece más ligera de lo que es y es más fácil dejarse seducir. ${ }^{656}$

Debido a las grandes dificultades de la arquitectura para encontrar el carácter, para ser múltiple y bella, el diletante que no pueda lograr esto caerá, siempre en relación con sus predecesores, o bien en lo estéril y sobrecargado, o bien en lo chabacano y vacuo. Pero una obra arquitectónica que solo tiene existencia a través de la belleza es completamente nula si falla esto. ${ }^{657}$

Debido a su naturaleza ideal conduce a lo fantástico más fácilmente que cualquier otro arte, que es lo más dañino en este contexto. Debido a que solo los menos pueden elevarse a una educación libre de acuerdo con las meras leyes de la belleza, el arquitecto diletante cae ligeramente en la arquitectura sentimental y alegórica, y busca el carácter de esta manera, pese a saber que no se puede encontrar en la belleza. ${ }^{658}$

655. En esto reside la clave de la aportación de este texto frente al Baukunst de 1795: habida cuenta que la arquitectura ya está inserta en la sociedad, incluso la arquitectura producida por un diletante (y muy especialmente esa), tiene capacidad de transformación de la sociedad. Debido a su naturaleza, tal y como Goethe desarrolló en el Baukunst de 1795, la introducción de "orden y medida" es ineludible y, por tanto, la sociedad puede beneficiarse de ello.

656. La arquitectura producida por un arquitecto diletante está inmersa en las corrientes del momento y, por tanto, tiene mayor potencial seductor.

657. Crítica a todo barroquismo empezando por el de la antigüedad, en la línea de comentarios de Winckelmann: "y como los arquitectos vieron que no podían aventajar ni igualar a sus predecesores en belleza, trataron de suplir su falta por la riqueza y la profusión" (1985: 556). Recuérdese el comentario de Goethe sobre la arquitectura romana tras visitar Paestum en una carta a Herder el 27.10.1787: "Encuentro especialmente bella la época griega, que en la romana echo de menos algo de corporeidad." (V. It., III: 1320).

658. Se podría interpretar este pasaje como un acto de autocrítica del propio Goethe. La referencia más evidente sería su entusiasmo juvenil frente al gótico, en el que confundió la arquitectura "sentimental y alegórica" con un posible acceso a su fin más elevado. Igualmente está aquí resonando su postura frente a las arquitecturas exóticas (china, egipcia...) que "sorprenden" a los poco "formados". Véase el apartado "Historia de la arquitectura". 
Baudilettantism, ohne den schönen Zweck erfüllen zu können, schadet gewöhnlich dem physischen Zweck der Baukunst, der Brauchbarkeit und Bequemlichkeit.

\section{Nutzen fürs Ganze:}

Macht gesitteter

Regt, im Fall der Roheit, einen gewissen Kunstsinn an, und verbreitet ihn da, wo der Künstler nicht hinkommen würde.

\section{Schaden fürs Ganze:}

Die Publizität und Dauerhaftigkeit architektonischer Werke macht das Nachteilige derselben, welches oben angegeben worden, allgemeiner und fortdauernder und perpetuiert den falschen Geschmack, weil hier, wie überhaupt in Künsten, das Vorhandene und überall verbreitete wieder zum Muster dient. Die erste Bestimmung der schönen Bauwerke setzt sie mit den bedeutendsten und erhöhtesten Momenten des Menschen in Verbindung, und die Pfuscherei in diesen Fällen verschlechtert inn also gerade da wo er am perfektibelsten sein könnte.

Alte Zeit in Deutschland:

Mehr Handwerk.
La arquitectura diletante, sin poder servir al bello fin, por lo general daña el fin físico de la arquitectura, la utilidad y la comodidad. ${ }^{659}$

Beneficio para todos:

Hace más civilizado. 660

En el caso de la rudeza, estimula un sentido del arte y lo difunde donde el artista no llegaría. ${ }^{661}$

Perjuicio para todos:

La publicidad y la permanencia de las obras arquitectónicas constituyen su desventaja, que se han comentado más arriba, más generales y continuas, y perpetúan el falso gusto, porque aquí, como en todas las artes, lo existente y en todas partes nuevamente diseminado sirve de modelo. ${ }^{662}$ La primera disposición de los bellos edificios los conecta con los momentos más importantes y más elevados del ser humano, y la torpeza en estos casos lo empeora justo donde podría ser el más perfecto.

Épocas remotas en Alemania: Más artesanía.

659. De nuevo enuncia aquí una crítica feroz al barroco y al rococó. En la arquitectura elevada la búsqueda de la belleza parte de la asunción de los condicionantes inmediatos y, por tanto, no es concebible una arquitectura bella que no sea útil. 660. Coincide, por tanto, con el beneficio para el sujeto aclarado anteriormente.

661. Complementariamente al punto anterior, la arquitectura producida por un diletante penetra de una manera acrítica en la sociedad y, por tanto, tiene capacidad de llegar allí donde la sofisticación del artista no llega.

662. En relación con la historia de la arquitectura podría estar refiriéndose al predominio de la tradición gótica. 
Neue Zeit in Deutschland:

Reisen nach Italien und Frankreich und besonders Gartenliebhaberei haben diesen Dilettantism sehr befördert.

Dilettant sucht mehr zum Ursprung der Baukunst zurückzukehren:

a) Rohes Holz, Rinden etc.

b) Schwere Architektur, dorische Säulen.

c) Nachahmung gothischer Baukunst.

d) Architektur der Phantasmen und Empfindungen.

e) Christmarkts Baukunst, kleinliche Nachäffung großer Formen.

Mangel an echten Baumeistern in Verhältnis gegen das Bedürfnis schöner Baukunst treibt zum Dilettantism, besonders da die wohlhabenden baulustigen zu zerstreut leben.

\section{Ausland:}

Was von Deutschland gesagt, gilt in Ganzen vom Ausland.
Épocas recientes en Alemania:

Los viajes a Italia y Francia, y especialmente la afición a los jardines, han promovido mucho este diletantismo.

El diletante busca volver al origen de la arquitectura:

a) Madera cruda, corteza, etc.

b) Arquitectura pesada, columnas dóricas.

c) Imitación de la arquitectura gótica.

d) Arquitectura de fantasmas y sensaciones.

e) La arquitectura de mercado de navidad, pequeña imitación de grandes formas.

La falta de auténticos maestros constructores en proporción a la necesidad de una bella arquitectura impulsa el diletantismo, especialmente cuando los constructores acomodados viven demasiado distraídos.

\section{Extranjero:}

Lo que se dice de Alemania se aplica en su totalidad al extranjero. 
663. Goethe distingue entre el "arquitecto diletante" (los beneficios, perjuicios, etc. para él y los demás de sus obras) y la "arquitectura diletante". Esa arquitectura diletante es la que permite educar a la sociedad y, en la medida que es vulgar y accesible a todos, es beneficiosa porque ayuda a todos a "iniciar" el camino del arte. Ese papel educador ya no lo puede hacer el artista, en la medida en que se ha alejado de la "gente".
El objeto de atención en este esquema no es buscar una suerte de esencialidad en la arquitectura, como sería el caso del Baukunst (1795), sino que se analiza el efecto concreto de la arquitectura producida por un diletante, es decir, aquel que no puede considerarse un arquitecto, y alude a la arquitectura diletante, es decir, aquella que no alcanza el listón de obra de arte. ${ }^{663}$ De hecho, son explícitas las referencias a la teoría arquitectónica del segundo ensayo de Baukunst. Bien podría considerarse, en este sentido, este esquema como un desplazamiento de las tesis del Baukunst (1795) hacia el análisis de los efectos. Puede reconocerse temas como la preminencia de la construcción sobre la imitación de la naturaleza, la dependencia entre el material y el fin, la unidad de utilidad y belleza en una armonía sensitiva e intelectualmente perceptible, entre otros.

El proyecto Über den Dilettantismus abarca -o pretende abarcar - la totalidad de las manifestaciones artísticas. Y el caso de la arquitectura reviste en este sentido ciertas particularidades. En la medida que implica medios técnicos, económicos y ejecutores muy diversos no puede ser llevada a cabo en plenitud de sus posibilidades por un diletante. Requiere de un conocimiento experto. El diletante tiene que apoyarse en arquitectos profesionales (como fue el caso en la experiencia concreta del propio Goethe). Pero, pese a estas limitaciones, la arquitectura emprendida por un diletante entraña ciertas ventajas. Goethe, Schiller y Meyer reconocen al arquitecto diletante la posibilidad de alcanzar mayores cuotas de libertad en su producción, precisamente por la ausencia de restricciones disciplinarias. Esto implica su renuncia a la belleza y una agudizada tendencia a lo sublime que lleva a su producción a tener un elevado impacto ético. La arquitectura, en sus propios términos, hace más civilizada a la sociedad incluso cuando esta está ejecutada por un diletante dado que el intrínseco sentido de la utilidad y de orden (fundamentado en las matemáticas y geometría) que ella implica se irradia incluso entre la población menos cultivada. En otras palabras, la representación artística (arquitectónica) de las formas matemáticas transmite un sentido de orden y medida que moldea la sociedad con arreglo a criterios que se presuponen morales.

Pero las desventajas prevalecen cuando la arquitectura está dirigida por diletantes. Precisamente porque la arquitectura no exige habilidades en la imitación figurativa, puede resultar en apariencia más sencilla en el plano compositivo que otras artes. Esta sería la razón por la que tantos diletantes se dedican a ella, pese a que sea aquella menos indicada para el diletantismo. La consecuencia inmediata de ello es que el arquitecto diletante se deja embaucar por las tendencias de su tiempo, encubriendo así sus carencias. Y, precisamente por gozar de mayor libertad creativa, el resultado de ello son edificios que tienden a los extremos. Al no poder alcanzar el carácter que le correspondería, el poder productivo libre se orienta hacia una arquitectura alegórica que dota a los edificios de una apariencia fantástica y los aleja de la satisfacción de los fines inmediatos (utilidad y materialidad). Esta desventaja supone un elevado riesgo para la sociedad en la medida en que incluso la mala arquitectura es pública y permanece, afectando por tanto negativamente al gusto de la sociedad. La tendencia moderna al viaje, por ejemplo, habría favorecido que por medio de los arquitectos 
diletantes se hayan introducido modelos de arquitectura que no satisface sus fines más elevados.

En resumen, la arquitectura diletante, si bien tiene consecuencias fatales sobre el gusto de la sociedad, no pierde su influencia ética. Incluso la arquitectura diletante tiene un efecto moral en la sociedad a través del lenguaje matemático y su concreción sensitiva, "hace más civilizada a la sociedad". En el contexto del arquitecto diletante (al que le atribuyen más influencia que al arquitecto artista), la arquitectura se entiende como un mecanismo de socialización a través de su carácter sensorial, sin por tanto prescribir leyes morales. Quizás fuese este un intento por parte de Goethe de salvar el subjetivismo en el que pueden incurrir las teorías de la percepción sensible en la medida en que queda cancelado por unos criterios de juicio promovidos con fines educadores. 



\section{Incursiones en la arquitectura}

había aprendido cómo la privilegiada nación griega procedió a fin de desarrollar, en el ámbito propio de la polis el arte más elevado [...]. Por otra parte, creía haber aprendido también de la naturaleza cómo, siguiendo una ley, pone manos a la obra para producir configuraciones vivientes, modelos de todo arte. Lo tercero que me ocupaba eran las costumbres de los pueblos. Quería aprender de ellas cómo del encuentro de necesidad y libre albedrío, de impulso y querer, de movimiento y resistencia nace una tercera cosa que no es ni arte ni naturaleza, sino ambas al mismo tiempo, algo necesario y fortuito, intencional y ciego: quiero decir, la sociedad humana. (1997: 75-76)

Arte, naturaleza y cultura ocuparon intensamente la atención de Goethe durante su viaje a Italia, y fueron objeto de profundización en años posteriores. ${ }^{664} \mathrm{En}$ el terreno específico 
664. Sobre esta cuestión, la influencia de Schiller fue determinante. Así lo refiere: "también Schiller sentíase incitado a fomentar sin tregua y de consuno las consideraciones referentes a la Naturaleza, el arte y las costumbres. En este respecto seguíamos sintiendo la necesidad de tratar las materias por medio de tablas y símbolos" (1991, D. y A., II: 509). Posterirmente, tal y como ha quedado puesto en evidencia en Von Deutscher Baukunst (1823), por medio de esta inclinación hacia la incorporación de la cultura a sus investigaciones se atenuará su defensa del clasicismo.

665. Texto presentado en el I Congreso Internacional La Cultura y la Ciudad en Granada y publicado en "El paisaje en la ciudad. El parque del IIm en Weimar visto por Goethe", en Juan Calatrava, Francisco García Pérez, David Arredondo Garrido (eds.), La Cultura y la Ciudad. Granada: Editorial Universidad de Granada, 2016.

666. Este capítulo corresponde una fusión de dos artículos: Rubio, A. y Calduch, J. "Goethe y la arquitectura teatral", en EGA. Revista de expresión gráfica arquitectónica. 2016, 21(28), pp. 44-51 y Calduch, J. y Rubio, A. "Los dibujos para escenografías de Goethe", en EGA. Revista de expresión gráfica arquitectónica. 2017, 22(31), pp 162-171. de la arquitectura esto, si cabe, se aprecia con mayor claridad. Tan es así que no puede entenderse ni su producción teórica (tal y como ha sido objeto de estudio en capítulos anteriores), ni su práctica arquitectónica (como proyectista, promotor o, incluso, constructor) sin la concurrencia de esta terna. En lo que sigue se proponen cuatro maneras de acceder a esta cuestión. Son cuatro incursiones en la arquitectura, llevadas a cabo por Goethe a lo largo de su vida, en las que se evidencian las tensiones a las que puede conducir la interacción entre estos tres componentes.

En "El paisaje en la ciudad"665 cobra la naturaleza el protagonismo. En el parque del IIm en Weimar Goethe pudo experimentar el cruce entre dos maneras de abordar el estudio de la naturaleza: la botánica y el paisajismo. Ambas se dan lugar en el parque por medio de la jardinería. Una jardinería, eso sí, atravesada por la arquitectura, omnipresente en todas sus facetas.

En "Arquitectura teatral y escenografía"666 se presentan dos facetas complementarias en Goethe. Como dramaturgo y director del teatro de Weimar se interesó por la arquitectura teatral. El tipo de teatro descrito por Vitruvio y su adaptación a la época moderna propuesta por Palladio en su teatro Olímpico de Vicenza fueron los cauces por donde canalizó sus ideas. Todo esto quedó plasmado en varios esbozos dibujados y en el proyecto elaborado junto con el arquitecto Coudray tras el incendio del teatro de Weimar en 1825. En segundo lugar, en sus propuestas escenográficas se alejó de los modelos vitruvianos y palladianos, eliminando el frons scænæ arquitectónico y decantándose por los decorados pintados. De este modo, la arquitectura ficticia escenificada se ajustaba a cada representación, pero se diferenciaba del carácter apropiado de la arquitectura del edificio.

En "Mito, naturaleza y arquitectura"667 se evidencia cómo, con ocasión de su viaje a Sicilia, Goethe quedó marcado por la interacción de esta terna. En primer lugar, una cierta predisposición mitologizante preside sus descripciones. En segundo lugar, incluye en su narración digresiones sobre geología, geografía y botánica. Por último, se detiene en pormenorizadas alusiones a sus experiencias artísticas, donde destacan aquellas referidas a la arquitectura. De resultas de ello, Goethe combinó en Sicilia la experiencia del mito antiguo a la íntima convicción de que sentir lo natural y lo griego, en lo que a la arquitectura concierne, le une a un sentido con vigencia en su época.

En "Proyectos de escaleras"668 se presenta la relación de Goethe a lo largo de su vida con este tema tan específicamente arquitectónico. La representación en perspectiva del espacio y los aspectos ornamentales fueron sus primeras manifestaciones. Su trabajo como responsable de las obras de reconstrucción del Schloss de Weimar y, en concreto, de su escalera imperial, le llevaron a colaborar con el proyectista en el intento de superar la mera construcción para elevarla a la categoría de arte. Pero donde desplegó todas sus facultades como arquitecto fue en la remodelación de su vivienda en Frauenplan (Weimar). Los problemas funcionales y representativos de las dos escaleras que construyó en esta residencia ponen en evidencia hacia dónde orientaba su idea de arquitectura pero, también, sus limitaciones como arquitecto de las que siempre había sido consciente. 


\section{A. EL PAISAJE EN LA CIUDAD}

Kunst: eine andere Natur, auch geheimnisvoll, aber verständlicher; denn sie entspringt aus dem Verstande.

Johann W. Goethe, Maximen und Reflexionen ${ }^{669}$

El 7.11.1775 Goethe llegó a Weimar, donde fijó definitivamente su residencia. En mayo del año siguiente se instaló en una casa con jardín (Ahrendt y Aepfler, 1994) ${ }^{670}$ regalo del Gran Duque, en la orilla derecha del IIm, situada aproximadamente a un kilómetro del Palacio ducal [Schloss] ubicado en el margen izquierdo. El Palacio, con las anexas Puerta y Torre de la Bastilla del recinto fortificado, servían de charnela entre el núcleo urbano y el parque desplegado a ambos lados del río. Desde su casa hasta la ciudad, Goethe podía seguir un doble camino alternativo: ir por la orilla izquierda del IIm tras cruzarlo por un pequeño puente rústico, o hacerlo por el lado derecho bordeando el parque de la Estrella pasando el río por el Sternbrücke [Puente de la Estrella] (1653-1658). Tanto por una ruta como por la otra, para llegar al Palacio o la ciudad, el escritor tenía que atravesar el parque. Así, en la vivencia cotidiana de sus primeros años en Weimar el parque se convirtió en el tránsito obligado del campo a la ciudad.

En 1778, Goethe viajó a Dessau visitando el parque del Schloss Wörlitz, un jardín a la inglesa hecho entre 1769-1773 por Friedrich Wilhelm von Erdmannsdorff. Dibujó ese palacete traslapado por un bosquecillo de árboles jóvenes (Fig. 47), dejando así constancia gráfica de su viaje y evidenciando su interés por el paisajismo inglés despertado por este parque. Cuando por entonces

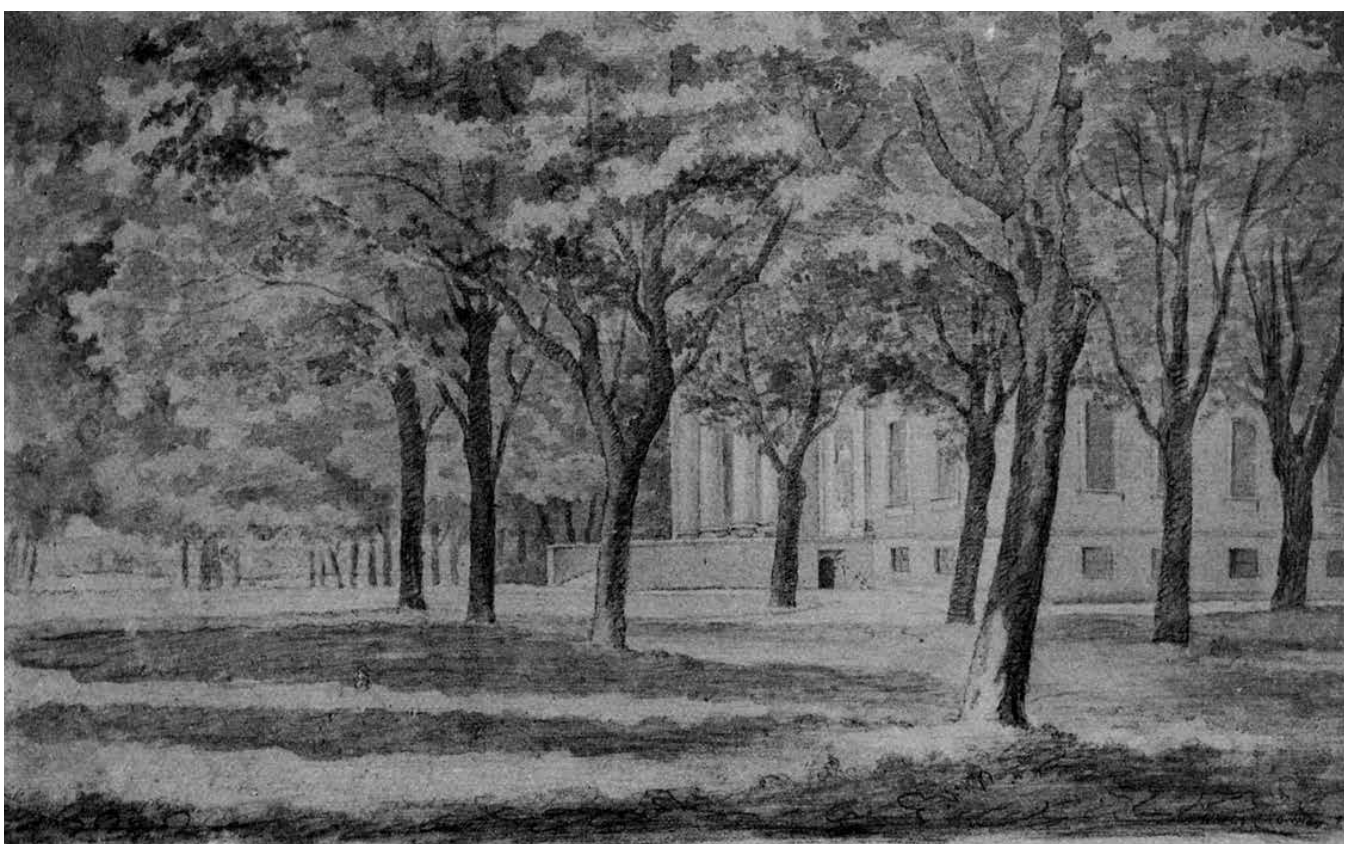

667. Texto presentado en una versión previa en el congreso internacional Imaginare il Mediterraneo. L'architettura e le arti en la Università di Napoli Federico II (16-17 de enero de 2017) y publicado como "Arquitectura, ciencia y mito. Goethe en Sicilia", en A. Maglio, F. Mangone y A. Pizza (ed.), Immaginare il Mediterraneo. Architettura arti fotografia. Nápoles: artstudioppaparo, 2018, pp. 1320. En gran medida la versión aquí transcrita es, en cambio, deudora de A. Rubio Garrido, "Goethe entre los antiguos: naturaleza y arquitectura", en VLC arquitectura, 5: 1, 2018, pp. 127-151.

668. Texto publicado como J. Calduch Cervera y A. Rubio Garrido, "Proyectos de escaleras de Goethe", en Archivo de arte valenciano, 2018, pp. 209-222.

669. Johann W. Goethe, Sämtliche Werke in 18 Bänden, vol. 9, n 1105 , Zurich, Artemis Verlag, 1977, p. 638. "Arte, otra Naturaleza, misteriosa también, pero más inteligible, ya que brota del intelecto."(1991, I: 441). 670. Permaneció en esta casa hasta trasladarse a su residencia de la ciudad (1792), aunque siguió utilizándola toda su vida como lugar de aislamiento para trabajar.

Fig. 47. Johann W. Goethe, Schloss Wörlitz visto a través de los árboles del parque, 1778. En Femmel [1958] 1972. I: 197 
Fig. 48. Johann W. Goethe, Goethes Gartenhaus in Weimar [La casa de campo de Goethe en Weimar], fecha desconocida. En Femmel [1958] 1972, VIb: 26

Fig. 49. Johann W. Goethe Floßbrücke (Naturbrücke) im Weimarer Park [Puente de maderos (puente natural) en el parque de Weimar], 1777/1778. En Femmel [1958] 1972, I: 195

671. Fue incluido en la exposición del Círculo de Bellas Artes de Madrid titulándolo: "Puente de maderos (puente natural) en el parque del IIm" ( $n^{\circ} 5$ del catálogo) (Arnaldo, 2008).

672. Refiriéndose a esa relación entre la ciudad y el campo en aquellos momentos y su reflejo en la estética, Assunto alude al: "lazo profundo entre sociedad y naturaleza, y ya que la sociedad era la ciudad, y naturaleza el campo, este lazo se manifiesta estéticamente como una continuidad entre la ciudad y el campo", en Rosario Assunto, La antigüedad como futuro. Estudios sobre estética del neoclasicismo europeo, Madrid, Visor, 1990 [1973], p. 69. asumió la responsabilidad de la transformación del parque del Ilm en Weimar siguió ese modelo.

Años después tuvo un cierto protagonismo en la construcción de una pequeña casa de recreo "a la romana" [Römisches Haus] (1792-1797) (Beyer et al., 2001) en el extremo sur del parque, obra del arquitecto Johann August Arens, que Goethe conoció en 1787 en Roma. La casa está emplazada en el margen izquierdo del río, en lo alto de una ladera del cauce. Este pabellón crea un contrapunto con la casa de Goethe situada en la otra orilla tanto espacial como visual y conceptualmente, evocando el paisaje y la arquitectura clásicos como término de su evolución estética que había partido de su propia vivienda rural.

Su casa como muestra de la arquitectura tradicional alemana, el parque como tránsito del campo a la ciudad, ajustado al modelo de la jardinería inglesa donde asume protagonismo el Sternbrücke y el recuerdo del mundo clásico reflejado en la Römische Haus son, pues, las sucesivas etapas que jalonan la vinculación de Goethe con el parque del IIm.

\section{La casa de Goethe en el campo}

Existe un pequeño dibujo a pluma (Fig. 48) donde aparece la casa de Goethe junto al IIm en un terreno inclinado con la vegetación

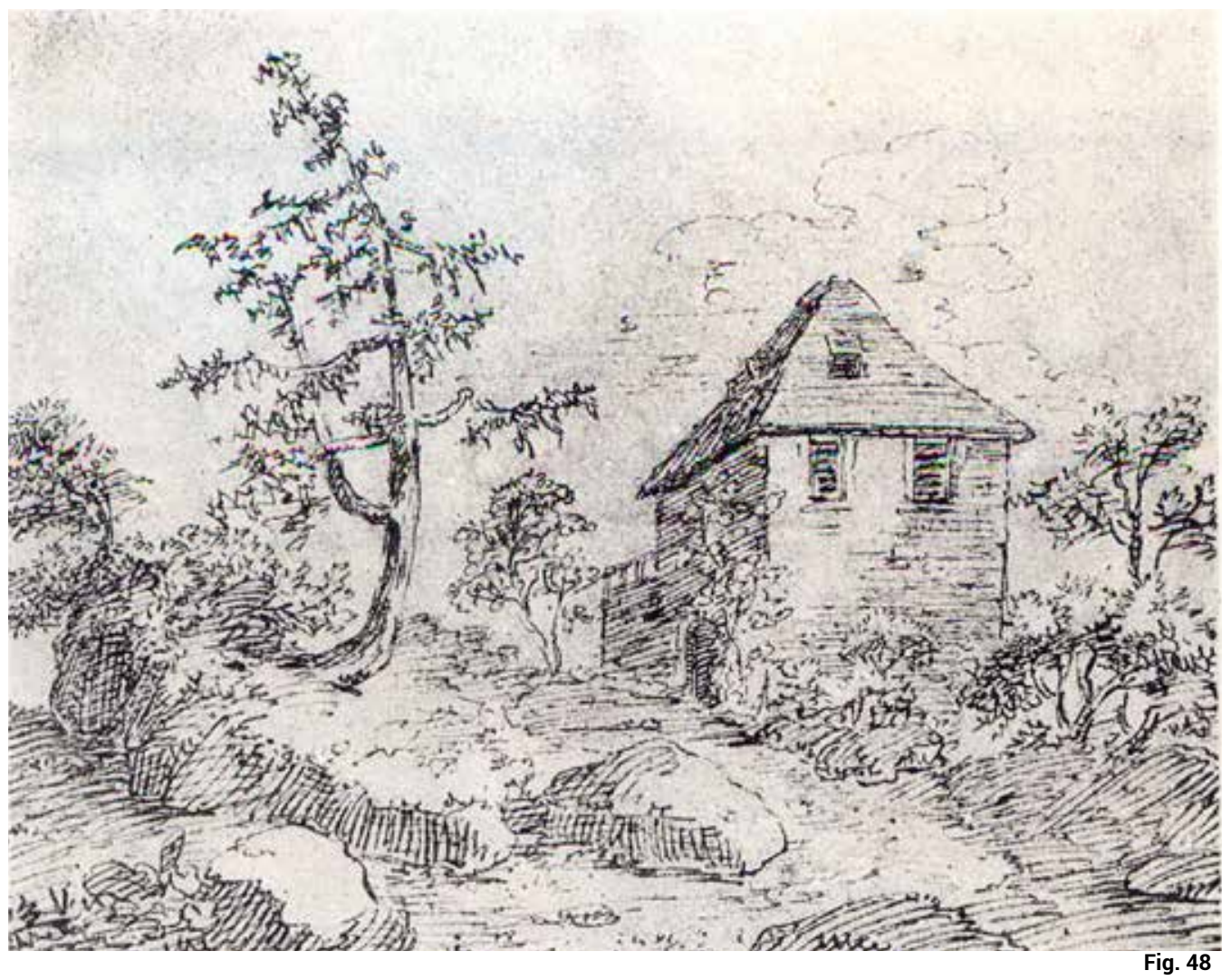


creciendo de manera silvestre, dando más la impresión de un terreno inculto que de un jardín. El dibujo corresponde a las fachadas norte y este, con la puerta encarada hacia arriba de la pendiente, y se aprecia un pequeño cuerpo con terraza añadido en la fachada sur construido por Goethe y ahora desparecido. A pesar de su proximidad a la ciudad y su integración posterior en el parque, parece una vivienda rural similar a los dibujos de paisajes alemanes con edificios agrícolas (establos, pocilgas, molinos, cabañas, granjas...) que Goethe realizaba frecuentemente en aquellos años. No por casualidad esta vivienda sirvió posteriormente como ejemplo de la casa tradicional alemana (Mebes, 1908: 115).
No es la única representación de su residencia hecha por Goethe. Un dibujo (Fig. 49) ${ }^{671}$ posiblemente desarrollado a partir de un esbozo (I: 192, Floßbrücke en el parque de Weimar, 1777/1778), representa la casa en la lejanía, rodeada por la campiña, como fondo de una escena invernal con unas figuras en primer plano (interpretadas como Charlotte von Stein o el propio Goethe con Fritz von Stein) cruzando el río por un puentecillo. Hay, pues, una clara implantación del edificio en su entorno rural como contrapunto a la ciudad e incluso al parque. ${ }^{672}$

Aún se conocen otros dibujos de esta casa hechos por Goethe ${ }^{673}$ incluido uno del interior (I: 179, Escaleras de la casa del jardín de Goethe en Weimar, 1777) que podría tratarse de un ejercicio de perspectiva. ${ }^{674}$

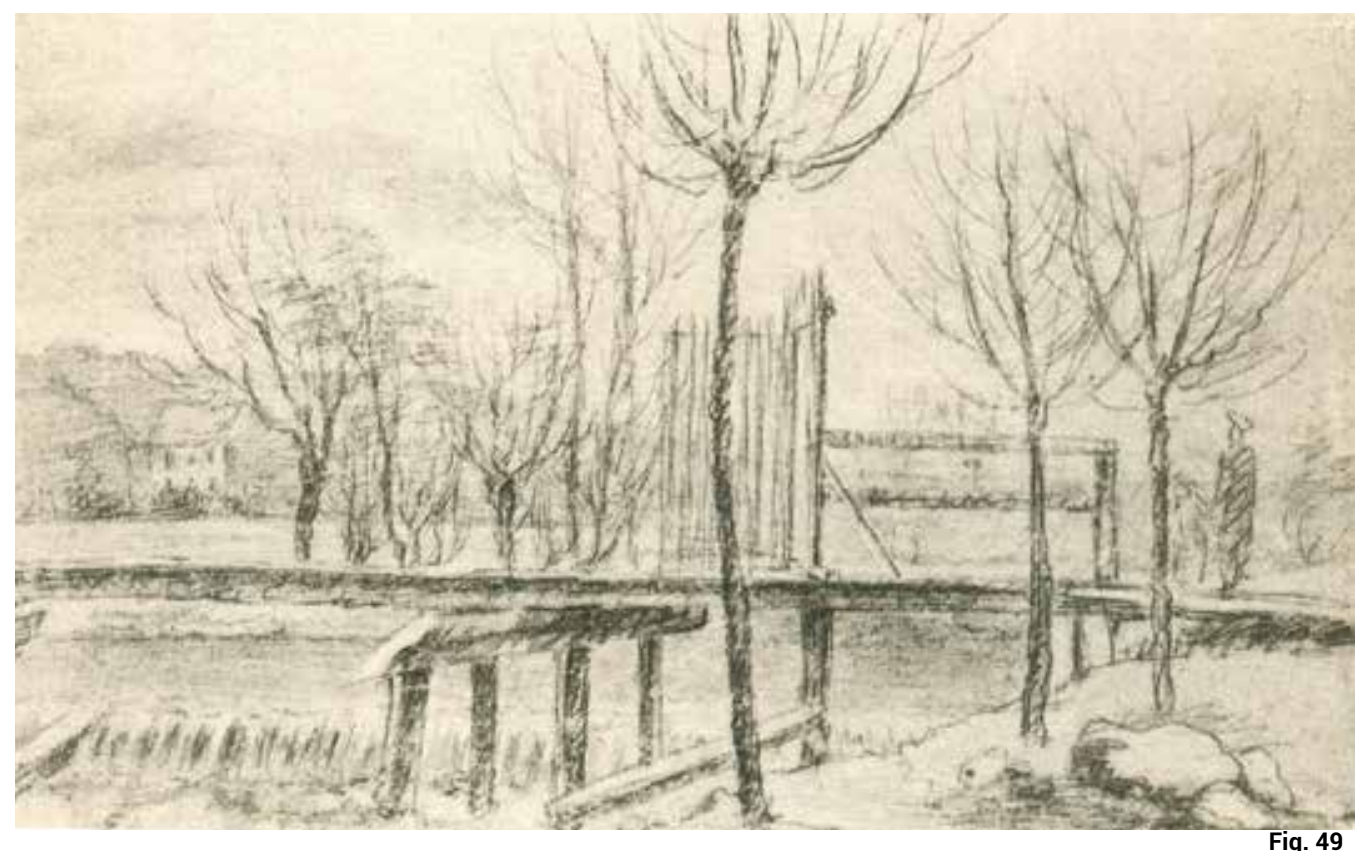

673. I: 220, Casa del jardín de Goethe en Weimar desde la parte trasera, 1779/1780. Recogido también en la exposición mencionada (Arnaldo, 2008, nº 6); IVa: 267, Casa del jardín de Goethe, 1792; IVa: 268, Esbozo de la Casa del Jardín de Goethe, 1792

674. Goethe dibujó escaleras, bien como ejercicios de perspectiva (I: 301 rs., 1776/77; III: 118, 1787/88), o con fines proyectuales, por ejemplo, la escalera imperial del Schloss construida por Heinrich Gentz en 1801 (IVb: 93; Vla: 163, ¿1801?), o las de su propia casa urbana (IVb: 77, ¿1792?; IVb: 78, 7.6.1792; IVb: 79, 7.6.1792; IVb: 80, 2.10.1786 IVb: 81, 7.6.1792; IVb: 82, 7.6.1792). Hablando de estas últimas le dijo a Eckermann el 21.3.1830: "Yo, por ejemplo, traje de Italia el gusto por las grandes y bellas escaleras y por efecto de ello estropeé esta casa pues sus habitaciones resultan ahora más chicas." (1991, III: 210). 675. Recogido también por Paul Mebes (1908, II: 122) como ejemplo de obra alemana. 
Fig. 50. Johann W. Goethe, Sternbrücke (Schlossbrücke) in Weimar [Puente de la Estrella (Puente del Palacio) en Weimar], ¿1785? En Femmel [1958] 1972, I: 277

Fig. 51. Johann W. Goethe Schloss und Brücke [Palacio y puente], hacia 1790. En Femmel [1958] 1972, IVa: 269 676. Gaspar Merian, Topographia Superioris Saxoniae, Frankfurt am Main, Eigenverlag, (hacia 1650), en concreto los grabados: Fürstliche Residenz Stalt Weimar y Deli. Veß Canals. Und Furstlichen Lustgarten in Weimar (pp. 187-189). En el segundo se ven los pasos entre los parterres convertidos en canales. Hoy las huellas del trazado geométrico casi han desaparecido.

677. La imagen del Palacio no representa la realidad tal como entonces se encontraba tras el incendio sino una posible propuesta de Goethe que no se ejecutó.

678. Otros dibujos similares son VIb: 184: Un arco de

Puente de la Estrella. Puente del Palacio de Weimar, hacia 1780; VIb: 183: Un arco del Puente de la Estrella, hacia 1780 .

679. Por ejemplo, Eckermann con fecha 10.2.1829 escribe: “Encontré hoy a Goethe rodeado de mapas y planos relativos a la construcción del puerto de Bremen, empresa grandiosa por la que se interesa mucho" (1991, III: 160). 680. Marchán Fiz escribe que la fragmentación llega

\section{El Puente de la Estrella [Sternbrücke] y el parque}

La mayoría de los dibujos de Goethe del Puente de la Estrella ${ }^{675}$ nos muestran su ojo principal desde abajo enmarcado por la vegetación de ribera de grandes árboles y abundante follaje. En algunos, por encima del puente, aparecen diferentes edificios como la Torre (Fig. 50), el ala sudeste del Palacio sin cubierta tras el incendio de 1774 (I: 264, ¿1783?) o el molino situado aguas abajo visto a través del arco (I: 249, 1781).

En un apunte a lápiz y carboncillo

(Fig. 51), el puente y el Palacio se ven desde el sur como fondo de un paisaje protagonizado por grandes árboles junto al río. Es lo que contemplaría Goethe cuando iba desde su casa a la ciudad por la vertiente derecha. Sin embargo, en vez del arbolado representado como crecido de manera espontánea junto a la corriente, lo que posiblemente vería serían los restos del jardín geométrico del parque de la Estrella tal como figura en grabados anteriores. ${ }^{676}$ Hay, pues, en el mismo dibujo, una clara voluntad de camuflar el jardín ortogonal de tipo francés sustituyéndolo por el parque paisajista inglés que él propuso. El contrapunto a este dibujo sería el I: 265 (Puente de la Estrella - puente del Palacio-y Palacio en Weimar, fachada este, ¿1783?), tomado de norte a sur, con la vista del puente a contracorriente aguas abajo, cuando el río se ensancha por el azud que canalizaba el agua al molino. Una barca completa la imagen. EI puente y el Palacio, ${ }^{677}$ como construcciones, aparecen como fondo y contraste de la vegetación y el agua que constituyen los elementos naturales del dibujo. ${ }^{678}$
Aunque Goethe era el responsable de las obras públicas, por las que mostró activo interés, ${ }^{679}$ sin embargo estos dibujos apuntan a un objetivo muy distinto. La visión del Sternbrücke y los edificios es siempre desde la orilla del río quedando, así, parcialmente ocultos por la vegetación. No son, por lo tanto, dibujos que pretendan mostrarnos sus cualidades formales, estructurales, constructivas o funcionales. 0 sea, no son dibujos arquitectónicos con fines descriptivos o técnicos. El Palacio y el puente, como obras humanas, son el contrapunto racional y artificial a la naturaleza simbolizada por la vegetación y el río. La construcción, como obra de arte, se erige así frente a la naturaleza como otra naturaleza más inteligible. La racionalidad de la arquitectura contrasta con la espontaneidad de la naturaleza equilibrándose mutuamente entre sí. Y, desde esta perspectiva, la libertad formal del parque inglés expresa mucho mejor ese contraste que la rigidez formal del anterior jardín francés.

A medida que los diversos fragmentos ${ }^{680}$ iban poblando el parque del IIm los recogía Goethe en sus dibujos. Por ejemplo, las ruinas artificiales del Luisenkloster, que estaban en el origen del parque, son reflejadas por Goethe en sus trabajos (Fig. 52) ${ }^{681} \mathrm{La}$ reflexión sobre las ruinas, donde la naturaleza recupera lo que el arte le ha arrebatado, fue un tema recurrente del pensamiento de Goethe, especialmente tras su regreso del viaje a Italia. ${ }^{682}$ También las construcciones rústicas, como cabañas o chozas, frecuentes en los jardines ingleses, encontraron eco en el parque del IIm con la Borkenhäuschen (1778), igualmente dibujada por Goethe. ${ }^{683}$ Incluso la esfinge que en el parque preside la gruta del manantial de aguas minerales (1784- 

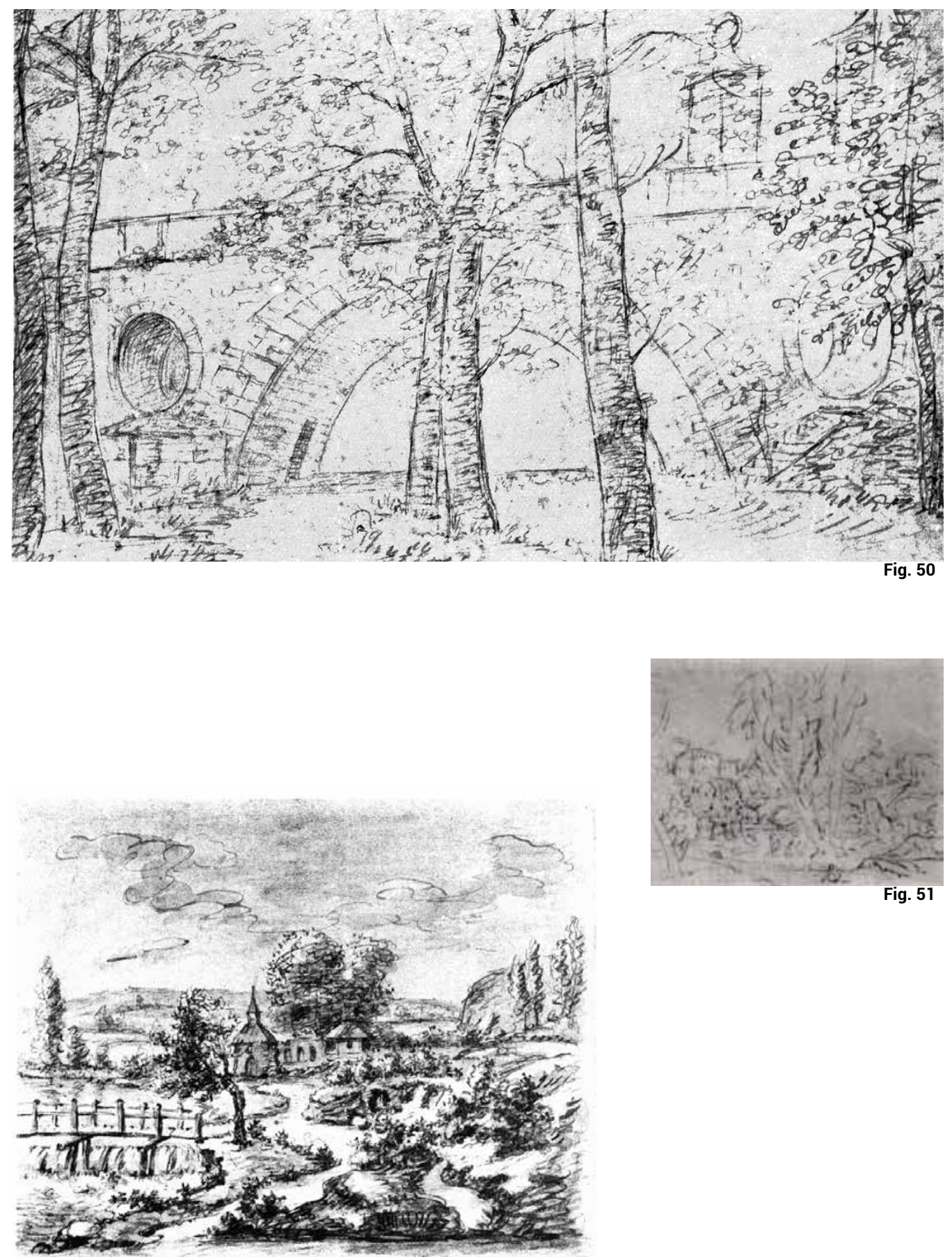

Fig. 52 a "convertirse incluso en la categoría por antonomasia de la modernidad artística." $Y$ añade: "lo moderno, tanto desde la atalaya del sujeto transcendental ilustrado e idealista como desde la empiria artística, se gesta y despliega bajo el síndrome de la fragmentación." (2010: 212).

Fig. 52. Johann W. Goethe, Luisenkloster im Weimarer Park [Luisenkloster en el parque de Weimar], hacia 1780. En Femmel [1958] 1972, I: 225 681. I: 204, Luisenkloster, 9.7.1778;; IVb: 44, Muro en ruinas encuadrado por arbustos y árboles, 1781; I: 246 rs., Croquis del muro en ruinas -tal vez un croquis preparatorio del anteriorenero 1781

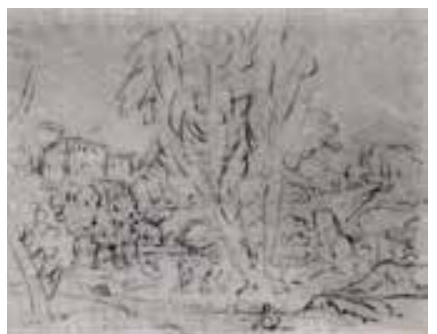

682. De nuevo, el tema de las ruinas se encuentra como motivo en los dibujos: IVa: 24 , Ruinas de templo, hacia 1800; IVa: 25, Ruinas de templo, hacia 1800

683. VIb: 178, Cabaña de paja en el Luisenkloster del parque del IIm, 1778. 
684. En un dibujo (VIb: 71, Paisaje imaginario del sur de Italia con villa junto al mar y esfinge, verano/otoño 1787) hay una esfinge similar a la del parque el IIm.

685. Ahora se han eliminado los peldaños semicirculares centrales de acceso al basamento del banco, similares al original romano. Existen dos dibujos de Goethe (IVb: 234, Bühnebild, c. 1790; IVb: 235, Götterhain, c. 1790) que aunque no se refieren a esta obra (ya que están fechados antes de su construcción), recogen esta misma solución de peldaños.
1786) atrajo a un Goethe interesado por las antigüedades egipcias. ${ }^{684}$ Aunque no conocemos ningún dibujo que lo represente, el llamado Banco Pompeyano del parque (1799) recuerda el sepulcro de Mamia que Goethe cita cuando narra su visita a aquella ciudad romana (12.3.1787) (V. It., III: 1169). ${ }^{685}$

Por último, hay que mencionar un croquis del Tempelherrenhaus (18111823) actualmente en ruinas (Fig. 53) que, a diferencia de todos los dibujos anteriormente mencionados, es un apunte hecho con los sistemas de representación propios del dibujo arquitectónico (una sección y una perspectiva volumétrica) definiendo el modo

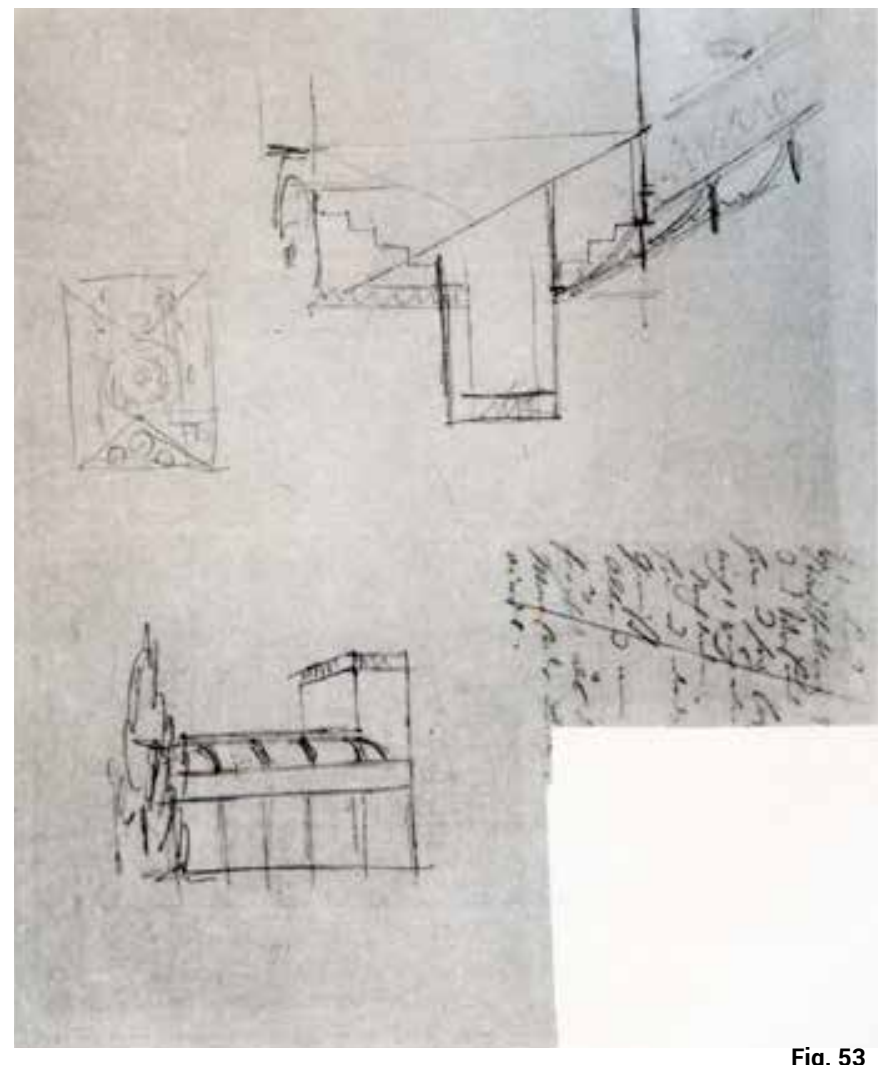

de acondicionar este edificio para encuentros o reuniones sociales. Tiene, pues, unos fines claramente proyectuales que lo convierten en algo completamente distinto a los anteriores dibujos paisajistas, que buscan transmitirnos las cualidades estéticas de la jardinería y el parque como objeto de arte.

\section{La Casa Romana [Römisches Haus] (1791- 1797)}

Cuatro son los tipos de dibujos hechos por Goethe relacionados con la Römische Haus y que apuntan a cuestiones que van desde la definición gráfica de la obra a su papel en la concreción del paisaje clásico.

En el dibujo arquitectónico IVb: 97

(Fig. 54), Goethe estudió varias alternativas a la composición de la fachada trasera y la distribución en planta del local posterior, incluyendo la escalera de bajada al jardín desde la planta principal. Hay también un conjunto de alzados de pabellones de jardín contemporáneos a la construcción de la Römische Haus, hechos con el grafismo arquitectónico. ${ }^{686}$ Todavía hay que mencionar una planta general incluyendo el jardín de esta casa (Vla: 151, Plano del jardín y planta de la Casa Romana, 1793). Posiblemente todos estos dibujos, elaborados cuando la obra estaba en ejecución, tendrían por finalidad definir las ideas que Goethe quería transmitir al arquitecto. Son, en esencia, dibujos proyectuales. 


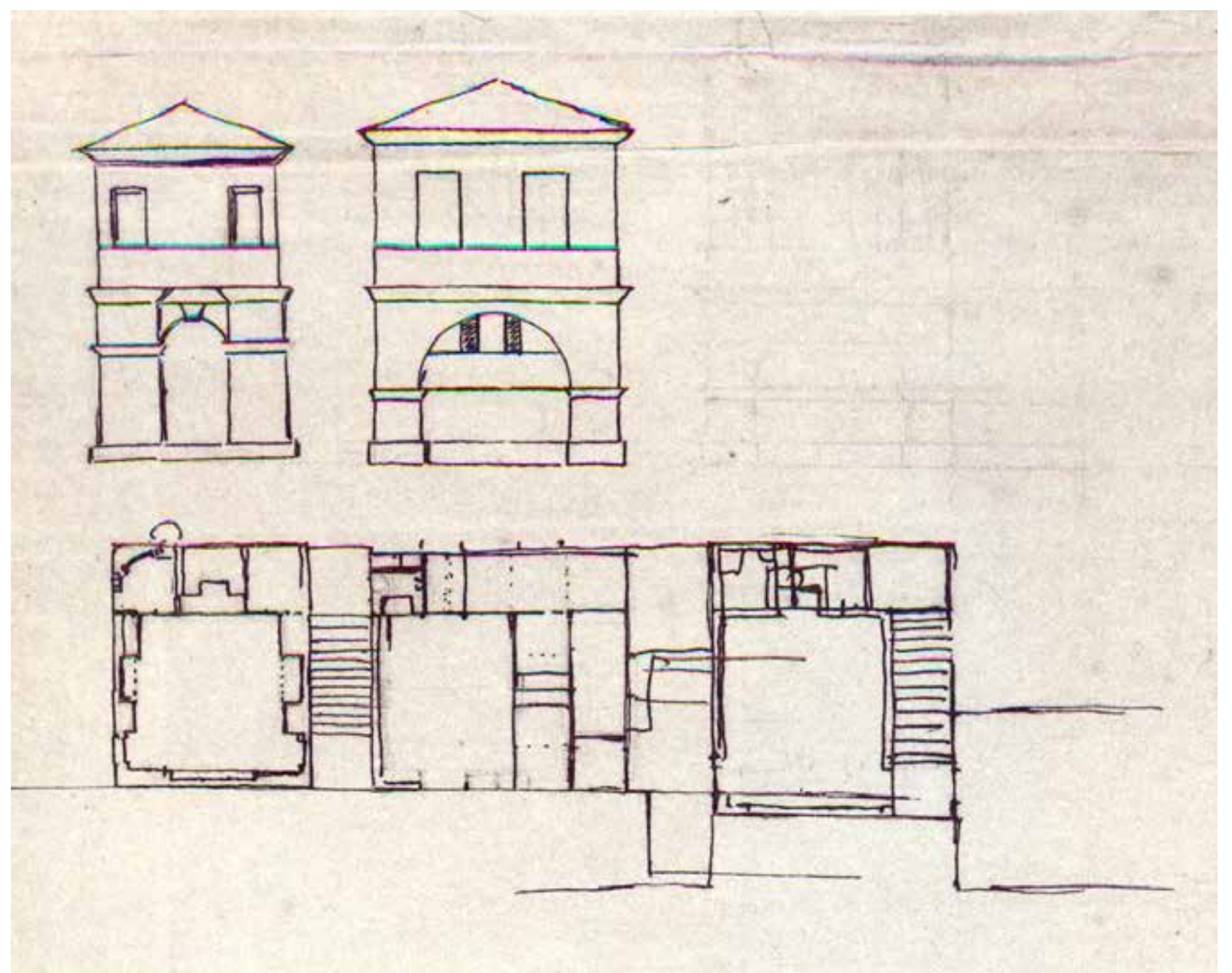


Fig. 53. Johann W. Goethe, Tempelherrenhaus im Weimarer Park [Tempelherrenhaus en el Parque de Weimar], ¿1821/23? En Femmel [1958] 1972, IVb: 129

Fig. 54. Johann W. Goethe Römische Haus [Casa Romana], 1792/1795. En Femmel [1958] 1972, IVb: 97

Fig. 55. Johann W. Goethe, La Casa Romana en un paisaje de montaña, agosto 1808. En Femmel [1958] 1972, IVa: 99 686. IVb: 112, Fachadas de pabellones de jardín y capitel dórico (hacia 1795); IVb:

113, Alzado de un pabellón de jardín (hacia 1795); IVb: 114, Alzado de un pabellón de jardín (hacia 1795); IVb:

115, Alzado de un pabellón de jardín y un portal (1791/95).

687. IVa: 101, la Casa

Romana con un personaje recostado en primer término (agosto, 1808); IVa: 100, La Casa Romana con un personaje (agosto, ¿1808?). Son tres dibujos similares, si bien el último parece un apunte preparatorio de los otros dos. En todos ellos es visible la bóveda de cimentación actualmente enterrada. 688. II: 159, Templo junto al mar. Fantasía (Italia, abril-mayo 1787); II: 172, Costa italiana junto a Taormina (¿mayo 1787?); II: 248, Paisaje del Tiber y villa Madama (junio/julio 1787); II: 293, Templo en una colina y bahía de un lago (otoño/ invierno 1878); II: 299, Paisaje inventado: villa sobre una roca y restos de columnas
Años después, Goethe realizó unos dibujos con un carácter muy distinto representando un paisaje montañoso con la fachada posterior de la Römische Haus sobre la ladera recayente al cauce del IIm. ${ }^{687}$ En este caso, con la obra ya terminada, lo que pretende es evocar el paisaje clásico. Estos dibujos recuerdan unas panorámicas de las costas italianas del sur la mayoría inventadas, hechas durante su viaje, donde el protagonismo siempre recae sobre un templo clásico coronando una montaña. ${ }^{688}$ En ellos es la arquitectura la que aporta un sentido concreto al paisaje como contraste con la vegetación, la pendiente de terreno y la orilla del agua. Y es la reiteración del mismo tema lo que nos aclara la imagen que Goethe tiene del paisaje clásico y que pretende rememorar en el parque del IIm con la Casa Romana.
A diferencia de esta fachada posterior, los dibujos de la fachada principal (Fig. 56) ${ }^{689}$ responden de un modo más literal a la imagen de un templo antiguo debido al pórtico de columnas y, en consecuencia, construyen explícita y visualmente un paisaje clásico. El pabellón de jardín (fachada posterior) en una escarpada pendiente y el templo clásico (fachada principal) son, pues, las dos interpretaciones del clasicismo presentes en el parque del IIm.

Goethe manifestó un doble interés por la naturaleza que fue evolucionando en estudios paralelos: la botánica y el paisajismo. Cada uno de ellos le orientó hacia un tipo distinto de aproximación: el trabajo científico y la manifestación artística. Pero ambos se cruzan en el arte de la jardinería, haciéndose eco de la interpretación de Kant como metáfora literal de la naturaleza, como el "bello

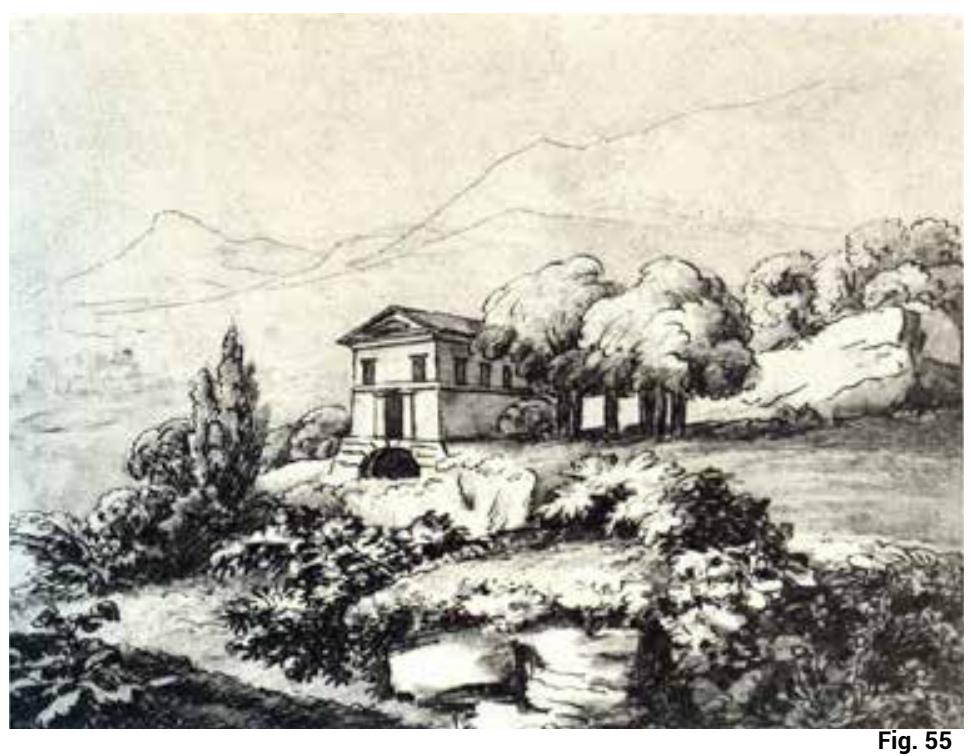


arreglo de sus productos", equiparándola, así, a la pintura (2007: 230). Bajo su responsabilidad el parque del IIm en Weimar fue un laboratorio donde Goethe pudo experimentar sus ideas introduciendo, de alguna manera, la naturaleza y el paisaje en la ciudad. $Y$ es a través de los dibujos paisajistas de sus distintos componentes, hechos a lo largo de décadas, como podemos rastrear la evolución de sus ideas sobre el arte de la jardinería. (invierno 1787/88); Vlb: 89, Templo en una costa rocosa (¿1787/88?).

Fig. 56. Johann W. Goethe, Park und Römisches Haus in Weimar [Parque y Casa Romana en Weimar], 1794. En Femmel [1958] 1972, IVa: 266 689. Esta imagen se repite en el dibujo IVa: 266 rs., Parque y Casa Romana en Weimar, hacia 1794, probablemente un apunte preparatorio.

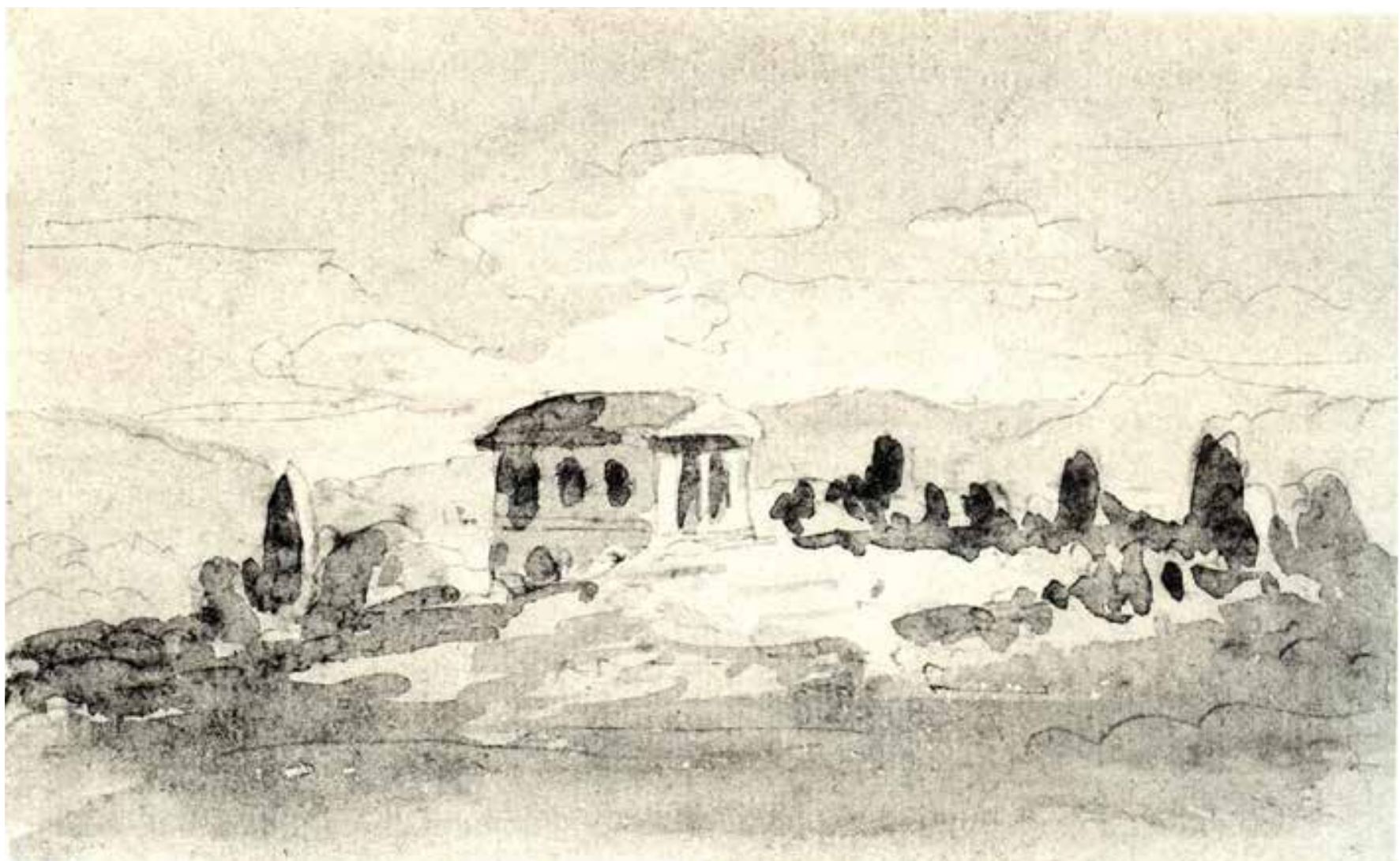

Fig. 56 
Fig. 57. Johann W. Goethe. Entwurfsskizze für das Lauchstädter Theater [Boceto de proyecto para el teatro de Lauchstädt], 1797. En Ewald 1995, fig. 60.1

Fig. 58. Johann W. Goethe Giebelfront vom alten Theater in Lauchstädt [Frontón del viejo teatro de Lauchstädt], después de 1825. En Femmel [1958] 1972, Vla: 177

\section{B. Arquitectura teatral y escenografía}

La condición de dramaturgo de Goethe, y su vinculación como responsable y gestor del teatro de Weimar se reflejaron en su pensamiento sobre la arquitectura teatral y quedaron plasmados en sus dibujos. Desde su nombramiento (1776) como miembro del Geheimen Consilium [Consejo Privado] del Gran Duque de Weimar, Goethe realizó diversos encargos relacionados con el teatro y su arquitectura. Ese mismo año, asumió la gestión del teatro amateur de la corte de Weimar profesionalizándolo. Dirigió el Weimarer Hoftheater (Steiner, 1779/80) (Ewald,
1999: figs. 54 y 55) desde su inauguración hasta 1817. Entre 1798 y 1800, intervino (con Friedrich Beuther) en las mejoras funcionales y estéticas de dicho teatro proyectadas por el arquitecto de Stuttgart Thouret (Ewald, 1999: fig. 57), y obtuvo de Friedrich Gilly durante su estancia en Weimar un croquis para su reforma (28.08.1798) (Ewald, 1999: fig. 58). En Lauchstädt, residencia estival de la corte desde 1793, alentó la construcción de un nuevo teatro cuyo proyecto inicial (Steiner, 1797) fue revisado posteriormente por $\mathrm{H}$. Gentz (1801) (Ewald, 1999: figs. 61 y 62), siendo el responsable de las obras el propio Goethe (1802-1803).

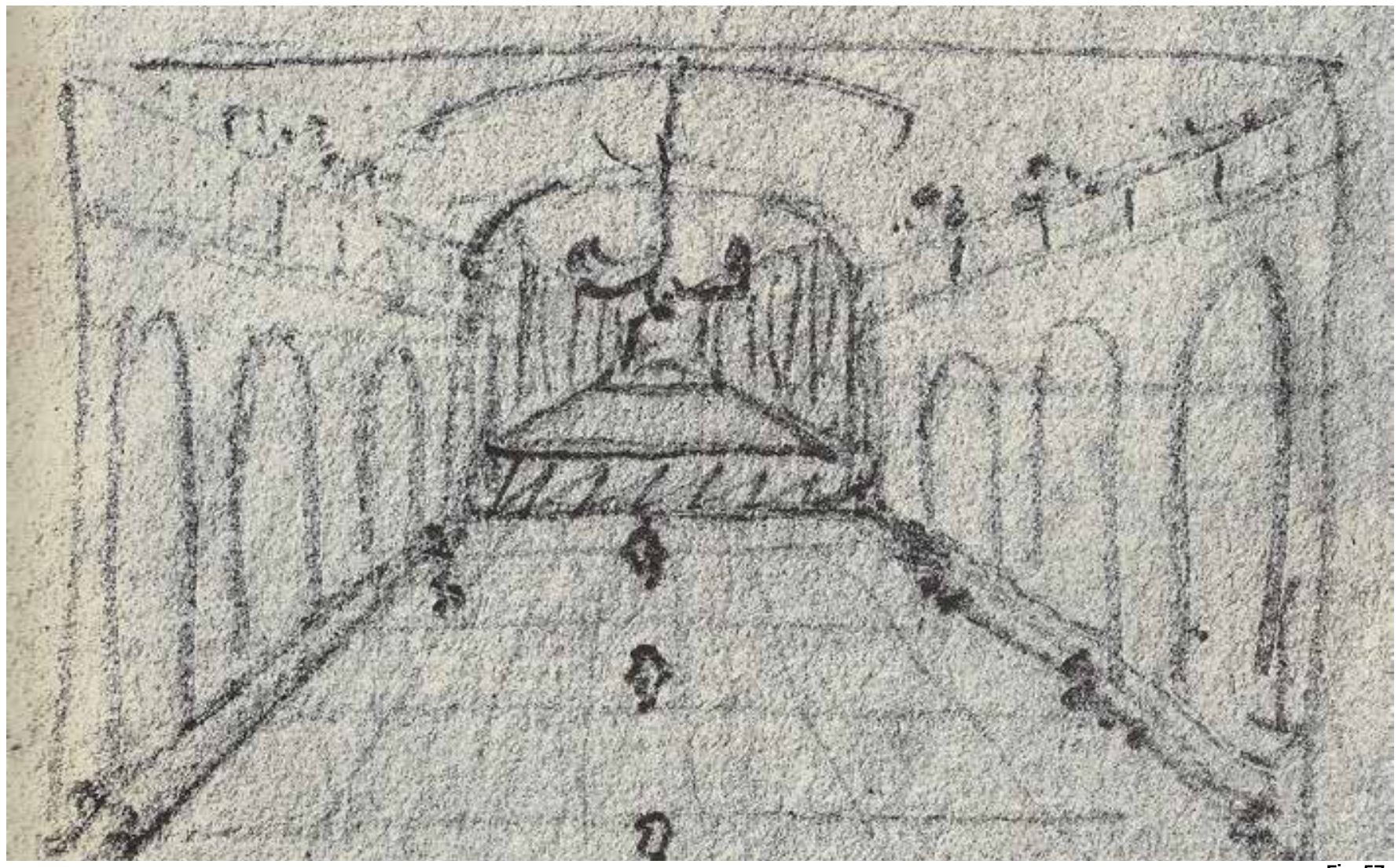


Este interés del escritor por la arquitectura teatral lo atestiguan sus numerosos intercambios epistolares y su trato con arquitectos como Ludwig Friedrich Catel, ${ }^{690}$ Johann Jakob Friedrich Weinbrenner ${ }^{691}$ o Karl Friedrich Schinkel. ${ }^{692}$

En una carta al Duque Carl August del 15 de agosto de $1797,{ }^{693}$ Goethe distingue claramente el teatro como edificio de la arquitectura ficticia de los decorados. Para Goethe la arquitectura teatral [Theaterarchitektur] plantea el reto de compatibilizar la meta seria y elevada que reclama dicho arte con la elegancia que caracteriza lo que rodea al teatro como espectáculo. Por el contrario, la escenografía [theatralische Baukunst] debe responder, apropiadamente, a los requisitos de cada representación. Con este planteamiento recuperaba la teoría teatral vitruviana ${ }^{694}$ entrando en el debate suscitado desde el Renacimiento por los desajustes entre el tratado y los restos arqueológicos. La diferenciación planteada por Goethe alude a las discrepancias entre lo señalado por Vitruvio al explicar el trazado del teatro como construcción (1995: 205-206) y lo correspondiente al escenario [frons scænæ] con su estructura arquitectónica como fondo, los tinglados laterales para las bambalinas y los lugares previstos para los decorados pintados en perspectiva (1995: 257) según los tipos de escenas: trágica, cómica y satírica (1995:

207-208). Dos cuestiones que Goethe abordó de manera distinta abriendo dos visiones paralelas: la relativa al edificio y la escenografía

\section{El edificio}

\section{Del tipo teatral...}

Además de los problemas mencionados, su adaptación del teatro a las necesidades modernas tenía que resolver su implantación en un local cerrado y cubierto, y superar las divergencias entre la representación antigua y la moderna. El teatro Olímpico en Vicenza de Palladio aportaba una adaptación plausible del tipo antiguo a las nuevas necesidades. Al visitarlo Goethe escribió: 'El teatro Olímpico es un teatro antiguo, realizado en pequeño y de una belleza indecible' (1991, III: 1069).

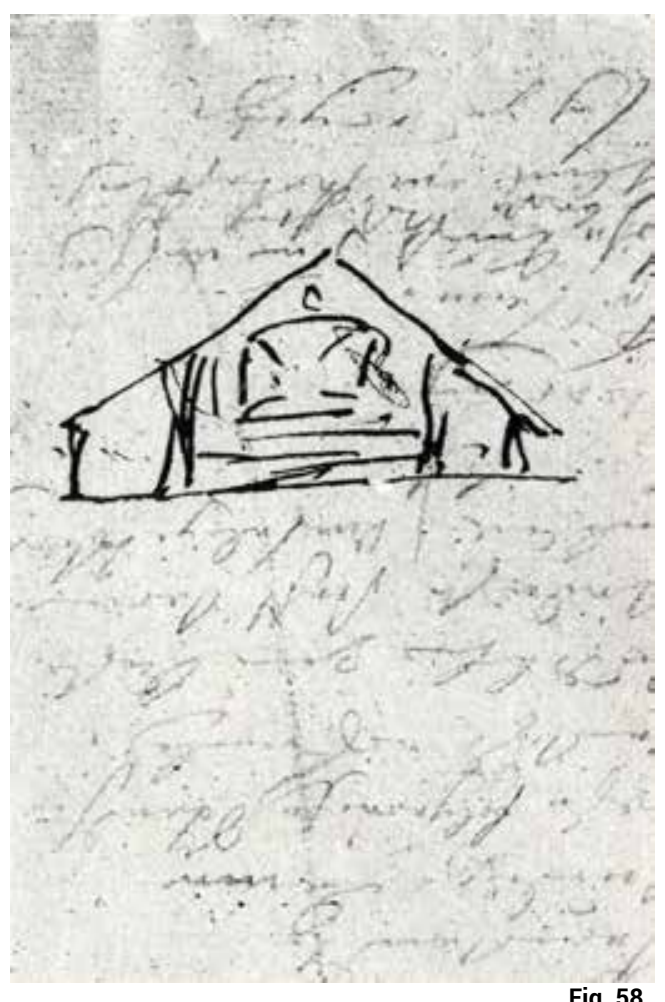

690. En 1802, Catel le envió a Goethe su Vorschläge zur Verbesserung der Schauspielhäuser (1802).

691. Goethe recibió en 1809 su ensayo Über Theater in architectonischer Hinsicht (1809) y en 1815 visitó su Karlsruher Hoftheater (1804) 692. En agosto 1820 visitó a Goethe, intercambiando ideas y proyectos al respecto. 693. "En la arquitectura teatral, la gran dificultad estriba en que están a la vista los principios de la genuina arquitectura, y tiene que diferir de ellos convenientemente. La arquitectura en sentido más elevado expresa una existencia seria, elevada, sólida; apenas puede, sin ser débil, participar de lo elegante; en el teatro, por el contrario, todo tiene que ser de apariencia elegante. La escenografía debe ser ligera, limpia, variada, y debe representar lo magnífico, elevado, noble. Las decoraciones tienen que hacer sobre todo cuadros, en especial el fondo de escena, el decorador tiene que ir un paso más allá que el pintor de paisajes, el cual también sabe modificar la arquitectura según su necesidad." (Goethe, 2004: 6182 y ss.).

694. Goethe conocía la traducción de Vitruvio de Galiani que había comprado en Venecia durante su viaje a Italia (1991, III: 1100).

Fig. 59. Johann W. Goethe Theater [Teatro], 1820/1822. En, Femmel [1958] 1972, Vla: 175 


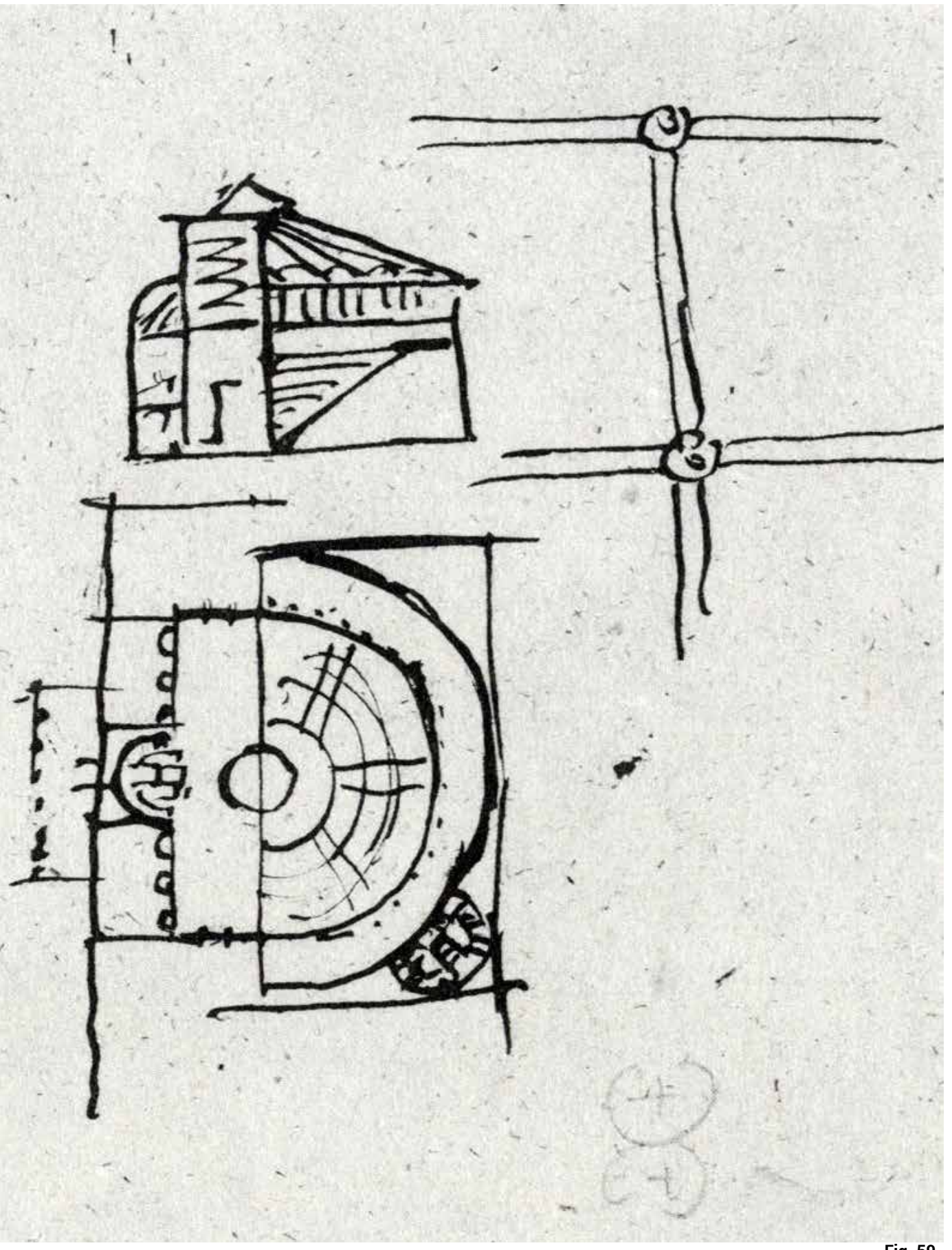


Hay dos croquis de Goethe de teatros muy similares entre sí que quizás corresponden a los estudios y debates sostenidos con el arquitecto de la corte Coudray (Figs. 59 y 60 ).

En ambos se representa un teatro en planta y sección con una solución muy parecida (más desarrollada en la fig. 60), por lo que es posible que uno sea una copia del otro, aunque con algunas diferencias entre ellos. Respecto a los aspectos comunes, es incuestionable que Goethe se remonta directamente a Vitruvio (en la versión dibujada por Galiani) y a la solución dada por Palladio.
Algunas de las soluciones que tomó del Vitruvio de Galiani son: el detalle de la sección del graderío (fig. 59) que Galiani recoge en perspectiva en la lámina del teatro griego (Fig. 62), la altura del proscenio casi al mismo nivel que el pavimento de la orquesta (figs. 58 y 59) y el pórtico exterior tras el escenario señalado por Vitruvio (1995: 213) que en la fig. 3 queda reducido a un pórtico emergente, y se convierte, en la fig. 60 , en un gran patio con un paseo cubierto rodeándolo, más acorde con el tratadista romano (1995: 213-215).
Fig. 60. Johann W. Goethe. Theater [Teatro], 1819/1825 En Femmel [1958] 1972, IVb: 130

Fig. 61. B. Galiani. Pianta del Teatro Romano, 1758. Tavola XVI

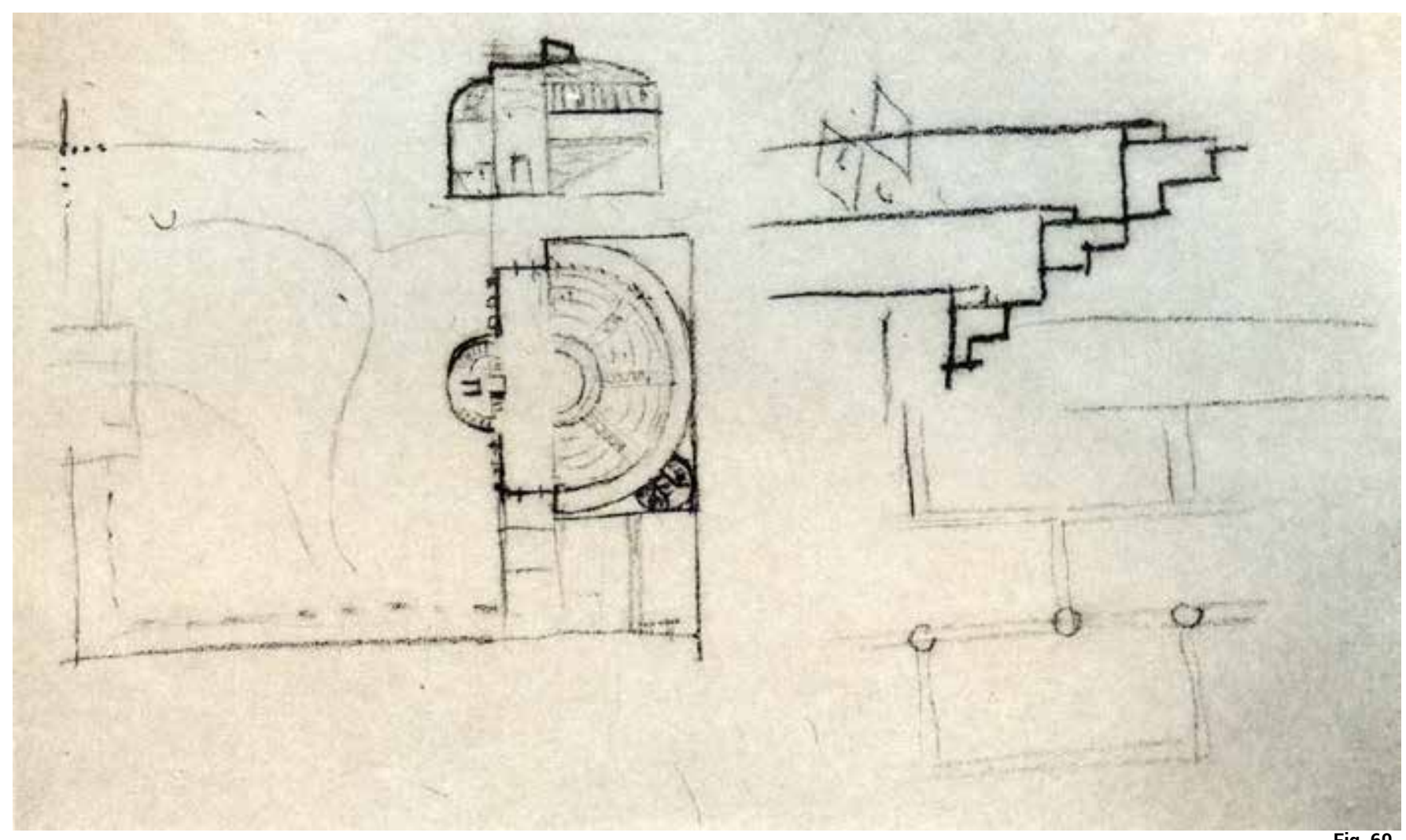


Fig. 62. Galiani. Pianta del Teatro Greco, 1758. Tavola XVII

Fig. 63. A. Palladio. Planta del teatro Olímpico en Vicenza, 1585. En Polacco, 1965: 70 695. El origen de esta solución pudo estar en el aprovechamiento de las laderas montañosas para el graderío quedando el acceso en la parte inferior junto al escenario.
Este pórtico, los paseos y el jardín tras el escenario (fig. 59) evidencian uno de los problemas más relevantes en la adaptación del tipo antiguo a las necesidades modernas. Este espacio, según Vitruvio (1995: 213), era para resguardar a los espectadores en caso de lluvia y servía como acceso del público al teatro así como a los deambulatorios, vomitorios y graderíos a través de dos pasos laterales junto al escenario, tal como lo dibujó Galiani (fig. 60). ${ }^{695}$ Sin embargo, en el teatro moderno estas funciones de entrada y acceso a la sala lo asume el foyer situado no detrás del escenario sino justo en el lado opuesto, tras el patio de butacas. ${ }^{696}$

Goethe repite la solución palladiana de encerrar en una envolvente rectangular y una cubierta (distinta en cada dibujo: semicónica o semiesférica, recordando la propuesta de Catel) al graderío y el pórtico
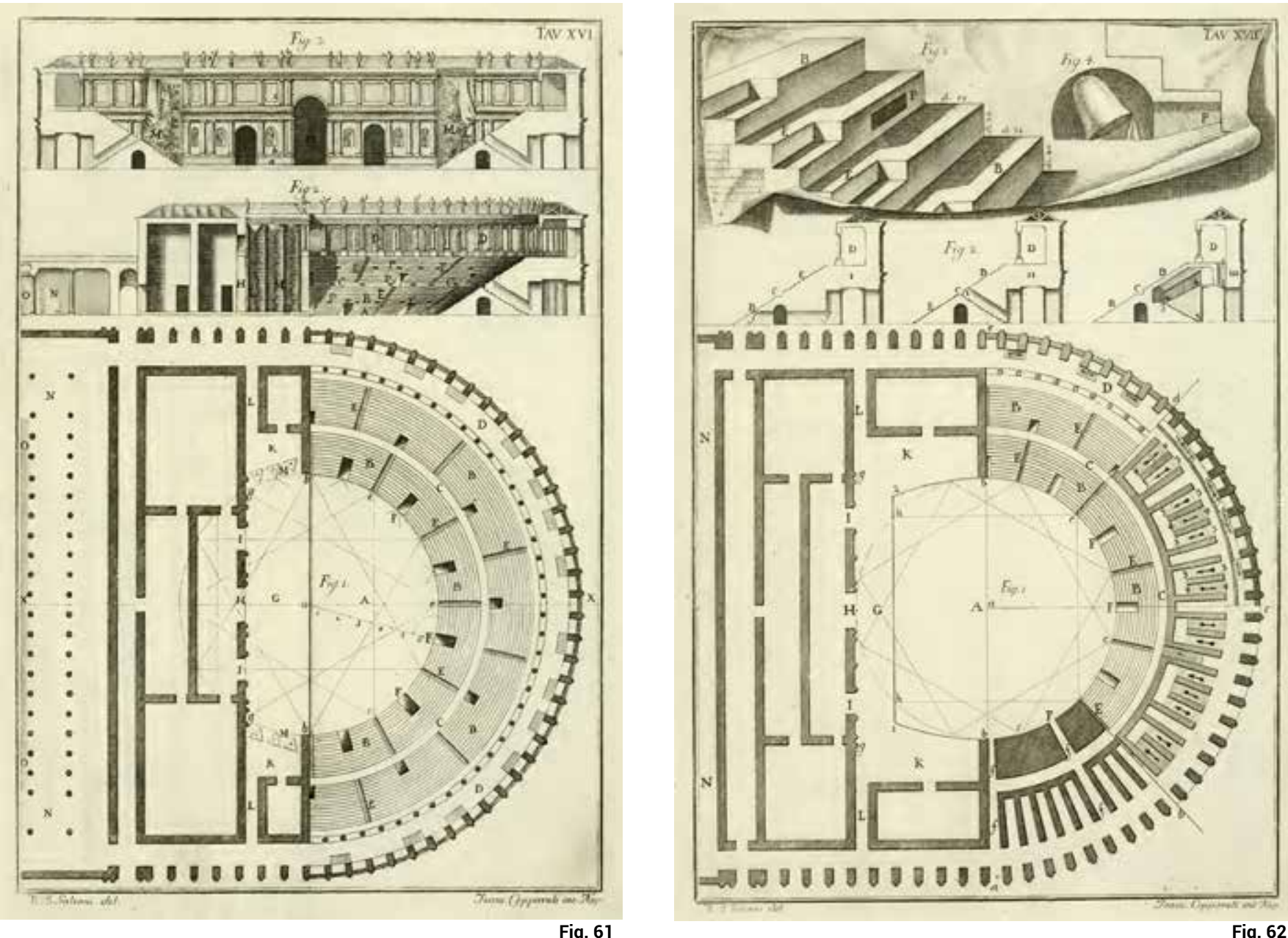

Fig. 61 
superior (Vitruvio, 1995: 205) dejándolos autónomos e independientes. Es como si un teatro antiguo al aire libre se hubiera encerrado en un espacio prismático, abarcándolo. La dimensión reducida, similar al ejemplo de Palladio, hace también en este caso innecesarios los vomitorios de salida a las gradas y los deambulatorios bajo ellas, pero obliga a incluir unas escaleras perimetrales encajadas entre el paramento curvo de la cávea y el muro exterior. En los dos laterales del escenario, de un modo mucho más claro en la fig. 66 , se aprecian unas piezas destinadas a los vestuarios, almacenes y máquinas, tal como establecía Vitruvio. En este sentido, Goethe no hacía más que reflejar las necesidades funcionales de los edificios teatrales que tan bien conocía.

Otra cuestión donde Palladio, y Goethe tras él, se alejan de Vitruvio es en el desarrollo en planta de las gradas que anulan casi totalmente el espacio semicircular para la orquesta frente al escenario. Existe un dibujo de Goethe, hecho a compás, que parece un estudio de la solución en planta del graderío mediante semicircunferencias concéntricas. En cambio, sí recuperaron del tipo vitruviano la inclinación del graderío. Goethe manifiesta así su interés por resolver problemas acústicos y visuales heredados del teatro italiano barroco. ${ }^{697}$

En resumen, en los estudios de Goethe del tipo teatral el modelo que sigue es vitruviano aunque asumiendo por lo general las adaptaciones de Palladio para adecuarlo a su condición de espacio cerrado. Con esta postura se posicionaba contra la evolución del tipo de edificio teatral que se había producido desde el s. XVI.

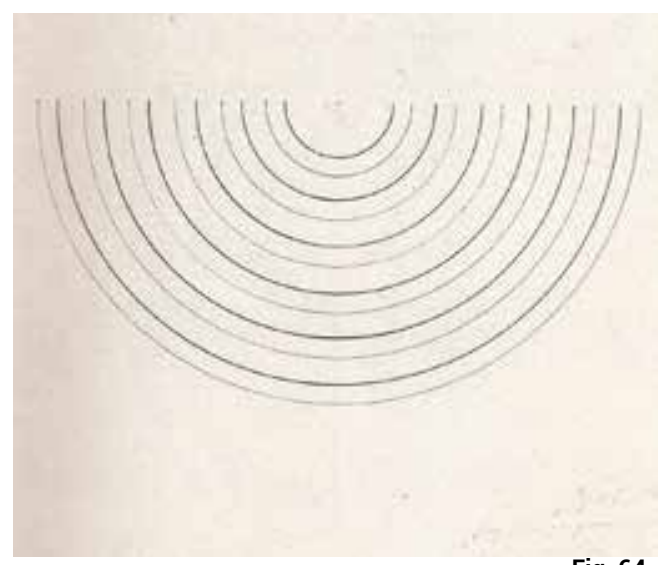

Fig. 64
696. En el teatro de Lauchstädt de Gentz (1801) esto se resolvió adosando exteriormente al muro curvo del patio de butacas un volumen de planta rectangular y cubierta a dos aguas. Una solución similar al proyecto de F. Gilly para el concurso del Nationaltheater berlinés (¿1799?) donde la entrada se enfatiza con un pórtico de columnas dóricas griegas.

697. Está por comprobar si las medidas anotadas en el dibujo se corresponden con las dadas por Vitruvio (1995: 205).

Fig. 64. Johann W. Goethe Halbkreise [Medio círculo], 1790-1800. En Femmel [1958] 1972, IVb: 258

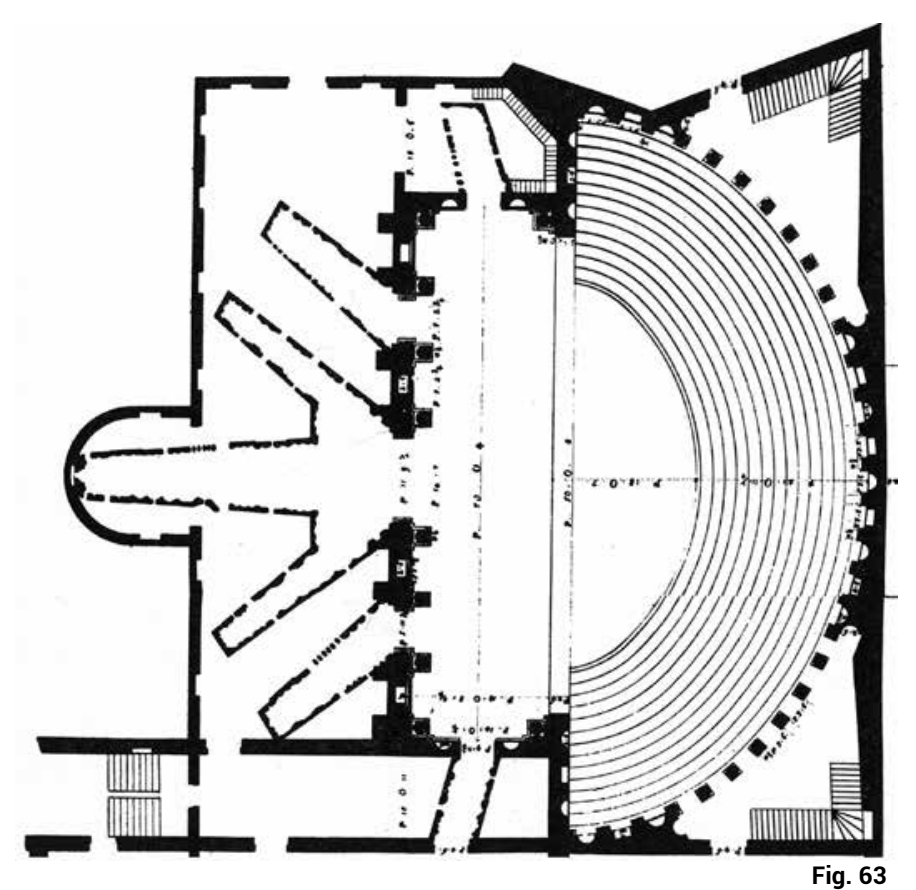




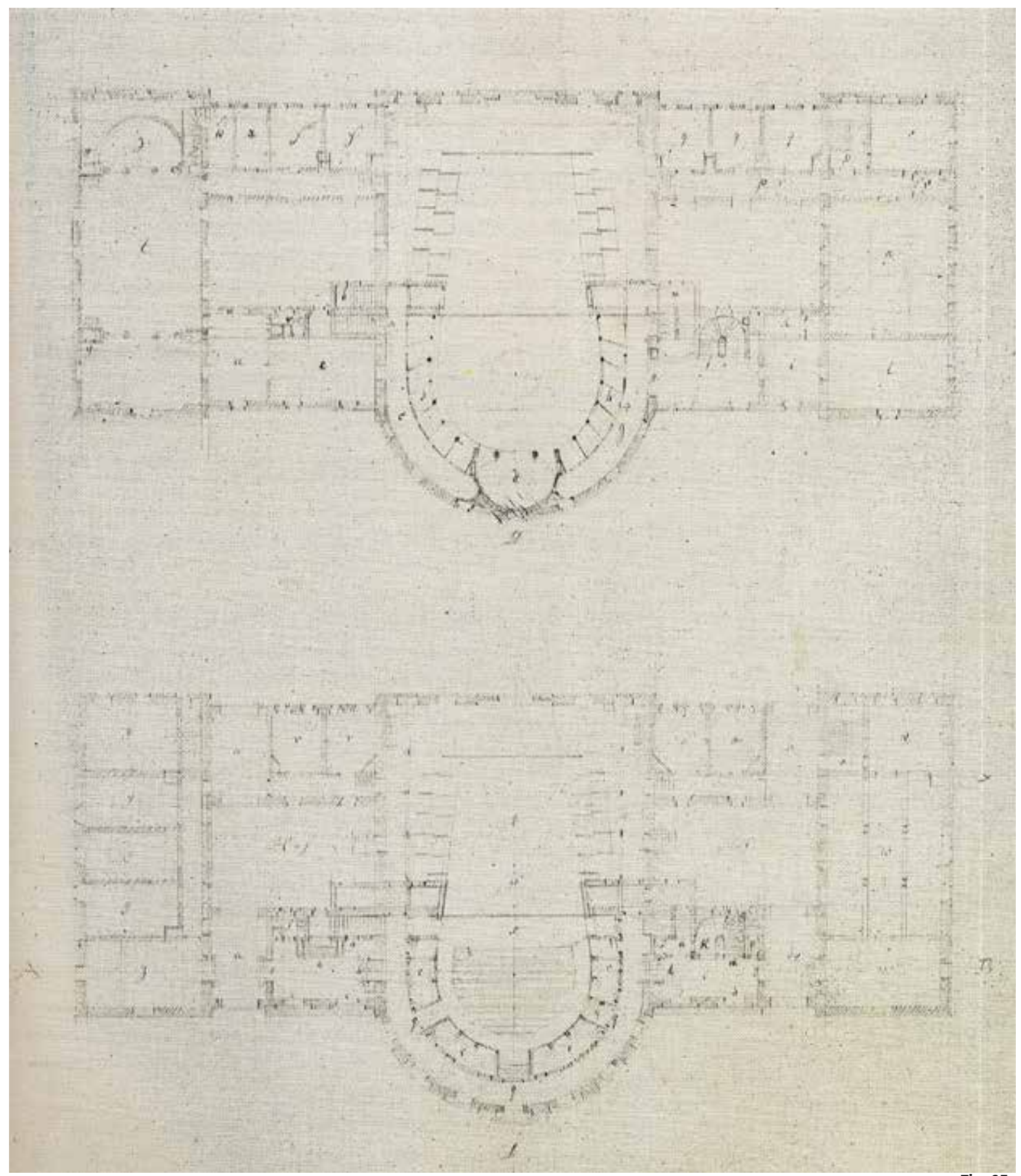




\section{... al proyecto de teatro.}

La noche del 22 de marzo de 1825 ardió el teatro de Weimar. Apenas dos días después, el jueves 24 según relata Eckermann, Goethe decía:

Con este incendio nos ha ocurrido una cosa notable. Pues habéis de saber cómo este invierno en las largas horas de las veladas me entretuve con Coudray en trazar los planos de un hermoso teatro nuevo adecuado a las exigencias y comodidades de Weimar. Repasamos los planos y diseños de los mejores teatros alemanes, y tomando lo mejor de todos ellos logramos uno que creo que vale la pena. (1991, III: 289)

\section{El domingo 27 de marzo Eckermann} escribe: "Goethe nos hizo ver el plano del nuevo teatro que, según nos anunciara el día antes, representaba un hermoso edificio, tanto por dentro como por fuera." (Goethe, 1991, I: 289). Según estas declaraciones en apenas cinco días Goethe y Coudray habrían completado el proyecto de teatro que debía sustituir al incendiado.

Se conoce también un dibujo de Goethe de una fachada de teatro con un pórtico central de columnas sobre un basamento y coronado con un frontón triangular, siguiendo una clara composición palladiana. Recuerda el pórtico tras el escenario de la fig. 59 y hace comprensible el desplazamiento de este volumen emergente ante el acceso desde esa situación a la fachada opuesta tras el muro curvo de la cávea.
Fig. 65. Goethe y Coudray Erster Entwurf zu neuem Weimarer Hoftheater [Primer proyecto para el nuevo teatro de Weimar], 1825. En Ewald 1999, fig. 64

Fig. 66. Johann W. Goethe Theaterfassade [Fachada de teatro], después de 1820. En Femmel [1958] 1972, Vla: 176

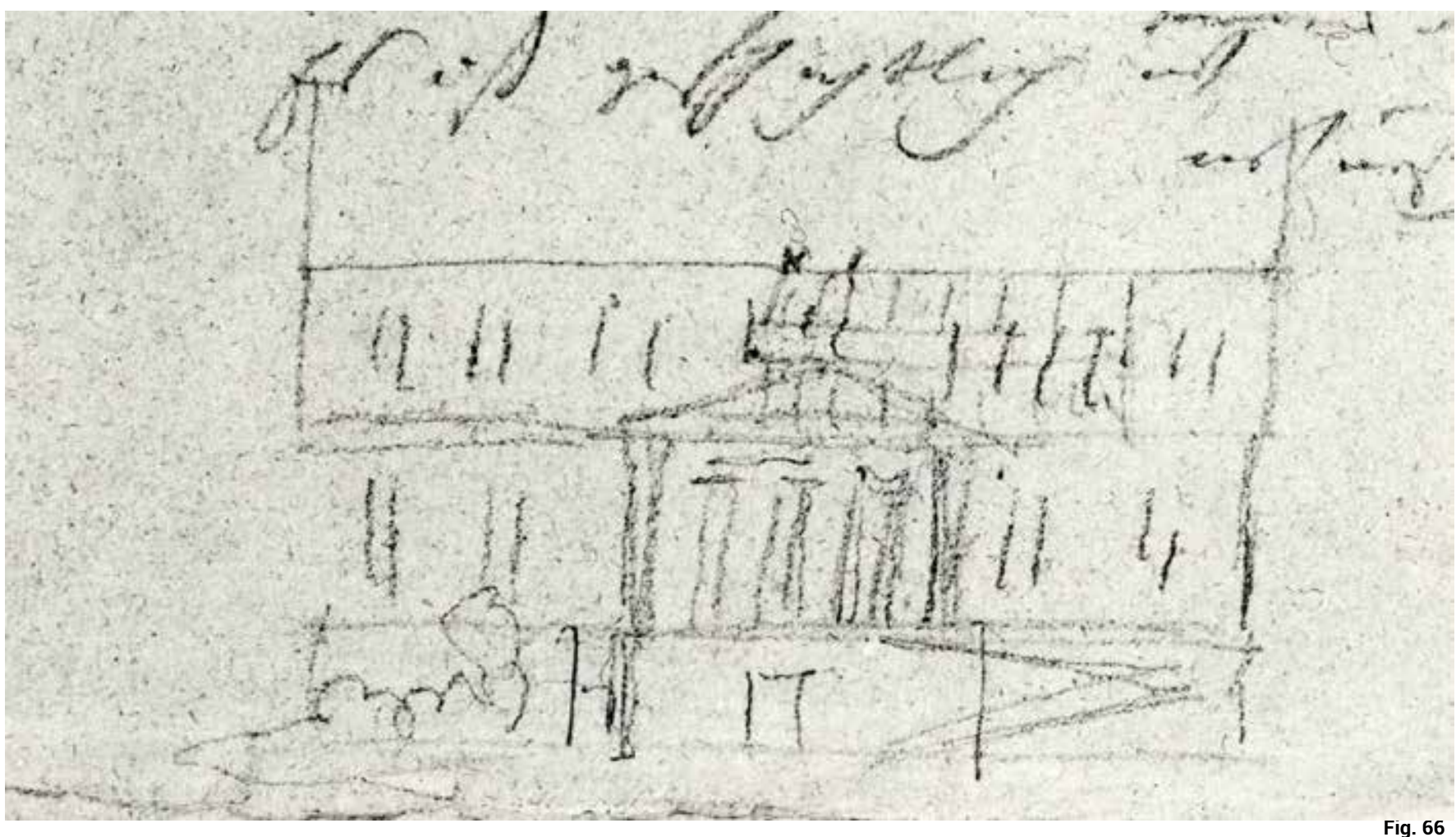


Fig. 67. Goethe y Coudray. Zweiter Entwurf zu neuem Weimarer Hoftheater, Ansicht [Segundo proyecto para el nuevo teatro de Weimar, alzado], 1825. En Ewald 1999, fig. 67
A diferencia de los dibujos antes comentados, ahora el teatro proyectado asume toda una serie de demandas propias de las representaciones del momento. A ambos lados del cuerpo central formado por el patio de butacas y la profunda escena con sus bambalinas, se despliegan dos grandes alas laterales que funcionan como foyer con sus salones, y como vestuarios y almacenes para las tramoyas y decorados. Goethe explica así su propuesta:

\section{Los dos palcos de detrás de las butacas y los pocos bancos que había, resultaban insuficien- tes. Pues bien: a esa falta hemos proveído no- sotros colocando una serie de palcos alrededor del patio de butacas y otra en el segundo piso, entre el balcón y la galería. Gracias a lo cual, sin aumentar apenas las proporciones de la sala, logramos habilitar las localidades necesarias. (1991, I: 288-289)}

Bien porque esta solución fuese insatisfactoria (al duplicar los accesos a los dos laterales del patio de butacas), bien por intrigas de la corte (que aspiraba a un teatro a la moda, impugnando por ejemplo el volu- men curvo emergente del patio de butacas), pese a que fue modificado dando lugar a un tercer proyecto, finalmente, con las obras ya empezadas, este proyecto fue definitivamente rechazado (Ewald, 1999: 153). Fue el hijo del arquitecto de la corte Carl Friedrich Christian Steiner quien asumió el proyecto definitivo (Ewald, 1999: figs. 65 y 66). El domingo 1 de mayo, le decía Goethe desilusionado a Eckermann:

Sea como fuere, tendréis un teatro pasadero, no según yo lo había deseado y pensado. Irá usted a él y también iré yo; y aquí no ha pasado nada. El gran duque -siguió diciendo Goethe- me dijo que, a juicio suyo, un teatro no tenía que ser ninguna maravilla arquitectónica, en lo que no le falta razón en términos generales. Además que, según él, se trataba de un establecimiento para sacar dinero, y esta opinión que, a primera vista, parece tan prosaica, no deja de tener, si bien se mira, su lado elevado. (1991, I: 295)

Se frustraba, así, el esfuerzo más importante de Goethe en la esfera de la arquitectura teatral.

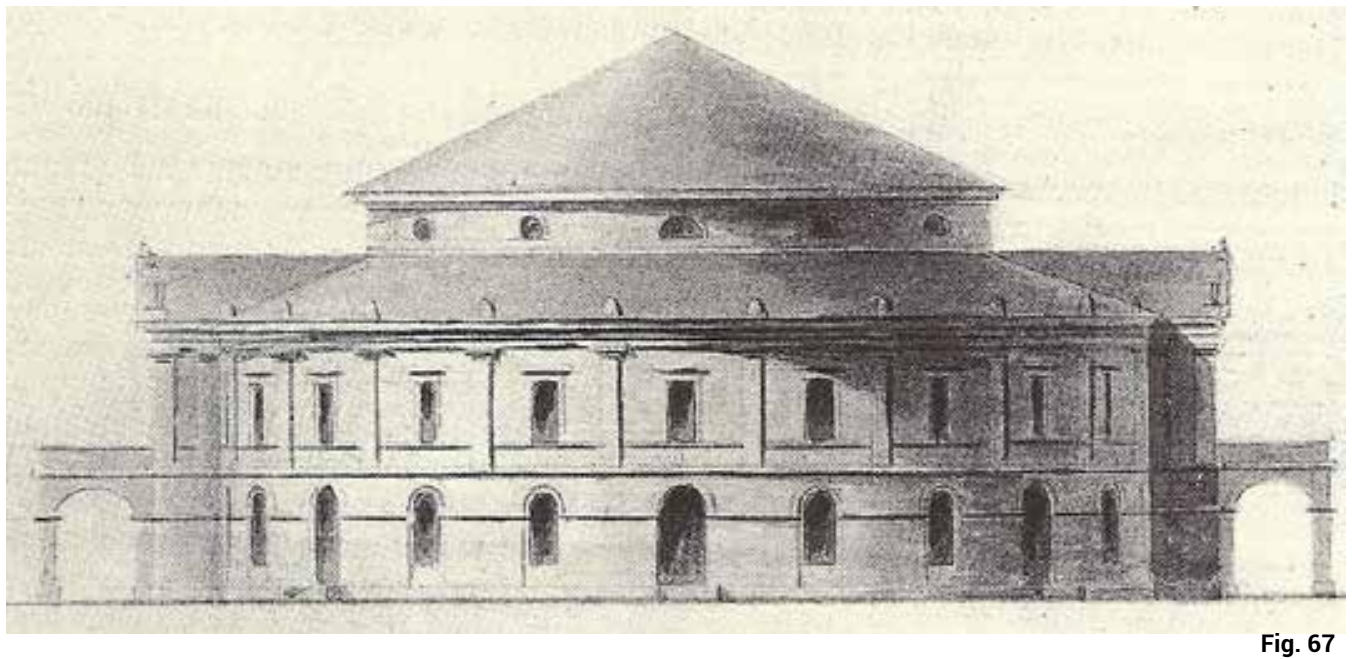




\section{La escenografía}

La vocación de Goethe como dramaturgo y dibujante originaba una doble conexión entre el texto y las imágenes escenográficas que lo arropan: por un lado, al escribir una obra, las situaciones dramáticas se concretaban a la vez en palabras e imágenes; $y$, por el otro, al representarla, los actores se movían por la decoración que proyectaba.

Sus dibujos del tipo teatral manifiestan su adscripción vitruviana tamizada por el teatro Olímpico de Palladio, adaptando el modelo antiguo a las necesidades de las representaciones modernas. Además, sus conocimientos como dramaturgo y gestor del teatro de Weimar le hacían experto en arquitectura teatral, lo que se puso de manifiesto en el proyecto realizado con el arquitecto Coudray para el nuevo Weimarer Hoftheater en 1825 (Ewald, 1999: fig. 64).

Pero esa vinculación con Vitruvio vía Palladio, resultaba problemática en la configuración del escenario. A este respecto Goethe escribía al Duque Carl August el 15.08.1797:

\section{La escenografía [theatralische Baukunst] debe ser ligera, limpia, variada, y debe representar lo magnífico, elevado, noble. Las decoraciones tie- nen que hacer sobre todo cuadros, en especial el fondo de escena, el decorador tiene que ir un paso más allá que el pintor de paisajes, el cual también sabe modificar la arquitectura según su necesidad (2004: 6182 y ss.)}

Con esta postura Goethe estaba, en gran medida, obviando las directrices de Vitruvio así como la solución de Palladio.
De la arquitectura real a la ficticia

Vitruvio es confuso cuando al tratar del teatro habla del escenario y los decorados. Por un lado en el libro $V$ describe el fondo de la escena (frons scænæ) como una arquitectura de columnas y órdenes superpuestos (1995: 206). Pero luego comenta que en el escenario habrá unos espacios previstos para los decorados que se cambian según la pieza representada (1995: 207). Además, en la introducción del libro VII alude de nuevo a los decorados teatrales explicando que en ellos se representan edificios pintados en perspectiva (1995: 257). Así pues, Vitruvio menciona dos fondos del escenario diferentes: una arquitectura construida con arcos y puertas de acceso al proscenio, como mostraban los restos arqueológicos, y unos decorados pintados según el tipo de espectáculo: trágico, cómico y satírico, de los que no existían pruebas, aunque se aceptaban por lo recogido en el tratado.

La simultaneidad de ambos tipos de escenarios alternativos, estructura arquitectónica real y decorado pintado, era problemática. El Renacimiento se decantó por el decorado pintado en perspectiva como fondo escénico (Damisch, 1997) obviando la arquitectura real, tal como se encuentra en los trabajos de Peruzzi (Fagiolo y Madonna, 1987) y en el tratado de su discípulo Serlio. ${ }^{698}$ Palladio, por el contrario, en su ilustración del Vitruvio de Barbaro y en su teatro Olímpico proyectó un frons scænæ como una fachada arquitectónica por cuyas embocaduras aparecen calles en trampantojos en perspectiva (fig. 68) intentando compatibilizar las dos exigencias vitruvianas.
698. Para las escenas teatrales de Serlio, S. (1982), Libro segundo de arquitectura: sobre la perspectiva, cap. III; fol. 25 anverso: Escena cómica, reverso: Escena trágica; fol. 26, anverso: Escena satírica. Damisch (1997: 180) desarrolla esta cuestión analizando el "problema de los procedimientos por los cuales se podía pasar de una perspectiva totalmente imaginaria [...a...] la del teatro [...] con una profundidad y volúmenes reales." 

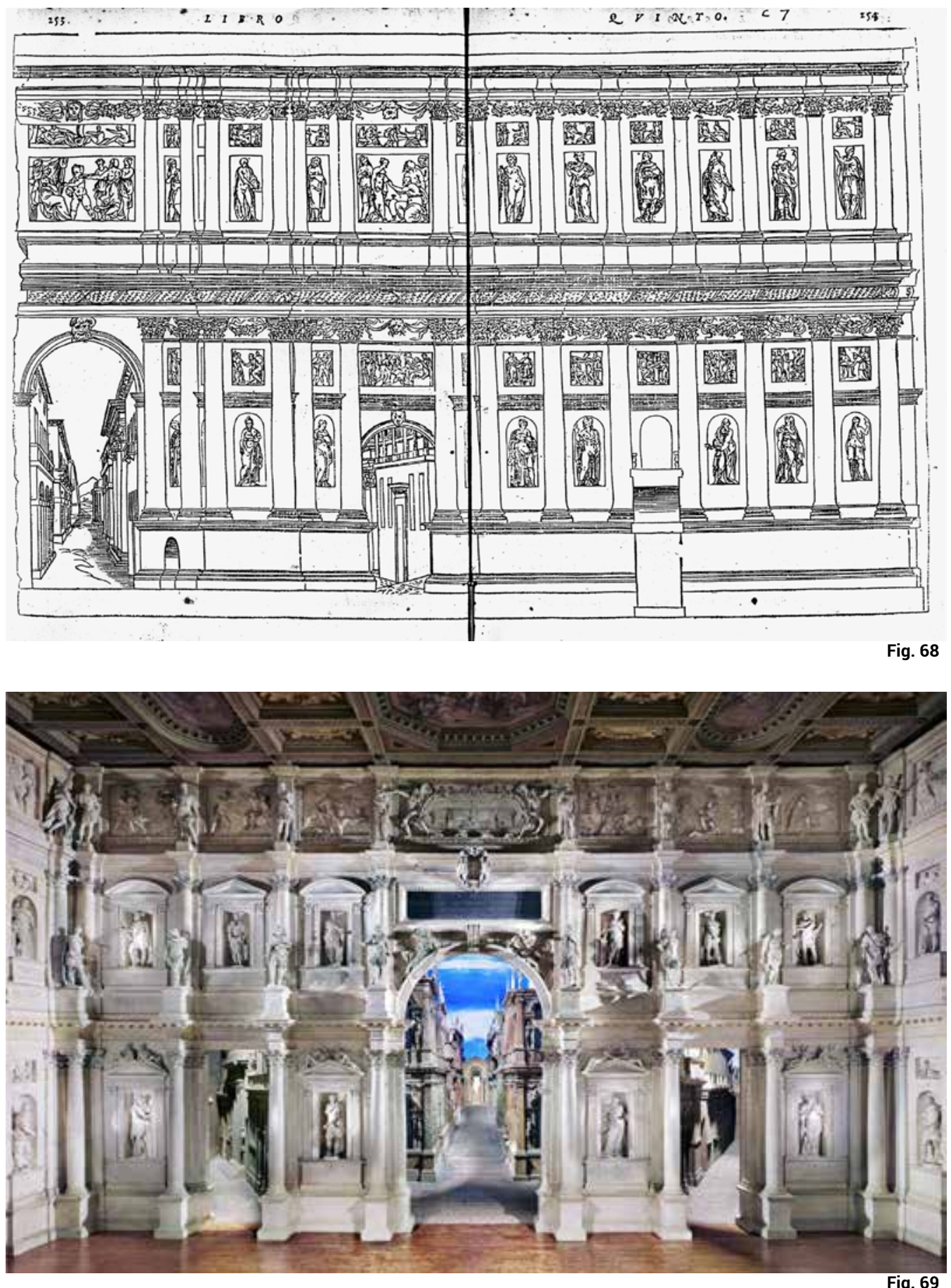
Inicialmente Goethe consideraba el frons scænæ como parte del edificio teatral siendo, por lo tanto, una única y permanente escenografía cualquiera que fuera la obra representada. Por ejemplo, en los dibujos escenográficos para la representación de su tragedia Eginhard (IVa: 126 y IVb: 229 rs) (Fig. 70) el croquis con su arquitectura simétrica real del fondo del escenario y el ábside elevado al que se accede por una escalinata recrea el ambiente regio de un salón, posiblemente el del trono de Carlomagno dado el argumento de este texto. En esta obra y otras similares como en la obra El sueño de una noche de verano de Shakespeare (Fig. 71) la estructura arquitectónica permanente del fondo era la escenografía idónea.

Pero esto no era lo habitual. Por el contrario, la arquitectura escénica permanente solía ser inapropiada a las historias representadas en cada ocasión. En consecuencia, la incompatibilidad entre el frons scænæ arquitectónico y los decorados efímeros experimentó un proceso evolutivo intentando superarla. Aunque en el teatro Olímpico palladiano el espacio adquiere profundidad visual con las perspectivas forzadas tras las aperturas del frente escénico, la superficie útil para la representación queda constreñida al proscenio delante del muro del fondo. En el

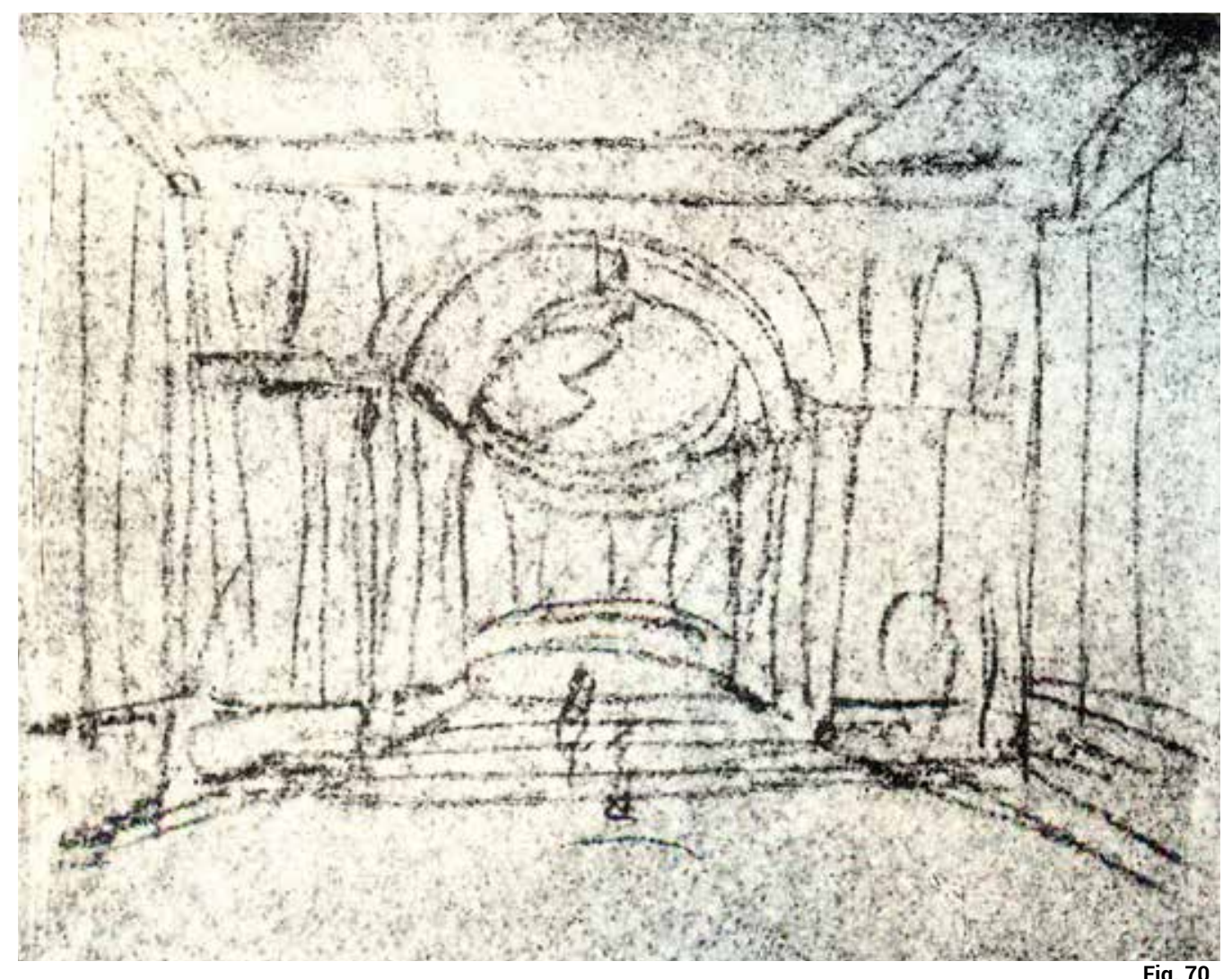

Fig. 68. A. Palladio. Frons scænæ del teatro, 1567. En Barbaro, 1567: 253-245

Fig. 69. Palladio y Scamozzi Escenario del Teatro Olímpico de Vicenza, 1580. Fotografía de Candida Höfer, Teatro Olimpico Vicenza II 2010, Ben Brown Fine Arts

Fig. 70. Johann W. Goethe. Szenischer Entwurf zu der nicht vollendeten Tragödie "Eginhard" aus der Zeit Karls des Großen [Proyecto escénico para la inacabada tragedia „Eginhard" en tiempos de Carlomagno], 1807/08. En Femmel [1958] 1972, IVb: 219 rs. 
Fig. 71. Johann W. Goethe. Zwei Skizzen zu einer „Einheitsbühne" für Fr. Tiecks Inszenierung von Shakespeares "Sommernachtstraum" [Dos bocetos de una "escena única" para la escenificación de Fr. Tieck del "Sueño de una noche de verano" de Shakespeare], después de 1828. En Femmel [1958] 1972, IVb: 221 teatro de Sabbioneta de Vincenzo Scamozzi (1588-1590) se eliminó el fondo arquitectónico y el escenario ganó profundidad para el espectáculo. Desde entonces ese espacio fue aumentando, convirtiéndose en un gran contenedor neutro apropiado para cualquier función y los decorados pintados desmontables generaban la ilusión ambiental pertinente. En el teatro Farnese de Parma (1618-1628) Aleo- tti planteó una nueva solución de compromiso. El recuerdo del fondo de escena arquitectónico se convirtió en una gran estructura que dejaba en su centro una abertura de la anchura del proscenio, como si la Puerta Real que señala Vitruvio abarcase toda la embocadura del escenario. Así, finalmente, la escenografía se independizaba de la arquitectura del edificio pudiendo discurrir libremente por los

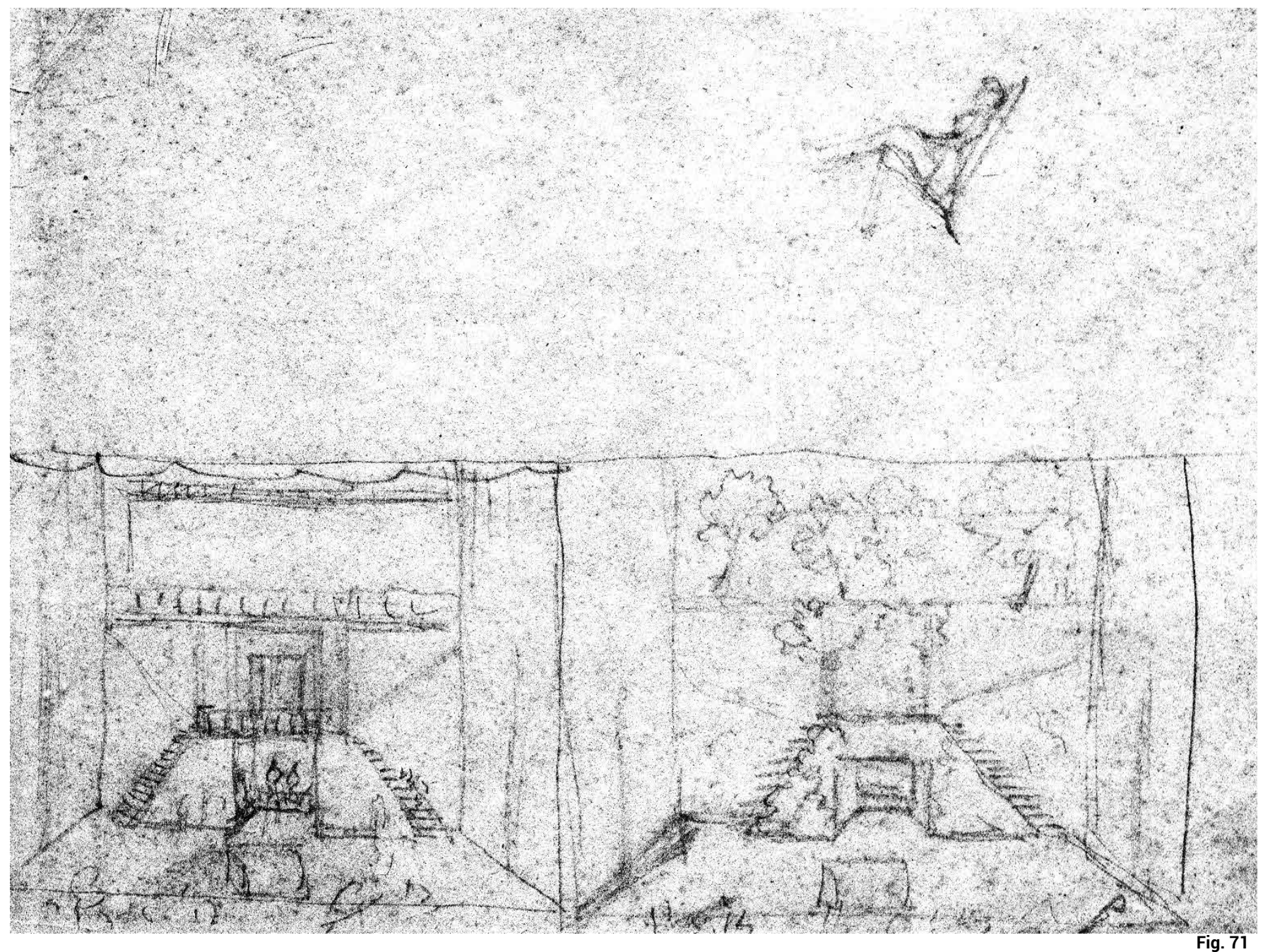


espacios ficticios de los decorados pintados según las necesidades de la obra representada. La arquitectura real del teatro y la ficción espacial creada por la escenografía divergían definitivamente.

Esta fue la vía que adoptó Goethe para el Weimarer Hoftheater: un escenario vacío y profundo preparado para cualquier montaje o decorado, por complejo que fuera. Una solución muy alejada ya del tipo vitruviano que el propio Goethe había ensayado en sus dibujos del edificio teatral antiguo pero que respondía a las necesidades de las representaciones del momento. Para Goethe la arquitectura teatral y el espacio escenográfico ficticio discurrían ya por cauces distintos.

\section{Más allá del pintor}

Si el pintor reproduce la realidad en sus cuadros, el decorador, según Goethe, le sobrepasa al duplicarla, construyendo un espacio real por donde se mueven los actores. Los decorados, escribió Vitruvio (1995: 257), deben conseguir la apariencia de auténticos edificios.

Goethe ideaba tanto las escenas de sus propias obras como las de los montajes teatrales que programaba, recogiéndolas en dibujos de decorados imaginados donde, a veces, aparecen los personajes actuando. En unos casos, la decoración recreaba ambientes reales como las casamatas del bastión de la Boccare de Verona (del ingeniero Leoni) (Fig. 72) cuyos dibujos le sirvieron como modelo para el salón de los Capuletos en su adaptación de Romero y Julieta de Shakespeare (Fig. 73).

En otras ocasiones levantaba en el escenario las ideas imaginadas por otros artistas como Piranesi recogidas en sus gra-
Fig. 72. Johann W. Goethe. Verona. Kassamatten der Bastion dell Boccare [Casamatas del bastión de la Boccare], 1790/1795. 93×162 mm. En Femmel [1958] 1972, Vla: 203

Fig. 73. Johann W. Goethe Theaterprospekt "Romeo und Julia" [Perspectiva teatral "Romeo und Julia"], 1812/1819. En Femmel [1958] 1972, Vla: 128

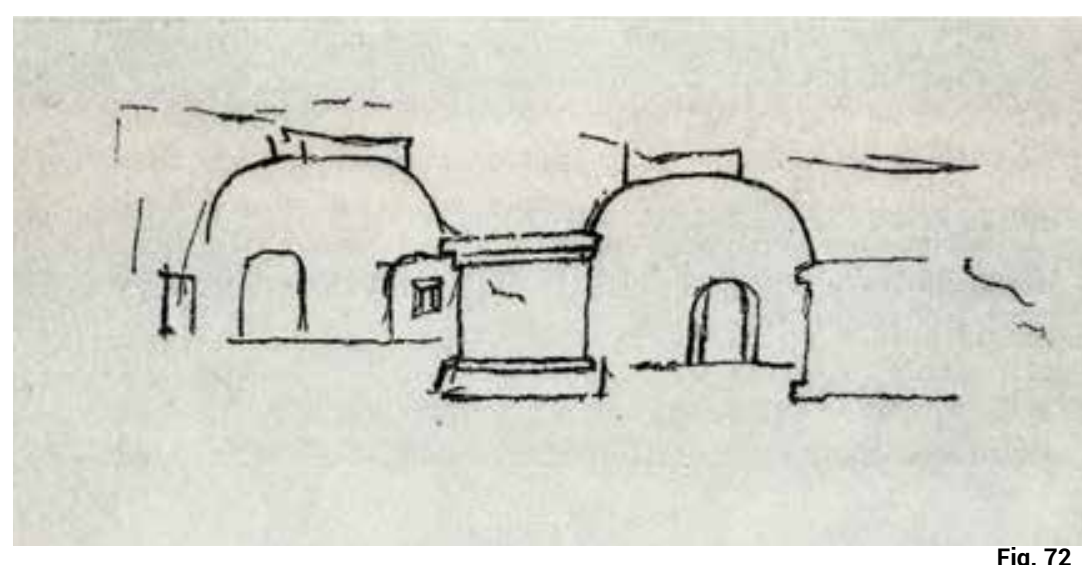

Fig. 72

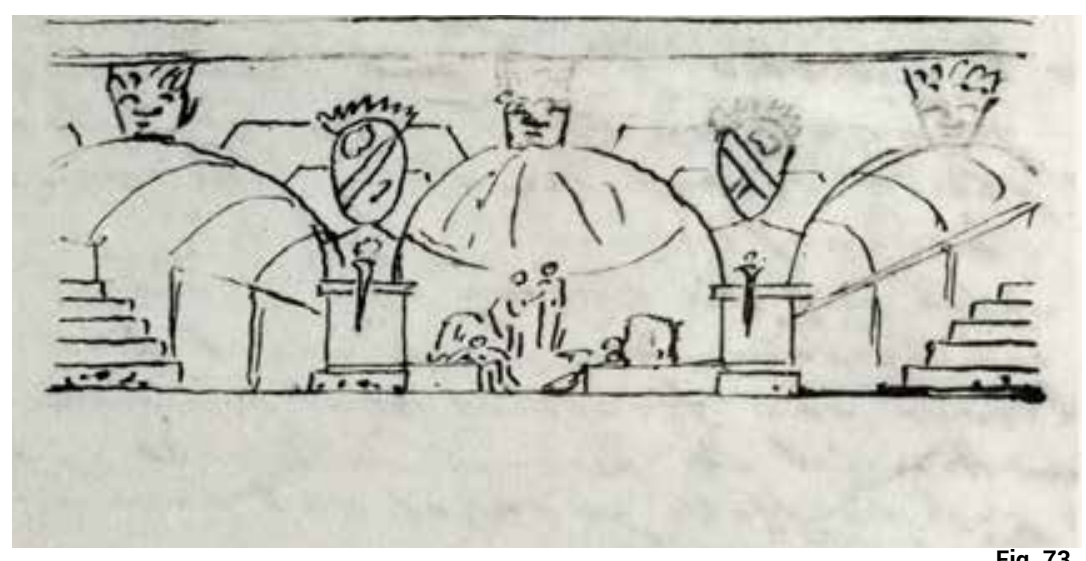


Fig. 74. Giovanni B. Piranesi. Campidoglio antico, 1743. En Ficacci, 2001: 61

Fig. 75. Johann W. Goethe Theaterprospekt [Perspectiva teatral], después de 1793. En Femmel [1958] 1972, IVb: 250 Fig. 76. Galli Bibiena. Architetture e prospettive (p. V), 1740 Fig. 77. Johann W. Goethe Theaterprospekt [Perspectiva teatral], 1800/1810. En Femmel [1958] 1972, IVb: 245

Fig. 78. Johann W. Goethe. Bühnenbildentwurf zu dem Singspiel "Die Liebe auf dem Dache" von Fr. J. (?) Fischer (Wahl)? [Proyecto de escenografía para el musical 'Die Liebe auf dem Dache'], 1807. En Femmel [1958] 1972, IVb: 214

Fig. 79. Johann W. Goethe Säulenstümpfe [Columnas truncadas], 1806/1810. En Femmel [1958] 1972, Vla: 169 bados (IVb: 250, IVb: 251 y IVb: 251 rs.) (Figs. 74 y 75). Así, la arquitectura dibujada hacía un recorrido inverso, yendo de la imagen a la realidad asumiendo un halo de verosimilitud en el espacio.

En el teatro barroco los personajes viven la angustia del desplazamiento del hombre del centro del universo. Recordemos autores como Shakespeare o Calderón admirados por Goethe. La perspectiva oblicua de Galli Bibiena (Fig. 76), cuyo libro tenía Goethe en su biblioteca (Ruppert, 1958: 339), trasladaba este enfoque al escenario. Goethe exploró las posibilidades y el significado que le brindaban esos decorados con vistas angulares (Arnheim, 1984) (Fig. 77).

Convertir en lugares físicos verdaderos y a escala real sitios y atmósferas imaginados en dibujos impulsó a Goethe a explorar decorados pintorescos, domésticos o misteriosos como fondo adecuado a dramas medievales (Fig. 78), aquelarres de brujas o ruinas clásicas. Los estilos vedados al arquitecto clasicista en edificios permanentes podían, sin embargo, servirle al decorador para sus fines en espacios efímeros.

La Fig. $\mathbf{7 9}$ posiblemente corresponde a la decoración tercera de El despertar de Epiménides de Goethe. En los paralipómenos enviados para orientar a Iffland el 24.05. 1814 , tras la decoración primera (un conjunto de edificios clásicos) y la segunda (edificios destruidos por el Demonio de la Guerra) describe la decoración tercera refiriéndose al Demonio de la Tiranía:

A su mandato cúbrase de verde la ruina; trepa la hiedra, brotan matas; musgo y hierba cubren las capas horizontales de la piedra. A espaldas de la casita templo yérguense cipreses, mejor dicho, todo un bosque.

(Aquí habrían de unirse el arquitecto y el paisajista para producir el efecto sorprendente y halagüeño. Se ha de procurar sobre todo, que se ensombrezca hasta el último rastro de alegría que pudiera quedarle a las ruinas. A discreción de los maestros se deja el disponer los efectos de luz). (1991, IV: 423)

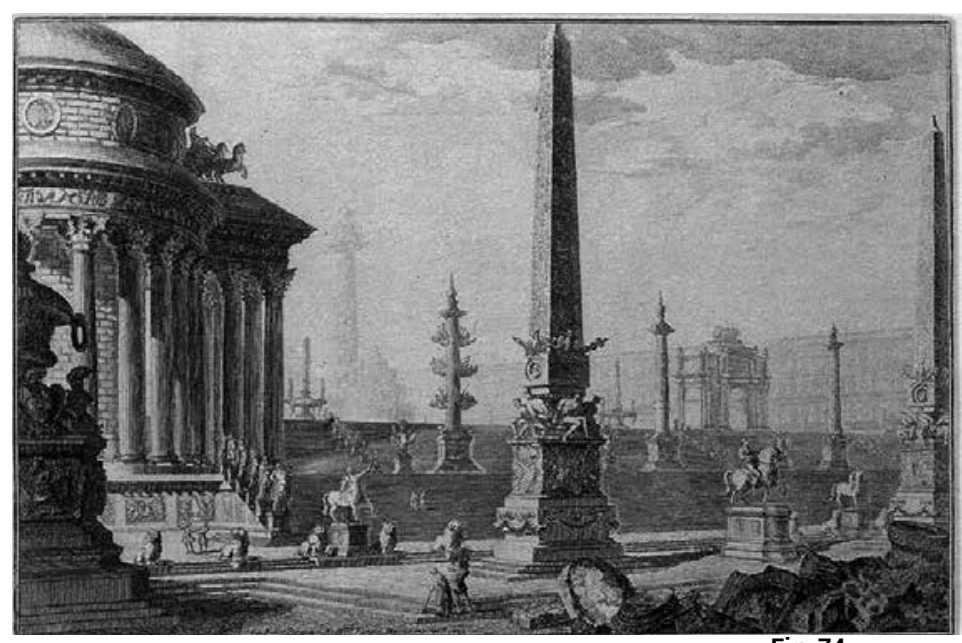

Fig. 74

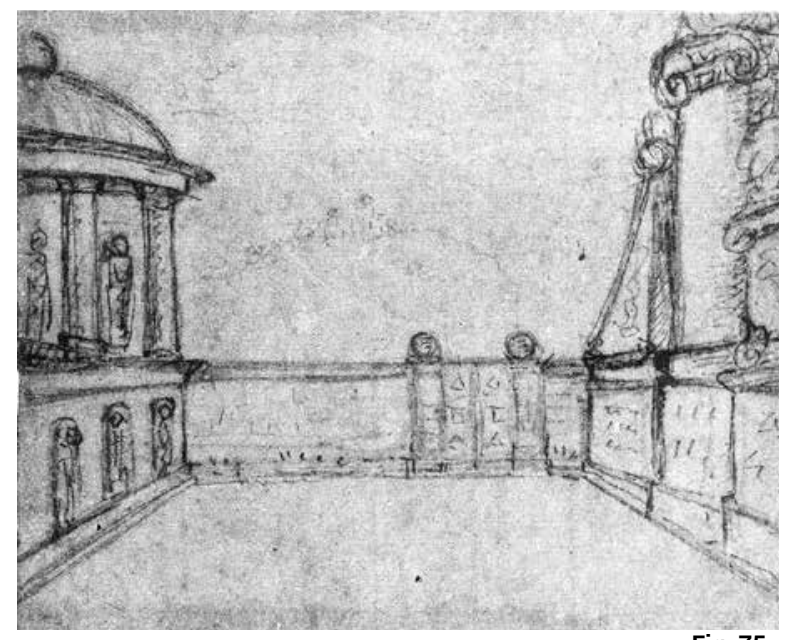

Fig. 75 

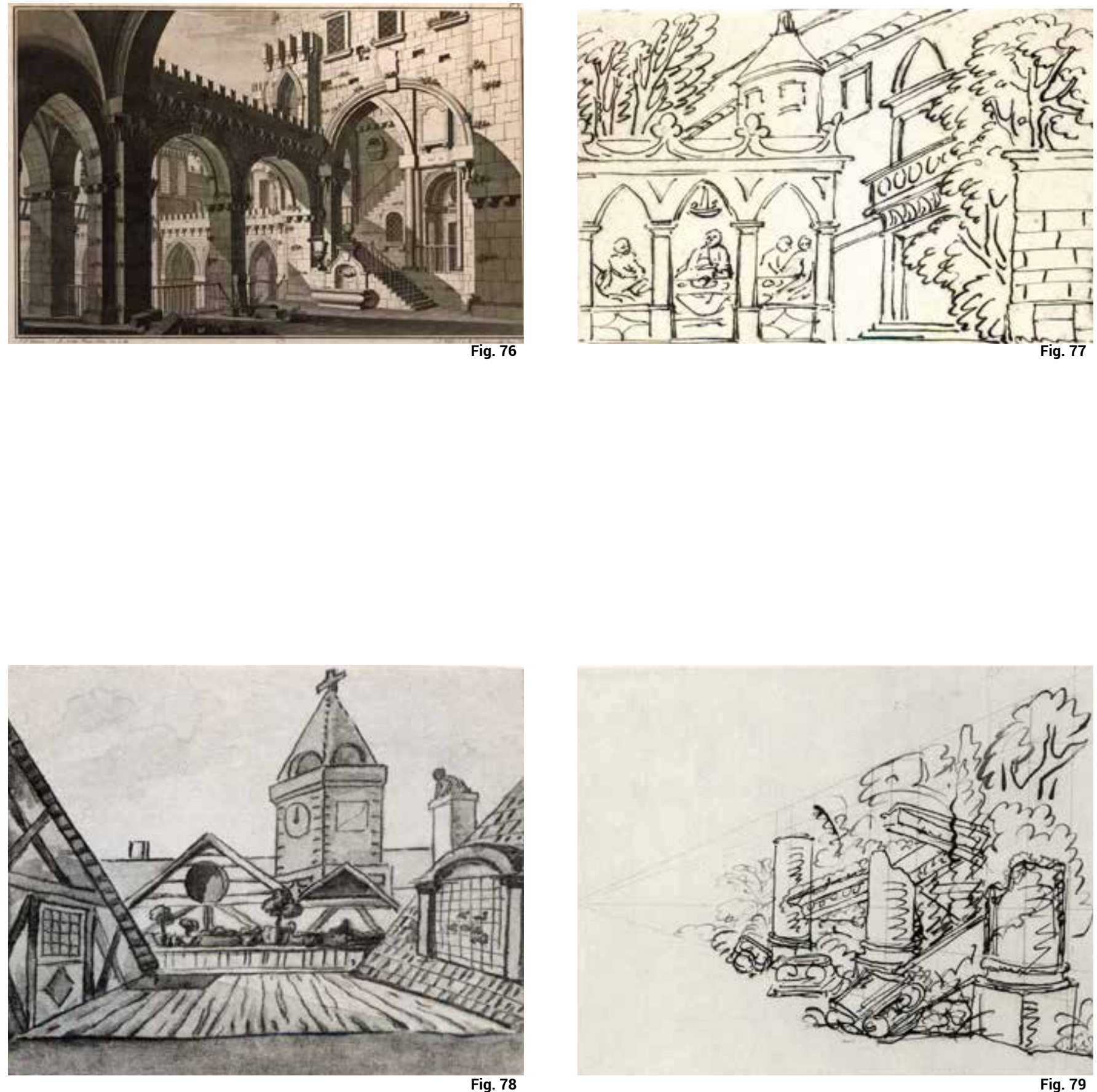
De la escena cuarta posterior escribe: "Pues en este preciso momento, merced a un acertado mecanismo, vuelve a restaurarse el edificio" (1991, IV: 425) de la escena primera desapareciendo las ruinas y la vegetación que las invadía. Algo que la decoración hacía posible ante los ojos asombrados de los espectadores que veían la transformación de las ruinas en edificios en sólo unos minutos con el simple cambio de decorado.

La extensa dedicación al dibujo de Goethe le condujo a orientar su experiencia hacia aquellos montajes escenográficos que hiciesen factible cualquier espacio representado en el papel. Tal vez a esta posibilidad de traspasar el límite de la representación gráfica haciéndola realidad construida sobre el escenario es a lo que se refiere cuando escribe que "el decorador tiene que ir un paso más allá que el pintor de paisajes".

En lo que a la escenografía se refiere, Goethe se aleja de Vitruvio al no asumir sin más el carácter arquitectónico del fondo de escena. En sus bocetos teatrales, por el contrario, combina el uso de la arquitectura real para los fines dramáticos con el empleo de la tecnología más avanzada de su tiempo para reproducir efectos sorprendentes e inauditos ajenos a la arquitectura real que los acoge. Sin embargo, frente a esta postura, en sus estudios del tipo arquitectónico teatral, Goethe manifestó su adscripción a algunos de los principios establecidos por Vitruvio y recuperados por Palladio tales como: la forma semicircular del graderío y su característica inclinación (favoreciendo, entre otras, la proximidad a la escena), la reducción del espacio útil para la representación al proscenio ante el fondo escénico, la renuncia a palcos o la simplicidad volumétrica del edifi- cio emergiendo el semicilindro del graderío al exterior.

Sin duda el tipo arquitectónico recuperado por Goethe tenía incuestionables virtudes funcionales respecto del tipo barroco italiano que se había impuesto durante el siglo XVIII por Europa. Resolvía, entre otros, numerosos problemas de visibilidad y de acústica, adelantándose en cierta medida a su tiempo al anticipar la evolución protagonizada por la rebelión germana contra el teatro italianizante y que culminará en el Festspielhaus de Bayreuth (1872-1876, Richard Wagner, el arquitecto Otto Brückwald y el director de escena Carl Brandt). No obstante, su fórmula de escena sin arco de embocadura y sin profundidad impediría la celebración de obras en las que el mismo Goethe estuvo implicado como director, como autor y como decorador.

Esta aparente contradicción interna hace de la aproximación de Goethe a la arquitectura teatral un delicado compromiso entre su concepción de la arquitectura y de la escenografía. Hacia 1798, en ocasión de la reforma interior del teatro de Weimar, Schiller y Goethe discutieron sobre sus deseos de hacer un "teatro, como el teatro antiguo sin las decoraciones de los nuevos; únicamente con una arquitectura sencilla que permita múltiples escenarios." Se trataba, a fin de cuentas, de idear una construcción que gozase de la capacidad de transformación que le atribuía a la Urpflanze (planta primitiva) conteniendo en su interior toda la multiplicidad necesaria para su posible adaptación posterior sin la necesidad de recurrir a los decorados. La intuición moderna del espacio flexible capaz de incorporar actividades diferentes parece sobrevolar ese deseo. 


\section{Mito, naturaleza y arquitectura}

En ocasión de su viaje por Italia, siguiendo la ya instaurada tradición del Grand tour, Goethe quedó marcado por una llamativa terna en Sicilia. En primer lugar, una cierta predisposición mitologizante preside las descripciones de su estadía, recreadas años después en su Italienische Reise. Son múltiples las referencias literarias vinculadas a la mitología clásica que los paisajes, las anécdotas o los personajes le sugieren. En segundo lugar, incluye en su narración digresiones sobre geología, geografía y botánica, ejemplificando un vivaz interés por el estudio concienzudo de la naturaleza siciliana. Por último, en línea con sus previas vivencias en tierras transalpinas, Goethe se detiene en su correspondencia en pormenorizadas descripciones de sus experiencias artísticas. En el caso de Sicilia, destacan aquellas referidas a la arquitectura. Fruto de todo ello son, de hecho, obras literarias como su inconclusa Nausikaa, obras científicas como el arranque de Versuch die Metamorphose der Pflanzen zu erklären (1789/1790) o avances de su teoría de la arquitectura plasmada en el Baukunst (1795). De resultas, un vínculo oculto puede intuirse entre su aproximación a la naturaleza de la isla de Sicilia, su arquitectura y la presencia del mito. En el presente artículo se analiza esta inicial coincidencia temporal y geográfica con el fin de dilucidar si se pueden encontrar vínculos de mayor calado entre mito, arquitectura y ciencia.

\section{Sicilia: Goethe entre los Antiguos}

El 3 de septiembre de 1786, "a las tres de la madrugada", Goethe emprende el anhelado viaje a Italia. ${ }^{699}$ Tal y como él mismo confesaba en su transcripción años después, este viaje, además de cargado de esperanzas de reconquistar su motivación creativa tras su paso por la corte de Weimar, había constituido su más terrible pesadilla. ${ }^{700}$ Negó durante largo tiempo la necesidad de emprender el viaje, de suerte que pasó a ser tabú. Evitaba leer en latín, rehuía el contacto con aquellos que la visitaran, esquivaba las tan comentadas reproducciones de las antigüedades griegas y romanas... Con esta predisposición de espíritu parte el consejero áulico a tierras transalpinas, cargado de añoranza, nostalgia y esperanza. Tiene, además, este viaje el carácter de una huida, "pues de otro modo no habría podido salir de allí" (1958, V. It. III: 15). Es más, esta huida tiene "hasta la forma material, policíaca de tal: huye del consejero áulico Goethe al comerciante Jean Philipp Möller, que luego resulta ser un cuarentón aprendiz de pintura en Roma." (Ortega y Gasset, 1933: 33-34) $)^{701}$

Este cariz de irrealidad, esta construcción autoestimulada del carácter fantástico de su viaje, cobra especial dramatismo siete meses después del comienzo, a las puertas de la "reina de las islas". ${ }^{702}$ Goethe ha podido entretanto introducirse y profundizar en la cultura italiana, la historia del arte clásico, las escuelas de pintura florentina y veneciana,... Esta iniciación en ámbitos tan diversos culminó tras las seis semanas de estancia en Sicilia (29.03-15.05.1787): "Italia sin Sicilia no deja imagen en el alma; aquí es
699. Goethe intentó con anterioridad emprender en dos ocasiones este viaje. En una de ellas, llegó incluso a divisar desde Suiza la tierra italiana a sus pies. Por otra parte, y como buena muestra del impulso mitificador que sobrevuela el viaje, en su inconsumible intento de construirse a sí mismo Goethe localiza en su más tierna infancia la semilla de esta necesidad: al regreso de su periplo por el norte de Italia, su padre trajo abundantes imágenes en forma de relato, grabados que colgaron por la casa. Incluso le regaló una góndola de juguete. 700. Su Italienische Reise se basa en cartas y diarios escritos durante el viaje, y una serie de artículos publicados posteriormente. Su edición hasta alcanzar la composición definitiva se dilató (1816: primera parte y 1817: segunda parte, en la que incluye su viaje a Sicilia) hasta 1829, cuando Goethe suma un tercer apartado y lo titula en su versión definitiva como Italienische Reise, literalmente "El viaje italiano". Goethe regresará a Italia entre el 13 de marzo y el 20 de junio de 1790 en compañía de la gran duquesa. Esta vez visitó solo Venecia. Un tercer viaje fue planeado con Meyer para el verano del año 1795, pero en octubre de 1796 será abortado. Retomarán infructuosamente este proyecto en mayo de 1797. Más allá de la publicación de su diario de 
viaje, algunas de las más renombradas obras de Goethe son influencia directa de Italia. Tal es el caso de Römische Elegien, Venetianische Epigramme y Wilhelm Meister. petu realista del Sturm und Drang clasicismo residde mein Heil nur inductivos, de manera que "en que comunesmalesrespectivamen

701. Con intención de viajar de incógnito se presentaba a veces como el barón Von Müller, pintor alemán, se inscribió en Roma como Johann Philipp Möller, comerciante de Leipzig, y el 8.11.1786 escribe: "ahora me he transformado en el barón Rondanini" (1958, III: 90).

702. "Ya veremos hasta dónde llega el poder de esa reina de las islas" (1958, III: 150) 703. 0 incluso allende los límites europeos: "Sicilia me habla de Asia y África, y encontrarse en el punto maravilloso al que convergen tantos radios de la Historia universal no es ninguna pequeñez." (1958, III: 144).

704. «¿Quién podrá ser ese amigo que me anuncian con tanto misterio? ¡Con tal que no lo desatienda para mi odisea por las islas!» (1958, III: 137). Véase sobre las coincidencias entre Italienische Reise y la Odisea Peter Sprengel, "Sizilien als Mythos. Das Sizilienbild in Goethes Italienischer Reise" (Albert Meier (ed.), 1987: 159-179).

705. De hecho, el conjunto de la publicación está imbuida por esta predisposición mitologizante. Goethe encabeza la edición definitiva de Italienische Reise con el moto "Et in Arcadia ego" [Yo también en Arcadia], vinculando explícitamente su experiencia en tierras transalpinas con el legado de la literatura idílica del XVIII. Lo interesante aquí es resaltar el hecho de que Goethe reivindique su derecho a considerarse "en" esa tierra mitológica. Sobre el vínculo de la experiencia concreta de su viaje con el mundo mitológico se regresará en el último apartado.

706. Respecto a Caltanisetta, Goethe reconoce que "hubiéramos querido disponer del carro alado de Triptolemo para huir de aquella monotonía" (1958, III: 180). Enna es donde se dio el rapto de Proserpina (1958, III: 182). Evitan hospedarse en El León de Oro, siguiendo la recomendación de una inscripción que dice así: "Viajero, sea quien fueras, guárdate en Catania de la posada El León de Oro, pues es peor que si cayeres en las garras de cíclopes, sirenas y escilas, todos juntos" (1958, III: 184)

707. Según el mito, las rocas que el tuerto Polifemo arrojó contra Ulises (1958, V. It. III: 189) 708. De nacimiento Giuseppe Balsamo, hijo de un arruinado artesano de Palermo, Cagliostro viajó por toda Europa adquiriendo las más variadas y excéntricas identidades. Las indagaciones de Goethe se llevaron a cabo en Palermo durante los días 13 y 14 de abril siguiendo la pista primero de rumores y, posteriormente, consultando la memoria elaborada por un jurisperito por encargo del gobierno francés. Llegó incluso a visitar a su familia (1958, V. It. III: 163-169)

709. Presentará años después un estudio sociológico para la Freitagsgesellschaft (impreso en Neue Schriften I, 1792) y, por último, escribirá la obra Kophtischen Lieder transformada en la comedia en prosa Der Groß-Cophta (1792), la referencia más importante del tratamiento de la figura de Cagliostro en Goethe (von Wilpert, 1998: 157-158). Se inicia así con Goethe (y con la obra de Schiller Der Geisterseher, 1789) una rica tradición literaria que tomará a Cagliostro como referente, de la que participan autores como Alexandre Dumas, Orson Welles o, más recientemente, Umberto Eco.

710. "Dich verwirret, Geliebte, die tausendfältige Mischung / Dieses Blumengewühls über dem Garten umher; / Viele Namen hörest du an, und immer verdränget / Mit barbarischem Klang einer den andern im Ohr. / Alle Gestalten sind ähnlich, und keine gleichet der andern; / Und so deutet das Chor auf ein geheimes Gesetz." Se trata de los seis primeros versos del poema „Die Metamorphose der Pfanzen zu erklären”, elaborada entre el 17 y 18 de junio de 1798. donde está la clave de todo." (1958, V. It. III: $144)^{703}$

Goethe se refiere a Sicilia siempre con un halo de misterio, de incertidumbre. Confiesa, a la espera de fijar su fecha de partida desde Nápoles (y más allá de su confesado miedo a los viajes marítimos) que en lo "Tocante a mi viaje a Sicilia, aún está la balanza en manos de los dioses; la manecilla oscila acá y allá." (1958, V. It., III: 137). Sicilia es, desde el puerto, una visión lejana; el mar es el umbral que ha de cruzar para emprender su "odisea por las islas", dice en una ocasión. El parecido con Ulises cuando se ve cautivado por los encantos de unas ninfas en una isla paradisiaca y llega a olvidar su casa es intencionado. ${ }^{704}$ Tan es así que a su regreso a la península confesará que, a raíz de su experiencia en Sicilia, "por primera vez esa palabra de Odisea cobra para mí vida." (1958, V. It. III: 205).

Durante su estancia, en múltiples ocasiones Goethe relaciona sus experiencias con los grandes mitos de la Antigüedad. ${ }^{705} \mathrm{Se}$ refiere a Triptolemo para evadirse del tedio en Caltanissetta, al antiguo Enna, desconfía al tiempo que sigue las recomendaciones de un "bienintencionado admonitor" en Catania pese a "haber exagerado algo mitológicamente el peligro", por mencionar algunas. ${ }^{706}$ Incluso, por momentos, el mito se hace realidad y basta atender a lo real para remitirse a lo mitológico, como cuando a los pies del Etna tuvieron ocasión de aproximarse por mar a las rocas de Jaci, los siete Scogli de Ciclopi. ${ }^{707}$ No sin frustración, Goethe tuvo que renunciar a tan premonitoria excursión, en la que -no casualmente- esperaba profundizar en sus conocimientos de geología. 
Muestra de esta predisposición mitologizante es la manera en la que Goethe se enfrenta a la biografía del conocido timador, charlatán e impostor Cagliostro (1743-1795). Esta figura interesó a Goethe desde 1781 por su atribuida personalidad demoníaca en contraste con las olas racionalizadoras de su tiempo. Cual si de una "aventura" detectivesca se tratase, en sus propios términos, se recrea en pormenores relativos a su indagación sobre su vida y su familia en ocasión de su visita a Palermo con una identidad falsa. ${ }^{708}$ Basándose en estas pesquisas, Goethe abocetará la ópera Die Mystifizierten (tal y como anuncia a P. C. Kayser el 14.08.1787). ${ }^{709}$ Pero en lo que aquí es relevante, se manifiesta una vez más la conjunción en Sicilia para Goethe entre lo ficticio y lo real en un sentido mítico $y$, tal y como se apuntará en lo que sigue, una decidida predisposición hacia el estudio científico del mismo fenómeno.

\section{Arte y naturaleza: la idea de arquetipo}

Te desconcierta, amada, la mezcla infinita De esta multitud de flores en torno al jardín. Escuchas muchos nombres y siempre suprime Con bárbaro sonido el uno al otro. Similares son Todas las formas y ninguna a otra se asemeja. $\mathrm{Y}$ así apunta el coro hacia una ley secreta. ${ }^{710}$

Durante su juventud, en sintonía con el pensar prerromántico del Sturm und Drang, para Goethe la naturaleza era una totalidad que se aprehendía desde la experiencia. Con claras resonancias de la obra de Herder, aunque también de Rousseau, Klopstock y Ossian, en este periodo la atención de Goethe no se volcó en fenómenos singulares de la naturaleza. No cabe encontrar estudios pormenorizados, ni siquiera recreaciones literarias de sus particularidades en esta época. La naturaleza le interesaba como un todo del que el ser humano es parte, al que le insufla su fuerza por medio de los sentidos y por medio de la cual puede reencontrar su yo íntimo. Una buena muestra de esta paradigmática reacción germana a la Ilustración (francesa) puede encontrarse en el Die Leiden des jungen Werthers (1774).

En contraste, casi dos décadas después, Goethe publicó Versuch die Metamorphose der Pflanzen zu erklären (1789/1790). En su aproximación a la naturaleza ahí plasmada, Goethe sintetiza la transición hacia el reconocimiento de un orden natural que todo lo rige. Recuérdese la influencia que en sus estudios de botánica tuvo el sistema de clasificación de las plantas de Linneo. Goethe ya conocía desde 1765 su obra (probablemente la publicación Systema natturae, 1751), que pudo estudiar junto con el profesor C. G. Ludwig en Leipzig. ${ }^{711}$ A partir de noviembre de 1786 sus estudios de botánica se intensifican. Centra su atención en el Philosophia botánica (1751), que llevará consigo al viaje a Italia y al que se refiere con el significativo apelativo "mein Linné" en sus múltiples referencias recogidas en Viajes italianos. Su aproximación a la naturaleza durante el viaje está, pues, fuertemente mediada por estas lecturas y aporta las claves de este crucial giro en su concepción de la naturaleza. ${ }^{712}$ Fundamentalmente Goethe identifica en la hoja de una planta la clave de la ley con arreglo a la cual toda la diversidad de la planta se manifiesta (cotiledón, tallo, nudos, flores y fruto) (Fig. 80).
Será publicada en 1800 en el grupo de elegías de la Neuen Schriften.

711. Goethe menciona en "Poesía y verdad" (parte II, libro $\mathrm{VI}$ ) sus estudios de infancia sobre historia natural, de entre cuyos autores destaca Haller, Linneo y Buffon (1958, II: 1604).

712. Más tarde incluso escribirá sobre la influencia de Linneo en su teoría de la metamorfosis de las plantas en una carta a Zelter del 07.11.1816 y en el ensayo Der Verfasser teilt die Geschichte seiner botanischen Studien mit de 1817.

Fig. 80. Johann W. Goethe. Durchgewachsene Rose [Rosa en crecimiento], principio del XIX. En Femmel [1958] 1972, Vb: 122. Correspondiente al capítulo $\mathrm{XV}$ (§103 y §104) de Versuch die Metamorphose der Pflanzen zu erklären 
713. La intención de Goethe al desarrollar la teoría de la metamorfosis no es la de encontrar el origen de la evolución de las plantas, en un sentido por ejemplo darwiniano. Señala en cambio una forma específica de conformidad a leyes. En su acepción germana, pues, el prefijo Ur- de Urpflanze no adquiere un significado cronológico, sino más bien procesual o si se prefiere generalizante. Las traducciones más extendidas al castellano, "planta originaria" o "planta primitiva", inducen por tanto a error. En su lugar sería más preciso hablar de "planta arquetípica". La cita completa es: "Allí [en la playa de Nápoles] se me deparó una buena ilustración sobre temas de Botánica. Le ruego [von Stein] diga a Herder que pronto habré dado con la planta primitiva, temiéndome tan sólo un nadie querrá reconocer en ella el resto del mundo vegetal. Mi famosa teoría de los cotiledones está ya tan sublimada, que sería difícil ir más allá." (1958, V. It. III: 144).

714. Las cursivas no están en el original. La búsqueda de la planta primitiva se sustenta, pues, inicialmente en una intuición bajo el marco teórico proporcionado por su estudio del Linneo. En ello insistirá en el jardín botánico de Palermo el 17 de abril: "A la vista de tantas nuevas y renovadas formas vegetales volvió a acometerme otra vez
De esta forma única proviene el resto por medio de la transformación surgida de su crecimiento. Esta transformación recibe el apelativo de "metamorfosis" y se rige por una ley única en todo el dominio de las plantas, la "ley secreta" que vincula la singularidad de cada parte a la organicidad del conjunto. Y, al igual que en un progenitor pueden reconocerse los rasgos de su descendencia, cual transmisión de un código de identidad, en el arquetipo se puede "reconocer [...] el resto del mundo vegetal". ${ }^{713}$

Opera así el arquetipo a dos niveles: individualmente, proporciona una ley que da coherencia interna a cada planta; sistémicamente, vincula genealógicamente al mundo vegetal. Es, en suma, el medio para compren-$$
\text { veral. En suma, el medio para compren- }
$$

der el fenómeno: son las ideas creadoras que guían a la naturaleza; el medio para poder apropiarse por la razón de la multiplicidad de lo real, poder hacerse cargo del mundo en su pluralidad de manifestaciones. Así lo resumía enfáticamente:

Me acuerdo muchas veces de Rousseau y de sus hipocondríacas lamentaciones, y, sin embargo, comprendo cómo pudo descentrarse organismo tan hermoso. De no sentir yo tanto interés por las cosas de la Naturaleza y ver que en la confusión aparente puede compararse y ordenarse centenares de observaciones, al modo como el agrimensor prueba con una diagonal muchas mediciones aisladas, más de una vez me tendría a mí mismo por loco. (1958, V. It. III: 138) 
Puede aplicarse en el estudio de las plantas, los fenómenos geológicos y meteorológicos, las formas de las nubes... Y en el arquetipo cabe reconocer el conjunto de lo real que de él deriva por medio de la ley que en este se manifiesta paradigmáticamente. Así lo intuyó inicialmente en el jardín botánico de Padua:

Aquí, en medio de esta nueva diversidad que se me ofrece, vuelve a cobrar cada vez mayor vida en mí esa idea de que quizá todas las formas vegetales se deriven de una sola. Sólo con arreglo a ese criterio sería posible el determinar verdaderamente generaciones y variedades, lo que hasta ahora, a juicio mío, se ha hecho con harta arbitrariedad. (1958, V. It. III: 47) $)^{714}$
Goethe insiste en estudiar las plantas aislando aquellas características que tienen en común, una suerte de estructura interna de la planta compartida por todas que, con arreglo a su intuición de la Urpflanze, remonta su origen a una matriz plenipotenciaria: el arquetipo. De hecho, estos arquetipos no son entidades abstractas, encapsuladas conceptualmente. Dan pie a lo nuevo, están sujetos a una infinita productividad creadora de nuevas formas. Por eso Goethe se interesó tanto en el crecimiento de las plantas, como demuestra el siguiente extracto de su cuaderno de viaje a Sicilia donde analiza las plántulas de las habas en cuatro estadios de desarrollo (Fig. 81).
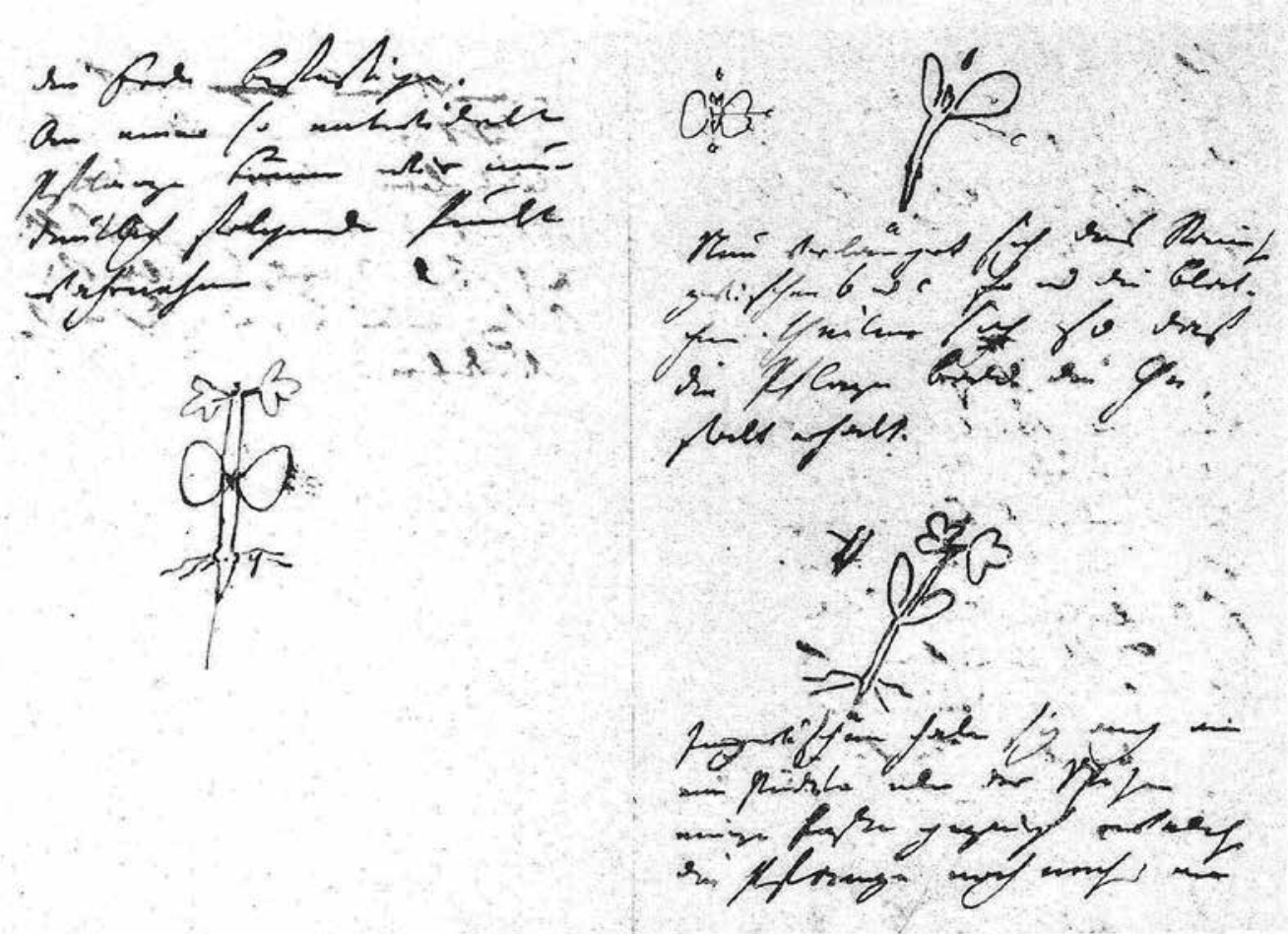

la antigua manía de si no podría yo descubrir entre aquel tropel de plantas la planta primitiva. ¡Porque tiene que haber una planta así! ¿Cómo, si no, podría yo reconocer que esta o la otra forma es una planta, de no estar todas ellas plasmadas según un modelo?" (1958, V. It. III: 170).

Fig. 81. Johann W. Goethe. Keimpflanze der Bohne [Plántula de haba], 1787. En Femmel [1958] 1972, Vb: 56 
715. En concreto sobre Goethe desataca que "hizo observar claramente [...] que el problema futuro para los naturalistas será, por ejemplo, cómo el toro adquirió sus cuernos y no para qué son usados." (Darwin, 2009: nota 2, 42-43).

716. "Ich stehe gegenwärtig in Fall mit den Naturphilosophen, die von oben herunter, und mit den Naturforschen, die von unten hinauf leiten wollen. Ich wenigstens finde mein Heil nur in der Anschauung, die der Mitte steht." Así se expresa Goethe en una carta a Schiller el 30.06.1798 (1998, 4: 31, 565).

Fig. 82. Johann W. Goethe. Verzweigungssysteme, Architektursilhouette [Sistema de crecimiento, silueta de arquitectura], marzo/mayo 1787. En Femmel [1958] 1972, Vb: 52
Así lo refleja en Nápoles, el 17 de mayo, a su regreso del viaje de Sicilia:

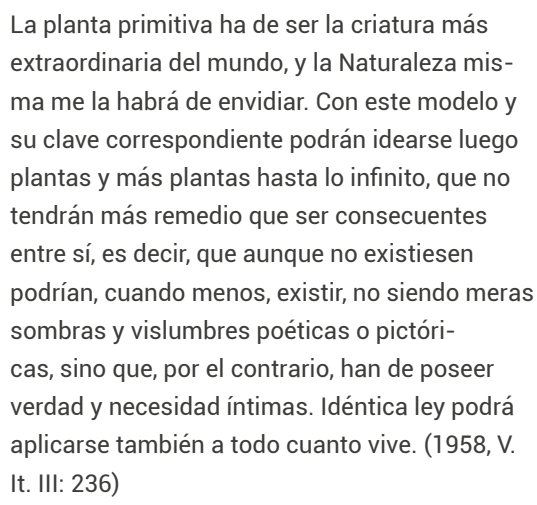

Sería interesante confrontar esta propuesta transmutacional a la teoría evolucionista de Darwin, máxime si se recuerda la polémica mención que este último hace en su introducción histórica a la tercera edición del Origen de las especies. Allí asume que diversos autores (Goethe, doctor Erasmus Darwin [abuelo de Charles] y Geoffroy Saint-Hilaire), en diversas localizaciones (Alemania, Inglaterra y Francia, respectivamente) "Ilegasen a la misma conclusión sobre el origen de las especies en los años 1791-1795."715 Ciertamente Goethe prefigura en sus observaciones sobre la estructura de las plantas el estudio detallado de Darwin sobre los animales en la medida en que ambos se alejan de la "ley de desarrollo progresivo", posteriormente defendidas con vehemencia por Lamarck. Pero, al tiempo, las diferencias entre ambos son llamativas. Quizás aquella que más convenga ahora traer a colación sea una radical divergencia en la manera de entender la temporalidad de la evolución: en tanto que para Darwin la diversidad de las especies se entiende como fruto de una evolución "cronológica" (cada especie tiene un antecedente previo), para Goethe la diversidad se da simultáneamente en diferentes localizaciones y por diferentes causas, algo así como una evolución "sincrónica", ajena a la búsqueda de un esencial origen. Nótese, adicionalmente, que Goethe nunca hablará de especies dado que lo que le interesaba era una única ley que trascendiera la multiplicidad de lo real.

En última instancia, la singularidad de la aproximación de Goethe a las teorías evolutivas se da dentro del marco de su reacción contra la parcelación de los saberes en la Ilustración y desde la Naturphilosophie. En su propuesta de la Urpflanze se entrecruzan esferas que desde la teoría de los trascendentales habían quedado demarcadas. Se mezclan en su seno observaciones empíricas con elementos especulativos, razonamientos inductivos con los deductivos, de manera que "los filósofos de la naturaleza desciendan de lo alto, y [...] la investigación de la naturaleza se conduzca desde abajo hacia arriba [...] hacia la intuición, que es el centro."716

No puede entenderse su incursión hacia la "verdad y necesidad íntimas" de la naturaleza sin intermediación de capacidades propias de la esfera del arte: la naturaleza, con arreglo a su mirada estetizada, es capaz de crear nuevas formas ajustadas a la ley que subyace en las estructuras identificadas como comunes a todas las plantas. Por su parte, el arte emularía, reformulando la teoría clásica de la mímesis, la capacidad creativa de la naturaleza, su potencialidad. De igual modo, no puede entenderse el arte sin la concurrencia de conceptos propios de la esfera epistemológica o científica: "Pero yo quiero demostrar que las artes conocidas de 
los hombres son idénticas a acontecimientos naturales" (1958, M. y R., l: 359, nº 626).

Arte y naturaleza se entrelazan, pues, por medio del mecanismo de la mímesis. El conocimiento artístico y el científico comparten un marco común, que no es otro que el conocimiento humano, disponiendo así en un mismo plano epistemológico ambos. Y, por último, la práctica artística y su producto se identifican con los acontecimientos naturales. Esta convergencia, entre el arte y la naturaleza, entre la poesía y la botánica, se manifiesta en múltiples vertientes a lo largo de su viaje por Sicilia. En Palermo, por ejemplo, fusiona ambas esferas que comparten un designio común:
Esforcéme, pues, por inquirir en qué se diferenciasen unas de otras las muchas formas divergentes. Y siempre hube de encontrarlas más semejantes que distintas, y si echaba mano de mi terminología botánica, no había inconveniente, pero tampoco me servía de nada, sino de inquietarme, sin hacerme adelantar un paso. Estropeóse, pues, mi poético designio, desapareció el jardín de Alcinoo y abrióseme un jardín universal. ¿Por qué habremos de ser nosotros, los modernos, tan distraídos, y por qué nos habrán de acuciar exigencias que no podemos lograr ni cumplir? (1958, V. It. III: 236)

Otra clara muestra de ello sería un dibujo tomado posiblemente en Sicilia, en el que convergen dos de sus más destacados intereses en la isla: la arquitectura y la botánica (Fig. 82).

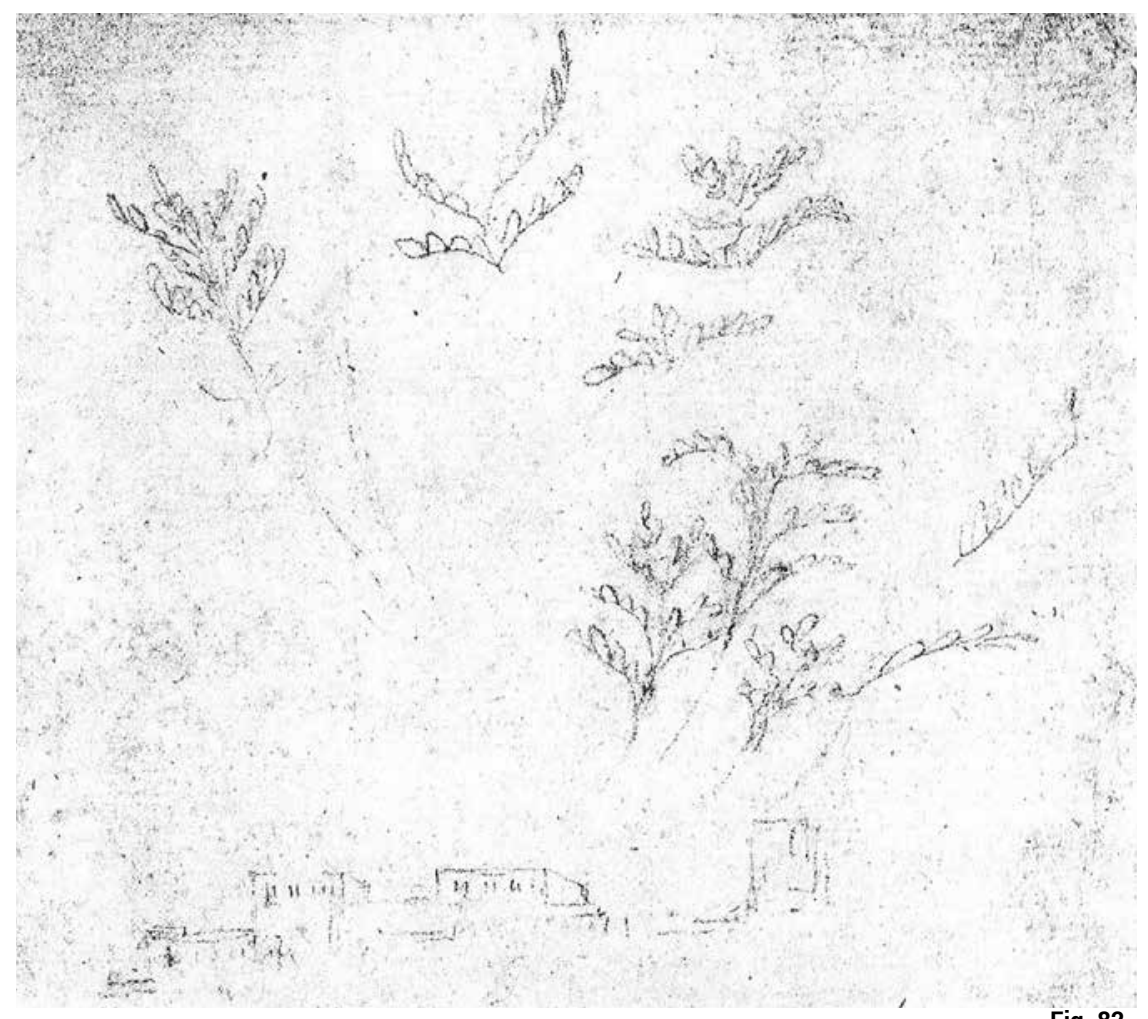

Fig. 83. Johann W. Goethe Antikes Theater von Taormina [Teatro antiguo de Taormina], 07.05.1787. En Femmel [1958] 1972, III: 32

717. La forma más evolucionada de este cambio es el inconcluso tratado Baukunst (1795) que ha sido objeto de un estudio pormenorizado más arriba.

Fig. 84. Johann W. Goethe. Zerbrochene Säulen vor einem Tempel in Girgenti [Columnas quebradas de un templo en Agrigento], 25 abril 1787. En Femmel [1958] 1972, VIb: 188 
718. La idea de las ruinas desperdigadas entre la naturaleza, la idea de que la naturaleza "recupera" lo que es suyo arruinando a obra de arquitectura, induce a una doble reflexión: la caducidad de la acción humana con el paso del tiempo, pero también, el papel de la naturaleza en ese proceso donde las cosas materiales vuelven a su origen: tiempo $-\mathrm{y}$, por tanto, historia desde claves culturales- y naturaleza se entrelazan.

Los dibujos de ruinas, con la vegetación subiendo entre los tambores de las columnas, son elocuentes de ese doble papel.

719. "Encuentro especialmente bella la época griega, que en la romana echo de menos algo de corporeidad" (1958, V. It. III: 132).

720. Goethe empezó más seriamente el estudio de la obra de Winckelmann en diciembre de 1786 en Roma

\section{Arquitectura y naturaleza}

Dos experiencias de Goethe en Sicilia formulan en tono de intuición la maduración que durante su estancia en la isla operó en él en lo referente a la arquitectura. El domingo 7 de mayo de 1787, Goethe y Kniep visitaron las ruinas del antiguo Tauromenium. Esta vivencia quedó plasmada tanto en sus dibujos

(Fig. 83) como en su relato del viaje.

Así describirá sus impresiones relativas al teatro (de origen griego y restaurado por los romanos):

Quien sube a las alturas de los muros de roca que no lejos de la marina se yerguen abruptos, encuentra dos cumbres unidas por un semicírculo. Cualquiera que fuere la forma que la Naturaleza diérele al paraje, el arte ha venido a secundarla, formando con ello un semicircular anfiteatro para los espectadores; muros y otras edificaciones anexas de ladrillo han suplido los corredores y atrios necesarios. Al pie del semicírculo escalonado construyeron transversalmente el escenario, uniendo con él entrambas rocas, y remataron de esa suerte la más enorme obra de Naturaleza y arte. (1958, V. It. III: 189)

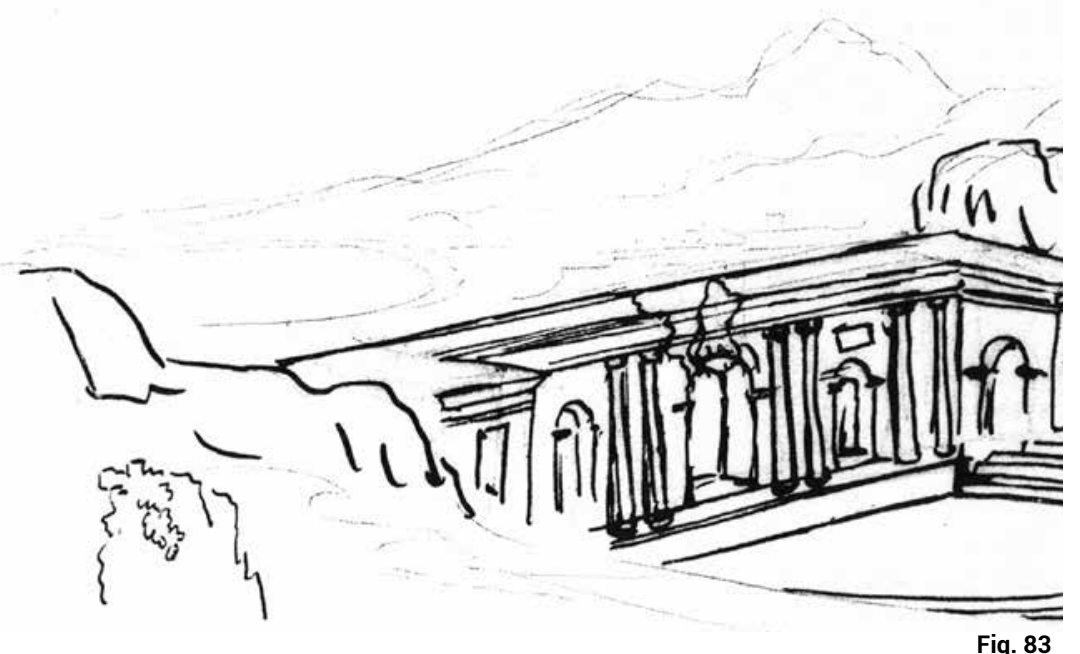

Algo similar le ocurrió, en segundo lugar, con la capilla de Monte Pellegrino: Goethe queda fascinado por la síntesis entre naturaleza, arquitectura y arte. En su solitaria visita al templo el 6 de abril, Goethe se detiene en pormenorizadas descripciones sobre cómo había sido situado en el interior de la montaña, aprovechando una cueva que hacía las veces de coro, "sin quitarle su tosca forma natural". El ascenso a la iglesia y el convento en romería, la "primitiva" combinación de los rituales y pomposidad católicos sicilianos, la transpiración en los muros de su curativa agua, el musgo en sus paramentos... lo embelesan. Y todo y reconociendo que la "parte exterior de la iglesia no tiene nada de atrayente ni sugestivo", Goethe no pudo sustraerse al encanto de su interior cavernario:

\section{Retumbaba ahora en la cueva el cántico de los sacerdotes, manaba el agua en la fuente situada junto al mismo altar, y las colgantes rocas del atrio, de la verdadera nave de la iglesia, daban todavía mayor recogimiento a la escena. Reinaba un gran silencio en aquella aspereza que parecía muerta de nuevo, una gran pulcritud en un antro salvaje; el oropel del culto católico y, sobre todo, del siciliano, todavía aquí próximo a su natural sencillez. (1958, V. It. III: 154)}

Las ruinas del teatro en Taormina o la iglesia de Santa Rosalía muéstranse claramente para Goethe como ejemplos de la convivencia entre arquitectura y naturaleza. La primera, en un sentido puramente contemplativo, en tanto que a la segunda se añade la profundidad antropológica de la versión cristianizada del mito. ¿En qué medida afectó esto a Goethe en su concepción de la arquitectura en general? 
Durante su estancia en Italia, el interés de Goethe por la arquitectura se agudizó. En Roma se dedicó intensamente al dibujo, priorizando ejercicios de perspectiva y dibujos arquitectónicos, estudió los tratados clásicos y las obras arquitectónicas de referencia, conoció y debatió con arquitectos (como Arens, Cassas...) y estudiosos de la arquitectura, y visitó las ruinas con interés de estudioso guiado por especialistas. Ello se concretó paradigmáticamente en un viraje desde su entusiasmo juvenil por el gótico (Von Deutscher Baukunst, 1772) hacia el clasicismo de raíz palladiana. ${ }^{717}$ Su experiencia a este respecto en Sicilia no deja de ser ambigua.

Una vez conocidos los ejemplos de Sicilia, en Agrigento y Segesta, en su segunda visita a Paestum destaca del templo de Poseidón "que es la idea más magnífica que llevaré conmigo plenamente al Norte. El templo del centro [el mayor y mejor conservado] es también, a mi juicio, preferible a todo cuanto aún se ve en Sicilia" (1958, V. It. III: 204). Los ejemplos de la arquitectura griega en la isla no parecieron encajar en el patrón de belleza que había estado madurando. Y ello pese a que ya en la primera visita a Paestum (previa al viaje a Sicilia) había destacado la extrañeza que le causaron estas ruinas clásicas: "la primera impresión sólo podía ser de asombro. Hallábame en un mundo enteramente extraño [...] aquellas masas de columnas, tan apretadas, chatas, cónicas, antójasenos pesadas y hasta terribles." Acostumbrado a la delicadeza de las obras romanas que había podido estudiar en Asís o en Roma, la robustez e incluso rudeza del dórico arcaico griego le causó rechazo inicialmente, aunque reconociese posteriormente que: "sin embargo, me repuse en seguida, recordé la historia del arte, evoqué los tiempos cuyo espíritu encontraba adecuada aquella arquitectura, representé el severo estilo de la plástica, y en menos de una hora ya me sentí familiarizado con aqueIlo" (1958, V. It. III: 143).

Por otra parte, las ruinas en Sicilia no le habían dejado indiferente, pese a los anteriores comentarios. Se había operado ya en él un cambio en la manera de concebir la arquitectura. Del templo de la Concordia en Agrigento comenta: "su esbelta arquitectura aproxímale ya a nuestra escala de lo bello y grato" (1958, V. It. III: 175) (Fig. 84). ${ }^{718}$ Extrañeza y admiración mézclanse, pues, en sus apreciaciones hacia los restos de la civilización griega en Sicilia, que ya empezaba a mostrársele en su superioridad respecto de la romana. ${ }^{719}$ Esta preferencia por la cultura helénica la había heredado de Winckelmann y, en Sicilia, lo hizo de una manera muy concreta. ${ }^{720} \mathrm{Grecia}$ sublimó la belleza de la naturaleza como así lo atestigua paradigmáticamente en Taormina. ${ }^{721}$
(13.12.1786), aunque lo conocía ya desde su juventud en Leipzig 1765/66 (con especial interés estudió Gedanken über die Nachahmung der grieschischen Werke inder Malerei und Bildhauerkunst, de 1755) (1958, P. y V. II: 1644-1645).

721. En palabras de Assunto, "la antigüedad siempre se presenta como mediadora entre la naturaleza y la historia" (1990: 173).

722. Sobre esto, Goethe escribirá abundantemente a su regreso del viaje a Italia. Son notables a este respecto pasajes de Propyläen, Dichtung und Wahrheit y el soneto "Natur und Kunst", sobre los que no conviene ahora extenderse. En este artículo se ha intentado centrar la discusión en la medida de lo posible a aquella producción directamente relacionada

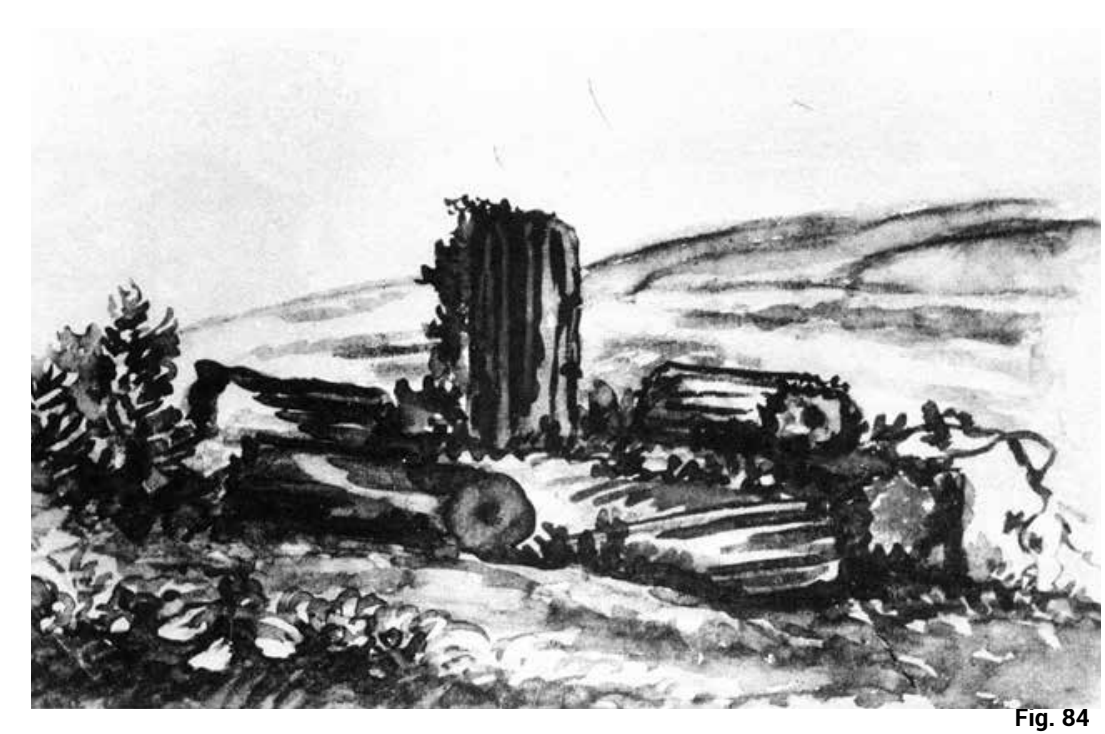


bien temporal, bien temáticamente, con sus experiencias sicilianas.

723. III: 144 (25 marzo 1787) y III: 47 (27 de septiembre 1786), respectivamente.

724. "Mir ward bei diesem Umgang das Gefühl, der Begriff, die Anschauung dessen, was man im höchsten Sinne die Gegenwart des klassischen Bodens nenne dürfte. Ich nenne dies die sinnlich geistige Überzeugung, das hier das Große war, ist und sein wird" (MA, 15: 542).

725. Así lo defiende acertadamente Cometa en "Goethe y el paisaje siciliano" (Arnaldo (ed.), 2002: 141-144).

726. "Wer das Dichten will verstehen, / Muß in's Land der Dichtung gehen; / Wer den Dichter will verstehen,

/ Muß in Dichters Lande gehen." (MA, XI.1.2: 129). 727. "El mito es como un relato de lo que podría haber ocurrido si la realidad coincidiera con el paradigma de la realidad." (Ferrater Mora, 1964: 210).

728. "Moderne Welfen und Ghibellinen" (WA, 41.2: 276). 729. En referencia al mito, Goethe afirmará años más tarde: "Si bien se pueden formular consideraciones filosóficas, incluso religiosas acerca de este objeto, como también ocurre, sin embargo pertenece por completo realmente a la poesía." (WA, 27: 312).

730. La misma palabra "metamorfosis" alude a este significado. Del griego me-
A este respecto, en Sicilia Goethe hace experiencia de una máxima que poco después, a su regreso en Roma, supo sintetizar con rotundidad y que lo entronca con el problema paradigmático del clasicismo europeo: establecer en qué medida naturaleza y arte se oponían, y hasta qué punto el arte bello adquiría plena consciencia de su carácter artístico en la medida en que se aproximase a la naturaleza. ${ }^{722}$ Se aleja así Goethe definitivamente del ímpetu realista del Sturm und Drang:

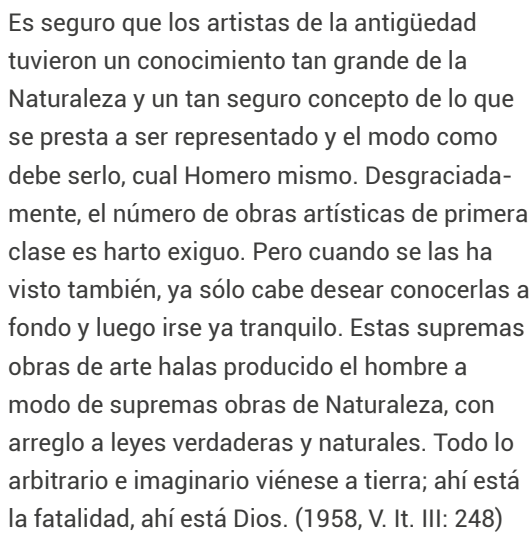
tuvieron un conocimiento tan grande de la Naturaleza y un tan seguro concepto de lo que se presta a ser representado y el modo como debe serlo, cual Homero mismo. Desgraciadamente, el número de obras artísticas de primera clase es harto exiguo. Pero cuando se las ha visto también, ya sólo cabe desear conocerlas a fondo y luego irse ya tranquilo. Estas supremas obras de arte halas producido el hombre a modo de supremas obras de Naturaleza, con arreglo a leyes verdaderas y naturales. Todo lo arbitrario e imaginario viénese a tierra; ahí está la fatalidad, ahí está Dios. (1958, V. It. III: 248)

\section{Mito y arquetipo}

Durante su estancia en Sicilia, Goethe visitó los lugares más renombrados de la Antigüedad (Selinunte, Siracusa y Agrigento), que estudió y dibujó en detalle. Analizó sus paisajes, su historia, la geología, la botánica. Profundizó en sus conocimientos sobre la mitología clásica (compró y releyó la Odisea en Palermo). Trazó el plan para su interpretación de Nausikaa y trabajó en Tasso. Avanzó su teoría de la metamorfosis, gestada en su estancia en Nápoles (e intuida en Padua el 27 de septiembre). ${ }^{723}$ Entre las vivencias de
Goethe en Sicilia pueden, pues, destacarse la atención a su geografía, a sus paisajes y manifestaciones naturales, y por otra parte a la presencia al arte, en su estudio y práctica. Un todo que se entrelaza, bajo una predisposición "mitologizante", como se apuntó al comienzo.

No en vano, Sicilia fue para Goethe el único lugar mitológico que pudo visitar. Una aproximación a la isla que ya tiempo atrás había cultivado con Proserpina (1778-1779), que retomará años después. El viaje a Sicilia bien puede entenderse como una apropiación del mito griego en sus múltiples facetas. Así lo confiesa él mismo: "En este viaje he tenido la verdadera intuición, el sentimiento, el concepto de lo que podría llamar, en el más alto sentido, la presencia del suelo clásico; quiero decir la convicción, formada en el espíritu a través de los sentidos, de que aquí estuvo la verdadera grandeza, y que aquí está y aquí estará". ${ }^{724}$ Pisar la tierra del mito, aprehender el paisaje siciliano era condición sine qua non para la comprensión del mito, como años más tarde confirmará: ${ }^{225}$

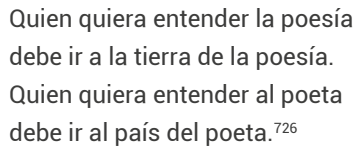

En el mito concurren necesariamente lo ficticio y lo real. ${ }^{727}$ Sería, en este preciso sentido, una explicación posible de lo real si lo real se ajustase a lo idealizado. Tiene el carácter de lo atemporal, de lo que se revuelve contra la contingencia del tiempo. Se sitúa fuera del tiempo real, en definitiva. Pero, simultáneamente, se expresa en clave particular, de relato concreto, si no anecdótico. Se eleva así como paradigma, trasciende 
lo particular al elevarlo a general. El mito formula en clave de relato una esencia, una condensación de sentido de lo real.

Visto así, un claro paralelismo se manifiesta entre el mito y el arquetipo, tal y como lo formula Goethe en su teoría de la Urpflanze. Si el mito es la unidad de sentido en la multiplicidad de relatos (puede contarse de diversas formas, pero siempre quedará respetado el sentido último), el arquetipo análogamente supone la unidad de la multiplicidad de lo real. Comparten, además, su potencial explicativo: tanto el mito como el arquetipo son mecanismos racionalizadores de aquello que previo a su intermediación se presenta críptico. Presentan un sentido (que no una verdad) de lo real. Por último, comparten también su capacidad creativa. Para Goethe, el mito aspira "a brindar contenido, forma y figura a la imaginación, de modo que pueda ocuparse de ella y edificar como en algo real". ${ }^{728}$ Por lo tanto, considerado en su naturaleza poética, el mito produce representaciones de la realidad con igual claridad que pueda hacerlo la ciencia respecto de la naturaleza por medio del arquetipo. ${ }^{729} \mathrm{Y}$, al tiempo, ambos desvelan el carácter hermenéutico de lo real, lo muestran en tanto que imágenes sujetas a múltiples e inagotables metamorfosis. ${ }^{730}$ Los mecanismos de la metamorfosis de las plantas operan igualmente en el arte, en tanto que segunda "Naturaleza", con el carácter de lo atemporal: ${ }^{731}$

Sólo los poemas están libres del destino fatídico y rechazan la muerte; gracias a tus poemas, vivirás siempre, Homero.

Ninguna obra se alza sin que la asalte la vejez, sin que la destruyan los días inicuos, por más que levantes hacia las estrellas montañas magníficas y con mármol emules las cálidas pi- rámides. Ninguna muerte daña el ingenio, vaga seguro por todas partes, la poesía conserva su renombre para siempre intacto. ${ }^{732}$

Este vínculo del arte con la naturaleza por medio del mito, reforzándose mutuamente, a la luz de lo previamente expuesto adquiere asimismo relevancia en la arquitectura desde el prisma de las genuinas experiencias de Goethe en la isla. ${ }^{733} \mathrm{La}$ predisposición hacia lo griego, que le debía a Winckelmann, le permitió dar forma a una intuición que se presenta en Sicilia de forma primaria en la síntesis entre arquitectura y naturaleza en Taormina o Santa Rosalía. Las ruinas de Agrigento le posibilitaron superar esta aproximación casi pintoresquista para, en paralelo con sus estudios sobre botánica y geología, poder materializar su convergencia por medio de la identificación de una ley que rige sus respectivos despliegues desde la unidad hacia la multiplicidad.

De regreso del viaje a Sicilia, Goethe se referirá a Homero, en un sentido que Schiller supo sintetizar en Über naive und sentimentale Dichtung: "Ellos [los antiguos] sentían naturalmente, nosotros sentimos lo natural". ${ }^{734} \mathrm{~A}$ lo que añadirá que "por primera vez esa palabra de Odisea cobra para mí vida." (1958, III: 205). En Sicilia, por lo tanto, Goethe combinó la experiencia del mito antiguo a la íntima convicción de que sintiendo lo natural y lo griego, en lo que a la arquitectura concierne, puede proporcionarle una ley común de la que puede aun extraer sentido en su presente. Visto desde el mito, para Goethe la Urpflanze es a la naturaleza lo que el arquetipo griego dórico a la arquitectura. tamojwsiz, está compuesta por el prefijo meta ["meta", más allá], la palabra morjh ["morfé", figura o forma] y la raíz-osiz ["-osis", que indica cambio de estado].

731. "En la naturaleza, como en el arte, como en la arquitectura, todas las formas tienen su lógica interna" (Masiero, 2003: 155). Años después, en sus propios términos: "Arte, otra Naturaleza, misteriosa también, pero más inteligible, ya que brota del intelecto." (1991, nº 1103, I: 441).

732. Séneca, Epigramas IV y $\mathrm{V}$.

733. La experiencia del mito rodeado de la Naturaleza que le dio lugar, tiene para Goethe un efecto potenciador: "no podía haber para mi comento mejor de la Odisea que ese animado ambiente" (1958, III: 191).

734. "Tocante a Homero, diríase que se me ha caído una venda de los ojos. Las descripciones, los símiles, etc., nos resultan poéticos y son, no obstante, indeciblemente naturales [...]. Permíteme expresar brevemente mi pensamiento en esta forma: representan la existencia, en tanto nosotros solemos pintar el efecto; describen lo terrible, en tanto nosotros describimos terriblemente; exponen lo agradable, mientras nosotros buscamos agradar, etcétera." (1958, III: 204). 
735. "¿Qué impresión tan grata la de ocuparse en algo que sólo a medias conocemos! De suerte que nadie debería regañar al diletante por aplicarse a un arte que nunca aprenderá, ni censurar tampoco al artista si saliéndose de los límites de su arte, complácese por discurrir en un campo vecino." (1991, II: 1280).

736. La casa de madera la compró su abuela (1733) y a su muerte (1754) su padre, "que era muy entendido en achaques de técnica arquitectónica", la reformó (1991, III: 439 y 446). En 1768 criticó la escalera por no adecuarse al uso de varias familias, ya que debió localizarse "a un lado, como en Leipzig, y teniendo cada piso su puerta que poder cerrar". (1991, III: 636).

737. En un texto de Goethe y Schiller ("Uber den dilettantismus" 1797), reprochaban al diletante su desconocimiento de las técnicas y problemas concretos del trabajo artístico (Arnaldo, 2008: 22).

738. Por ejemplo, entre las obras oficiales y en relación con la llamada Römische Haus (Casa romana) construida por Arens (1792-1797) estudió distintos alzados de pabellón de jardín relacionados con este tipo de casa de campo (Femmel, 1972, IVb: 112; IVb: 113; IVb: 114; IVb: 115), dibujó varias alternativas para la fachada (Femmel, 1972, IVb, 97) y una planta general de situación

\section{Proyectos de escaleras}

\begin{abstract}
Es ist eine so angenehme Empfindung, sich mit etwas zu beschäftigen, was man nur halb kann, daß niemand den Dilettanten schelten sollte, wenn er sich mit einer Kunst abgibt, die er nie lernen wird, noch den Künstler tadeln dürfte, wenn er über die Grenze seiner Kunst hinaus in einem benachbarten Felde sich zu ergehen Lust hat.

Goethe, Die Wahlverwandtschaften, Zweiter Teil, Drittes Kapitel (1808-1809)
\end{abstract}

Ya anciano, durante sus largas conversaciones con Eckermann el 21.3.1830 Goethe le confesó: "Yo, por ejemplo, traje de Italia el gusto por las grandes y bellas escaleras y por efecto de ello estropeé esta casa, pues sus habitaciones resultan ahora más chicas." (1991, III: 210) Se refería a su residencia en Frauenplan de Weimar que había remodelado años antes siendo la manifestación más representativa de su tarea como arquitecto diletante. En su juventud Goethe criticó las escaleras construidas por su padre en su casa de Frankfurt. ${ }^{736}$ Así pues, estaba reconociendo que había incurrido en un error similar.

Frente al arte Goethe diferenciaba entre el aficionado vulgar, el auténtico aficionado, el diletante y el verdadero artista. EI simple amateur "trata a la obra de arte como un objeto con el que se topa en la plaza del mercado", y sólo le exige que "parezca natural para así poder disfrutar de ella de una forma natural y a menudo tosca y vulgar". Por el contrario, el auténtico aficionado es capaz de comprender las pautas y normas que ha seguido el artista y "siente que debe subir al nivel del artista para disfrutar de la obra." (1991, III: 125 y 126) Ambos, cualquiera que sea el nivel en el que aprecian y entienden el arte, tienen en común que no lo practican.

Según Goethe: "La comprensión y la práctica siguen caminos muy diferentes." (1991, III: 102) El ejercicio práctico, más restringido, es lo que comparten el diletante $\mathrm{e}^{737}$ y el artista. El primero es un aficionado culto [wahre Liebhaber] que a su capacidad de juzgar y valorar las obras, añade, por gusto, su ejercicio. Las críticas de Goethe al diletante que nunca dominará el arte que practica no ocultan su simpatía hacia el aficionado convertido en diletante, porque alcanza un mejor disfrute y conocimiento artísticos. Escribe: "el aficionado que aún no posee bastante soltura de mano para sacarle a todos y cada uno de los objetos una copia airosa, afánase por lograr lo más principal y asimilarse aquello que para él tiene un carácter notable que particularmente háblale al alma." (1991, III: 939) Pero eso no convierte al diletante en artista. Durante su viaje a Italia, el 17.2.1787 refiriéndose a sí mismo comenta:

\section{para hacer bien algo es menester la práctica de toda la vida. \\ $Y$, sin embargo, no debe el aficionado arredrarse, por poco que se esfuerce. [...] Solo que no debe- mos equipararnos a los artistas, sino proceder a nuestro modo. (1991, III: 1152)}

El verdadero artista, además de cultivar profesionalmente el arte ha de estar dotado de aptitudes naturales: "En todas las artes hay cierto grado que puede alcanzarse con las disposiciones ingénitas, por así decirlo, exclusivamente. Pero al mismo tiempo es imposible rebasarlo como el arte no venga en nuestra ayuda." (1991, Mx. No 1114 I: 442).

Goethe se consideraba un diletante que practicaba el dibujo, la escultura y la 
arquitectura, aunque era consciente de sus limitaciones que le alejaban del trabajo de un consumado artista o arquitecto.

En Italia el 5.7.1787 escribe: "he empezado a cultivar más seriamente la arquitectura, y todo se me hace sorprendentemente fácil (es decir, la idea, pues la práctica requiere toda la vida)." (1991, III: 1282)

Conocer las bases y principios teóricos de la arquitectura en los que estaba empeñado era algo diferente a ser diestro en la ejecución de las obras. Suponía dar el salto de la idea a la práctica y pasar de ser un diletante a convertirse en un profesional. Goethe distinguía, además, entre el simple maestro constructor y el verdadero arquitecto que domina su arte. Dos ámbitos que siempre mantuvo claramente diferenciados. Por un lado, su interés por la teoría y la realización como diletante de dibujos arquitectónicos fueron algunas de las aficiones que cultivó asiduamente. Y por otro, su desempeño del cargo de Supervisor de obras de Ingeniería y Arquitectura en la corte del Gran Duque Karl August de Weimar le habituó con el trato de maestros constructores y arquitectos, así como con la gestión y responsabilidad de los trabajos de edificación que se estaban ejecutando, tomando incluso parte activa en cuestiones de diseño. ${ }^{738}$

Estos cuatro niveles de aproximación de Goethe a la arquitectura (como aficionado culto, como teórico, como gestor y como arquitecto diletante), se reflejan de manera elocuente analizando sus aproximaciones a una pieza específicamente arquitectónica: la escalera. En un primer momento, realizó láminas de ruinas medievales y detalles arquitectónicos incluyendo dibujos de escaleras. Durante su viaje a Italia se avivó su vocación artística y su interés por la arquitectura ${ }^{739}$ realizando ejercicios, a veces copiados de los tratados clásicos (Serlio, Palladio, Scamozzi, Vignola...). Como responsable de las obras de Weimar participó activamente en los trabajos y proyectos en ejecución. Un paso más hacia la labor del arquitecto profesional, fue su protagonismo en el diseño y construcción de las escaleras durante la reforma de su propia vivienda. Fue entonces cuando asumió sus limitaciones que le alejaban de ser un auténtico arquitecto.

\section{La escalera como tema plástico}

Tras su regreso de Leipzig donde empezó a practicar las artes plásticas y el estudio de la arquitectura, ${ }^{70}$ dibujó la criticada escalera de la casa paterna (Fig. 85). Se representa en perspectiva la parte inferior de las zancas inclinadas de madera, la barandilla metálica y el despiece del pavimento en damero. El diseño de la barandilla se destaca gráficamente y se apuntan los adornos de la madera bajo los peldaños. Durante su estancia en Estrasburgo había viajado a la ciudad de Zabern (Saverne) alabando la escalera del palacio episcopal que tiene una barandilla de hierro similar (1991, III:670). En definitiva, era la ornamentación lo que resaltó Goethe en este dibujo.

\section{Tras instalarse en Weimar}

(7.11.1775) el Gran Duque le regaló la casa del guardabosques junto al IIm siendo ésta su primera residencia. Se conserva un dibujo (Fig. 86) del vestíbulo de esta vivienda con la puerta de acceso a la derecha, la entrada de la sala a la izquierda y la escalera al fondo. Están representados los tres tramos adosados a las paredes que cierran el espacio. Las líneas fugadas del arranque inferior y las del
(Femmel, 1972, Vla: 151). Un dibujo (Femmel, 1972, IVb: 97) parece incluir estudios para la fachada posterior de esta construcción incluyendo tres plantas con la ubicación de la escalera de salida al jardín cuya solución, finalmente realizada, Goethe había criticado en una carta a Meyer del 5.8.1796. Sobre sus proyectos para la reconstrucción del teatro de Weimar, que redactó con el arquitecto Coudray, véase Ewald (1999, figs. $64,66,67$ y 68). También participó en la escalera de la Biblioteca Anna-Amalia de Weimar (entradas en su Diario del 27 de marzo y 28 de abril de 1825).

739. En varias ocasiones incluso se hizo pasar por arquitecto. (1991, III: 1074 y 1114).

740. Siendo adolescente sus estudios de matemáticas le ayudaron a "poder trazar mis bocetos arquitectónicos con más precisión" (1991, III: 498). En Leipzig practicó dibujo y pintura en la academia de arte de Adam Friedrich Oeser y grabado con Johann Michael Stock, leyó a Winckelmann (1991, III, 609-621) y estudió algunos grabados de Palladio. De regreso en Frankfurt escribía a Oeser (noviembre 1768) que se ejercitaba en el dibujo y estudiaba arquitectura. 
Fig. 85. Johann W. Goethe Escalera en la casa de Goethe en Frankfurt, 1768/1770. En Femmel [1958] 1972, I: 56 Fig. 86. Johann W. Goethe. Caja de escalera, s. f. ¿1777? En Femmel [1958] 1972, I: 179 rs.

741. Una perspectiva de Goethe de la misma época (1776/1777) (Femmel 1972, I: 301 rs.) representa una escalera en esquina adosada a los muros.

742. Femmel 1972, III: 110; III: 111; III: 112; III: 113; III: 115; III: 116; III: 117; III: 118.

Fig. 87. Johann W. Goethe. Sistema de escaleras, 1787/1788? En Femmel [1958] 1972, III: 118

Fig. 88. S. Serlio (1537-1551), Libro II: folio 19 anv. tramo superior visto por debajo son el motivo principal de la lámina. ${ }^{741}$ Estos ejemplos confirman que para Goethe el dibujo de escaleras en perspectiva era idóneo para representar el espacio arquitectónico.

En Roma había seguido un curso del que dice: "Inauguró Verschaffelt un curso de Perspectiva, y allí nos reuníamos por las tardes numerosa concurrencia, que escuchaba sus lecciones y en seguida las llevaba a la práctica." (1991, III: 1301). Existen algunos ejercicios en perspectiva realizadas en esos momentos, ${ }^{742}$ entre ellos uno (Fig. 87) copiado del tratado de Serlio (Fig. 88). En el modelo aparecen seis ejemplos de escaleras en distintas posiciones. Goethe lo simplifica eliminando tres: el arranque descendente situado en la parte inferior izquierda, la que sube adosada al muro del fondo y la que aparece tras el arco de la derecha. Tampoco dibujó el desnivel del pavimento bajo el arco.

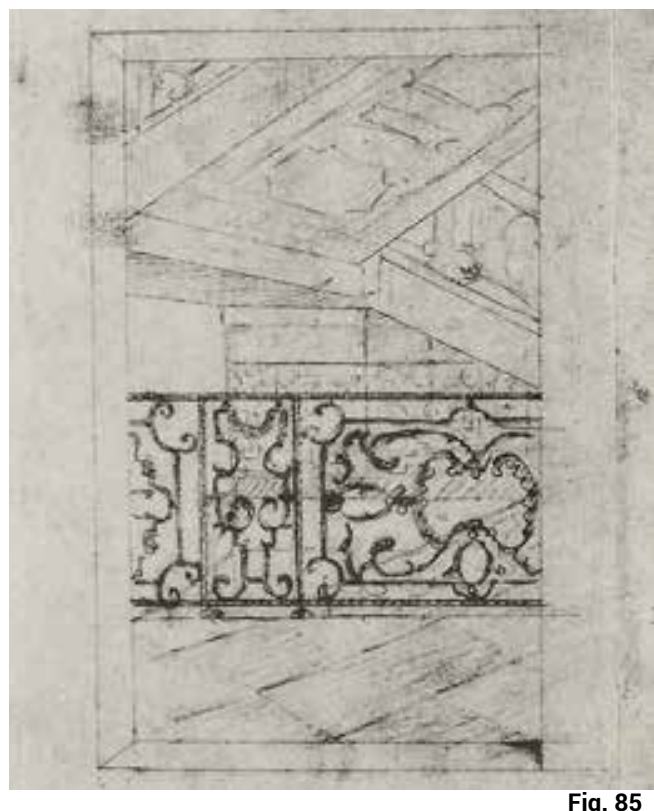

Hay un pentimento en el encaje del perfil de los peldaños en el tramo más alejado, y el portón del fondo aparece completo y no parcialmente traslapado.

El motivo principal de la lámina es una escalera con planta en $T$ de dos tramos ascendentes en la misma dirección y sentido opuesto que confluyen en un rellano del que sube un tramo único en dirección perpendicular a los dos inferiores.

Sin entrar en un análisis del dibujo quiero destacar dos cuestiones en relación con las escaleras. Bajo la meseta donde confluyen los tres tramos, hay un hueco adintelado que Serlio ha dibujado con sus dovelas. Aunque Goethe las insinúa no las representa correctamente porque el hueco casi toca el perfil de la escalera posterior y la huella del primer peldaño descendente prácticamente desaparece. Algo similar ocurre con el arco bajo el tramo superior donde la cuarta huella

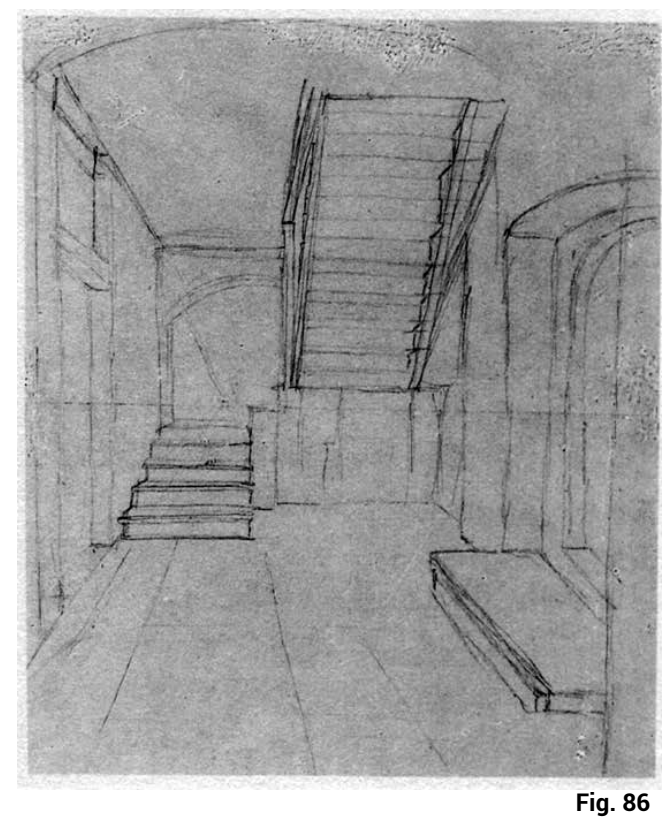


ascendente roza la línea del arco sin dejar espacio para la dovela en ese punto. Estos aspectos ponen en evidencia el desconocimiento o escaso interés de Goethe por los aspectos constructivos de la arquitectura que dibujaba.

Los ornamentos y la perspectiva como representación del espacio son las cuestiones que quería controlar en estos dibujos.
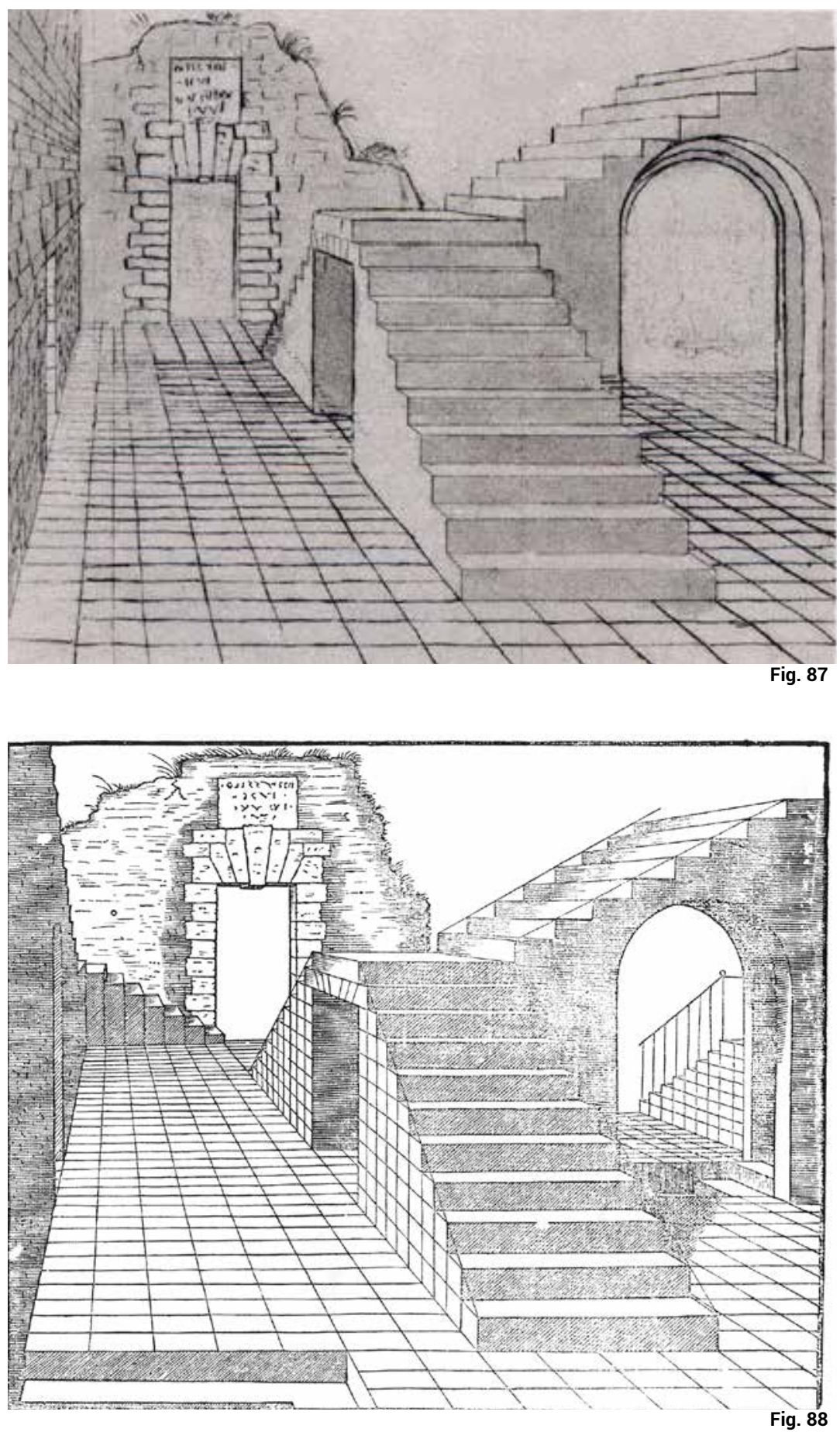
743. En 1797 dibujó una planta esquemática (Femmel, 1972, Vla: 160 rs.) que se ha relacionado con la casa que Schiller pensaba adquirir y reformar, donde se representa una escalera en $L$ que conduce a un pequeño distribuidor. Otro dibujo (Femmel, 1972, Vla: 161) de 23.12.1794 recoge cuatro plantas de escaleras, dos en $U$, una en $L y$ otra de tres tramos en forma de $S$, junto a un alzado de una escalera de madera que podrían estar relacionados con la casa de Schiller en Jena y la escalera exterior del Belvedere en el jardín.

744. Los días 14,15 y 16 de marzo de 1787 estuvo en Caserta y, aunque no menciona la escalera la conoció porque visitó el palacio nuevo del que hace un comentario (1991, III: 1175).

\section{La escalera como tema arquitectónico}

La idea de arquitectura de Goethe quedó apuntada en el manuscrito inédito Baukunst (1795). En él establece una jerarquía de los fines de la arquitectura. El fin inmediato [der nächste] se satisface con una forma ajustada a la materialidad y la función. El fin elevado [der höhere] se alcanza cuando, además de satisfecho el fin inmediato, se dan las condiciones para el despliegue del carácter del edificio. Por último, el fin superior [der höchste] introduce la ficción poética en la arquitectura. Así como el artesano cumple con el fin inmediato y es necesario un artista para hacer de un edificio una obra de arte para los sentidos, se requiere un genio para que esta alcance valores poéticos.

En este mismo escrito vincula el disfrute de la arquitectura a su recorrido. Las escaleras, como piezas de tránsito entre espacios a varios niveles, sintetizan tanto la utilidad como el recorrido. Son, en consecuencia, un modo idóneo para gozar de la arquitectura.

Goethe alabó las escaleras de la primitiva casa de Frankfurt antes de la reforma por su estilo simple y funcional (1991, III: 437). Pero no se limitó a valorar estas obras sino que él mismo se implicó en intervenciones puntuales sobre aspectos de diseño de escaleras como evidencian distintos dibujos suyos donde trata sobre cuestiones distributivas o funcionales. ${ }^{743}$ Son ejemplos donde Goethe aborda el fin inmediato [der nächte] de la arquitectura.

Pero el sentido artístico que corresponde al fin superior [der höhere] era una cuestión diferente. Evocando su niñez Goethe habla del edificio municipal de consejos de
Frankfurt [Römer] donde se realizaban los actos públicos más importantes. Escribe: "Solíamos ganarnos la buena voluntad de los porteros para poder subir la nueva y clara escalera imperial, pintada al fresco." (1991, III: 442) La escalera imperial prestigiaba y simbolizaba al poder social. En Italia pudo contemplar algunas escaleras de este tipo como la del palacio nuevo de Caserta de Vanvitelli. ${ }^{74} Y$ dado su interés, tendría noticias de la Residenz del obispo de Würzburg de Balthasar Neumann, cuya escalera imperial es la más imponente de Alemania del siglo XVIII.

El Schloss de Weimar sufrió un importante incendio el 6.5.1774. Desde $1777 \mathrm{La}$ Comisión para la Reconstrucción del Palacio estaba bajo la dirección de Goethe que se responsabilizó de las labores de rehabilitación y de las demás iniciativas en las obras oficiales. Su implicación no se redujo sólo a su papel como director y gestor, sino que se extendía, también, a los aspectos de diseño que debatía con los proyectistas.

De las obras del palacio hay distintos dibujos sobre parcelaciones, edificios afectados y ordenación de pabellones en torno a una explanada (IVb: 121; IVb: 121 rev.; IVb: 123), diseños del muro y el portón de acceso al patio de armas (IVb: 116; IVb: 117; IVb: 124), y varios esquemas de fachada (IVb: 122). Las obras cogieron impulso en 1800 con el arquitecto H. Gentz (1766-1811) quien proyectó la escalera imperial [Gentzches Treppenhaus] tras la puerta frente al puente de la Estrella [Sternbrücke], una de las primeras escaleras monumentales del clasicismo alemán (Illert, 1988: 35). Como acostumbraba Goethe debió jugar un papel activo en este proyecto.

Generalmente una escalera imperial se sitúa perpendicular y lateralmente al paso 
de carruajes, con un tramo inferior hasta una meseta de donde parten dos tramos simétricos laterales y paralelos al central que ascienden en dirección opuesta hasta el piso superior. Sin embargo, aquí el desarrollo es diferente porque la escalera y la vía entre la puerta y el patio de armas están superpuestas en la misma dirección. En consecuencia, el arranque de la escalera es doble en los laterales del paso con distintos tramos que van confluyendo hasta el superior que termina ante una columnata de orden dórico griego. A diferencia de la solución ortodoxa aquí no existe una única caja de escaleras sino dos ámbitos claramente diferenciados. Flanqueando la vía de carruajes hay dos colum-

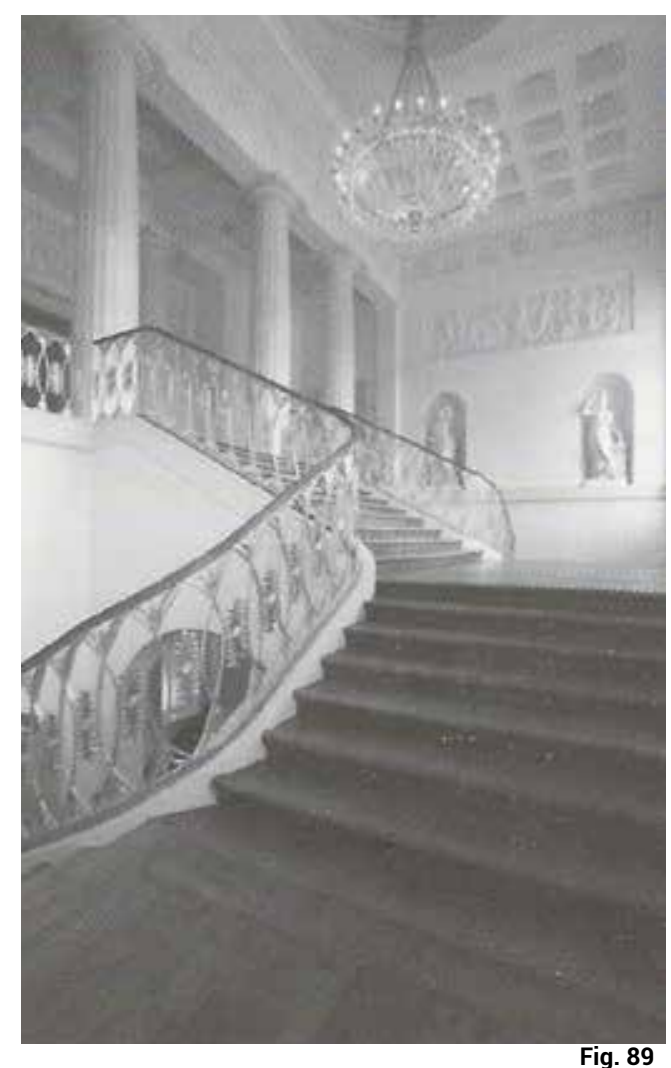

natas entre las que suben unos escalones ${ }^{745}$ y un paso que termina en unos peldaños $y$ un rellano. A este punto se llega, también, desde otro tramo distinto perpendicular al paso rodado. En estos dos rellanos laterales simétricos empieza propiamente la caja de escaleras que condensa su representatividad (Fig. 89). Adosados a los muros laterales suben unos tramos que giran $90^{\circ}$ por el muro de fachada hasta encontrarse en una nueva meseta central de donde arranca la parte final superior hasta la columnata y el vestíbulo de los salones principales del palacio [Festsaal]. ${ }^{746}$

Goethe, dibujó una perspectiva (c. 1801) (Fig. 90) del espacio de la caja. ${ }^{747} \mathrm{El}$

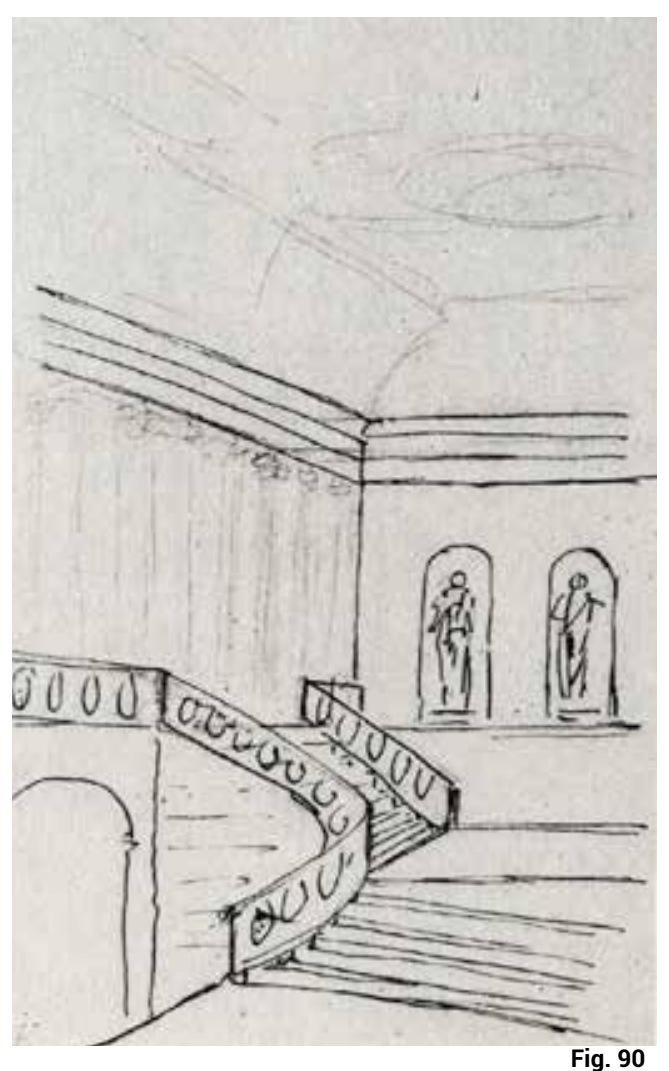

745. Los peldaños entre un pórtico de columnas los menciona durante su viaje a Italia al hablar del templo de Minerva en Asis, y lo recogió en un dibujo del templo de Segesta en Sicilia (VIa: 140) (1991, III: 1113-1114; 1217-1218). En el Baukunst (1795) trata este problema como ejemplo de la evolución arquitectónica de la basa aislada bajo la columna.

Fig. 89. Schloss Weimar. Caja de la escalera imperial. Tramo superior (2014, foto de Juan Calduch)

746. Hay un esquema de Goethe (Vla: 163) de una planta simétrica palladiana (ca. 1801), tal vez relacionado con esa zona del Schloss en esos momentos en obras.

Fig. 90. Johann W. Goethe. Caja de escalera, 1801. En Femmel [1958] 1972, Vla: 163 747. Se ha planteado alguna duda sobre la autoría de este dibujo (Bothe, 2000: 165-190). 
748. Un detalle frecuente en las escaleras imperiales y que Goethe había utilizado en la de su casa.

749. Goethe la ocupó en junio de 1792 aunque no fue oficialmente su dueño hasta 1794 como regalo del Duque cuando le concedió el título nobiliario (Pielmann, 1998: 175).

Fig. 91. J. F. Steiner. Casa de Goethe en Frauenplan. Estado previo antes de la reforma, c. 1792. En Ewald, 1999: 43 falso techo con el tondo central para pinturas al fresco, ${ }^{748}$ la columnata, las hornacinas con esculturas, las barandillas y la luz frontal frente al tramo central descendente son los elementos que arropan el rito de bajar ceremonialmente desde los recintos palaciales más nobles, dándole a la escalera el carácter buscado.

Hay que destacar dos aspectos. Primero: si en el tipo de escalera imperial el punto de arranque del tramo inferior es único y asume la máxima relevancia al potenciar el paso entre el carruaje y la escalera, aquí es el desembarco superior el que tiene ese protagonismo al unificar en un solo itinerario el encuentro de la escalera con el vestíbulo porticado. Segundo: la conexión de los tres tramos superiores finales recuerda la escalera imperial en T del dibujo de Serlio copiado por Goethe, como si aquella perspectiva le hubiera orientado a la solución arquitectónica pertinente.
Para Goethe, el valor de la escalera consiste en arropar y resaltar con la arquitectura algunas actividades emblemáticas de la sociedad. Es el lugar donde el estatus del propietario se muestra a su medio social cuando abre su morada en momentos singulares de la vida pública. A diferencia de la finalidad sólo utilitaria de las escaleras privadas, la importancia arquitectónica de una escalera singular como ésta del Schloss consiste en subrayar la ceremonia de auto-celebración del estamento aristocrático que la recorre en ocasiones especiales.

Trasladar este sentido del palacio a la vivienda burguesa es lo que se había propuesto Goethe en su propia casa. Se trataba de llevar, aunque con una estructura arquitectónica más modesta, el significado arquitectónico de las escaleras de lo público y aristocrático a la esfera de lo doméstico y burgués sin menoscabo de su condición representativa.

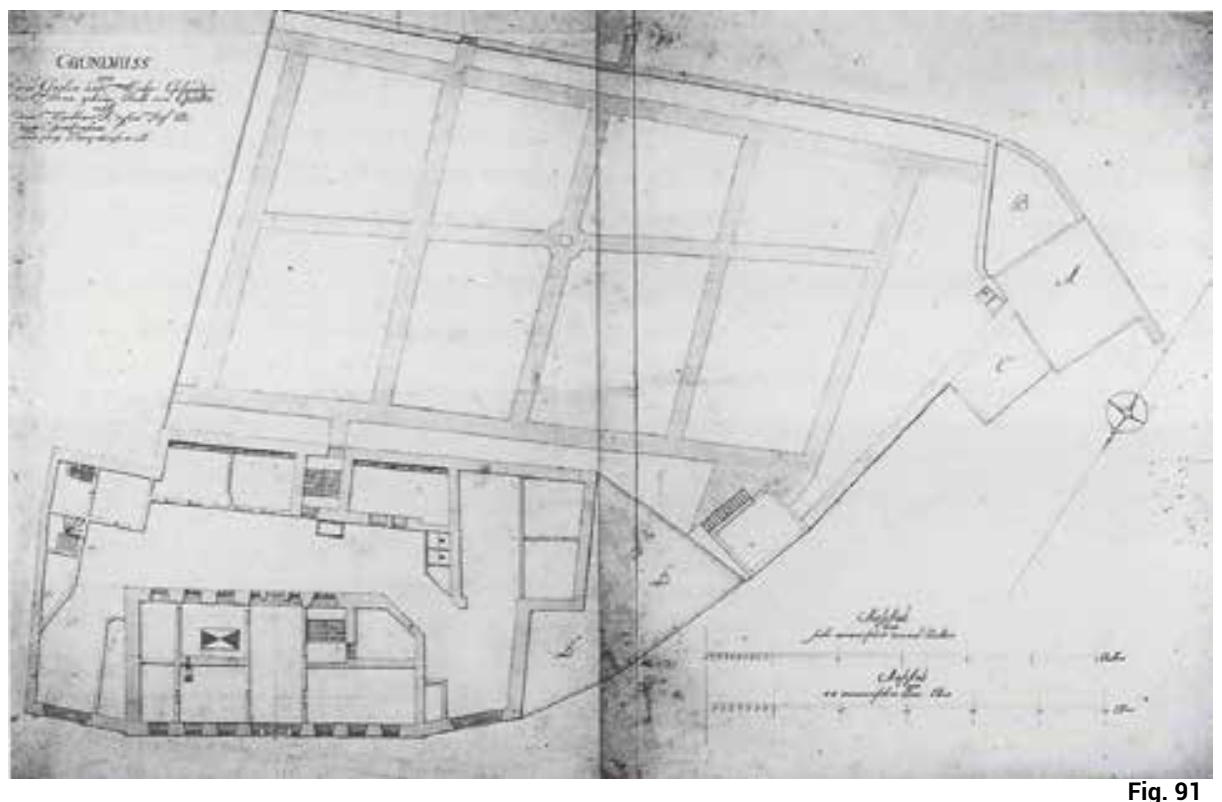




\section{La escalera como obra}

Cuando en 1792 Goethe se instaló en Frauenplan de Weimar ${ }^{749}$ le pidió al arquitecto J. F. Steiner (1774-1840) el levantamiento del inmueble que pensaba reformar (Fig. 91). Estaba formado por dos bloques principales separados por un patio y otras dependencias comunicados por varias escaleras, y un jardín posterior. El volumen de fachada es de doble crujía y en planta baja tiene un zaguán central pasante, dos alas simétricas a los lados y portones de carruajes de entrada y salida al patio en los extremos. Consta, además, de piso noble y cubierta habitable inclinada a dos aguas.

Goethe hizo varios bocetos y una detallada relación de las obras previstas (Ewald, 1999: 122). El cuerpo trasero de una crujía recayente al jardín se destinó en la planta baja a zonas de servicios, y en el piso a las habitaciones privadas. En la planta noble de la fachada estaban en enfilada las estancias de carácter social (Urbinozimmer, Junozimmer, Gelber Saal, Deckenzimmer, Majolikazimmer, Sammlungszimmer), el comedor (Esszimmer) y un pequeño oficio (Obere Küche).

Las reformas se hicieron entre junio de 1792 y el verano de $1795^{750}$ y consistieron en adecuar el edificio a las necesidades residenciales y representativas de Goethe y su familia. ${ }^{751}$ Además de solventar estas cuestiones funcionales, los principales objetivos fueron: por un lado, dar relevancia al acceso desde el zaguán a la planta noble mediante una escalera de peldaños suaves (a la italiana) que permitiera recorrerla disfrutando del espacio arquitectónico. Por otro, conectar los salones de la zona delantera con el jardín posterior mediante un cuerpo pasante sobre el patio (Brückenzimmer) con una pequeña escalera al vestíbulo de salida (Gartenzimmer). En tercer lugar, crear una atmósfera clasicista con la decoración interior resaltada por la gran colección de objetos y obras de arte que poseía. Existen varios dibujos de Goethe de cenefas con grecas y esvásticas, posiblemente extraídas de motivos pompeyanos, destinados a este fin. ${ }^{752}$ Por último, quería reconstruir la fachada al jardín con una solución clasicista palladiana algo que, por cuestiones de coste, abandonó. ${ }^{753}$

Todos esos objetivos se reflejan de un modo elocuente en un dibujo (Fig. 92) que recoge: una planta de distribución del piso noble (aunque superponiendo el tramo inferior de la escalera en planta baja), la proyección de la fachada al jardín, una sección por el Brückenzimmer, otra parcial del muro de la caja de escaleras con la entrada superior a la vivienda, un capitel y su perfil posiblemente del recercado de la puerta que está entre ellos (tal vez la misma que aparece en la sección parcial), dos detalles del alzado de un paramento interior y un esquema a línea que podría ser la distribución de la zona privada de uso personal.

Respecto al primer objetivo, Goethe proyectó simultáneamente en las mismas fechas dos escaleras conectadas entre sí: la principal y representativa (Treppenhaus), y otra para el uso privado residencial (Internes Treppenhaus).

La escalera principal condensaba la primera y más emblemática imagen de la casa que Goethe quería mostrar a sus amigos y visitantes. ${ }^{754}$ Igual que en el edificio preexistente, la caja de escaleras ocupa la segunda crujía a la derecha del zaguán. Pero su desarrollo y amplitud para las expectati-
750. H. Meyer, amigo de Goethe, vivió en la casa unos años y se responsabilizó de las obras durante su ausencia (1792) cuando acompañó al Duque en la campaña contra Francia. En diciembre de 1792, la estructura de la Brückenzimmer estaba concluida, el volumen de la caja de escalera preparado y la fachada exterior restaurada (Goethe, 2004: 4904). Las obras menores se prolongaron hasta finales de 1798 (Pielmann, 1998: 176). Hay un croquis en planta de Goethe que parece corresponder a la distribución de sus aposentos privados (Femmel, 1972, IVb: 9 rs.).

751. El ambiente de una gran residencia urbana burguesa de principios del siglo XIX en Alemania está magistralmente recreado por Thomas Mann en su novela Buddenbrooks. Verfall einer Familie (1901). 752. Femmel, 1972, IVb: $83,85,85$ rs. y 89 . En julio de 1794 Goethe encargó al arquitecto de Dresde Ch. F. Schuricht la decoración de la caja de escalera y la fachada (2004, 5108 y ss.). 753. Femmel, 1972, IVb: 91 , 92 y 92 rs. Ewald, 1999: 112. Fig. 92. Johann W. Goethe. Planta ideal de la casa de Goethe (primer piso), posterior a 1793. En Femmel [1958] 1972, IVb: 91

754. Refiriéndose a esta mansión de Goethe el joven Jean Paul le contaba a su amigo Christian Otto: "Su casa impresiona, es la única 


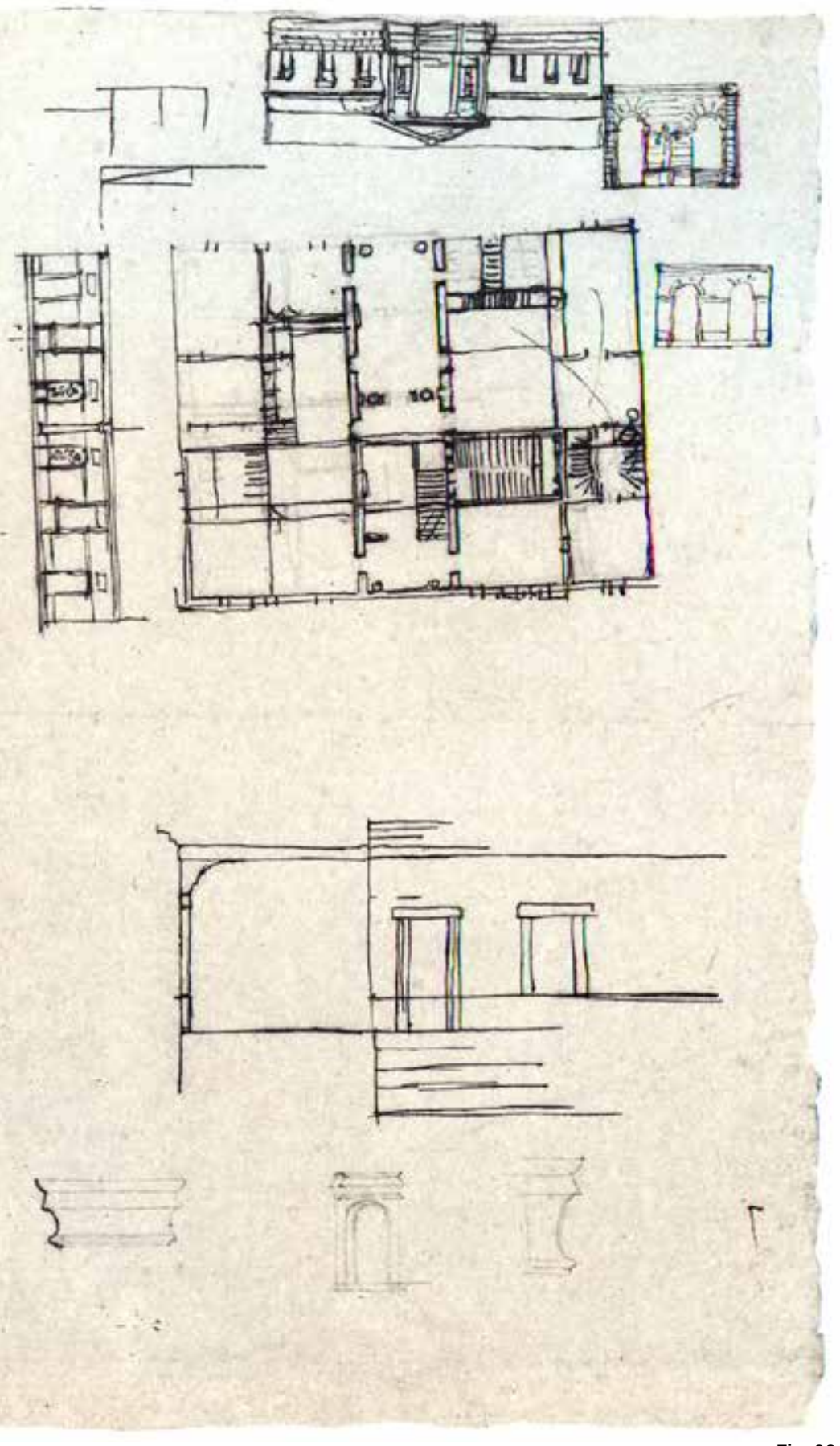


vas de Goethe eran inadecuados y había que prolongarla con un tramo inferior saliendo del espacio de la caja e invadiendo el zaguán. Los dos croquis del muro con arcos corresponden a la sección por el zaguán frente a la puerta de entrada. En uno de ellos se ve un arranque de escaleras en el arco derecho pero no en el izquierdo, que indican dos recorridos: por la izquierda se va hasta el patio posterior y por la derecha se llega al tramo inferior de la escalera como muestra la planta. Una sección por la escalera (Fig. 93), con el zaguán y la Sala Amarilla [Gelber Saal] a la izquierda, y el paso a los aposentos privados de Goethe a la derecha, confirma esta interpretación. En esta solución el recorrido de subida discurriría adosado al paramento exterior donde están las ventanas, y el último tramo llegaría
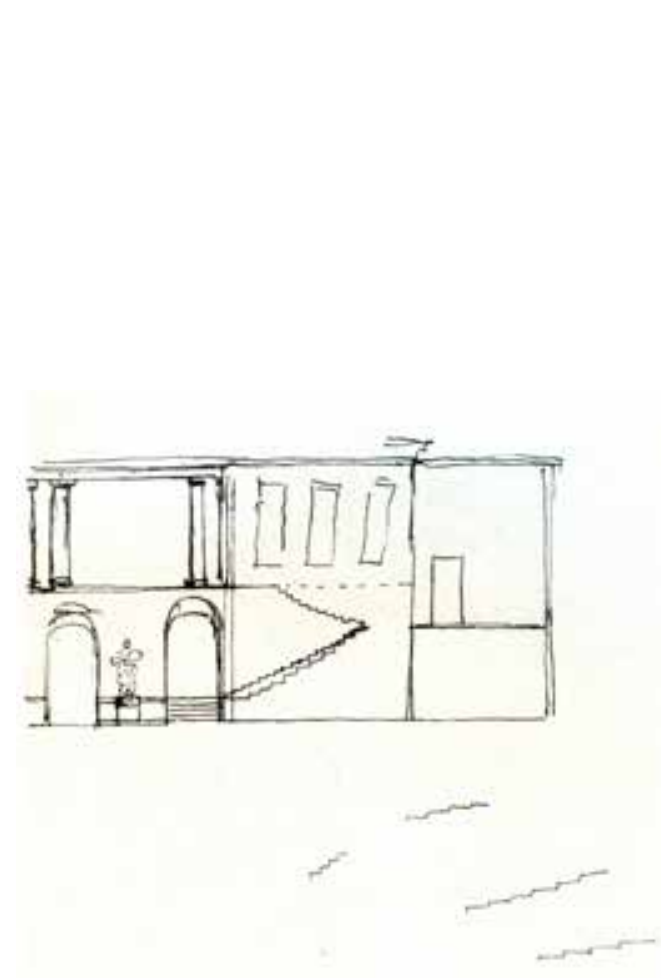

Fig. 93 hasta la meseta con el paso de entrada a la izquierda del muro como aparece en el apunte de sección (Fig. 92). Finalmente, el tramo superior se adosó al muro exterior enfrentado a la puerta desplazada a la derecha.

En consecuencia, la escalera ocupa dos zonas distintas: el zaguán en la parte inferior y la caja en la superior. Y, en cada una de ellas el espacio arquitectónico tiene un significado distinto y se resuelve de un modo diferente. La construcción escenográfica en el zaguán y la voluntad de enfatizar el desembarco en el piso superior frente a la enfilada de puertas debía implicar un coste excesivo porque esta solución se abandonó. No se modificó el zaguán y se alojó el tramo inferior de la escalera en la crujía contigua a la caja. (Fig. 94) La solución construida se

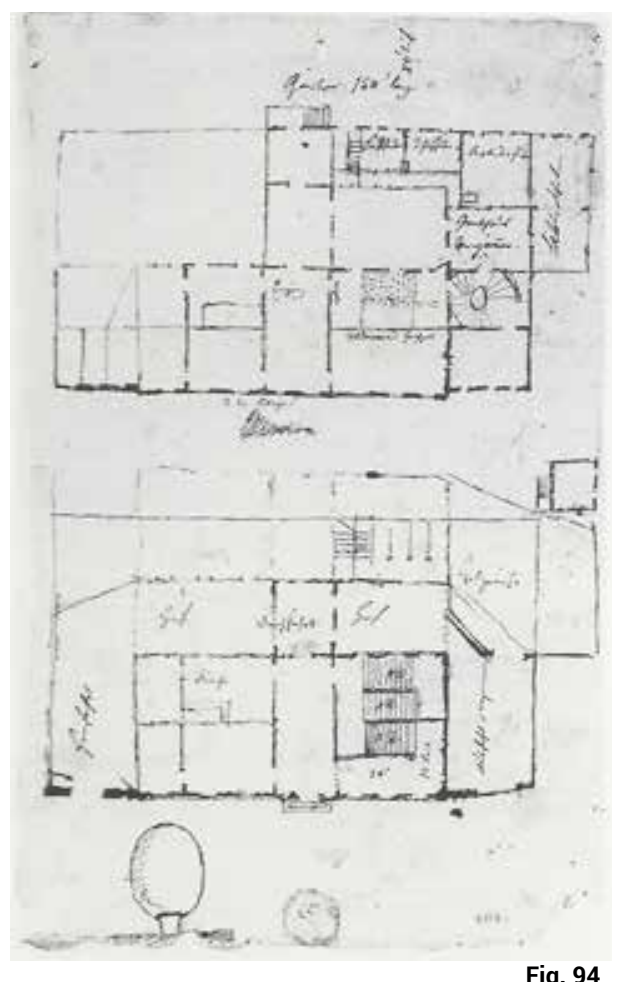

en Weimar en gusto italiano, con semejantes escaleras, un panteón lleno de cuadros y estatuas." Citado en Klauß (1991: 14).

Fig. 93. Johann W. Goethe. Boceto arquitectónico para la reconstrucción de la casa de Goethe, s.f. En Femmel [1958] 1972, IVb: 93

Fig. 94. K. F. Zelter. Plantas esquemáticas de la casa de Goethe, c. 1814. Ewald, 1999: Fig. 51 
755. Femmel (1972, IVb: 77, 78 y 79), los tres fechados el mismo día: 7.6.1792.

Terminadas las obras de albañilería, los carpinteros empezaron a preparar la escalera según consta en la factura de esa misma fecha (GSA. Ka. X, 2 BI. 44) aunque el 10.10.1792 manifestaba en una carta a Meyer que "Dado que los albañiles han trabajado tan lentamente, la escalera no va a estar terminada".

Fig. 95. Johann W. Goe-

the, Caja de escalera de la casa de Goethe en Weimar, 07.06.1792. En Femmel [1958] 1972, IVb: 79

Fig. 96. Casa de Goethe en Weimar. Caja de escaleras, 2014. Fotografía de Juan Calduch

756. Además de los usos residenciales las escaleras de caracol siempre habían servido para la subida a torres y campanarios. En esas fechas desarrolla en tres tramos paralelos en S. De manera poco satisfactoria en la planta baja arranca en sentido contrario a la dirección de la entrada desde el vestíbulo y el espacio escenográfico de la caja sólo se descubre al llegar al primer rellano. Goethe quiso dar la máxima ostentación a este espacio como demuestran las tres perspectivas desde los rellanos intermedio y superior que dibujó. ${ }^{755}$

En estas imágenes hay algunas diferencias, sobre todo ornamentales, respecto al estado actual. La más llamativa es el dibujo de una sola puerta en vez de dos en el rellano intermedio, situada a eje del tramo superior

(Fig. 95), que comunica con la escalera interior (fig. 94). Así pues, ambas escaleras son contiguas sólo separadas por un muro. La puerta no dibujada por Goethe (Fig. 96) lleva a un espacio poché entre ellas.

En la sección de la caja de escaleras (fig. 93) la meseta intermedia está a la altura del pavimento del cuerpo trasero lo que le obligaba a modificar las pendientes de la zanca como muestra el pentimento en el di- bujo. Pero la intención de hacer los peldaños suaves, reflejados en cuatro esbozos, descartaba esta solución. Si se quería una escalera por la que transitar a un ritmo pausado para admirarla, la situación de la meseta no podía condicionarse al nivel del pavimento tras el muro. En consecuencia, entre el descansillo y las zonas privadas quedaba una cierta altura que habría que salvar.

Hablando de la funcionalidad de la escalera en la casa de Frankfurt antes de la reforma Goethe escribe: "Una escalera de caracol conducía a habitaciones que no concordaban entre sí, habiéndose compensado mediante peldaños la desigualdad de los pisos." (1991, III: 436). En el dibujo de Goethe (Fig. 92) se insinúa una escalera de caracol que une tres niveles diferentes: el de las salas nobles (Urbinozimmer) que están más altas, el de las habitaciones privadas de Goethe situadas a una altura intermedia, y el de la meseta de la escalera principal que se encuentra a una cota inferior. En su opinión una escalera de caracol capaz de compensar
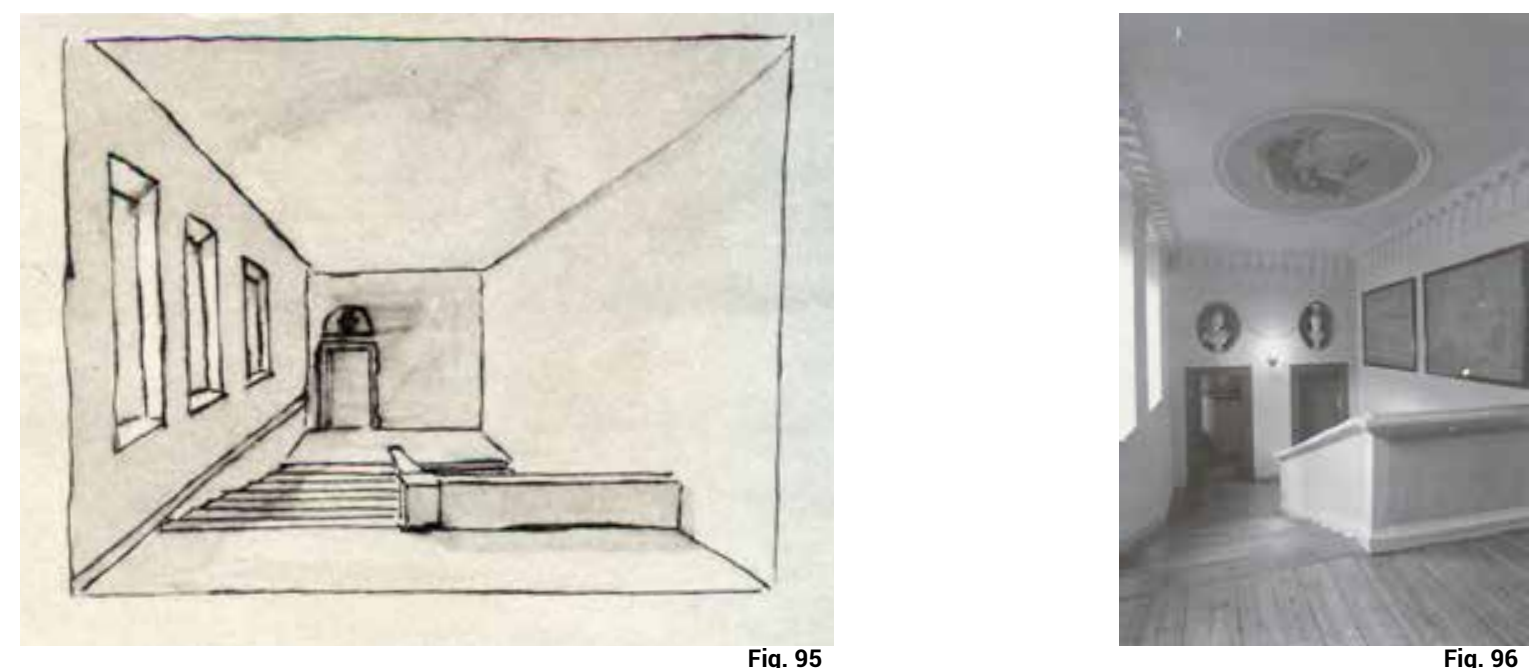
con peldaños esta "desigualdad de los pisos" era la idónea.

Tradicionalmente en edificios domésticos las escaleras de caracol resolvían óptimamente los aspectos funcionales con el mejor aprovechamiento del espacio. ${ }^{756}$ En Italia Goethe pudo admirar las escaleras de este tipo que Palladio había dibujado y construido. ${ }^{757}$ De la del Convento della Carità en Venecia escribe que era "la escalera de caracol más bella del mundo [...] cuán bella sea puede inferirse del hecho de que el propio Palladio la dé por buena." (1991, III: 1082).

Tres láminas con cuatro plantas de la escalera interior (Figs. 97, 98 y 99) nos permiten conocer las cuestiones que quería resolver. Además de conectar las tres alturas (salas, estancias privadas y rellano) la escalera sigue ascendiendo hasta la zona habitable bajo cubierta. La forma ovalada de la planta era la que mejor encajaba en el perímetro trapezoidal del espacio. Incluso hay un esquema (Fig. 99) donde se enfatiza esa forma para liberar un paso entre los cuerpos delantero y posterior.

El ajuste de los peldaños para salvar las diferencias de alturas entre los pisos es el principal problema funcional. En los croquis se tantean varias alternativas. En dos de ellos (Figs. 97 y 98) se dibujan cuatro contrahuellas (numeradas en Fig. 98) entre la zanca de la escalera principal y el nivel de los aposentos posteriores. Sin embargo, en el tercero, que parece posterior por su trazado limpio con instrumental, hay cinco contrahuellas (Fig. 99). Lo mismo ocurre con los peldaños que salvan los niveles entre las zonas trasera y delantera. En un caso (Fig. 97) se dibujan cinco contrahuellas, en otro (Fig. 98) se numeran seis y en el tercero (Fig. 99) hay seis. ${ }^{758}$ La puerta que comunica con los aposentos privados se emplaza en el centro de un ancho rellano, pero la que conecta las dos escaleras tiene un emplazamiento forzado ante la ne- (c. 1795) Goethe dibujó la planta de una columna monumental con una escalera de caracol en el centro. (Femmel 1972, IVb: 132).

757. Palladio representó

en su tratado escaleras circulares y elípticas tanto con núcleo macizo como hueco, en tipos genéricos, en modelos imaginados como la casa de los griegos o la basílica antigua y en palacios y villas (Palladio, 1580, I: 62, 63,65 ; II: 6, 13, 39, 44, 52, 53), y construyó las del Convento della Carità en Venecia y la villa Emo entre otras (Chastel, 1965: 11-22)

Fig. 97. Johann W. Goethe Planta de la escalera de caracol de la casa de Goethe en Weimar, antes del 7.6.1792. En Femmel [1958] 1972, IVb: 82

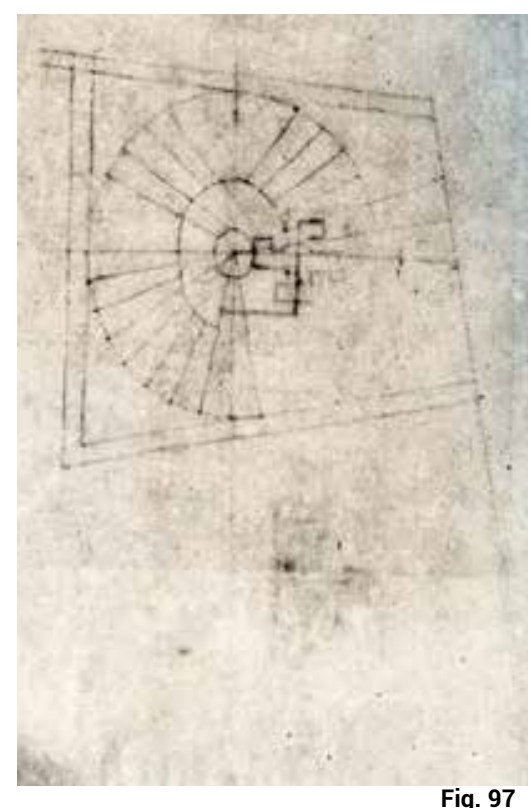

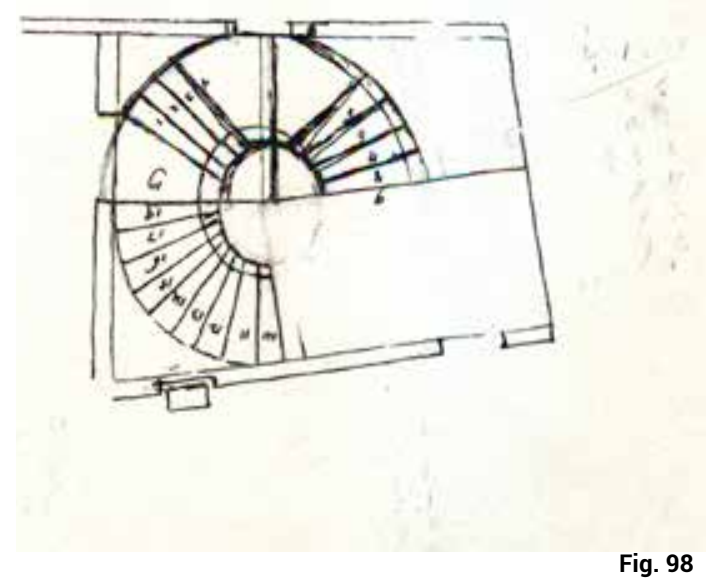

Fig. 98

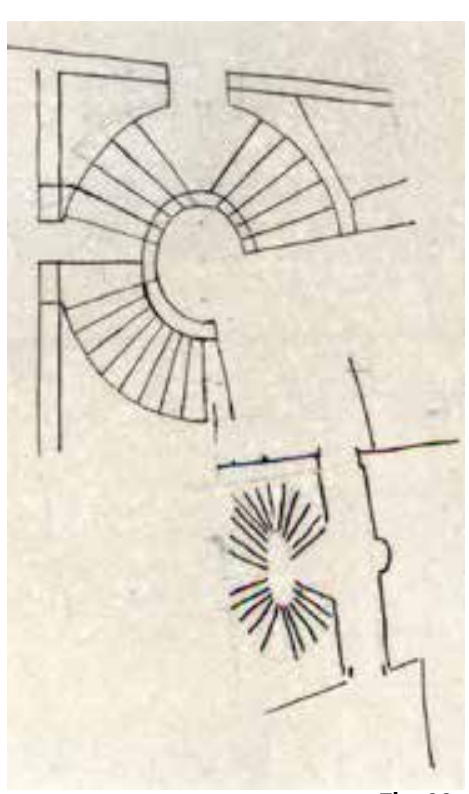

Fig. 99 
Fig. 98. Johann W. Goethe. Planta de la escalera de caracol de la casa de Goethe en Weimar, antes del 7.6.1792 En Femmel [1958] 1972, IVb: 80

Fig. 99. Johann W. Goethe.

Dos proyectos (plantas) de la escalera de caracol de la casa de Goethe en Weimar, antes del 7.6.1792. En Femmel 1972, IVb: 81

758. En la realidad hay cuatro contrahuellas entre el descansillo y el pavimento del cuerpo posterior y cinco entre este cuerpo y el delantero. cesidad de respetar el eje del tramo superior de la escalera principal, y su anchura que está determinada por las proporciones de los huecos en la caja. Esto explica las dudas entre el eje de la puerta y la situación de la meseta en este punto (Fig. 99), así como los tanteos del trazado de un peldaño más, y el hecho de que, finalmente, no esté situada en el centro del rellano. También la situación del centro de la escalera, posiblemente por todos estos problemas, es objeto de reajustes (Fig. 98) desplazando ligeramente la entrada a la zona privada para mantenerla a eje del descansillo. A diferencia de todos estos problemas y pruebas, el paso desde la Urbinozimmer no tiene dificultad porque queda un espacio holgado desde el que arranca el tramo que sube a la cubierta.

Observando estos dibujos hay una cuestión que, por su ausencia, parece no preocupar a Goethe. La escalera del Convento della Carità no sólo es excepcional por su forma y diseño sino también, de una manera relevante, por su magnífica construcción en piedra con los peldaños de una pieza volados que van superponiéndose. Son una lección magistral de arquitectura porque diseño, forma, construcción y materia forman una unidad coherente y perfectamente trabada. La construcción de la escalera interior en la casa de Goethe es de estructura de madera y se apoya en dos pilarcitos en el hueco central para asegurar su estabilidad. Viendo los dibujos de Goethe está clara su preocupación por resolver la conexión funcional de los espacios, pero su materialización y construcción la dejaba en manos de los maestros de obras y carpinteros. Esta cuestión es elocuente porque nos permite entender el modo específico en que Goethe se enfrentaba a la arquitectura.

\section{Goethe, arquitecto diletante}

Para Goethe, el arte de la arquitectura se alcanza cuando se han satisfecho dos fines previos que atañen a la materia y su uso. En su opinión, siguiendo la estela del Renacimiento, el arte de la arquitectura posee su propio ámbito autónomo que está por encima de la mera construcción situada al nivel inferior de las artesanías y trabajos mecánicos. Consideraba que la creatividad arquitectónica se canaliza a través del proyecto y los problemas derivados de su ejecución son competencia de alarifes y maestros de obras, muy distintos de los intereses culturales y estéticos que mueven al verdadero arquitecto. Pese a su gran admiración por Palladio no supo ver que la calidad de sus obras se asienta, de un modo relevante, en su profundo conocimiento de los materiales y trabajos constructivos debido a su formación como aprendiz de cantero en el taller que le había convertido en un consumado maestro constructor.

Entre quien sólo se interesa por los aspectos teóricos, formales y utilitarios de las obras y el que es capaz de comprender el problema globalmente, integrando la materia y su construcción para convertir el proyecto en la realidad física del edificio, está la brecha que separa al arquitecto diletante del verdadero arquitecto. Goethe fue consciente de que no había superado este hiato, a pesar de su indudable interés y sus continuas aproximaciones al mundo de la arquitectura. 




\section{ÚLTIMAS REFLEXIONES \\ FINAL THOUGHTS}



puede observarse en este respecto que siempre, en todos los trances políticos de monta, encuéntranse muy a gusto aquellos que abrazan un partido, pues aprovechan con júbilo lo que les resulta verdaderamente favorable, y sobre lo desfavorable hacen la vista gorda, lo apartan o hasta saben sacarle el jugo. Pero el poeta que por su propia naturaleza debe ser y mantenerse imparcial, trata de compenetrarse con las situaciones de ambos partidos beligerantes, y cuando toda mediación es imposible, debe resolverse a acabar de un modo trágico. ¡Y de qué ciclo de tragedias no nos veíamos amagados por el vertiginoso moverse del mundo! (C. Fr., III: 451)

Goethe fue un atento observador de ámbitos tan dispares como la política, el arte, la ciencia... Buena muestra de ello es la diversidad de temas tratados en su obra, así como las amistades que durante décadas cultivó y la biblioteca que atesoró. En estas áreas, allá donde centró su atención, su posición respecto de las polémicas entre sus contemporáneos fue difícilmente clasificable. Por poner un ejemplo, y tal y como recogía a su regreso a Weimar de la campaña de Francia, su posicionamiento respecto de la Revolución Francesa fue harto ambigua. Parafraseando a Thomas Mann (1932), Goethe bien puede ser considerado como "un representante de la época burguesa", esto es, un conservador crítico a la politización cívica. Pero fue igualmente un conspicuo defensor del cambio político en la fragmentada Alemania. Todo a un tiempo.

En ocasiones se ha querido salvar este escollo hermenéutico identificando etapas, fases en su producción, que apuntarían hacia una suerte de evolución a lo largo de su vida. Pero lo cierto es que pensar la obra de Goethe como una progresión desde el ímpetu aforado de juventud a la sabiduría clasicista tras su paso por Italia que se marchita en una calmada y erudita vejez, no hace justicia a los conflictos a los que tuvo que enfrentarse ni a la complejidad de sus propuestas. Goethe afrontó con singular atención el solapamiento de dos mundos. Presenció y participó activamente en el reajuste fruto del agotamiento de un mundo y la irrupción de otro con clara vocación mediadora, cuando no trágica.

\section{Entre el clasicismo y la modernidad}

El terreno de la arquitectura no ha escapado de aquel artificio exegético, singularmente acusado quizás por la polarización de sus posicionamientos en esta disciplina a lo largo de su vida articulada a partir de dos series, Von Deutscher Baukunst (1772 y 1823) y Baukunst (1788 y 1795). Hasta tal punto pueden tensarse sus propuestas arquitectónicas que cabe identificar tanto enunciados propios del siglo XVIII como propuestas de indudable vigencia, que pueden de manera singular concretarse en una persistente tensión entre clasicismo y modernidad. Pese a que esta tensión se reconoce con especial claridad en el Baukunst (1795), sin duda su aportación más significativa a la disciplina, se manifiesta en múltiples ámbitos de su producción tanto teórica como práctica. Conviene, por tanto, desentrañar cuáles fueron los polos de tensión y cómo Goethe se enfrentó a ellos.

\section{Ensayo y tratado}

En la redacción del Baukunst (1795), Goethe tiene como referencia en su estructura y ordenación los tratados que le habían servido para estudiar la arquitectura. En este sistema teórico los dibujos arquitectónicos juegan 
un papel central, hasta el punto que pueden entenderse como medio de conocimiento y no sólo como meras ilustraciones. Así lo entiende Goethe al acompañar su texto de un nutrido corpus gráfico. Pero, por otra parte, su obra ya no comparte el fin didáctico y pragmático de los tratados. Bajo el influjo de los escritos históricos y teóricos de los que se nutre, su objetivo se sitúa a otro nivel: se trataba de justificar el papel de lo clásico en la renovación de la arquitectura. Goethe, de hecho, no está redactando un texto ni para el artista, ni para el creador genial, sino para el entendido, en un sentido cercano a los ensayos de Laugier, Sulzer o Winckelmann, por citar algunos. En efecto, la brecha entre el artista y el espectador que inaugura la estética moderna, esto es, que el entendido en una materia pueda juzgar con mayor precisión que el propio creador, estuvo en el origen de la crisis del género de la tratadística. De esta forma, la reflexión teórica ya no recae en aquel que ejerce, sino en un estudioso y, en el caso de la arquitectura, supuso una merma por el interés en la técnica.

En este sentido se combinan, por tanto, dos modelos canónicos. Si el planteamiento (fundamentalmente la relación del texto y los dibujos, las partes que constituyen la obra, etc.) remite a los tratados renacentistas, cuestiones sobre la teoría y, paralelamente, la ausencia de cuestiones constructivas lo alejan de esos referentes y lo aproximan a un ensayo teórico siguiendo la pauta del XVIII. El Baukunst (1795) estaría, por lo tanto, a caballo de esos dos tipos de escritos sobre arquitectura y situaría a Goethe en el centro de la transición moderna. Esto queda evidenciado igualmente en el resto de su producción teórica. En la serie sobre la arquitectura alemana puede identificarse un progresivo distanciamiento respecto de la dialéctica entre materia y forma, objeto de atención privilegiado en su Baukunst (1788). $\mathrm{Y}$, de hecho, la manera en la que Goethe aborda sus tentativas de ejercer como arquitecto ilustran esta deriva. Tanto en sus incursiones proyectuales, como en su papel de gestor de obras, Goethe pudo hacer experiencia de la imposibilidad de ejercer plenamente en la arquitectura sin la asistencia de alguien con los necesarios conocimientos técnicos, de los que él carecía.

\section{Objetivismo y relativismo}

Por otra parte, esta distancia entre la teoría y la práctica tiene su correlato entre el artista y el espectador por medio del objeto artístico. Si la tratadística confiaba aun en la enunciación de criterios objetivos de composición de la arquitectura, con la Querelle des anciens et des modernes se consolidó una estética que cuestionaba la atemporalidad inapelable de los criterios clásicos. Se abrió así la posibilidad de concebir la belleza de la arquitectura sujeta a criterios subjetivos, y alentó la tensión entre el objeto artístico y su receptor.

En este sentido, en la teoría arquitectónica de Goethe la condición previa y la categoría de la adecuación atienden sin matices a una estética del objeto en la medida en que las condiciones que imponen el material y la utilidad establecen normas que emanan de la propia arquitectura. De igual manera, en una adscripción explícita a la tratadística renacentista, la proporción atiende aun a una estética del objeto. Pero con la exigencia reiterada de la preminencia del carácter sobre la proporción, Goethe está apelando específicamente a criterios de una estética de la 
recepción y se sitúa, antes bien, en la órbita de la armonía de los sentidos, pudiendo considerarse un claro precedente de la teoría de la Einfühlung.

En este punto se hace evidente, de nuevo, el talante mediador de Goethe entre dos mundos. Por un lado, apela a la teoría clásica desde Vitruvio donde la venustas es algo objetivo que se puede delimitar (carácter, proporciones...), y, por el otro, no obvia la deriva de este concepto que se inicia con Perrault (la belleza relativa al medio social) que se cruza y refuerza con las teorías del gusto inglesas: la belleza es relativa y cambia con la sociedad. Goethe quiere encontrar una solución que unifique ambas posturas. Se trataría de conservar la idea de belleza absoluta, aquella que remite a la tradición griega en el sentido winckelmanniano, e introducir simultáneamente el papel de los sentidos. Su oposición a la teoría de las proporciones basada en criterios meramente matemáticos o de la composición como sistema de proyectación iría en ese mismo sentido.

En definitiva, las ideas de Goethe en esta materia, por un lado, se enlazan con la tradición moderna francesa derivada de la Querelle des anciens et des modernes y, por otro, se integran en la constelación de teorías de ciertos arquitectos tratadistas con los que tenía relación. Schinkel, en sus notas para un tratado (1810), entiende la "adecuación al fin" como el principio fundamental de la arquitectura que incluye tanto los aspectos materiales como espirituales o Weinbrenner en su Architektonisches Lehrbuch (1819) hace depender las proporciones del uso y el material. En definitiva, Goethe o bien comparte o bien anticipa esas ideas.

\section{Imitación y racionalidad}

Para salvar esta difícil combinación entre la percepción sensible y el mantenimiento espartano del valor permanente de lo clásico en la arquitectura, Goethe parece intuir un camino a seguir. Para ello se hace eco de dos cuestiones que centraron de un modo especial, en aquellas mismas fechas, su interés y sus investigaciones. Por un lado, la búsqueda de la Urpflanze, origen de toda la flora, concepto sustancial en su pensamiento científico. Por otro, y en sintonía con esa búsqueda, la tesis de la morfología, entendida como la formación y modificación por causas diversas de las plantas mediante metamorfosis. Una idea aplicable también por extensión a la forma y transformación de cualquier organismo. Dos conceptos teóricos, con proyección a otras esferas de conocimiento muy diversas, surgen de estas investigaciones. El primero, la convicción de que existe un arquetipo a partir del cual, en segundo lugar, por procesos de metamorfosis vinculados a cuestiones morfológicas surgen todas las variantes posteriores.

En el terreno de la práctica arquitectónica, los intentos de Goethe de recuperar el tipo arquitectónico teatral heredado de Vitruvio vía Palladio son un claro exponente de esta tensión entre la imitación y morfología. Por una parte, recuperaba elementos característicos del tipo clásico, al tiempo que le exigía capacidad de adaptación a las circunstancias concretas que debía hacer frente. Su arquitectura teatral, por tanto, debía albergar la capacidad de transformación propia de la Urpflanze y ajustarse al arquetipo. El reflejo de estas ideas aflora igualmente en el campo de la teoría arquitectónica, especialmente en el Baukunst (1795), tanto en el 
borrador final como en los esbozos previos. Por un lado, el orden dórico griego o antiguo [Altes], como lo denomina Goethe, surgido en su opinión de las primitivas construcciones de madera que remitirían directamente a la naturaleza, sería el arquetipo indiscutible de la arquitectura. Ese orden evolucionó por diversas circunstancias dando origen a un proceso de metamorfosis del que surgieron los otros órdenes griegos y, en consecuencia, la diversidad arquitectónica. Pero se trata de un lenguaje variado legitimado por su adscripción genealógica y se aleja, por tanto, del relativismo que Goethe empezaba ya a identificar entre sus contemporáneos y que, años después, se concreta en su vejez en la denuncia de la deriva de la arquitectura hacia el "historicismo", al comentar el caso de la catedral de Colonia y su ensayo Von Deutscher Baukunst de 1823.

Esto conlleva, por una parte, asumir la vigencia de la imitación en la arquitectura y recuperar, así, la adscripción racionalista propia de su significado ilustrado: el arte no imita formas naturales, sino que por medio de la verosimilitud consigue imitar los procesos naturales. No se reduce al sentido visual y da cabida, por tanto, a la multiplicidad sensitiva que Goethe reivindica. Pero, por otra parte, dada la asunción de la forma adecuada como condición previa, la arquitectura se retrae, en su imitación, a un estadio anterior a los procesos de racionalización. En línea con las teorías de Winckelmann, Hirt y Galiani, Goethe asume que hay un trasvase de formas de la arquitectura originaria en madera a la consolidada en piedra que apunta hacia un retraimiento consustancial a la arquitectura, una suerte de resistencia contra la modernidad.

\section{Goethe y la autonomía de la arquitectura}

Este impulso mediador de Goethe en el terreno específico de la arquitectura pivota, por tanto, entre el mundo del clasicismo que se agota y la irrupción imparable de la modernidad. Y, tal y como lo plantea, diríase que la disciplina arquitectónica le acompaña. En efecto, para sostener su posicionamiento, Goethe reivindica simultáneamente la capacidad de la arquitectura de incorporar las nuevas claves estéticas, al tiempo que se retrae en lógicas pre-modernas, casi atávicas. Identifica en la arquitectura un medio artístico en el que la irrupción de la modernidad encuentra resistencias, al tiempo que precisamente por su resistencia proporciona un sólido apoyo en su revisión de la modernidad como fenómeno fragmentador, desacelerador del vitalismo o la cultura.

De hecho, estos elementos a los que Goethe apunta implícitamente no son otros que aquellos en los que la tradición autonomicista se volcó. Es más, la tensión entre clasicismo y modernidad en la arquitectura que ha sido mostrada anteriormente se reproduce en clave estética en la estructura interna de la dialéctica de la autonomía y fue abanderada por dos incuestionables referentes de su producción. Si, por una parte, Goethe reconoció explícitamente la aportación de Kant en el terreno estético-teleológico, no puede por menos que suscribir ciertas tesis de Schiller al compartir con él la necesidad de aportar por medio del arte herramientas para construir una sociedad más elevada. Frente a ellos Goethe también tuvo que posicionarse $y$, en el terreno concreto de la arquitectura, bien podría decirse que adelantó las polémicas que marquen indeleblemente los subsi- 
guientes debates entre la arquitectura que se otorga leyes a sí misma (una autonomía de la autodeterminación o trascendental) y otra comprometida con la sociedad (a la que se apela como moderna). Unas polémicas que se sustentan en una compleja articulación entre arquitectura, naturaleza y sociedad.

\section{Naturaleza y sociedad}

Para Kant, la autonomía en el arte forma parte de un proyecto más amplio de autonomía del hombre respecto de las determinaciones naturales y sociales. Está fundamentalmente vinculada a la autonomía del Juicio como una facultad del alma, distinta de la razón y el entendimiento. El orden kantiano está determinado, en primer lugar, por el sujeto que trasciende y que, en la experiencia de la realidad, permite la trascendencia del objeto en la medida en que se concibe como una representación. La obra de arte se considera no ya como una cosa en sí, por tanto, sino como una representación en relación al sujeto (en su doble papel de creador y espectador). Esto se hace especialmente explícito en Goethe al recuperar el papel mediador del genio como aquel que estructura la obra de arte con arreglo a reglas previas, ya constatables en la naturaleza. Sobre esto apunta:

se enfrentan dos partidos, dos modos de pensar [...]. Nosotros pugnamos por la perfección [Vollkommenheit] de una obra de arte en sí y de por sí, y ellos piensan en el efecto de ésta hacia el exterior [Wirkung nach außen], por el cual el verdadero artista ni se preocupa. [...] es un infinito servicio de nuestro viejo Kant para el mundo, y puedo decir que también para mí, el que en su Crítica del Juicio separe enfáticamente arte y naturaleza y les conceda ambas el derecho de actuar sin finalidad a partir de grandes principios. [...] Naturaleza y arte son demasiado gran- des como para partir de finalidades, y tampoco las precisan, pues relaciones hay por doquier $y$ la vida es relaciones. (WA IV.46: 222-223)

Visto así, bien podría situarse la obra de Goethe en la estela decimonónica de l'art pour l'art. Pero el caso de la arquitectura es particular, tal y como Kant formuló después de su "Analítica de lo bello" y Goethe recoge en su obra. El cumplimiento de su utilidad es una condición previa a todo juicio de gusto. De ahí que no haya forma de juicio de la arquitectura en la que no intervenga también la razón, en la medida en que evalúa su adecuación a un fin, estableciéndose por tanto una interna e insalvable limitación de su autonomía. Así, la expresión de "ideas estéticas" en el caso de Kant, en tanto que representaciones de la imaginación que dan pie al libre juego de las facultades, se ve restringida a ideas compatibles con su orientación a un fin objetivo. La combinación entre belleza y utilidad quedará mediada desde entonces por la expresión de ideas morales, llevando la estética de la arquitectura más allá de las teorías clasicistas. De ahí que Goethe reconozca en el Baukunst que "La arquitectura no es un arte imitativo, sino un arte para sí, pero no puede renunciar a la imitación en su más alto grado." (1795: 7). La arquitectura es un arte para sí en la medida en que sigue apoyándose en verdades inmutables y atemporales, por una parte, y detente la capacidad de trasladar las reglas de la naturaleza e incorporarlas a la forma estética, por otra. Pero, siendo un arte útil, da acceso a unas "ideas estéticas" que involucran lo ajeno a sí misma y exigen por su parte la imitación cuando alcanza la ficción poética, desbordando en su grado más elevado su universo propio. 


\section{Arquitectura y sociedad}

Este es el nudo gordiano de la delicada síntesis entre la objetividad de lo clásico como modelo y la subjetividad de las teorías de la Einfühlung. Y marca, de igual manera, un claro límite de su aplicabilidad a la arquitectura. En buena medida el intento de Goethe de congeniar sus teorías morfológicas con la arquitectura estaba abocado a generar tensiones dado que, inevitablemente, la asunción de las características intrínsecas a esta disciplina supone una limitación de la aplicación de estos esquemas. La arquitectura, a diferencia de artes autónomas como la poesía o la música, está determinada por condicionamientos ajenos que dificultan por fuerza el despliegue de la idea morfológica. La exigencia de comunicabilidad (tal y como, por cierto, ya adelantó Kant), esto es, la inevitable pertenencia a una cultura y momento histórico, parece un escollo insalvable y, de hecho, bien podría considerarse una de las razones fundamentales de haber dejado inconcluso el Baukunst (1795).

Pocos años después, Goethe emprendió de nuevo sus estudios sobre la arquitectura en un sentido que muestra a las claras esta dificultad. Trabajó en mayo de 1799 junto a Schiller y Meyer en una clasificación de las artes que quedó plasmada en los apuntes Über den Dilettantismus (1799). En esta, la arquitectura hereda la conceptualización propuesta por Goethe en el Baukunst (1795) con la salvedad de adquirir una nueva finalidad. Allí dicen: "Introduce orden y medida, y también educa en lo útil y necesario a luchar por una apariencia bella y cierta libertad" (DKV, I: 18, 754), caracterización que va más allá del caso concreto del producto del arquitecto diletante. La arquitectura, fren- te al resto de artes, tiene la virtud de, dado su fundamento útil, llegar con mayor facilidad a todas las personas. La buena y mala arquitectura permanece y sirve de referencia, tiene un efecto moral en la sociedad. Aquí resuena con contundencia la teoría del arte educador de Schiller, objeto de acaloradas discusiones. Siendo la adecuación al fin su condición previa al tiempo que la fuente de su potencial belleza, y siendo la adecuación al fin un criterio comprensible por cualquiera, la arquitectura hace más civilizada a la sociedad en la medida en que hace comprensible el proceso civilizador. Hace de lo útil, esto es, de lo necesario, belleza y, en esa medida, tiene capacidad de elevar a la sociedad.

\section{Mediación y tragedia}

En Goethe se ha podido entrever una cierta aspiración de síntesis o reconciliación entre clasicismo y modernidad que se concreta en la identificación en ambos casos de empujes y resistencias. Por una parte, el clasicismo proporciona el sustento objetivo del lenguaje universal y único; por otra, corre el riesgo de alejar la experiencia directa del hecho artístico y reducirse a la aplicación matemática de unas proporciones. A su vez, la modernidad asume la tradición iniciada en la Querelle según la cual la validez del juicio estético individual se antepone, en su sentido histórico, al imperativo de autoridad (la imitatio); pero, al tiempo, en su deriva relativista, la modernidad (el relativismo en la belleza) conduce hacia la arbitrariedad de los lenguajes y, en última instancia, hacia el pluralismo historicista (el universalismo cede frente a las expresiones contingentes e históricas de cada cultura). Si bien es cierto que esta tensión entre 
modernidad y clasicismo puede identificarse en la producción de Goethe en general, en el ámbito de la arquitectura proporciona claves elocuentes del desafío que supuso para esta disciplina la irrupción de la autonomía.

La lucha contra la disolución del clasicismo, por una parte, su reivindicación como elemento renovador, sin renunciar a las categorías modernas ligadas a la irrupción de la autonomía (el genio creador, la subjetividad, el discurso emancipador...), por otra, han de considerarse las claves de su proyecto arquitectónico madurado al socaire de un tiempo convulso. Apoyándose en el clasicismo, Goethe pudo establecer leyes autónomas para la arquitectura basadas en el criterio de perfección. Pero, al tiempo y principal escollo con Schiller, no podía aceptar la identidad entre la idea y lo individual en una obra clásica, dado que implicaría asumir que la idea no puede hacerse experiencia, no puede hacerse sensible. Goethe, en definitiva, buscó la articulación entre naturaleza, arquitectura y sociedad llevando al clasicismo más allá de sí mismo. Un proyecto en el que se volcó con ímpetu en los turbulentos años a caballo de los siglos XVIII y XIX. Un proyecto del que se distanció con la íntima convicción de no ser capaz de llevarlo a término. En este sentido, se entrevé en Über den Dilettantismus el potencial unificador de la arquitectura entre estas tres esferas. Eso sí, a condición de que la arquitectura renuncie a su grado más elevado, es decir, asumiendo un grado de mediocridad. Lo que da a su impulso mediador indudables tintes trágicos. 
I may observe, that in all important political emergencies, those spectators are most fortunate who join one of the contending parties; what is really favourable to them they are able to enjoy; what is unfavourable they keep out of sight, decline it, or turn it to their advantage. But the poet, who from his very nature is and must remain free from party feelings, seeks to comprehend the state of the case from both points of view, when, if an adjustment is impossible, he must make up his mind to end tragically. And with what cycle of tragedies did we not see ourselves threatened by the raging of the world-whirlwind! (Campaign in France: 296)

Goethe was an attentive observer of diverse fields: politics, art, science... A good example of this is the diversity of topics he discussed in his work, as well as the friendships he cultivated for decades and the library he treasured. His position on the controversies among his contemporaries in these areas he focused his attention on was hard to pinpoint. To give an example, and as he picked up on his return to Weimar from the campaign in France, his position on the French Revolution was very ambiguous. Paraphrasing Thomas Mann (1932), Goethe may well be considered "a representative of the bourgeois era", that is, a conservative who criticized civic politicization. But he was also a conspicuous advocate of political change in fragmented Germany. All at once.

To avoid this hermeneutical pitfall some authors have identified stages, phases in his production, which would point an evolution of sorts throughout his life. But the truth is that Goethe's work seen as a progression, from the momentum of youth to classical wisdom after his time in Italy, withering into a calm and erudite old age, does no justice to the conflicts he had to face nor the com- plexity of his proposals. Goethe faced with singular attention the overlap of two worlds. He witnessed and actively participated in the readjustment resulting from the exhaustion of one world and the emergence of another with a clear mediating, if not tragic, vocation.

\section{Between classicism and modernity}

Architecture did not escape that exegetical artifice. Moreover, this may be singularly pointed in this field by the polarization of his positions throughout his life articulated through two series: Von Deutscher Baukunst (1772 and 1823) and Baukunst (1788 and 1795). In his architectural proposals one can identify both eighteenth-century statements and unquestionably current proposals, which can only materialize in a persistent tension between classicism and modernity. Although this tension is clearly recognizable in Baukunst (1795), no doubt his most significant contribution to the discipline, it manifests itself in multiple areas of his theoretical and practical production. It is therefore appropriate to unravel what the poles of tension were and how Goethe faced them.

\section{Essay and treatise}

In the writing of Baukunst (1795), Goethe uses for reference in regards of structure and arrangement the treatises he used to study architecture. In this theoretical system, architectural drawings play a pivotal role, to the point that they can be understood as a means of knowledge and not only mere illustrations. This is Goethe's understanding, shown in his accompanying the text with a large graphic corpus. But, on the other hand, his work no longer shares the didactic and pragmatic 
end of the treatises. Under the influence of historical and theoretical writings he used as a reference, his goal is on a different level: to justify the role of the Classic in the renovation of architecture. Goethe is indeed writing a text neither for the artist, nor for the brilliant creator, but for the connoisseur, in a sense close to Laugier, Sulzer or Winckelmann's essays, to name a few. As a matter of fact, the gap between artist and spectator, which started with modern aesthetics (an expert can judge more accurately than the creator himself), was at the origin of the crisis of the genre of treatise. Theoretical reflection then no longer depends on the one who creates, but on a scholar. In the case of architecture, this brought decreasing interest in technique.

Thus, two canonical models are combined. On the one hand, the approach derived from Renaissance treaties: relation of the text and the drawings, parts constituting the work, etc. On the other, attending to theoretical issues and avoiding constructive matters distances it from those referents, drawing it closer to a theoretical essay following the guideline of the 18th century. Baukunst (1795) would therefore be halfway between these two types of writings on architecture and place Goethe at the very centre of the modern transition. This is also evidenced in the rest of his theoretical production. In the series on German architecture, a progressive distancing from the dialectic between matter and form is noticeable identified, an object of privileged attention in his Baukunst (1788). And, in fact, the way Goethe addresses his attempts to practice as an architect illustrates this drift. Both in his projective incursions, and his role as project manager, Goethe was able to experience the impossibility of exerci- sing fully in architecture without the assistance of someone with the necessary technical knowledge, which he lacked.

\section{Objectivism and relativism}

On the other hand, this distance between theory and practice has its correlation between the artist and the spectator through the artistic object. While treatises still relied on the enunciation of objective criteria of architecture composition, the Querelle des anciens et des modernes consolidated an aesthetic that questioned the unappealable timelessness of the classical criteria. This opened the possibility of conceiving architectural beauty as relying on subjective criteria and encouraged the tension between the artistic object and its receiver.

In this sense, in Goethe's architectural theory the "previous condition" and the category of adequacy attend to the aesthetics of the object without nuances insofar as the conditions imposed by materials and the building's utility establish norms that emanate from architecture itself. Similarly, in an explicit ascription to Renaissance treatise, proportion still serves an aesthetic of the object. But with the repeated requirement to put character over proportion, Goethe is specifically appealing to an aesthetic criterion of reception and is located, rather, in the realm of the harmony of the senses, and can be considered a clear precedent of the Einfühlung theory.

At this point it becomes again evident Goethe's mediatorial position between two worlds. On the one hand, he appeals to the classical theory from Vitruvius on, where venustas is an objective, measurable quality (character, proportions ...). On the other, he does not obviate the drift of this concept 
that begins with Perrault (beauty depending on social environment) that intersects and reinforces itself with English theories of taste: beauty is relative and changes with society. Goethe wants to find a solution that unifies both positions. The idea would be to preserve the idea of absolute beauty, which points to Greek tradition in a Winckelmannian sense, all the while introducing the role of the senses. His opposition to the theory of proportions based on purely mathematical criteria or of composition as a projection system would go in the same direction.

In short, Goethe's ideas in this area, on the one hand, are linked to the modern French tradition derived from the Querelle des anciens et des modernes and, on the other, are integrated into the constellation of theories from certain architects with whom he was related. Schinkel, in his notes for a treatise (1810), understands "adequacy to the end" as the fundamental principle of architecture that includes both material and spiritual aspects, or Weinbrenner in his Architektonisches Lehrbuch (1819) considers proportions as depending on use and material. In short, Goethe either shares or anticipates those ideas.

\section{Imitation and rationality}

To save this difficult combination between sensitive perception and Spartan maintenance of the permanent value of classical architecture, Goethe seems to intuitively find a way forward. To do this, he echoes two issues that drew his interest and research especially at the same time. On the one hand, the search for the Urpflanze, the origin of all flora, a substantial concept in his scientific thinking. On the other, and in line with that research, the thesis of morphology, understood as the plants' formation and modification through metamorphosis. An idea also applicable by extension to the form and transformation of any organism. Two theoretical concepts, with projection onto other very diverse spheres of knowledge, arise from these investigations. The first one is the conviction that there is an archetype from which, secondly, through a process of metamorphosis linked to morphological issues all subsequent variations arise. In the field of architectural practice, Goethe's attempts to recover the theatrical architectural type inherited from Vitruvius via Palladio are a clear example of this tension between imitation and morphology. On the one hand, he recovered characteristic elements of the classical type, while requiring to adapt them to the specific circumstances to be faced. His theatre architecture, therefore, had to combine the capacity of transformation of the Urpflanze and respect the archetype. The reflection of these ideas also emerges in the field of architectural theory, especially in the Baukunst (1795), both in the final draft and in the previous sketches. On the one hand, the Greek or ancient Doric order [Altes], as Goethe calls it, emerged in his opinion from primitive wooden constructions that would directly imitate nature, would be the unquestionable archetype of architecture. This order evolved by various circumstances giving rise to a metamorphosis process from which the other Greek orders emerged and, consequently, architectural diversity. But it is a varied language legitimized by its genealogical ascription and, therefore, moves away from the relativism that Goethe was already beginning to identify among his contemporaries. Years later, at his old age, he would 
denounce the drift of architecture towards "historicism", putting forward the case of the Cologne Cathedral and in his essay Von Deutscher Baukunst of 1823.

This entails, on the one hand, assuming the validity of imitation in architecture and thus recovering the rationalist ascription of its enlightened meaning: art does not imitate natural forms, but by means of verisimilitude manages to imitate natural processes. It is not reduced to the visual sense and therefore accommodates the sensitive multiplicity that Goethe claims. But, on the other hand, given the assumption of the appropriate form as a previous condition, architecture withdraws itself, in its imitation, to a stage prior to the rationalization processes. In line with Winckelmann, Hirt and Galiani's theories, Goethe assumes that there is a form transfer from the original architecture in wood to the one that consolidated in stone pointing towards a consubstantial withdrawal to the architecture, a sort of resistance against modernity.

\section{Goethe and the autonomy of architecture}

This mediating impulse of Goethe's in the specific field of architecture pivots, therefore, between the fading Classical world and the unstoppable irruption of modernity. And, as he puts it, one could say architectural discipline accompanies him. Indeed, to support his position, Goethe claims simultaneously architecture's ability to incorporate new aesthetic milestones, while retracting in pre-modern, almost atavistic logics. He identifies in architecture an artistic medium in which the irruption of modernity finds resistance, while -precisely because of its resistance- it provi- des solid support in its revision of modernity as a fragmenting phenomenon, decelerating vitalism or culture itself.

In fact, these elements Goethe implicitly points out are none other than those on which the autonomist tradition would focus. Moreover, the tension between classicism and modernity in architecture shown above is reproduced in an aesthetic way in the internal structure of the dialectic of autonomy and was conducted by two unquestionable referents of its production. If, on the one hand, Goethe explicitly recognized Kant's contribution in the aesthetic-teleological field, he subscribed nonetheless certain Schiller's thesis by sharing with him the need to contribute through art tools to build a higher society. Goethe had to confront them and, specifically in field of architecture, it could be said that he advanced the controversies that marked indelibly the debates between an architecture issuing itself laws (an autonomy of self-determination or transcendental) and another committed to society (which is considered modern). Controversies based on a complex articulation between architecture, nature and society.

\section{Nature and society}

For Kant, autonomy in art is part of a broader project of autonomy of mankind from natural and social determinations. It is fundamentally linked to the autonomy of Judgment as a trait of the soul, distinct from reason and understanding. The Kantian order is determined, in the first place, by those who transcend and, in the experience of reality, allow the object to transcend to the extent that it is conceived as a representation. The work of art is considered not only as a thing in itself, therefore, but 
as a representation in relation to the subject (in its double role as creator and spectator). This is especially explicit in Goethe by recovering the mediating role of genius as one who structures the work of art according to previous rules, already verifiable in nature. On this point:

two games, two ways of thinking are faced [...]. We strive for perfection [Vollkommenheit] of a work of art in and of itself, and they think about its effect on the outside [Wirkung nach außen], for which the true artist does not even care. [...] It is an infinite service of our old Kant to the world, and I can say that also for me, that in his Critique of Judgement he emphatically separates art and nature and grants both the right to act without purpose based on great principles. [...] Nature and art are too big to start with goals, and they don't need them because relationships are everywhere, and life is relationships. (WA IV.46: 222-223)

From this point of view, Goethe's work could well be placed in the nineteenth century principle of l'art pour l'art. But the case of architecture is peculiar, as Kant formulated after his "Analytics of the beautiful" and Goethe takes up in his work. The fulfilment of its usefulness is a precondition for any taste judgement. Hence, there is no way to judge architecture in which reason doesn't also intervene, insofar as it evaluates its adequacy to an end, thus establishing an internal and insurmountable limitation to its autonomy. Thus, the expression of "aesthetic ideas" in the case of Kant, as representations of the imagination that promote the free play of the faculties, is restricted to ideas compatible with their orientation to an objective end. The combination of beauty and utility will be mediated from the on by the expression of moral ideas, taking the aesthetics of architec- ture beyond classicist theories. Thus, Goethe acknowledges in Baukunst that "Architecture is not an imitative art, but an art for itself, but it cannot give up imitation in its highest degree." (1795: 7). Architecture is an art for itself to the extent that it continues to rely on immutable and timeless truths, on the one hand, and has the ability to translate the rules of nature, incorporating them into aesthetic form, on the other. But, being a useful art, it gives access to "aesthetic ideas" that involve that which is alien to it and demand imitation when reaching poetic fiction, overflowing its own universe in its highest form.

\section{Architecture and society}

This is the Gordian knot of the delicate synthesis between classical objectivity as a model and the subjectivity of the Einfühlung theories. And it marks all the same a clear limitation to its applicability in architecture. To a large extent, Goethe's attempt to connect his morphological theories with architecture was bound to generate tensions since the assumption of the intrinsic characteristics of this discipline inevitably implies a limitation of the application of these schemes. Architecture, unlike autonomous arts such as poetry or music, is determined by external conditions that make it difficult to deploy the morphological idea. The requirement of communicability (as, by the way, Kant already advanced), that is, the inevitable belonging to a culture and a historical moment, seems an insurmountable obstacle. In fact, it could be considered one of the fundamental reasons of having left the Baukunst (1795) unfinished.

A few years later, Goethe undertook again his studies on architecture in a sense that clearly shows this difficulty. He worked 
in May 1799 with Schiller and Meyer in a classification of the arts that was reflected in the notes Über den Dilettantismus (1799). In this text, architecture inherits the conceptualization proposed by Goethe in the Baukunst (1795) except for a new purpose being acquired. There they say: "Introduce order and measure, and also educate in the useful and necessary to fight for a beautiful appearance and a certain freedom" (DKV, I: $18,754)$, a characterization that goes beyond the specific case of the product of the dilettante architect. Architecture, compared to the rest of arts, has the virtue of, given its useful foundation, reaching more easily everyone. Good and bad architecture remains and serves as a reference. It has a moral effect on society. Here, Schiller's educative art theory resonates forcefully, a largely discussed topic between them. Being the adequacy to the end a previous condition at the same time as the source of its potential beauty, and being the adequacy to the end a criterion understandable by anyone, architecture makes society more civilized to the extent that it makes the process of civilization understandable. It makes that which useful, that is, the necessary, into a thing of beauty and, to that extent, it has the ability to elevate society.

\section{Mediation and tragedy}

In Goethe it has been possible to glimpse a certain aspiration of synthesis or reconciliation between classicism and modernity that is specified in the identification in both cases of thrusts and resistances. On the one hand, classicism provides the objective support of a universal and unique language; on the other, it risks moving the direct experience away from the artistic fact and reducing it to a mathematical application of proportions. At the same time, modernity assumes the tradition initiated in the Querelle according to which the validity of individual aesthetic judgment precedes, in its historical sense, the imperative of authority (imitation); but, at the same time, in its relativistic drift, modernity (relativism in beauty) leads to the arbitrariness of languages and, ultimately, to historicist pluralism (universalism yields to the contingent and historical expressions of each culture). While it is true that this tension between modernity and classicism can be identified in Goethe's production in general terms, in the field of architecture it provides eloquent clues to the challenge posed by the irruption of autonomy in this discipline.

The fight against the dissolution of classicism, on the one hand, its claim as an element for renewal, without renouncing the modern categories linked to the irruption of autonomy (creative genius, subjectivity, emancipatory discourse ...), on the other, must be considered the keys of his architectural project matured during these agitated times. Relying on classicism, Goethe was able to establish autonomous laws for architecture based on the criterion of perfection. But, at the same time, and being his main obstacle with Schiller, he could not accept identifying the idea and the individual in a classic work, since it would imply assuming that ideas cannot become experiences, cannot be made felt. Goethe, in short, sought the articulation between nature, architecture and society, bringing classicism beyond itself. A project in which he turned with impetus in the turbulent years between the eighteenth and nineteenth centuries. A project from which he distanced 
himself with the intimate conviction of his own inability to carry it out. In this sense, the unifying potential of architecture between these three spheres was revealed in Über den Dilettantismus. Of course, provided that architecture renounces its highest form, that is, assuming a degree of mediocrity. Which gives its mediating impulse an undoubtedly tragic demeanour. 



\section{BIBLIOGRAFÍA DE REFERENCIA}

En esta bibliografía no se pretende recoger de forma exhaustiva la ingente bibliografía secundaria que trata sobre un tema tan transversal como la "autonomía", atendiendo a autores sometidos a una intensa labor de investigación como son Kant, Schiller $y$, muy especialmente, Goethe y a áreas de conocimiento tan amplias como la estética, la arquitectura o las bellas artes. Son objeto de mención aquí las obras que han sido citadas en el trabajo o que han servido de referencia directa. 


\section{Normas de abreviación:}

$\begin{array}{ll}\text { ed. } & \text { edición } \\ \text { trad. } & \text { traducción } \\ \text { pr. } & \text { prólogo } \\ \text { es. pr. } & \text { estudio preliminar } \\ \text { n. } & \text { notas } \\ \text { intr. } & \text { introducción } \\ \text { dir. } & \text { dirección }\end{array}$

WA: Goethes Werke, Nachträge zur Weimarer Ausgabe, Paul Raabe (ed.), Múnich DKV: Sämtliche Werke. Briefe, Tagebücher und Gespräche, 40 in 45 Bänden in 2 Abteilungen, Karl Eibl et al. (ed.), Frankfurt am Main: Deutscher Klassiker Verlag

BA: Berliner Ausgabe. Vollständig in 22 bänden und einem Supplementband. Berlin En lo que respecta (1991), Obras completas (IV vols.), Rafael Cansinos Assens (recopilación, traducción, estudio preliminar, prólogos y notas), México: Aguilar, se ha adoptado el siguiente criterio:
M. y R.
"Máximas y reflexiones", tomo II, pp. 339-469
A. S.
"Las afınidades electivas", tomo II, pp. 1198-1347
Eck.
"Eckermann. Conversaciones con Goethe", tomo III, pp. 13-424
P. y V.
"Poesía y verdad", tomo III, pp. 427-879
Part. Auto.
"Particularidades autobiográficas", tomo III, pp. 880-1009
W.
"Winckelmann", tomo III, pp. 1013-1030
V. It.
"Viajes italianos", tomo III, pp. 1031-1410
D. y A.
"Diarios y anales", tomo IV, pp. 9-228 
VV. AA. (1984), Autonomous Architecture. Harvard Architectural Review, vol. 3, Cambridge: MIT Press

VV. AA. (1987), Arte, arquitectura y estética en el siglo XVIII, Akal: Madrid

VV. AA. (1990), Estudios sobre la Crítica del Juicio, Madrid: Visor

VV. AA. (1995), Autonomie der Kunst. Zur Aktualität von Kants Ästhetik, Berlín: Akademie Verlag

VV. AA. (1997), Saeculum tamquam aureum, U. Ecker y C. Zintzen (ed.). Hildesheim

VV. AA. (2007), Historisches Wörterbuch der Philosophie, Joachim Ritter (ed.).

Basilea: Schwabe

Adorno, Th. W. (2003), Notas sobre literatura, vol. 11, Alfredo Brotons Muñoz (trad.), Rolf Tiedemann (ed.), Gretel Adorno, Susan Buck-Morss y Klaus Schultz (colaboradores), Madrid: Akal -- (2004), Teoría Estética. Obra Completa, Vol. 7, Jorge Navarro Pérez (trad.), Rolf Tiedemann (ed.), Gretel Adorno, Susan Buck-Morss y Klaus Schultz (colaboradores), Madrid: Akal -- (2006), Minima Moralia. Reflexiones desde la vida dañada. Obra completa, vol. 4, Rolf Tiedemann (ed.), Joaquín Chamorro Mielke (trad.). Madrid: Akal

Ahrendt, D. y Aepfler, G. (1994), Goethes Gärten in Weimar, Leipzig: Seemann Henschel Verlag

Alberti, L. B. (1977) [1485], De re AEdificatoria, Francisco Loçano (trad.), facsímil de la edición original de 1582, València: Albatros
Argan, G. C. (2010), Lo artístico y lo estético, Domenico Moscufo (ed. y trad.), Madrid: Casimiro libros

Arnaldo, J. (ed.) (2008), Johann Wolfgang von Goethe. Paisajes, Madrid: Círculo de Bellas Artes .- (ed.) (2012), Goethe. Naturaleza, arte, verdad, Madrid: Círculo de Bellas Artes

-- (2019), Vemos lo que sabemos. La cultura de la visión en Goethe, Madrid: Abada

Arnheim, R. (1978), La forma visual de la arquitectura, Barcelona: Gustavo Gili .- (1984), El poder del centro. Estudios sobre la composición en las artes visuales, Madrid: Alianza

Assunto, R. (1990), "Palladio e l'occhio dei literati", en André Chastel y Renato Cevese, Andrea Palladio: nuove contributi, CISAAP, Milán: Electa, pp. 32-38

.- (1990) [1973] La antigüedad como futuro. Estudios sobre la estética del neoclasicismo europeo, Madrid: Visor

Aureli, P. V. (2008), The project of autonomy: politics and architecture within and against capitalism, Nueva York: Princeton Architectural Press

Baioni, G. (1988), Classicismo e rivoluzione. Goethe e la rivoluzione francese, Guida

Bapp, K. (1921), Aus Goethes griechischer Gedankenwelt, Leipzig: Sarastro

Baumgarten, A. G. (1961), Aesthetica, Olms: Hildesheim -- (1975), Reflexiones filosóficas acerca de la poesía, José Antonio Míguez (trad.), Buenos Aires: Aguilar 
Baumgartner, H. M. y Korten, H. (1996), Friedrich Wilhelm Joseph Schelling, Múnich: Beck

Beyer, A. et al. (2001), Das Römische Haus in Weimar, Múnich-Viena: Carl Hanser Verlag

Biemel, W. (1959), Die Bedeutung von Kants Begründung der Ästhetik für die Philosophie der Kunst, Colonia: Kölner Universität

Bisky, J. (2000), Poesie der Baukunst. Architekturästhetik von Winckelmann bis Boisserèe, Weimar: Hermann Böhlaus Nachfolger

Boime , A. (1996), El arte en la época del bonapartismo. 1800-1815, vol. 2 de Historia social del arte moderno, Madrid: Alianza

Bonet, A. et al. (1985), Polémica arquitectos ingenieros en España. Madrid: Siglo $\mathrm{XIX}$

Bothe, R. (2000), "Gentz oder Goethe, das ist hier die Frage. Anmerkungen zum Treppenhaus und Festsaal im Weimarer Schloss", en Deutsche Baukunst um 1800, R. Wegner (ed.), Colonia: Böhlau Verlag, pp. 165-190

Boullée, E.-L. (1968), Essais sur l'art, J. M. Perouse de Montclos (ed.), París

Bowie, A. (1999), Estética y subjetividad. La filosofía alemana de Kant a Nietzsche y la teoría estética actual, Madrid: Visor

Bozal, V. (ed.) (1996), Historia de las ideas estéticas y de las teorías artísticas contemporáneas, Madrid: Visor

Bürger, P. (1987), Teoría de la vanguardia, Jorge Gardía (trad.), Helio Piñón (pr.), Barcelona: Península
.- (1995), "Ende der Avantgarde?", en Neue Rundschau, vol. 106 -- (1996), Crítica de la estética idealista, Madrid: Visor

Busch, W. (ed.) (1987), Funkkolleg Kunst. Eine Geschichte der Kunst im Wandel ihrer Funktionen, Múnich: Piper

Cacciari, M. (1995), Architecture and Nihilism: On the Philosophy of Modern Architecture, Yale University Press

Calatrava, J. (1992), La teoría del Arquitectura y de las Bellas Artes en la Encyclopédie de Diderot y D'Alembert, Granada: Diputación Provincial de Granada - (1999), Arquitectura y cultura en el Siglo de las Luces, Granada: Editorial Universidad de Granada - (2005), "Vitruvio y la teoría de la Arquitectura", en Estudios sobre historiografía de la arquitectura, Granada: Universidad de Granada, pp. 19-60

Calatrava, J. García Pérez, F. y Arredondo Garrido, D. (eds.) (2016), La Cultura y la Ciudad. Granada: Editorial Universidad de Granada

Calduch Cervera, J. (2013a), "Goethe dibujante de arquitectura", en EGA. Revista de Expresión Gráfica Arquitectónica, 18(21), pp. 40-51

.- (2013b), "Del texto al dibujo: las imágenes de la basílica de Fano", edic. digital: hhtp://etsavega.net/ dibex/, 9.10.2013 .- (2014a), "Goethe en Italia. Los dibujos de ruinas", en El dibujo de viaje de los arquitectos, Las Palmas de Gran Canaria, pp. 179-186 
.- (2014b), "El tratado de Vitruvio ilustrado", en Cuaderno de Notas, 15, pp. 95 y ss.

.- (2014c), “Poner ante los ojos el texto de Vitruvio: la representación de la arquitectura en el tratado", $\mathrm{Pa}$ lapa, vol I, $n^{\circ} 2,3^{a}$ época, pp. 84 y ss. - (2017a), Andrea Palladio. La arquitectura dibujada en los tratados, Alicante: Publicacions Universitat d'Alacant

.- (2017b), «De Goethe a Le Corbusier. Variaciones sobre el recorrido arquitectónico", en La recherche patiente. Le Corbusier, cincuenta años después. Jorge Torres y Clara Mejía (ed.). València: General de Ediciones, pp. $100-113$

Calduch Cervera, J. y Rubio Garrido, A. (2016), "El paisaje en la ciudad. El parque del Ilm en Weimar visto por Goethe", en Juan Calatrava, Francisco García Pérez, David Arredondo Garrido (eds.), La Cultura y la Ciudad. Granada: Editorial Universidad de Granada .- (2017), "Los dibujos para escenografías de Goethe", en EGA. Revista de Expresión Gráfica Arquitectónica, 22(31), pp. 162-171

.- (2018a), "Baukunst. Goethe's Notes for a Treatise on Architecture", en E. Castaño Perea y E. Echeverría Valiente (ed.), Architectural Draughtsmanship. From Analog to Digital Narratives. Springer, pp. 1205-1220 -- (2018b), "Proyectos de escaleras de Goethe", en Archivo de arte valenciano, pp. 209-222

Calinescu, M. (2003), Cinco caras de la modernidad. Modernismo, vanguardia, decadencia, kitsch, postmodernismo, Madrid: Tecnos

Cassirer, E. (1948), Kant, vida y doctrina, México: Fondo de Cultura Económica .- (1975), Idee und Gestalt:Goethe, Schiller, Hölderlin, Kleist, Darmstadt: Wissenschaftliche Buchgessellschaft - (1997), Filosofía de la llustración, México: Fondo de Cultura Económica

Casula, M. (1974), “A. G. Baumgarten entre G. W. Leibniz et Chr. Wolff", en Archives de Philosophie, 42-4, pp. 547-575

Cervera Vera, L. (1978), El Códice de Vitruvio hasta sus primeras versiones impresas, Madrid .- (1982), "Vitruvio, su época, formación cultural y personalidad", en Boletín de Bellas Artes, n 10, pp. 151-196

Choay, F. (1986) [1980], La regola e il modelo. Sulla teoria dell'architettura e dell'urbanistica, Roma: Officina Edizioni

Claramonte J. (2010), La república de los fines: contribución a una crítica de la autonomía del arte y la sensibilidad, Murcia: Cendeac

Collins, P. (1998) [1970], Los ideales de la arquitectura moderna. Su evolución (1750-1950), [1965], Barcelona: Gustavo Gili

Colquhoun, A. (1985), Essays in Architectural Criticism: Modern Architecture and Historical Change, Cambridge: MIT Press

Cometa, M. (1993), Duplicità del classico. II mito del tempio di Giove Olimpico da Winckelmann a Leo von Klenze, Palermo: Medina 
-- (1999), Il romanzo dell'architettura. La Sicilia e il Grand Tour nell'età di Goethe, Roma-Bari: Laterza

-- (2017), Fantasmagorie. La cultura visuale dell'età di Goethe, Roma-Macerata: Quodlibet

Damisch, H. (1997) [1987], El origen de la perspectiva, Madrid: Alianza

Darwin, Ch. (2009), El origen de las especies, Edición conmemorativa, Antonio Zulueta (trad.). Madrid: Espasa-Calpe

Diderot, D. (1981), Investigaciones filosóficas sobre el origen y la naturaleza de lo bello, Madrid: Aguilar .- (1993), Oevres esthétiques, París: Classiques Garniers

Diderot, D. y Alembert, J. d' (dir.) (1751-1772), L'Encyclopédie ou Dictionnaire raisonné des sciences, des arts et des métiers, París

Eckermann, J. P. (2005), Conversaciones con Goethe, Rosa Sala (ed. y trad.), Barcelona: Acantilado

Eco, U. (1965), Apocalípticos e integrados. Barcelona: Lumen .- (1983), "Cultura como espectáculo", en La estrategia de la ilusión. Mondadori

Einem, H. von (1972), Goethe. Studien, Múnich: Wilhelm Fink Verlag -- (1982), Man denke sich den Orpheus. Goethes Reflexion über die Architektur als verstummter Tonkunst, Múnich: Akademie der schönen Künste

Eurípides (1995), Ifigenia entre los tauros, Madrid: Gredos

Ewald, R. (1999), Goethes Architektur. Des Poeten Theorie und Praxis, Weimar: Ullerich Verlag
Feil, E. (1987), Antithetik neuzeitlicher Vernunft: "Autonomie-Heteronomie“ und "rational-irrational", Götingen: Vandenhoeck \& Ruprecht

Femmel, G. (ed.) (1972) [1958], Corpus der Goethezeichnungen (10 Tomos), Leipzig: Veb. E. A. Seemann, Buch und Kunstverlag

Ferri, S. (1953), "Note archeologico-critiche al testo di Vitruvio", en Parola del passato, XXX, pp. 214-224

Ficacci, L. (2001), Giovanni Battista Piranesi. Catalogo completo delle acquaforti. Colonia: Taschen

Fichet, F. (1979), La theorie architecturale a l'age classique: Essai d'anthologie critique, Bruselas: P. Mardaga

Fiedler, L. (1984), "Überquert die Grenze, schließt den Graben", en VV. AA (1988), Wege aus der Moderne. Schlüsseltexte der Postmoderne-Diskussion, W. Welsch (ed.). Weinheim, pp. 47-74

Flesche, H. (1950), "Goethe und die Baukunst", en Abhandlungen der Braunschweigischen Wissenschaftlichen Gesellschaft 2, pp. 206-210

Fontius, M. (1977), "Produktivkraftentfaltung und Autonomie der Kunst. Zur Ablösung ständischer Voraussetzungen in der Literaturtheorie", en Literatur im Epochenumbruch, G. Klotz y W. Schröder (ed.). Berlín, pp. 409-529

Forssman, E. (2000), "Von deutscher Baukunst. Goethe und Schinkel", en R. Wegner (ed.), Deutsche Baukunst um 1800, Colonia: Böhlau Verlag

Foster, H. (ed.) (1983), The Anti-Aesthetic. Essays on Postmodern Culture, Seattle: Bay Press 
Foucault, M. (2008), Vigilar y castigar. Nacimiento de la prisión, Madrid: Siglo $\mathrm{XXI}$

-- (2009), Las palabras y las cosas. Una arqueología de las ciencias humanas, Madrid: Siglo XXI

Franzini, E. (2000), La estética del siglo XVII, Madrid: Visor

Freccero, J. (1986), "The Fig and the Laurel. Petrarch's Poetics", en VV. AA. (1986), Literary Theory/Renaissance Texts, Patricia Parker y David Quint (ed.). Baltimore: The Johns Hopkins University Press, pp. 20-32

Fredel, J. (1994), "Autonomie der Kunst", en Historisch-kritisches Wörterbuch des Marxismus, vol. 1, Hamburgo: Argument-Verlag, pp. 774-779

Gadamer, H.-G. (2007), Verdad y método, Ana Agud Aparicio y Rafael de Agapito (trad.), Salamanca: Sígueme

Gaiger, J. (2009), “Dismantling the frame: site-specific art and aesthetic autonomy", en British Journal of Aesthetics 49, pp. 43-58

Galilei, G. (2003), Diálogo acerca de dos nuevas ciencias, Teófilo Isnardi (pr.) y José San Román Villasante (trad.), Buenos Aires: Losada

Gaos, J. (1962), Las 'Críticas' de Kant, Caracas: Universidad Central de Venezuela

García Morente, M. (1975), La filosofía de Kant, Madrid: Espasa-Calpe

Geertman, H. (1993), "Vitruvio, la realtà architettonica e la progettazione di porte templari", en Bulletin Antieke Beschaving, XVII

Germann, G. (1991), Vitruve et le vitruvianisme: introduction à l'historie de la théorie architecturale, Laussane: Presses Polytechniques et Universitaires Romandes

Germer, S. (1988), Historizität und Autonomie. Studien zu Wandbildern im Frankreich des 19. Jahrhunderts. Ingres, Chassériau, Chenavard und Puvis de Chavannes, Hildesheim: Olms

Giavarina, A. G. (2006-2007), "Palladio e le antichità dell'Umbria", Annali di architettura. Rivista del Centro Internazionale di Studi di Architettura Andrea Palladio di Vicenza

Goethe, J. W. (1965-1978), Berliner Ausgabe. Vollständig in 22 bänden und einem Supplementband. Berlin Aufbau .- (1980), Goethe on Art. J. Cage (ed. Trad.), Londres: Scolar Press .- (1990), Goethes Werke, Nachträge zur Weimarer Ausgabe, Paul Raabe (ed.), Múnic .- (1991), Obras completas (IV vols.), Rafael Cansinos Assens (recopilación, traducción, estudio preliminar, prólogos y notas), México D.F.: Aguilar Tomo I: "Máximas y reflexiones" (pp. 339-469) "Esbozo de una teoría de los colores" (pp. 473-734) Tomo II: "Las afinidades electivas" (pp. 1198-1347)

Tomo III: "Eckermann. Conversaciones con Goethe" (13-424) "Poesía y verdad" (pp.427-879) "Particularidades autobiográficas" (pp. 880-1009) "Winckelmann" (pp. 1013-1030) "Viajes italianos" (pp. 1031-1410) Tomo IV: "Diarios y anales" (pp. 9-228) 
-- (1994), Baukunst. Dal Gotico al Classico negli scritti sull'architettura, Vittorio Ugo (ed.), Palermo: Medina Mediterranea Editrice in Architettura - (1997), Teoría de la naturaleza. Diego Sánchez Meca (trad. y n.). Madrid: Tecnos

-- Sämtliche Werke. Briefe, Tagebücher und Gespräche, 40 in 45 Bänden in 2 Abteilungen [ 40 números en 45 volúmenes en dos secciones], Karl Eibl et al. (ed.), Frankfurt am Main: Deutscher Klassiker Verlag (1998), Tomo I-18: Ästhetische Schriften 1771-1805, Friedmar Apel (ed.)

(1998), Tomo I-19: Ästhetische Schriften 1806-1815, Friedmar Apel (ed.),

(1991), Tomo II-3: Italien-Im Schatten der Revolution. Briefe, Tagebücher und Gespräche vom 3. September 1786 bis 12. Juni 1794, Karl Eibl (ed.),

(1998), Tomo II-4: Mit Schiller. 1794-1799 (parte 1), Volker C. Dörr y Norbert Oellers (ed.)

-- (1999), Escritos de arte, Miguel Salmerón (trad., int. y n.), Madrid: Síntesis

González Moreno-Navarro, J. L. (1993), El Legado Oculto de Vitruvio, Madrid: Alianza

Gros, P. (1975), "Structures et limites de la compilation vitruvienne dans les livres III et IV du De architectura", en Latomus, n³4, pp. 986-1009 .- (1997), "Vitruvio e il suo tempo", en Vitruvio, De architectura, Antonio
Corso (trad.), Turín: Giullio Einaudi, pp. IX-LXXVII

Guyer, P. (1979), Kant and the Claims of Taste, MA y Londres: Cambridge - (1987), Kant and the Claims of Knowledge, Cambridge: Cambridge University Press

-(2002), "Free and Adherent Beauty: A Modest Proposal", en The British Journal of Aesthetics 42, pp. 357-366 .- (2011), "Kant and the Philosophy of Architecture" en The Journal of Aesthetics and Art Criticism, Special Issue: The Aesthetics of Architecture: Philosophical Investigations into the Art of Building, pp. 7-19

Habermas, J. (1981), "Arquitectura moderna y posmoderna", en Revista de Occidente 42, Madrid, noviembre 1984, pp. 95-109

Hanslick, E. (1854/1990), Vom Musikalisch-Schönen. Ein Beitrag zur Revision der Ästhetik der Tonkunst, D. Strauß (ed.)

Hauser, A. (1993), Historia social de la literatura y del arte, Barcelona: Labor

Hautecoeur, L. (1943-1957), Histoire de l'architecture classique en France, Paris: A. et J. Picard. - (1953), Révolution et Empire, 1792-1815, París : A. et J. Picard

Hegel, G. W. F. (1989), Estética, Raúl Gabás (trad.), Barcelona: Península -- (2009), Fenomenología del Espíritu, Manuel Jiménez Redondo (ed., trad., intr. y n.), Valencia: Pre-Textos

Henrich, D. (1957), "Der Begriff des Schönen in Schillers Ästhetik", en Zeitschrift für philosophische Forschung II, pp. 527-548 
Herder, J. G. (1994), Sämtliche Werke, B. Suphan (ed.), Hildesheim: Olms-Weidmann

Hermann, W. (1973), The theory of Claude Perrault. Londres

Hernandez, A. (1972), Grundzüge einer Ideengeschichte der französischen Architekturtheorie von 1560-1800, Basilea: Buchruckerei National-Zeitung

Horkheimer, M. y Adorno, Th. W. (2006), Dialéctica de la llustración. Fragmentos filosóficos, Juan José Sánchez (intr. y trad.), Madrid: Trotta

Horn-Oncken, A. (1967), "Über das Schickliche", en Abhandlungen der Akademie der Wissenschaften in Göttingen, 3/70, Göttingen

Illert, W. (1988), Das Treppenhaus im deutschen Klassizismus. Worms: Manuskripte zur Kunstwissenschaft

Jauss, H. R. (2004), Las transformaciones de lo moderno. Estudios sobre las etapas de la modernidad estética, Madrid: Machado Libros

-- (1976), La literatura como provocación, Barcelona: Península

John, E. (2012), "Beauty, Interest, and Autonomy", en The Journal of Aesthetics and Art Criticism, vol. 70:2, pp. 193202

Kant, I. (1990), Fundamentación de la metafísica de las costumbres, Madrid: Espasa Calpe

- (2004), ¿Qué es la Ilustración?, Roberto R. Aramayo (ed.), Madrid: Alianza

.- (2006), Crítica de la razón práctica, Manuel García Morente (trad.), Salamanca: Sígueme
.- (2007), Crítica del Juicio, Manuel García Morente (trad.), Madrid: Tecnos

.- (2009), Crítica de la razón pura, Manuel García Morente (trad.), Madrid: Tecnos

Keudell, E. von (1931), Goethe als Benutzer der Weimarer Bibliothek, Weimar: Herman Böhlaus Nachfolge

Klauss, J. (1991), Goethes Wohnhaus. Weimar: Klassikerstätten

Knell, H. (1985), Vitruvs Architekturtheorie. Versuch einer Interpretation, Darmstadt: Wissenschaftliche Buchgesellschaft

Koch, H. (1951), Vom Nachleben des Vitruv. Baden-Baden: Verlag von Kusnt und Wissenschaft

Koselleck, R. (2007), Crítica y crisis. Un estudio sobre la patogénesis del mundo burgués, R. de la Vega y J. Pérez de Tudela (trad.), Trotta: Madrid

Koslowski, P. (1987), Die postmoderne Kultur. Gesellschaftlich-kulturelle Konsequenzen der technischen Entwicklung. Múnich

Kristeller, P. O. (1986) [1951-1952], “El sistema moderno de las artes", en El pensamiento renacentista y las artes, Madrid: Taurus, pp. 179-240

Kühnlenz, F. (1959), "Vom Nützlichen durchs Wahre zum Schönen. Die Architektur in Goethes Leben und Schaffen", en: Deutsche Architektur 8/7, Berlín

Kruft, H.-W. (1982), "Goethe und die Architektur", en Pantheon-Internationale Zeitschrift für Kunst, XL Jahrgang München, pp. 282-289 - (1990), Historia de la teoría de la arquitectura, 2 vols., Madrid: Alianza 
Leach, N. (1997) Rethinking Architecture: A Reader in Cultural Theory, Londres: Routledge

Leibniz, G. W. (2011), "Meditaciones sobre el conocimiento, la verdad y las ideas", E. de Olaso (tr.), en Discurso de metafísica. Monadología. Escritos, Javier Echeverría (es. int.). Madrid: Gredos

Lessing, G. E. (1990) [1766], Laocoonte o sobre los límites de la pintura y la poesía, Madrid: Visor

Liess, R. (1985), Goethe vor dem Straßburger Münster. Zum Wissenschaftsbild der Kunst, Leipzig: Seemann

Lippman, E. (1992), A History of Western musical Aesthetics, Lincoln: University of Nebraska Press

Lowe, D. y Sharp, S. (2005), Goethe \& Palladio, Great Barrington: Lindisfarne Books

Luhmann, N. (1995), Die Kunst der Gesellschaft, Fráncfort: Suhrkamp

Mandelkom, K. R. (1982), "Kunst- und Literaturtheorie der Kalssik und Romantik", en Neues Handbuch der Literaturwissenschaft, vol. 14, K. von See y otros (ed.), Wiesbaden

Marchán Fiz, S. (2000), La estética en la cultura moderna, Madrid: Alianza .- (2012) [2010], La disolución del clasicismo y la construcción de lo moderno, Salamanca: Ediciones Universidad de Salamanca

Marcuse, H. (2010), Eros y civilización, BarceIona: Planeta

Marrades Millet, J. (2005), "Expresividad musical y lenguaje", en Episteme, vol. 25 $\mathrm{n}^{0} 1$, pp. 29-51

Masiero, R. (2003), Estética de la arquitectura, Madrid: Machado libros
Mebes, P. (1908), Um 1800. Architektur und Handwerk im letzten Jahrhundert ihrer traditionellen Entwicklung herausgegeben von..., vol. II, Múnich: F. Bruckmann

Meier, A. (ed.) (1987), Un paese indicibilmente bello. II Viaggio in Italia di Goethe e il mito della Sicilia, Palermo: Sellerio editore

Merker, N. (1974), Illuminismo tedesco. Età di Lessing, Laterza

Miller, R. D. (1970), Schiller and the Ideal of Freedom. A Study of Schiller's Philosophical Works UIT Chapters on Kant, Oxford: Clarendon Press

Montesquieu (1962), "Essai sur le goût", en Oeuvres complètes, vol. II, París: Gallimard

Moritz K. Ph. (1962), Schriften zur Asthetik und Poetik, Max Niemeyer (ed.), Tübingen - (1979), Götterlehre: oder mythologische Dichtungen der Alten, Berlín: Insel Verlag -- (2009), "Ensayo de unificación de todas las bellas artes y ciencias bajo el concepto de lo acabado en sí mismo", M. G. Burello (trad.), en Pensamiento de los confines 25, Buenos Aires: Guadalquivir

Morrison, H. (1952), L- Sullivan, Prophet of Modern Architecture. Nueva York

Müller, M. (ed.) (1972), Autonomie der Kunst, Fráncfort del Meno: Suhrkamp

Müller-Wolff, S. (2007), Ein Landschaftsgarten im IImtal: die Geschichte des herzoglichen Parks in Weimar, Colonia-Weimar: Böhlau Verlag 
Norberg-Schulz, Ch. (1979), Genius Loci: Towards a Phenomenology of Architecture, Nueva York: Rizzoli

Neumeyer, F. (1995) [1986], Mies van der Rohe. La palabra sin artificio. Reflexiones sobre arquitectura 1922/1968, Madrid: El Croquis Editorial

Ögüt, R. N. (1999), The autonomy of Art and Aestheticism in Architecture, Ankara: METU Faculty of Architecture Press

Oncina, F. (ed.) (2011), Schopenhauer en la historia de las ideas, Madrid: Plaza y Valdés

Oncina, F. y Ramos, M. (ed.) (2006), Ilustración y modernidad en Friedrich SchiIler en el bicentenario de su muerte, València: Universitat de València

Ortega y Gasset, J. (1933), "Pidiendo un Goethe desde dentro", en Revista de Occidente, pp. 33-34. Madrid

Ortíz y Sanz, J. (1987), Los diez libros de Archîtectura de M. Vitruvio Polión traducidos del latín, y comentados por..., València: Albatros (edición facsímil, Imprenta Real, Madrid, 1787)

Osman, M. et al. (ed.) (2002), Mining Autonomy. Perspecta: The Yale Architectural Journal, vol. 33, Cambridge: The MIT Press

Paetzold, H. (1983), Ästhetik des deutschen Idealismus: zur Idee ästhetischer Rationalität bei Baumgarten, Kant, Schelling, Hegel und Schopenhauer, Wiesbaden: Steiner

Palladio, A. (1570), I quattro libri dell'architettura, Venecia: Francesco de' Franceschi, Domenico imp.

Pareyson, L. (1983), Etica ed estetica in SchiIler, Milán: Mursia
Pérez Gómez, A. (1987), L'architecture et la crise de la science moderne, Bruselas: P. Mardaga

Perisco, E. (1947), Scritti, critici e polemici, Milán: Rossa and Ballo

Pevsner, N. (1983), Estudios sobre arte, arquitectura y diseño. Del manierismo al romanticismo, era victoriana y siglo $X X$, Barcelona: Gustavo Gili

Pfeiffer, H. et al. (ed.) (1987), Art Social und Art Industriel: Funktionen der Kunst im Zeitalter des Industrialismus, Múnich: W. Fink Verlag

Pielmann, E. (1998), "Goethes Treppenhäuser", en Goethe-Jahrbuch, 115, pp. 171-181

Polacco, L. (1965), "La posizione di Andrea Palladio di fronte all'Antichità", en Bolletino del Centro Internazionale di Studi Andrea Palladio, nº VII, pp. 59-76

Porphyrios, D. (1982), Sources of Modern Eclecticism, Londres: Academy Editions

Ribbat, E. (1978), “Die Romantik: Wirkungen der Revolution und neue Formen literarischer Autonomie", en Geschichte der deutschen Leteratur vom 18. Jahrhundert bis zum Gegenwart, vol. I/2, Viktor Žmegač (ed.), Königstein: Beliz Atenäum, pp. 92-142

Ritter, J. (ed.) (2007), Historisches Wörterbuch der Philosophie, Basilea: Schmabe

Rodríguez Ruiz, D. (1986), “El orden dórico y la crisis del vitruvianismo a finales del siglo XVIII: la interpretación de Pedro José Márquez", en Fragmentos, ${ }^{\circ}$ 8-9 .- (2000), "Diez libros de Arquitectura: Vitruvio y la piel del clasicismo", en 
Vitruvio (2000), Los diez libros de Arquitectura, Jose Luis Oliver Domingo (trad.), Madrid: Alianza, pp. 11-51

Rubert de Ventós, X. (1978), El arte ensimismado, primera edición de 1963, Barcelona: Península

Rubio Garrido, A. (2015a), "Hacia una estética de la arquitectura. Kant y la crisis del clasicismo", en Textos fundamentales de la estética de la arquitectura. València: General de Ediciones, pp. 198-217

.- (2015b), “El desafío de la expresión en la arquitectura", en Actas I Congreso internacional de la Red Española de Filosofía. Valencia: Universidad de Valencia, III: 49-61

.- (2016), "Enigma as Moral Requirement in the Wake of Ledoux's Work: Autonomy and Expression in Architecture", en Architecture Philosophy 2(1), pp. 63-82

-- (2017), “Hibridación y refundación en la arquitectura: parámetros de una paradójica relación desde el concepto de autonomía", en Arquitectonics. Mind, Land \& Society 30, 2017, pp. 169-182

- (2018), "Goethe entre los antiguos: naturaleza y arquitectura", en VLC arquitectura 5(1)

Rubio Garrido, A. y Calduch Cervera, J. (2016), "Goethe and Theater Architecture", en EGA. Revista de Expresión Gráfica Arquitectónica. 21(28), pp. 44-51 .- (2017), "Baukunst. El pensamiento arquitectónico de Goethe", en Quintana 15 , pp. 255-267

Rubio Garrido, A. y Takkal, A. (2014), "Arte Sonoro y la dialéctica entre las artes y el arte", en ¡Chum, chum, pim, pam, pum, Olé! Pioneros del Arte Sonoro en España, de Cervantes a las Vanguardias, Miguel Molina (ed.), Lucerna: Weekend Proms, pp. 24-32

Rüfner, V. (1955), “Homo secundus Deus. Eine geistesgeschichtliche Studie zum menschlichen Schöpfetum", en Philosophiches Jahrbuch der Görres-Gesselschaft, vol 63/2. Friburgo

Ruppert, H. (ed.) (1958), Goethes Bibliothek. Katalog, Weimar: Arion Verlag

Rykwert, J. (1980), The First Moderns: The Architects of the Eighteenth Century, Cambridge

.- (1996), The Dancing Column. Cambridge: MIT Press

Safranski, R. (2015), Goethe. La vida como obra de arte, Raúl Gabás Pallás (trad.), Barcelona: Tusquets

Sauder, G. (1982), "Ästhetische Autonomie als Norm der Weimarer Klassik", en Friedrich Hiller (ed.), Normen und Werte, Heidelberg: Carl Winter-Universitätverlag, pp. 130-150

Scranton, R. L. (1974), "Vitruvius' Arts of Architecture", en Hesperia, XLIII, pp. 494-499

Schelling, F. W. J. von (1999), Filosofía del arte, Virginia López-Domínguez (es. pr., trad. y n.), Madrid: Tecnos

Schiller, F. (1990), Kallias; Cartas sobre la educación estética del hombre, Jaime Feijóo y Jorge Seca (trad.), Madrid: Anthropos - (1991), Escritos sobre estética, Juan Manuel Navarro Cordón (ed. y es. pr.), María José Callejo Herranz y Jesús González Fisac (trad.), Madrid: Tecnos 
Serlio, S. (1982), Tutte l'opere d'architettura et prospettiva, Francesco de' Franceschi, Venecia, 1537-1551. Serlio, S., The five books of Architecture (facsímil de la edición de Londres, 1611). Nueva York: Dover Publications, Inc.

Shaftersbury, A. A. C. (2010), Soliloquy, or Advice to an Author, Gale ECCO

Solà-Morales, I. de (2003a), Inscripciones, Barcelona: Gustavo Gili -- (2003b), Diferencias. Topografía de la arquitectura contemporánea, Barcelona: Gustavo Gili .- (2004), Eclecticismo y vanguardia y otros escritos, Barcelona: Gustavo Gili

.- (2005), Metrópolis, X. Costa (ed.), Barcelona: Gustavo Gili

Staiger, E. (ed.) (1977), Der Briefwechsel zwischen Schiller und Goethe. Frankfurt am Main: Insel Verlag

Subirats, E. (1986), La flor y el cristal, Barcelona: Anthropos

-- (1991), Metamorfosis de la cultura moderna, Barcelona: Anthropos

Sulzer, J. G. (1773), Allgemeinen Theorie der schönen Künste, 2 vols., Leipzig

Szambien, W. (1986), Les projets de I'an II. Concours d'architecture de la période révolutionnaire, París

.- (1993), Simetría, gusto, carácter.

Teoría y terminología de la arquitectura en la época clásica. 1550-1800, Juan A. Calatrava (trad.), Madrid: Akal Arquitectura

Szondi, P. (1992), Poética y filosofía de la historia I: Antigüedad clásica y modernidad en la estética de la época de Goethe. La teoría hegeliana de la poesía, Madrid: Visor
Tabarroni, G. (1971-72), "Vitruvio nella storia della scienza e della tecnica", en Atti della Accademia delle Scienze dell' Istituto di Bologna. Classe di scienze morali. Memorie, LXVI, pp. 1-37

Tafuri, M. (1978), Retórica y Experimentalismo, Sevilla: Universidad de Sevilla .- (1978), Scritti Rinacimentali di Architettura, Milán .- (2003), Teorías e historia de la arquitectura, Madrid: Celeste

Takkal, A., Horrox, K. y Rubio-Garrido, A. (2018), "The issue of space in a prison art therapy group: a reflection through Martin Heidegger's conceptual frame", en International Journal of Art Therapy, 23:3, pp. 136-142

Tatarkiewicz, W. (2000), Historia de la estética, 2 vols., Madrid: Akal .- (2002), Historia de seis ideas. Arte, belleza, forma, creatividad, mimesis, experiencia estética, Madrid: Tecnos

Tedeschi, E. (1962), Teoría de la arquitectura, Buenos Aires: Nueva Visión

Thielscher, P. L. (1961), "Vitruvius Mamurra”, en Paulys (1961), Realencyclopädie der Klassischen Altertumswissenschaft, vol. IX A1, pp. 427-489

Tilliette, X. (1970), Schelling, une philosophie en devenir, París: Librairie Philosophique J. Vrin.

Todorov, T. (1996), "Introduction. Goethe sur l'art", en: Goethe, Johann Wolfang, Écrits sur l'art, París: Flammarion, pp. 5-71

Torres, J. y Mejía, C. (ed.) (2017), La recherche patiente. Le Corbusier, cincuenta años después, València: General de Ediciones 
Valéry, P. (2004), Eupalinos o el arquitecto / El alma y la danza, José Luis Arantegui (trad.), Madrid: Antonio Machado libros

Vidler, A. (2008), Histories of the Immediate Present: Inventing Architectural Modernism, Cambridge: The MIT Press

Vilar, G. (2010), Desartización: paradojas del arte sin fin, Salamanca: Ediciones Universidad de Salamanca

Vitruvio (1980), Los diez libros de arquitectura, Agustín Blánquez (trad.), Barcelona: Iberia

-- (1997), De Architectura, Antonio Corso y Elisa Romano (trad. y anot.), Pierre Gros (ed.), Turín: Giulio Einauldi -- (2000), Los diez libros de Arquitectura, Jose Luis Oliver Domingo (trad.), Madrid: Alianza

Vitruvius Pollio, Marcus (1914), The Ten Books of Architecture, Morris Hicky Morgan (trad.), Herbert Langford Warren (ed.). Harvard University Press

Warneken, B. J. (1973), "Autonomie und Indienstnahme. Zu ihrer Beziehung in der Literatur der bürgerlichen Gesellschaft", en Goth, Joachim (1973), Rhetorik, Ästhetik, Ideologie. Aspekte einer kritischen Kulturwissenschaft. Stuttgart: Metzler, pp. 79-115

Wetz, F. J. (1996), Friedrich W.J. Schelling zur Einführung, Hamburgo: Junius

Wilpert, G. von (1998), Goethe-Lexikon. Stuttgart: Alfred Kröner

Winckelmann, J. J. (1985) [1762 y 1764], Historia del arte en la antigüedad seguida de Observaciones sobre la arquitectura de los antiguos, Barcelona: Ediciones Orbis SA. Incluye:
“Winckelmann" por J. W. Goethe, pp. 9-3

Wittkowski, W. (ed.) (1990), Revolution und Autonomíe. Deutsche Autonomieästhetik im Zeitalter der Französischen Revolution. Ein Symposium, Tubinga: Max Niemeyer

Zammito, J. H. (1992), The Genesis of Kant's Critique of Judgment, Chicago y Londres: Chicago University Press

Zurko, E. de (1958), La teoría del funcionalismo en arquitectura, Buenos Aires: Nueva Visión

\section{Fuentes}

Barbaro, D. (1567), I dieci libri dell'Architettura tradotti e commentati da... Francesco Marcolini, Venecia

Blondel, J.-F. (1771-1777), Cours d'Architecture ou Traité de la décoration, distribution \& construction des bâtiments, París: Dessaint

Boffrand, G. (1745), Livre d'architecture contenant les principes generaux de cet art, París

Büchsenschuß, J. (2009), Goethe und die Architekturtheorie, tesis doctoral dirigida por Fritz Neumeyer presentada en la TU Berlin. Publicada en Kovac Verlag en 2010

Durand, J. N. L. (1802), Précis des leçons d'architecture, París

Galiani, B. (1758), M. Vitruvii Pollioni de Architectura libri decem. L'Architettura di M. Vitruvio Pollione colla traduzione italiana e comento del Marchese..., Nápoles: Stamperia Simoniana

Goethe, J. W. (1795), Baukunst, 1795. Goetheund Schiller- Archiv (GSA 25/W 3606) 
Guattani, G. A. (1786-1789), Monumenti antichi inediti ovvero notizie sulle antichità e belle arti di Roma per.. (Roma, p. XXI)

Hellersberg, H. (2006), Architekturvostellungen in der deutschen Literatur der Goethezeit, tesis doctoral defendida en la Neuphilologischen Fakultät der Ruprecht-Karls-Universität Heildelberg

Laugier, M.-A. (1753), Essai sur l'architecture. París

Le Camus de Meziere, N. (1780), Le génie de l'architecture ou l'analogie de cet art avec nos sensations, París

Perrault, Ch. (1688-1697), Parallèle des Anciens et des Modernes, Jean Baptiste Coignard

Perrault, Cl. (1683), Ordonnance des cinq espèces de colonnes selon la méthode des anciens, París

.- (1684), Les dix libres de l'Architecture de Vitruve corrigez et traduits nouvellement en François, avec des Notes \& des Figures, $2^{\mathrm{a}}$ edición revisada y ampliada, París

Quatremère de Quincy, A.-C. (1788-1825), Encyclopédie méthodique: Architecture, París

Rameau, P. (1722), Traté de l'harmonie réduite à son principe naturel, París

Rubio-Garrido, A. (2015), Autonomía y expresión en la arquitectura. La antinomia de la modernidad al hilo de Claude Nicolas Ledoux. Presentada en la Facultad de Filosofía y Ciencias de la Educación de la Universitat de València en el marco del Programa de Doctorado de Pensamiento Filosófico Contemporáneo, dirigida por Julián
Marrades Millet y Juan Calatrava

Escobar

Schiller, F. y Humboldt, W. von (1830), Briefwechsel zwischen Schiller und Wilhelm v. Humboldt, Stuttgart y Tübingen: Cotta'schen Buchhandlung

Sulzer, J. G. (1771), Allgemeine Theorie der Schönen Künste. Leipzig

Viel de Saint-Maux, L.-J. (1787), Lettres sur l'architecture, París

Vitruvius (1552), De Architectura libri decem, original procedente de la Biblioteca Estatal de Baviera, digitalizado el 29 de junio de 2009

Voltaire (1749), Des embellissements de Paris, París 



\section{CRÉDITOS \\ FOTOGRÁFICOS}

\section{PARTE I. LA AUTONOMÍA COMO DESAFÍO}

1. Philibert de l'Orme (1568), Le premier tome de l'architecture, 2 2a edición, París, lámina 51

2. Caspar David Friedrich (c. 1828-1835), Ostermorgen [Mañana de Pascua], óleo sobre lienzo, Madird: Museo Thyssen-Bornemisza, nº Inv. 792 (1973.24)

3. Claude-Nicolas Ledoux (c. 1800), Coup d'oeil du théatre de Besançon [Golpe de vista al teatro de Besançon], grabado sobre cobre, publicado en L'Architecture considérée sous le rapport de l'art, des moeurs et de la législation, 1804, tomo primero, París, calle Neuve d'Orléans: imprenta de H.-L. Perroneau, lámina 113

\section{PARTE II. GOETHE Y EL ARTE DE LA CONSTRUCCIÓN}

1. Johann W. Goethe (1795), Manuskript und Notizen mit der alten Aufschrift, Über Baukunst. 1795' [Manuscrito y notas con la vieja inscripción, Sobre la Arquitectura. 1795], GSA 25/W 3606, p. 6

2. Johann W. Goethe (hacia 1792), Tempelfassade [Fachada de templo], (188x143 mm. Lápiz, tinta con pluma, lavado a sepia), en Femmel [1958] 1972, IVb: 95

3. Johann W. Goethe (1794), Park und Römisches Haus in Weimar [Parque y Casa Romana en Weimar], en Femmel [1958] 1972, IVa: 266 
